Editora Poisson

\section{Gestão da Produção em Foco Volume 17}

1a Edição

Belo Horizonte

Poisson

2018 
Editor Chefe: Dr. Darly Fernando Andrade

\section{Conselho Editorial}

Dr. Antônio Artur de Souza - Universidade Federal de Minas Gerais

Dra. Cacilda Nacur Lorentz - Universidade do Estado de Minas Gerais

Dr. José Eduardo Ferreira Lopes - Universidade Federal de Uberlândia

Dr. Otaviano Francisco Neves - Pontifícia Universidade Católica de Minas Gerais

Dr. Luiz Cláudio de Lima - Universidade FUMEC

Dr. Nelson Ferreira Filho - Faculdades Kennedy

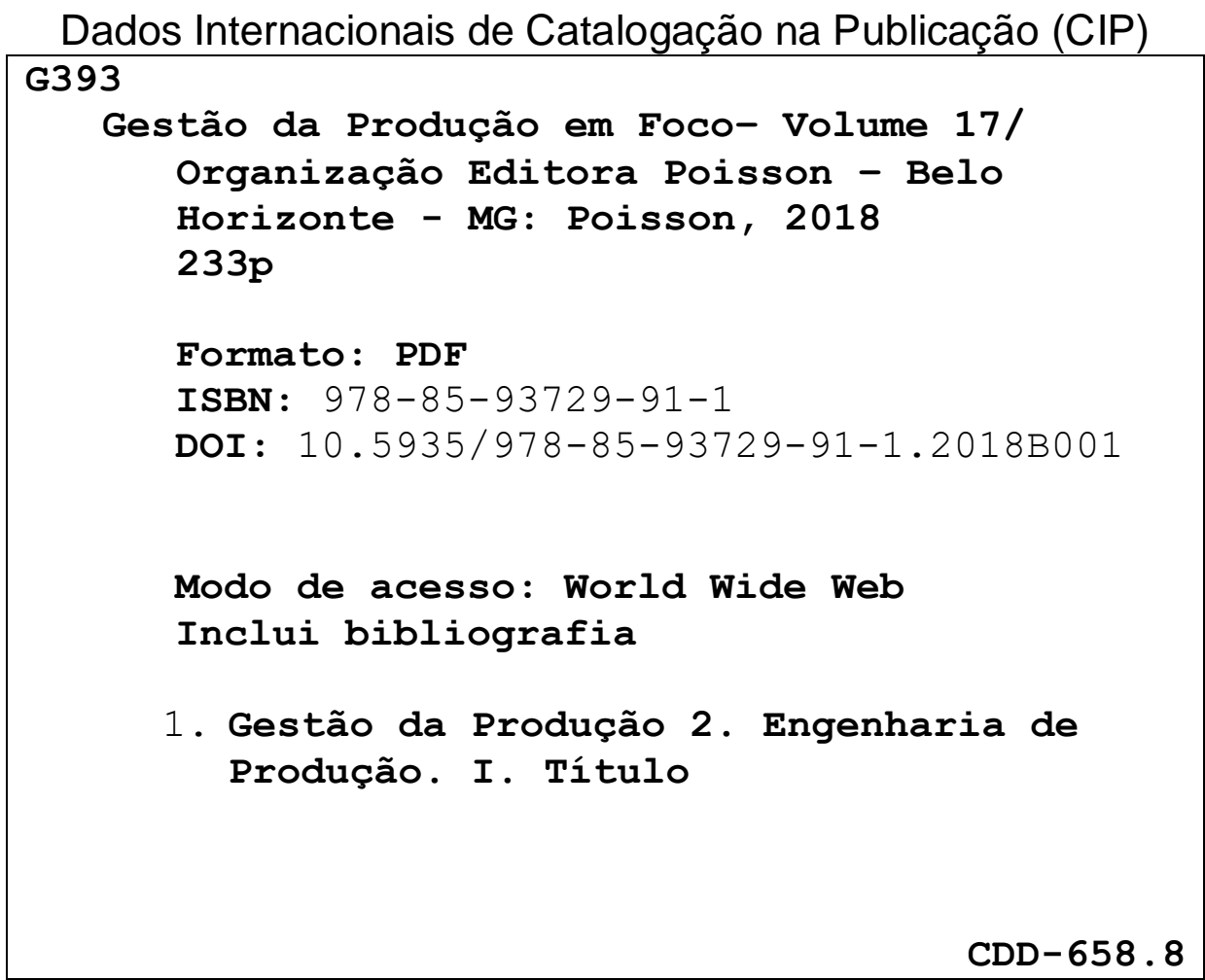

O conteúdo dos artigos e seus dados em sua forma, correção e confiabilidade são de responsabilidade exclusiva dos seus respectivos autores.

$\underline{\text { www.poisson.com.br }}$

contato@poisson.com.br 


\section{SUMÁRIO}

Capítulo 1: Proposta de aplicação de RFID no setor logístico de empresa Petrolífera

Talita Ramos Barcellos, Rubens Aguiar Walker, Marcos dos Santos, Ruben

Gutierrez, Fabricio da Costa Dias

Capítulo 2: Utilização das ferramentas da produção enxuta nas bancas de pesponto da cidade Franca-SP para o aumento da produtividade

Luciana Rodrigues Pires, Geandra Alves Queiroz, Jaqueline Guimarães Borges, June Tabah

Capítulo 3: Análise dos dez indicadores logísticos vitais na logística propostos por Rey (2004) em um PSL do Estado do Rio de Janeiro...... Vinicius Marques da Silva Freitas, Lígia do Carmo Martins Damasceno, Bianka Coutinho Alvim Figueira Mendes

Capítulo 4: O problema de sequenciamento com restrição de recursos: uma proposta de melhoria de um estudo de caso no setor calçadista.

Mayara Fernanda Silva e Santos, Luana Alves Cota Souza, Cecília Rocha Gonçalves, Salvador Pereira de Carvalho Junior, Mayra Cristina dos Santos

Capítulo 5: Análise dos indicadores de produção industrial das regiões do Brasil utilizando modelos de regressão linear Josemar Coelho Felix, Kéllen Bárbara Nascimento Furtado, Edilaine Gonçalves Araújo, Robert Cruzoaldo Maria

Capítulo 6: Diagnóstico do setor de manutenção de uma indústria metalúrgica da cidade de Campina Grande - Pb

Danielle Freitas Santos, Emerson Santos Aguiar

Capítulo 7: Análise de desempenho em transportes de granéis líquidos na cabotagem

Filipe de Castro Quelhas

Capítulo 8: Utilização da técnica FMEA como ferramenta de identificação de causas de falhas

Gabriel Augusto Rodrigues de Freitas, Rafael Cezar Menezes, Mario Santos de Oliveira Neto, Natali de Freitas Alves 


\section{SUMÁRIO}

Capítulo 9: Caracterização do relacionamento interorganizacional entre construtoras e fornecedores de materiais de construção

Jefferson Augusto Krainer, Christiane Wagner Mainardes Krainer, Cezar Augusto

Romano

Capítulo 10: Marco de trabajo para la programación de la producción agrícola a pequeña escala bajo un modelo de resiliencia Leonardo Hernán Talero Sarmiento, Laura Yeraldín Escobar Rodriguez, Edwin Alberto Garavito Hernández

Capítulo 11: Utilização da curva ABC como proposta de melhoria para a gestão de estoques em uma confecção de lingeries Luciana Mendonça, Talyson Xavier Ribeiro

Capítulo 12: Modelo de diagnóstico da maturidade do processo de planejamento e controle da produção fundamentado nos princípios da construção enxuta.

Maria Luiza Abath Escorel Borges, Henrique Sérgio Rêgo de Holanda Sá Sobrinho

Capítulo 13: Formulação de uma política de estoque para materiais MRO de implementos hidráulicos

Mateus Frechiani Bitte, Helio Zanquetto Filho

Capítulo 14: Manufatura Enxuta: Os desafios enfrentados pelas empresas durante o processo de implantação

Nayara Gimenez Barbosa

Capítulo 15: compostos de bens e serviços na gestão da produção: um estudo de caso em uma empresa de móveis planejados

Vitor Hugo dos Santos Garcia, Gelson da Silva Veda, Rayanne Cristina Oliveira da Silva Araújo, Flávio de São Pedro Filho, Váldeson Amaro Lima 


\section{SUMÁRIO}

Capítulo 16: Aplicação de uma Rede Neural Artificial na estimação de velocidade de um motor de corrente contínua...

Arlei Fonseca Barcelos, Juliana Ribas Monteiro, Wallace de Almeida Gomes

Capítulo 17: Gestão da tecnologia da produção: um estudo de caso sobre layout de um datacenter

Marcone Freitas dos Reis, Mariana de Carvalho Fernandes, Auricélio da Silva Leite de Oliveira, Leticia de Oliveira dos Santos, Marcos do Espirito Santo da Paixão

Capítulo 18: Análise da viabilidade da utilização do Software Warehouse Management System na gestão de armazenagem de produtos e materiais

Maurício Massami Kuroda, José Tomadon Júnior

Capítulo 19: Carga de trabalho mental: análise bibliométrica de literatura

Tiago Machado e Silva, Sergio Luiz Ribas Pessa

Capítulo 20: Manual para o Desenvolvimento de Embalagens de Alimentos Preparados Congelados

Harry Rodrigues Júnior, Marco Aurelio de Carvalho

Capítulo 21: Análise ergonômica dentro de um posto administrativo em uma escola pública do município de Manaus-Am

Autores: 


\section{Gapítulo 1}

\section{PROPOSTA DE APLICACÃO DE RFID NO SETOR LOGÍSTICO DE EMPRESA PETROLÍFERA}

\section{Talita Ramos Barcellos}

Rubens Aguiar Walker

\section{Marcos dos Santos}

\section{Ruben Gutierrez}

\section{Fabricio da Costa Dias}

Resumo: O presente estudo de caso aborda o setor logístico de uma empresa multinacional do ramo perfuração de petróleo. Apresentando todo conceito e ramificação da logística e tendo como objetivo conhecer as suas principais deficiências desde o setor de recebimento ao setor de armazenamento onde cada processo foi devidamente analisado e registrado. Foram encontradas diversas dificuldades como: Materiais sem identificação, divergência entre o estoque físico e o estoque contábil, material sem registro no sistema, armazenamento planejado indevidamente, custos excessivos, entre outros pontos negativos. Com o objetivo de solucionar esses problemas e trazer melhorias para o setor foi implantado um plano de ação referente a um inventário desses materiais, onde todos os materiais foram avaliados, realocados e receberam placas identificadoras, o que resultou na solução de grande parte dos problemas encontrados. Como proposta efetiva de solução, foi apresentado o sistema RFID (Radio frequency identification) de rastreamento, retratando todo o conceito, instalação e integração, destacando todos os benefícios e vantagens como também possíveis desvantagens obtidas com a implantação.

Palavras-chave: Logística; Inventário; RFID; Estoque; Armazenamento. 


\section{1 - INTRODUÇÃO}

A palavra logística é proveniente do grego "logistikos" que significa cálculo e raciocínio no sentido matemático, segundo NEVES (2005). Um dos primeiros indícios da aplicação de um sistema logístico foi reconhecido através de atividades militares, a princípio o exército persa necessitou de um grande apoio da marinha em 481 A.C, com cerca de 3.000 embarcações para comportar o exército, com o objetivo de facilitar a movimentação das tropas.

Uma das primeiras publicações registradas sobre a logística e suas técnicas foi em 1917 de autoria do Tenente-Coronel Thorpe dos Fuzileiros navais dos EUA. No livro "Logística Pura: a ciência da preparação para a guerra" Thorpe defende que: "A estratégia e a tática proporcionam o esquema da condução das operações militares, enquanto a logística proporciona os meios"

Muito além de guardar algum material em um determinado local, o setor do almoxarifado requer administração e organização em vários parâmetros específicos: A localização do armazém: Para tomada de decisão em relação ao local do armazém é indicado uma pesquisa territorial, levando em consideração a facilidade de acesso a vias e/ou estradas. $O$ layout e dimensionamentos da área de estocagem: Determinar a localização do material de forma que possa otimizar o espaço. O planejamento da rota da frota dos veículos: Visando otimizar o tempo de entrega e gastos de transporte desnecessários. A seleção dos fornecedores: Escolhendo fornecedores confiáveis em relação a qualidade dos materiais, também levando em consideração a melhor forma de pagamento e prazos. O planejamento de pedido de compras para reabastecimento: Evitando desperdícios de materiais que não são requisitados. Os colaboradores que estarão manipulando os materiais dentro do armazém: Pessoas treinadas e capacitadas com entendimento em segurança, e muitos outros segmentos que compõem o gerenciamento do estoque.

Pode-se encontrar diversos conceitos relacionados a logística: De acordo com Ballou (1998), a logística empresarial procura identificar como a administração pode prover melhor nível de rentabilidade nos serviços de distribuição aos clientes e consumidores, através de planejamento, organização e controle efetivo para as atividades de movimentação e armazenagem que visam facilitar o fluxo de produtos

Segundo Bowersox, Closs (2001, p. 255) "controle de estoque é um processo rotineiro necessário ao cumprimento de uma política de estoque. O controle abrange as quantidades disponíveis uma determinada localização e acompanha suas variações ao longo do tempo". Porém, controlar um estoque com segurança não é tarefa fácil. Por ser um setor em constante mudanças e processos todo cuidado é pouco, a disciplina é fundamental para evitar perdas, e gastos desnecessários.

Segundo Dias (2008, p. 25) alguns pontos são indispensáveis para controlar o estoque com eficiência.

- Levantar o que, de fato, precisa permanecer em estoque.

- Planejar a periodicidade da compra de material para reabastecimento.

- Determinar, através de pesquisas nas requisições, a quantidade certa a ser comprada, que supra a necessidade sem que haja falta, ou compra de emergência.

- Estar alinhado com setor de compra para ter agilidade e precisão nos processos de aquisição dos materiais.

- Realizar o recebimento e armazenamento dos materiais estocados conforme a demanda.

- Identificar e remover materiais sem condições de uso.

- Manter o Inventário do estoque sempre atualizado e exato.

A evolução do inventário é o processo de contagem de materiais é válido desde os primeiros sinais da existência da logística. Obter informações quantitativas é importante independendo do tipo de estoque.

Inventário manual - atualmente no mercado, estão disponíveis diversos tipos de sistemas facilitadores no processo de inventário de estoque, entretanto, antigamente, a forma manual era a única forma de concluir esse processo.

De acordo com LEAL COSTA. (2002) pode-se adotar métodos para a execução prática: Determinar o período de tempo a qual o inventário será realizado, escolher a metodologia para este processo, destinar 
pessoas para o trabalho, ter a relação dos materiais, prover materiais necessários tal como: Papel, lápis, luvas, lista de materiais, etc. Ter os materiais agrupados para a facilitação da contagem, ter o acompanhamento da contagem, observar a diferença entre a contagem física da contagem apontada no sistema, registrar qualquer dificuldade encontrada.

Inventário por Scanner -com o passar do tempo, tecnologias foram sendo desenvolvidas e o Scanner passou a ser adotado como facilitador do processo de inventário. Segundo DE ARAUJO (2009) os códigos representam gráficos através de linhas. A leitura dessas linhas é feita por um scanner que emite um laser de cor avermelhada.

Apesar de ser uma evolução, o processo de inventário por código de barras tem suas desvantagens. Uma vez que o código de barras é danificado, a identificação fica comprometida, sendo ele de papel a probabilidade de dano é muito grande.

A origem do sistema RFID foi o físico escocês Sir Robert Alexander Watson-Watt (18921973) é reconhecido como o inventor do sistema de radar. Segundo Santini (2006), o sistema de RFID surgiu através dos sistemas de radar que foram utilizados na Segunda Guerra Mundial. O objetivo do radar era informar a aproximação de aviões ainda distantes. Porém havia dificuldade em identificar dentre as aeronaves quais delas eram aliadas e quais eram as inimigas.

Um sistema RFID é, de acordo com Bhatt \& Glover (2007), a forma abreviada de Radio frequency identification, em português, identificação por radiofrequência. É uma tecnologia utilizada para identificação que consiste em utilizar frequências de rádio ou variações magnéticas para prover a comunicação. O alvo dessa tecnologia é rastrear e localizar determinados produtos.

O sistema RFID é uma tecnologia sem fio que tem como objetivo a coleta automática de dados. (Porto, 2005)

O sistema RFID é composto uma configuração composta por três integrantes base: os Tag's, o leitor e antena. Essa estrutura pode ser alterada dependendo do tipo de etiqueta aplicada e os dados que serão armazenados, (WEIS, 2003).

O Problema de gerir um estoque de grande porte com eficiência é sempre um desafio para os gestores, além do controle exigir organização e destreza, o planejamento precisa ser alinhado como um todo, desde a compra de materiais até a saída de material do estoque. Tanto para estoque voltado para venda quanto para o estoque voltado para consumo próprio. Qualquer erro no planejamento tem por consequência custos maiores.

\section{Como reduzir o custo do setor logístico utilizando as funções de estoque adequadas?}

Aplicar as algumas funções do estoque é primordial para o bom andamento do setor. A garantia do abastecimento de materiais evita, por exemplo, desperdícios ocasionados pelo atraso no fornecimento e possíveis riscos de dificuldade no fornecimento. Pode-se também, buscar economias em escala comprando lotes econômicos e buscando ser flexível ao atendimento às requisições do setor. O planejamento eficiente minimiza os erros e mantém o setor mais preparado para eventuais oscilações e problemas inesperados.

Problemas de controle na saída e entrada dos materiais fazem com que haja uma diferença muito grande entre o estoque físico e o estoque contábil. A divergência entre a quantidade de material estocado e o número apresentado do sistema utilizado para o controle gera problemas sérios ao setor logístico. Com o sistema apresentando uma quantidade maior que no físico pode-se ter materiais em falta, que quando requisitados, implicará em uma compra de emergência podendo atrasar a entrega. Por sua vez, tendo mais itens no físico que o número apresentado do sistema, pode-se gerar compra de materiais trazendo custos desnecessários.

\section{Como alinhar o estoque físico com o estoque contábil?}

Como solução, pode-se planejar um inventário de todo o estoque físico. Deve-se garantir que no decorrer do levantamento não haja movimentação no setor, para que haja exatidão no relatório. Uma vez tendo a quantidade exata de material no físico é necessário alinhar com o sistema utilizado. Uma forma de manter o controle essa etapa é realizar o procedimento de identificação do material e atualização no sistema do mesmo no ato do recebimento

Acompanhando os procedimentos do setor, foi identificado pequenas falhas. Todas elas 
justificadas por problemas no controle do estoque. Um problema muito frequente é a falta de identificação de muitos materiais fazendo com que muitos deles se percam, e por não estarem contabilizados perdem a certificação necessária para o uso.

Qual a melhor forma de identificar os materiais no estoque?

Os materiais são identificados através de um Part Number ou Número de série já prédeterminado pelo fabricante. Para identificar um material já recebido uma forma eficaz é identificar esse Part Number e de imediato elaborar o fator identificador que pode ser representado por etiquetas ou placas informativas que contenham os dados do material exposto. Realizar esse processo de identificação no ato do recebimento de materiais influenciará no melhor controle do estoque, que estará alinhado evitando a perda de itens e facilitará a localização do mesmo quando for requisitado.

A empresa estudada neste trabalho tem como seu principal problema o gerenciamento de estoque. Todo material está locado em um armazém terceirizado, apesar da movimentação dos materiais serem de responsabilidade do armazém, o layout é montado de acordo com o pedido da empresa cliente. Apesar disto, não há um sistema de rastreio de que atenda a necessidade de localizar o material com exatidão.

\section{Como rastrear o material de estoque com eficiência?}

No caso da empresa estudada, utilizar um software que rastreie o equipamento online em tempo real, além de melhorar o controle do setor, reduziria grande parte dos problemas de controle pois evitaria desperdícios.

\section{O Objetivos Específicos são:}

Propor redução do custo do estoque através de aplicação de ferramentas especificas de controle.

Rastrear itens armazenados facilitando a localização dos mesmos.

Propor controle do estoque de forma que o físico esteja alinhado com o contábil.

Elaborar um inventário que possa identificar os materiais com o objetivo de ter um controle interno eficaz.
Esse trabalho se torna relevante para a empresa no momento que propõe melhorias no setor e redução de custos e desperdícios. Também gera benefícios a sociedade local, com a implantação de um sistema de ponta trará treinamento e conhecimento a comunidade quem presta serviços ligados à empresa. Assim como torna-se objeto de estudo para a comunidade cientifica que terá mais um feedback sobre a aplicação prática e seus resultados.

\section{METODOLOGIA}

Segundo Fonseca (2002, p. 20):

"Diferentemente da pesquisa qualitativa, os resultados da pesquisa quantitativa podem ser quantificados. Como as amostras geralmente são grandes e consideradas representativas da população, os resultados são tomados como se constituíssem um retrato real de toda a população alvo da pesquisa. A pesquisa quantitativa se centra na objetividade. Influenciada pelo positivismo, considera que a realidade só pode ser compreendida com base na análise de dados brutos, recolhidos com o auxílio de instrumentos padronizados e neutros. A pesquisa quantitativa recorre à linguagem matemática para descrever as causas de um fenômeno, as relações entre variáveis, etc. A utilização conjunta da pesquisa qualitativa e quantitativa permite recolher mais informações do que se poderia conseguir isoladamente."

De acordo com Cervo et. Al (2007) a função da pesquisa descritiva é a análise e registo de dados sem que haja modificação dos mesmos, gerando ferramentas para solucionar os problemas apontados;

Uma vez que a elaboração desse trabalho tenha sido realizada através de livros, dissertações, artigos e relatórios da empresa, pode-se classifica-lo por pesquisa bibliográfica. Foram utilizados relatórios da empresa estudada, informações a partir de questionários como também um estudo de caso visando conhecer mais sobre detalhes sobre o assunto.

O universo do trabalho é a implantação do sistema RFID de rastreamento, no setor logístico. A amostra escolhida é uma empresa multinacional que atua no setor de petróleo e gás que cujo nome não será divulgado, localizada na Baixada Fluminense do Rio de Janeiro devido ao meu fácil acesso aos 
documentos e acompanhamento na rotina da empresa.

Os dados foram extraídos de registros, relatórios e antigos inventários da empresa no período do segundo e terceiro trimestre do ano de 2016 e também de pesquisas bibliográficas tais como: artigos, sites, teses e livros.

Os dados obtidos no estudo serão tratados através da análise quantitativa, através de representações gráficas para aprimorar o esclarecimento dos fatos.

\section{3- ESTUDO DE CASO}

O presente estudo de caso foi realizado na empresa no qual terá o nome preservado. A empresa em questão é uma empresa multinacional com origem na Noruega que presta serviços de perfuração com objetivo de extrair petróleo.

De porte de uma frota com mais de 65 plataformas que abrange navios de perfuração, jack-up, semi-submersíveis e plataformas de concurso para operações em águas rasas e ultraprofundas, em ambos os ambientes agressivos e benignos. Sua sede se localiza em Londres e tem um total de seis escritórios regionais em todo o mundo: Oslo, Dubai, Houston ,Cingapura, Rio de Janeiro e Ciudad del Carmen.

A base logística que armazena equipamentos e consumíveis das sondas de perfuração em operação na costa brasileira está localizada em Duque de Caxias, Baixada Fluminense do Rio de Janeiro. A área interna de $x x \mathrm{~m}^{2}$ armazena consumíveis, materiais de embarque imediato e/ou materiais que não devem estar expostos á alterações climáticas, e sua área externa de $1500 \mathrm{~m}^{2}$ por sonda, armazenam equipamentos alocados de acordo com a sonda a qual pertencem

Iniciou-se o projeto de inventário de 4 sondas exemplo, que serão nomeadas como: Sonda T, Sonda E, Sonda S e Sonda O.

O plano de ação do processo de inventariado de materiais procedeu da seguinte forma: Um colaborador do almoxarifado, munido do último inventário criado, início a contagem dos materiais, onde os materiais do inventário antigo tiveram suas quantidades atualizadas, os materiais não encontrados fisicamente foram excluídos da lista e materiais encontrados que não estavam na listagem foram adicionados, O gráfico 1 demonstra a divergência de quantidade entre o inventário antigo e o atual.

Gráfico 1- Divergência inventário

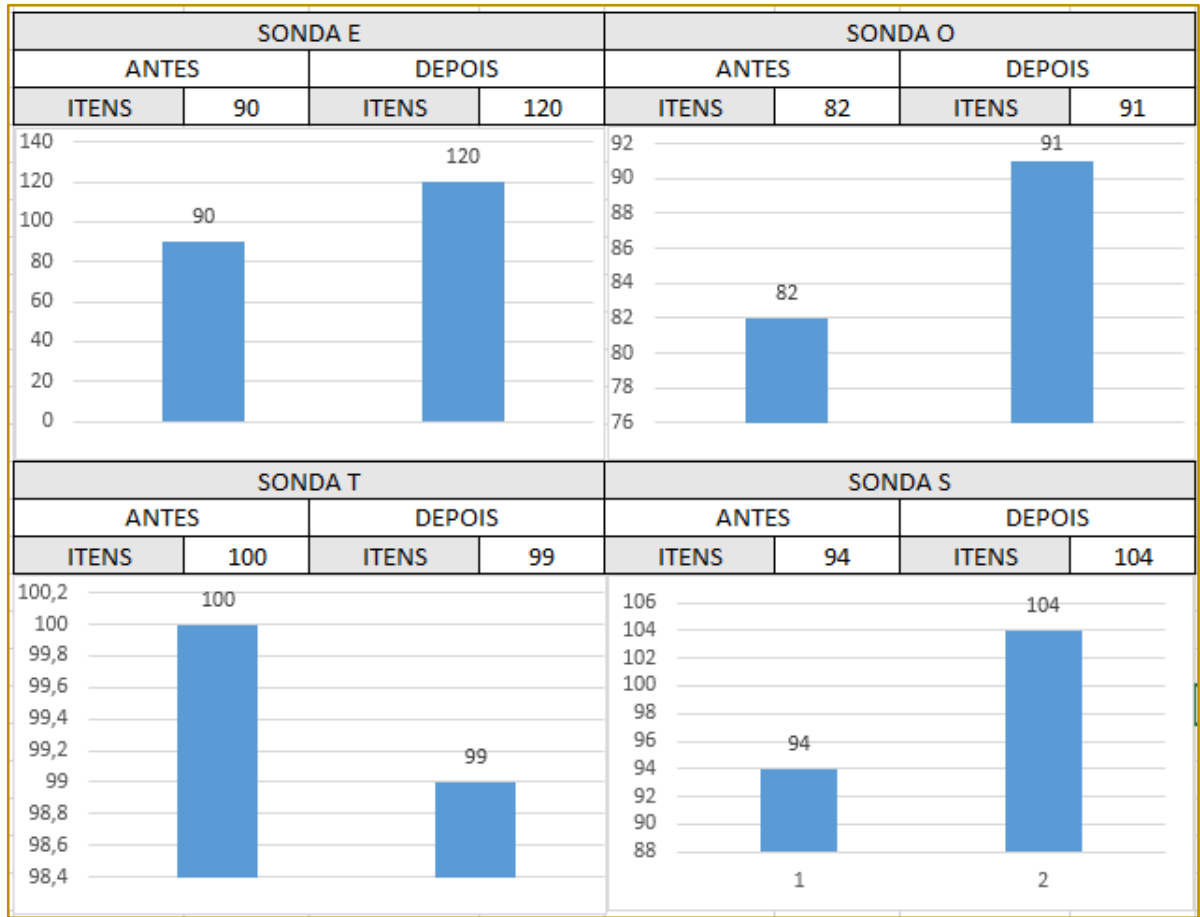

Fonte: Autor 
Pode-se observar discrepâncias na quantidade de todas as ondas.

O processo de identificação dos materiais prosseguiu da seguinte forma: Para identificar o material era levado em consideração o PN (Part Number), a sonda a qual o material pertence, o peso em KG, SN (Serial Number), MFG (Manefacture PN). Devido os matérias de sonda serem expostos à corrosões de matéria e intervenções climáticas, a identificação a olho nu e sem conhecimento prévio de alguns itens era inviável, nesses casos, o material era identificado através do conhecimento e experiência do profissional de almoxarife, identificando o nome do matéria, o PN era pesquisado no sistema posteriormente.

Etiquetagem do material - uma vez que o material fora identificado, inicia-se o processo de etiquetagem. A etiqueta era impressa, plastificada e anexada ao material contendo as seguintes informações: Nome do Item, dimensão, quantidade de material, a sonda a qual ele pertence, a referência interna que nada mais que a linha da planilha em que se encontra o inventário.

Avaliação de material -uma vez que os materiais foram identificados, iniciou-se o processo de avaliação dos materiais. Nesse processo cada material era avaliado por um cooperados de conhecimento técnico, com o objetivo de verificar se o material ainda estava em condições de uso ou necessitava de certificação. Os materiais sem possibilidade de utilização foram destinados à destruição

Abaixo segue o gráfico $2 \mathrm{com}$ a quantidade de materiais descartados por sonda:

Gráfico 2: Comparativo de descarte de materiais

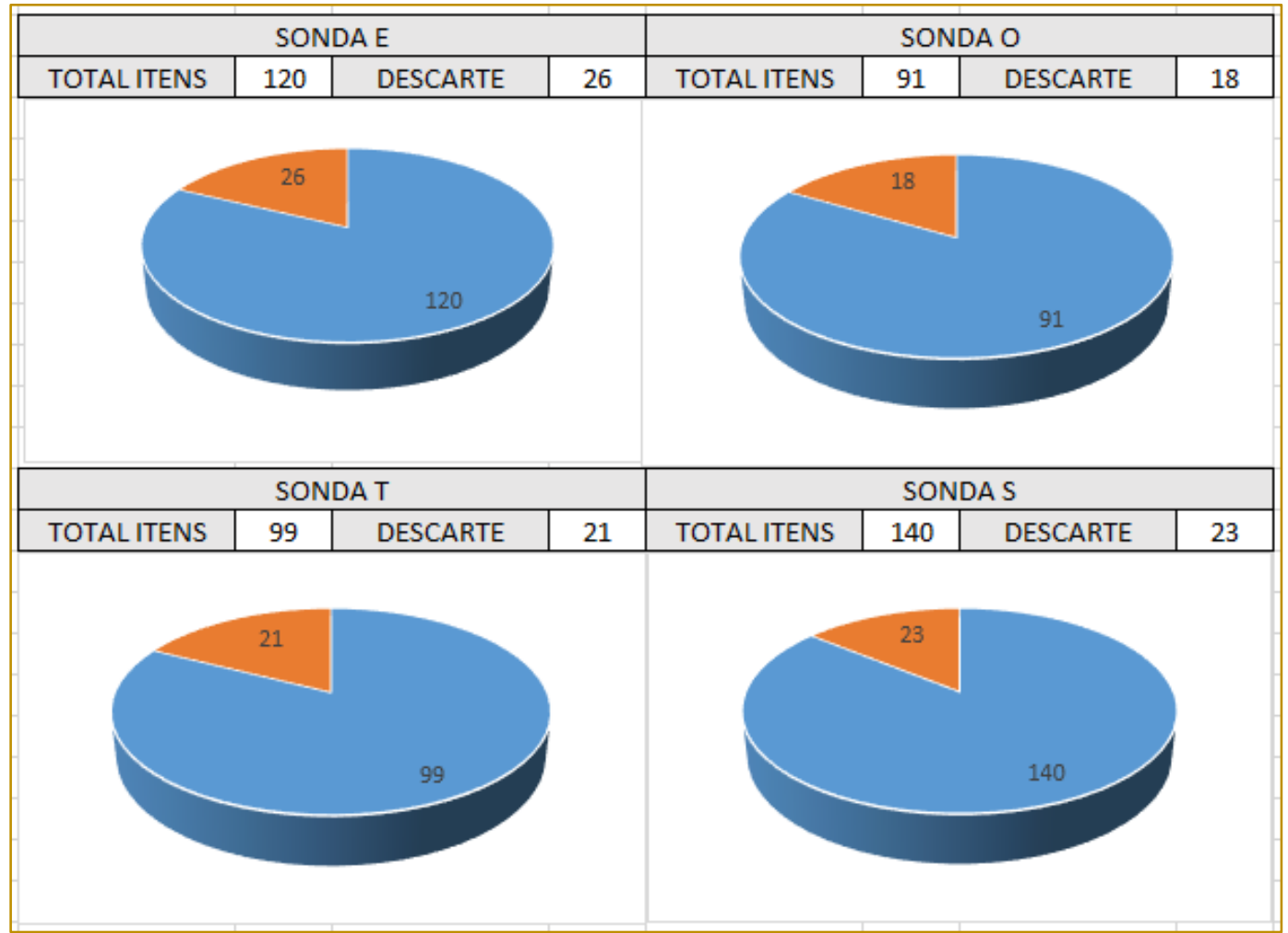

Fonte: Autor

O descarte desses materiais já reduziu de custos quanto ao espaço utilizado para o armazenamento dos mesmos.

\section{1 - INVENTÁRIO FÍSICO X CONTÁBIL}

Com o inventário físico em mãos, inicia-se o alinhamento do resultado no sistema utilizado pela empresa. Através do PN, o cooperador responsável atualiza o inventário contábil item a item. Com o objetivo de evitar discrepâncias, foi criada uma nova locação 
no sistema, para que todos os itens que constam no inventário sejam adicionados na nova locação, eliminando o risco de haver itens antigos

\section{2 - PROPOSTA DE SOLUÇÃO}

Com solução válida, este estudo de caso tem como proposta de melhoria a implantação do sistema de rastreamento via ondas de rádio, o RFID.

Passo a Passo de implantação do Sistema.

Para se instalar o sistema RFID é necessário cumprir todo um processo. Para que o sistema funcione corretamente deve-se funcionar em conjunto com todos os seus componentes. Implantar o sistema não requer apenas conhecimento sobre as etapas e da estrutura tecnológica, mas também da aplicação de inovações, uma vez o sistema instalado, todo o processo usual será alterado.

Existem pontos que influenciam diretamente na implementação do sistema RFID, esses pontos são adaptáveis, e suas limitações definem o melhor sistema a ser implantado, porém, independente dessas limitações o sistema RFID é moldável para cada necessidade pela sua diversidade de etiquetas. Algumas definições básicas devem ser discutidas inicialmente para se identificar as funções mais adequadas para evitar eventuais problemas nas leituras.

Uma vez determinados os itens que receberão a leitura, o sistema será configurado de acordo com os leitores e Tags. A quantidade de leitores implicará na escolha da frequência. Com a definição dos elementos, a escolha da quantidade e tipo de antenas serão definidos de acordo com a amplitude da área a ser coberta e a potência transmitida. Devido a sua compatibilidade, o sistema RFID é capaz de ser integrado ao sistema e internet utilizados no local e agir em conjunto. Como todo sistema, o RFID também requererá manutenções, no planejamento da implantação o fator da manutenção é um fato a ser bem definido com o próprio fornecedor a ser escolhido.

\section{4 - RESULTADOS E ANÁLISE}

O presente estudo teve como objetivo resolver problemas no setor logístico de uma empresa do setor petrolífero. Foi implantado um plano de ação para a realização de um processo de inventário onde todos os materiais da base foram avaliados, identificados e armazenados corretamente, resolvendo parte dos problemas mencionados.

Com a prática do inventário houve descarte dos materiais sem condições de uso, uma vez que o pagamento do espaço da locação era equivalente a área ocupada por materiais e tendo o resultado de redução de 19\% houve redução de custos relacionado ao pagamento da área utilizada para armazenagem. O gráfico 3 abaixo representa o total de material descartado.

Gráfico 3: total de material descartado

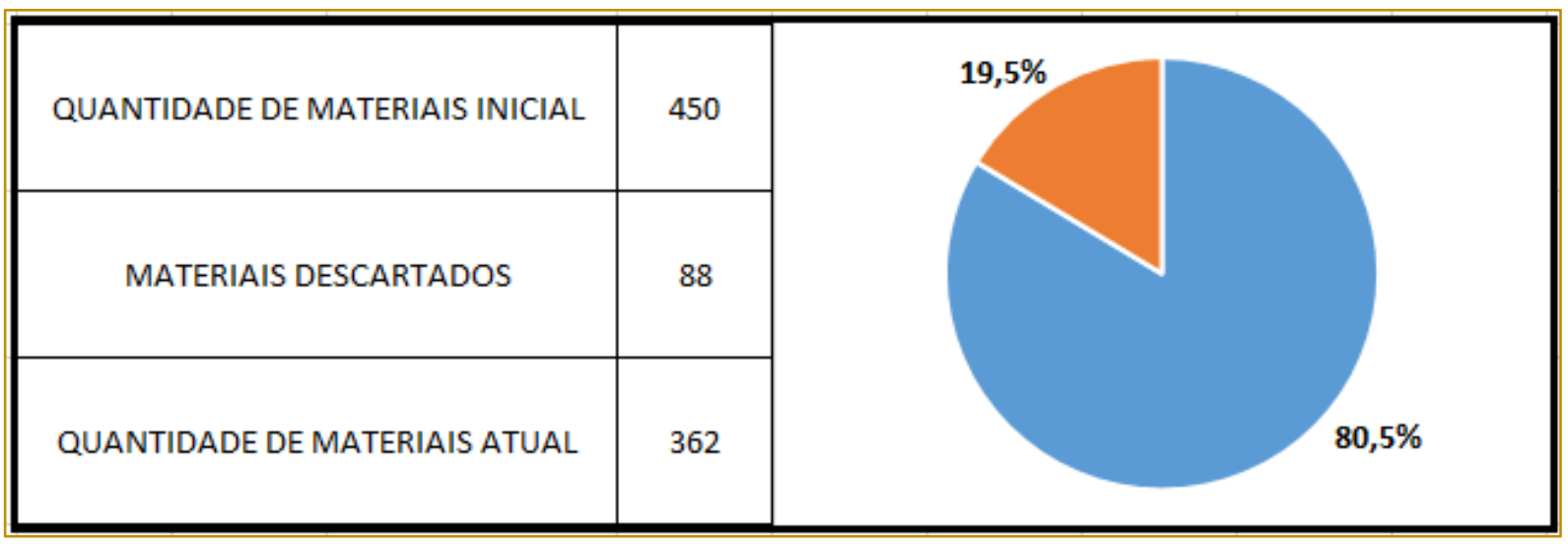

Fonte: Autor

Uma vez que a lista de material armazenado foi atualizada, iniciou-se o processo de atualização no sistema, onde cada material ela adicionado a locação correta de acordo com sua sonda. Para que não houvesse registros antigos mencionados na nova 
listagem, os itens foram adicionados em nova locação tendo assim a quantidade declarada no sistema e no físico entraram em alinhamento.

Como solução provisória para a identificação dos materiais foram criadas etiquetas contendo todos os dados encontrados referente ao equipamento. Essa identificação foi feita por um profissional de conhecimento técnico. Esse procedimento facilitou a contagem e organização dos materiais.

A proposta principal deste estudo de caso é a implantação da tecnologia RFID. Esse sistema tem capacidade de atender as necessidades principais apresentadas. A tabela 1 demonstra a comparação entre o processo de inventário feito manualmente e o resultado projetado pela hipótese da instalação do sistema.

Tabela 1: Comparação entre o processo de inventário feito manualmente e o resultado projetado pela hipótese da instalação do sistema

\begin{tabular}{|c|c|c|c|}
\hline Problema & Inventário Manual & Inventário RFID & $\begin{array}{l}\text { Análise pós } \\
\text { implantação }\end{array}$ \\
\hline Tempo de inventário & 20 dia por sonda & 1 dia por sonda & $\begin{array}{c}\text {-Redução de mão de } \\
\text { obra trabalhada }\end{array}$ \\
\hline $\begin{array}{l}\text { Estoque físico } \mathrm{X} \\
\text { contábil }\end{array}$ & $\begin{array}{l}\text { Atualização de itens } \\
\text { individualmente }\end{array}$ & $\begin{array}{l}\text { Atualização de itens } \\
\text { automaticamente }\end{array}$ & $\begin{array}{c}\text {-Redução de mão de } \\
\text { obra trabalhada } \\
\text {-Resultado preciso }\end{array}$ \\
\hline $\begin{array}{l}\text { Identificação de } \\
\text { materiais }\end{array}$ & $\begin{array}{c}\text { Etiquetas produzidas } \\
\text { manualmente }\end{array}$ & TAG fixada no material & $\begin{array}{l}\text {-Identificação } \\
\text { permanente }\end{array}$ \\
\hline $\begin{array}{l}\text { Rastreamento de } \\
\text { material }\end{array}$ & Não há & $\begin{array}{l}\text { Rastreamento via } \\
\text { ondas de rádio }\end{array}$ & -Precisão no rastreio \\
\hline
\end{tabular}

\section{5 - CONCLUSÃO}

O presente estudo teve como objetivo conhecer e solucionar problemas no setor logístico de uma empresa petrolífera. Os problemas foram levantados através de pesquisar com os funcionários, e de estudos no setor.

Foi implantado um plano de ação de processo de inventario, onde todos os materiais foram identificados, analisados, devidamente analisados e tiveram sua quantidade ajustada no sistema, o que trouxe provisórias soluções para parte dos problemas mencionados.

\section{REFERÊNCIAS}

[1]. Ballou, Ronald H. Bussiness Logistics Management (4th Edition). Ptentice Hall, 1998

[2]. BHATT, H.; GLOVER, B. Fundamentos de RFID: Rio de Janeiro:Altas Books, 2007.
A proposta de melhoria de baseia na instalação do rastreamento via RFID, Pode-se ter por consequência dessa aplicação:

A redução do custo de estoque pois eliminara riscos de possíveis desperdícios e perdas. A sincronia automática do sistema com o inventariado.

A identificação permanente dos materiais com TAG's fixas contento todas as informações do material

O alinhamento automático do inventario com o sistema

O rastreio dos materiais através de ondas de rádio, principal objetivo desta tecnologia

[3]. BOWERSOX, Donald J.; CLOSS, David J. Logística empresarial: o processo de integração da cadeia de suprimentos. São Paulo: Atlas, 2001. 
[4]. CERVO, A.L.; BERVIAN, P. A.; DA SILVA R. Metodologia Científica. 6a․ Ed. São Paulo: Pearson Prentice Hall, 2007

[5]. DE ARAUJO, Marco Antônio. Administração de Produção e Operações - uma abordagem prática. Brasport. 2009

[6]. DIAS, Marco Aurélio P. Administração de materiais: princípios, conceitos e gestão. 5. ed. São Paulo: Atlas, 2008.

[7]. FONSECA, J. J. S. Metodologia da pesquisa científica. Fortaleza: UEC, 2002. Disponível

em: $<w w w$.ufrgs.br/cursopgdr/downloadsSerie/derad00 5.pdf >. Acesso em: 05 de agosto de 2016

[8]. LEAL COSTA Fábio. J.C.. Introdução à Administração de Materiais em Sistemas Informatizados, Editco Comercial Ltda. 2002
[9]. NEVES, Marco Antônio Oliveira. Qualificação de fornecedores de serviços logísticos. 2005. Disponível em: Acesso em 15 de julho, 2016.

[10]. PORTO. T. Entendendo um pouco sobre RFID, nov. 2005.

[11]. SANTINI, Arthur Gambin. RDIF.2006. Trabalho de conclusão de Curso (Graduação) Curso de Sistemas de Informação. Centro Universitário de Votuporanga, Votuporanga.2006

[12]. WEIS Stephen Weis. Security and Privacy in Radio-Frequency Identification Devices. Master thesis, Massachusetts Institute of Technology (MIT), MIT, Massachusetts, USA.(2003) 


\section{Bapítulo 2}

\section{UTILIZACÃO DAS FERRAMENTAS DA PRODUCÃO ENXUTA NAS BANCAS DE PESPONTO DA CIDADE FRANCA-SP PARA O AUMENTO DA PRODUTIVIDADE}

\section{Luciana Rodrigues Pires}

\section{Geandra Alves Queiroz.}

Jaqueline Guimarães Borges

June Tabah

Resumo: O município de Franca/SP é considerado um polo do setor coureirocalçadista. O aumento da produção das empresas deste setor e a busca pela redução de custos e tempo no processo produtivo culminaram em uma política de subcontratação de processos. Neste contexto, se insere as bancas de pesponto, encontradas em grande número no município de Franca. As quais tem o papel de realizar uma etapa do processo produtivo do calçado: o processo de pesponto. A terceirização deste processo, ao mesmo tempo que favorece a redução de custos é identificado como gargalo em muitas empresas deste setor. A produção enxuta é uma filosofia de gestão da produção que colabora para o aumento da produtividade e da redução de custos e atualmente é aplicada nas empresas dos mais diversos setores. Deste modo, a pesquisa teve como objetivo estudar as possíveis melhorias da produtividade do processo de produção de pesponto a partir das ferramentas da Produção Enxuta em uma banca de pesponto da cidade de Franca/SP. O estudo de caso dessa pesquisa permitiu observar que as práticas da produção enxuta proporcionam melhores resultados na capacidade produtiva e na redução de custo.

Palavras-chave: Polo calçadista; Produção enxuta; Bancas de pesponto; Produtividade. 


\section{INTRODUÇÃO}

A alta concorrência do mercado econômico submete as empresas encontrarem alternativas que possam melhorar o seu desempenho, reduzir os custos sem perder a qualidade e a satisfação dos clientes. A indústria calçadista se insere neste contexto, uma vez que almeja melhorias para se tornar mais competitiva. Devido à alta produção uma das formas encontradas é a subcontratação de processos em algumas empresas, afim de eliminar gargalos, reduzir custos e aumentar a flexibilidade da produção. Um dos processos subcontratados na indústria calçadista é o pesponto, por ser uma atividade artesanal e com pouca exigência de maquinários (SATURI; ARAÚJO; ANDRADE, 2004).

Este processo é executado nas bancas de pesponto as quais os proprietários, em sua maioria, são ex-funcionários de indústrias calçadista, por isso possuem as técnicas para executar a operação de forma satisfatória. Porém, muitas vezes, por falta de investimento, atuam em espaços improvisados sem praticas ideais de profissionalismo e sem o conhecimento necessário nas áreas administrativas, tornando seus negócios amadores e obtendo baixa produtividade. Diante disso, torna-se necessário a aplicação de técnicas que visem a melhoria no processo produtivo do pesponto. Uma estratégia de produção que pode ser utilizada é a Produção Enxuta.

A Produção Enxuta, no inglês Lean Manufacturing, vem sendo cada vez mais utilizada por empresas de diversos setores que buscam melhorar seu desempenho, visto que, a adoção dessa filosofia possibilita melhores resultados de custo, produtividade, qualidade, prazo de entrega e flexibilidade. Pois tem como fundamento eliminar os desperdícios de toda a cadeia produtiva e a busca pela melhoria contínua (WOMACK; JONES, 2004; LIKER, 2005).

As principais práticas, técnicas e ferramentas frequentemente utilizadas são na Produção Enxuta são: Mapeamento do fluxo de valor, 5S, Kaizen, Kanban, Fluxo contínuo, Jidoka, Just-in-time, Células de manufatura, Pokayoke entre outras; de forma integrada, permitindo que a produção seja flexível e adaptável apesar de suas especificações.

A realização dessa pesquisa torna-se relevante ao analisar o alto número de bancas de pesponto no município de Franca e a sua importância na economia regional. Porém, as vezes esses negócios não atuam nos padrões ideais, com honorários extensos, em espaços improvisados e sem conhecimentos necessários para impulsionar sua produtividade (LOURENÇO; BERTANI, 2008). Por isso, o objetivo dessa pesquisa é identificar as possíveis melhorias que as de ferramentas da Produção Enxuta podem gerar ao processo produtivo do pesponto.

O autor Yoshino (2008) ressalta algumas vantagens que a Produção Enxuta proporciona as empresas do ramo calçadista. Como utilizar menores estoques, gerar menos defeitos e produzir maior e sempre crescente variedade de produtos; tendo em vista a necessidade de atuar com estações e tendências. Ou seja, une alta produtividade, qualidade e baixos custos com lead time menores. O autor ainda afirma que houve um avanço teórico e prático, na aplicabilidade e conceitos da Produção Enxuta no segmento coureiro-calçadista, porém, no entanto, faz-se necessário uma maior aplicação dos conceitos teóricos desta estratégia de gestão da produção na prática. Deste modo, entende-se que há a necessidade de desenvolver estudos que busquem maneiras para aumentar a eficiência das bancas de pesponto.

Por isso, esse estudo pautou-se nessas possíveis melhorias e para 0 seu desenvolvimento foram estudados conceitos e técnicas sobre os temas: Produção Enxuta e setor calçadista, por intermédio da literatura específica disponível. Além de utilizar uma banca de pesponto de Franca como objeto de estudo, para que se pudesse compreender as etapas do processo produtivo.

\section{MÉTODO CIENTíFICO}

De acordo com Miguel (2012) a importância metodológica de um trabalho advém da necessidade de embasamento científico adequado, geralmente caracterizado pela busca da melhor abordagem de pesquisa. No presente trabalho, optou-se por utilizar o método de estudo de caso, frequentemente aplicado na engenharia de produção. Ele consiste na análise aprofundada de um ou mais casos, com o uso de múltiplos instrumentos de coleta de dados. Segundo Gil (2002) esse é um método utilizado quando a pesquisa envolve $\mathrm{o}$ estudo profundo $\mathrm{e}$ exaustivo de um ou poucos objetos, de modo que permita o seu amplo e detalhado conhecimento. 
A pesquisa se construiu em um único estudo de caso, que foi conduzido levando em consideração as etapas propostas por Miguel (2012). A primeira etapa foi definir a estrutura teórica, por meio do embasamento conceitual sobre Produção Enxuta e processos produtivos calçadistas. Posteriormente foi definida a empresa que seria alvo do estudo de caso e o roteiro de entrevista aplicado na mesma.

A coleta de dados foi feita mediante a autorização dos gestores da banca de pesponto. Os dados foram apurados em duas visitas ao local, por meio de observações diretas in loco e entrevistas, utilizando um roteiro de entrevista com perguntas relacionadas ao tema.

Os instrumentos de pesquisa utilizados foram: entrevistas com os envolvidos no processo de produção da banca de pesponto, buscando envolver todos os níveis hierárquicos; questionários relacionados à produtividade, lead time de produção, entre outras questões relacionadas à área. Em seguida foi compilado os dados e descritos em forma narrativa que será apresentado na seção do estudo de caso.

\section{PRODUÇÃO ENXUTA}

\subsection{ORIGEM E PRINCÍPIOS}

A Produção Enxuta, no inglês Lean Manufacturing, foi introduzida no Japão pela Toyota, na década de 1940, no final da Segunda Guerra Mundial, momento no qual os japoneses identificaram a necessidade de melhorar seu sistema produtivo, dado que nesse período houve escassez de recursos e a demanda por automóveis era baixa e variada (OHNO, 1997).

Womack e Jones (2004) classificam a produção enxuta em cinco princípios básicos são eles:

Especificar o valor: ponto de partida do pensamento enxuto, consiste em compreender as necessidades do cliente a um preço específico em um momento específico.

Identificar o fluxo de valor: compreender quais etapas e processos são necessários para que
- produto ou serviço seja fabricado e entregue para ao cliente final; nessa etapa, comumente, são identificados os principais desperdícios.

Fluxo: após a eliminação de etapas que geram desperdícios, é preciso fazer com que as etapas fluam sem esperas e interrupções. Para que isso ocorra é necessário haver uma mudança de mentalidade: o produto e suas necessidades devem ser os focos e não as máquinas e equipamentos.

Produção puxada: fabricar o que os clientes desejam de maneira adequada e no momento correto, permitindo que o cliente puxe o produto; dessa forma é possível minimizar os desperdícios frequentemente encontrados em sistemas "empurrados".

Perfeição: buscar a perfeição por meio da integração dos quatro princípios anteriores, visando à melhoria contínua.

Esses princípios têm como finalidade tornar as organizações mais flexíveis e capazes de atender às necessidades dos consumidores. Dessa forma, ressaltam que os processos estão divididos em três atividades:

Atividades que agregam valor (AV): atividades que agregam valor segundo o cliente, isso torna o produto ou serviço mais valioso, pois significa que os mesmos estão dispostos a pagar por elas;

Atividades que não agregam valor (NAV): são as atividades que, aos olhos do consumidor não agregam valor ao produto ou serviço, classificando-se como desperdícios e devem ser eliminadas imediatamente; e

Atividades necessárias, mas que não agregam valor: atividades que, para o cliente final, não aumentam o valor do produto ou serviço final, porém são necessárias. São desperdícios difíceis de serem suprimidos em curto prazo.

A vista disso, Shingo (1996) afirma que o Sistema Toyota de Produção (STP) se baseia na eliminação contínua e sistemática desses desperdícios dos sistemas de produção, visando eliminar os custos desnecessários. Segundo Onho (1997) esse é o passo preliminar para qualquer organização implementar o STP. Abaixo, na tabela 1, estão destacados os principais desperdícios: 
TABELA 1 - Desperdícios de produção.

\begin{tabular}{|c|c|}
\hline Desperdício & $\begin{array}{c}\text { Descrição } \\
\text { Superprodução }\end{array}$ \\
\hline Espera & $\begin{array}{c}\text { Produzir excessivamente ou cedo demais } \\
\text { informações }\end{array}$ \\
\hline Transporte & Movimento excessivo de pessoas peças e informações; \\
\hline Processamento & Utilização inadequada de máquinas e sistemas; \\
\hline Estoque & Armazenamento excessivo e falta de informação; \\
\hline Movimento & Desorganização do ambiente de trabalho \\
\hline Produtos defeituosos & Problemas de qualidade do produto. \\
\hline
\end{tabular}

Fonte: Baseado em Onho (1997).

Em suma, essa é a grande finalidade do Sistema Toyota de Produção, eliminar todas as origens de desperdícios nas organizações. Atualmente a filosofia Enxuta é vista como uma forma de pensar para as empresas, pois adotam esse sistema visando aumentar o lucro através da redução de custos (WOMACK; JONES, 2004).

\subsection{PRÁTICAS DA PRODUÇÃO ENXUTA}

A seguir serão apresentadas algumas das principais técnicas, práticas e ferramentas adotadas na produção enxuta. Tendo como base os estudos de revisão bibliográfica de Yoshino (2008) e Godinho Filho (2004).

Mapeamento do Fluxo de Valor - É uma ferramenta simples que ajuda visualizar e entender o fluxo de material e de informação que o produto segue o fluxo de valor, desde o consumidor até o fornecedor. A partir dessa técnica é possível enxergar os desperdícios e suas origens no fluxo de valor.

Programa 5S - Essa prática objetiva reduzir desperdícios, erros, defeitos e acidentes de trabalho. Auxiliam a gestão visual e a implementação da produção enxuta. São cinco tarefas representadas por palavras em japonês iniciadas pela letra " $S$ ", as quais no português são traduzidas e acrescentadas pela palavra senso, são eles:

Seiri (senso de utilização): separar os objetos que são utilizados com frequência, o que for desnecessário deve ser retirado;

Seiton (senso de organização): organizar os materiais que permanecerão na área, identificando e colocando cada objeto no lugar devido;
Seiso (senso de limpeza): manter o ambiente limpo, seguro e agradável;

Seiketsu (senso padronização): manter a organização, arrumação e limpeza, fazendo com que as atividades anteriores se tornem padrão;

Shitsuke (senso de disciplina): compromisso e disciplina pessoal para manter os padrões definidos.

A utilização dessa prática permite um ambiente mais limpo e arrumado, com isso é possível ter um maior controle visual das atividades executadas na empresa, contribuindo para a aplicação das demais ferramentas enxutas (LIKER, 2005).

Kaizen - É uma prática de melhoria contínua que consiste em três passos: primeiro, criar um padrão; segundo, segui-lo; terceiro, encontrar o melhor caminho para sua utilização infinita.

Trabalho Padronizado - Essa ferramenta visa manter a alta eficiência de produção, porém evitando recorrências de produtos defeituosos, erros operacionais e acidentes. O trabalho padronizado facilita a obtenção de qualidade, pois elimina variação de processos e retrabalhos.

Fluxo Contínuo - Significa processar um item de cada vez, diretamente sem interrupções de um processo para outro. O Lean Enterprise Institute (2003) argumenta que o Fluxo Contínuo representa "produzir e movimentar um item por vez (ou um lote pequeno de itens) ao longo de uma série de etapas de processamento, continuamente sendo que em cada etapa se realiza apenas o que é exigido pela etapa seguinte". 
Autonomação (Jidoka) - Significa automação com inteligência humana (OHNO,1997). Ela permite que os equipamentos tenham a capacidade de distinguir as peças boas das ruins automaticamente (LEAN INSTITUTE ENTERPRISE, 2003).

Just-in-time - A expressão significa "no momento certo", segundo Ohno (1997) é um processo de fluxo, no qual as atividades ocorrem no momento em que são necessárias e somente na quantidade necessária.

Esta prática visa a eliminação dos desperdícios almejando qualidade, menor custo, menor tempo de produção e lead time de entrega. O JIT almeja atingir esses objetivos com a redução de estoques, pois declaram que estes tendem a ocultar os problemas e são utilizados para evitar descontinuidades do processo produtivo quando há problemas de produção, como paradas para manutenção corretiva ou retrabalho. Dessa forma, a diminuição dos estoques pode auxiliar a visualização e eliminação dos problemas ocultos e esta redução é atingida por meio da eliminação das causas geradoras da necessidade de manter os estoques.

Kanban - É um termo japonês que significa "sinal" ou "cartão". É um dispositivo sinalizador que autoriza e dá instruções para a produção ou para a retirada de itens em um sistema puxado (LEAN ENTERPRISE INSTITUTE, 2003). Ou seja, funciona de acordo com a demanda do cliente, o qual é responsável por dar início à produção, além de permitir a obtenção em tempo exato da produção da empresa.

Células de Manufatura - Consiste nas localizações das estações de trabalhos por produtos semelhantes (LEAN ENTERPRISE INSTITUTE, 2003). O layout celular é uma forma de contribuir com o fluxo contínuo, pois origina células de trabalho associadas por produtos e não por processos. A separação por células possibilita que as peças ou documentos sejam processados um por vez ou em lotes pequenos, reduzindo assim o tempo de transporte ou espera do produto.

Gestão Visual - Qualquer dispositivo de comunicação utilizado no ambiente de trabalho capaz de criar um espaço transparente aos funcionários e facilitar a visão de como a atividade deve ser realizada e quais os padrões estabelecidos (GAMBI, 2011).
A gestão visual está vinculada a melhoria no acesso visual dos funcionários às ferramentas, atividades de produção e indicadores de desempenho do sistema de produção, de maneira que a situação do sistema seja entendida rapidamente por todos os envolvidos.

Total Productive Maintenance (TPM) Segundo Lean Enterprise Institute (2003) o termo "Productive" se refere a maximização de uso dos equipamentos, por meio da redução de tempo de troca, paradas, refugo, e a palavra "total" é utilizada pois, abrange todos os níveis operacionais e o ciclo de vida do equipamento, isto é, efetiva as ações de acordo com o estado que a máquina se encontra.

Operário Multifuncional - É uma habilidade referente à realização do trabalho por operadores que manipulam muitas maquinas ou vários processos em um mesmo arranjo físico (OHNO, 1997).

Poka-Yoke (Dispositivo à prova de erros) Esse conceito ficou conhecido como Zero Defeito. De acordo com Feld (2000) são recursos que ajudam os operadores a evitar erros em seu trabalho tais como escolha de peça ou ferramenta errada, montagem incorreta de uma peça, ou esquecimento de um item que influencia na montagem do produto.

Produção Nivelada - Consiste na combinação uniforme do volume de produção por um longo período de tempo. Esta prática visa alcançar um mix de produção que reduza estoques de determinados itens, dando, ao mesmo tempo, certa flexibilidade ao sistema.

\section{SETOR CALÇADISTA}

No início do processo de desenvolvimento das industrias calçadista, no Rio Grande do Sul, a produção era realizada de forma artesanal, hoje em dia o cenário mudou, há muita automação nos processos. A alta concorrência do mercado econômico estimula as empresas buscarem a satisfação de seus consumidores, por isso investem mais em design e conforto dos modelos (ZINGANO; OLIVEIRA, 2014).

É nesse cenário competitivo que o setor calçadista brasileiro se faz um dos mais influentes do mundo. Em decorrência dos inúmeros fornecedores de matéria prima, máquinas e componentes, aliados aos 
avanços tecnológicos. É com esta estrutura altamente capacitada, que o Brasil exporta atualmente para mais de 150 países (ABICALÇADOS, 2015).

A pesquisa teve como foco o centro produtor calçadista de Franca-SP, o qual segundo Garcia (1996) teve sua formação vinculada, basicamente, à expressiva atividade de criação de gado de corte na região desde meados do século XIX.

A produção calçadista é realizada de forma descontinua, na qual o fluxo produtivo ocorre em diferentes etapas, como mostra a figura abaixo:

FIGURA 1 - Fluxo produtivo do calçado. Fonte: Yoshino (2008).

Modelagem $\rightarrow$ Corte $\rightarrow$ Preparação $\rightarrow$ Pesponto $\rightarrow$ Montagem $\rightarrow$ Acabamento

A seguir serão descritos os processos de fabricação do calçado. Tendo como base os estudos de revisão bibliográfica de Yoshino (2008) e Diedrich (2002).

Modelagem - É nesse processo que ocorre a definição de como será o sapato. Existe muita preocupação com o design, conforto, cores, formas, materiais, entre outras características. Geralmente, essas decisões são tomadas por estilistas e designers.

Corte - A parte superior do calçado é conhecida como cabedal. Ele é composto por diversas peças de couro, tecidos e espumas. Todos esses materiais que compõe o sapato são cortados com base nos moldes fornecidos pelo setor de modelagem.

As peças podem ser cortadas de forma manual utilizando lâminas e moldes de cartolina; ou por meio de prensas hidráulicas, operadas por funcionários qualificados para que não haja desperdícios dos materiais, como: couro, forro e aviamentos.

Essas máquinas são chamadas de balancim de ponte ou de braço, funcionam com o auxílio de facas para o corte da peça de couro, denominada de vaqueta. Quando a matéria-prima utilizada é o couro, o cortador deve estar atento ao sentido das fibras, a elasticidade e a existência de defeitos para definir as posições do corte e minimizar o desperdício de material.

Preparação - Nesse setor as peças cortadas são preparadas para próxima etapa, o pesponto. A preparação engloba pequenas atividades, como: pintura, carimbo, entretelação e chanfração. Abaixo estão alguns exemplos:

Pintura: Essa etapa geralmente é realizada dentro de cabines específicas, com o objetivo de deixar o couro na cor desejada.
Carimbo: Processo realizado com uma máquina que marca o couro, com a identificação do tamanho do sapato, referência e data de fabricação.

Entretelação: Processo de colocação de reforço entre couro e o forro, com a finalidade de dar sustentação ao couro.

Chanfração: Esse processo é feito nas bordas das peças, para melhorar a união das mesmas. Por meio de uma máquina especializada é feito um chanfro, para que não fique marques de sobreposição nas peças.

Pesponto - É nessa etapa que ocorre a costura das peças do sapato, formando o cabedal, parte de couro do sapato. As operações podem ser subdivididas em duas: colagem e pesponto (costura). Na colagem, se faz a colagem, dobração, passação de fita de reforço. Já no pesponto costura-se as peças em máquinas próprias.

As máquinas utilizadas no setor são desiguais. Pois ferramentas manuais coexistem com instrumentos mecânicos, de marca, modelo e ano de fabricação diferente. O setor comporta várias atividades, desde a preparação até a costura.

As máquinas de costura com CNC (Controle Numérico Computadorizado) são utilizadas, principalmente, na junção das peças, mas já existe maquinários capazes de estabelecem a largura do ponto, a espessura do material, o tempo de imobilização do material e a grossura do fio.

A atividade do pesponto é normalmente o gargalo da produção, principalmente quando existem operações com um ciclo muito grande. Por esse motivo algumas empresas preferem terceirizar esse processo 
Montagem - Processo responsável por dar forma ao sapato. Está fase é composta por várias atividades simultâneas que quase não se diferem, independente do modelo de sapato fabricado.

O primeiro passo é fixar o cabedal em uma forma plástica com o formato de pé, posteriormente ocorre a preparação da palmilha, a montagem do bico (máquina de monta bico), fechamento do lado dos calçados, montagem da base traseira (máquina de montagem da parte traseira) e a última atividade é rebater o bico e a base.

Acabamento - Na etapa de acabamento, o calçado passa por vários pequenos processos. Ele recebe o solado e a forma é retirada de seu interior. Além de escovação, limpeza, pintura de acordo com o pedido do consumidor, revisão do produto, correção de possíveis erros e embalagem do calçado.

Tendo em vista a complexibilidade de algumas das etapas acima descritas e também a alta produção calçadita, as empresas do ramo acabam optando pela subcontratação, afim de eliminar gargalos, reduzir custos e aumentar a flexibilidade da produção. Um dos processos subcontratados na indústria calçadista é o pesponto, por ser uma atividade artesanal e com pouca exigência de maquinários (SATURI; ARAÚJO; ANDRADE, 2004).

Segundo Garcia (1996) é comum ocorrer a subcontratação do processo de pesponto nas indústrias calçadistas do Brasil. Isso é necessário pois, semelhante à produção da Toyota no Japão, as empresas calçadistas também necessitam fabricar lotes pequenos com alta variedade utilizando a mesma linha de produção (DIEDRICH, 2002). Essa prática além de agilizar o processo de produção reduz os custos relacionados com a mão-deobra. Para as empresas maiores, ao mesmo tempo que reduz custos, aumenta a flexibilidade e evita a ocorrência de gargalos no processo produtivo. É nesse cenário que a produção enxuta pode trazer benefícios as empresas, uma vez que ela une simultaneidade, alta produtividade, qualidade e baixos custos com lead time menores.

De acordo com os estudos de Yoshino (2008) a estrutura teórica da produção enxuta consiste em uma das maiores alternâncias no paradigma nas empresas calçadistas, com a transição da Produção em Massa para a era da Produção Enxuta. Esse sistema, quando bem implementado, pode proporcionar benefícios as empresas que atuam com grande variedade produtiva. Pois, permite que as fábricas utilizem menores estoques e mesmo assim obtenham um aumento da capacidade produtiva com alta variedade.

\section{ESTUDO DE CASO}

O estudo de caso foi realizado em uma banca de grande porte do município de Franca. Com a finalidade de manter o sigilo dos dados e informações da banca, nesse artigo ela será chamada de Empresa A. A escolha dessa empresa se deve a facilidade de acesso, pois a pesquisadora possuía contato com 0 proprietário. Mas também pela vantagem de estudar uma banca que já utilizava as ferramentas da produção enxuta, o que viabilizou um maior conhecimento prático.

Para o desenvolvimento do estudo de caso foi realizada uma visita inicial, para conhecer o processo produtivo, o espaço e divisão dos funcionários. Após o primeiro contato foi feito uma entrevista, utilizando o roteiro de entrevista como base para condução do estudo de caso. Ela teve duração média de uma hora e além disso, houve contatos via email e telefone. Esta coleta de dados foi realizada por meio observações in $10 c 0$ e entrevista semiestruturada com o gerente geral de pesponto.

O propósito deste estudo de caso, foi observar, na prática, o funcionamento da banca de pesponto, além de poder analisar como as ferramentas da produção enxuta são utilizadas nesse ramo produtivo.

O estudo foi feito em uma das unidades de bancas de pesponto que uma empresa francana possui. Ao todo, levando em consideração as três bancas de pesponto, essa empresa possui por volta 166 colaboradores, divididos em 42 grupos mais um grupo suporte em cada unidade. Cada grupo é composto por um pespontador e duas coladeiras, já o grupo de suporte que faz a preparação inicial do pesponto é composto por um pespontador e uma coladeira. Na primeira unidade estão reunidos 20 grupos padrão e 1 de suporte e nas demais 11 grupos padrão e 1 de suporte.

A empresa A adota um sistema de classificação de nível de dificuldade dos pares, são três níveis, assim é possível que os supervisores dividam os trabalhos para que todos os grupos consigam atingir a média de produção diária. Esse grau de dificuldade é estabelecido após a cronoanálise. Também 
com base na cronoanálise foi definido que a banca possui o período de três dias para devolver a mercadoria finalizada a matriz.

Relatou-se que a produção diária gira em torno de mil e duzentos a mil trezentos e cinquenta pares por dia na primeira unidade, essa variação pode ocorrer de acordo com o grau de dificuldade de cada modelo. Já as outras duas bancas, cada uma produz seiscentos e cinquenta pares por dia. Sendo que cada grupo padrão possui uma produção, média, diária de cinquenta e cinco a sessenta pares. De acordo com as informações obtidas na empresa a capacidade produtiva aumentou significativamente após a implantação das ferramentas, mostrando que é possível obter melhorias com o projeto de pesponto enxuto.

A sequência produtiva das bancas é: riscação do couro; a preparação que é realizada pelos grupos de suporte; posteriormente é feito a aplicação do pré-ilhós, não são todos os modelos de calçados que passam por essa etapa, apenas aqueles que são desenvolvidos com algum detalhe técnico diferente, como por exemplo o forro invisível. Depois é realizado a preparação das coladeiras; a forração do calçado; o viés; o pesponto; a aplicação de ilhós; o fix pin e por último a revisão de todos os calçados, conforme ilustrado na figura 2, para que possa manter um alto nível de qualidade.

FIGURA 2 - Fluxo produtivo do processo de pesponto.

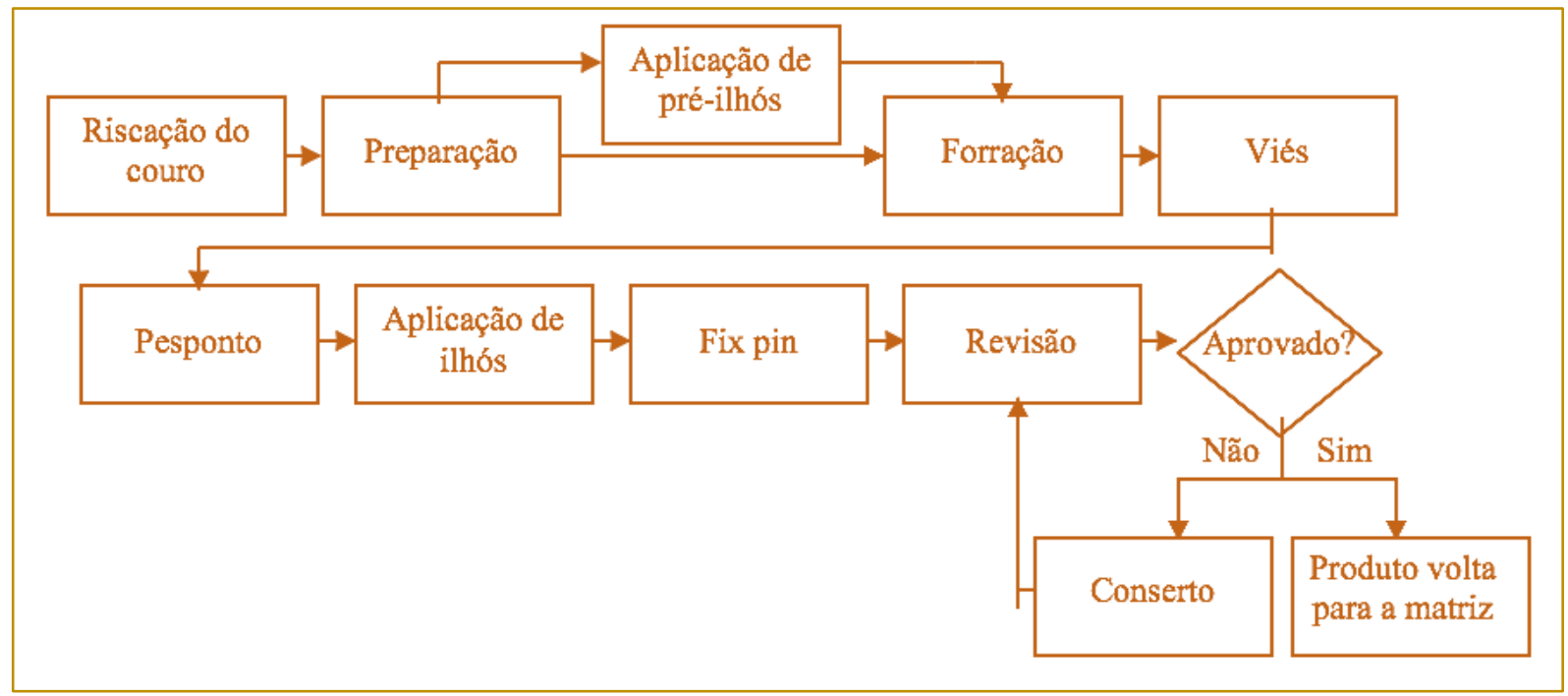

O principal indicador utilizado pela empresa A é a qualidade, ela preza sempre por um produto diferenciado no mercado. Esse indicador é controlado por meio de um check list, preenchido pelos encarregados de cada grupo. Esse check list é referente a cada ficha de trabalho, nele o encarregado anota todas as informações que é conferido pelas revisoras. Posteriormente o gerente geral do pesponto confere o trabalho das revisoras, preenche uma ficha de revisão final e controla os indicadores por meio de planilhas eletrônicas.

Como já citado anteriormente, a empresa possui o conhecimento das ferramentas de produção enxuta e aplicam inúmeras delas no processo produtivo. De acordo com o relato dos responsáveis da empresa, o maior desafio para a implantação dessa filosofia foi mudar a cultura organizacional, uma vez que os funcionários já estavam adaptados a forma de trabalho anterior, ou seja, foi preciso tirálos da zona de conforto. Diante disso, os gestores alegaram que a estratégia utilizada foi transformar os poucos colaborados, mostrando o valor do trabalho e a capacidade de cada um, além de capacitá-los a mudança por meio de treinamentos. 0 comprometimento dos funcionários é um ponto a ser destacado, isso foi substancial para a implantação da produção enxuta.

Atualmente a empresa utiliza a maioria das ferramentas da produção enxuta. Possuem Mapa do Fluxo de Valor bem definido pela matriz, aborda questões relacionadas aos custos, estoques, produtividade, fluxo e perda de material durante o processo. O Programa $5 S$ foi uma das primeiras ferramentas utilizada 
na empresa, lá os funcionários são orientados a deixar o ambiente de trabalho o mais organizado e limpo possível, com a finalidade de auxiliar na utilização das outras práticas enxutas, como a gestão visual e a padronização dos processos. Nas unidades de pesponto o trabalho dos grupos são altamente padronizados, em detrimento dos treinamentos, da supervisão diária do gerente de pesponto e também por possuírem as fichas e o contratipo, permitindo que todos os colaboradores tenham acesso aos mesmos detalhes técnicos, padronizando ao máximo o processo.

A produção do pesponto utiliza parcialmente a prática de fluxo contínuo, pois, após o grupo de suporte iniciar o pré-preparo dos calçados as fichas são encaminhadas aos demais grupos que fazem todas as operações até a finalização do produto. Analisando cada grupo essa ferramenta é aplicada, porém, a nível geral da empresa não é possível implantar a ferramenta em detrimento da alta variedade de modelos. Portanto, o objetivo de utilizar o fluxo contínuo de forma parcial é evitar desperdícios de tempo em setups como de troca de linhas e agulhas. Além disso, com a utilização desta prática a empresa reduz as perdas de movimentação utilizando essa prática.

As ferramentas Just in time e Kanban são pouco utilizadas na banca, pois o principal ponto de referência da empresa é o rigoroso planejamento da matriz, eles determinam a ordem de produção, uma vez que pode ser necessário alterar a fabricação de um pedido em virtude da solicitação da sede. A empresa A também utiliza a gestão visual, existem quadros que mostram aos colaborados os indicadores de produção diária, facilitando assim a integração deles com a empresa. Outra prática utilizada na empresa são os dispositivos a prova de erros, o principal deles é o contratipo, que possui todos os detalhes técnicos, permitindo além da padronização do trabalho a redução de erros no processo produtivo.

Essas práticas começaram a ser implantadas, aproximadamente, a dez meses, visando melhorar a eficiência do processo. O gerente de pesponto, responsável pela implantação das ferramentas, informou que foram registrados ótimos resultados como 0 aumento da produtividade, redução de perdas de matérias primas (cola e linha) e também a redução de desperdícios de tempo e movimentações. Uma vez que o layout da empresa foi reformulado para favorecer essas implementações. De acordo com o seu relato a capacidade produtiva da empresa é alta e muito variada, isso segundo ele era um dos pontos críticos na produção antes de implantar as práticas, pois era necessário um maior período de tempo para a fabricação dos produtos. Mas, atualmente é possível produzir muito e com excelente qualidade. São vários os fatores determinantes, como: a capacitação dos funcionários, o contratipo (modelo do calçado) que acompanha todas as fichas com as informações técnicas, o sistema detalhista de revisão e principalmente a utilização das ferramentas da produção enxuta.

\section{CONSIDERAÇÕES FINAIS}

A produção enxuta mostra-se como uma filosofia de gestão da produção constituída por princípios e práticas que objetivam eliminar os desperdícios dos sistemas produtivos com a finalidade de conseguir melhores resultados produtivos, com redução de custos, mantendo a qualidade e velocidade de entrega.

Ao longo da pesquisa bibliográfica foi possível notar a falta de métodos ou norma padrão para a implantação dessa filosofia. Uma das razões encontradas é que cada empresa possui suas características específicas e problemas variados. Portanto, as implementações acontecem de formas distintas nas organizações.

No estudo de caso foi possível compreender que existem fatores internos que influenciam na implantação das ferramentas enxutas, o principal deles é a mudança cultural, muitos funcionários reagem de forma negativa quando são desafiados a mudar a maneira como trabalhavam. É nesse momento que a postura gerencial pode reverter essa situação, estimulando os colaborados a aceitarem os novos parâmetros.

Este estudo de caso também permitiu observar na prática como uma banca de pesponto aplica a produção enxuta em seus processos, deixando de lado o estereótipo de atividade amadora e de baixa produtividade. É importante ressaltar que a empresa $A$ é considerada uma exceção, pois ainda é difícil encontrar bancas como tamanha organização e utilização de técnicas gerenciais. São vários os casos que os proprietários acreditam que só o conhecimento do processo produtivo é 
suficiente para o sucesso das bancas de pesponto.

De forma geral, buscou-se na pesquisa fundamentar que existem práticas da Manufatura Enxuta que podem contribuir no sistema produtivo das bancas de pesponto, proporcionando melhores resultados em custo, produtividade, qualidade e velocidade de entrega.

Mesmo sendo uma pesquisa de um único estudo de caso, espera-se com ela orientar as empresas do setor calçadista que desejam melhorar seus indicadores produtivos, uma vez que a filosofia produção enxuta possui uma estrutura capaz de se adaptar a cada organização.

\section{REFERÊNCIAS}

[1]. ABICALÇADOS - Associação Brasileira das Indústrias de Calçados. Relatório Anual, 2015. Disponível em: <http://www.abicalcados.com.br>. Acesso em: 05 maio.2016.

[2]. DIEDRICH, H. Utilização de conceitos do Sistema Toyota de Produção na melhoria de um processo de fabricação de calçados. (Trabalho de conclusão de curso de mestrado com ênfase em Engenharia de Produção). Universidade Federal do Rio Grande do Sul. Porto Alegre, 2002.

[3]. FELD, W. M. Lean Manufacturing: tools, techniques and how to use them. Boca Raton: St. Lucie Press, 2000.

[4]. GAMBI, L. D. N. Recomendações para a implementação de conceitos e técnicas de produção enxuta em empresas, fabricantes de produtos sob encomenda, do aglomerado industrial de Sertãozinho. Dissertação (Mestrado). Escola de Engenharia de São Carlos Universidade de São Paulo, São Carlos, 2011.

[5]. GARCIA, R. C. Aglomerações setoriais ou distritos industriais: Um estudo das indústrias têxtil e de calçados no Brasil. Campinas, 1996.

[6]. GIL, A. C. Como elaborar projetos de pesquisa. 4. ed. São Paulo: Atlas, 2002.

[7]. GODINHO FILHO, M. Paradigmas estratégicos de gestão da manufatura configuração, relações com o planejamento e controle da produção e estudo exploratório na indústria de calçados. Tese (Doutorado) Universidade Federal de São Carlos, São Carlos, 2004.

[8]. LIKER, J. K. O modelo Toyota: 14 princípios de gestão do maior fabricante do mundo. Porto Alegre: Bookman, 2005.
Deste modo sugere-se como pesquisas futuras seja estudado a fundo, com múltiplos casos, quais as ferramentas da produção enxuta que mais impactam na produtividade da banca de pesponto. Além de buscar compreender e delinear possíveis métodos para a implantação delas no processo produtivo. E dessa forma talvez contribuir com o crescimento da economia regional de Franca.

\section{AGRADECIMENTO}

Os pesquisadores agradecem ao Conselho Nacional de Desenvolvimento Científico e Tecnológico (CNPq) pelo apoio financeiro, tornando possível a realização desta pesquisa.

[9]. LEAN ENTERPRISE INSTITUTE. Léxico Lean: Glossário ilustrado para praticantes do pensamento lean. São Paulo: Lean Institute Brasil, v. $1.0,2003$

[10]. LOURENÇO, E. A. D. S.; BERTANI, I. F. Reestruturação Produtiva no setor calçadista de Franca/SP: O caso das bancas. III Simpósio Lutas Sociais na América Latina, 2008. Disponível em: $<$ http://www.uel.br/grupo-

pesquisa/gepal/terceirosimposio/edvania.pdf>. Acesso em: 24 jan. 2017.

[11]. MIGUEL, P. A. C. (Org). Metodologia de pesquisa em Engenharia de Produção e Gestão de Operações. 2. ed. Rio de Janeiro: Elsevier ABEPRO, 2012.

[12]. OHNO, T. O Sistema Toyota de Produção: além da produção em larga escala. Porto Alegre: Bookman, 1997

[13]. SATURI, E. M.; ARAÚJO C. A.; ANDRADE R. F. D. A estratégia para atuação em Cluster's: o caso das bancas de pesponto de Franca. XXIII Simpósio de Gestão da Inovação Tecnológica. Curitiba, 2004.

[14]. SHINGO, S. O sistema Toyota de produção do ponto de vista da Engenharia de Produção. Porto Alegre: Bookman, 1996.

[15]. WOMACK, J. P.; JONES, D. T. A mentalidade enxuta nas empresas: elimine desperdícios e crie riqueza. Rio de Janeiro: Elsevier, 2004.

[16]. YOSHINO, R. T. Proposta de um sistema de produção enxuta para o segmento calçadista. Tese (Doutorado). Escola de Engenharia de São Carlos da Universidade de São Paulo. São Carlos,2008. 
[17]. ZINGANO, E. M.; Oliveira, J. C. D Caracterização do complexo Calçadista Brasileiro e as causas da queda de seu desempenho na última década. Rio Grande do Sul, 2014.
Disponível

em:< https://online.unisc.br/seer/index.php/cepe/article/vi ew/5429 > . Acesso em: 24 out. 2016. 


\section{Capítulo 3}

\section{ANÁLISE DOS DEZ INDICADORES LOGISTICOS VITAIS NA LOGISTICA PROPOSTOS POR REY (2004) EM UM PSL DO ESTADO DO RIO DE JANEIRO}

\section{Vinicius Marques da Silva Freitas}

\section{Lígia do Carmo Martins Damasceno}

\section{Bianka Coutinho Alvim Figueira Mendes}

Resumo: Este artigo teve como objetivo analisar os dez indicadores logísticos que são estratégicos para avaliação de desempenho de um Prestador de Serviços Logísticos (PSL), situado no município do Rio de Janeiro. O referencial teórico baseou-se nos conceitos relacionados a indicadores logísticos, concentrando-se nos estudos de Rey $(2003,2004,2009)$. Foi realizado um estudo de caso em um PSL localizado no Estado do Rio de Janeiro. A coleta de dados se deu por meio de entrevistas semi estruturadas com os profissionais do setor de logística da empresa pesquisada, com as quais se buscou apurar se os indicadores apontados como vitais na logística por Rey (2004) são relevantes para um PSL. Como conclusão foi possível afirmar que dos 10 indicadores aplicados, oito foram conceituados como relevantes para a empresa estudada.

Palavras-chave: Indicadores Logísticos; PSL; Logística. 


\section{INTRODUÇÃO}

De acordo com Novaes (2001) a logística tem evoluído significativamente, e nos tempos atuais se constitui um dos principais elementos na estratégia competitiva das organizações e o ponto decisivo da cadeia de produção, agindo em harmonia com o moderno conceito de Gerenciamento da Cadeia de Suprimentos. Neste sentido, a logística assume um papel decisivo e importante na captação e manutenção de clientes, tornando-se ferramenta estratégica para as empresas.

As empresas modernas têm procurado identificar uma forma de responder questões para o sucesso de suas operações logísticas, sendo a principal delas: como monitorar o seu desempenho logístico?

O ponto de partida para tal resposta se dá no processo de avaliação de desempenho de sistemas logísticos, que atualmente é o grande desafio da logística. Os indicadores de desempenho logístico equipam o PSL com as ferramentas necessárias para melhorar constantemente a eficiência de seus processos, reduzir custos e criar benefícios que podem conduzi-lo pelo caminho de uma melhor produtividade e rentabilidade no agressivo ambiente das operações logísticas.

Neste contexto, surge a necessidade de responder a seguinte pergunta: Quais os são os indicadores logísticos de maior relevância a um PSL para avaliação de seu desempenho?

Este artigo buscou identificar os dez indicadores logísticos que são estratégicos para avaliação de desempenho de um PSL brasileiro, situado no Município do Rio de Janeiro. Para atingir tal objetivo, realizou-se uma pesquisa bibliográfica sobre os temas relacionados ao estudo e apresentado um estudo de caso, no qual foram expostos os indicadores logísticos estratégicos para avaliação de desempenho de um PSL.

A motivação para o artigo pode ser justificada por meio da afirmação de Ballou (2014, p. 352) de "que as atividades logísticas devem ser encaradas como processo contínuo, cujo desempenho deve ser monitorado". Assim, a mensuração e a avaliação do desempenho logístico são tarefas importantes para os PSLs, pois fornecem resultados do que está ocorrendo e mostram quais são as limitações e onde estão localizadas.

\section{REFERENCIAL TEÓRICO}

\subsection{INDICADORES LOGÍSTICOS}

O aprimoramento do sistema logístico pode ser fundamentado em indicadores chave de desempenho, ou Key Performance Indicator (KPI), que medem ou avaliam o desempenho dos processos chave, ou seja, dos processos que estão diretamente relacionados ao alcance das estratégias das empresas envolvidas (KAPLAN; NORTON, 1997).

Kerzner (2006) afirma que os KPIs mensuram a qualidade do processo para atingir os resultados finais determinados, avaliados por meio de critérios previamente definidos e detalha o significado de cada letra, assim sendo:

Key $(\mathrm{K})$ : principal contribuinte para o sucesso ou fracasso:

Perfomance (P): elementos mensuráveis, quantificáveis, ajustáveis e controláveis;

Indicators (I): representação razoável do desempenho presente e futuro.

Segundo Dornier et. al (2000, p. 69), os indicadores Logísticos ou Indicadores Chave de Desempenho, "são ferramentas chaves do sistema de controle, permitindo ações e decisões coerentes e orientadas para a estratégia". Corroborando com esta ideia, Lima (2001) afirma que os indicadores de desempenho permitem que as avaliações sejam feitas com base em fatos, dados, informações quantitativas, o que oferece maior convicção às conclusões.

Para Van Bellen (2002, p.5) o objetivo dos indicadores:

É de agregar e quantificar informações de uma maneira que sua significância fique mais aparente. Os indicadores simplificam as informações sobre fenômenos complexos tentando melhorar com isso o processo de comunicação.

De acordo com Takashina e Flores (1996), os indicadores logísticos são fundamentais para o planejamento e para o controle dos processos nas organizações, pois através deles é feita a análise crítica para a tomada de decisões. A escolha dos aspectos a serem avaliados é o fator de maior relevância na determinação da escolha dos indicadores logísticos, eles devem respeitar os objetivos da empresa; as metas estipuladas pelos gestores e devem ser compreensíveis, precisos e objetivos. 
Classificação e utilização dos indicadores na logística

Diversos autores desenvolveram estudos voltados à estruturação e classificação dos indicadores aplicáveis à logística. Para definição de cada tipo e sua respectiva descrição, foi usada como base a teoria de três obras, sendo classificados conforme o quadro 1:

Quadro 1 - Classificação dos indicadores logísticos

\begin{tabular}{|c|c|c|}
\hline $\begin{array}{l}\text { Classificação do Indicador } \\
\text { Logístico }\end{array}$ & Descrição & Abordagem \\
\hline $\begin{array}{l}\text { Indicadores de Custo ou } \\
\text { Indicadores Financeiros }\end{array}$ & $\begin{array}{c}\text { Medem o custo dos recursos nos diferentes } \\
\text { processos logísticos. }\end{array}$ & $\begin{array}{c}\text { Bowersox e Closs (2010) } \\
\text { Dornier et. al(2000) Ballou } \\
(2014)\end{array}$ \\
\hline $\begin{array}{l}\text { Indicadores de serviço ao } \\
\text { cliente }\end{array}$ & $\begin{array}{c}\text { Examinam a capacidade da empresa de } \\
\text { satisfazer seus clientes. }\end{array}$ & $\begin{array}{l}\text { Bowersox e Closs (2010) } \\
\text { Dornier et. al(2000) }\end{array}$ \\
\hline $\begin{array}{l}\text { Indicadores de } \\
\text { produtividade }\end{array}$ & $\begin{array}{c}\text { Relação entre o resultado produzido e a } \\
\text { quantidade de recursos para gerar este } \\
\text { resultado. }\end{array}$ & $\begin{array}{l}\text { Bowersox e Closs (2010) } \\
\text { Dornier et. al(2000) Ballou } \\
(2014)\end{array}$ \\
\hline Indicadores de qualidade & $\begin{array}{l}\text { São indicadores projetados para determinar a } \\
\text { eficiência de um conjunto de atividades. }\end{array}$ & $\begin{array}{l}\text { Bowersox e Closs (2010) } \\
\text { Dornier et. al(2000) Ballou } \\
(2014)\end{array}$ \\
\hline Indicadores de tempo & $\begin{array}{c}\text { Medem se as funções logísticas estão sendo } \\
\text { realizadas no tempo fixado pela organização } \\
\text { ou cliente. }\end{array}$ & $\begin{array}{l}\text { Bowersox e Closs (2010) } \\
\text { Dornier et. al(2000) }\end{array}$ \\
\hline
\end{tabular}

Fonte: Adaptado de Bowersox e Closs (2010), Dornier et. al(2000) e Ballou (2014).

Classificação e utilização de indicadores logísticos segundo Rey

Rey (2009) classifica os indicadores logísticos em 4 (quatro) grupos principais: indicadores de custos, produtividade, qualidade e tempo e afirma que pelo ponto de vista logístico, para que um conjunto de indicadores seja de qualidade devem ser cruzados aos processos básicos da logística: Suprimentos e manufatura, serviço ao cliente e processamento de pedidos, planejamento e administração de materiais, transporte e distribuição e armazenagem.

Ainda de acordo com Rey (1999 apud SCHMITT, 2002), os indicadores devem ser elaborados com base na estratégia da empresa e propõe a construção de uma matriz, onde são definidos os quatro grupos de indicadores de desempenho versus os cinco processos logísticos. O quadro 2 apresenta de maneira genérica, uma matriz para avaliação de desempenho logístico.

Quadro 2 - Matriz para indicadores de desempenho.

\begin{tabular}{|c|c|c|c|c|}
\hline \multirow{2}{*}{ Processos } & \multicolumn{4}{|c|}{ Indicadores } \\
\hline & Custos & Produtividade & Qualidade & Tempo \\
\hline Suprimento e Manufatura & & & & \\
\hline $\begin{array}{l}\text { Serviço ao client } \\
\text { processamento de pedid }\end{array}$ & & & & \\
\hline $\begin{array}{l}\text { Planejamento e adminis } \\
\text { de materiais }\end{array}$ & & & & \\
\hline Transporte e distribuição & & & & \\
\hline Armazenagem & & & & \\
\hline
\end{tabular}

Fonte: Rey (1999, apud SCHMITT, 2002) 
Após a definição da estrutura da matriz, de acordo com os processos que empresa queira medir, o segundo passo é preencher a tabela com os indicadores necessários. Rey (2003) sugere alguns critérios para a definição dos indicadores:

Que satisfaçam a necessidade de medir o desempenho individual de cada processo;

Que permitam medir as inter-relações de cada processo com os demais;

Que possam quantificar as contribuições de cada processo específico para otimização da estratégia logística em geral;

Que sejam mensuráveis;

Que sejam padronizados para permitir posterior benchmarking.

O benchmarking tem como objetivo possibilitar a organização confrontar os resultados de suas atividades logísticas com os melhores de sua área ou do mundo em geral. Além disso, um bom conjunto de indicadores permite a empresa participar com maior clareza de exercícios de benchmarking, pois terá um maior suporte para comparar custo, qualidade, produtividade e rapidez das funções logísticas (REY, 1999 apud SCHMITT, 2002).

Rey (2003) afirma que os indicadores de desempenho de um sistema logístico devem ser medidos com uma frequência apropriada, considerando a variabilidade da atividade a ser medida. Alguns tipos de indicadores necessitam de uma verificação diária, enquanto outros podem ser acompanhados com um maior espaço de tempo.

Indicadores de desempenho vitais na logística

A partir de um estudo realizado em Atlanta EUA em que foram avaliados os resultados preliminares do desempenho logístico na América Latina, Rey (2004) definiu que para estimar o comportamento das operações logísticas em cadeias de suprimentos são úteis 10 (dez) indicadores, chamados de sinais vitais na Logística, apresentados no quadro 3:

Quadro 3 - Indicadores de desempenho vitais na logística

\begin{tabular}{|c|c|}
\hline \multicolumn{2}{|c|}{ Indicador de desempenho logístico } \\
\hline 1 & Porcentagem de Pedidos Perfeitos \\
\hline 2 & Índice de atendimento do pedido ou Order Fill Rate \\
\hline 3 & Porcentagem de Erros de Previsão de Entrega \\
\hline 4 & Porcentagem de Custo Total de Vendas \\
\hline 5 & Ciclo total do pedido do cliente \\
\hline 6 & Ciclo total de ordem de compra a fornecedores \\
\hline 7 & Porcentagem da utilização da frota de transporte \\
\hline 8 & Capacidade de Armazenamento \\
\hline 9 & Produtividade por hora/homem no Centro de Distribuição \\
\hline 10 & Rotatividade de Inventários \\
\hline
\end{tabular}

Para a construção de um sistema eficiente de logística, Rey (2004) determina que é fundamental considerar a configuração das atividades e processos que garantam 0 cumprimento do objetivo da instituição. A partir do momento que as pessoas envolvidas começarem a colocar em prática esse pensamento e os indicadores passarem a fazer parte das atividades diárias, todos na empresa terão plena consciência sobre os melhores modos de executar tarefas e assim, passarão a otimizar os recursos e cumprir objetivos da estratégia logística da organização. 


\section{METODOLOGIA}

Esta pesquisa pode ser classificada como um estudo de caso qualitativo. Apesar do caráter mais subjetivo, a pesquisa qualitativa proporciona maior flexibilidade ao pesquisador. Além disso, outra característica importante desta modalidade de pesquisa é o fato de a mesma oferecer "descrições ricas e bem fundamentadas, além de explicações sobre processos em contextos identificáveis" (VIEIRA, 2006, p.18).

No presente estudo interessa ao pesquisador analisar os indicadores logísticos vitais para avaliação de desempenho de um PSL, e para tanto foram utilizados como método de pesquisa a pesquisa bibliográfica e a pesquisa de campo. A pesquisa bibliográfica foi realizada em livros, teses, revistas especializadas, dissertações e demais publicações pertinentes ao tema. Em seguida, foi elaborada uma pesquisa de campo, cujo objeto de estudo foi uma empresa prestadora de serviços logísticos a fim de verificar na mesma os conceitos levantados na pesquisa bibliográfica.

A empresa objeto do estudo de caso atua no ramo de consultoria e logística e está situada no município do Rio de Janeiro. Seu objetivo principal é oferecer soluções completas e integradas para toda cadeia de suprimentos, adaptadas as necessidades de seus clientes. Com intuito de preservar o nome original da empresa, adotou-se um nome fictício: empresa ABC LTDA.

A ABC LTDA exerce a função de Prestadora de Serviços Logísticos (PSL) e conta com um quadro de 107 funcionários. Sua estrutura organizacional é formada por: gerente de contrato; gerente de CD; supervisor de CD; encarregados de processos; líderes operacionais; analistas operacionais; assistentes e auxiliares de logística. Seus principais clientes são unidades de saúde, empresas públicas e privadas.

O PSL conta com uma estrutura de $6.700 \mathrm{~m}^{2}$ divididos em 2 Centros de Distribuição (CD). O espaço foi dividido de forma a atender as condições exigidas dos mais diversos produtos, de acordo com suas faixas de temperatura, além das condições de segurança. A operação junto ao cliente ocorre através do: fluxo operacional; do fornecimento de equipe especializada; equipamentos; e do monitoramento e controle das operações.
Para a logística de transporte a ABC LTDA utiliza o modal rodoviário. Sua frota conta com 22 caminhões das mais variadas capacidades, com rastreamento em todos eles, e possuem travamento automático das portas, sendo elas destravadas apenas no destino.

Vale ressaltar que as informações acima foram coletadas na entrevista com o gerente de $C D$, que é o responsável por toda a atividade logística, incluindo os dois CDs da empresa.

\section{COLETA DE DADOS}

Foram escolhidas como fonte de coleta de dados a entrevista e a pesquisa documental por meios de relatórios internos. Utilizou-se um roteiro de entrevista previamente estabelecido necessário para obter juntamente ao entrevistado as informações referentes à identificação da empresa e suas operações; sua área de atuação e rotina logística diária. Os dados da pesquisa foram coletados por meio de entrevistas estruturadas, e as perguntas foram baseadas nos conceitos de Rey (2003, 2004, 2009).

As entrevistas foram efetuadas no ambiente de trabalho da empresa ABC LTDA, no período de 20 de maio de 2015 a 04 de junho de 2015 e tiveram duração aproximada de 15 a 20 minutos.

Quanto aos sujeitos da pesquisa, de um universo de 107 colaboradores, foram selecionados para a entrevista os profissionais que são familiarizados com indicadores de desempenho logístico na sua rotina diária de trabalho. Os entrevistados limitaram-se a um grupo de 14 pessoas, ocupantes dos cargos de: gerente de contrato; gerente de CD; supervisor de CD; encarregados de processos e analistas operacionais.

Os dados foram tabulados com o auxílio do software Microsoft Excel® e analisados por meio do cruzamento dos mesmos com os conceitos apresentados na pesquisa bibliográfica, e os resultados serão expostos a seguir.

\section{APRESENTAÇÃO E ANÁLISE DOS DADOS}

Para responder a problemática do presente trabalho foi sugerida aos entrevistados a análise dos 10 indicadores citados por Rey 
(2004) na seção 2.2.2, quadro 3, como vitais para operações logísticas. Também foi solicitado aos profissionais que classificassem a relevância ou não dos mesmos. As respostas permitiram identificar quais dos indicadores vitais na logística são utilizados pela empresa ABC LTDA.
Conforme 0 gráfico 1 , dentre os 10 indicadores possíveis, $7 \%$ dos entrevistados afirmaram usar pelo menos 4 dos indicadores listados, 86\% informaram a utilização de 5 a 7 indicadores e $7 \%$ dos profissionais fazem uso de 8 a 10 indicadores logísticos citados.

Gráfico 1 - Análise do uso dos indicadores vitais na logística

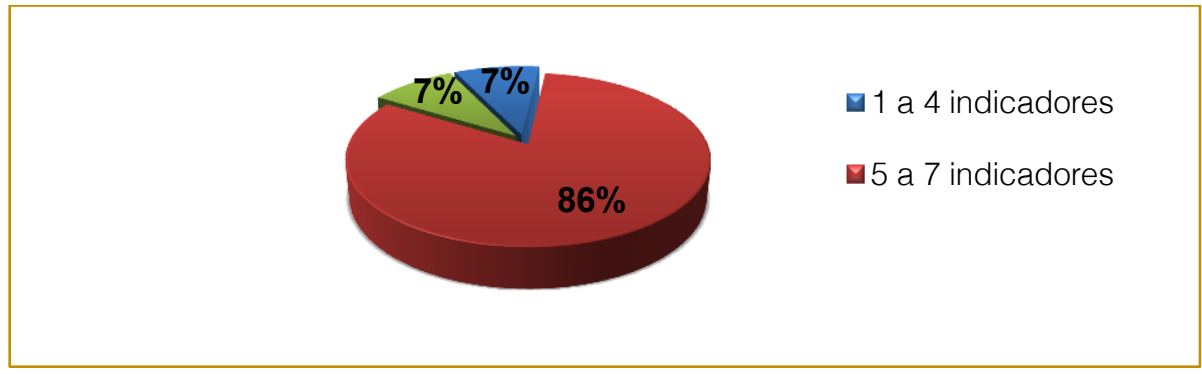

Fonte: Dados da pesquisa

Para uma melhor compreensão dos dados foi necessário montar uma matriz, cruzando os 10 indicadores propostos com a porcentagem de profissionais que afirmaram usar o indicador na sua rotina logística. O Quadro 4 abaixo demonstra a divisão das respostas e aponta os indicadores mais utilizados pela empresa ABC LTDA, que são: a Capacidade de armazenamento; a Porcentagem da utilização da frota de transporte e o Índice de atendimento do pedido ou Order Fill Rate.

Quadro 4 - Indicadores de desempenho usados pelos profissionais entrevistados

\begin{tabular}{|c|r|c|}
\hline \multicolumn{2}{|c|}{ Indicador de desempenho logístico } & $\begin{array}{c}\text { Uso por parte dos } \\
\text { profissionais }\end{array}$ \\
\hline 1 & Capacidade de Armazenamento & $100 \%$ \\
\hline 2 & Porcentagem da utilização da frota de transporte & $100 \%$ \\
\hline 3 & Índice de atendimento do pedido ou Order Fill Rate & $100 \%$ \\
\hline 4 & Porcentagem de Erros de Previsão de Entrega & $57 \%$ \\
\hline 5 & Potatividade de Inventários & $50 \%$ \\
\hline 6 & Porcentagem de Custo Total de Vendas & $50 \%$ \\
\hline 7 & Ciclo total do pedido do cliente & $50 \%$ \\
\hline 9 & Ciclo total de ordem de compra a fornecedores & $29 \%$ \\
\hline 10 & Produtividade por hora/homem no Centro de Distribuição & $7 \%$ \\
\hline
\end{tabular}

Fonte: Dados da pesquisa

Em relação à capacidade de armazenamento: o indicador é usado na empresa estudada para identificar a porcentagem real de ocupação do Centro de Distribuição (CD) e detectar, caso necessário, à necessidade de mudança na utilização da capacidade de armazenagem. De acordo com relatórios internos, no mês de abril de 2015 o percentual de ocupação do CD da ABC LTDA foi de
$67 \%$, e em maio do mesmo ano o percentual foi de $62 \%$.

Quanto à porcentagem da utilização da frota de transporte, os dados não foram disponibilizados pela empresa, entretanto o gerente entrevistado afirmou que o PSL estudado se preocupa em medir e controlar o desempenho de seu transporte, a fim de 
garantir que a capacidade disponível de seus veículos seja totalmente utilizada.

No que tange o índice de atendimento do pedido ou Order Fill Rate: o processamento de pedidos conforme citado por Ching (2010), Pozo (2007) e Balllou (2014) na seção 2, é uma atividade primária na logística, ou seja, é essencial para garantir a realização da tarefa logística por parte do PSL. Na empresa ABC LTDA este indicador é utilizado para mensurar a porcentagem de pedidos atendidos, na quantidade e especificações solicitadas pelo cliente semanalmente, a fim de garantir a eficiência no serviço e reconhecimento de sua competência nas atividades logísticas desempenhadas. O gráfico 2 exemplifica 0 uso do indicador na empresa estudada.

Gráfico 2 - Exemplo do uso do indicador: índice de atendimento do pedido.

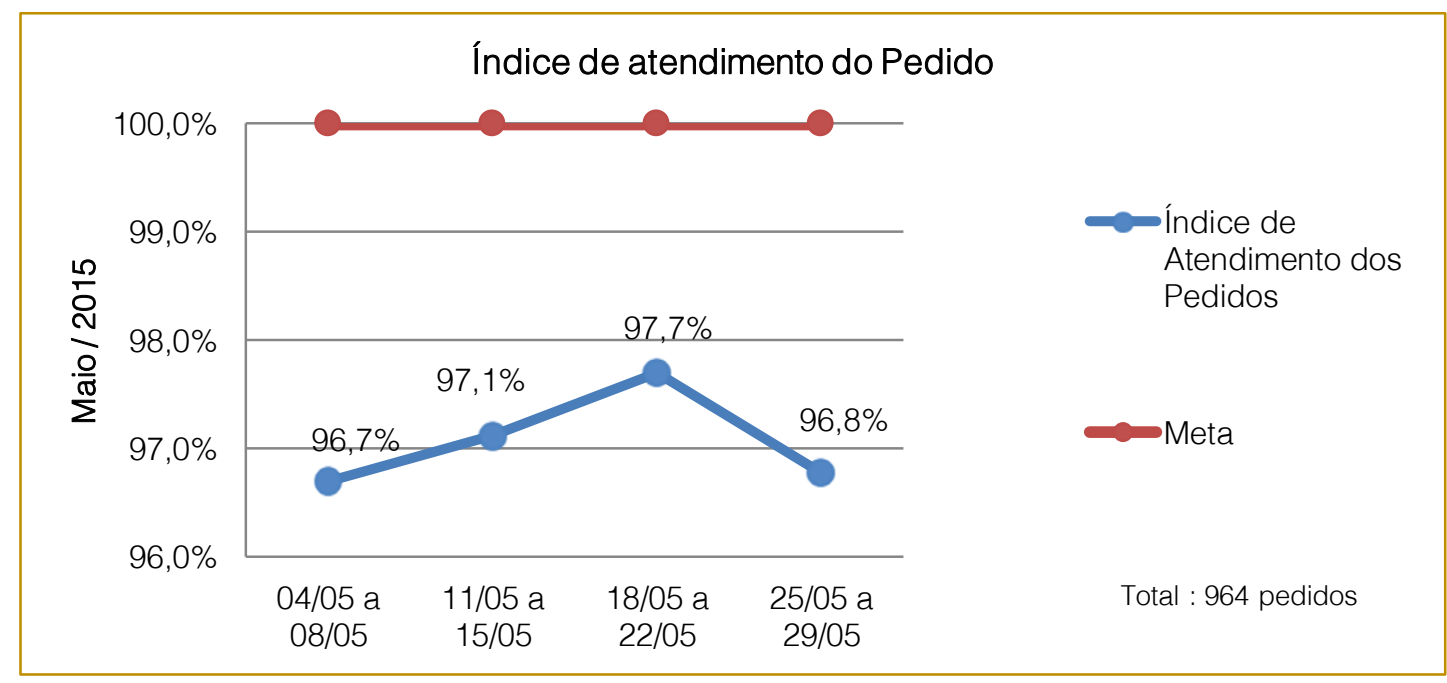

Fonte: Dados da empresa ABC LTDA.

Para uma melhor compreensão dos dados, a respeito da relevância dos indicadores logísticos, tornou-se necessário apresentar um quadro com o mesmo formato do exposto na seção 2.2.2, cruzando os 10 indicadores propostos com a porcentagem de profissionais que afirmaram ser relevante o uso dos mesmos. Desta forma, o Quadro 5 aponta os indicadores com maior relevância segundo os profissionais da empresa $A B C$ LTDA.

Quadro 5 - Indicadores logísticos com maior relevância para avaliação de desempenho da empresa $\mathrm{ABC}$

\begin{tabular}{|c|c|c|}
\hline 1 & Capacidade de Armazenamento & $100 \%$ \\
\hline 2 & Porcentagem de Pedidos Perfeitos & $100 \%$ \\
\hline 3 & Porcentagem da utilização da frota de transporte & $86 \%$ \\
\hline 4 & Ciclo total do pedido do cliente & $86 \%$ \\
\hline 5 & Rotatividade de Inventários & $71 \%$ \\
\hline 6 & Porcentagem de Erros de Previsão de Entrega & $71 \%$ \\
\hline 7 & Índice de atendimento do pedido ou Order Fill Rate & $71 \%$ \\
\hline 8 & Porcentagem de Custo Total de Vendas & $71 \%$ \\
\hline 9 & Ciclo total de ordem de compra a fornecedores & $50 \%$ \\
\hline 10 & Produtividade por hora/homem no Centro de Distribuição & $29 \%$ \\
\hline
\end{tabular}


Percebe-se que dos 10 indicadores propostos, oito apresentaram uma porcentagem de avaliação da relevância acima de $70 \%$, o que indica a importância destes para análise de desempenho da empresa ABC LTDA.

Os resultados demonstram a importância da utilização de indicadores de desempenho para uma PSL, e reforça a teoria de Rey (2003), que conforme mencionado na seção 2.2.2 destaca que os indicadores devem contribuir para otimização da estratégia logística da empresa e que devem satisfazer a necessidade de medir o desempenho individual de cada processo.

Os principais indicadores citados como relevantes são: capacidade de armazenamento, já apresentado nesta seção; porcentagem da utilização da frota de transporte; porcentagem de pedidos perfeitos; ciclo total do pedido do cliente, apresentados a seguir:

Percentual de Pedidos Perfeitos: a opção de escolha deste indicador foi devido à sua importância em representar o desempenho logístico perfeito, isto é, diz respeito à eficiência do desempenho de todas as atividades logísticas de forma integrada. O percentual de pedidos perfeitos é um ótimo indicador para a prática de benchmarking que conforme citação de Rey (1999 apud SCHMITT, 2002) na seção 3.1.1, tem como objetivo possibilitar a organização confrontar os resultados de suas atividades logísticas com os melhores de sua área ou do mundo em geral. Este indicador é utilizado pela empresa estudada para calcular a taxa de pedidos sem erros em cada estágio do pedido do cliente. Relatórios fornecidos pela empresa apontam que em abril de 2015 o índice de pedidos perfeitos foi de $90 \%$, e em maio de 2015 de $92 \%$.

Ciclo total do pedido do cliente: este indicador leva em consideração o tempo total de resposta entre a realização do pedido até a data de entrega ao cliente. O ciclo total do pedido do cliente é um indicador de tempo e que conforme apontado no Quadro 1, medem se as funções logísticas estão sendo realizadas no tempo fixado pela organização ou cliente.

A empresa pesquisada utiliza 0 indicador para garantir um bom nível de confiabilidade do serviço a seus clientes, a fim de garantir um diferencial competitivo. O gráfico 3 demonstra o uso do indicador na empresa ABC LTDA.

Gráfico 3 - Exemplo do uso do indicador: ciclo total do pedido do cliente

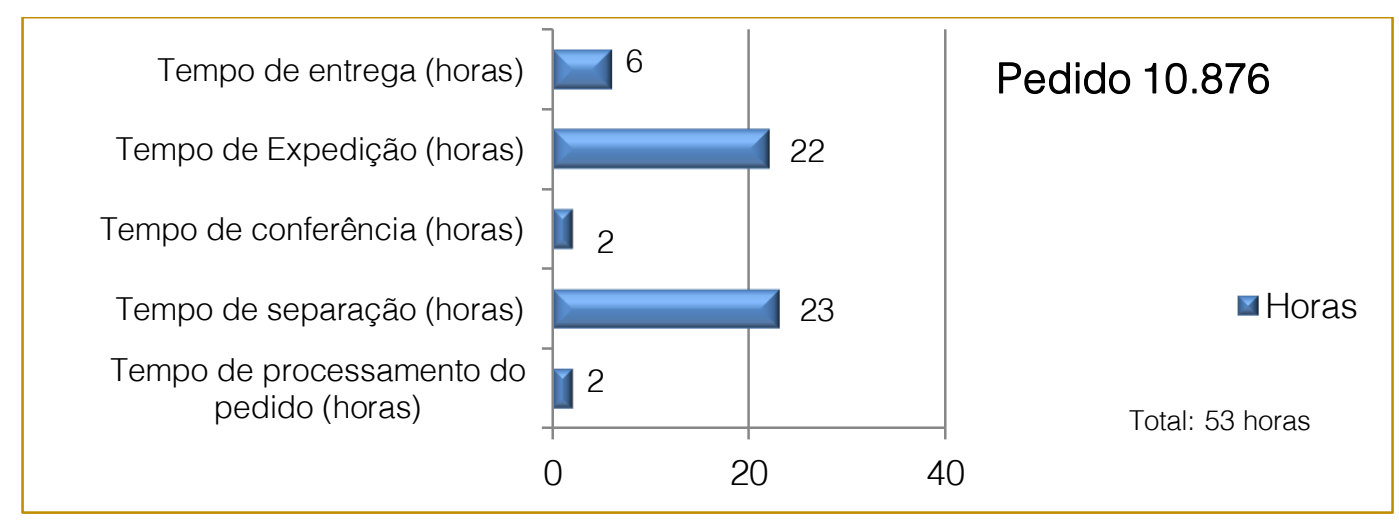

Fonte: Dados da empresa ABC LTDA

Por fim, buscou-se investigar se na empresa estudada os profissionais fazem uso de indicadores diferentes dos apresentados como vitais para logística, conforme gráfico 4. 
Gráfico 4 - Outros Indicadores relevantes nas atividades logísticas da empresa ABC LTDA.

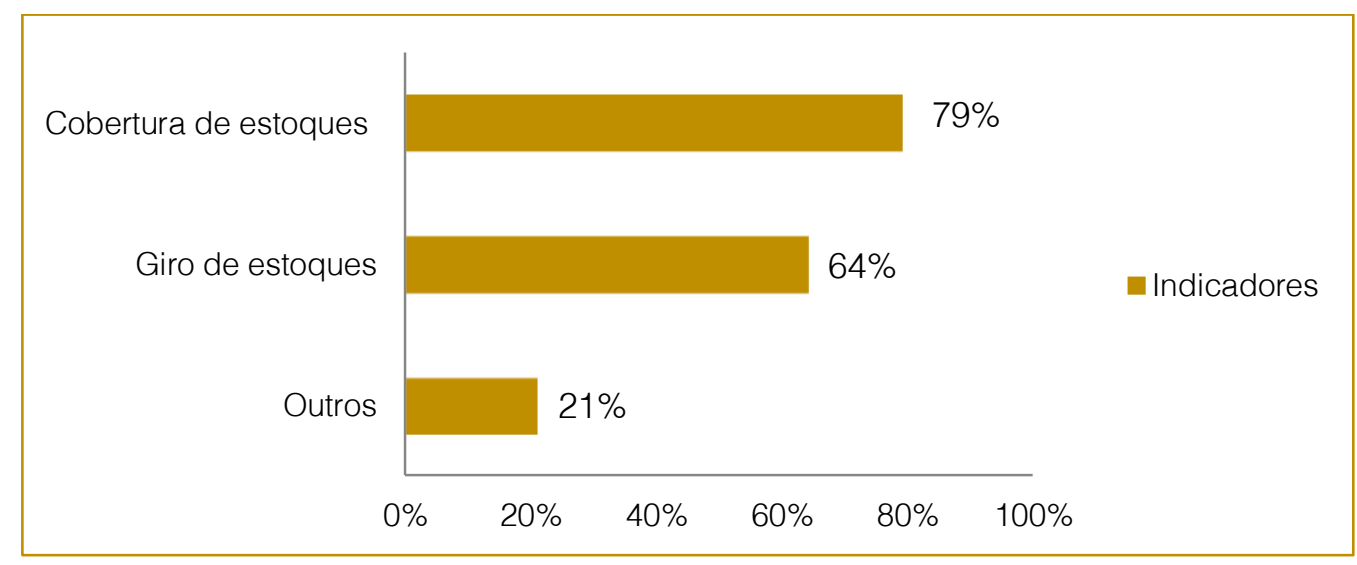

Fonte: Dados da pesquisa

Conforme se observa no gráfico $4,79 \%$ dos entrevistados apontaram 0 indicador cobertura de estoque como essencial em sua rotina logística e $64 \%$ informou que o indicador giro de estoque é importante para seus processos. Outros indicadores foram mencionados, porém não atingiram uma porcentagem considerada relevante, a soma desses indicadores chega a $21 \%$.

\section{CONCLUSÃO}

A partir da revisão bibliográfica foi possível observar um modelo de indicadores já existente desenvolvido pela doutora em logística Maria Fernanda Rey (2004), onde foi possível estabelecer quais indicadores seriam aplicados na pesquisa de campo. Após adotar como referência os 10 indicadores chamados de sinais vitais na logística, tornouse possível pesquisar por meio de entrevistas e observação na empresa estudada, se estes são relevantes para um PSL.

Através do estudo de caso foi possível conhecer a rotina logística da empresa $A B C$ LTDA, além de permitir visualizar $O$ funcionamento dos indicadores logísticos por ela usados e avaliar quais dos indicadores propostos são utilizados no cotidiano da mesma. O acesso às informações foi em parte restrito, pois a empresa estudada não autorizou que seu nome fosse exposto, visando à proteção dos dados.
Pode-se afirmar que o objetivo da pesquisa foi alcançado e a problemática respondida, visto que, a análise de dados apontou que os indicadores destacados por Rey (2004) são relevantes para avaliação de desempenho. Dos 10 indicadores aplicados, oito foram conceituados como relevantes para a empresa estudada, a análise dos dados apresentou também 2 indicadores considerados essenciais pelos profissionais entrevistados, finalizando assim com um número considerado ideal pelo pesquisador de 10 indicadores.

Assim, conclui-se que os indicadores logísticos são excelentes ferramentas para avaliação de desempenho de um Prestador de Serviços Logísticos, sendo estes na logística de extrema importância, uma vez que, funcionam como apoio a tomada de decisões. Entretanto, é fundamental que traduzam a estratégia da empresa e estejam em sintonia com o ambiente externo.

É importante destacar que os indicadores aqui apresentados podem ser modificados e facilmente aplicados em diferentes tipos de Prestadores de Serviços Logísticos. Caso a empresa necessite focar em processos e subprocessos específicos não apresentados neste trabalho, é possível aplicar novos indicadores utilizando a matriz citada no trabalho na seção 2.2.1, quadro 2, onde são consideradas as atividades exercidas pela empresa cruzando com os quatro grupos de indicadores. 


\section{REFERÊNCIAS}

[1]. BALLOU, Ronald. Logística empresarial: transportes, administração de materiais e distribuição física. São Paulo: Atlas, 2014.

[2]. BOWERSOX, Donald; CLOSS, David. Logística empresarial: o processo de integração da cadeia de suprimento. São Paulo: Atlas, 2010.

[3]. DORNIER, Philippe-Pierre, ERNST, Ricardo, FENDER, Michel, KOUVELIS, Panos. Logística e Operações Globais: textos e casos. São Paulo. Ed. Atlas. 2000.

[4]. KAPLAN, Robert S.; NORTON, David P. A estratégia em ação: Balanced Scorecard. Rio de Janeiro: Campus, 1997. 344 p.

[5]. KERZNER, H. Gestão de Projetos: As Melhores Práticas. 2.ed. Porto Alegre: Bookman, 2006.

[6]. LIMA, O. F. J. Análise e avaliação do desempenho dos serviços de transporte de carga. In: Caixeta-Filho, J. V. e R. S. Martins (eds.) Gestão logística do transporte de cargas. Ed. Atlas: São Paulo, 2001.

[7]. NOVAES, Antônio G. Logística e gerenciamento da cadeia de distribuição. Rio de Janeiro: Campus, 2001.

[8]. REY, Maria Fernanda. Estratégia corporativa de logística, operaciones \& redes de abastecimiento. In: Programa de alta dirección en logística, operaciones y gerencia de redes de abastecimiento. Atlanta: Latin America Logistics Center. 2003. Disponível em: <http://www.alexlogistica.com/docs/file/Logistica\% 20Summary\%20Light.pdf>. Acesso em: 30/01/2015

[9]. Reporte

Benchmarking: Indicadores de Desempeño
Logístico em América Latina. Atlanta: Latin America Logistics Center. 2004. Disponível em: <http://www.ramos.utfsm.cl/doc/146/sc/KPI_LATAM _2004.pdf.> Acesso em: 27/01/2015.

[10]. Resultados del Benchmarking Logístico - APLA 2008/9. In: III Estudio De Benchmarking Logistico Aplicado A La Industria Petroquimicia Y Quimica Latinoamericana. Atlanta: Apla, 2009. Disponível em: < http://www.apla.com.ar/archivos/publicaciones/apla -reporte-benchmarking-3-edicion-.pdf > Acesso: $17 / 01 / 2015$

[11]. SCHMITT, H. B. Modelo de avaliação de desempenho de operadores logísticos atuantes no setor agrícola de cargas a granel. Dissertação (Mestrado em Engenharia de Produção) Universidade Federal de Santa Catarina, 2002. Disponível em: <https://repositorio.ufsc. br/xmlui/bitstream/handle/1 23456789/84022/187849. pdf?sequence=1\&isAllow ed $=\mathrm{y}>$. Acesso 30/01/2015.

[12]. TAKASHINA, Newton Tadachi; FLORES, Mario César Xavier. Indicadores da qualidade e do desempenho: como estabelecer metas e medir resultados. Rio de Janeiro: Qualitymark,1996.

[13]. VAN BELLEN, Hans Michael. Indicadores de sustentabilidade: uma análise comparativa. Rio de Janeiro: FGV, 2002

[14]. VIEIRA, Marcelo Milano Falcão. Por uma boa pesquisa qualitativa em administração. In: VIEIRA, Marcelo Milano Falcão ; ZOUAIN, Deborah Moraes (Orgs.). Pesquisa Qualitativa em Administração. 2. ed. Rio de Janeiro: FGV, 2006. p. 13-28. 


\section{Capítulo 4}

\section{O PROBLEMA DE SEQUENCIAMENTO COM RESTRICZÃO DE RECURSOS: UMA PROPOSTA DE MELHORIA DE UM ESTUDO DE CASO NO SETOR CALCADISTA}

\section{Mayara Fernanda Silva e Santos}

\section{Luana Alves Cota Souza}

\section{Cecília Rocha Gonçalves}

\section{Salvador Pereira de Carvalho Junior}

Mayra Cristina Silva Santos

Resumo: O fator determinante para o sucesso de um projeto é o sequenciamento das atividades. Sendo assim, o Problema de Sequenciamento em Projetos com Restrição de Recursos (PSPRR) tem por objetivo determinar o menor tempo possível de execução das atividades que o constituem, a partir os tempos de execução das tarefas, as respectivas quantidades de recursos necessárias e o total de recursos disponíveis. Estudos prévios sobre o tema levaram Artigues et al. (2003) a propor um modelo básico ao PSPRR. O objetivo deste trabalho é expandir a aplicação do modelo encontrado na literatura, por meio da implementação de melhorias com intuito de aperfeiçoar o desempenho computacional na resolução do modelo. Além disso, foi proposto um estudo de caso em uma empresa de calçados, para aplicação do modelo em estudo. De acordo com os dados descritos neste estudo podemos concluir que a indústria só produz para entrega. Novos pedidos serão aceitos de acordo com a disponibilidade de recursos na linha de produção. Como o makespan foi reduzido, conclui-se que é possível atender uma quantidade maior de pedidos. Pode-se dizer, então, que o objetivo previamente estipulado foi executado e obteve-se o resultado esperado, o qual viabilizou o estudo.

Palavras - chave: PSPRR, Disponibilidade de Recursos, Makespan. 


\section{INTRODUÇÃO}

De acordo com a Associação Brasileira das Indústrias de Calçados (ABICALÇADOS, 2016) o ramo calçadista, em seus primores, concentrava-se na Região Sul do país, contando com 2.700 empresas espalhadas por seus principais polos produtores. Tal expressividade de desenvolvimento no setor de transformação deve-se, principalmente, aos imigrantes que se fixaram na região.

Hoje em dia, a produção de calçados não mais se concentra no sul, mas espalha-se por todos os estados do país. Pode-se destacar os estados emergentes da região Nordeste que alcançaram um lugar especial no setor de calçados no cenário nacional e internacional.

No artigo, foi feito um estudo de tempos e de movimentos na linha de montagem, de uma empresa cearense, centrada em um único modelo de calçado injetado, visando determinar o tempo padrão para cada operação, procurando calcular o tempo gasto para que cada operador efetuasse sua atividade e por fim propor melhorias no desenvolvimento do modelo inicialmente estudado.

O uso da ferramenta de estudos de tempos e movimentos tem como objetivos, em primeiro lugar eliminar esforços desnecessários ao executar uma operação; procurar adaptar os empregados a sua função; estabelecer normas para execução do trabalho enfim descobrir métodos que venham proporcionar melhorias no processo produtivo bem como aumento da produção.

Objetivando garantir seu espaço no mercado, as empresas buscam por ferramentas que tragam melhoria da eficiência operacional. Nesse cenário, o sequenciamento eficiente da produção de bens ou serviços pode assegurar a otimização do tempo de processamento, fazendo com que sejam cumpridas as datas estabelecidas entre fornecedor e clientes e que se tenha uma melhor utilização dos recursos existentes. Esses fatos e dados auxiliam no aumento da capacidade produtiva e na redução de custos de produção, proporcionando maior competitividade e consolidação da empresa.

A metodologia utilizada neste trabalho é descrita em cinco etapas: A primeira etapa discorre sobre tomada de decisões e suas implicações. Já a segunda etapa concretizase por meio da aquisição de conhecimentos através da revisão de literatura a respeito do tema apresentado, visando fazer um levantamento do maior número possível de informações relevantes, além de discorrer sobre o modelo de melhoria do PSPRR, na qual foram feitas algumas alterações. $\mathrm{Na}$ etapa seguinte, a terceira, foi exposta um estudo de caso, o qual foi descrito a organização e análise do estudo além de mudanças serem propostas ao modelo. $\mathrm{Na}$ quarta etapa, a melhoria foi implementada por meio de modelagem matemática. Por fim, na quinta etapa são apresentadas as conclusões.

\section{REFERENCIAL TEÓRICO}

\subsection{A TOMADA DE DECISÃO SOB INCERTEZA}

Rosenhead et al. (1972) nota que "pode ser possível converter um problema de incerteza em um problema de risco, pela avaliação subjetiva de probabilidades, e quando utilizada apropriadamente pode ser uma valiosa simplificação. No entanto, alguns aspectos do futuro são verdadeiramente incompreensíveis, mesmo no sentido de probabilidade".

Certo número de critérios podem ser distinguidos para tomada de decisão sob incerteza. Alguns dos mais importantes para a minimização problema são: 1- Minimax. minimizar a pior realização do makespan que pode ocorrer; 2- Minimin: minimizar o melhor resultado que pode ocorrer, o que é uma abordagem otimista, ao contrário do Minimax que é pessimista; 3- Pesar minimax. minimizar a maior diferença possível no makespan entre a política a ser selecionada e o makespan ideal para uma determinada realização; 4Minimizar o objetivo na expectativa (WALD, 1950; SAVAGE, 1951)

O RCPSP estocástico é uma distribuição de probabilidade conhecida para os cenários de duração, onde é selecionada uma política que minimiza o preço esperado do projeto makespan, dentro de uma classe específica de políticas.

Assavapokee et al. (2008) afirma que, por causa de informações incompletas sobre a distribuição de probabilidade conjunta dos parâmetros incertos no problema, tomadores de decisão são muitas vezes incapazes de tomar decisões de longo prazo com o melhor desempenho médio. 
Um tomador de decisão deve estar preocupado não só com a forma como o desempenho de um cronograma varia de acordo com o real, mas também com a forma como o desempenho real comparado com o desempenho ideal que poderia ter sido alcançado caso a informação perfeita estivesse disponível antes da programação.

A partir da análise do estudo de caso do artigo "Estudo de Tempos em uma indústria e comércio de calçados e injetados LTDA", realizado em uma indústria de calçados, verificou-se a possibilidade de rearranjo das atividades que se encontravam de forma sequencial, com o intuito de reduzir o tempo de duração das atividades.

O Problema de Sequenciamento em Projetos com Restrição de Recursos (PSPRR) é constituído, de forma geral, como definido por Brucker et al. (1998), por um conjunto $V$ de atividades $(1,2, \ldots, n)$, e um conjunto $R$ de recursos $(1, \ldots, m)$. Cada atividade $i \in V$ necessita de uma quantidade constante rik de unidades do recurso $k$ para ser executada. Segundo Vieira et al. (2010), a atividade $i$ é executada sem ser interrompida em pi unidades de tempo. Cada tipo de recurso $k \in R$ está disponível em uma quantidade constante de $R$ k unidades. Os valores de $R$ k, rik e pisão maiores ou iguais a zero. Algumas relações de precedência entre as atividades são definidas a priori. Dadas tais condições, o objetivo é minimizar o makespan, Cmax = $\max c \in \mathrm{VSi}$

,onde Si é a data de inicio da atividade i, ou seja, minimizar o $\mathrm{S} n+1$.

Deblaere et al. (2003) e Artigues et al. (2003) apresentam uma formulação de Programação Linear Inteira Mista para o PSPRR como sendo um problema de fluxo de recursos, Para Goldbarg e Luna (2000), os modelos matemáticos que são formulados baseados na Programação Linear Inteira Mista podem ser mais complexos, no âmbito computacional, do que os modelos que utilizam a Programação Linear. Sendo assim, iremos propor a aplicação deste tipo de programação em uma empresa do ramo calçadista.

O RCPSP tem sido largamente estudado na literatura, e existe um grande número de possíveis aplicações, especialmente em matéria de gestão da produção, como mencionado em Klein (2000).

\subsection{FORMULAÇÃO BÁSICA DO PSPRR}

O PSPRR, de acordo com Brucker et al. (1998), é formulado por um conjunto de $n$ atividades ( $V$

$=1,2, \ldots, n)$ e $m$ recursos renováveis, visando a otimização do tempo de processamento de um projeto. As relações de precedências devem ser respeitadas.

Artigues et al. (2003) apresentaram um modelo para o PSPRR, tendo os seus termos explanados a seguir.

Sejam:

$V=\{1,2, \ldots, n\}$ : conjunto das atividades;

$R=\{1,2, \ldots, m\}$ : conjunto dos recursos;

E: conjunto das atividades em que a relação de precedência é conhecida, ou seja, uma atividade só será iniciada após a conclusão da atividade antecessora;

$s$ e $t$. atividades fictícias que representam o início e o fim do projeto, respectivamente;

rik. quantidade do recurso $k$ essencial para realizar a atividade $i$; $i$ tempo de processamento da atividade $i$,

$M$ e $N$ : constantes arbitrárias suficientemente grandes; fijk. fluxo do recurso $k$ da atividade $i$ para a atividade $j$; xij: variável binária que indica se a atividade $i$ precede $j$; Si. data de início da atividade $i$.

Dessa forma, escreve-se o modelo como apresentado em Artigues et al. (2003): 
Figura 1: Modelo matemático

$\begin{array}{lll}\min & C_{\max } & \\ \text { s.a. } & x_{i j}=1 & \forall(i, j) \in E \\ & S_{j}-S_{i}-M x_{i j} \geq p_{i}-M & \forall i \in V \cup\{s\}, \forall j \in V \cup\{t\} \\ & f_{i j k}-N x_{i j} \leq 0 & \forall i \in V \cup\{s\}, \forall j \in V \cup\{t\}, \forall k \in R \\ & \sum_{j \in V \cup\{t\}} f_{i j k}=r_{i k} & \forall i \in V \cup\{s\}, \forall k \in R \\ & \sum_{i \in V \cup\{s\}} f_{i j k}=r_{j k} & \forall j \in V \cup\{t\}, \forall k \in R \\ & C_{\max } \geq S_{i}+p_{i} & \forall i \in V \\ & f_{i j k} \in \mathbb{N} & \forall i \in V \cup\{s\}, \forall j \in V \cup\{t\}, \forall k \in R \\ & x_{i j} \in\{0,1\} & \forall i \in V \cup\{s\}, \forall j \in V \cup\{t\}\end{array}$

Fonte: Artigues (2003)

A função objetivo, descrita em (1), visa minimizar o tempo total de execução do projeto (Cmax). Na equação (2), as restrições garantem as relações de precedência. As relações de sequenciamento entre as atividades são representadas pelas restrições apresentadas em (3). As restrições em (4) denotam a possibilidade de fluxo de um tipo de recurso entre duas atividades. Já as restrições em (5) e (6) representam a conservação do fuxo, ou seja, da quantidade de recursos que entra e sai de cada atividade. Em (7) o tempo total de execução do projeto é definido. Finalmente, (8) e (9) representam os domínios das variáveis de decisão, fijk e xi.

\subsection{MODELO DE MELHORIA DO PSPRR}

A modelagem utilizada foi apresentada por Vieira (2011) em busca de uma redução no makespan do processo, e neste artigo foram propostas 5 melhorias para o modelo com o intuito conseguir uma diminuição no tempo computacional do mesmo. As cinco melhorias propostas foram: a substituição das constantes $\mathrm{M}$ e $\mathrm{N}$ e do valor Cmax, e uma alteração em duas restrições.

A constante $\mathrm{M}$, que diz respeito a um valor suficientemente grande relacionado ao sequenciamento e tempo de processamento foi substituída pelo somatório de todos os tempos de processamento p, para cada atividade i, na restrição 3 .
Já a constante $\mathrm{N}$, que se refere ao fluxo de recurso do processo foi substituído pelo valor máximo da quantidade do recurso k, rk, para cada atividade i, na restrição 4.

$\mathrm{Na}$ função objetivo, valor de Cmax foi trocado por Si[t], ou seja, o makespan é igual a data de início da última atividade fantasma $t$. Devido a essa troca, não há mais necessidade da 7 restrição proposta no artigo.

Nas restrições referentes ao recurso (restrições 5 e 6), foi adicionado que i precisa ser diferente de $t$ (atividade final) e j precisa ser diferente de s (atividade inicial), já que uma atividade predecessora i não poderá ser a última do processo, do mesmo modo que uma atividade antecessora não pode ser a primeira do mesmo.

\section{ESTUDO DE CASO}

A partir da análise do estudo de caso do artigo "Estudo de Tempos em uma indústria e comércio de calçados e injetados LTDA", proposto por Figueiredo, Oliveira e Santos (2011), realizado em uma indústria de calçados, verificou-se a possibilidade de rearranjo das atividades que se encontravam de forma sequencial, com o intuito de reduzir o tempo de duração das atividades.

A empresa Terramaris Indústria e Comércio de Calçados é uma empresa genuinamente cearense, cujo foco é a produção de sandálias no mercado nacional. Seus produtos visam atender o público feminino e 
masculino, englobando a faixa etária infantil, juvenil e adulto. Seu maior diferencial é a gestão inteiramente regional.

O processo produtivo é caracterizado por Produção por Encomenda, na qual o planejamento do processo só ocorrerá após a venda do produto.

Os objetivos do artigo foram: conhecer e descrever o processo produtivo da empresa, coletar dados através de observação realizada no setor em estudo, identificar os problemas enfrentados no setor analisado, estudar as operações dividindo-as em elementos, cronometrar cada elemento, avaliar o ritmo do operador em diversos ciclos, calcular o tempo padrão, sugerir o aperfeiçoamento do sistema, produtivo de acordo com a implementação do Procedimento Operacional Padrão - POP e estratificar resultados.

O setor avaliado pelo artigo, para a realização do trabalho foi a linha de montagem. A linha de montagem é composta por uma esteira, na qual são realizadas as operações sequenciais, como fixar a alça no solado, fixar as etiquetas e, por fim, acondicionar as sandálias na embalagem. As operações são realizadas por uma equipe formada por homens e mulheres, onde cada funcionário é direcionado para uma função.

O artigo optou por descrever a montagem de um único produto, o South África 2010, sandália masculina adulta da Coleção África Mania, pelo fato de a empresa dispor de uma linha de produtos de extensa variedade.

\subsection{DESCRIÇÃO DAS FUNÇÕES DOS OPERADORES}

O arranjo físico da linha de montagem é dividido em sete operações, e cada operador é responsável por uma função.

A seguir são definidos o operador e as funções a eles atribuídos, segundo Figueiredo, Oliveira e Santos (2011).

1ㅇ Operador: Abastecer a esteira com os pares de solados e as etiquetas que estão empilhados à frente. Principais atividades: 1. abastecer a esteira com solados; 2. colocar etiquetas sob esteira ao lado dos solados.

$2^{\circ}$ Operador: Colocar alça no solado esquerdo utilizando a ferramenta bico de pato, é com esse objeto que o operador consegue fazer o encaixe da alça nos três furos do solado. Principais atividades: 1. pegar a alça e solado esquerdo; 2. encaixar o primeiro furo do solado no bico de pato e colocar a alça no primeiro furo; 3. encaixar a alça no furo esquerdo do solado; 4. encaixar a alça no furo direito do solado e repõe na esteira.

$3^{\circ}$ Operador: Colocar alça no solado direito. É praticamente a mesma função do segundo, a diferença é que este executará sua função com o solado direito. Principais atividades: 1. pegar a alça e solado direito; 2. encaixar o primeiro furo do solado no bico de pato e encaixa alça; 3. encaixar a alça no furo esquerdo do solado; 4. encaixar a alça no furo direito do solado e repor na esteira;

$4^{\circ}$ Operador: Colar as alças com o auxílio de um pincel na parte superior da alça que já se encontra fixada nos solados direito e esquerdo, sobre a esteira. A cola passa por um processo de secagem na estufa localizada na esteira, tendo como finalidade ativar a cola para que possa aderir devidamente à etiqueta. Principais atividades: 1. molhar o pincel na cola; 2. passar cola na alça do solado direito e esquerdo; 3. passar cola nas etiquetas que ficam sob a esteira.

$5^{\circ}$ Operador: Colocar trava anel e código. Esse operador é responsável por unir solado direito com solado esquerdo usando a trava anel, a mesma tem um formato de barril em uma extremidade, e na outra o formato de uma flecha onde será formando o par de calçados. Principais atividades: 1. pegar trava; 2. passar trava por entre as alças dos solados e fecha a trava.

$6^{\circ}$ Operador: Colar etiquetas nas alças. Após os solados terem passado pelo quarto operador é chegado o momento de receber a etiqueta onde o operador fixa as etiquetas nas alças. Elementos: 1. pegar a primeira etiqueta e fixar na alça do solado esquerdo; 2. pegar a segunda etiqueta e fixar na alça do solado direito.

$7^{\circ}$ Operador: Embalar produto. O último operador tem a responsabilidade de colocar o "produto acabado" em suas respectivas embalagens e em seguida depositar no caixote localizado ao seu lado. Principais atividades: 1. pegar a embalagem e abre; 2 . colocar produto na embalagem e finalizar colocando o produto no caixote.

A Tabela 1 a seguir descreve os tempos cronometrados de acordo com as respectivas operações. 
Tabela 1: Tempo das operações

\begin{tabular}{|c|c|c|}
\hline OPERADOR & OPERAÇÕES & TEMPO (segundos) \\
\hline 1 & Abastecer a esteira com solados e etiquetas & 5,112 \\
\hline 2 & Colocar alça no solado direito & 4,857 \\
\hline 3 & Colocar alça no solado esquerdo & 4,492 \\
\hline 4 & Passar cola nas alças e na etiqueta & 3,312 \\
\hline 5 & Colocar trava-anel & 3,306 \\
\hline 6 & Fixar as etiquetas nas alças & 2,416 \\
\hline 7 & Embalar o produto acabado e colocar no caixote & 5,446 \\
\hline
\end{tabular}

Fonte: Figueiredo, Oliveira e Santos (2011)

\section{ANÁLISE E DISCUSSÃO DOS} RESULTADOS

O problema ao qual este trabalho está focado é a alocação de 7 tarefas, com o objetivo de reduzir o makespan para agilizar o processo de fabricação de sandálias.

Após análise dos resultados obtidos no artigo, notou-se a possibilidade de reorganizar a disposição das atividades, de forma que o makespan seja minimizado.
Desse modo, percebeu-se que as tarefas 2 e 3 podem ser feitas simultaneamente, assim como as tarefas 5 e 6 , pelo fato de não apresentarem uma relação de dependência e, além disso, encontra-se disponível o número de recursos necessários. A linha de montagem permanece com 7 operadores, sendo que cada operador continua desempenhando uma tarefa. A diferença é que os operadores estão dispostos de maneira a realizar as atividades de acordo novo modelo, representado a seguir na Figura 2.

Figura 2: Nova disposição das atividades

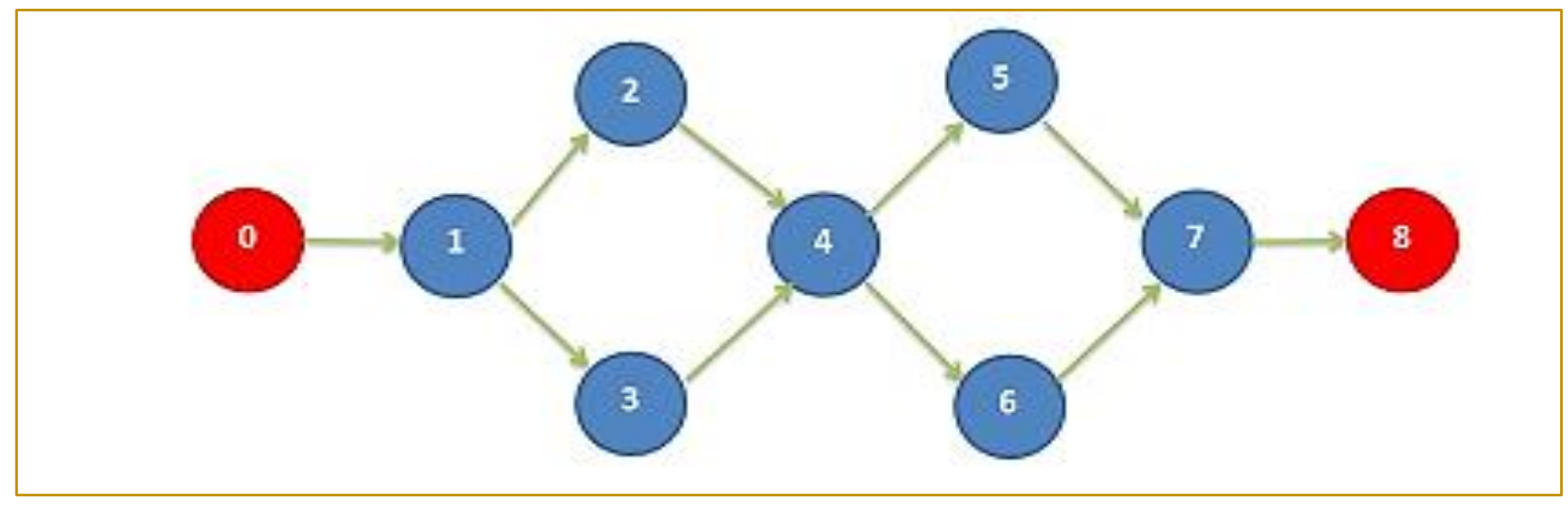

Fonte: Elaborado pelos autores

As atividades 0 e 8 representadas na figura, referem-se às atividades fantasma, utilizadas para indicar o início e fim do projeto.

\subsection{MODELAGEM}

Para verificar se 0 modelo proposto apresentará um tempo de duração menor que o tempo encontrado no artigo, foi utilizado a linguagem de programação GLPK com o solver simplex.

A primeira etapa foi programar o novo modelo, baseado na formulação básica do PSPRR. Definiu-se:

$\mathrm{O}$ conjunto das $\mathrm{n}$ atividades do projeto. $\mathrm{V}=\{0$, $1,2,3,4,5,6,7,8\}$ 
O conjunto das atividades levando em consideração a precedência. $E=(0,1) ;(1,2)$; $(1,3) ;(2,4) ;(3,4) ;(4,5) ;(4,6) ;(5,7) ;(6,7) ;(7,8)$

$\mathrm{O}$ conjunto dos $\mathrm{m}$ recursos renováveis, no caso, temos apenas um recurso, o operador. $R=\{1\}$
Os recursos mínimos do tipo renovável. $\mathrm{Rk}=7$

O tempo de processamento (pi) de cada atividade.

Tabela 2 - Tempo De Processamento das Atividades

\begin{tabular}{|c|c|}
\hline ATIVIDADE & TEMPO $(\mathrm{s})$ \\
\hline 0 & 0 \\
\hline 1 & 5.112 \\
\hline 2 & 4.875 \\
\hline 3 & 4.492 \\
\hline 4 & 3.312 \\
\hline 5 & 3.306 \\
\hline 6 & 2.416 \\
\hline 7 & 5.446 \\
\hline 8 & 0 \\
\hline
\end{tabular}

Fonte: Elaborado pelos autores

A quantidade de recurso (rik) que cada atividade necessita para ser executada:

Tabela 3- quantidade de recurso por atividade

\begin{tabular}{|c|c|}
\hline Atividade & $\begin{array}{c}\text { Quantidade } \\
\text { de Recurso }\end{array}$ \\
\hline 0 & 7 \\
\hline 1 & 1 \\
\hline 2 & 1 \\
\hline 3 & 1 \\
\hline 4 & 1 \\
\hline 5 & 1 \\
\hline 6 & 1 \\
\hline 7 & 7 \\
\hline 8 & \\
\hline
\end{tabular}

Fonte: elaborado pelos autores

Atividades fictícias s e t.

$$
\begin{aligned}
& s=0 \\
& t=8
\end{aligned}
$$

Posteriormente, obteve-se a solução do modelo com as melhorias implementadas do PSPRR.
Após realizadas os procedimentos descritos acima, verificou-se que o no novo modelo composto por 7 atividades reais, sendo 4 delas simultâneas, e 2 fictícias, obteve-se o makespan de 22,051 segundos. Ao comparar com o modelo do artigo, onde as atividades se encontravam em sequência, houve uma redução de 6,890 segundos no processo. 


\section{CONCLUSÃO}

$\mathrm{Na}$ empresa em questão, trabalha-se com o estoque de pedidos de produtos, ou seja, se produz somente para entrega e não para estoque. $\mathrm{O}$ atendimento de novas solicitações de pedidos e produtos pelos clientes depende da disponibilidade de recursos na linha de produção da empresa. Como o makespan foi reduzido, é possível atender

\section{REFERÊNCIAS}

[1]. ABICALÇADOS. Associacação Brasileira de Calçados. Disponível em: < http://www.abicalcados.com.br>. Acesso em 22 julho. 2016.

[2]. ARTIGUES, C.; LEUS, R. Robust optimization for resource-constrained Project scheduling with uncertain activity, 2012.

[3]. ARTIGUES, C.; MICHELON, P. e REUSSER, S. Insertion techniques for static and dynamic resource-constrained project scheduling. European Journal of Operational Research Vol. 149, p. 249-267, 2003.

[4]. ASSAVAPOKEE, T; REALFF, M. J; AMMONS JC. A new min-max regret robust optimization approach for interval data uncertainty. J Optim Theory Appl 137:297-316, 2008a.

[5]. BIANCO, L.; CARAMIA, M. A new formulation for the Project scheduling problem under limited resources, 2011.

[6]. BRUCKER, P.; KNUST, S.; SCHOO, A. e THIELE, O. A Branch and Bound Algorithm for the Resource-Constrained Project Scheduling Problem. European Journal of Operational Research. Vol. 107, p.272-288, 1998.

[7]. DEBLAERE, F.; DEMEULEMEESTER, E. L.; HERROELEN, W. S. e VONDER, S. V. Robust Resource mais pedidos, gerando maior faturamento para a empresa. Vale ressaltar que o modelo proposto não leva em consideração aspectos relacionados ao fator humano. Com relação às melhorias propostas e aplicadas ao modelo, conclui-se que foram de grande serventia para otimizar o processo, e a partir delas conseguiu-se chegar ao objetivo principal do estudo, comprovando a relevância do tema abordado.

[8]. Allocation Decisions in Resource Constrained Projects. Decision Science 38, p. 5-37, 2007.

[9]. FIGUEIREDO, F. J. S.; OLIVEIRA T. R. C.; SANTOS A. P. B. M. Estudo de tempos em uma indústria e comércio de calçados e injetados LTDA. ENEGEP. Belo Horizonte, p. 12-26, 2011.

[10]. GOLDBARG, M.C.; LUNA, H.P.L. Otimização combinatória e programação linear: modelos e algoritmos. 5. ed. Rio de Janeiro: Campus, 2000.

[11]. KLEIN, R. Scheduling of resourceconstrained projects. Kluwer, Amsterdam, 2000.

[12]. ROSENHEAD, J; ELTON, M; GUPTA, S. K. Robustness and optimality as criteria for strategic decisions. Operational Research Quarterly (19701977) Vol. 23, No. 4 (Dec., 1972), pp. 413-431.

[13]. SAVAGE, L. J. The theory of statistical decision. J Am Stat Assoc 46:55-67, 1951.

[14]. VIEIRA, C. S.; MONTALVÃO, E. H. R.; MARTINS, F. R.; MATTIOLI, G. G.; HANCKUK, L. H. Modelo de

[15]. programação linear inteira para o problema de sequenciamento em projetos com restrição de recursos, 2011. WALD, A. Statistical decision functions. Wiley, London, 1950. 


\section{Bapítulo 5}

\section{ANÁLISE DOS INDICADORES DE PRODUCÃO INDUSTRIAL DAS REGIÕES DO BRASIL UTILIZANDO MODELOS DE REGRESSÃO LINEAR}

\section{Josemar Coelho Felix}

Kéllen Bárbara Nascimento Furtado

\section{Edilaine Gonçalves Araújo}

\section{Robert Cruzoaldo Maria}

Resumo: O objetivo do presente trabalho é descrever o comportamento da economia das cinco regiões brasileiras perante a crise financeira utilizando equações de regressão linear simples. O estudo foi realizado com dados da produção física regional do IBGE de 2013 até 2015. O intuito é verificar se com a utilização de modelos de previsão, como cálculos de regressão linear simples, consegue-se compreender os cenários econômicos distintos de cada região do Brasil. Foi constatado que as regiões Sul e Sudeste apresentaram uma tendência de decaimento do seu setor de produção física nos últimos anos. Já para o Nordeste, as análises apontam que a região apresenta certa estabilidade no período analisado. As regiões Norte e Centro Oeste mostraram um comportamento otimista, crescendo de uma forma considerável, mesmo com a crise econômica. Constatou-se que apesar da crise ser nacional, ela não impacta de maneira igualitária em todas as regiões e que existem setores que apesar da crise cresceram.

Palavras-chave: Economia; Tendência; Regressão Linear. 


\section{INTRODUÇÃO}

Nos últimos anos, percebe-se um cenário de incerteza na economia brasileira, marcada por um período de recessão. Desta forma, os investidores ficam mais cautelosos diante de um cenário nebuloso e dasafiador. Por outro lado, alguns investidores podem aproveitar a ocasião para reestruturar seus negócios, diverificar sua produção ou até procurar novos mercados para seus produtos. Neste trabalho utilizou-se de uma ferramenta considerada simples para coompreender o comportamento da economia das diversas regiões e o grau de resiliência de cada uma perante uma economia adversa.

Assim, o IBGE - Instituto Brasileiro de Geografia e Estatística, a partir da Pesquisa Industrial Mensal Produção Física - Regional, produz indicadores de curto prazo desde a década de 1970. Esses indicadores mostram o comportamento da produção das indústrias em geral, extrativas e de transformação. O objetivo das pesquisas realizadas pelo IBGE é acompanhar a evolução da produção industrial no Brasil através deste índice. Os dados são coletados pelas suas agências locais através de visitas, entrevistas e questionários. Os resultados são enviados para uma agência única através de um sistema de informática próprio.

De posse desses dados, aplicou-se a técnica de análise de regressão linear simples com o intuito de verificar qual é a tendência do comportamento dos cenários econômicos de cada região do país.

\section{FUNDAMENTAÇÃO TEÓRICA}

\subsection{ANÁLISE DE REGRESSÃO}

A análise de regressão é uma técnica estatística para modelar e investigar a relação entre duas ou mais variáveis e pode ser usada para prever novas observações, otimizar processos ou para controlá-los. Para Gujarati (2000), Neter et al. (2005) e Soares (2010), a análise de regressão estuda a dependência da característica de interesse, em relação a uma ou mais variáveis, com o objetivo de estimar o valor médio da característica de interesse em função dos valores conhecidos das variáveis de controle. Montgomery e Runger (1999) afirmam que é classificado como modelo de regressão, o método de modelagem matemática que mostre como é a relação existente entre uma variável dependente contínua com variáveis independentes.

Quando consegue-se um modelo com uma variável independente linear, se classifica como regressão linear simples e se houver mais de uma, é caracterizado por modelo linear múltiplo (MONTGOMERY \& RUNGER, 1999). Esses modelos podem explicar relação entre fenômenos e quando avaliado com um determinado número de fatores é possível ter uma estimativa de futuros resultados (FIGUEIREDO; SARMENTO; SILVA, 2010).

O modelo de regressão linear simples (MRLS) é representado pela seguinte equação, segundo Montgomery e Runger (1999):

$$
y=\beta_{0}+\beta_{1} X_{i}+\varepsilon_{i}
$$

O termo $\varepsilon$ é chamado de erro aleatório, sendo assumido como normal e independentemente distribuído, com média zero e variância constante e desconhecida. Segundo Souza (2010), a equação 1 é dita simples, pois representa a relação entre uma característica de interesse e uma variável de controle. Além disso, a equação é linear nos parâmetros, uma vez que nenhum dos parâmetros aparece com expoente ou está sendo multiplicado ou dividido por outros parâmetros.

\subsection{TENDÊNCIA}

Segundo Tubino (2007), tendência é uma previsão baseada em séries temporais que parte do princípio de que a demanda futura será uma projeção dos valores passados. Dentre as técnicas para previsão da tendência existem duas mais importantes, quais sejam: a baseada na equação linear e a de ajustamento exponencial, sendo que esta última se baseia em dois fatores - a previsão da média exponencial móvel na demanda e uma estimativa exponencial da tendência. No caso deste trabalho, a ênfase será dada o modelo linear. 
Para o cálculo dos parêmtros da equação 1 e futura geração da equação linear, apresenta-

$$
\begin{aligned}
& \beta_{1}=\frac{n\left(\sum X Y\right)-\left(\sum X\right)\left(\sum Y\right)}{n\left(\sum X^{2}\right)-\left(\sum X\right)^{2}} \\
& \beta_{0}=\frac{\sum Y-\beta_{1}\left(\sum X\right)}{n}
\end{aligned}
$$

Onde:

$$
\begin{aligned}
& Y=\text { Previsão para o período } X ; \\
& B_{0}=\text { Ordenada à origem, ou } \\
& \text { intercepção no eixo dos } Y ; \\
& B_{1}=\text { Coeficiente angular; } \\
& X=\text { Período para previsão; } \\
& n=\text { número de períodos observados. }
\end{aligned}
$$

Utilizou-se dessas equações matemáticas para o cálculo dos parâmetros (coeficientes angulares e intercepto) para os dados dos indicadores da produção física regiona, conforme metodologia apresentada a seguir.

\section{METODOLOGIA}

Antes de apresentar o cenário estudado e a forma da coleta dos dados, faz-se necessário descrever o IBGE - Instituto Brasileiro de Geografia e Estatística que é a principal instituição provedora de informações do País.

Este instituto levanta dados dos mais diversos segmentos da sociedade civil, bem como dos órgãos das esferas governamentais, sejam elas federal, estadual ou municipal. O IBGE traz a público uma visão mais completa do país e este artigo se utiliza de uma das suas funções principais que é a produção e análise de informações estatísticas publicadas no documento da Pesquisa Industrial Mensal da Produção Física Regional do Brasil.

Os indicadores regionais são pesquisas realizadas pelo IBGE que utilizam dados primários da Pesquisa Industrial Mensal de Produção Física (PIM-PF). Essa pesquisa utiliza uma amostra intencional, a partir das informações da Pesquisa Industrial Anual de Empresas e da Pesquisa Industrial Anual de Produto iniciada no ano de 2010. Este artigo pretende utilizar esses dados para gerar modelos de regressão lineares a fim de analisar o comportamento da economia das regiões do Brasil em um determinado período, para fazer um comparativo com a realidade de cada uma delas. O presente trabalho usa de associações com a crise que gerou uma mudança no mercado de trabalho e faz uma reflexão da recessão da economia brasileira e de políticas de ajustes econômicas. Dessa forma, constata-se o grau de intensidade de compreensão atual com o difícil momento vividos pelo país (POCHMANN, 2015).

\subsection{CENÁRIO ESTUDADO}

Foram escolhidos para o desenvolvimento deste trabalho os dados sobre os Indicadores da Produção Industrial, segundo a divisão regional por estado da indústria geral do Brasil, nos quatro trimestres dos anos de 2013, 2014 e 2015. Os dados representam um procedimento de cálculo de índices, baseado no método de Laspeyres. Esses cálculos têm como base a razão entre o valor da produção no período t e o mesmo valor no período 0 (zero), que serve de base ao índice, ambos valorados aos preços do período-base e é apresentado na equação 4. 


$$
L_{0, t}=\frac{\sum_{i=1}^{n} p_{i 0} p q_{i t}}{\sum_{i=1}^{n} p_{i 0} p q_{i 0}}
$$

Onde:

$P_{\text {io }}$ é o preço do produto i no período 0;

qio é a quantidade do produto i no período 0; e

qit é a quantidade do produto i no período t.

\subsection{COLETA DE DADOS}

Segundo o IBGE, os valores de produção foram coletados a partir de questionários aplicados em empresas de grande representatividade de cada estado brasileiro. O estudo de análise de regressão foi realizado desmembrando os dados que estavam apresentados anualmente, para que eles pudessem ser observados de forma mensal. Os estados disponíveis eram Amazonas, Pará, Minas Gerais, Espirito Santo, Rio de Janeiro, São Paulo, Paraná, Santa
Catarina, Rio Grande do Sul, Mato Grosso e Goiás além da Região Nordeste. Nesta proposta, uniu-se os estados por região e calculou-se a média dos mesmos, sendo os estados de Goiás e Mato Grosso representando o centro oeste e os estados do Amazonas e Pará representando o Norte.

\section{RESULTADOS E DISCUSSÕES}

Diante dos dados e também da análide da conjuntura econômica mediante os efeitos do ajuste fiscal implementado pelo governo da época, especialmente sobre o mercado de representação industrial do Brasil, gerou-se os gráficos e os parâmetros apresentados a seguir.

Iniciou-se os estudos pela região sul, cujos resultados são apresentados no Gráfico 1.

Gráfico 1 - Pesquisa Industrial Mensal da Região Sul.

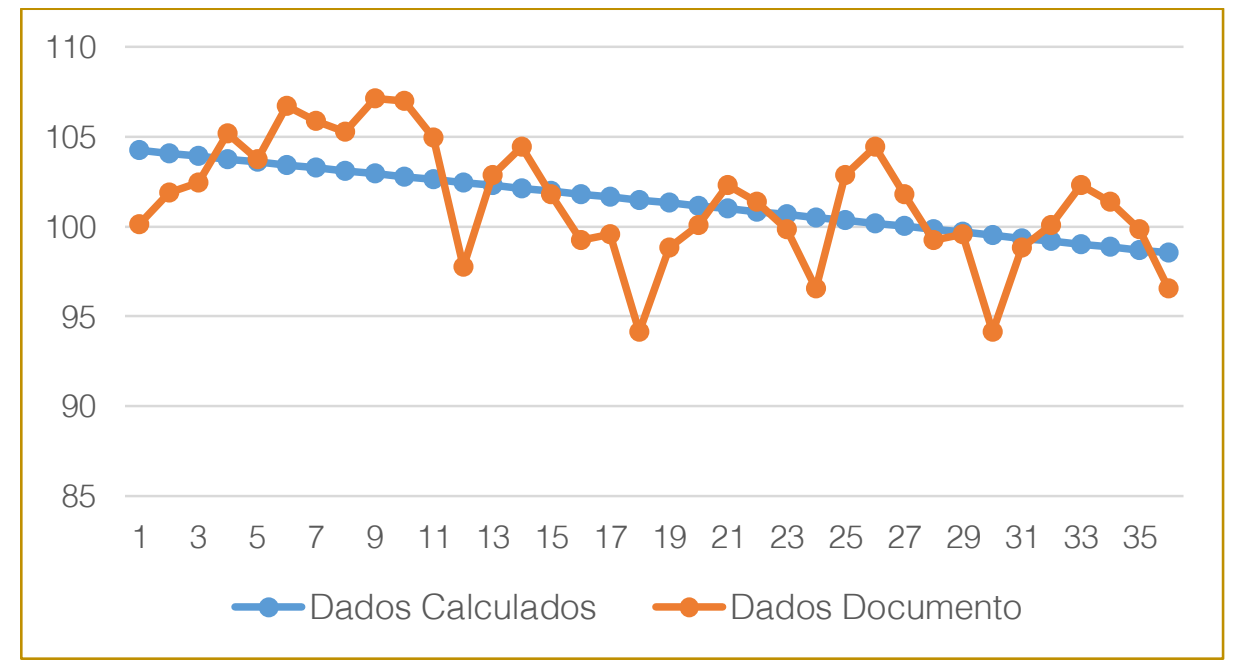

Fonte: Pesquisa Industrial Mensal Produção Física Regional (2016).

Mattei(2011) afirma que a industria da região sul estava em período de alanvancagem e desenvolvimento distribuído pela maior parte do estado, com excessão da região Oeste, no qual a predominância da indústria agroalimentar. Também o autor citado acima vê a necessidade de discutir o comportamento dos principais indicadores macroeconômicos, pois o estado de Santa Catarina, por exemplo, chegou a apresentar 
taxas de crescimento superiores às taxas do país. Mas este estado de grande relevância para a economia tem graves problemas com o quadro de desigualdades regionais que historicamente conforma a geografia nacional. Um dos fatores do grande declínio da produção física da região sul mostrado no Gráfico 1, que apresenta uma reta de coeficiente angular de -0.1629 e termo independente de 104.41, foi o fato da região ser relevantemente industrializada e esses setores em questão foram muito impactados pela crise financeira e política do Brasil.

Ao contrário da região sul, a região norte apresentou crescimento, conforme aponta o Gráfico 2.

Grafico 2 - Pesquisa Industrial Mensal da Região Norte.

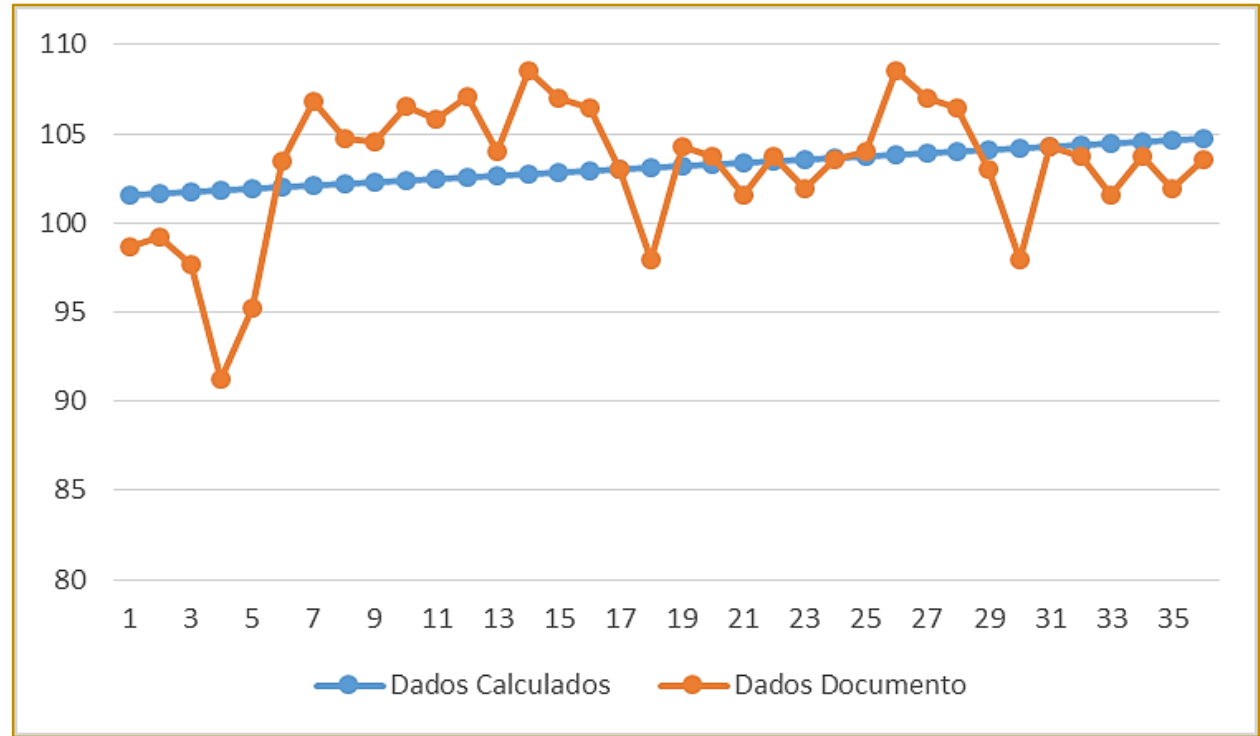

Fonte: Pesquisa Industrial Mensal Produção Física Regional (2016).

Desde o descobrimento do Brasil a amazônica se ancora em uma economia baseada na produção de commodities. Os setores de pecuária, agronegócio, energia, minérios e produtos da floresta são produtos de destaque na estratégia de sobrevivência de setores privados e públicos da Amazônia brasileira. Outros produtos como a carne, soja, alumínio, madeira e borracha e outros produtos em estado bruto, com grau de industrialização pequeno também faz parte da produção dessa região (BARATA, 2017). Com a realidade dos últimos anos, as necessidades básicas tiveram uma maior valorização na mesa do consumidor, o que pode justificar o Gráfico 2, sobre crescimento da região norte, onde a linha azul se refere ao cálculo da equação de regressão linear com coeficiente angular de 0.090148 e o termo independente de 101.0614.

No que tange a região nordeste, nota-se que houve estabililade no período analisado, como pode ser observado no Gráfico 3. 
Gráfico 3 -Pesquisa Industrial Mensal do Nordeste.

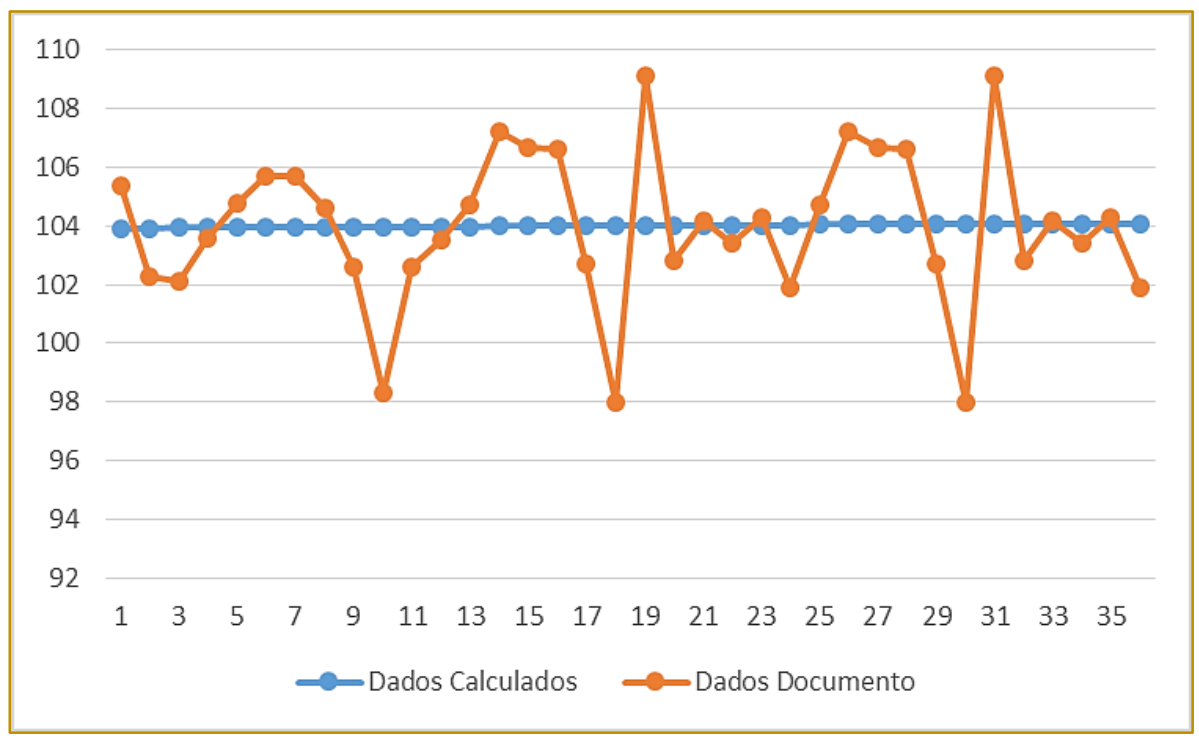

Fonte: Pesquisa Industrial Mensal Produção Física Regional (2016).

Pereira e Taques (2014) relatam que é histórico o baixo desenvolvimento econômico da região Nordeste, em detrimento do clima e de tentativas frustradas de programas governamentais. Mas nos últimos anos foi elevado os números de contratos de microcréditos, no qual revelaram aumento no desempenho da região. Houve também uma redução da taxa de desemprego, desigualdade e de pessoas abaixo da linha da pobreza e, consequentemente um aumento dos salários médios, emprego e do Produto Interno Bruto - PIB da região. Muitas indústrias viram nisso uma oportunidade para seus negócios e se instalaram nas regiões metropolitanas das capitais nordestinas.
Porém, essa estabilidade na produção nesta região pode ser em parte explicada pelo aumento do vigor econômico do nordeste, que não foi tão impactado pelos cortes realizados pelo governo, como seria em tempos anteriores. A produção industrial, conforme a linha azul do Gráfico 3, que se refere ao cálculo da equação de regressão linear, evidencia esta estabilidade, ao mostrar um coeficiente angular de 0.004890 e termo independente de 103.9206.

O Centro Oeste apresentou um expresivo crescimento no período, apesar de ser perceptível pelo Gráfico 4 uma certa oscilação.

Grafico 4 - Pesquisa Indústrial Mensal do Centro Oeste.

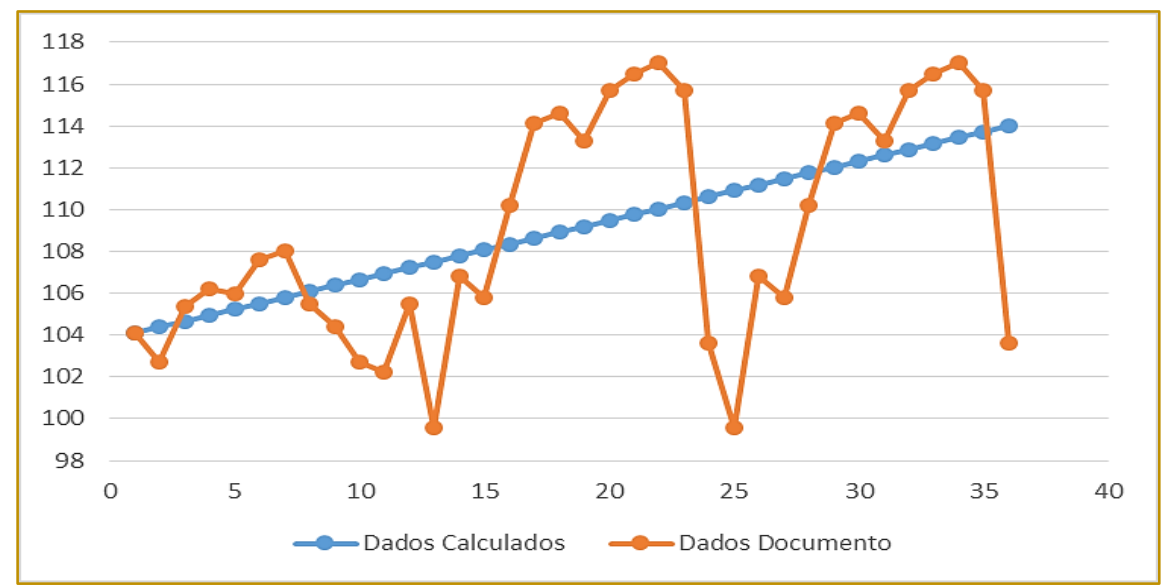

Fonte: Pesquisa Industrial Mensal Produção Física Regional (2016). 
Os estados de Goiás e Mato Grosso têm uma grande representação no desenvolvimento agrícola da região Centro Oeste. Desde a década de 90 houve grandes mudanças na política agrícola que refletiram no desenvolvimento da região, principalmente através de um processo intensivo de modernização da agricultura se destacando como produtor de grãos para o mercado interno e externo (BEZERRA, 2004). Conforme a linha azul do Gráfico 4, que se refere ao cálculo da equação de regressão linear com coeficiente angular de 0.2830 e termo independente de 103.822, evidencia-se como - setor coerentemente com a situação brasileira obteve uma expansão de sua produção física.

Por fim, chega-se à região Sudeste, bastante afetada pela crise, como corrobora o Gráfico 5.

Grafico 5 - Pesquisa Industrial Mensal do Suldeste.

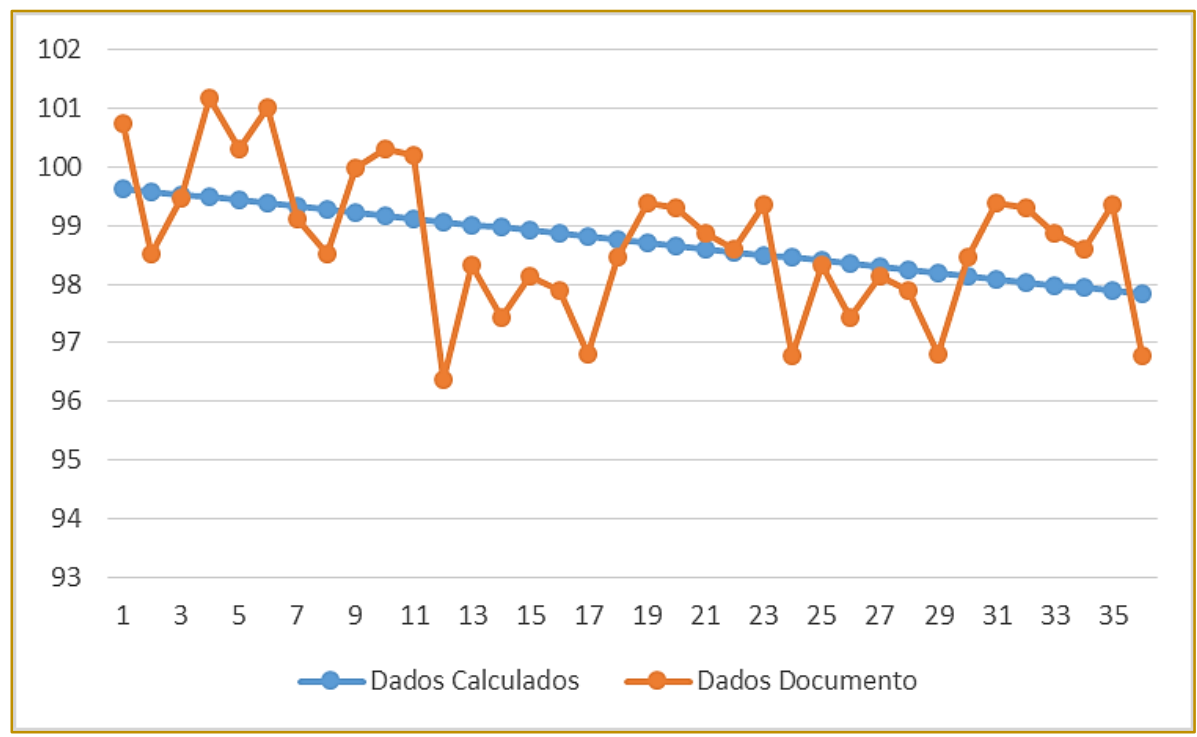

Fonte: Pesquisa Industrial Mensal Produção Física Regional (2016)

Comparando as análises feitas pelo o IBGE e outros autores da literatura, consegue-se confirmar uma maior concentração econômica no Sudeste, sendo considerada a região mais rica do país. Apesar que, nas últimas décadas, mais especificamente a partir dos anos 1970, houve esforços, principalmente do governo federal, com o objetivo de desenvolver as demais regiões (CASALI, 2010). Logo, como reflexo da crise atual vivida pelo Brasil, é confirmada a tendência com a linha azul do Gráfico 5, que se refere ao cálculo da equação de regressão linear com coeficiente angular negativo de 0.05161 e termo independente de 99.69012. No entanto, o valor não é tão grande, o que demonstra certa resiliência da economia da região sudeste.

\section{CONCLUSÃO}

Com o avanço dos processos da manufatura presenciado nos últimos anos, foram desenvolvidas diversas técnicas para tentar prever situações e evitar surpresas. Ou seja, trabalhar com metodologias capazes de realizar previsões quantitativas tornou-se uma questão de sobrevivência para as organizações. Sob este contexto, este trabalho relatou sobre a aplicação da regressão linear simples, com o objetivo de compreender qual é o sentido de crescimento ou decaimento da economia por regiões brasileiras. A proposta principal do artigo foi apresentar alguns dados de uma pesquisa de campo realizada pelo IBGE em determinados estados a fim de facilitar a estratégia de investimento em alguns setores e foi possível constatar que, neste momento de crise, os investimentos menos sensíveis são os relacionados à agricultura.

A utilização de cálculos de regressão linear simples permitiu verificar a tendência dos cenários econômicos de cada região do país. Foi constatado que as regiões Sul e Sudeste apresentaram uma tendência de decaimento 
do seu setor de produção física. Assim como a região Nordeste, que pelas análises concluiu que a região irá ter uma tendência a crescer de forma muito pequena, muito próxima da estabilidade. As regiões Norte e Centro Oeste mostraram um comportamento otimista, crescendo de uma forma considerável.

Form utilizado dados de 2013 até 2015 do IBGE, além de considerações de levantamento bibliográficos sobre

\section{REFERÊNCIAS}

[1]. BARATA, Lauro E. S.. A economia verde: Amazônia. Cienc. Cult., São Paulo, v. 64, n. 3, 2012 Available from $<$ http://cienciaecultura.bvs.br/scielo.php?script=sci _arttext\&pid=S0009-

67252012000300011\&lng=en\&nrm=iso $>$. access on 13 Jan. 2017

[2]. BEZERRA, Luiza Maria Capanema. O desenvolvimento agrícola da região centro-oeste e as transformações no espaço agrário do estado de Goiás. Revista Caminhos de Geografia, Uberlândia, jun. 2004. Disponível em: <http://www.seer.ufu.br/index.php/caminhosdegeo grafia/article/view/15339/8638>. Acesso em: 13 jan. 2016.

[3]. CASALI, Giovana F. Rossi; SILVA, Orlando Monteiro da; CARVALHO, Fátima M. A.. Sistema regional de inovação: estudo das regiões brasileiras. Rev. econ. contemp., Rio de Janeiro , v. 14, n. 3, p. 515-550, Dec. 2010. Available from

$<$ http://www.scielo.br/scielo.php?script=sci_arttext \&pid=S1415

$98482010000300004 \& \operatorname{lng}=e n \& n r m=i s o>. \quad$ access on $13 \quad$ Jan. 2017.

http://dx.doi.org/10.1590/S141598482010000300004.

[4]. FIGUEIREDO, Ciro Jose Jardim de; SARMENTO, Breno Carvalheiros; SILVA, Milton Helio Lima da. Regressão múltipla aplicada em um processo de destilação por arraste a vapor de óleo essencial de piper aduncum L. In: ENCONTRO NACIONAL DE ENGENHARIA DE PRODUÇÃO,2010, São Carlos: XXX Enegep, 2010. p. 2 - 9

http://www.ibge.gov.br/home/disseminacao/evento s/missao/default.shtm. Acesso: 13 de Jan. de 2017 característica das regiões do Brasil. A ferramenta apontou uma coerência das equações com a realidade atual da economia. Ficou evidente também, através dos parâmetros calculados, a difícil situação econômica do Brasil.

Por fim, sugere-se para estudos futuros, o acompanhamento das equações aqui calculadas, a fim de verificar se estão mantendo a tendência de produção física.

[5]. MACHLINE, Claude. Planejamento e controle de produção na indústria nacional de bens de equipamento. Rev. adm. empres., São Paulo , v. 25, n. 2, p. 5-28, June 1985.

[6]. MATTEI, Lauro. Economia catarinense: crescimento com desigualdades regionais. In:V ENCONTRO DE ECONOMIA CATARINENSE, 2011, Florianópolis. Universidade Comunitária Regional de Chapecó, 2011. Disponível em: <http://www.apec.unesc.net/V_EEC/sessoes_temati cas/Desenvolvimento e meio ambiente/ECONOMIA CATARINENSE CRESCIMENTO COM DESIGUALDADES REGIONAIS.pdf>. Acesso em: 13 jan. 2016.

[7]. MONTGOMERY, D. C.; RUNGER, G. C. Applied Statistics and Probability for Engineers 2 ed. New York: John Wiley \& Sons, 1999.

[8]. PEREIRA, Leandro dos Santos; TAQUES, Fernando Henrique. O desenvolvimento econômico na região nordeste do brasil sob a ótica das microfinanças. in: iv semana do economista e iv encontro de egressos, 2014, Ilhéus. 2014. p. 1 - 9.

[9]. POCHMANN, MARCIO. Ajuste econômico e desemprego recente no Brasil metropolitano. Estud. av., São Paulo, v. 29, n. 85, p. 7-19, Dec. 2015. Available from

$<$ http://www.scielo.br/scielo.php?script=sci_arttext \&pid=S0103-

$40142015000300002 \& \operatorname{lng}=e n \& n r m=i s o>$. access on 14 Jan. 2017.

http://dx.doi.org/10.1590/S010340142015008500002

[10]. SOARES, Joyce Dória Rodrigues. Modelagem matemática na previsão de colheita de bananeira: regressão linear múltipla $x$ redes neurais artificiais. Lavras: UFLA, 2010. 


\section{Bapítulo 6}

\section{DIAGNÓSTICO DO SETOR DE MANUTENÇÃO DE UMA INDUSTRIA METALURGICA DA CIDADE DE CAMPINA GRANDE - PB}

\section{Danielle Freitas Santos}

Emerson Santos Aguiar

Resumo: A manutenção consiste em uma premissa de gestão cuja função é viabilizar meios para prevenir, corrigir ou renovar determinado equipamento ou maquinário, objetivando evitar falhas, atentando-se as condições das instalações físicas e equipamentos. As ações de manutenção são essenciais para o segmento industrial, que depende da efetividade deste setor para dar continuidade as suas atividades fabris com excelência. Nesse sentido, a pesquisa admite como objetivo diagnosticar o setor de manutenção de uma indústria metalúrgica da cidade de Campina Grande - PB, evidenciando suas principais atividades de gestão da manutenção. O estudo ainda viabiliza a proposição de alguns pontos de melhoria em relação às ações de manutenção. Para tanto, assumiu-se a pesquisa como exploratório-descritiva, de caráter qualitativo. Os dados obtidos foram coletados por meio de observações in loco, entrevistas com os gestores e a base de arquivos e relatórios da empresa. Mediante isso, pôde-se verificar que o setor de manutenção em estudo admite características tradicionais, baseando sua atuação em intervenções corretivas. Porém, ações de manutenção preventiva começaram a ser implementadas como forma de desenvolver um parâmetro preventivo que auxilie o planejamento da manutenção. O plano de manutenção preventiva anual foi colocado em prática, apesar de sua efetividade não ocorrer em totalidade. Ações relativas à adequação a norma NR12 também foram consolidadas como forma de desenvolver um ambiente de trabalho mais seguro e eficaz. Portanto, o setor de manutenção da empresa encontra-se em processo de transição de uma abordagem tradicional e dispendiosa para um escopo moderno baseado em planejamento e gestão participativa, onde a manutenção auxilia a produção, de modo a promover uma maior produtividade e resultados mais significativos.

Palavras-chave: Diagnóstico de manutenção; Indústria metalúrgica. 


\section{INTRODUÇÃO}

A alta competitividade, um ambiente que exige flexibilidade às mudanças tecnológicas e de gestão e a busca por resultados positivos rápidos, caracterizam a indústria moderna brasileira. Para adequar-se a esse cenário é importante adotar práticas de gestão que viabilizem a condução das operações de modo eficiente e que integre as principais áreas da empresa. Dentro desse contexto dinâmico, o setor de manutenção consiste em um ponto crucial no âmbito industrial, uma vez que o funcionamento adequado e eficiente dos equipamentos e do maquinário depende da eficácia e da capacidade de resposta da manutenção às ocorrências, sejam estas associadas a quebras, reparos ou serviços de lubrificação.

Segundo Cabral (1998), a manutenção pode ser determinada como o conjunto de ações que visam assegurar o funcionamento adequado das máquinas e instalações, de modo que haja intervenções rápidas e corretas, no intuito de evitar avarias ou baixo rendimento. Envolve conservação, adequação, substituição e prevenção, com a finalidade de garantir a disponibilidade e a confiabilidade do maquinário.

A manutenção, como função estratégica das organizações é responsável direta pela disponibilidade dos ativos, e tem importância capital nos resultados da empresa (OTANI E MACHADO, 2008). Além disso, deve estar associada a aspectos organizacionais como qualidade, segurança, custo de reparação, disponibilidade e confiabilidade, evidenciando a necessidade de um gerenciamento integrado com demais setores fabris, de forma a garantir um desempenho excelente em termos de adequação dos serviços de manutenção, capacidade de resposta às ocorrências e eficiência do setor.

Dessa forma, a partir da relevância da temática abordada, a pesquisa objetiva a elaboração de um diagnóstico do setor de manutenção de uma indústria metalúrgica da cidade de Campina Grande - PB, evidenciando os principais aspectos em relação à gestão da manutenção e propondo pontos de eventuais melhorias na condução das atividades. Os dados foram obtidos mediante visitas in loco, entrevistas com os gestores e revisão do acervo documental da empresa, viabilizando a análise do setor de manutenção, suas operações e abrangência. A partir disso, foi possível identificar eventuais práticas de gestão associadas à manutenção, bem como foram propostas sugestões de melhorias no setor como forma de auxiliar um gerenciamento mais eficiente.

\section{REFERENCIAL TEÓRICO}

O contexto contemporâneo no qual as empresas encontram-se inseridas exige alta competitividade e isso implica na busca pela otimização da produtividade. Nesse âmbito, o papel do maquinário admite relevância fundamental, pois sua operacionalização eficaz irá determinar uma produção mais eficiente. Logo, a manutenção surge como função crucial no desempenho das linhas de produção.

Segundo Monchy (1989), a manutenção consiste em escolher os meios para prevenir, corrigir ou renovar, de acordo com a utilização do material e do que seja economicamente crítico, visando otimizar o custo total de propriedade. Slack et al. (2009) afirmam que a manutenção compreende ao termo usado para a forma como as empresas tentam evitar falhas cuidando de suas instalações físicas e equipamentos, dessa forma, a manutenção é vista como um conjunto de técnicas que objetivam a otimização da produção.

Hoje, a manutenção precisou adaptar-se as mudanças de mercado e gestão e ampliar seu escopo de atuação. De acordo com Pinto e Xavier (2001), a manutenção deve garantir a disponibilidade das funções dos equipamentos e instalações visando atender as exigências de produção, objetivando aspectos como confiabilidade, segurança, custos e meio ambiente. O objetivo da manutenção moderna consiste em manter não apenas o bom estado do equipamento, mas a sua funcionabilidade. Dessa forma, a manutenção assume uma importância estratégica na estrutura das empresas com reflexos diretos ao nível de operação e logística (BRISTOT ET. AL, 2012).

Existem diversas terminologias para os tipos de manutenção existentes, de acordo com Furmann (2002), grande parte destas se baseia na forma temporal de atuação, seja mediante previsão ou falha funcional do maquinário. A forma como a intervenção é executada irá determinar as características dos tipos de manutenção. Dessa forma, os tipos de manutenção mais conhecidos são os seguintes: 
- Manutenção corretiva;

- Manutenção preventiva;

- Manutenção preditiva.

Cada tipo de manutenção irá se adequar ao planejamento realizado, as necessidades de manutenção da empresa, a disponibilidade de mão-de-obra qualificada e de recursos adequados à execução dos serviços de manutenção. A seguir estão dispostas as principais peculiaridades sobre cada tipo de manutenção.

\subsection{MANUTENÇÃO CORRETIVA}

A manutenção corretiva é aquela realizada após a falha do equipamento, visando recompor suas funções requeridas (FURMANN, 2002). De acordo com a AFNOR (2016), a manutenção corretiva consiste na operação de manutenção efetivada após a ocorrência da falha, visa à atuação para a correção de uma falha no equipamento ou no seu desempenho. Exige a observância de duas condições: (i) a ocorrência efetiva da falha; e (ii) a observação de um desempenho abaixo do esperado.

Kach e Felden (2011) afirmam que a manutenção corretiva acontece apenas quando há a incidência de uma parada na produção oriunda de uma falha ou quebra de equipamento, afetando diretamente a produção por interrupções que podem levar horas ou até mesmo dias, a depender do nível de criticidade da falha, da capacidade de resposta da manutenção e da disponibilidade de peças e materiais de reposição.

Segundo O'Connor (2005), inclui todas as ações necessárias para levar um sistema de um estado de falha para um estado operacional ou disponível. Dessa forma, a manutenção corretiva é bastante onerosa do ponto de vista econômico, em virtude da interrupção da produção e de impactos no lucro. Para as indústrias modernas, tal manutenção não é a mais adequada, pois não possibilita segurança para o cumprimento de prazos em um plano de produção (BELMONTE E SCANDELARI, 2005).

\subsection{MANUTENÇÃO PREVENTIVA}

A manutenção preventiva é a atuação realizada de forma a reduzir ou evitar a ocorrência de falhas ou redução no desempenho de determinado equipamento, obedecendo a um plano preventivo, baseado em intervalos de tempo definidos (PINTO E XAVIER, 2001). A norma NBR 5462 (ABNT, 1994) caracteriza manutenção preventiva como aquela que é efetuada em intervalos de tempo pré-determinados ou mediante critérios bem definidos, visando reduzir a probabilidade de falhas ou a degradação do desempenho de um item específico.

Não se espera a ocorrência da falha para que a intervenção seja efetivada. Há um planejamento que indique a necessidade de realização da intervenção no equipamento como forma de evitar uma redução no desempenho do maquinário e até mesmo uma possível parada da linha de produção. A manutenção preventiva influencia diretamente na confiabilidade (REIS ET AL., 2013), e agrega maior segurança à operacionalização do maquinário.

Segundo Xavier (2003), o sucesso da efetividade de um plano de manutenção preventiva consiste no fato da correta determinação dos intervalos de tempo das intervenções, visando reduzir períodos de tempo inferiores ao necessário, e assim o uso desnecessário de peças de reposição e de paradas não desejadas. Esse tipo de manutenção admite como fundamentos principais: a maximização da confiabilidade e disponibilidade do equipamento, a ampliação do ciclo de vida do maquinário, melhorias evidentes na condução dos trabalhos de manutenção, melhoria no gerenciamento de estoques, reduz improvisos e incrementa a segurança na realização das atividades.

\subsection{MANUTENÇÃO PREDITIVA}

A manutenção preditiva também é conhecida como manutenção de condição ou com base no estado do equipamento. Segundo Chiochetta et al. (2004), a manutenção preditiva consiste em um conjunto de atividades de acompanhamento das variáveis ou parâmetros que indicam a performance ou desempenho do maquinário, de forma sistemática, possibilitando a identificação da real necessidade de intervenção.

A norma NBR 5462 (ABNT, 1994) conceitua a manutenção preditiva como aquela que permite garantir uma qualidade do serviço de serviço desejada, com base na aplicação sistemática de técnicas de análise do sistema de manutenção, utilizando-se de meios de supervisão central ou de amostragem, 
visando reduzir as intervenções de manutenção preventiva e corretiva.

Mirshawka (1991) assinala como principais benefícios deste tipo de manutenção: a previsão de falhas com antecedência suficiente para que os equipamentos sejam desativados em segurança, reduzindo riscos de acidentes e interrupções do sistema produtivo; a redução dos prazos e custos de manutenção pela informação antecipada das falhas a serem reparadas; e a melhoria nas condições de operação dos equipamentos visando obter menor desgaste e maior rendimento e produtividade.

A utilização desta técnica de manutenção preditiva é a grande quebra de paradigma nos tipos de manutenção (BRISTOT ET. AL, 2012). Essa categoria de manutenção visa à consolidação de estratégias de manutenção, onde realizam-se análises e acompanhamento do desempenho do maquinário, mediante as especificações do fabricante e os relatórios ou modelos de performance já implementados. Além disso, possibilita um menor custo em comparação com os demais tipos de manutenção, por se tratar de uma abordagem fundamentada no planejamento e na predileção das ocorrências.

\section{ASPECTOS METODOLÓGICOS}

\subsection{CARACTERIZAÇÃO DA PESQUISA}

O referido estudo admite como metodologia a pesquisa do tipo exploratório-descritiva. Em relação ao tipo de abordagem, classifica-se como qualitativa, uma vez que não admite tabulação de dados. A pesquisa ainda abrange caráter documental e se caracteriza como uma pesquisa de campo. No que concerne aos procedimentos, estabeleceu-se um estudo de caso sobre o setor de manutenção de uma indústria metalúrgica da cidade de Campina Grande - PB. Para tanto, utilizou-se como instrumento de coleta de dados, observações in loco, entrevistas com os gestores e a base de arquivos e relatórios da empresa.

\subsection{A EMPRESA}

A indústria avaliada atua no mercado nacional há mais de 50 anos, produzindo bens relacionados ao mercado da construção civil. Possui um portfólio em torno de 1.500 itens, entre: fechaduras, dobradiças, ferrolhos, telhas em perfis metálicos, trancas e cadeados. Admite uma área construída de cerca de $25.000 \mathrm{~m}^{2}$, contando com equipamentos de alta tecnologia e um centro de distribuição moderno. Emprega 402 funcionários, dentre funcionários efetivos, estagiários, aprendizes e pessoal da diretoria.

O sistema produtivo abrange os seguintes setores: perfil, polimento, cromagem, produção, pintura, montagem automática de dobradiças, montagem automática de fechaduras, zincagem, injetoras, verniz, montagem e embalagem, encartelado, estamparia, parafusos, cilindros, corte, relaminação, desengraxamento, clear-clad, fabricação de caixas, ETE (estação de tratamento de esgotos) e atividades terceirizadas. Há ainda os centros de custo de apoio ao sistema de produção, que envolvem: PCP, compras, manutenção, almoxarifado, gerência de projeto, expedição e embarque. A Figura 1 apresenta o fluxo do sistema produtivo da empresa. 
Figura 1 - Fluxograma do Sistema Produtivo da Empresa

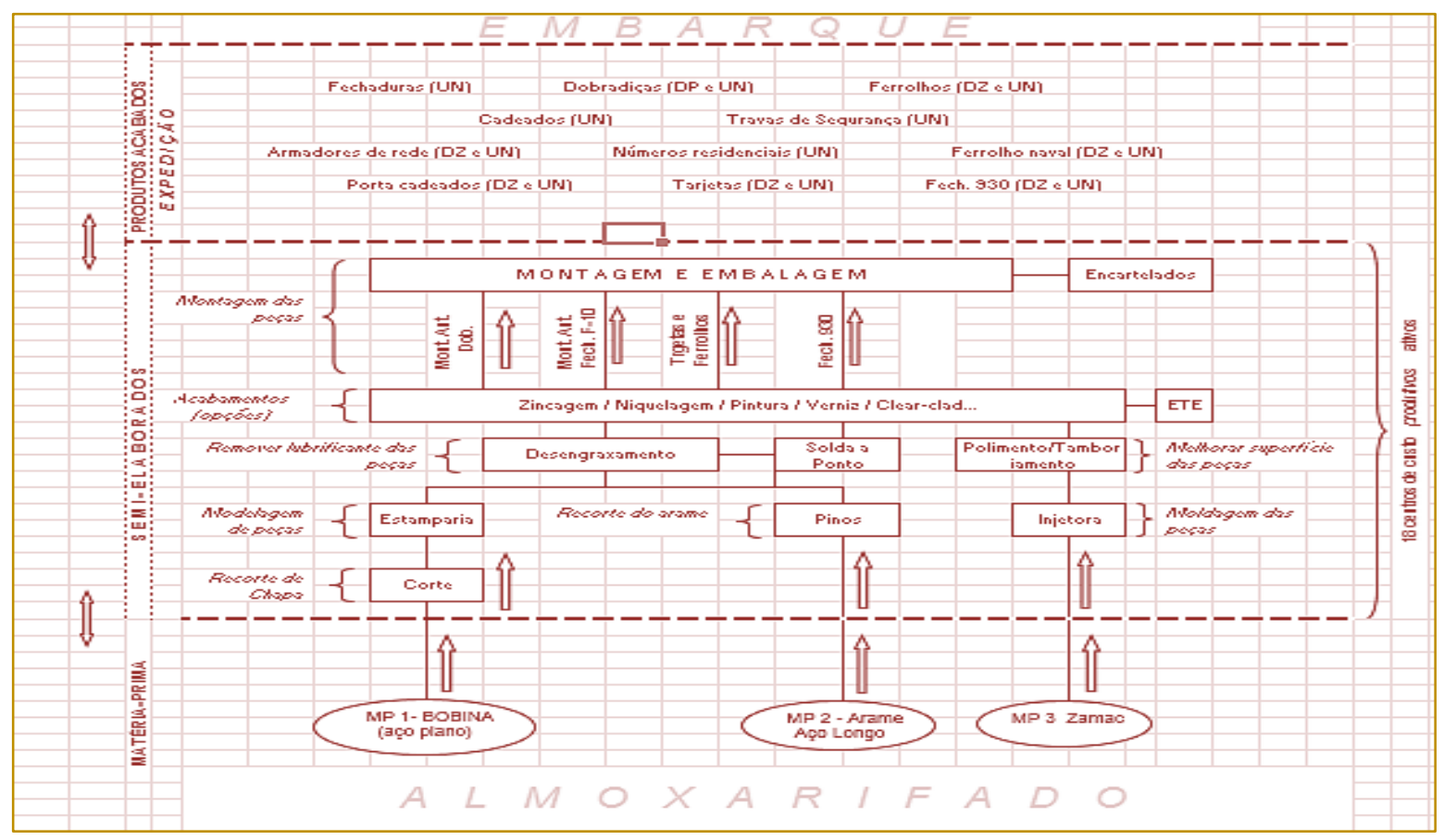

Fonte: Arquivo da Empresa (2017)

\section{DIAGNÓSTICO DO SETOR DE MANUTENÇÃO}

\subsection{O SETOR DE MANUTENÇÃO}

O setor de manutenção da empresa consiste no segmento de apoio principal ao processo produtivo. Disponibiliza as atividades de melhoria de maquinário, construção de peças, ações corretivas frequentes de todos os equipamentos e máquinas da empresa e ainda executa os planos de manutenção preventiva anual e trimestrais. Os principais serviços de manutenção realizados pelo setor são: reparos e substituição de peças, manutenção das instalações elétricas prediais e de maquinário, reaperto de estruturas, contenção de vazamentos de óleo e/ou ar, operações de lubrificação, entre outros. Apenas quando os serviços estão fora da capacidade da manutenção é que são acionadas empresas terceirizadas.

As áreas que admitem uma maior demanda pelos serviços da manutenção são a zincagem, que compreende a um ambiente de extremo cuidado por abranger a manipulação direta de produtos químicos, fato que implica na aceleração do processo de corrosão das peças e materiais; e a estamparia por ser o setor de maior abrangência da fábrica, responsável pela fabricação de grande parcela das peças e que detém a maior quantidade de maquinário, a maioria com tempo de vida útil de mais de 20 anos.

São realizadas as preventivas trimestrais com média de quatro máquinas por trimestre. Essas intervenções costumam não afetar a produtividade do maquinário, porém demandam um relativo tempo de horas de execução, fato que pode reter a mão-de-obra já escassa. Cabe ao setor ainda a efetivação do plano de manutenção preventiva anual. $\mathrm{O}$ planejamento é executado por todo o pessoal da manutenção durante um período de 15 dias, onde a produção é totalmente paralisada.

O setor ainda agrega nove mecânicos fabris, dois eletricistas, dois mecânicos civis, cinco aprendizes, além de duas estagiárias que atuam como intermediárias entre o setor de manutenção e os demais setores fabris. A média de ordens de serviço atendidas chega a 250 por mês, atendendo a um total médio de horas em execução de 950 horas.

\subsection{GERENCIAMENTO DA MANUTENÇÃO}

A empresa já detinha algumas práticas relacionadas à gestão da manutenção. O conceito de manutenção corretiva é à base da maioria das ações ligadas a esse âmbito, 
porém há um planejamento trimestral e anual de manutenção preventiva, onde as máquinas consideradas críticas são submetidas a essa revisão. A determinação desse fator de criticidade é fundamentada na análise dos supervisores, do gerente de manutenção e da diretoria industrial, que através de estatísticas provenientes dos relatórios de máquinas e da experiência com a rotina de manutenção, estipulam quais serão as máquinas que exigem maior atenção nesse plano.

Não foi observado o uso efetivo de alguma metodologia ou ferramenta específica de gestão da manutenção. As ações de planejamento são baseadas nos relatórios e na identificação das necessidades do maquinário fabril por parte dos gestores, não havendo nenhum suporte teórico no gerenciamento dos serviços de manutenção. O controle das atividades de manutenção ocorre por intermédio dos relatórios de manutenção com periodicidade mensal. Tais relatórios envolvem aspectos como: quantidade de ordens de serviço, tempo de execução das atividades, ordens de serviços críticas, horas paradas por maquinário, mensuração de intervenções corretivas, preventivas e de melhoria e as horas trabalhadas pelos operadores.

Outra atividade relevante para a manutenção corresponde à interface com o setor de compras, de forma a viabilizar a aquisição e reposição de peças e materiais imprescindíveis ao setor. O setor utiliza o software Data Sul EMS® (Figura 2), para a efetivação das solicitações de compra. O referido sistema agrega ações de manufatura, distribuição, controle de estoque, compras, finanças, contabilidade e departamento fiscal, possibilitando uma interface simples, porém interativa e abrangente, auxiliando no processo de gestão da manutenção e da empresa como um todo.

Figura 2 - Interface do Sistema DataSul EMC®

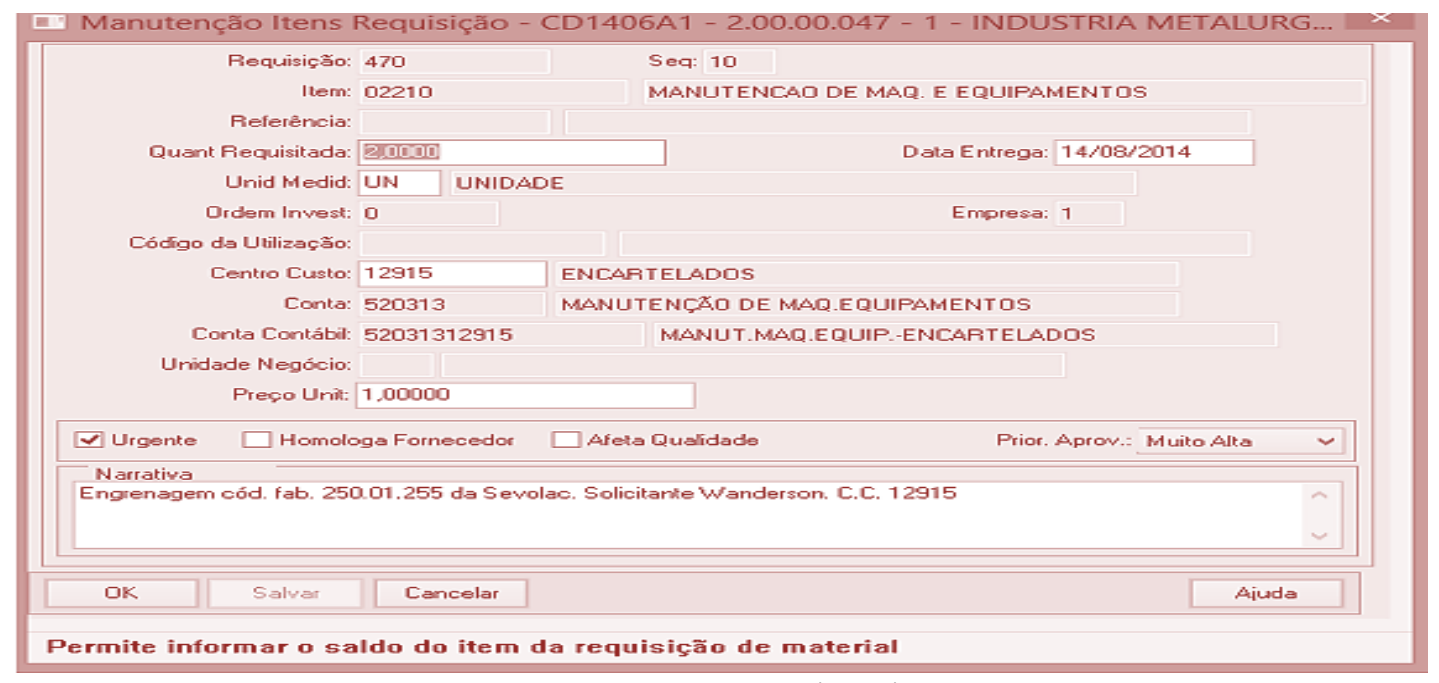

Fonte: Arquivo da Empresa (2017).

A elaboração do planejamento de manutenção preventiva foi um ponto de destaque observado na rotina do setor. Tendo em vista a complexidade do processo de produção e o fato de alguns itens exigirem um ciclo de produção mais longo, foi necessário incluir uma quantidade significativa de máquinas neste plano de ação, apesar do tempo exigido para execução ser bastante limitado. A programação da manutenção preventiva admite a duração de um mês entre as visitas aos setores, o reconhecimento das necessidades de maquinário, o planejamento de horas dos executantes, as necessidades de compras adicionais, as reuniões entre os responsáveis do setor e a efetivação do plano de manutenção preventiva propriamente dito.

O maquinário envolvido no plano de manutenção preventiva envolveu um total de 18 máquinas, entre pontes rolantes, linhas da zincagem e cromagem, injetoras, máquinas de montagem de fechaduras, polidoras, máquinas de montagem de dobradiças e retificas. Apesar da utilização de toda mãode-obra disponível na execução da preventiva, não foi possível concluir todo o 
planejamento no período estabelecido. As máquinas que não puderam ser revisadas neste período foram realocadas para as atividades de intervenção mecânica rotineiras da empresa.

Figura 3 - Plano de Manutenção Preventiva

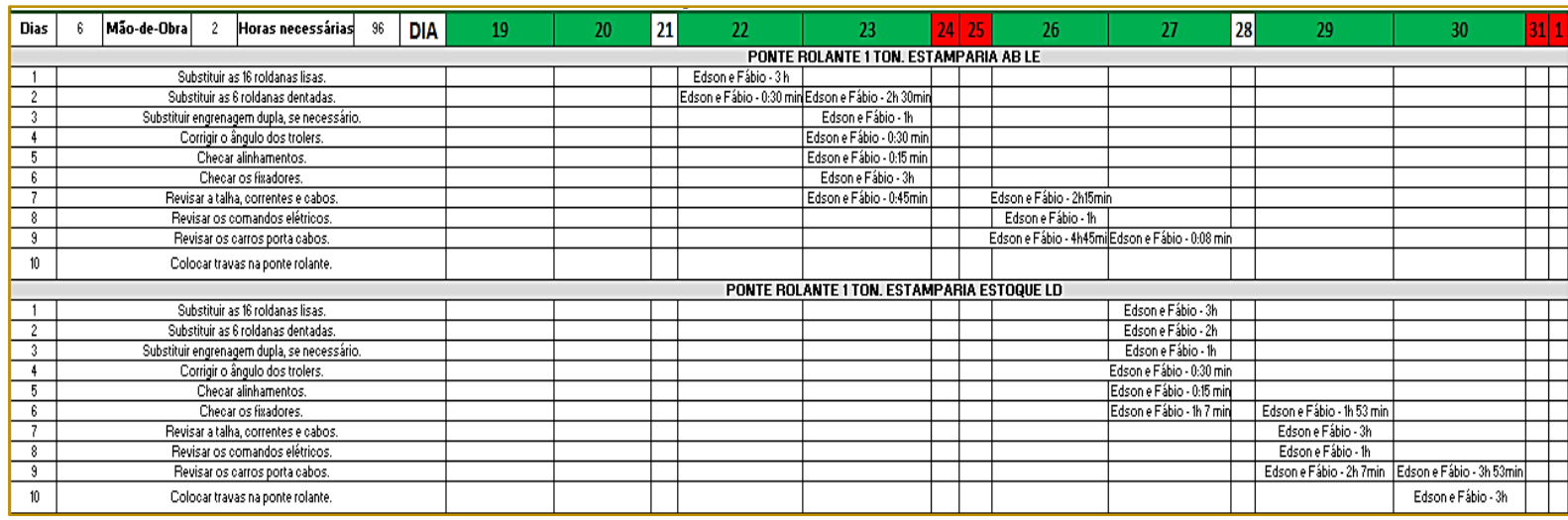

Fonte: Arquivo da Empresa (2017).

Uma atividade extra do setor de manutenção corresponde a verificação de aspectos relacionados à Norma Regulamentadora NR12 - Segurança no Trabalho em Máquinas e Equipamentos. Realizou-se uma programação de máquinas mediante a conformidade com os requisitos da norma. Além disso, estabeleceu-se um plano de ação envolvendo a NR12, baseado nos requisitos da norma envolvendo:

- Arranjo físico e instalações;

- Instalações elétricas;

- Dispositivos de partida,

- Acionamento e paradas;

- Sistemas de segurança;

- Dispositivos de paradas de emergência;

- Meios de acesso permanentes;

- Componentes pressurizados;

- Transporte de materiais;

- Aspectos ergonômicos;

- Riscos adicionais;

- Manutenção, inspeção, preparação, ajustes e reparos; sinalização;

- Manuais;

- Procedimentos de trabalho e segurança;

- Projeto, fabricação, importação, venda, locação, leilão, cessão a qualquer titulo, exposição e uso;

- Capacitação.

O plano de ação da NR12 foi desenvolvido para todo o maquinário da empresa, como forma de garantir que todas as máquinas e equipamentos possam estar adequados à norma, evitando assim uma maior ocorrência de acidentes e riscos para os operadores e o processo produtivo como um todo.

\subsection{SUGESTÕES DE MELHORIA ACERCA DA GESTÃO DA MANUTENÇÃO}

Alguns pontos necessitam de uma atenção mais prolongada como o planejamento das ações preventivas. Deve haver um estudo mais detalhado das reais necessidades de manutenção do maquinário considerado crítico, como forma de estabelecer um plano mais efetivo que agregue uma quantidade significativa de equipamentos e para que as atividades de manutenção nestes possam ser otimizadas. As preventivas trimestrais devem ser avaliadas com maior ênfase, de forma a garantir a efetividade dessas ações, reduzindo a ocorrência de intervenções corretivas nos equipamentos que passarem pelo plano trimestral de manutenção.

O treinamento e capacitação dos colaboradores também configura um aspecto importante. Seria necessário investir na qualificação dos mecânicos e eletricistas como forma de aperfeiçoar o serviço realizado e reduzir os custos da contratação de serviços terceirizados, além de viabilizar novas alternativas de intervenções de manutenção que não as mais tradicionais e que demandam maior tempo. 
O uso de metodologias de gestão da manutenção como o Programa 5S's, Manutenção Produtiva Total - TPM, a Análise das Causas Raízes de Falhas - RCFA e Análise de Modo e Efeito de Falha - FMEA podem favorecer a consolidação da manutenção na empresa, viabilizando um modelo de gestão eficiente.

\section{CONSIDERAÇÕES FINAIS}

Fica evidente a relevância do gerenciamento da manutenção no âmbito organizacional, principalmente em se tratando de ambientes fabris, com consideráveis números de máquinas e equipamentos. Apesar da gestão da manutenção ser bastante conhecida e difundida, muitas empresas ainda insistem em utilizar técnicas mais tradicionais de manutenção, implicando em altos custos, paradas desnecessárias e prejuízos para a produção.

O diagnóstico do setor de manutenção identificou que apesar da empresa ser de médio porte e conhecer técnicas mais modernas de manutenção, muitas das intervenções foram resolvidas por intermédio da manutenção corretiva, o que eleva os custos, demanda grande parte da mão-de-

\section{REFERÊNCIAS}

[1] Associação Brasileira de Normas Técnicas (ABNT). NBR 5462. Rio de Janeiro, 1994.

[2] Association Française de Normalisation (AFNOR). Disponível em: < http://www.maintenancepredictive.com/v1/public_d nc/contents/files/definition_maintenance_predictive. pdf $>$. Acesso em 27 de março de 2016.

[3] Belmonte, D. L.; Scandelari, L. Gestão do Conhecimento: Aplicabilidade Prática na Gestão da Manutenção. 8 f. Universidade Tecnológica Federal do Paraná, Curitiba, 2005.

[4] Bristot, V. M.; BRISTOT, V. M; Schaeffer, L.; Gruber, V. Manutenção preditiva em indústrias de revestimentos cerâmicos. Revista Cerâmica Industrial. V. 17 (1). 2012.

[5] Cabral, J. S. Organização e Gestão da Manutenção: dos conceitos à prática. Lisboa: Lidel, 1998.

[6] Chiochetta, J. C.; Hatakeyama, K.; Marçal, R. F. M. Sistema de Gestao da Manutenção para a Pequena e Média Empresa. XXIV Encontro Nacional de Engenharia de Produção - ENEGEP. Florianópolis, 2004. obra e ocasiona paradas na produção. Porém, as ações envolvendo as práticas de manutenção preventiva começam a ser consolidadas e a fazer parte da rotina operacional da empresa, caracterizando um processo de transição entre a abordagem tradicional de manutenção corretiva e um enfoque mais efetivo com foco na prevenção e no planejamento.

As intervenções preventivas passaram a admitir maior relevância na gestão da manutenção da empresa, tanto os gestores como os próprios mecânicos comprovaram a eficiência da realização de um plano de ação preventivo, como forma de reduzir as paradas e proporcionar uma maior vida útil às máquinas e equipamentos.

Além disso, não foi constatado o uso de nenhuma ferramenta ou metodologia específica de gerenciamento da manutenção. A aplicação da filosofia $5 S$ ou até mesmo de um programa de Manutenção Produtiva Total - TPM poderia criar um ambiente de manutenção mais organizado, limpo, com ações de intervenção mais eficientes, consumindo um intervalo de tempo menor e garantindo uma maior disponibilidade das máquinas e equipamentos.

[7] Furmann, J. C. Desenvolvimento de um modelo para melhoria do processo de manutenção mediante a análise de desempenho de equipamentos. (Dissertação de Mestrado em Engenharia de Produção). Universidade Federal de Santa Catarina. Programa de Pós-Graduação em Engenharia de Produção. Florianópolis, 2002.

[8] Kach, S. C.; Felden, C. R. Gestão do sistema de manutenção com utilização das inovações tecnológicas disponíveis para otimização dos processos. Semana Internacional das Engenharias Fahor. Faculdade Horizontina. 2011 .

[9] Mirshawka, V. Manutenção Preditiva: Caminho para Zero Defeitos. São Paulo: Makron Books; McGraw- Hill, 1991.

[10] Monchy, F. A função manutenção. São Paulo: Durban, 1989.

[11] O'connor, P. D. T. Pratical Reliability Engineering. London: WIP, 2005.

[12] Otani, M.; Machado, W. V. A proposta de desenvolvimento de gestão da manutenção industrial na busca da excelência ou classe mundial. Revista Gestão Industrial. v. 04, n. 02, 2008. 
[13] Pinto, A. K.; Xavier, J. N. Manutenção: função estratégica. Rio de Janeiro: Qualitymark, 2001.

[14] Reis, A. C. B.; costa, A. P. C. S.; Almeida, A. T. Diagnóstico da gestão da manutenção em indústrias de médio e grande porte da região metropolitana do Recife. Produção, v. 23, n. 2, 2013
[15] Slack, N.; Chambers, S.; Johnston, R. Administração da Produção. 3a edição, São Paulo: Atlas, 2009.

[16] Xavier, J. N. Manutenção - Tipos e tendências. 2003. Disponível em: < www. manter.com >. Acesso em 27 de dezembro de 2016. 


\section{Gapítulo 7}

\section{ANÁLISE DE DESEMPENHO EM TRANSPORTES DE GRANÉIS LIQUUDOS NA CABOTAGEM}

\section{Filipe de Castro Quelhas}

Resumo: O presente artigo apresenta o cenário atual do transporte de cabotagem no Brasil. Fez-se um breve estudo descritivo de como se situa o transporte de cabotagem, avaliando e apontando as principais dificuldades e sugerindo as reformas necessárias no setor. Esta pesquisa tem por objetivo geral descrever 0 panorama nacional de transporte de cargas por cabotagem, enfatizando a necessidade que as empresas deste setor têm de alcançar maior competitividade, através da oferta de serviços logísticos com melhor gestão e desempenho. Adicionalmente, o trabalho objetiva, ainda: apresentar uma revisão bibliográfica do transporte de cabotagem no Brasil e apontar a importância da utilização desse modal no processo distributivo de granéis líquidos. 


\section{INTRODUÇÃO}

O presente artigo oferece o cenário atual do desempenho do transporte de cabotagem no Brasil. Fez-se um breve descritivo do contexto em que se situa tal segmento do transporte marítimo, avaliando as condições para a sua viabilidade $e$ apontando os principais entraves e reformas necessárias no setor.

O tema escolhido justifica-se devido à crescente competitividade imposta pela globalização; as organizações buscam permanentemente padrões de excelência e a busca do aperfeiçoamento contínuo passou a ser fator chave às organizações. Neste sentido, o transporte é fator essencial nas cadeias de suprimento, afinal, é um elo de ligação entre os fornecedores, os fabricantes, os distribuidores, os clientes, os clientes dos clientes.

De acordo com Ballou (1998) os gastos com transporte podem variar de $2 \%$ a $12 \%$ do valor das vendas, dependendo do setor. A busca constante da eficiência e a eficácia do transporte são uma forma de melhorar significativamente $\mathrm{o}$ desempenho da organização.

Quando se fala eficiência, são os processos internos da organização em que as pessoas trabalham para conseguir alcançar o melhor resultado. Eficácia são os procedimentos externos da organização, na busca da excelência dos clientes.

Para que isso aconteça na logística, é mister que haja excelência em quatro áreas: integração das atividades, planejamento das necessidades, gestão das capacidades e boa execução diária desse planejamento.

Assim, as empresas de transporte de carga, dentro dos seus diversos segmentos, assumem papel de vital importância no processo do aumento da produtividade e no cumprimento dos objetivos logísticos de redução de custos e melhoria do nível do serviço oferecido aos clientes.

Diante dessas considerações questiona-se se, numa abordagem logística, se setor de transporte de cabotagem atende adequadamente toda a movimentação de mercadorias com qualidade e segurança.

Diante desse questionamento, esta pesquisa tem por objetivo geral descrever o panorama nacional de transporte de cargas por cabotagem, enfatizando a necessidade que as empresas deste setor têm de alcançar maior competitividade, através da oferta de serviços logísticos capazes de vencer tempo e distâncias na movimentação de bens, de forma eficaz e eficiente, ao menor custo possível, objetivando sua permanência e melhoria de posicionamento no mercado.

Adicionalmente, o trabalho objetiva, ainda: apresentar uma revisão bibliográfica do transporte de cabotagem no Brasil e apontar a importância da utilização desse modal no processo distributivo de granéis líquidos.

A metodologia usada para a realização deste trabalho foi a revisão bibliográfica. Utilizou-se como fonte de consulta livros, trabalhos publicados, artigos de revistas e jornais e publicações eletrônicas que abordam o tema em análise.

\section{DESENVOLVIMENTO DA CABOTAGEM NO BRASIL}

O transporte geralmente se desenvolve devido a fatores sobrepostos tais como economia, geografia, política, aspectos militares, tecnologia entre outros. A priori, quase todo desenvolvimento do transporte é econômico na origem. A preocupação principal dos primeiros seres humanos era a procura de alimentos e às vezes vestimentas. Com a sua evolução, suas necessidades aumentaram, freqüentemente além do que sua economia local pudesse suprir.

Maneiras de transportar mercadorias de distantes lugares tiveram que ser arquitetadas adicionando ao custo das mercadorias, o frete.

Rodrigues (2004, p. 22), afirma que,

[...] na maior parte das indústrias, a atividade de transporte representa um dos elementos mais importantes na composição do custo logístico. Nas nações desenvolvidas, os fretes costumam absorver cerca de $60 \%$ do gasto logístico total e entre $9 \%$ e $10 \%$ do Produto Nacional Bruto (PNB), onde a contratação de serviços de transporte busca eficiência e qualidade, com base em relacionamentos de parceria.

Então, como se percebe, a geografia está intimamente relacionada à economia. A localização geográfica dos recursos materiais define quais as rotas que darão acesso a estes recursos e quais utilidades econômicas 
serão criadas, que são as utilidades de lugar e tempo, objeto da logística.

De acordo com Ballou (1998, p. 10) estes "são termos econômicos que simplesmente significam ter mercadorias onde e quando elas são necessárias".

Portanto, a geografia e a carência de recursos forçam a procura de novas fontes de insumos, bem como mercados para a venda da produção. A princípio existem os portos e, a necessidade de explorar e desenvolver o novo território obriga o desenvolvimento de ferrovias, rodovias bem como a utilização de rios e lagos com destino ao interior.

Mais especificamente no transporte de cargas, a história registrada no Brasil tem seu início na época do descobrimento, o qual se deu (o transporte), obviamente, graças à tecnologia de transporte então disponível: os ombros dos nativos e suas primitivas embarcações. Nesta época, a atividade econômica tinha sua iniciação.

De acordo com Rodrigues (2004) em 1840, a navegação brasileira tem seu início na era do vapor, e, catorze anos mais tarde inaugura sua primeira estrada de ferro.

\begin{abstract}
A expansão do setor industrial e agrícola brasileiros, no final do século XIX, trouxeram consigo a necessidade de um sistema de transportes mais adequado à demanda. Vários estudos e planos viários foram elaborados, visando a melhoria das comunicações, a maior parte deles propondo soluções ferroviárias. Aproximadamente entre 1870 e 1930, as ferrovias brasileiras desempenharam um papel decisivo no escoamento dos produtos agrícolas -sobretudo o café - do interior para os portos, articulando-se logisticamente com a navegação de longo curso. Os investimentos e a operação eram privados e independentes entre si, sendo implantados com bitolas diferentes, não interligando os sistemas ferroviários regionais. (RODRIGUES, 2004, p. 41).
\end{abstract}

Segundo o mesmo autor, ainda no último período do século XIX, mudanças importantes ocorriam afetando a política, a economia e a sociedade brasileira de uma maneira geral. O café transforma-se em alavanca de desenvolvimento para o país. Surgem novas indústrias e as cidades de São Paulo e Rio de Janeiro assumem a posição de pólos econômicos.
Em 1907, o censo registra 3.258 estabelecimentos industriais e que 0 transporte de mercadorias continua a ser trabalho do braço humano ou dos animais de carga. Alguns produtos eram transportados por ferrovia sendo que em 1908, a malha ferroviária já somava, no país algo próximo a 17.000 quilômetros de extensão. (RODRIGUES, 2004).

Com a Primeira Guerra Mundial, no período de 1914 a 1918, praticamente interrompe a importação de produtos manufaturados para - Brasil, o que estimula a criação de novos estabelecimentos industriais. Ao final da Primeira Guerra, a navegação volta a ocupar lugar de destaque entre os meios de transporte no país. Neste momento da história, a Cia Lloyd Brasileiro é a maior empresa, fundada em 1918. (RODRIGUES, 2004).

No início do século $X X$, com a criação do avião e, de acordo com Rodrigues (2004), no Brasil em 1927, implanta-se o transporte aéreo regular doméstico para passageiros e cargas com a fundação da Viação Aérea Riograndense.

Em 1930 assume o poder Getúlio Vargas com crescente intervenção na economia. Foi um governo que incentivou o processo industrial; a economia entra num período de recuperação e esse progresso tendo acelerado o mercado consumidor, encontrou problemas de abastecimentos com o sistema de transporte prevalecente na época: a navegação e a ferrovia. (RODRIGUES, 2004).

Em 1937 é criado o Departamento Nacional de Estradas e Rodagem- DNER, que em 1944, apresentou O Plano Rodoviário Nacional. No período de 1931 a 1944 haviam sidos construídos 1512 quilômetros de estradas federais. Coube ao DNER implantar a malha rodoviária que serve hoje ao setor de transportes no Brasil. (RODRIGUES, 2004).

Segundo Rodrigues (2004) com a Segunda Guerra Mundial as trocas comerciais entre as nações foi interrompida afetando diretamente a economia brasileira: o transporte rodoviário chega à beira do colapso, em função das dificuldades de importação do petróleo. O transporte marítimo de cabotagem na costa brasileira torna-se inseguro, e navios mercantes são afundados por submarinos inimigos.

Em 1944, a rede ferroviária passa por séria crise financeira, além de operar como um 
conjunto de subsistemas regionais, sem ligação entre si e a navegação de cabotagem, que por muito tempo permitira a interligação entre as várias regiões do país, decaía por falta de reposição de navios.

As três décadas seguintes foram totalmente voltadas ao incremento rodoviário, período iniciado pelo governo de Kubitschek como "Era Rodoviária", pois atinge no final da década de 6045.295 quilômetros, em 1977 a 75.933 e em 1980 a 78.000 .

De acordo com Lopes (2000, p. 84):

Nas últimas décadas, o Brasil teve seu desenvolvimento sustentado pelos pesados investimentos em rodovias. Longe de apontar qualquer exclusivismo em relação ao transporte rodoviário, deve-se compreender que conectar o país de norte a sul através de rodovias foi a forma mais rápida e barata de se integrar todas as regiões. Atrás dos caminhos abertos pelos tratores seguiam os caminhões e carros, levando produção agrícola e mineral. $O$ Brasil optou pelas rodovias no final da década de 50, quando a indústria automobilística se instalou no país e as empreiteiras perceberam a possibilidade de ganhar dinheiro, desde que os trilhos caíssem em desuso. A rodovia foi associada à idéia de modernidade, enquanto a estrada de ferro se tornou símbolo de país ultrapassado.

Somente na da década de 90, começa-se a investir mais nos modais ferroviários e a modernização dos portos começa a dar ênfase na cabotagem pela costa e pelos rios do Brasil; no entanto, mesmo assim, mais de $70 \%$ do transporte de carga ainda é feito no modal rodoviário. (RODRIGUES, 2004).

\subsection{DADOS DO CRESCIMENTO DA CABOTAGEM NO BRASIL}

Em uma última pesquisa realizada pela COPPEAD (2004), dados apontam uma pequena evolução na cabotagem, como pode ser analisada a seguir, distinguindo-se as evoluções de granéis sólidos, líquidos e carga geral. Nota-se, contudo, um crescimento quase insignificante de $3 \%$ na taxa de crescimento de granéis líquidos com uma participação decrescente de $32 \%$ para $27 \%$, no período de 2001 a 2004 - Figura1:

Figura 1

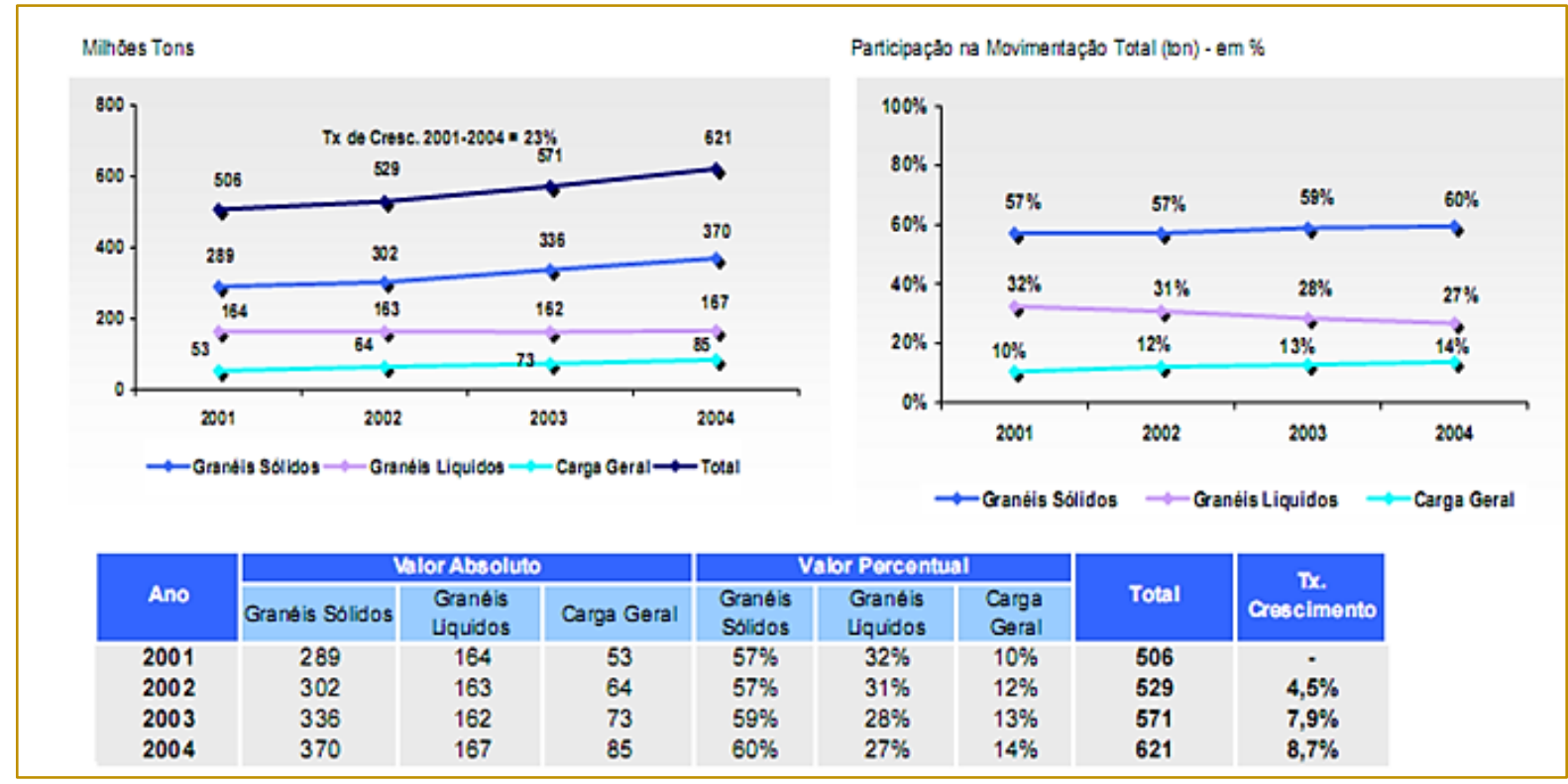

Fonte: Antaq, analisado por COPPEAD (2004, p. 1).

Em geral (granéis sólidos, líquidos e carga geral), tiveram a representatividade de crescimento de apenas $11 \%$ no período de 2001 a 2004. 
Gráfico 1 -

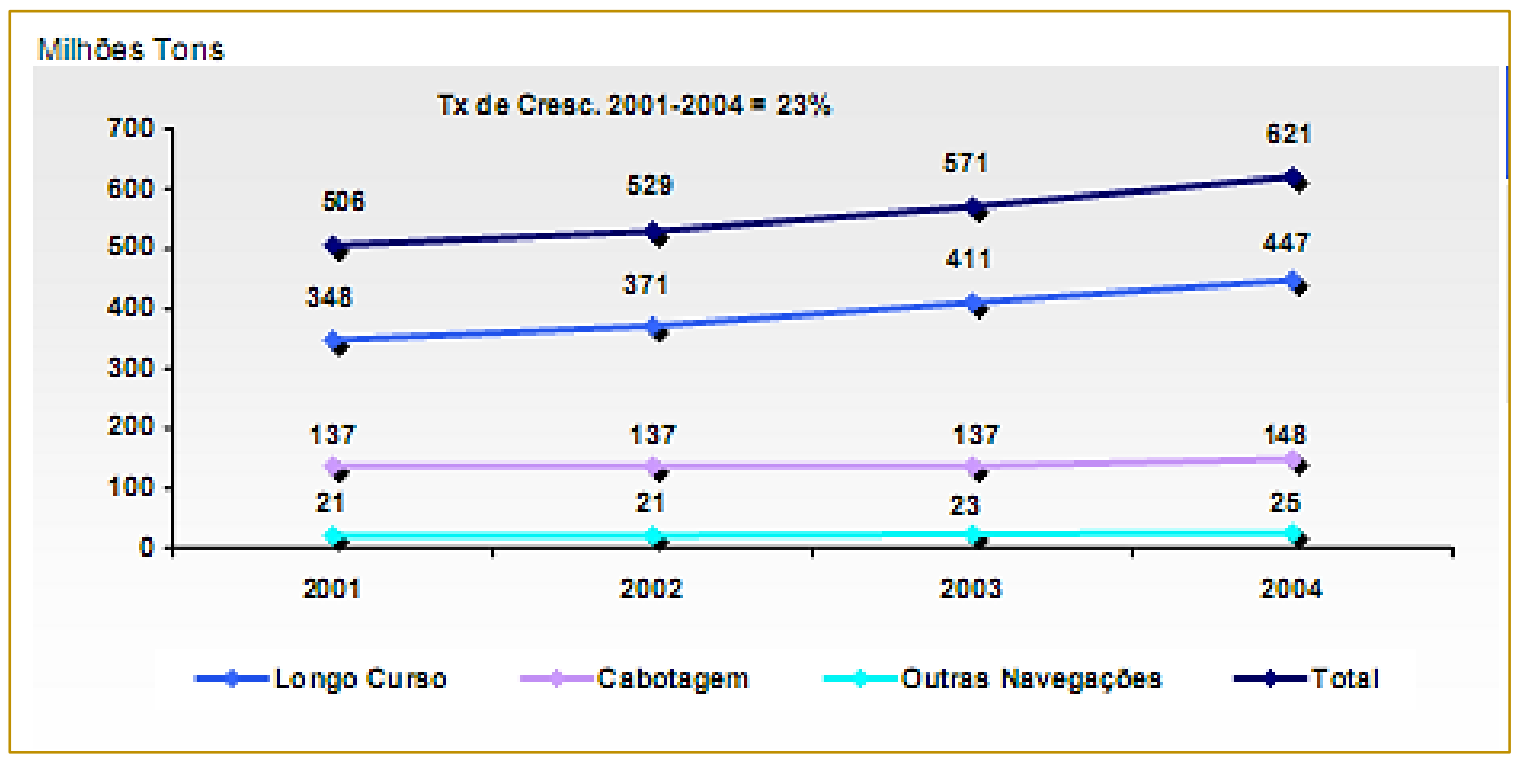

Fonte: Antaq, analisado por COPPEAD (2004, p. 4)

Entre os produtos mais transportados pela cabotagem estão o petróleo, derivados de petróleo e óleo, porém, somente na importação dos mesmos como segue (Tabela 1):

Tabela 1

\begin{tabular}{|c|c|c|c|c|c|c|c|c|}
\hline PortorTerminal• & Carvăol Coque & Petróleo & Fertilizantes & Trigo & Adubo & $\begin{array}{c}\text { Derivados } \\
\text { de } \\
\text { petroleo }\end{array}$ & Enxofte & Óleo \\
\hline $\begin{array}{l}\text { ALMTE. BARROSO } \\
\text { (PETROBRAS)-SP }\end{array}$ & - & $67,04 \%$ & - & - & - & - & - & - \\
\hline PRAIA MOLE-ES & $59,92 \%$ & - & - & - & - & - & - & - \\
\hline PARANAGUA-PR & - & - & $64,61 \%$ & - & - & - & - & - \\
\hline $\begin{array}{l}\text { MAXIMINIANO DA FONSECA } \\
\text { (PETROBRAS)-RJ }\end{array}$ & - & $32,96 \%$ & - & - & - & - & - & - \\
\hline SEPETIBA-RJ & $22,72 \%$ & - & - & - & - & - & - & - \\
\hline SANTOS-SP & - & - & - & $22,56 \%$ & $55,36 \%$ & - & $28,40 \%$ & - \\
\hline CUBATĀO-SP & $14,72 \%$ & - & - & - & - & - & - & - \\
\hline ULTRAFÉRTIL-SP & - & - & - & - & $28,46 \%$ & - & $71,60 \%$ & - \\
\hline ITAQUI-MA & - & - & - & - & & $96,29 \%$ & - & - \\
\hline TUBARĀO-ES & - & - & $12,85 \%$ & - & - & - & - & - \\
\hline $\begin{array}{l}\text { ALMTE ALVES CĀMARA } \\
\text { (PETROBRAS)-BA }\end{array}$ & - & - & - & - & - & - & - & $100,00 \%$ \\
\hline FORTALEZA-CE & - & - & - & $15,35 \%$ & - & - & - & - \\
\hline RIO DE JANEIRO-RJ & - & - & - & $14,00 \%$ & - & - & - & - \\
\hline RECIFE-PE & - & - & - & $11,35 \%$ & - & - & - & - \\
\hline OUTROS & $2,64 \%$ & - & $22,54 \%$ & $36,73 \%$ & $16,19 \%$ & $3,71 \%$ & - & - \\
\hline TOTAL & $100,00 \%$ & $100,00 \%$ & $100,00 \%$ & $100,00 \%$ & $100,00 \%$ & $100,00 \%$ & $100,00 \%$ & $100,00 \%$ \\
\hline
\end{tabular}

Fonte: Antaq, analisado por COPPEAD (2004, p. 10) 
Gráfico 2 - Fonte Antaq, 2010.

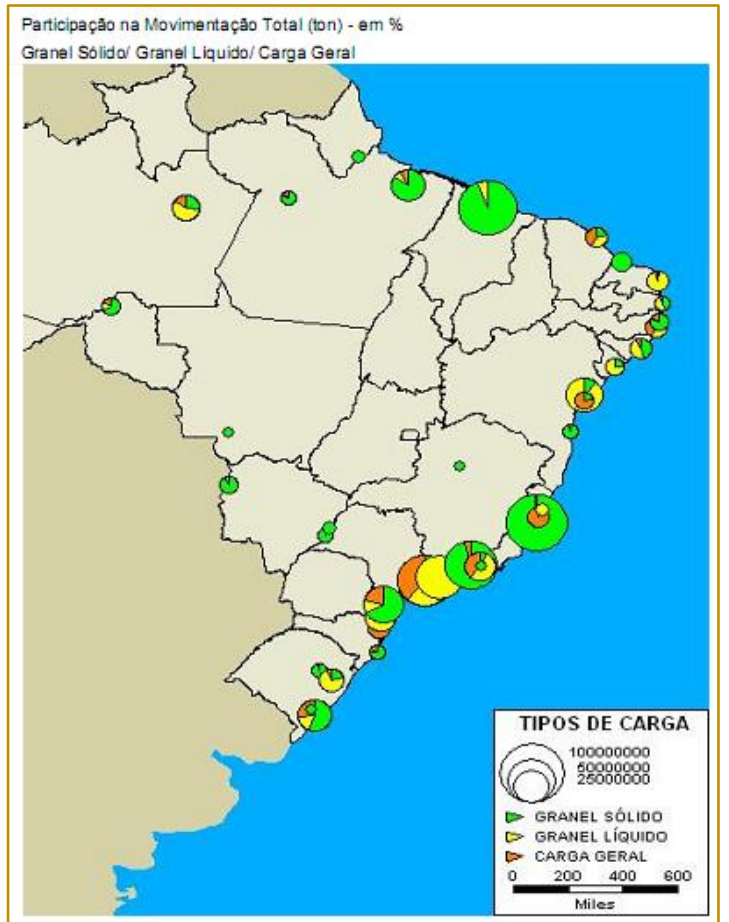

\section{A LOGIISTICA EMPRESARIAL}

Atualmente a logística empresarial é um ramo instigante e em desenvolvimento, uma das mais importantes ferramentas para os administradores atuais. (CHING, 1999).

Para todos os fins, a prática moderna da logística empresarial forma uma nova disciplina, o que não quer dizer que as atividades necessárias de transporte, manutenção de estoques e processamento de pedidos sejam novidades. (CHING, 1999).

Contudo, somente recentemente uma filosofia integrativa esteve à disposição para conduzir seus caminhos, visando à redução de custos e a disponibilização de produtos aos clientes, no local certo, na condição adequada e na hora requerida. (CHING, 1999).

O tratamento das atividades logísticas nas empresas pode ser assim classificado em várias fases, de acordo com o grau de inter-relação existente entre os diversos agentes da cadeia. Esse relacionamento inicia-se na fase em que a empresa trata os problemas logísticos somente em sua óptica interna, passa em seguida pelos primeiros passos rumo à integração empresa-cliente, progride posteriormente em direção ao tratamento integrado empresas- fornecedores e atinge a fase da logística integrada. (CHING, 1999, p. 20).

A gestão da logística e operações globais é mais um grande desafio para as empresas, e também uma grande oportunidade. A gerência tem explorado à exaustão as oportunidades de redução de custos na manufatura. O mesmo não ocorre na logística, em que tais oportunidades ainda são enormes. Essa realidade torna a melhoria na logística tão importante para a estratégia corporativa quanto a melhoria na manufatura e no marketing. (DORNIER et al., 2000).

\subsection{PAPEL ESTRATÉGICO}

Uma pesquisa realizada em 1994, pelo The Conference Board (um grupo de pesquisa/educação econômica localizada em New York), mostrou que muitas empresas estavam consolidando todas as suas funções logísticas de várias regiões em uma unidade organizacional encabeçada por um novo diretor sênior indicado.

Outro estudo da University of Maryland, realizado em 1995, descobriu que há uma mudança na visão das empresas, as que utilizam as melhores práticas estão começando a consolidar as funções de logística em centros de operações em vez de 
manter seus sistemas logísticos descentralizados. (DORNIER et al., 2000).

Segundo Dornier et al. (2000), quanto ao papel estratégico, a maioria das funções de operações e logística permanece relegada aos tradicionais papéis reativos/táticos. A alta direção das corporações enxerga operações e logística como tática por natureza, projeta a estratégia sem suas considerações e relegaIhe um papel de minimização de custo.

Existem diversas razões para essa atitude gerencial ultrapassada, segundo Fender, citado por Dornier et al. (2000), entre elas:

- A dominância funcional de certas áreas na formulação da estratégia corporativa: Altos executivos aparentemente preferem focar atividades relacionadas ao ambiente externo, em vez daquelas - como logística - que tratam das atividades internas. Essa atitude perpetua o padrão da dominância funcional estabelecida por finanças e marketing.

Conseqüentemente, gerentes de operações e logística tipicamente não têm sido incluídos na formulação da estratégia corporativa; (ERNEST, In: DORNIER et al., 2000).

- Uma visão de curto prazo das contribuições de operações/logística: Tipicamente, a alta direção enxerga a função de operações / logística como uma unidade de combate a incêndios que constantemente enfrenta e resolve crises. Os gerentes de logística são avaliados e compensados por seu desempenho nos números de curto prazo e recebem poucos incentivos para focar metas e desempenho de longo prazo; (ERNEST, In: DORNIER et al., 2000).

- Uma crença de que operações e logística são especialidades técnicas e não funções estratégicas do negócio: Operações e logística freqüentemente são vistas como funções técnicas, formadas por especialistas com qualificações e implementação das estratégias. Ao integrar operações e logística ao processo decisório, as empresas podem obter uma vantagem competitiva por meio da racionalização dos recursos necessários para realizarem essa tarefa. O marketing compreende as necessidades dos clientes, mas operações e logística são responsáveis por entregar ao cliente final. Empresas líderes superam a tradição e passam a enxergar esta especialidade como uma fonte de vantagem competitiva. (ERNEST, In: DORNIER et al., 2000).

\subsection{PROCESSO DA ESTRATÉGIA}

O conceito de estratégia e o processo de formulação da estratégia são inseparáveis em qualquer definição organizacional real.

O processo de formulação da estratégia tem uma série de objetivos críticos, incluindo segundo Fender citado por Dornier et al. (2000):

Definição dos atores-chaves e seus papéis na formulação e implementação da estratégia;

- A decisão do tipo e seqüência de interações que os principais atores devem ter;

- A designação da natureza, intervalo e extensão dos fluxos de informação entre os atores;

- A determinação da forma e abrangência da comunicação a respeito do processo de formulação da estratégia entre vários constituintes dentro e fora da empresa;

- A sugestão de ferramentas e metodologia de suporte a serem usadas como parte do processo.

Um modelo simples de trabalho, é sugerido por Kouvelis, citado por Dornier et al., (2000) para suportar o processo de desenvolvimento da estratégia de operações e logística. Esse modelo é detalhado na figura 1 a seguir: 
Gráfico 3 - Modelo para o desenvolvimento da estratégia de operações e logística nas decisões corporativas.

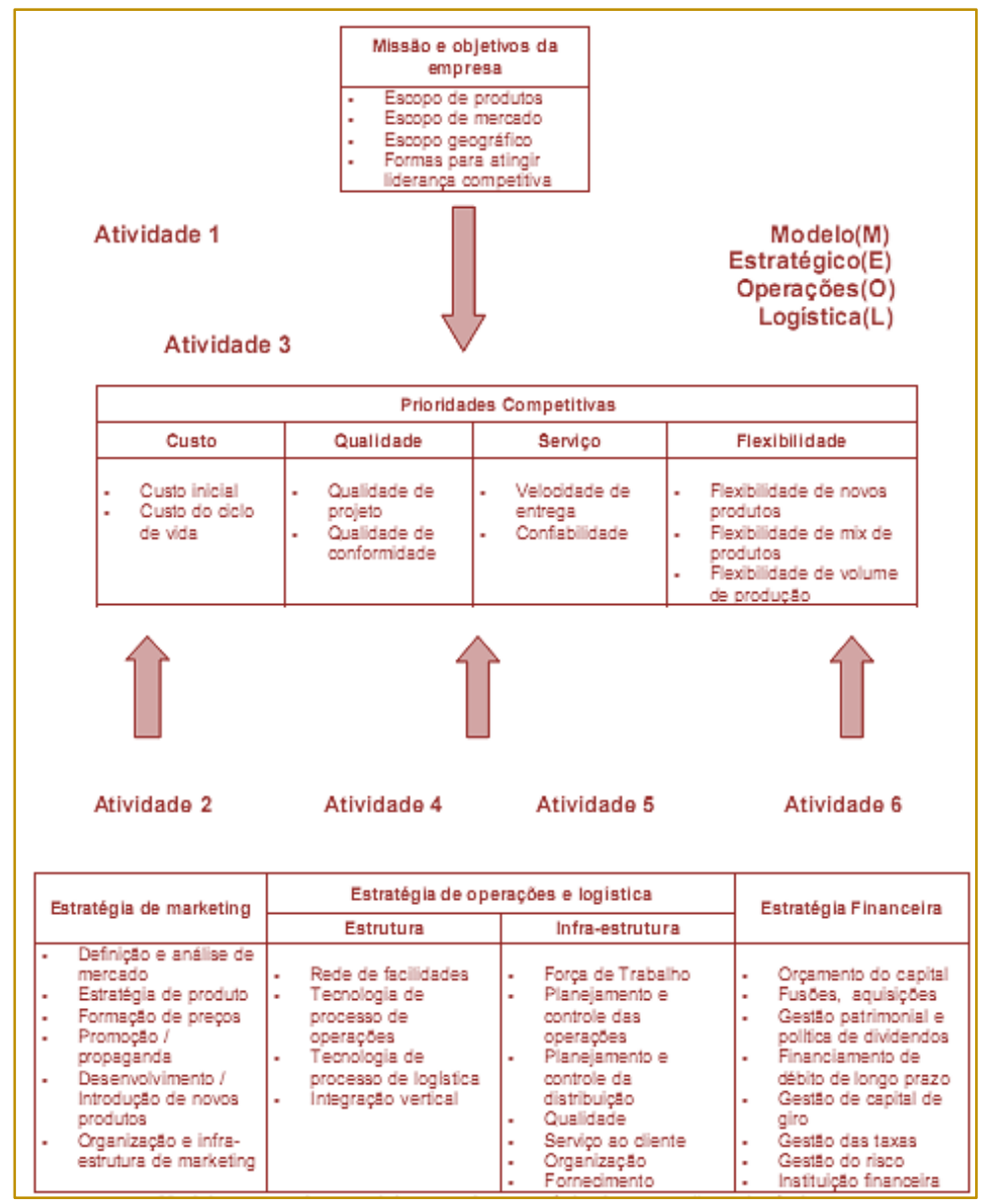

Fonte: Kouvelis, In: Dornier et al. (2000, p. 99)

O modelo proposto por Kouvelis, citado por Dornier et al. (2000) compõe-se de seis atividades principais no planejamento corporativo, que são:

- Atividade 1: Definição da missão e objetivos da empresa;

- Atividade 2: Desenvolvimento das estratégias de marketing para atender a esses objetivos;

- Atividade 3: Identificação das prioridades competitivas da empresa para diferentes mercados;

- Atividade 4: Escolhas estruturais como parte do desenvolvimento de uma estratégia de operações e logística que suportam as prioridades competitivas estabelecidas anteriormente;

- Atividade 5: Desenvolvimento da infraestrutura necessária para suportar as escolhas estruturais da estratégia de operações e logística;

- Atividade 6: Desenvolvimento das estratégias financeiras que suportam os objetivos e prioridades competitivas das empresas. (KOUVELIS, In: DORNIER et al., 2000).

O objetivo deste modelo estratégico é facilitar o debate corporativo na formulação de uma estratégia de operações e logística que suporta com sucesso as prioridades competitivas do mercado. Uma estratégia bem sucedida deve levar a avanços em termos de produtos ou processos, ou pelo menos suportar as necessidades da empresa melhor que as funções de operações e logística dos principais concorrentes. (KOUVELIS, In: DORNIER et al., 2000).

O processo de formulação deve ser visto como dinâmico, fluindo de forma suave entre os níveis de atividades (isto é, interações 
entre atividades 1 e 2, atividades 2 e 5, atividades 4 e 6 , etc.), em vez de processos estáticos seqüenciais. A interação do modelo é ajudar a desenvolver um processo de discussão dos assuntos no nível corporativo. Ao mesmo tempo o processo reconhece explicitamente que a estratégia deve ser orientada para o negócio e para o mercado, em vez de orientada para a função. (KOUVELIS, In: DORNIER et al., 2000).

\section{A LOGÍSTICA ATUAL PARA DISTRIBUIÇÃO DE GRANÉIS LÍQUIDOS}

O modelo atual de logística aplicada na distribuição de granéis líquidos, mais especificamente combustíveis, não traduz em melhor atendimento aos seus clientes, rapidez, menor custo total e no caso de produtos perigosos de menor risco. Portanto quem não está utilizando a melhor forma logística, está perdendo vantagens competitivas de curto e longo prazo.

Observa-se que as empresas de distribuição de combustíveis têm uma forte ação de marketing, ou seja, o sistema está focado em marketing, fugindo do enfoque sistêmico amplamente discutido neste trabalho, em itens anteriores.

Em um modelo sistêmico, a logística envolve os seguintes sub-sistemas:

- Marketing (área comercial/vendas, central de atendimento);

- Operações (bases de distribuição e armazenagem);

- Transportadores (granéis líquidos);

- Clientes (postos de gasolina).

Com base na descrição teórica anteriormente registrada, verifica-se que o sistema "logística" não recebe tratamento estratégico, apenas tem o papel de reduzir custos e otimizá-lo. Através de uma análise subjetiva, a logística atual utilizada pelas distribuidoras de granéis líquidos apresenta alguns pontos que merecem uma avaliação, ou seja, como ocorre na logística:

- - O pedido é feito pelo cliente numa central de atendimento da distribuidora de granéis líquidos (combustíveis) com 24 horas de antecedência;

- O número de veículos das transportadoras está dimensionado para os dias de pico de demanda, ou seja, de segunda à sexta-feira;

- Os clientes fazem compras fracionadas todos os dias da semana;

- - Compras diárias aumentam a necessidade de controle de Marketing sobre débitos/créditos e liberações;

- Entregas todos os dias para os clientes, representam maior risco de acidentes e derrames ambientais no posto;

- Custos de investimento direto e indireto elevado nas bases de armazenagem e carregamento das distribuidoras, por estar preparada para atender o pico;

- - O cliente faz pedidos de menor volume e diários, trabalha com estoque baixo e menor capital de giro;

- Maior custo variável no transporte, devido a viagens com mais de uma entrega;

- Menor produtividade/dia por caminhão, devido as viagens com mais de uma entrega;

- - Custo de investimento e fixo maior para as transportadoras para atender a demanda estabelecida pelo pico.

Diante dessas informações, há questões que devem ser apresentadas e respondidas, que interferem diretamente, como custo ou ganho para o cliente: Qual o capital de giro ideal? Qual a perda financeira por antecipação de compra? Qual o risco ambiental e de acidente a cada compra de produto? Qual a oportunidade de obter condições comerciais melhores em troca de compras programadas e consolidadas. Qual o custo para manter um funcionário dedicado para o recebimento, conferência e controle de qualidade? Quanto poderia ser reduzido (custo) se diminuísse o volume de documentos para processar (pagamento/contabilidade/fiscal). Em relação aos outros subsistemas, quais questões precisam ser quantificadas? Quanto isso custa ou representa em termos de valores, para os demais subsistemas, se o cliente optar pelo atendimento fracionado?

Conclui-se então que se o modelo de entregas fracionadas faz a cadeia perder várias oportunidades de reduzir custos, e com isso terá perdas financeiras, que não poderão ser recuperadas. É fundamental que seja 
revisto esse modelo a fim de criar uma oportunidade onde o cliente, marketing, operações ou transportador, não estejam privilegiados, e sim equilibrados, cada um obtendo a vantagem pela escolha da melhor opção compra e entrega, com vantagens financeiras, entre outras.

Esta é a realidade atual na distribuição, não houve nenhum planejamento estratégico a fim de que fosse estabelecida uma estratégia conjunta com marketing e outros setores, além do cliente e transportadores, para que fosse implementada a logística de menor custo, avaliando-se as oportunidades de investimentos e custos.

\subsection{A CABOTAGEM COMO OPÇÃO DE REDUÇÃO DE CUSTOS}

De acordo com Nazário citado por Mello (2001) o sistema de transporte no Brasil, que ficou vários anos sem receber investimentos significativos, está passando por um momento de transição no que diz respeito às possibilidades de utilização de mais de um modal na movimentação de cargas ao longo de toda a cadeia de suprimentos.

Isso ocorre principalmente pelo processo de privatização de ferrovias e portos, pela Lei de Modernização dos Portos, a execução de obras infra-estruturais e também pela iniciativa de vários embarcadores e prestadores de serviços logísticos. É consenso entre os estudiosos e envolvidos no sistema de transporte que, com o uso de mais de um modal, a integração destes, o custo de transporte cai, gerando redistribuição das cargas. (MELLO, 2001).

Siscaro citado por Mello (2001) aponta a concordância quanto ao fato de que a integração com outros modais diminui os custos para o setor rodoviário. Como cada vez mais se busca a redução nos custos logísticos e maior confiabilidade no serviço prestado, o uso de mais de um modal no Brasil surge como grande oportunidade para as empresas tornarem-se mais competitivas, visto que o modal rodoviário predomina na matriz de transporte do Brasil, mesmo para produtos e trechos onde não é o mais competitivo.

De acordo com Sousa citado por Mello (2001), "o que mais desfavorece a opção rodoviária é justamente a distância".
A má conservação das estradas faz com que o consumo de combustível aumente e, o valor do frete seja assim aumentado. Os prejuízos se acumulam porque é preciso vencer enormes distâncias e os fretes tornam-se bastante significativos. Apesar de os custos com frete serem mais altos, o transporte rodoviário ainda prevalece em relação a, por exemplo o transporte pela ferrovia ou hidrovia. Persiste uma cultura, ou melhor, uma opção pelo modo rodoviário no Brasil que pode ser gradativamente mudado.

A aprovação da Lei 9.611 de 19/02/98 que regulamenta 0 transporte multimodal e a utilização do Operador de Transporte Multimodal (OTM) serve também como estímulo para o uso de mais de um modo de transporte, pois isto tem como lógica a agregação de valor pelo uso das vantagens de cada um destes modais, o que pode ser caracterizado tanto pelo serviço como pelo custo. (MELLO, 2001).

Soares citado por Mello (2001) comenta que, com a integração dos modais rodoviário, ferroviário, fluvial e a cabotagem, o custo de transporte deve cair, gerando redistribuição das cargas. Pondera, por exemplo, que cargas com mais de 500 quilômetros a percorrer deverão deixar o modal rodoviário e passar à outras opções.

Outro fator que pode auxiliar na decisão de se optar por outro modal é o alto custo dos pedágios na rodovia. Este leva, as empresas a pensar em novas formas, mais baratas de escoamento de sua produção.

Por exemplo, a Rigesa Celulose, Papel e Embalagens, que atua na fabricação de papel e caixas de papelão, optou pela navegação de cabotagem para transportar papel "Kraft" entre suas fábricas do Norte e Sul do país, devido à redução de custos significativa de 5 milhões de reais entre os anos de 1994 e 1999. (DORNIER et al., 2000).

Independente de muitos outros exemplos que podem ser citados é possível dizer que ocorre, e deve ocorrer gradativamente uma migração de cargas transportadas pelo modal rodoviário, para outros tipos de modais. A constatação prática disto é, a diminuição da quantidade de carga a ser movimentada pelos transportadores rodoviários de carga. 
4.2 O PORQUE DA FALTA DE INVESTIMENTOS EM CABOTAGEM

Em 16 de fevereiro de 1995, o Presidente Fernando Henrique Cardoso encaminhou ao Congresso Nacional Proposta de Emenda Constitucional no 07-A, que elimina preceitos fundamentais que asseguram a manutenção de uma frota mercante nacional configurados no artigo 178 de nossa Constituição Federal. (VERMELHO, 2007).

A emenda está em vigor desde sua publica no DOU 16/08/1995. Pretende o Governo Federal que o citado artigo limite-se à seguinte redação:

Art.178. "Art. 178. A lei disporá sobre:

I - a ordenação dos transportes aéreo, marítimo e terrestre;

II - a predominância dos armadores nacionais e navios de bandeira e registros brasileiros e do país exportador ou importador;

III - o transporte de granéis;

IV - a utilização de embarcações de pesca e outras.

$\S 1 .^{\circ}$ A ordenação do transporte internacional cumprirá os acordos firmados pela União, atendido o princípio de reciprocidade.

$\S 2$. . Serão brasileiros os armadores, os proprietários, os comandantes e dois terços, pelo menos, dos tripulantes de embarcações nacionais.

$\S 3$. A navegação de cabotagem e a interior são privativas de embarcações nacionais, salvo caso de necessidade pública, segundo dispuser a lei."

(ÍNDICE FUNDAMENTAL DE DIREITO, 2007).

Em sua proposta, o então Presidente Fernando Henrique Cardoso, redigiu:

Inclua-se no Ato das Disposições Constitucionais Transitórias o seguinte artigo, onde couber: Enquanto não se editar a lei de que cuida o parágrafo único do artigo 178, modificado pela Emenda Constitucional número 07-A, de 1995. A Navegação de Cabotagem e a Interior permanecerão privativas de embarcações nacionais, salvo em casos de necessidade pública. (VERMELHO, 2007).

Vários deputados fizeram votos em separado, e o que mais reflete a problemática da logística de cabotagem foi da deputada Socorro Gomes ao afirmar:
Quanto à navegação de cabotagem e à de interior, ao retirar-se o princípio constitucional que garantem serem privativas de embarcações nacionais, salvo caso de necessidade pública, segundo dispuser a lei e lançá-las a Legislação Ordinária, como pretende a Emenda, é inegável que o governo demonstra inequívoca disposição a abrir nossa navegação de cabotagem e de interior a embarcações estrangeiras. É inaceitável que a título de um mero enxugamento do texto Constitucional e de uma assumida flexibilização do nosso transporte aquaviário, possibilitemos a operação interna de embarcações de países que obedecem o princípio da reciprocidade. A elite dirigente brasileira costuma decidir olhando a experiência estrangeira, dos países desenvolvidos. O transporte interno, de mercadoria e pessoas, em quase todos os países do mundo, é feito quase que exclusivamente por empresas nacionais. A navegação de cabotagem é privativa de embarcações nacionais nas principais potências marítimas, citando-se como exemplo os Estados Unidos, França e Japão, Holanda, Alemanha, Grécia etc. Nos Estados Unidos, o "Merchant Marine Act", de 1920, estabelece em sua seção 27, que a navegação de cabotagem só pode ser realizada por navios de propriedade de cidadãos norte-americanos, tripulados por nacionais e que tenham sido construídos nos Estados Unidos. O proprietário, no caso, significa estar sobre controle de norte-americanos $75 \%$ do capital da empresa de navegação, exigência que se repete à empresa que explore a navegação de longo curso. 0 Japão, proprietário de uma das maiores frotas marítimas do mundo, reserva às embarcações japonesas a navegação de cabotagem no país e exigem serem japoneses os navios e seus proprietários. As corporações comerciais devem ser sediadas no país, controladas por japoneses ou por pessoas jurídicas com seu centro de decisão no Japão, sendo seus representantes cidadãos japoneses. Também o tráfego doméstico é restrito as embarcações japonesas. Na Argentina, o artigo 1ํ do Decreto Lei no 19.142 de 1944, determina que a navegação de cabotagem será praticada exclusivamente por barcos argentinos, sob o comando argentino e com parte da tripulação composta por nacionais. Para se ter noção dos cuidados que os Estados Unidos tomam com sua navegação costeira, na Rodada Uruguai do 
GATT não permitiram incluir, no item sobre serviços, a liberação de transporte marítimo internacional e também o de contagem. Da mesma forma que os países citados, a obrigatoriedade de utilização de embarcações nacionais na navegação de cabotagem no Brasil é uma constante histórica nas constituições brasileiras desde as Constituições de 1891, permanecendo intocada nas Cartas de 1934, 1946, 1967 e 1988. A Emenda Constitucional proposta pelo governo não encontra parâmetro de comparação em nenhuma das nações desenvolvidas ou consideradas em desenvolvimento em todo o mundo. Pelo contrário, pretende criar no Brasil uma situação privilegiada para as grandes frotas marítimas, não se importando que os países de origem dessas mesmas frotas estabeleçam reservas para protegerem seus interesses e de suas empresas de navegação. (VERMELHO, 2007).

Esta situação legal explica a falta de incentivo da União. As maiores frotas ainda possuem embarcações obsoletas, com décadas de existência, como pode-se observar abaixo:

\section{GLOBAL TRANSPORTE OCEÂNICO S.A:}

Tabela 2 -

\begin{tabular}{|c|c|c|c|c|c|c|}
\hline Embarcação & Tipo & $\begin{array}{c}\text { Tipo de } \\
\text { navegação }\end{array}$ & Ano & TPB & Situação & Observação \\
\hline Alamoa & $\begin{array}{c}\text { Supridores de } \\
\text { plataformas } \\
\text { marítimas (suplly) }\end{array}$ & $\begin{array}{c}\text { Apoio } \\
\text { marítimo }\end{array}$ & 1978 & 9981 & Própria & \\
\hline Global africa & Roll-on/roll-off & $\begin{array}{c}\text { Cabotagem, } \\
\text { longo curso }\end{array}$ & 1986 & 10000 & Própria & Afretada \\
\hline Global bahia & Tanque químico & Cabotagem & 1985 & 7859 & $\begin{array}{c}\text { Propriedade } \\
\text { de: bryggen } \\
\text { shipping \& } \\
\text { trading }\end{array}$ \\
\hline $\begin{array}{c}\text { Global } \\
\text { maceio }\end{array}$ & Tanque químico & $\begin{array}{c}\text { Cabotagem, } \\
\text { longo curso }\end{array}$ & 1983 & 15088 & Própria & \\
\hline Global rio & Graneleiro & Cabotagem & 1998 & 14500 & Própria & \\
\hline
\end{tabular}

Fonte: Antaq (2010).

\section{FLUMAR TRANSPORTES DE QUIMICOS E GASES LTDA:}

Tabela 3 - Fonte: Antaq (2010).

\begin{tabular}{|c|c|c|c|c|c|}
\hline Embarcação & Tipo & Tipo de navegação & Ano & TPB & Situação \\
\hline Angelim & Tanque químico & Cabotagem & 1985 & 10259 & Própria \\
\hline Araucária & Tanque químico & Cabotagem, longo curso & 1983 & 10260 & Própria \\
\hline Jataí & Tanque químico & Cabotagem, longo curso & 1979 & 4450 & Própria \\
\hline
\end{tabular}


3.PETRÓLEO BRASILEIRO S.A - PETROBRAS:

Tabela 4 - Fonte: Antaq (2010).

\begin{tabular}{|c|c|c|c|c|c|}
\hline Embarcação & Tipo & Tipo de navegação & Ano & Tpb & Situação \\
\hline Anchova & Lancha & $\begin{array}{c}\text { Apoio marítimo, apoio } \\
\text { portuário. }\end{array}$ & 1976 & 19 & Própria \\
\hline Apolo & Rebocador/empurrador & Apoio portuário & 1969 & & Própria \\
\hline Bonsucesso & Lancha & $\begin{array}{c}\text { Apoio marítimo, apoio } \\
\text { portuário. }\end{array}$ & 1975 & 19 & Própria \\
\hline Jupiter & Rebocador/empurrador & Apoio portuário & 1959 & 52,47 & Própria \\
\hline Jurupema & Petroleiro & Cabotagem & 1976 & 131105 & Própria \\
\hline Netuno & Rebocador/empurrador & Apoio portuário & 1959 & 52,47 & Própria \\
\hline Orion & Rebocador/empurrador & $\begin{array}{c}\text { Apoio marítimo, apoio } \\
\text { portuário. }\end{array}$ & 1969 & & Própria \\
\hline Pedreiras & Petroleiro & Cabotagem, longo curso. & 1985 & 55019 & Própria \\
\hline Piraí & Petroleiro & Cabotagem, longo curso. & 1990 & 66876 & Própria \\
\hline Pirajuí & Petroleiro & Cabotagem, longo curso. & 1987 & 66876 & Própria \\
\hline Procion & Rebocador/empurrador & Apoio portuário & 1977 & 455 & Própria \\
\hline Rigel & Rebocador/empurrador & Apoio marítimo, apoio & 1978 & & Própria \\
\hline pagitarius & Rebocador/empurrador & Apoio marítimo, apoio & 1978 & 455 & Própria \\
\hline Scorpium & Rebocador/empurrador & Apoio portuário & 1978 & 455 & Própria \\
\hline Tangará & Rebocador/empurrador & Apoio marítimo, apoio \\
portuário. & 1976 & 1920 & Própria \\
\hline Taurus & Rebocador/empurrador & $\begin{array}{c}\text { Apoio marítimo, apoio } \\
\text { portuário. }\end{array}$ & 1978 & 455 & Própria \\
\hline Vega & Rebocador/empurrador & Apoio portuário & 1972 & & Própria \\
\hline
\end{tabular}

\section{CONSIDERAÇÕES FINAIS}

As organizações estão mudando sua visão em relação às oportunidades que a logística oferece para distribuir seus produtos, e sabem que, na maioria das vezes têm que envolver todo o sistema, a fim de identificar qual será o seu ganho, para que todos reconheçam e optem pela melhor opção.

A presente pesquisa procurou mostrar a dificuldade que a cabotagem tem em reduzir custos e aumentar investimentos, sem perder a qualidade da prestação do serviço, minimizando riscos e permanecendo flexível, para sempre buscar a melhor opção, a mais rentável.

No caso da cabotagem de granéis líquidos é preciso um maior investimento da União, principalmente.

O cenário brasileiro na área de infra-estrutura de transporte de carga é e será um dos grandes entraves ao crescimento econômico do Brasil, se não forem tomadas providências imediatas pelas autoridades governamentais, no sentido de que sejam viabilizados recursos financeiros, ajustes na regulamentação e planejamento para a cadeia logística de infraestrutura do transporte de carga.

A cadeia logística está baseada em uma matriz de transporte (ferroviário, rodoviário e hidroviário) totalmente distorcida na utilização dos modais que a integram e, em particular, a participação da hidrovia é praticamente inexistente, o modal rodoviário está saturado e a malha ferroviária logo chegará ao limite de sua capacidade de transporte.

No que tange ao sistema hidroviário, que é o modal que proporciona, segundo parâmetros mundiais, o menor custo de frete, no Brasil esse modal não tem tido a menor prioridade pelas autoridades governamentais. Compete, portanto, ao modal rodoviário suprir as lacunas dos outros modais na matriz de transporte, fato este que proporciona uma distorção e a conseqüente falta de competitividade da cadeia logística de infraestrutura.

A utilização das vias hidroviárias aumentaria expressivamente a competitividade dos produtos transportados, pois o custo desse transporte é significativamente menor do que o de qualquer outro modal. Os principais 
entraves na utilização deste modal são: baixa capacidade dos comboios; baixa intermodalidade; imposto sobre operações intermodais; baixa utilização das margens dos reservatórios; regulamentação que prevê o uso múltiplo das águas garantindo confiabilidade ao modal; barreiras ambientais que impedem o desenvolvimento sustentável do transporte fluvial.

A Cabotagem está voltando a ser uma nova realidade como meio de transporte no país, em razão principalmente dos menores custos comparados aos modais rodoviário e ferroviário em transportes de grande distâncias. A movimentação na cabotagem vem crescendo lentamente nos últimos anos, e é um volume incipiente dentro da matriz de transportes.

Como sugestão e concluindo, pode-se afirmar que para alavancar um maior crescimento do setor, algumas medidas devem ser tomadas tais como:

\section{REFERÊNCIAS}

[1] Antaq - Agência Nacional de Transportes Aquaviários. Frotas. Disponível em:<http://www.antaq.gov.br/NovositeAntaq/Frota/ ConsultarFrotaGeral.aspx>. Acesso em: 11 de set. de 2010.

[2]

\section{- Frota por empresa. Disponíve} em:<http://www.antaq.gov.br/NovositeAntaq/Frota/ ConsultarFrotaPorEmpresa.aspx>. Acesso em: 11 de set. de 2010.

[3] Ballou, Ronald H. Logística Empresarial: transportes, administração de materiais e distribuição física. São Paulo: Atlas, 1998.

[4] Ching, Hong Yuh. Gestão de Estoques na Cadeia de Logística Integrada - Supply Chain. 1 ed. São Paulo: Atlas, 1999.

[5] Coppead - Instituto Coppead de Administração. Indicadores de portos e transporte aquaviário - parte 1. Coppead, 2004. Disponível em: <http://www.centrodelogistica.com.br/new/frindices.htm\#1>. Acesso em: 11 de set. de 2010.

[6] Dornier, Phillipe-Pierre; Ernest, Ricardo; Fender, Michel; Kouvelis, Panes. Logística e Operações Globais: texto e casos. São Paulo: Atlas, 2000

[7] Índice Fundamental de direito - DJI. Emenda Constitucional no 7, de 15 de agosto de
- por ser um modal que necessita da interação com os outros modais a revisão da Lei de Transporte Multimodal em todos os seus aspectos, é fundamental.

- avançar na proposição de soluções institucionais que viabilizem os ganhos de escala necessários a uma redução dos custos de movimentação e na burocracia portuária.

- desenvolver políticas que conduzam ao aumento da participação e da competitividade da frota mercante nacional, propiciando uma maior regularidade de linhas.

- o custo de operação dos navios brasileiros, ainda é elevado em relação aos padrões internacionais, para isso é necessário uma maior flexibilização dos recursos do Fundo de Marinha Mercante, hoje destinados exclusivamente à construção de navios, sendo esses recursos também utilizados para cobrir custos operacionais.

1995. Disponível em:

<http://www.dji.com.br/constituicao_federal/ec007. htm>. Acesso em: 11 de set. de 2010.

[8] Lopez, José. M. C. Os custos logísticos do comércio exterior brasileiro. São Paulo: Aduaneiras, 2000.

[9] Mello, Romeu Zarske de. Alternativas para o posicionamento estratégico das empresas de transporte rodoviário de cargas (etc) sob uma abordagem logística. Dissertação apresentada ao programa de Pós-Graduação em Engenharia de Produção da Universidade Federal de Santa Catarina: Florianópolis, 2001.

[10] Disponível em: <http://teses.eps.ufsc.br/defesa/pdf/1698.pdf>.

Acesso em: 11 de set. de 2010.

[11] Rodrigues, Paulo Roberto Ambrosio. Introdução aos sistemas de transporte no Brasil e à Logística Internacional. 3 ed. São Paulo: Aduaneira, 2004.

[12] Vermelho. Revista teórica, política e de informação. As reformas econômicas de FHC. Disponível em:

<http://www.vermelho.org.br/museu/principios/ante riores. asp?edicao=38\&cod_not=737> . Acesso em: 11 de set. de 2010. 


\section{Bapítulo 8}

\section{UTILIZACÃO DA TÉCNICA FMEA COMO FERRAMENTA DE IDENTIFICAÇÃO DE CAUSAS DE FALHAS}

\section{Gabriel Augusto Rodrigues de Freitas}

Rafael Cezar Menezes

Mario Santos de Oliveira Neto

Natali de Freitas Alves

Resumo: Nos dias atuais, para fazer frente a grande competitividade nos diversos segmentos industriais, tem sido objetivo das empresas buscar características que as diferenciem de outras empresas e tornem seus processos produtivos cada vez mais eficientes e com uma produtividade maior em relação à concorrência. Assim, o presente estudo pretende apresentar conceitos e formas da aplicação da ferramenta técnica FMEA (Análise dos Modos de Falha e Efeitos - Failure Modes and Effects Analysis), visando melhorar a eficiência produtiva a fim de eliminar problemas de falhas em produtos e serviços, com o intuito de que as empresas ganhem vantagem competitiva e confiabilidade. Dessa forma pretende-se analisar através do FMEA, as causas de falhas potenciais nos processos de produção e serviços. Para se avaliar quão criticas são as causas de uma possível falha é utilizado o RPN (Numero de Prioridade de Risco - Risk Priority Number), composto do produto dos três fatores do FMEA: ocorrência, detecção e severidade. Logo que se identifica o RPN, as causas das falhas são ranqueadas, direcionando a atuação do gestor.

Palavras-chave: Falhas, FMEA, Produção, RPN. 


\section{INTRODUÇÃO}

A competitividade acirrada das empresas em uma economia globalizada exige vencer desafios e reduzir a probabilidade de quebras ou falhas nos processos produtivos.

É importante gerenciamento constante dos processos produtivos, buscando melhor produtividade, qualidade, evitando a ocorrência de falhas e perdas desnecessárias nos referidos processos.

Este artigo mostra que a partir dos conceitos da técnica FMEA é possível identificar falhas criticas com maior risco ocorrência, possibilitando a empresa atacar as causas das falhas, a partir da experiência do autor como estagiário em uma empresa do ramo de óleo e gás fornecedora de produtos especializados, demonstrando a aplicação do FMEA como método de identificação de prioridade de falhas no processo de produção e exploração de petróleo em uma plataforma.

\section{REVISÃO DA LITERATURA}

\subsection{ANÁLISE DE FALHAS}

Com o advento da aplicação da Gestão de Qualidade Total (TQM) e suas ferramentas tornou-se possível amenizar a ocorrência de falhas na fabricação dos produtos. Utilizandose O TQM consegue-se diagnosticar os fatores que estão em desacordo com o que foi traçado, possibilitando sua correção (DELGADO, 1997). A ocorrência de problemas está relacionada ao desempenho dos processos de fabricação. Quando ocorrem é importante que sejam resolvidos com eficiência em menor tempo a fim de reduzir os custos envolvidos. A análise de falhas consiste em investigar acidentes que possibilitem a ocorrência dessas falhas (CALARGE; DAVANSO, 2003).

\subsection{FALHAS}

A forma de prevenir falha em qualquer processo é aprimorar o desempenho das operações. As falhas podem ser controladas, e servem de aprendizado para que as empresas possam melhorar seu comportamento (SLACK et al, 2009). As empresas precisam saber a diferença entre as falhas e prestar atenção às graves, pois são elas que podem prejudicar todo o resto da produção. As coisas falham por vários motivos dentro da operação produtiva: projetos malfeitos; instalações ou pessoal que falharam; falhas no material ou informações; ações dos clientes; e outras (SLACK et al, 2009). Nenhum processo é perfeito, falhas podem ocorrer, e sempre há a possibilidade de que alguma coisa pode dar errada e assim deve-se minimizar possíveis falhas no processo (SLACK et al, 2009).São inúmeras assim classificadas:

\section{- Falha de projeto}

Ocorre quando uma característica de demanda não foi bem observada ou foi mal calculada. Pode acontecer por uma empresa ter uma demanda maior do que a esperada e não poder atender, ou por ter uma demanda menor e ter produzido mais sem o interesse do consumidor. O projeto adequado identifica as circunstancias em que a produção deve trabalhar e faz projetos de acordo com o dia a dia (LIMA, 2014).

\section{- Falha de instalação}

Acontece por que todas as instalações de uma empresa podem quebrar e paralisar alguns setores importantes da produção, causando prejuízos. As avarias nessas instalações podem ser totais ou parciais e esse comportamento vai ditar o grau de seriedade da falha. Em qualquer caso, os efeitos dessa paralisação é que vai determinar sua importância. Algumas falhas tem impacto significativo caso ocorram simultaneamente a outras falhas (WILMER, 2016).

\section{- Falha de pessoal}

Pode ocorrer de dois tipos: erros e violações. Os erros são enganos de julgamento, ou seja, quando um funcionário deveria ter feito algo diferente daquilo que foi feito e o resultado é algum desvio significativo da produção normal. Por exemplo: quando a demanda por determinado produto aumenta em função de algum evento para o qual não se fez o devido estoque. A violação é um ato claramente contrário ao procedimento operacional definido (CORREA, 2007).

\section{- Falha de fornecedor}

Em que o prazo de entrega ou a qualidade dos bens e serviços são ruins. Uma produção que depende muito de fornecedores tem maior probabilidade de falhar, assim quanto mais uma produção 
depende de fornecedores de materiais ou serviços, tanto maior será a probabilidade de falha se houver atraso ou defeito no padrão do material ou serviço fornecido (WILMERS, 2016).

\section{- Falha de cliente}

Ocorre quando os clientes usam mal os produtos e serviços. A falta de atenção, a incompetência ou a falta de cuidado do cliente pode causar a falha. As grandes organizações estão aceitando que tem responsabilidade de educar e treinar os clientes para usar seus produtos mais complexos, diminuindo ou minimizando as chances de falha. Por esse motivo já se pode observar em caixas automáticos de bancos a sequência de perguntas projetada de forma a tornar sua operação tão isenta de falhas quanto possível. Entretanto a ocorrência de falhas tendo como primeira causa à falha humana nos leva ao conceito de falha de oportunidade, que consiste em procurarmos ver, como oportunidades de examinar, por que ocorreram essas falhas e implementar procedimentos que eliminem ou reduzam a probabilidade de ocorrerem novamente em vez de se procurar identificar um culpado ou responsável pela falha (WILMERS, 2016).

\subsection{MEDIÇÃO DE FALHA}

Segundo Pena (2003) e Weber (2003), existem três modos de medir falhas:

\section{- Taxa de falhas}

Frequência com que uma falha ocorre, é calculada como o número de falhas dividido pelo número total de produtos testados, ou pelo tempo de operação (BROWN, 1998).

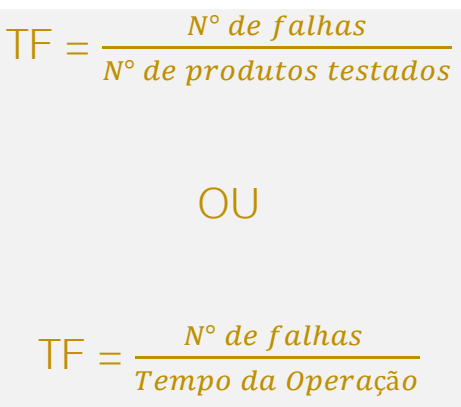

- Confiabilidade

A probabilidade de uma falha ocorrer, mede como um sistema, bem ou serviço se desempenha em um determinado período (MARCORIN E ABACKERLI, 1998).

\section{- Disponibilidade}

Período de tempo médio útil disponível para a operação entre falhas é dado pelas horas de operação dividida pelo número de falhas. A disponibilidade é o tanto que a produção está pronta para ser utilizada (SIMÕES FILHO, 2006).

. Análise dos modos de falha e efeitos

(FMEA - Failure mode and effect analysis)

Para Slack et al (2009) o FMEA é uma metodologia de Análise do Tipo e Efeito de Falha, ferramenta que busca por meio da análise das falhas potenciais e propostas de ações de melhoria evitar que ocorram falhas no projeto do produto ou do processo, identificando falhas antes que aconteçam, usando uma "lista de verificação" (Checklist) tabelas 1, 2 e 3:

- Qual é a probabilidade de ocorrer à falha?

- Qual seria a consequência da falha?

- Com qual probabilidade essa falha é detectada antes que afete o cliente? 
Tabela 1- Critério de análise e ranqueamento para a ocorrência de falha

\begin{tabular}{|lcc|}
\hline \multicolumn{1}{|c}{ Probabilidade de falha } & Possíveis taxas de falhas & Rank \\
\hline Extremamente alta: inevitáveis & $\geq 1 \mathrm{em} 2$ & 10 \\
\hline Muito alta & $1 \mathrm{em} 3$ & 9 \\
\hline Repetidas falhas & $1 \mathrm{em} 8$ & 8 \\
\hline Alta & $1 \mathrm{em} 20$ & 7 \\
\hline Moderadamente alta & $1 \mathrm{em} 80$ & 6 \\
\hline Moderada & $1 \mathrm{em} 400$ & 5 \\
\hline Relativamente baixa & $1 \mathrm{em} 2000$ & 4 \\
\hline Baixa & $1 \mathrm{em} 15000$ & 3 \\
\hline Remota & $1 \mathrm{em} 150000$ & 2 \\
\hline Quase impossível & $1 \mathrm{em} 1500000$ & 1 \\
\hline \hline
\end{tabular}

Fonte: Leal 2006

Tabela 2- Critério de análise e ranqueamento para a detecção da causa da falha

\begin{tabular}{|llc|}
\hline \multicolumn{1}{|c}{ Detecção } & \multicolumn{1}{c}{ Probabilidade de detecção da causa da falha } & Rank \\
\hline Absolutamen te incerta & $\begin{array}{l}\text { A manutenção não detecta a causa da falha potencial, ou não existe } \\
\text { manutença. }\end{array}$ & 10 \\
\hline Muito remota & Chancemuito remota de se detectar a causa da falha & 9 \\
\hline Remota & Chanceremota de se detectar a causa da falha & 8 \\
\hline Muito baixa & Chancemuito baixa dese detectar a causa da falha & 7 \\
\hline Baixa & Chancebaixa de se detectar a causa da falha & 6 \\
\hline Moderada & Moderada chance de se detectar a causa da falha & 5 \\
\hline Moderadamente alta & Moderadamente alta a chance de se detectar a causa da falha & 4 \\
\hline Alta & Chancealta de se detectar a causa da falha & 3 \\
\hline Muito alta & Chancemuito alta de se detectar a causa da fallha & 2 \\
\hline Quase certa & A manutenção quase certamen te detectará a causa da falha & 1 \\
\hline \hline
\end{tabular}

Fonte: Leal 2006

Tabela 3- Critério de análise e ranqueamento para a severidade da causa da falha

\begin{tabular}{|llc|}
\hline \multicolumn{1}{|c|}{ Efeito } & \multicolumn{1}{c|}{ Severidade do efeito } & Rank \\
\hline Perigoso & $\begin{array}{l}\text { Falha é perigosa, e ocorre sem aviso. Capaz de suspender a operação dos } \\
\text { sistemas e/ou en volve aspectos não complacentes com as regulações } \\
\text { gorven amentais }\end{array}$ & 10 \\
\hline Serio & $\begin{array}{l}\text { Os e feitos podem ser perigosos e/ou en volvem aspectos não complacentes } \\
\text { com regu lações governamentais }\end{array}$ & 9 \\
\hline Importante & Produto inoperável, com perda da função básica. Sistema in op erante. & 8 \\
\hline Impactante & Desempenho do produto sofre impacto. Sistema pode não operar. & 7 \\
\hline Significativo & $\begin{array}{l}\text { Desempenho do produto é degradado. Funções atreladas ao conforto podem } \\
\text { não operar. }\end{array}$ & 6 \\
\hline Moderado & Moderado efeito no desempenho do produto. Produto requer reparos. & 5 \\
\hline Baixo & Pequeno efeito no desempenho do produto. Produto não requer reparos. & 4 \\
\hline Desprezivel & Efeito desprezivel no desempenho do produto ou sistema. & 3 \\
\hline Muito desprezível & Efeito muito desprezivel no desempenho do produto ou sistema. & 2 \\
\hline Nenhum & Nenhum efeito. & 1 \\
\hline \hline
\end{tabular}

Fonte: Leal 2006 


\subsection{PREVENÇÃO DE FALHAS}

Para calarge e davanso (2003) pode-se previnir:

- Eliminando no projeto os pontos de falha potenciais;

- Construindo operações com recursos críticos parecidos na operação;

- Segundo os mesmos autores existem dispositivos que facilitam a prevenção de falhas, como:

- Sensores, feixes de luz, contadores digitais, ...;

- Gabaritos, Lista de verificação, ...

\subsection{TOLERÂNCIA DE FALHAS}

Qualquer produto pode conter falhas durante sua prestação. No entanto falhas mais graves podem gerar grandes prejuízos. Então, é necessária rápida detecção da falha e adotado procedimentos. A primeira fase na tolerância a falhas é a detecção de erros. Testes deverão ser executados para verificar suas ocorrências, a fim de tratamento adequado. Deste modo, fica claro que a eficiência de um esquema de tolerância a falhas está baseada na sua eficiência em detectar erros (WEBER, 2003).

\subsection{DETECÇÃO DE FALHAS}

A detecção da falha é a determinação de sua ocorrência; é a determinação de quais variáveis são mais relevantes no seu Diagnostico. Uma detecção prévia possibilita a prevenção de problemas, uma vez que o operador pode tomar decisões para evitar graves perturbações no processo. O diagnóstico determina o tipo, a localização, a magnitude e a duração da falha (MORAIS; ROLIM, 2004). Para Gusczak (2015) outros índices podem ser usados como balizadores:

- Números de componentes - quanto maior o número de componentes interdependentes de um sistema tanto menor será a confiabilidade.

- Tempo médio entre falhas:

$$
\text { TMEF }=\frac{\text { Hs de operaçoes }}{n \underline{0} \text { de Falhas }}
$$

- Disponibilidade: grau em que produção está pronta para funcionar.

$$
(D)=\frac{T M E F}{T M P R}
$$

Onde:

TMEF = tempo médio entre as falhas da produção

TMPR = tempo médio para reparo.

\subsection{ANÁLISE DE ÁRVORE DE FALHAS (FTA - FAULT TREE ANALYSIS)}

Procedimento lógico que começa com uma falha em potencial e trabalha para traz, com a finalidade de identificar todas as possíveis causas e, portanto, as origens dessa falha. A árvore e constituída de ramificações conectadas por dois tipos de nó E (que são as ramificações que precisam ocorrer para que o evento acima do nó ocorra), e as ramificações de nó OU (que são as ramificações que apenas uma precisa ocorrer para que o evento acima do nó ocorra) (MARTINS; LAUGENI, 2005) - figura 1.

Figura 1 - Diagrama FTA

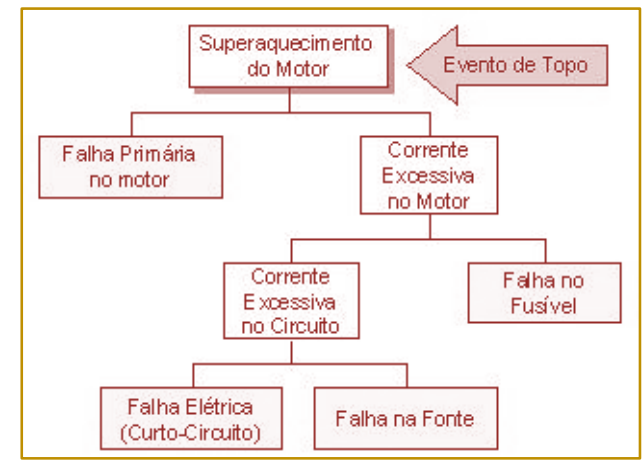

Fonte: Sergio Cutnei (2016) 


\subsection{MANUTENÇÃO}

Manutenção nada mais é do que a forma como as organizações tentam evitar as falhas cuidando de suas instalações físicas. É parte importante da maioria das atividades de produção. Ela é fundamental para dar confiabilidade aos equipamentos, uma vez que uma boa manutenção gera menos parada de maquinas (MORAIS et al, 2010).

\subsubsection{MANUTENÇÃO DE INSTALAÇÕES}

A manutenção de instalações tem por objetivo básico mantê-las operando nas condições para as quais foram projetadas, e também fazer com que retornem a tal condição, caso tenham deixado de exercê-la. As empresas estão dedicando cada vez mais atenção ao assunto, procurando novas técnicas de aumento de confiabilidade e melhorando a manutenção dos equipamentos. As atividades de manutenção de uma organização consistem na combinação de manutenção preventiva e corretiva, e mais recentemente os conceitos de manutenção preditiva e produtiva total (PASCHOAL, 2009).

\subsubsection{TIPOS DE MANUTENÇÃO}

\section{- Manutenção corretiva}

Recupera a capacidade produtiva de um equipamento que tenha perdido ou diminuído sua capacidade de produção. É realizada somente após a falha ter ocorrido. Sem dúvida, a mais usual entre nós (GUSCZAK, 2015). Segundo Viana (2002, p. 79) apud (FRAGOSO, 2011), a atividade para corrigir falhas decorrentes dos desgastes de máquinas ou equipamentos, consertos das partes que sofreram a falha: reparos, alinhamentos, balanceamentos, substituição de peças ou do próprio equipamento.

\section{- Manutenção preventiva}

Previne a ocorrência de um problema no processo através da realização de algumas atividades, como trocar peças, engraxar, limpar etc. A operação jamais poderá ser interrompida para manutenção sem a mesma ter sido programada. Deve-se estabelecer cronograma de manutenções (FERRAZ, 2011). Segundo Carvalho (2010), são vantagens:

- Criação de uma mentalidade preventiva na empresa;

- Aumento da vida útil do equipamento;

- Redução dos custos;

- Diminuição das interrupções do fluxo produtivo - programação de horários.

\section{- Manutenção preditiva}

Assim, segundo Martins e Laugeni (2005), "consiste em monitorar certos parâmetros ou condições de equipamentos e instalações de modo a antecipar a identificação de um futuro problema", realizando através da análise e acompanhamento de alguns aspectos ou condições de equipamentos e instalações preventivamente o problema para que não ocorra no futuro (PASCHOAL, 2009).

\section{- Manutenção produtiva total (TPM - Total Productive Maintenance)}

Vai muito além da forma de se fazer manutenção, ou seja, é uma filosofia gerencial que atua na forma organizacional, no comportamento das pessoas, no modo com que tratam os problemas, não só os de manutenção, mas todos ligados ao processo produtivo. O objetivo é atingir "zero falha ou quebra", buscando evitar que o equipamento quebre em operação. Não se preocupa somente com a melhoria dos equipamentos, mas principalmente com a melhoria das pessoas que são as responsáveis pela qualidade do produto (RIBEIRO, 2003) figura 2. 
Figura 2 - Pilares da TPM

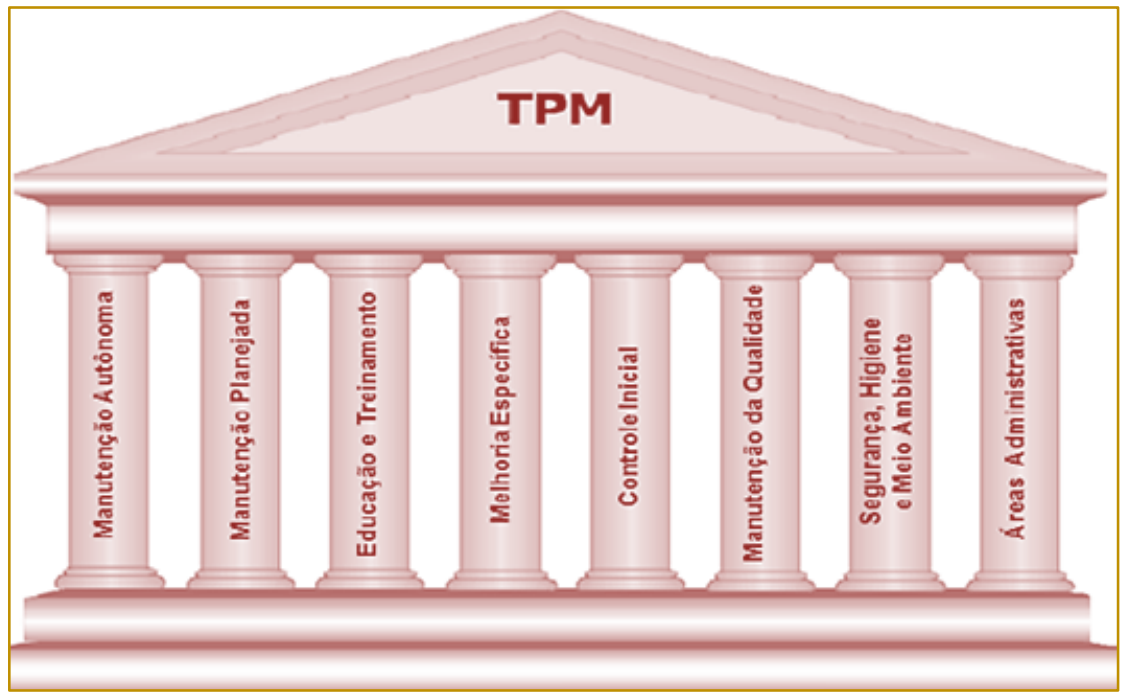

Fonte: Cézar (2014)

Alguns produtos podem chegar ao mercado apresentando falhas devido à falta de manutenção dos equipamentos que os produzem, bem como por falta de falta de treinamento dos colaboradores que os executam. É necessário equipamentos que favoreçam o desempenho das funções para fabricar um produto com a máxima qualidade (MARTINS; LAUGENI, 2005).

Normalmente, quanto mais manutenção, menor é a probabilidade de acontecerem falhas. A manutenção produtiva total é realizada por todos os funcionários de cada setor, o que ajuda a diminuir gastos e produzir bens de qualidade (TONDATO, 2004). Tem como metas:

- Melhorar a eficiência dos equipamentos;

- Realizar manutenção autônoma (em nível de consertos, prevenção e melhoria);

- Planejar manutenção, treinar pessoal em habilidades de manutenção;

- Conseguir comandar os equipamentos logo no inicio.

É um conceito surgido com a introdução dos métodos japoneses de melhoramento de produção, chamados de poka-yoke (sendo yokeru = prevenir e poka = erros $\mathrm{de}$ desatenção), está baseada no principio de que os erros humanos são inevitáveis até determinado grau. É importante prevenir esse tipo de erro antes que se tornem defeitos.
Dispositivos ou sistemas simples, preferencialmente baratos, incorporados em um processo para prevenir erros de falta de atenção dos operadores (JUNIOR, 2008). Para Silva (2005), são dispositivos como:

- Sensores / interruptores / feixes de luz em máquinas que somente permitem sua operação se a peça estiver posicionada corretamente;

- Gabaritos instalados em máquinas através dos quais uma peça deve passar para ser carregada ou tirada da maquina (orientação ou tamanho incorreto param o processo);

- Contadores digitais em máquinas para assegurar que o número correto de cortes, batidas ou furos tenha sido feito;

- Listas de verificação que devem ser preenchidas, seja para a preparação de uma atividade ou em sua conclusão.

- Exemplos de ações e mecanismos que auxiliam a prevenção de falhas pelo cliente:

- Travas na porta dos toaletes dos aviões, quando fechadas acendem a luz de aviso;

- Sinais sonoros nos caixas automáticos de banco (ATMS - automatic teller machines) avisam o cliente para assegurar a retirada do cartão; 
- Barras de leitura em atrações de parques de diversão ara assegurar que os clientes não excedam as limitações de altura;

\section{ESTUDO DE CASO}

Realizado a partir de um estudo de caso em uma empresa multinacional do seguimento de óleo e gás de grande porte na cidade do Rio de Janeiro-RJ, instalada em mais de 90 países sendo sua sede em Houston, TX USA. O tema abordado por esse artigo está diretamente ligado ao processo de produção de extração de petróleo em um campo de estação localizado no Campo de Peregrino, originário do bloco exploratório BM-C-7, da $2^{\underline{a}}$ rodada de licitações situado na poção sul da Bacia de Campos-RJ, a aproximadamente 85 $\mathrm{km}$ do município de Cabo Frio-RJ. Esse artigo apresenta a utilização da ferramenta FMEA para análise de falhas, para identificação da falha de maior prioridade para ações corretivas.

\subsection{CENÁRIO}

Faz-se necessário entender o processo de extração de petróleo. O processo de produção e extração de petróleo conta com uma estrutura formada por duas plataformas fixas amarradas ao um FPSO (navio flutuante de produção e armazenamento) através de linhas de escoamento e umbilicais elétricos, contando com 13 poços de produção em uma plataforma e 20 poços na outra. Uma das características desse campo explorado é que o seu óleo possui $1^{\circ}$ na escala API (American Petroleum Institute), o que faz que seja considerado o segundo óleo mais pesado já produzido no Brasil. Um óleo leve possui um grau de API maior que $30^{\circ}$; óleo médio grau entre $22^{\circ}$ e $30^{\circ}$; abaixo de $22^{\circ}$ são considerados óleos pesados. O valor do óleo no mercado é diretamente proporcional ao seu grau de API: quanto maior o grau API maior será o valor do produto no mercado.

\subsection{PROCEDIMENTO DE EXTRAÇÃO E PRODUÇÃO}

Para que uma elevação do óleo ocorra de forma natural é necessário que a pressão do reservatório seja maior que a pressão de superfície. Em razão do peso do óleo desse campo em especifico a pressão do reservatório é insuficiente para vencer o peso da coluna de fluidos, fazendo com que o gás/líquido não consiga submergir de forma natural, sendo necessária a adição de energia externa, nesse caso é a elevação artificial através do equipamento de bombeamento centrifugo submersível (BCS), que realiza a elevação artificial a partir da transmissão e transformação da energia elétrica em energia mecânica. Em seguida essa energia mecânica no motor, através da rotação, gera uma energia cinemática, criando um diferencial de pressão na região onde se encontra, fazendo com que aumente a pressão na região mais baixa resultando que os fluidos contidos nesse local se elevem até a superfície, onde o fluido é transportado pela linha de produção até uma estação coletora de óleo para armazenamento, e depois transportado para o refino.

\subsection{COMPONENTES DO SISTEMA BCS}

A elevação artificial através do BCS consiste em equipamentos de fundo e de superfície figura 3 :

\begin{tabular}{|c|c|}
\hline Fundo & Superfície \\
\hline - Motor Elétrico & - VSD (Variable Speed Drive) \\
\hline - Selo & - Transformador elevador \\
\hline - Admissão da Bomba & " Caixa de junção \\
\hline - Bomba Centrífuga de Múltiplos Estágios & - Cabos de alimentação de superfície \\
\hline - Cabo Elétrico de Subsuperfície & " Sistema de Superfície WellLift \\
\hline " Sensor de Fundo WellLift & \\
\hline
\end{tabular}


Figura 3 - Exemplo de sistema BCS - componentes básicos

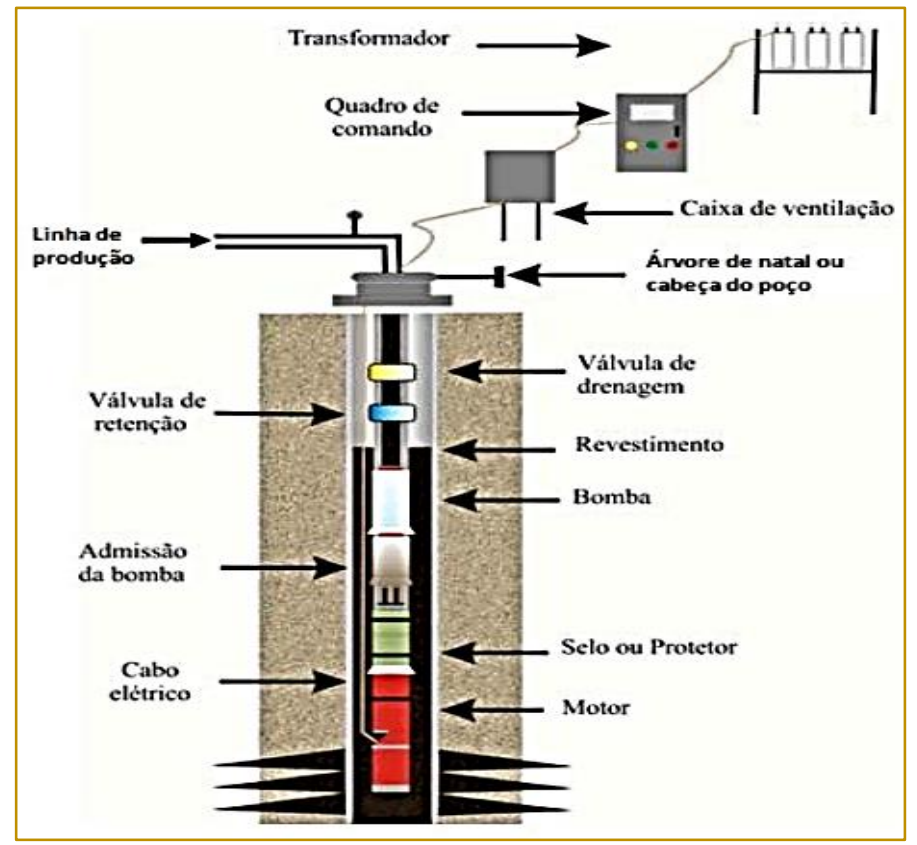

Fonte: Franca (2011)

Com a utilização dos variadores de frequência (VSD - Variable Speed Drive), que utilizam inversores PWM (Pulse Width Modulation) para variação da velocidade do motor, os equipamentos elétricos desse sistema estão sujeitos aos harmônicos de alta frequência que são transmitidos através dos longos cabos elétricos, podendo sofrer o fenômeno da reflexão de ondas viajantes (ressonância), o que acarretará sobretensões e sobrecorrentes causando uma diminuição da vida útil dos equipamentos - figura 4.

Figura 4 - variador de frequência (VSD)

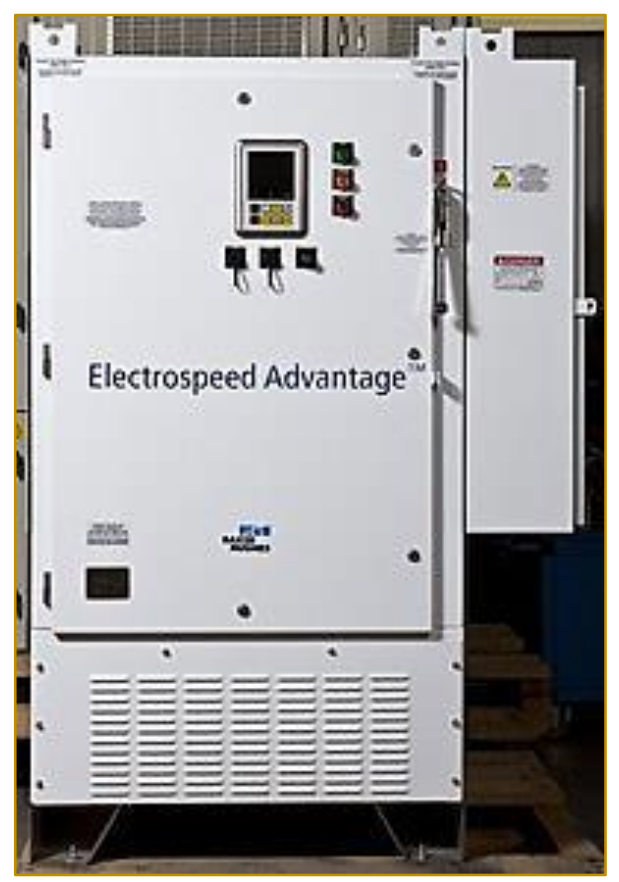

Fonte Baker Hughes (2013) 


\subsection{PROCEDIMENTO DE MONITORAMENTO E MANUTENÇÃO}

O processo de produção conta com um sistema de monitoramento e operação dos poços de produção que através do envio de dados dos parâmetros (pressão, temperatura, corrente) pelos sensores controla as variáveis de processo e armazena o registro histórico, sendo atualizado - figura 5.

Figura 5 - Monitoramento dos parâmetros do sistema BCS

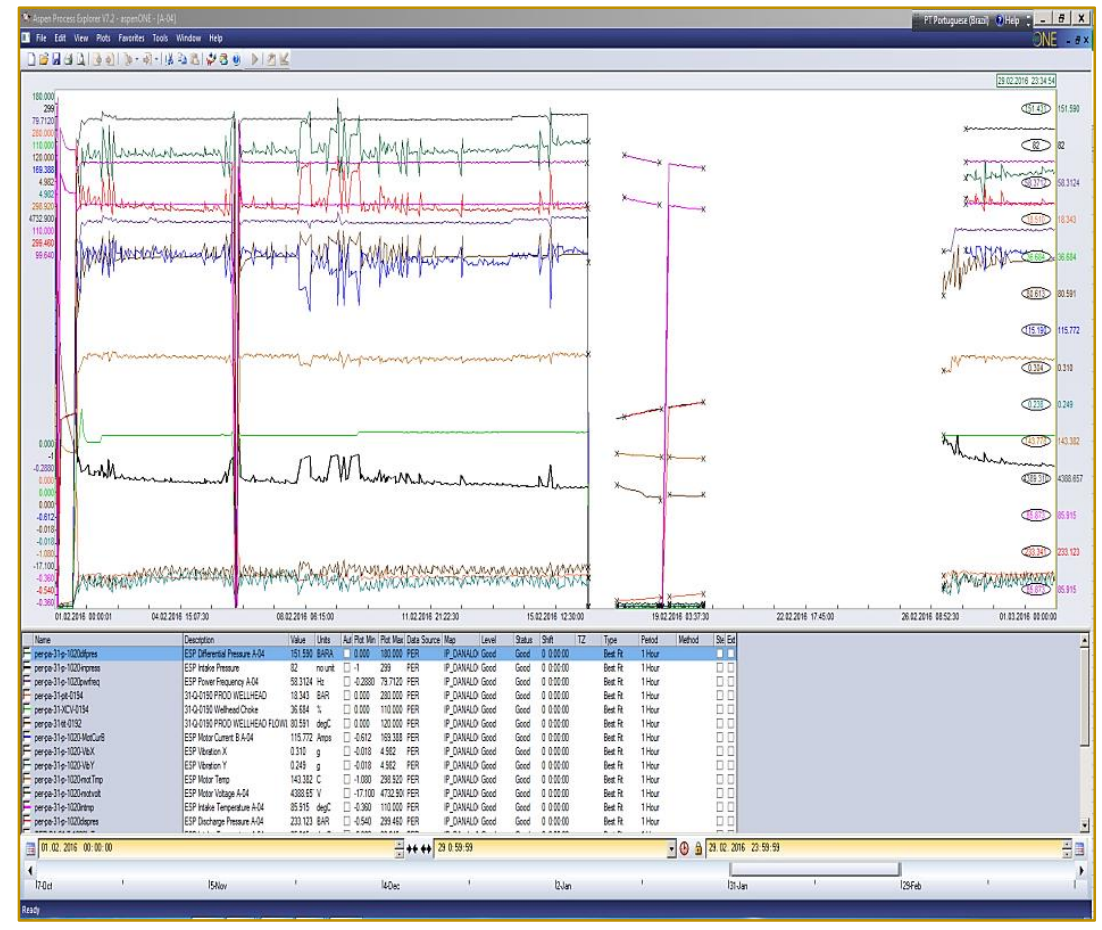

Fonte: AspenTech (2016)

O sistema BCS possui sensores e atuadores, dois transmissores de pressão, que enviam dados da pressão na cabeça do poço e da linha de produção, mais dois sensores no fundo do poço para monitorar a pressão e a temperatura abaixo do motor da bomba centrífuga. Com o monitoramento é possível planejar e realizar as manutenções preditivas e preventivas dos poços. Há planejamento de manutenção dos equipamentos para 3, 12, 24 e 36 meses que são realizadas de acordo com o aniversário de instalação do equipamento. É realizada uma parada anual de todos os seus processos de produção para realizar as manutenções de instalações e equipamentos, sendo possível analisar mais as falhas ocorridas.

\subsection{IDENTIFICANDO O PROBLEMA}

O processo de produção e extração de petróleo em um poço é um processo continuo, sendo apenas interrompido por gerenciamento da produção ou em caso de alarme de falha no sistema, exigindo do operador do sistema BCS gerar informe com as informações da causa da parada de produção para aplicação das medidas de proteção para o retorno da produção.

- Exemplo 1 - falha de plataforma ocorrida às 10:34h, onde é necessário paralisar a produção dos poços B-04, B-07, B-10, B-16, B-18, B-21, B-22 e B-27 devido a problemas na bomba de injeção de água.

Para toda parada é gerado relatório com os parâmetros do VSD informando a descrição da falha, a ação imediata tomada, análise da causa, ações propostas e comentários figura 6 . 
Figura 6 - Shutdown Report

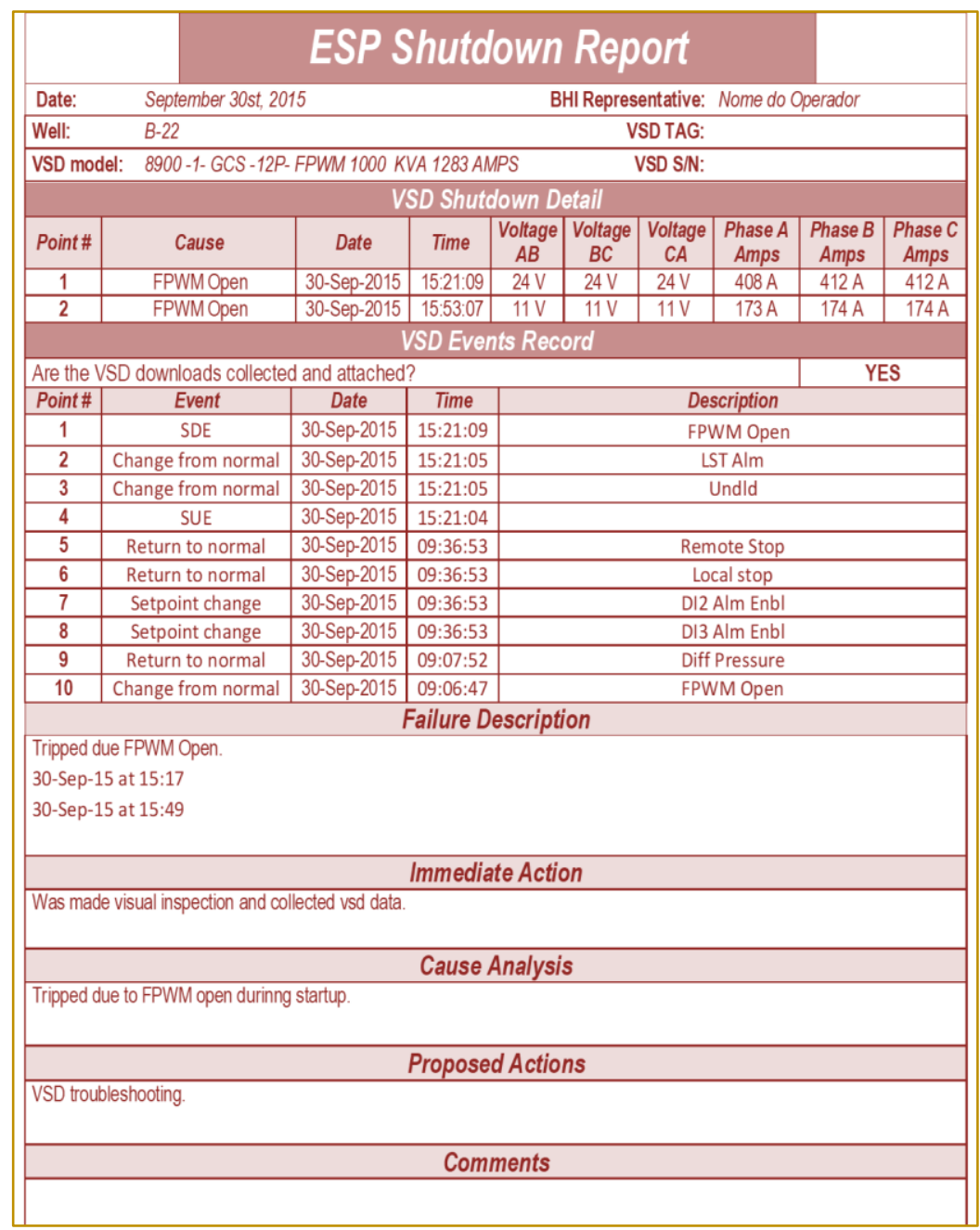

AspenTech (2016)

No período setembro/2015 - março/2016

plataformas, sendo 136 (12\%) por falha do foram aferidas 1.114 paradas nas duas sistema de BCS - tabelas 4 e 5.

Tabela 4 - Falhas de equipamento de fundo

\begin{tabular}{|c|c|c|}
\hline Tipo de Falha & Porcentagem & Quantidade \\
\hline Alta Temperatura do Motor $\left(160^{\circ} \mathrm{C}\right)$ & $0,1 \%$ & 1 \\
\hline Diff Pressure. & $1,6 \%$ & 18 \\
\hline Low Speed Trip & $0,7 \%$ & 8 \\
\hline Phase-Gound Fault & $0,2 \%$ & 2 \\
\hline Underload & $1,1 \%$ & 12 \\
\hline
\end{tabular}

AspenTech (2016) 
Tabela 5 - Falhas de equipamento de superfície

\begin{tabular}{|l|c|c|}
\hline \multicolumn{1}{|c|}{ Tipo de Falha } & Porcentagem & Quantidade \\
\hline Citibus Communication Fault & $0,2 \%$ & 2 \\
\hline FPWM Open. & $5,1 \%$ & 57 \\
\hline IOT & $0,6 \%$ & 7 \\
\hline Other Failure & $0,9 \%$ & 10 \\
\hline Over Voltage & $0,7 \%$ & 8 \\
\hline Overcurrent & $0,2 \%$ & 2 \\
\hline PCM Communication Error. & $0,2 \%$ & 2 \\
\hline Scada Stop & $0,2 \%$ & 2 \\
\hline Under Voltage & $0,3 \%$ & 3 \\
\hline VSD Failure - Scb & $0,2 \%$ & 2 \\
\hline \multicolumn{2}{|c|}{ AspenTech (2016) } \\
\hline
\end{tabular}

\section{CONCLUSÃO}

O estudo justifica a importância das medidas preventivas que devem ser tomadas para evitar a ocorrência de falhas nos sistemas tendo em vista o alto custo dos equipamentos e processos utilizados na produção e extração de petróleo. Foi possível constatar diversos tipos de falhas relacionadas ao sistema BCS.

A proposta da utilização da ferramenta FMEA no caso estudado visa identificar as causas raízes das falhas e reduzir as chances de ocorrência, aumentando a confiabilidade dos processos e dos produtos já estão em operação.

A ferramenta se mostra importante na percepção das causas das falhas já ocorridas para evitar que novas falhas ocorram,

\section{REFERÊNCIAS}

[1] Brown, Anthony EP. Analise de

Risco. Boletim Técnico do GSI/NUTAU/USP, Ano

III, n. 01, 1998.

http://www.Imc.ep.usp.br/grupos/gsi/wp-

content/boletim/3-1.doc

[2] Calarge, F.; Davanso, J. Conceito de dispositivos à prova de erros utilizados na meta do zero defeito em processos de manufatura. Revista de Ciência \& Tecnologia, v. 11, n. 21, p. 7-18, 2003.

https://www.researchgate.net/profile/Felipe_Calarg e/publication/237758382_Conceito_de_Dispositivos _Prova_de_Erros_Utilizados_na_Meta_do_Zero_D efeito_em_Processos_de_Manufatura_The_Concep t_of_Mistake_Proofing_Devices_Employed_in_Zero _Defect_Target_on_Manufacturing_Processes/links/ 548f6f5a0cf214269f263bd1.pdf priorizando as ações corretivas e preventivas necessárias.

Por meio da análise do modo de falha é possível perceber como elas ocorrerem nos componentes de um equipamento, sistema ou processo, tornando capaz de prever essas falhas e efeitos, sendo possível criar oportunidade de gerar mudanças para aumentar a probabilidade para funcionamento de forma adequada e segura, aumentando a produtividade.

Com O FMEA pretende-se melhorar processos, sistemas e equipamentos, antecipar a identificação e eliminação de erros, reduzir ou eliminar probabilidade de um mesmo tipo de falha ocorrer futuramente e aumentar a satisfação e confiabilidade da empresa cliente.

[3] Correa, Cármen R.; Cardoso Junior, Moacyr Machado. Análise e classificação dos fatores humanos nos acidentes industriais. Associação Brasileira de Engenharia de Produção, v. 17, n. 1, 2007. http://dx.doi.org/10.1590/S010365132007000100013

http://www.scielo.br/scielo.php?script=sci_arttext\& pid=S0103-65132007000100013

[4] Carvalho, Paulo Sérgio Silva. Vantagens da manutenção preventiva: um estudo de caso na empresa produtora da cal Tecnocal Ltda. em Arcos-MG. 2010. http://bibliotecadigital.uniformg.edu.br:21015/jspui/ bitstream/123456789/102/1/PauloSergioSCarvalhoEP.pdf

[5] Delgado, Joaquim Duarte Barroca. Sensibilização para a importância da Qualidade no 
mercado

actual. Millenium,

1997

http://repositorio.ipv.pt/handle/10400.19/750

[6] Ferraz, Guilherme Heinrik Fernandes Batista. Análise crítica de contratos técnicos como ferramenta para melhoria da gestão da manutenção. 2011 http://repositorio.unesp.br/handle/11449/119024

[7] Fragoso, Alexsandro. Campus de Curitiba Curso de Engenharia Elétrica. http://nupet.daelt.ct.utfpr.edu.br/tcc/engenharia/do c-equipe/2011_2_11/2011_2_11_monografia.pdf

[8] Gusczak, Ricardo et al. Universidade do Estado de Santa Catarina-Udesc Centro de Ciências Tecnológicas-CCT Engenharia de produção e Sistemas. http://www.producao.joinville.udesc.br/tgeps/tgeps/ 2015-1/RICARDO\%20GUSCZAK.pdf

[9] Junior, Eudes Luiz Costa. Gestão do processo produtivo. Editora Ibpex, 2008.

[10] Leal, Fabiano; DE PINHO, Alexandre Ferreira; de almeida, Dagoberto Alves. Análise de Falhas através da Aplicação do Fmea e da Teoria Grey failure Analysis through Fmea Application and Grey Theory. Revista Gestão Industrial, v. 2, n. 01 , p. 79-88, 2006

[11] Lima, Willian Teixeira. Desperdício no Processo de Produção do Pão Francês. 2014 http://201.59.77.242/biblioteca/pdf_monografias/ad ministracao/2014/7541.pdf

[12] Marcorin, Adílson José e Abackerli, Alvaro J. Revista de Ciência \& Tecnologia • V. 11, № 20 pp. 23-28. 1998.

http://www.unimep.br/phpg/editora/revistaspdf/rct2 Oart03

[13] Martins, Petrônio G; Laugeni, Fernando P. Administração da Produção. São Paulo: Saraiva, $2^{\underline{a}}$ ed., 2005. Autor(es): Rosemary Martins

[14] Morais, Danielle Costa; Cavalcante, Cristiano A. Virgínio; Almeida, Adiel Teixeira de. Priorização de áreas de controle de perdas em redes de distribuição de água. Pesquisa Operacional, v. 30, n. 1, p. 15-32, 2010. http://dx. doi.org/10.1590/S0101-

74382010000100002

http://www.scielo.br/pdf/pope/v30n1/02.pdf

[15] Morais, Diego Roberto; Rolim, Jacqueline G. Ferramenta inteligente para detecção de falhas incipientes em transformadores baseada na análise de gases dissolvidos no óleo isolante. 2004. Tese de Doutorado. Universidade Federal de Santa Catarina, Centro Tecnológico. Programa de Pós- graduação em Engenharia Elétrica. http://www.cpdee.ufmg.br/ joao/CE/Trabalho/Trab alho2011/ProblemaCromatografia/TESE_UFSC.pdf

[16] Paschoal, Débora Rodrigues de Souza et al. Disponibilidade e Confiabilidade: Aplicação da gestão da manutenção na busca de maior competitividade. Revista da Engenharia de Instalações no mar da FSMA no, v. 3, p. 1, 2009.

[17] http://www.salesiana.edu.br/EP/Artigos/RE V_ENG_3_artigo_3.pdf

[18] Pena, Miguel Carlos Medina. Falhas em transformadores de potência: Uma contribuição para análise, definições, causas e soluções. 2003. Tese de Doutorado. Universidade Federal de Itajubá.

http://saturno.unifei.edu.br/bim/0031227.pdf

[19] Ribeiro, Celso R. Processo de Implementação da Manutenção Produtiva Total (TPM) na Indústria Brasileira. Taubaté: UNITAU, Departamento de Economia, Contabilidade e Administração, 2003.

http://ppga.com.br/mba/2003/gpt/ribeirocelso_ricardo.pdf

[20] Slack, Nigel; Chambers, Stuart; Johnston, Robert. Administração da produção. Atlas, 2009.

[21] SILVA, Débora Eleonora Pereira da et al. Proposta para desenvolvimento de dispositivos de prevenção contra falhas em serviços, 2005. http://ri.ufs.br:8080/bitstream/123456789/353/1/Pro postaDesenvolvimentoDispositivos.pdf

[22] Simões Filho, Salvador. Análise de árvore de falhas considerando incertezas na definição dos eventos básicos. 2006. Tese de Doutorado. UNIVERSIDADE FEDERAL DO RIO DE JANEIRO. http://wwwp.coc.ufrj.br/teses/doutorado/inter/2006/ Teses/FILHO_SS_06_t_D_int.pdf

[23] Tondato, Rogério. Manutenção produtiva total: estudo de caso na indústria gráfica. 2004. http://www.lume.ufrgs.br/bitstream/handle/10183/51 67/000466112. pdf?sequence $=1$

[24] Weber, Taisy Silva. Tolerância a falhas: conceitos e exemplos. Apostila do Programa de Pós-Graduação-Instituto de Informática-UFRGS. Porto Alegre, 2003.

http://mo409a.googlecode.com/svnhistory/r22/trunk/ConceitosDependabilidade.pdf

[25] Wilmers, Rodolpho Antonio Mendonça. Administração das Operações Produtivas. http://unipvirtual.com.br/material/Recuperacao/Ead/ Administracao_Operacoes_Produtivas/geral_doc.d oc. 


\section{Gapítulo 9}

\section{CARACTERIZACẼOO DO RELACIONAMENTO INTERORGANIZACIONAL ENTRE CONSTRUTORAS E FORNECEDORES DE MATERIAIS DE CONSTRUÇÃO \\ Jefferson Augusto Krainer \\ Christiane Wagner Mainardes Krainer \\ Cezar Augusto Romano}

Resumo: A construção civil opera em uma cadeia de suprimentos com diversos fornecedores, logo um melhor relacionamento interorganizacional torna-se fundamental para a formação de parcerias duradouras evitando a interrupção de abastecimento de materiais, propiciando ganhos de produtividade, diminuindo a informalidade, reduzindo custos e desperdícios. O presente artigo tem como caracterizar o relacionamento interorganizacional entre construtoras e fornecedores de materiais de construção. Foi realizada uma pesquisa aplicada, descritiva e quantitativa em 100 empresas do setor da construção civil (50 construtoras e 50 fornecedores), sendo os resultados analisados por meio de estatística descritiva. 0 estudo evidencia que os elementos chave (confiança e cooperação, relacionamento de longo prazo e compartilhamento de informações) não estão presentes de forma efetiva e intensa. O relacionamento construtora/ fornecedores, normalmente estabelecido por meio de contratos de longo prazo, encontra-se em estágio competitivo, de nível comercial e de fornecimento comum. Não há formação de parcerias, mas, tão somente, um bom relacionamento comercial.

Palavras-Chave: Construção civil, Cadeia de suprimentos, Relacionamento interorganizacional, Fornecedores, Construtoras 


\section{INTRODUÇÃO}

A indústria da Construção Civil (CC) caracteriza-se por apresentar uma cadeia produtiva complexa, heterogênica, formada por um conjunto de atividades com graus diferentes de dificuldades, interligados por diversos produtos e processos tecnológicos variados (MELLO; AMORIM, 2009).

A cadeia de suprimentos da CC é caracterizada pela fragmentação, instabilidade, projetos únicos, e por ser composta por um sistema de múltiplas empresas ligadas comercialmente com o fim de realizar um empreendimento (ISATTO, 2005). O fato da indústria da CC ser fragmentada gera problemas de eficiência, como a falta de coordenação e integração entre as variadas faces funcionais da cadeia de suprimentos, em função da separação entre o projeto e a construção do empreendimento (XUE et al., 2005). Logo, o modo como são assumidos os processos de aquisição e de integração de fornecedores é fundamental para obtenção de resultados positivos, aumento da produtividade e para a redução de custos unitários (VRIJHOEF; KOSKELA, 2000; CHRISTOPHER, 2012).

Vale ressaltar que a indústria da CC opera em uma cadeia produtiva com muitos fornecedores, de forma que as relações interorganizacionais são uma realidade e impactam no desempenho das empresas da cadeia (ISATTO, 2005). O funcionamento em conjunto dos agentes envolvidos na cadeia de suprimentos garante a plena e correta execução das atividades dentro do canteiro de obras. Segundo Bandeira et al. (2009), a realização de parcerias duradouras evita a interrupção de abastecimento de materiais, diminui o risco de atrasos e multas contratuais, além de tornar a empresa confiável e de qualidade. Santos (2006) elenca três elementos chaves para a formação de parcerias: confiança e cooperação, relacionamento de longo prazo e compartilhamento de informações.

Para Isatto (2005), a cooperação entre empresas possibilita a realização de ações conjuntas e a transação de recursos para alcançar objetivos organizacionais. A cooperação é fundamental nos processos de inovação, obtenção de tecnologia e de abertura para mercados diferenciados, pois permite o acesso a complementação da produção, a recursos, o que pode reduzir riscos e/ou criar vantagem competitiva
(GUERRINI; VERGNA, 2011).

Dessa forma, pesquisas focadas no relacionamento interorganizacional entre construtoras e os fornecedores de insumos, como a presente, justificam-se pela necessidade da melhoria na coordenação e fluxo de matérias primas no processo produtivo da construção civil, propiciando ganhos de produtividade, mudança de paradigmas, propagação de tecnologia, diminuição da informalidade, redução de custos e desperdícios. Nesse contexto, esta pesquisa tem por objetivo caracterizar o relacionamento interorganizacional entre construtoras e fornecedores de materiais de construção.

\section{REVISÃO BIBLIOGRÁFICA}

Para Isatto (2005), a cadeia de suprimentos de um empreendimento de construção se desenvolve da mesma forma que o empreendimento, com início e fim bem definidos, o que dificulta a reprodução do arranjo de empresas da cadeia no futuro, tornando-a única.

Vrijhoef e Koskela (2000) acrescentam que a cadeia de suprimentos da construção civil é:

a) Convergente: os suprimentos convergem para o canteiro de obras;

b) Temporária: as organizações que se formam para a realização de um empreendimento único não costumam perdurar para o empreendimento seguinte e podem assumir uma configuração diferente da anterior;

c) Make-to-order. cada projeto cria um produto único e com pouca repetição.

Segundo Christofpher (2012), a gestão da cadeia de suprimentos, com foco nas relações, na confiança, no reconhecimento e na cooperação, é essencial para a busca por resultados positivos, aumento da produtividade, eficiência e redução de custos unitários. Afinal, o objetivo da gestão da cadeia de suprimentos é a eficiência em termos de produção e de custos para todo o sistema desde a produção das matérias primas até a distribuição dos produtos acabados (SIMCHI-LEVI et al., 2010). Além disso, a indústria da CC opera em uma cadeia produtiva com muitos fornecedores, serviços de comercialização e manutenção, logo as relações interorganizacionais são uma realidade no setor e com grande impacto no desempenho das empresas da cadeia 
(BANDEIRA et al., 2009).

Considerando que uma empresa, em geral, participa de mais de um tipo de operação, Fusco e Sacomano (2009), a partir da adaptação do modelo de Sharpe (1970), classificam os fornecedores de uma determinada organização em três níveis:

- Parceiro: valor envolvido alto, com risco alto;
- Preferencial: valor envolvido e risco médio;

- Comercial: valor envolvido e risco baixo.

Os tipos de relacionamentos clientes $x$ fornecedores sugeridos por Fusco e Sacomano (2009), com base no valor envolvido e no nível de risco, estão representados na Figura 1

Figura 1 - Relacionamento clientes $\mathrm{x}$ fornecedores

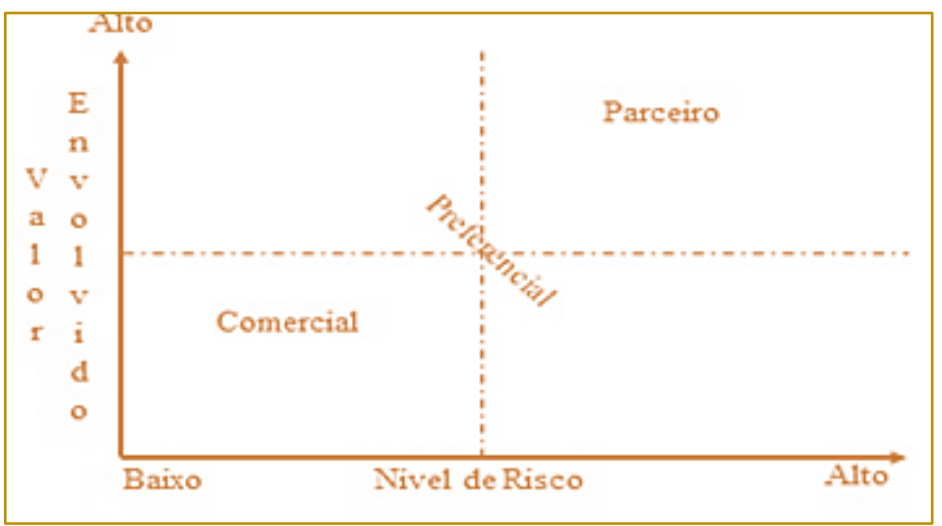

Fonte: Fusco e Sacomano (2009)

Santos (2006) reforça a importância da busca de parcerias entre os elementos da cadeia e que essa ação deveria ser constante dentro das empresas. A autora explica que a principal razão para isso é que a criação de parcerias tem como consequência um representativo impacto positivo na competitividade para ambos os agentes envolvidos.

Merli (1994) aborda três níveis de relacionamento operacional em razão do grau de desenvolvimento do que ele denomina comakership ou relacionamento de parceria, na qual as ações são tomadas em conjunto:

- Classe III (fornecedor comum): negociações estabelecidas com base em especificações de qualidade mínima; estoques de segurança; preços; lotes individuais a curto prazo; e inspeções sistemáticas dos suprimentos;

- Classe II (fornecedor "integrado" ou comakership "operacional"): qualidade garantida e autocertificada com base em critérios preestabelecidos; melhora sistemática da qualidade e dos preços dos produtos fornecidos; reabastecimento automático e sem estoque intermediário; ajuste dos preços baseado em critérios concordados; fornecimentos frequentes em pequenos lotes para pedidos "em aberto"; relacionamento de longo prazo e com revisões periódicas; responsabilidades globais pelos produtos fornecidos; ausência de inspeção de recebimento; e consultoria e treinamento dos fornecedores;

- Classe I (fornecedor comaker ou parceiro): comakership global com características de parceria; atividades operacionais da classe II; cooperação no projeto de novos produtos/tecnologias; investimentos comuns em planejamento e desenvolvimento e em realizações tecnológicas; e intercâmbio contínuo de informação sobre os processos e produtos.

Segundo Li et al. (2001) há quatro estágios de parceria, conforme ilustrado na Figura 2. 
Figura 2 - Estágios de Parceria

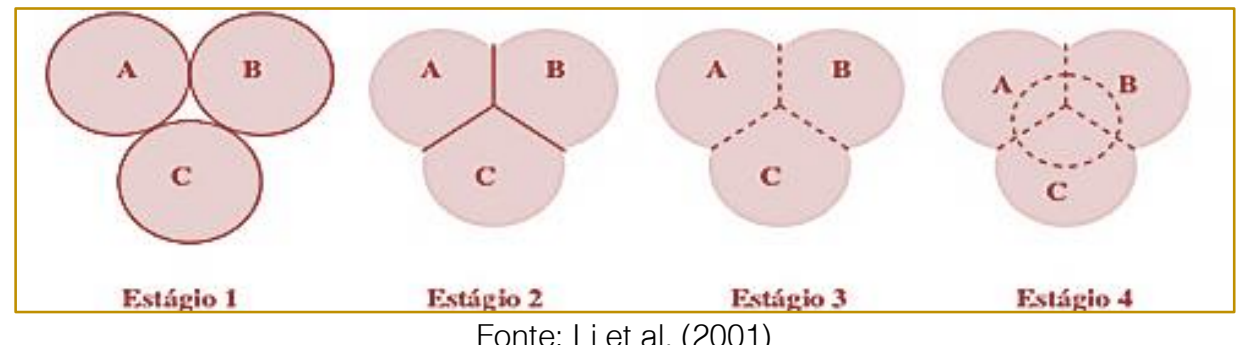

Fonte: Li et al. (2001)

- Estágio 1 (competitivo): as três empresas parceiras ( $A, B$, e C) estão em contato entre si em um único ponto. Elas não estão em busca de comprometimento e há um alto grau de confrontação, o que poderá resultar em disputas e conflitos. A parceria existe apenas para atender a exigências de contrato. É o caso mais comum em parcerias na construção civil;

- Estágio 2 (orientado para a cooperação): há uma maior comunicação e interação entre as partes devido à mudança de formato das organizações para se adaptarem ao empreendimento. Ainda assim, as fronteiras continuam impermeáveis e inflexíveis;

- Estágio 3 (integrado): intensificam-se ainda mais as comunicações e interações, havendo troca de conhecimentos e de recursos entre os parceiros;

- Estágio 4 (cooperação estratégica): forma-se uma aliança estratégica que promove uma comunicação efetiva, troca de conhecimentos, acesso a tecnologia e a recursos. Cria-se uma parceria baseada na confiança e no comprometimento.

Santos (2006) aponta três elementos chaves para a formação de parcerias: confiança e cooperação, relacionamento de longo prazo e compartilhamento de informações. Quando presentes estes elementos, reforça a autora, a probabilidade de um resultado positivo, como a ampliação do nível de valor agregado e a redução do desperdício, é maior.

A confiança se baseia na crença de que as partes têm o acordo de não agir em oposição aos interesses em comum (NEVES; GUERRINI, 2010).

A cooperação é essencial nos processos de inovação, aquisição de tecnologia e de abertura para mercados diferenciados, pois possibilita o acesso à complementação da produção, a recursos e a produtos, o que permite a redução de riscos e/ou em vantagens competitivas (GUERRINI; VERGNA, 2011). Neves e Guerrini (2010) afirmam ser necessário estrutura de informação, com métodos de criação, administração e comunicação, para que haja cooperação entre empresas.

O elemento relacionamento de longo prazo também garante maior confiança; é normalmente estabelecido por meio de contratos. Os contratos, além de consolidarem a confiança, permitem uma visão estratégica compartilhada e uma maior colaboração entre as empresas, pois um bom comprador trabalhará junto com o seu fornecedor, e vice-versa, para que ambos permaneçam fortes financeiramente (PURDY; SAFAYENI, 2000). Santos (2006) aduz que as relações de longo prazo permitem a elaboração de uma visão estratégica compartilhada e são estabelecidas por acerto de contratos de longo prazo, com renovação automática conforme $\mathrm{O}$ atingimento de resultados esperados.

O terceiro elemento chave para a formação de parcerias é o compartilhamento de informações, que pode se dar desde as especificações de produtos e projetos, planejamento e programações de compras, até o acesso total a uma base de dados dos clientes e/ou dos fornecedores. Tal elemento impulsiona a integração interorganizacional, na medida em que pode viabilizar a transferência de know-how e a realização conjunta de treinamentos e reuniões entre compradores e fornecedores (PURDY; SAFAYENI, 2000).

\section{METODOLOGIA}

Para o alcance do objetivo deste trabalho levou-se em consideração as percepções de dois agentes da cadeia de suprimento da 
construção civil: os fornecedores e as construtoras. Realizou-se uma pesquisa aplicada, descritiva e quantitativa. Os dados foram coletados em 50 construtoras e 50 empresas fornecedoras do setor da construção civil brasileira.

Optou-se por uma amostragem não probabilística, por conveniência, selecionando-se membros (construtoras) acessíveis da população (empresas que retornaram ao apelo da pesquisa). O mesmo se deu (amostragem não probabilística) com relação à coleta de dados junto aos fornecedores, logo, a presente pesquisa não pode ser considerada como representativa da população, as extrapolações e generalizações não são possíveis.

Como instrumento de coleta de dados foi aplicado um questionário subdividido em duas partes:

a) Perfil da organização e do entrevistado (9 questões fechadas de múltipla escolha);

b) Identificação dos elementos que constituem o relacionamento construtora-fornecedor (20 questões fechadas de múltipla escolha).

O questionário foi desenvolvido com base no referencial teórico pesquisado, tendo como fonte diretiva os trabalhos de Santos (2006) e de Bandeira et al. (2009).

Para transformar as variáveis qualitativas em quantitativas utilizou-se da escala de diferencial semântica que compreende um par de adjetivos ou frases antônimas. Os entrevistados distribuíram as respostas em uma escala de 1 a 7 pontos. Segundo Hair Jr et al. (2005), o número de categorias mais apropriado é de no máximo 7 níveis.

Os resultados foram analisados descritivamente, de forma comparativa, com vistas a identificar características relacionadas à gestão da cadeia de suprimentos das empresas construtoras e das fornecedoras.

Para facilitação da análise foram aplicadas medidas que resumem ainda mais os dados obtidos, apresentando valores que sejam representativos da série toda. Empregou-se dois tipos de medidas: as de posição central e as de dispersão. As medidas de posição utilizadas são: moda, mediana e média aritmética, e a medida de dispersão aplicada foi o desvio padrão. Um desvio padrão $<1$ significa que as respostas são coerentes e para um desvio $>3$, há uma alta variabilidade nas respostas (HAIR JR. et al.,2005).

\section{ANÁLISE DE RESULTADOS}

Primeiramente, a amostra foi identificada (empresas pesquisadas e pessoas respondentes). Compuseram a amostra 50 empresas construtoras e 50 empresas fornecedoras do ramo da construção civil. O Quadro 1 resume as características das organizações pesquisadas, retratando as respectivas ocorrências de destaque (em percentual). 
Quadro 1 - Perfil das empresas pesquisadas

\begin{tabular}{|c|c|c|c|}
\hline \multicolumn{2}{|c|}{ Perfil da Empresa Construtora } & \multicolumn{2}{|c|}{ Perfil da Indústria Fornecedora } \\
\hline Características & $\%$ & Características & \\
\hline \multirow{8}{*}{ Localidade } & Curitiba - 64\% & \multirow{8}{*}{ Localidade } & Curitiba $-46 \%$ \\
\hline & Pinhais - 6\% & & $\begin{array}{l}\text { Londrina }-8 \% \text {, Pinhais }-4 \% \text {, } \\
\text { Maringá }-2 \%\end{array}$ \\
\hline & São José dos Pinhais - 4\% & & $\begin{array}{l}\text { Almirante Tamandaré, Colombo - } \\
2 \%\end{array}$ \\
\hline & Campo Grande - 8\% & & Campo Largo, Campo Magro - 2\% \\
\hline & Bombinhas, Cascavel - $2 \%$ & & $\begin{array}{l}\text { Piraquara, São José dos Pinhais - } \\
2 \%\end{array}$ \\
\hline & $\begin{array}{l}\text { Campina Grande, Itapema, } \\
\text { Londrina }-2 \%\end{array}$ & & $\begin{array}{l}\text { Tijucas, Joinville - } 6 \% \text {, Caçador, } \\
\text { Bombinhas }-2 \%\end{array}$ \\
\hline & Passos, Brasília - 2\% & & Tambaú, Criciúma - 2\% \\
\hline & Rondonópolis, São Paulo - 2\% & & $\begin{array}{l}\text { São Paulo - 4\%, Porto Alegre, } \\
\text { Taboão da Serra - } 2 \%\end{array}$ \\
\hline \multirow{5}{*}{ Fundação } & Até 5 anos $-12 \%$ & \multirow{5}{*}{ Fundação } & Até 5 anos $-12 \%$ \\
\hline & Entre 5 e 10 anos - $16 \%$ & & Entre 5 e 10 anos - $22 \%$ \\
\hline & Entre 10 e 20 anos - 34\% & & Entre 10 e 20 anos - $28 \%$ \\
\hline & Mais de 20 anos - 32\% & & Mais de 20 anos $-36 \%$ \\
\hline & Não responderam - 6\% & & Não responderam - 2\% \\
\hline \multirow{4}{*}{$\begin{array}{l}\text { Tipo de } \\
\text { administração }\end{array}$} & Familiares - 38\% & \multirow{4}{*}{$\begin{array}{l}\text { Tipo de } \\
\text { administração }\end{array}$} & Familiares - 28\% \\
\hline & Profissionais - 40\% & & Profissionais - 58\% \\
\hline & Mista - 20\% & & Mista - 14\% \\
\hline & Outro $-2 \%$ & & Outro - 0\% \\
\hline \multirow{6}{*}{$\begin{array}{l}\text { Tipo de } \\
\text { constituição }\end{array}$} & Sociedade Limitada - $76 \%$ & \multirow{6}{*}{$\begin{array}{l}\text { Tipo de } \\
\text { constituição }\end{array}$} & Sociedade Limitada - 70\% \\
\hline & Capital Misto - 8\% & & Capital Misto - 0\% \\
\hline & SA Capital Aberto - 4\% & & SA Capital Aberto - $6 \%$ \\
\hline & SA Capital Fechado - 4\% & & SA Capital Fechado - 24\% \\
\hline & Outro $-6 \%$ & & Outro - 0\% \\
\hline & Não responderam - $2 \%$ & & Não responderam - 0\% \\
\hline \multirow{5}{*}{$\begin{array}{l}\text { Número de } \\
\text { funcionários }\end{array}$} & Até 19 funcionários - 52\% & \multirow{5}{*}{$\begin{array}{l}\text { Número de } \\
\text { funcionários }\end{array}$} & Até 19 funcionários - 12\% \\
\hline & Entre 20 e 99 funcionários - 22\% & & Entre 20 e 99 funcionários - 32\% \\
\hline & Entre 100 e 499 funcionários - 8\% & & $\begin{array}{l}\text { Entre } 100 \text { e } 499 \text { funcionários - } \\
20 \%\end{array}$ \\
\hline & Mais de 500 funcionários - $6 \%$ & & Mais de 500 funcionários - 26\% \\
\hline & Não responderam - 12\% & & Não responderam - 10\% \\
\hline \multirow{6}{*}{ Certificação } & Nenhuma - 54\% & \multirow{6}{*}{ Certificação } & Nenhuma - 58\% \\
\hline & PBPQ-H - 24\% & & PBPQ-H - 6\% \\
\hline & ISO $9001-28 \%$ & & ISO $9001-28 \%$ \\
\hline & ISO $14000-2 \%$ & & ISO $14000-10 \%$ \\
\hline & Outros - $2 \%$ & & Outros - 10\% \\
\hline & Não responderam - 4\% & & Não responderam - 0\% \\
\hline
\end{tabular}

Extrai-se dessa primeira aproximação que a maioria das organizações pesquisadas situam-se em Curitiba (64\% das construtoras e $46 \%$ dos fornecedores); têm mais de 5 anos de fundação (82\% e 86\%); tratam-se de sociedades limitadas (76\% e 70\%). Nota-se, também, que as construtoras são administradas tanto por familiares (38\%), quanto por profissionais (40\%) e os fornecedores, por profissionais (58\%); as construtoras (52\%) têm até 19 funcionários e os fornecedores (32\%) têm de 20 a 99 funcionários; as construtoras dispõem de
PBQP-H (24\%) ou não dispõem de nenhuma certificação (54\%) e os fornecedores detêm ISO 9001 (28\%) ou nenhuma certificação $(58 \%)$

Com relação aos respondentes, do que se infere do Quadro 2, a maioria pertence ao departamento de engenharia $(50 \%$ - nas construtoras) ou de vendas (44\% - nos fornecedores). Esclareça-se que os vendedores das empresas fornecedoras são trabalhadores especializados, em geral, engenheiros ou administradores de empresa. 
Quadro 2 - Perfil dos respondentes

\begin{tabular}{|l|c|l|c|}
\multicolumn{2}{c|}{ Perfil do Respondente } & \multicolumn{2}{c|}{ Perfil do Respondente } \\
\hline Direção & $\%$ & Cargo /Função & $\%$ \\
\hline Coordenação & $42 \%$ & Direção & $20 \%$ \\
\hline Gerência & $10 \%$ & Coordenação & $8 \%$ \\
\hline Engenheiro(a) & $28 \%$ & Gerência & $32 \%$ \\
\hline Técnico & $50 \%$ & Engenheiro(a) & $4 \%$ \\
\hline Compras & $2 \%$ & Vendedor & $44 \%$ \\
\hline Supervisores/mestre & $18 \%$ & Analista & $2 \%$ \\
\hline
\end{tabular}

$\mathrm{Na}$ sequência, deu-se início à análise descritiva propriamente dita. O Quadro 3 apresenta os resultados obtidos (medidas de localização e de dispersão) em relação às perguntas aplicadas as construtoras (P1 a P20).

Quadro 3 - Resultados obtidos - construtoras

\begin{tabular}{|c|c|c|c|c|c|}
\hline $\mathrm{P}$ & Pergunta & Média & Moda & Mediana & $\begin{array}{l}\text { Desvio } \\
\text { Padrão }\end{array}$ \\
\hline & $\begin{array}{l}\text { Qual o grau de comprometimento do fornecedor na participação e } \\
\text { contribuição no ciclo de desenvolvimento de seus próprios produtos? }\end{array}$ & 4,76 & 5 & 5 & 1,41 \\
\hline 2 & Há relacionamento operacional com os seus fornecedores? & 3,54 & 3 & 3,5 & 1,54 \\
\hline & $\begin{array}{l}\text { Qual o nível de confiança da empresa em relação a seus } \\
\text { fornecedores? }\end{array}$ & 5,72 & 6 & 6 & 0,83 \\
\hline 4 & $\begin{array}{l}\text { Qual a expectativa de que os seus fornecedores cumpram com o que } \\
\text { foi combinado? }\end{array}$ & 5,88 & 6 & 6 & 0,96 \\
\hline 5 & A relação entre a empresa e os fornecedores é duradoura? & 5,66 & 6 & 6 & 1,26 \\
\hline & $\begin{array}{l}\text { Há renovação automática de contrato de fornecimento quando se } \\
\text { atinge o desempenho e objetivo esperado? }\end{array}$ & 4,22 & 6 & 5 & 2,19 \\
\hline 7 & Há previsão de novos contratos com os seus atuais fornecedores? & 5,50 & 6 & 6 & 1,15 \\
\hline 8 & $\begin{array}{l}\text { Os seus fornecedores incentivam e investem no desenvolvimento de } \\
\text { novas tecnologias? }\end{array}$ & 4,70 & 5 & 5 & 1,45 \\
\hline 9 & $\begin{array}{l}\text { Os fornecedores têm acesso a formação de custos dos seus produtos } \\
\text { (empreendimentos)? }\end{array}$ & 2,88 & 1 & 2,5 & 1,77 \\
\hline 10 & $\begin{array}{l}\text { A empresa pressiona seus fornecedores para um aumento da } \\
\text { qualidade? }\end{array}$ & 5,30 & 6 & 6 & 1,54 \\
\hline 11 & $\begin{array}{l}\text { Como a empresa se percebe no que diz respeito a poder de barganha } \\
\text { sobre seus fornecedores? }\end{array}$ & 4,80 & 6 & 5 & 1,23 \\
\hline 12 & $\begin{array}{l}\text { O fornecedor oferece uma política de preço diferenciada para a } \\
\text { empresa? }\end{array}$ & 5,16 & 6 & 5 & 1,09 \\
\hline 13 & Seus fornecedores interferem nos programas de produção? & 3,32 & 2 & 3 & 1,79 \\
\hline 14 & $\begin{array}{l}\text { A empresa possui acordos de exclusividade de fornecimento nos seus } \\
\text { empreendimentos? }\end{array}$ & 2,84 & 1 & 2 & 2,06 \\
\hline 15 & $\begin{array}{l}\text { A empresa possui fornecedores que representam igual ou mais de } \\
50 \% \text { dos custos de fornecimento da empresa? }\end{array}$ & 3,54 & 1 & 4 & 2,22 \\
\hline 16 & $\begin{array}{l}\text { A empresa exige de seus fornecedores certificação de qualidade de } \\
\text { seus produtos e/ou processos? }\end{array}$ & 4,74 & 5 & 5 & 1,59 \\
\hline 17 & $\begin{array}{l}\text { Os fornecedores têm autonomia para a entrega de materiais sem } \\
\text { pedidos? }\end{array}$ & 1,48 & 1 & 1 & 1,07 \\
\hline 18 & $\begin{array}{l}\text { O fornecedor participa de reuniões com o corpo técnico e o setor de } \\
\text { suprimentos da empresa? }\end{array}$ & 3,18 & 1 & 3 & 1,83 \\
\hline 19 & $\begin{array}{l}\text { A empresa realiza processos seletivo para escolha de seus } \\
\text { fornecedores? }\end{array}$ & 4,04 & 5 & 4 & 1,69 \\
\hline 20 & $\begin{array}{l}\text { A empresa realiza processo de avaliação de desempenho de seus } \\
\text { fornecedores (insumos)? }\end{array}$ & 4,46 & 6 & 5 & 1,74 \\
\hline
\end{tabular}


$\mathrm{Na}$ visão das construtoras o relacionamento delas com os fornecedores tem as seguintes características de destaque: baseia-se na expectativa de que os fornecedores cumpram com o combinado $(5,88)$; nível de confiança moderado $(5,72)$; relação duradoura $(5,66)$; previsão de aquisição de novos contratos $(5,50)$; e política diferenciada de preço ofertada pelo fornecedor $(5,16)$.

Entretanto, as construtoras relatam que: exercem pressão sobre os fornecedores para aumento de qualidade (5,30); celebram poucos acordos de exclusividade de fornecimento (2,84); e não costumam compartilhar a informação de custo de seus produtos/empreendimentos $(2,88)$. Importante destacar que as construtoras oferecem aos fornecedores pouca autonomia para a entrega de materiais sem pedido para ressuprimento ou manutenção de estoque mínimo $(1,48)$.

Outros pontos a destacar são: pouca participação do fornecedor em reuniões do setor de suprimentos com o corpo técnico da empresa $(3,18)$; baixo nível de relacionamento operacional, tais como: consultorias, treinamentos, transferência de know-how, eventos de integração e troca de informações $(3,54)$; processos de seleção e de avaliação de fornecedores pouco desenvolvidos (4,04 e 4,46, respectivamente).

Os resultados obtidos, bem como as medidas de localização e dispersão, referente ao questionário aplicado nos fornecedores está apresentado no Quadro 4.

\section{Quadro 4 - Resultados Obtidos - Fornecedores}

\begin{tabular}{|c|c|c|c|c|c|}
\hline $\mathrm{P}$ & Pergunta & Média & Moda & Mediana & \begin{tabular}{|l|} 
Desvio \\
Padrão
\end{tabular} \\
\hline 1 & $\begin{array}{l}\text { Qual o grau de comprometimento da empresa na participação e } \\
\text { contribuição no ciclo de desenvolvimento dos produtos de seus clientes/ } \\
\text { construtoras? }\end{array}$ & 6,10 & 7 & 6,5 & 1,23 \\
\hline 2 & Há relacionamento operacional com os clientes/construtoras? & 5,34 & 7 & 6 & 1,57 \\
\hline 3 & $\begin{array}{l}\text { Qual o nível de confiança da empresa em relação a seus } \\
\text { clientes/construtoras? }\end{array}$ & 6,36 & 7 & 7 & 0,85 \\
\hline 4 & $\begin{array}{l}\text { Qual a expectativa de que os seus clientes/construtoras cumpram com o } \\
\text { que foi combinado na parceria? }\end{array}$ & 6,52 & 7 & 7 & 0,89 \\
\hline 5 & A relação entre a empresa e os clientes/construtoras é duradoura? & 6,28 & 7 & 7 & 0,96 \\
\hline 6 & $\begin{array}{l}\text { Há renovação automática de contrato de parceria quando se atinge o } \\
\text { desempenho e objetivo esperado? }\end{array}$ & 4,62 & 7 & 5,5 & 2,49 \\
\hline 7 & Há previsão de novos contratos com os seus parceiros? & 5,84 & 7 & 6 & 1,3 \\
\hline 8 & $\begin{array}{l}\text { Os seus parceiros incentivam e investem no desenvolvimento de novas } \\
\text { tecnologias? }\end{array}$ & 4,90 & 6 & 5 & 1,58 \\
\hline 9 & Os clientes têm acesso a formação de custos dos seus produtos? & 2,52 & 1 & 1 & 2,16 \\
\hline 10 & $\begin{array}{l}\text { Há uma pressão por parte de seus clientes/construtora para um aumento } \\
\text { da qualidade? }\end{array}$ & 3,72 & 1 & 3 & 2,08 \\
\hline 11 & $\begin{array}{l}\text { Como a empresa se percebe no que diz respeito a poder de barganha } \\
\text { quanto ao seu cliente (comprador)? }\end{array}$ & 4,40 & 4 & 4 & 1,48 \\
\hline 12 & $\begin{array}{l}\text { Existe uma política de preço diferenciada para clientes/construtoras que } \\
\text { mantem parceria com a empresa? }\end{array}$ & 6,06 & 7 & 7 & 1,41 \\
\hline 13 & Seus parceiros interferem nos programas de produção? & 3,42 & 1 & 4 & 2,08 \\
\hline 14 & $\begin{array}{l}\text { A empresa possui acordos de exclusividade de fornecimento nos } \\
\text { empreendimentos de seus clientes/construtoras? }\end{array}$ & 2,76 & 1 & 2 & 2,22 \\
\hline 15 & $\begin{array}{l}\text { A empresa possui clientes parceiros que representem igual ou mais de } \\
50 \% \text { do faturamento da empresa? }\end{array}$ & 3,70 & 1 & 3,5 & 2,36 \\
\hline 16 & Os seus parceiros exigem certificação de qualidade da sua empresa? & 4,42 & 7 & 5 & 2,04 \\
\hline 17 & A empresa tem autonomia para a entrega de materiais sem pedidos? & 2,48 & 1 & 1 & 2,15 \\
\hline $1 \varepsilon$ & $\begin{array}{l}\text { A empresa participa de reuniões com o corpo técnico e o setor de } \\
\text { suprimentos do cliente/construtor? }\end{array}$ & 4,04 & 5 & 4 & 1,86 \\
\hline & $\begin{array}{l}\text { A empresa participa de processos seletivos realizados por } \\
\text { clientes/construtores? }\end{array}$ & 26 & 5 & 4 & 1,85 \\
\hline 20 & O cliente/construtor avalia o desempenho da empresa? & 4,80 & 5 & 5 & 1,74 \\
\hline
\end{tabular}


Semelhante aos resultados obtidos com as construtoras, porém com maior intensidade, o relacionamento do fornecedor com seus clientes/construtoras tem as seguintes características: baseia-se na expectativa de que as construtoras cumpram com o combinado (6,52); nível de confiança moderado-alto $(6,36)$; e relação duradoura $(6,28)$.

Os fornecedores afirmam ter: elevado comprometimento, participação e contribuição no ciclo de desenvolvimento dos produtos dos clientes/construtoras $(6,10)$; política diferenciada de preço $(6,06)$; previsão de celebração de novos contratos $(5,84)$; um ambiente de cooperação operacional com seus clientes/construtoras (5,34); e sofrer pouca pressão por aumento de qualidade
$(3,72)$.

Os fornecedores firmam poucos acordos de exclusividade com os clientes/construtoras $(2,76)$ e não costumam compartilhar a informação de custos de seus produtos $(2,56)$. Por fim, importante salientar que as construtoras franqueiam aos fornecedores pouca autonomia na entrega de materiais sem pedido para ressuprimento ou manutenção de estoque mínimo $(2,48)$.

No Quadro 5 apresenta-se as diferenças das médias e desvios padrão das respostas dos construtores e dos fornecedores para cada pergunta do questionário. O sinal negativo significa que a média das respostas das construtoras foi inferior à média dos fornecedores.

Quadro 5 - Diferenças entre os resultados das construtoras e fornecedores

\begin{tabular}{|c|c|c|c|c|c|}
\hline \multirow[b]{2}{*}{$P$} & \multicolumn{2}{|c|}{ Construtoras } & \multicolumn{2}{|c|}{ Fornecedores } & \multirow[b]{2}{*}{ Diferença } \\
\hline & Média & $\begin{array}{l}\text { Desvio } \\
\text { Padrão }\end{array}$ & Média & $\begin{array}{l}\text { Desvio } \\
\text { Padrão }\end{array}$ & \\
\hline 1 & 4,76 & 1,41 & 6,10 & 1,23 & $-1,34$ \\
\hline 2 & 3,54 & 1,54 & 5,34 & 1,57 & $-1,80$ \\
\hline 3 & 5,72 & 0,83 & 6,36 & 0,85 & $-0,64$ \\
\hline 4 & 5,88 & 0,96 & 6,52 & 0,89 & $-0,64$ \\
\hline 5 & 5,66 & 1,26 & 6,28 & 0,96 & $-0,62$ \\
\hline 6 & 4,22 & 2,19 & 4,62 & 2,49 & $-0,40$ \\
\hline 7 & 5,50 & 1,15 & 5,84 & 1,30 & $-0,34$ \\
\hline 8 & 4,70 & 1,45 & 4,90 & 1,58 & $-0,20$ \\
\hline 9 & 2,88 & 1,77 & 2,52 & 2,16 & 0,36 \\
\hline 10 & 5,30 & 1,54 & 3,72 & 2,08 & 1,58 \\
\hline 11 & 4,80 & 1,23 & 4,40 & 1,48 & 0,40 \\
\hline 12 & 5,16 & 1,09 & 6,06 & 1,41 & $-0,90$ \\
\hline 13 & 3,32 & 1,79 & 3,42 & 2,08 & $-0,10$ \\
\hline 14 & 2,84 & 2,06 & 2,76 & 2,22 & 0,08 \\
\hline 15 & 3,54 & 2,22 & 3,70 & 2,36 & $-0,16$ \\
\hline 16 & 4,74 & 1,59 & 4,42 & 2,04 & 0,32 \\
\hline 17 & 1,48 & 1,07 & 2,48 & 2,15 & $-1,00$ \\
\hline 18 & 3,18 & 1,83 & 4,04 & 1,86 & $-0,86$ \\
\hline 19 & 4,04 & 1,69 & 4,26 & 1,85 & $-0,22$ \\
\hline 20 & 4,46 & 1,74 & 4,80 & 1,74 & $-0,34$ \\
\hline
\end{tabular}

As maiores médias (Quadro 05) referem-se ao nível de confiança (P3), à expectativa no cumprimento de acordos (P4) e ao tempo de duração da relação (P5). As menores médias observadas relacionam-se ao acesso na formação dos custos (P9), aos acordos de exclusividade de fornecimento (P14), e à autonomia dos fornecedores na entrega de materiais sem pedidos (P17).

Note-se (Quadro 05) que há diferença nas respostas das construtoras e dos fornecedores, retratando que os agentes têm percepções diferentes sobre seu relacionamento. O Quadro 6 sintetiza as principais diferenças de percepções. 
Quadro 6 - Resultados da análise descritiva

\begin{tabular}{|c|c|c|c|c|}
\hline Pergunta & Resultados da análise descritiva & Construtora & Fornecedor & Diferença \\
\hline \multirow[b]{2}{*}{ P2 } & $\begin{array}{l}\text { Fornecedores afirmam ter } \\
\text { relacionamento moderado a intenso. }\end{array}$ & \multirow[b]{2}{*}{3,54} & \multirow[b]{2}{*}{5,34} & \multirow[b]{2}{*}{1,80} \\
\hline & $\begin{array}{l}\text { A maioria das construtoras afirmam } \\
\text { relacionamento operacional baixo a } \\
\text { mediano. }\end{array}$ & & & \\
\hline \multirow{2}{*}{ P10 } & $\begin{array}{l}\text { Fornecedores relatam sofrer pouca } \\
\text { pressão (grau } 2 \text { e 3) para aumento } \\
\text { de qualidade }\end{array}$ & \multirow{2}{*}{5,30} & \multirow{2}{*}{3,72} & \multirow{2}{*}{1,58} \\
\hline & $\begin{array}{l}\text { Construtoras relatam fazer pressão } \\
\text { de moderada a elevada para } \\
\text { aumento de qualidade. }\end{array}$ & & & \\
\hline \multirow{2}{*}{ P1 } & $\begin{array}{l}\text { Fornecedores se declararam muito } \\
\text { comprometidos. }\end{array}$ & \multirow{2}{*}{4,76} & \multirow{2}{*}{6,10} & \multirow{2}{*}{1,34} \\
\hline & $\begin{array}{l}\text { Construtoras declaram que o } \\
\text { comprometimento é moderado. }\end{array}$ & & & \\
\hline \multirow{2}{*}{ P12 } & $\begin{array}{l}\text { Fornecedores afirmam ter política de } \\
\text { preço muito diferenciada. }\end{array}$ & \multirow{2}{*}{5,16} & \multirow{2}{*}{6,06} & \multirow{2}{*}{0,90} \\
\hline & $\begin{array}{l}\text { Construtoras, em sua maioria, } \\
\text { atribuíram grau variando de } 4 \text { a } 6 \text {. }\end{array}$ & & & \\
\hline \multirow{2}{*}{ P18 } & $\begin{array}{l}\text { Fornecedores declaram participar } \\
\text { com frequência de reuniões. }\end{array}$ & \multirow{2}{*}{3,18} & \multirow{2}{*}{4,04} & \multirow{2}{*}{0,86} \\
\hline & $\begin{array}{l}\text { Construtoras declaram que } \\
\text { fornecedores participam pouco. }\end{array}$ & & & \\
\hline
\end{tabular}

A maior discordância entre os respondentes é a existência de relacionamento operacional. Os fornecedores dizem atender às necessidades operacionais de seus clientes, enquanto a construtora sinaliza em sentido contrário (Quadro 6). Aliás, a relação operacional entre fornecedores e construtoras também demonstra fragilidade quanto à autonomia para entrega de materiais sem pedido (geralmente inexistente), à pouca celebração de contratos de exclusividade e ao acesso restrito aos custos de produção de ambos os agentes.

As construtoras afirmam fazer pressão moderada a elevada, porém os fornecedores afirmam sofrer pouca pressão para aumento da qualidade. Vale ressaltar que $58 \%$ dos fornecedores pesquisados não têm nenhum tipo de certificação de qualidade.

Outro ponto de discordância relaciona-se à confiança e à cooperação. Diferente do que para as construtoras, os fornecedores referem maior nível de confiança. Além disso, os fornecedores consideram-se muito comprometidos, porém as construtoras percebem fornecedores medianamente comprometidos. Logo, as construtoras, menos confiantes, não percebem a cooperação e o envolvimento que os fornecedores, mais confiantes, afirmam ter.

Quanto ao relacionamento de longo prazo, os respondentes sinalizam para uma relação duradoura, apesar dos resultados indicarem insatisfação das construtoras no que se refere aos serviços e produtos oferecidos pelos fornecedores. Em contrapartida, ainda que insatisfeitas, a existência de processos medianamente desenvolvidos de seleção e de avaliação dos fornecedores, a não intensificação das renovações automática de contratos e o não predomínio de acordos de exclusividade no fornecimento de materiais, contrapõem-se à consolidação da confiança e à extensão da cooperação desejadas numa parceria. Afinal, relacionamento de longo prazo consolidam a confiança, viabilizam uma maior colaboração entre as organizações, permitem a renovação automática de contratos e garantem a plena e correta execução das atividades do canteiro de obras (PURDY; SAFAYENI, 2000; SANTOS, 2006).

Por fim, as empresas pesquisadas apresentam baixa frequência de reuniões e interação, relacionamento operacional ineficaz e falta de transparência quanto a formação de custos. Logo, a relação construtora/fornecedor também não atende ao elemento compartilhamento de informação 
na formação de parceria proposto por Santos (2006).

\section{CONSIDERAÇÕES FINAIS}

A presente pesquisa teve por finalidade caracterizar 0 relacionamento interorganizacional entre construtoras e fornecedores de materiais de construção.

O estudo evidencia que os elementos chave propostos por Santos (2006) - confiança e cooperação, relacionamento de longo prazo e compartilhamento de informações - não estão presentes de forma efetiva, intensa, assim não há formação de parcerias.

Dentre os quatro estágios de parceria de Li et al. (2001), as empresas pesquisadas enquadram-se, na sua maioria, no estágio competitivo (estágio 1). As relações são pontuais, descompromissadas e a parceria existe apenas para atender a exigências de contrato.

Por apresentarem, em geral, valor envolvido e risco baixos, os fornecedores pesquisados classificam-se como de nível comercial, em conformidade com a tipologia de Fusco e Sacomano (2009)

As negociações entre construtora/fornecedor

\section{REFERÊNCIAS}

[1] Bandeira, Renata Albergaria de Mello, MELLO, Luiz Carlos Brasil de Brito e MAÇADA, Antonio Carlos Gastaud. Relacionamento interorganizacional na cadeia de suprimentos: um estudo de caso na indústria da construção civil. Produção, São Paulo, v. 19, ํo2, p. 376-387, 2009.

[2] Christopher, Martin. Logística e Gerenciamento da Cadeia de Suprimentos. 4 ed. São Paulo: CENGAGE Learning, 2012.

[3] Fusco, José Paulo Alves, SACOMANO, José Benedito. Alianças em redes de empresas. São Paulo: Arte \& Ciência, 2009.

[4] Guerrini, Fábio Müller, Vergna, José Rafael Gatti. Um modelo de atores e recursos para redes de cooperação entre empresas em obras de edificações. Produção, São Paulo, v. 21, nำ 1, p. 14-26, 2011

[5] Hair JR, Joseph F., Babin, Barry, Money, Arthur H. e Samouel, Phillip. Fundamentos de métodos de pesquisa em administração. Porto Alegre: Bookman, 2005. são estabelecidas com base em especificações de qualidade mínima, preços, lotes individuais de curto prazo e há inspeções sistemáticas dos suprimentos, logo, de acordo a classificação de Merli (1994), o nível de comakership das empresas pesquisadas é de Classe III (fornecedor comum).

Do que se percebe, o relacionamento interorganizacional entre as construtoras e os fornecedores pesquisados encontra-se no primeiro estágio evolutivo da classificação dos autores consultados nesta pesquisa. Não há, portanto, formação de parcerias, mas, tão somente, um bom relacionamento comercial entre as organizações.

As construtoras e os fornecedores costumam manter um relacionamento de longo prazo, normalmente estabelecido por meio de contratos, porém sem explorar os benefícios de uma visão estratégica compartilhada e de uma maior colaboração entre as empresas, conforme previsto por Safayeni e Purdy (2000). O fornecedor, em geral, busca vender seus produtos à construtora, sem se preocupar com o desempenho, como um todo, da cadeia produtiva do setor, o que, somado ao baixo compartilhamento de informações, contribui para a falta de coordenação e integração dessa cadeia.

[6] Isatto, Eduardo Luis. Proposição de um modelo teórica-descritivo para a coordenação interorganizacional de cadeias de suprimentos de empreendimentos de construção. Porto Alegre: Ufrgs, 2005. 305 p. Tese (Doutorado) - Programa de Pós-Graduação em Engenharia Civil, Universidade Federal do Rio Grande do Sul, Porto Alegre, 2005.

[7] LI, Heng, Cheng, Eddie W. L., Love, Peter E. D., e IRANI, Zahir. Co-operative benchmarking: a tool for partnering excellence in construction. International Journal of Project Management, v. 19, no 3, p. 171-179, 2001.

[8] Mello, Luiz Carlos B. de B., AMORIM, Sergio Roberto L. O subsetor de edificações da construção civil no Brasil: uma análise comparativa em relação à União Europeia e aos Estados Unidos. Production Journal, São Paulo, v. 19, no 2, p. 388-399, 2009.

[9] Merli, Giorgio. Comakership: a nova estratégia para os suprimentos. Rio de Janeiro: Qualitymark, 1994

[10] Neves, Flávia Vancim Frachone, GUERRINI, Fábio Müller. Modelo de requisitos e componentes técnicos para a formação e gerência 
de redes de cooperação entre empresas da construção civil. Gestão \& Produção, São Carlos, v. 17, ำ 1, p. 195-206, 2010.

[11] Purdy, Lyn. Safayeni, Frank. Strategies for supplier evaluation: a framework forpotential advantages and limitations. IEEE Transactions on Engineering Management, v. 47, no 4, p. 435-443, 2000 .

[12] SANTOS, Adriana de Paula Lacerda. Modelo procompras: formulação, implantação e avaliação da compra pró-ativa na construção de edifícios. Florianópolis: UFSC, 2006. 141p. Tese (Doutorado) - Programa de Pós-Graduação em Engenharia Civil, Universidade Federal de Santa Catarina, Florianópolis, 2006.
[13] Sharpe, William F. Portfolio theory and capital markets. New York: Mac Graw-Hill, 1970.

[14] Simchi-Levi, David, Kaminsky, Philip, Simchi-Levi, Edith. Cadeia de suprimentos, projeto e gestão: conceitos, estratégias estudos de caso. 3 ed. São Paulo: Bookman/Artmed, 2010.

[15] Vrijhoef, Ruben, Koskela, Lauri. The four holes of supply chain management in construction. European Journal of Purchasing \&Supply Management, v. 6, p. 169-178, 2000.

[16] Xue, Xiaolong, LI, Xiaolong, Shen, Qiping e Wang, Yaowu. An agent-based framework for supply chain coordination in construction. Automation in Construction, v. 14, no 3, p. 413-430, 2005 


\title{
Gapítulo 10
}

\begin{abstract}
MARCO DE TRABAJO PARA LA PROGRAMACIÓN DE LA PRODUCCIÓN AGRICOLA A PEQUEÑA ESCALA BAJO UN MODELO DE RESILIENCIA.
\end{abstract}

\section{Leonardo Hernán Talero Sarmiento}

Laura Yeraldín Escobar Rodriguez,

Edwin Alberto Garavito Hernández.

Resumo: O objetivo deste projeto é formular uma estrutura para a programação da produção agrícola em pequena escala (agricultura familiar), criando um mix de produção que integra vários tipos de produtos e minimiza o risco de seus preços; com o de aumentar a resiliência alimentar. O modelo de trabalho é validado com dados de preços de produtos comercializados em Bucaramanga, Santander, Colômbia, o artigo conclui que, a partir da diversificação, são gerados cenários de retornos de investimentos conservadores, com benefícios suficientes para uma unidade de produção agrícola de acordo com a quantidade de salários mínimos gerados.

Palavras chave: Produção em pequena escala, programação de produção, resiliência alimentar. 


\section{INTRODUCCIÓN}

La estrategia de producción agrícola local o producción a pequeña escala ha adquirido alta importancia puesto que tiene el beneficio de ser resiliente Barthel (2013). Lo anterior, es debido a que tiene un menor grado de riesgo productivo -en comparación con los monocultivos-, derivado la siembra de diversos tipos de productos. La siembra diversificada localizada en zonas cercanas a cabeceras municipales o periurbanas permite un mayor nivel de servicio a pesar de poder presentar costos más elevados que la producción agrícola a gran escala, puesto que se encuentra más cerca del consumidor final y, por tanto, no se ve tan afectada por daños en la infraestructura vial o cuando se presentan desastres naturales, temporadas climáticas o problemas de orden público (entre otros factores)

Por tanto, a partir del aumento en el nivel de servicio hacia los consumidores finales se puede generar un cambio hacia un sistema alimentario más resistente, el cual favorece la soberanía y le confiere a la cadena de suministros agrícolas robustez para soportar cambios bruscos en el sistema productivo. Ahora bien, para generar un esquema de producción a pequeña escala es necesario repensar el modelo contemporáneo de desarrollo regional que ha moldeado nuestro sistema alimentario actual (Hudson 2010), mediante la identificación de escalas apropiadas de producción (como las periurbanas a pequeña escala), sistemas para el procesamiento de alimentos, distribución y consumo; generando así economías más autónomas (TOTH; RENDALL; REITSMA, 2016) (CHRISTOPHERSON; MICHIE; TYLER, 2010).

Teniendo en cuenta lo anterior, el propósito de la presente investigación es formular un marco de trabajo para la programación de la producción agrícola a pequeña escala como alternativa para seleccionar un mix de productos a cultivar en una zona periurbana, mediante la selección de diversos productos agrícolas compuesto por verduras, hortalizas, leguminosas, frutas y tubérculos, el modelo es evaluado teóricamente en una zona agrícola del Departamento de Santander, Colombia. El cuerpo del presente trabajo consta de un capítulo denominado Planteamiento del problema, en el que se evidencia la necesidad de generar investigación aplicada en la industria agro productiva para cultivadores a pequeña escala y/o periurbanos, seguido de la Metodología, en donde es explicado el proceso para planear y programar la producción agrícola a partir de la selección de productos, construcción del mix de producción y la estimación del retorno de la producción. Finalmente, en la sección de Resultados, Discusiones, Conclusiones y Bibliografía.

\section{PLANTEAMIENTO DEL PROBLEMA}

A partir del crecimiento poblacional mundial y el impacto de los asentamientos en su entorno, las naciones han tenido que afrontar múltiples retos con el fin de mejorar la calidad de vida de sus habitantes y la sostenibilidad ambiental de sus procesos, teniendo en cuenta lo anterior, la Organización de Naciones Unidas (ONU) ha definido diversos objetivos a cumplir en 2030, a manera de llamado universal para poner fin a la pobreza, proteger el planeta y garantizar que todas las personas gocen de paz y prosperidad (ORGANIZACIÓN De Las NACIONES UNIDAS, 2016). (ASAMBLEA GENERAL DE LAS NACIONES, 2015).

Para responder con eficacia a dicho llamado, es necesario re direccionar esfuerzos en frentes de trabajo que procuren favorecer diversos objetivos de manera simultánea, a la par de cubrir la mayor cantidad de beneficiarios posibles, por tanto, para satisfacer dicho requerimiento es preciso trabajar en sinergia con los sectores de producción. Dentro de éstos, se resalta el sector agropecuario, el cual es fundamental para el progreso socioeconómico de una nación, puesto que, el desarrollo rural y la soberanía alimentaria comparten objetivos similares al propender por mejorar la calidad de vida de los campesinos y habitantes rurales Pachón-Ariza (2013)

Para el caso específico de Colombia, dicha población (campesinos y habitantes rurales), ha enfrentado adversidades económicas e inestabilidades sociales, encontrando que en el país un $27.8 \%$ de la población vive en pobreza (DIRECCIÓN De DESARROLLO RURAL SOSTENIBLE, 2015), aportando solamente un $6.7 \%$ al PIB (REVISTA DINERO, 2019) a pesar de ser un país con tradición agropecuaria y amplias zonas cultivables. Teniendo en cuenta lo anterior, el gobierno nacional ha proyectado fortalecer la economía, fomentando la igualdad y manteniendo un carácter ambientalmente responsable: Ordenamiento y desarrollo 
territorial; Cierre de brechas sociales con enfoque de derechos; Inclusión productiva; Desarrollo de una ruralidad competitiva con énfasis en el sector agropecuario; Elementos de sostenibilidad ambiental para el desarrollo rural; y Reforma institucional profunda. (DEPARTAMENTO NACIONAL DE PLANEACIÓN, 2015).

En concordancia con lo anterior, para generar el crecimiento y bienestar en el país es necesario establecer políticas dinámicas que recuperen sus producciones industriales y agropecuarias en un corto y mediano plazo, antes de que súbitos cambios de precios externos induzcan delicadas crisis económicas y sociales.(TORRES GONZALEZ, 2014), lo cual es acorde a lo expuesto por Toth (2016), quien indica que los sistemas de alimentos son vulnerables a cambios políticos, desastres naturales y crisis económicas.

De manera general, el panorama de pobreza, bienestar y seguridad alimentaria puede y debe ser estudiado a un nivel más detallado según la heterogeneidad propia de cada país. Para el caso de Colombia -y durante la presente investigación-, se realizaron estudios en el departamento de Santander debido a sus características económicas encontrándose como cuarto departamento que más aporta al Producto Interno Bruto (PIB) nacional (GOBERNACIÓN DE SANTANDER, 2016), presentando alta variabilidad topográfica que se traduce en la presencia de diversos climas (desde zonas cálidas con alta probabilidad de inundación hasta páramos), terrenos quebrados acompañados de balcones, mesetas y abanicos aluviales en conjunto con el impactante cañón del Chicamocha.

Si bien Santander se caracteriza por la diversidad de sus productos (debido a las características climáticas y topográficas anteriormente descritas), la producción primaria de la región sólo abastece aproximadamente el $50 \%$ de la población dentro del departamento (SECRETARÍA DE PLANEACIÓN GOBERNACIÓN DE SANTANDER, 2011), indicando que en Santander existe una potencial insuficiencia alimentaria. Suceso contradictorio a lo esperado, teniendo en cuenta que cuenta con la capacidad productiva de un millón de hectáreas con vocación agrícola, con reconocidos productores frutícolas, cacaoteros, citrícolas entre otros; a la par de ser el principal productor avícola de la nación con una cuota de mercado del 25\% (GOBERNACIÓN De SANTANDER, 2016).

La insuficiencia agroalimentaria persiste en diversos municipios tal cual exponen Talero y otros (2016) a partir del informe de la secretaría de planeación de la Gobernación de Santander (2011), como son el Área Metropolitana de Bucaramanga AMB comprendida por Bucaramanga, Girón, y Floridablanca-, y municipios cercanos a aquellos con función subregional. Lo anterior sumado a que el $70 \%$ de la población del departamento vive en las áreas rurales, el 95.4\% de los municipios en el territorio tienen como base de su economía el sector agropecuario (SECRETARÍA DE PLANEACIÓN GOBERNACIÓN De SANTANDER, 2011), las Unidades Productoras Agropecuarias (UPA) en un 85.4\% corresponden a minifundios 0 pequeños productores (DEPARTAMENTO ADMINISTRATIVO NACIONAL DE ESTADÍSTICA, 2014), y que la actividad agropecuaria se ha visto afectada en los últimos años, evidenciando un decrecimiento en los ingresos procedentes de actividades rurales, pasando del $61 \%$ al $54 \%$ en el periodo comprendido entre 2010-2014 (DIRECCIÓN DE DESARROLLO RURAL SOSTENIBLE, 2015) hace necesario el trabajo en conjunto de la academia, industria y estado en dicho sector mediante dos frentes.

El primero, mejorando la metodología de producción agrícola en regiones aisladas del Área Metropolitana de Bucaramanga, buscando con ello aumentar la soberanía alimentaria y disminuyendo los riesgos presentes en la cadena de producción agrícola, sobre todo, al tener en cuenta la deficiente infraestructura de los municipios alejados del AMB y las veredas distantes de las cabeceras municipales. El segundo, es aumentando la soberanía alimentaria en al AMB a partir de la diversificación de la producción en su cercanía puesto que, como plantea Gasperi: soportar la agricultura periférica a las ciudades se ha vuelto un problema de planeación urbana y seguridad alimentaria, puesto que es necesario garantizar una infraestructura adecuada, acceso al trabajo y disminución de costos (GASPERI et al., 2016) y es mediante la cercanía a la cabecera municipal y sus clientes finales que se disminuyen riesgos en la cadena productiva, aumentando la resiliencia alimentaria. 


\section{METODOLOGÍA}

El presente trabajo de investigación tiene como objetivo desarrollar una metodología para la programación de la producción agrícola a pequeña escala, bajo el concepto de resiliencia alimentaria (en este caso, aumento del nivel de servicio mediante el cultivo de múltiples productos en zonas periurbanas); buscando así aumentar la soberanía alimentaria a la par de disminuir el riesgo de inversión mediante la selección de productos con mayor estabilidad en sus precios. De manera general, la metodología se puede condensar en tres grandes etapas:

- Selección de productos.

- Construcción del mix de producción.

- Estimación del retorno.

\subsection{SELECCIÓN DE LOS PRODUCTOS}

La selección de los productos parte de la base de datos de precios de productos agrícolas comercializados en Bucaramanga, Santander (capital del departamento) para el periodo comprendido entre 2012/06/16 y 2016/12/30 publicada por Talero y otros
(2017), luego, de la base de datos son seleccionados aquellos productos que se cultivan en la cercanía del Área metropolitana de Bucaramanga, a partir de contrastar la información con documentos publicados por la Secretaría de Agricultura de Santander, generando así una base de información de 25 productos agrupados en tres categorías: 1) verduras, hortalizas y leguminosas, 2) frutas, y 3) tubérculos.

Es pertinente resaltar que, para la selección de los productos se descartaron en aquellos con duración superior a 18 meses, y especialmente para el caso de las frutas los cultivos permanentes, con el fin de modelar la programación de la producción agrícola como un ejercicio de inversión con un horizonte no muy amplio. Además, teniendo en cuenta que el proyecto busca cubrir requerimientos nutricionales para mejorar la soberanía y resiliencia alimentaria, se descartaron aquellos productos con fin industrial como variedades de Palma usadas para la industria de biocombustibles. Un resumen gráfico del proceso de depuración se puede apreciar en la

Figura 1.

Figura 1 Depuración del Dataset

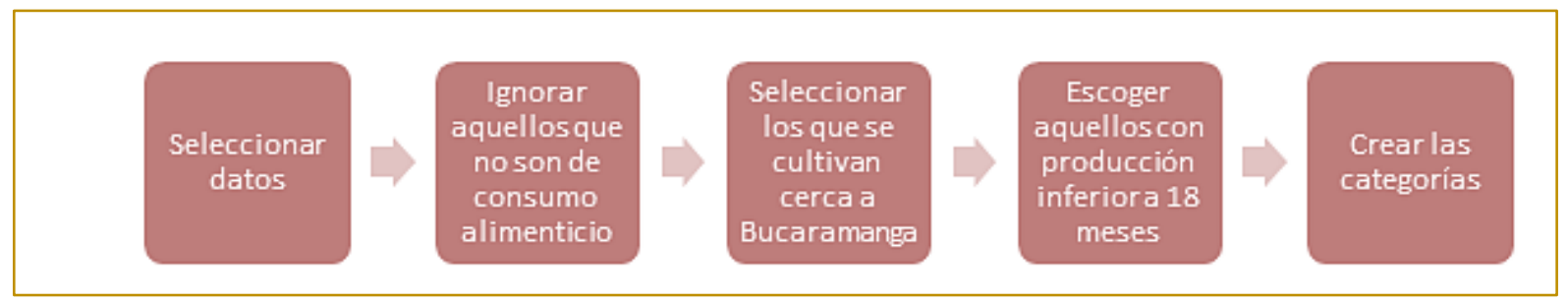

Los 25 productos escogidos para el presente trabajo y su respectiva categoría se consignan en la

Figura 2. Donde el color indica el grupo al que pertenece cada producto.

Figura 2 Productos utilizados durante las simulaciones 


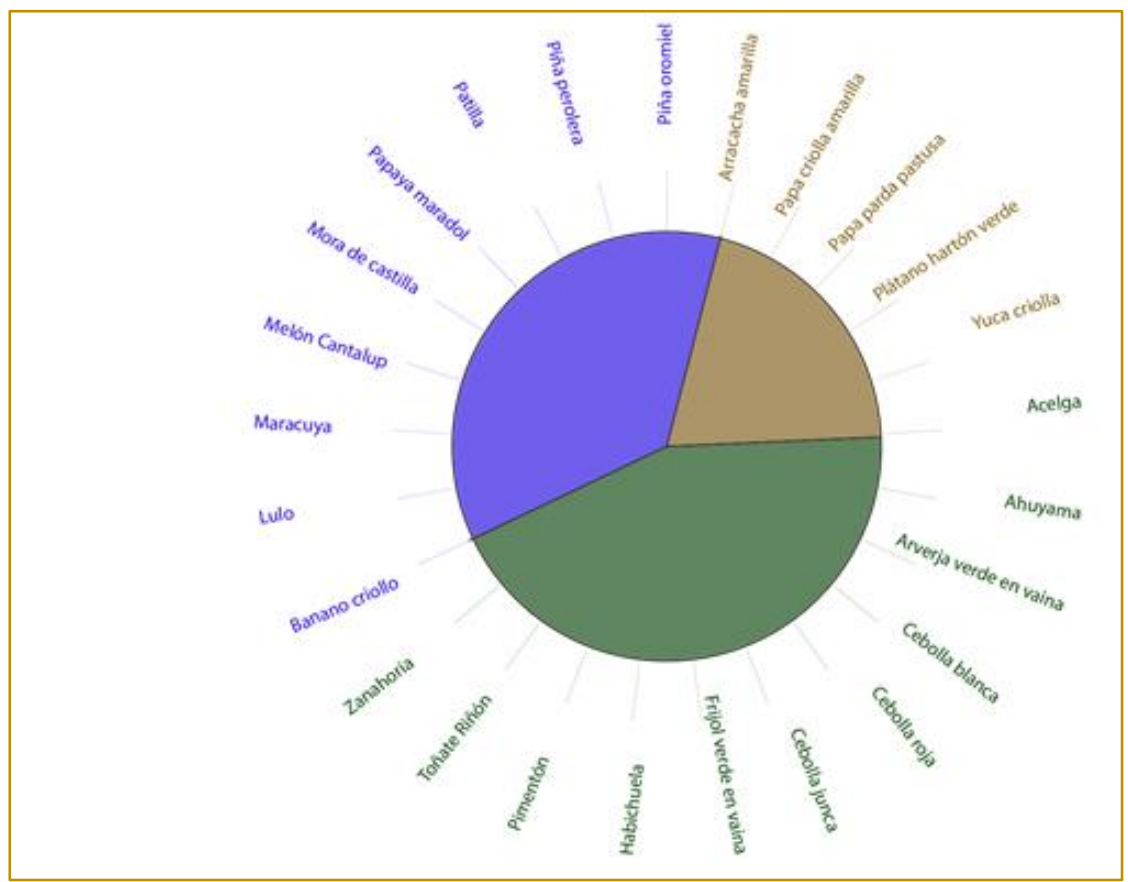

\subsection{CONSTRUCCIÓN DEL MIX DE}

\section{PRODUCCIÓN}

Con el fin de evaluar múltiples escenarios y bajo el supuesto de no cultivar todos los productos posibles; se construye un mix de producción a partir de la selección aleatoria de productos pertenecientes a cada categoría, buscando previamente que éstos tuvieran el menor riesgo. Para ello son calculados los valores medios de sus rentabilidades y la desviación estándar de las mismas, eliminando del Dataset aquellos productos con tendencia a la baja en sus precios.

Una vez determinado los posibles productos a cultivar en el mix, es propuesta una medida de riesgo a partir de la relación entre la desviación estándar de sus rentabilidades, dividida por la media de las mismas:

$$
R_{i}=\frac{\sigma_{i}}{x_{i}}
$$

Donde $R_{i}$ indica el riesgo perteneciente al comportamiento del precio de cada producto agrícola, $\sigma_{i}$ la desviación estándar de las rentabilidades de cada producto $i$ y $x_{i}$ el valor promedio de las rentabilidades respectivas. A partir de la medida individual se determinó el peso porcentual de riesgo de cada producto en el mix:

$$
P_{i=} \frac{R_{i}}{\sum_{j=1}^{n} R_{j}}
$$

De tal manera que, el área a cultivar es inversamente proporcional al peso porcentual de riesgo $P_{i}$, es decir, a mayor variabilidad ajustada en sus retornos, menor el área sembrada de dicho producto.

$$
A_{i} \propto \frac{1}{P_{i}}
$$

El mix, por tanto, constituiría la sumatoria de $n$ productos que ocupan $A_{i}$ espacios en un área conjunta máxima de una hectárea (10.000 $\mathrm{m}^{2}$ ), con un riesgo individual $R_{i}$ y una utilidad esperada individual de $U_{i}$. Una representación gráfica del comportamiento esperado de la metodología se consigna en la Figura 5, donde se desarrolla el ejercicio a modo de ejemplo con seis tipos de productos $(n=6)$, dos de cada tipo. En la figura se indica el porcentaje de área estimado ocupado por cada producto, su valor en metros cuadrados y el valor de utilidad esperada individual en pesos colombianos (COP). 
Figura 3 Representación gráfica de la planificación de la producción por unidad de área

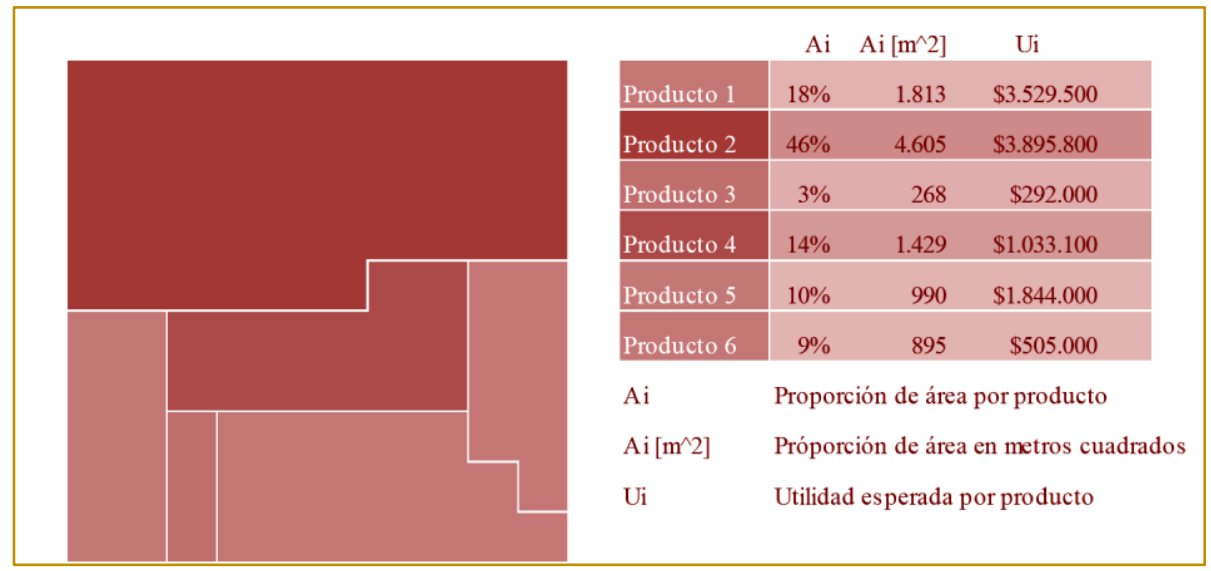

\subsection{ESTIMACIÓN DEL RETORNO}

A partir de los datos históricos de los precios se identifican mediante el software @Risk de

Figura 4). Una vez seleccionados los productos que conformarán el mix de producción, se generan sus precios a partir el último valor histórico registrado para cada uno de ellos y en cada iteración cambian según la función de probabilidad de su rentabilidad. El precio final de cada serie es multiplicado por un factor de utilidad, éste representa el margen de ganancia esperado y es estimado a partir del reporte de costos de producción agrícola generado por FEDESARROLLO (2012). la suite Pallisade, el comportamiento probabilístico de las rentabilidades de cada producto agrícola (Ver

El retorno final esperado, corresponde a la sumatoria de todas las ganancias estimadas a partir del precio final del producto, multiplicado por el coeficiente de utilidad, dicha ganancia esperada es multiplicada por la cantidad promedio de kilos producidos por unidad de área, y éste a su vez por el número de veces que se cultivaría dicho producto.

$$
\text { Retorno }=\sum_{i=1}^{n} A_{i} * \% U_{i} * k_{i} * m_{i}
$$

Figura 4 Ejemplo del comportamiento probabilístico de los precios de un producto agrícola

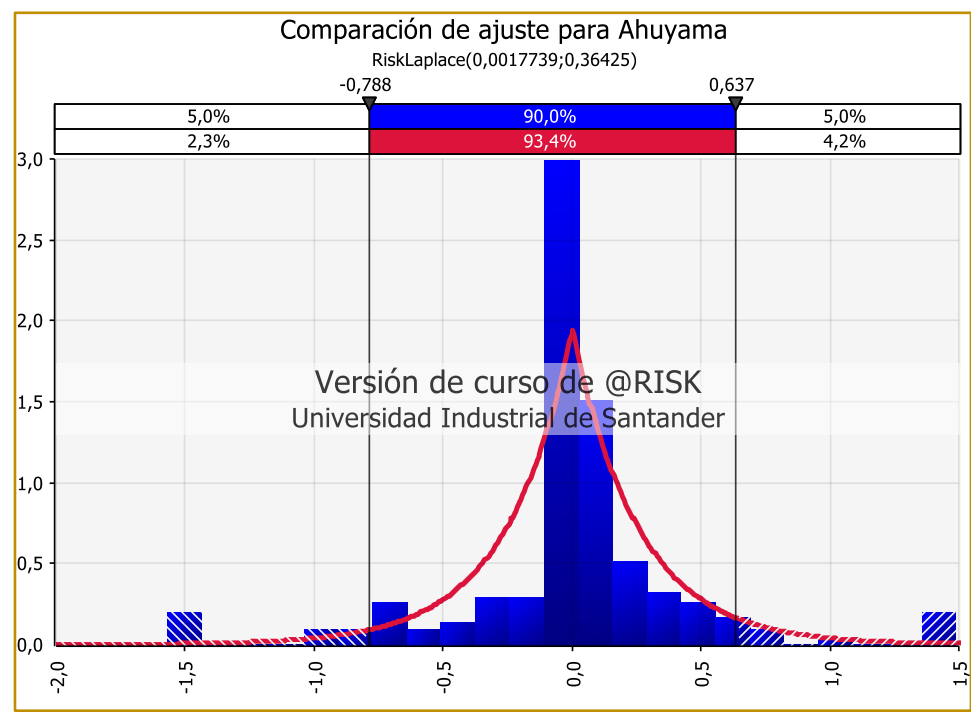

Donde $\% U_{i}$ representa el margen de ganancia por kilo del producto, $k_{i}$ la cantidad de producción en kilos por área, y $m_{i}$ la cantidad de veces que el cultivo $i$ es 
producido en la misma área durante el horizonte de planeación.

\section{RESULTADOS}

La metodología fue programada en MATLAB 2015, y se realizaron 100.000 de réplicas; para cada réplica se selecciona un total de nueve productos al azar, escogiendo tres de cada categoría. El máximo número de meses que comprendía el horizonte de planeación fue de catorce y corresponde al producto de la Piña Perolera; en contraste, el producto que más rotación tuvo fue la Acelga con siete producciones por periodo.
Las ganancias esperadas son consignadas en la Figura 5, indicando que, debido al enfoque de bajo riesgo lo más probable es encontrar utilidades bajas, presentando valores hasta los $\$ 26.438 .791$ COP en sus dos primeras clases, o lo equivalente a 34 salarios mínimos mensuales vigentes, que en promedio representan 2.4 salarios mínimos mensuales. Además, dependiendo de la configuración del mix, es posible encontrar valores que cuadruplican los valores más esperados.

Figura 5 Histograma de utilidades estimadas para la metodología propuesta

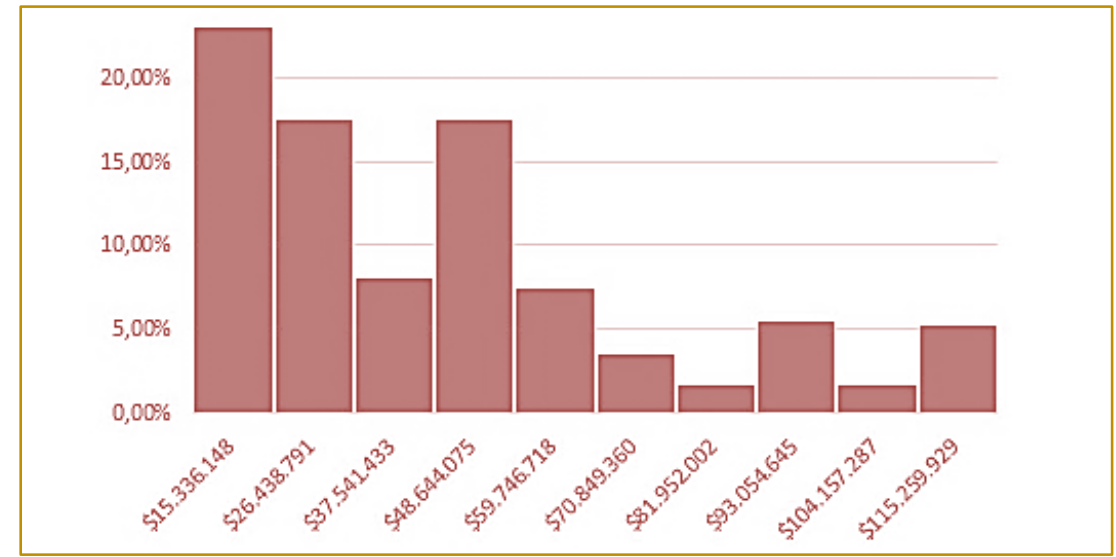

\section{DISCUSIÓN}

El presente trabajo propone una metodología para la toma de decisiones de planeación y programación de la producción agrícola, para ello, diversas características y supuestos han sido necesarios con el fin de establecer un marco de trabajo más sencillo bajo el principio metodológico de parsimonia o navaja de Ockham. Entre los supuestos para estimar la utilidad o ganancia esperada no se consideraron aquellos productos sustitutos que pueden suplir los requerimientos alimentarios y por tanto, diversificar el mix de producción a partir de la rotación de productos con corto horizonte temporal de cosecha, tampoco aquellos productos que a pesar de tener una media en sus rentabilidades negativas, se cultivan por ser tradicionalmente más rentables (debido al riesgo de la inversión).

Además, durante la formulación del marco de trabajo, se supuso que todos los productos agrícolas se mantenían en el horizonte del proyecto sin adversidad alguna, es decir, no se contemplaron catástrofes, fuertes cambios climáticos, cambios de orden público y afines, ahora bien, dicho supuesto es pertinente teniendo en cuenta que el objetivo principal de la metodología es producir una canasta o conjunto de productos que supla los requerimientos alimenticios de las familias campesinas, disminuyendo así el flujo de dinero mediante la adquisición de productos en abarroterías.

Es necesario para futuras investigaciones considerar elementos como el cambio climático, riesgos por contaminaciones cruzadas entre productos, uso y desgaste del suelo e impacto ambiental, con el fin de mejorar no sólo en grado de resiliencia de la producción agrícola, sino la huella de carbón derivada del sistema productivo.

\section{CONCLUSIONES}

La investigación de operaciones y gestión de procesos, son dos ramas de gran importancia para la ingeniería industrial y, por ende, los sectores productivos de la sociedad; sin embargo, los modelos y objetivos de los 
mismos han cambiado, haciendo necesario que la investigación aplicada contemple no solamente la optimización tradicional enfocada en optimizar funciones de costos/beneficios, sino variables más complejas de medir como el impacto de la huella de carbono, beneficiarios potenciales o, como en este caso, la resiliencia alimentaria.

Para ello es necesario partir de aproximaciones cualitativas al problema y,

\section{BIBLIOGRAFÍA}

[1] Asamblea General de las Naciones. Transformar nuestro mundo: la Agenda 2030 para el Desarrollo Sostenible. 2015.

[2] Barthel; Stephan y Isendahl; Christian. Urban gardens, agriculture, and water management: Sources of resilience for long-term food security in cities. 2013. Ecological Economics, 86, 224-234. doi:10.1016/j.ecolecon.2012.06.018

[3] Christopherson; S., Michie; J., y Tyler; P. Regional resilience: theoretical and empirical perspectives. 2010. Cambridge Journal of Regions, Economy and Society, 3(1), 3-10. doi:10.1093/cures/rsq004

[4] Departamento Administrativo Nacional de Estadística. Censo Nacional Agropecuario, Décimo segunda entrega de resultados 2014. 2014. (Mauricio Perfetti del Corral \& Carlos Felipe Prada Lombo, Eds.) (1.a ed.). Bogotá.

[5] Departamento Nacional de Planeación. Misión para la transformación del campo Colombiano. 2015. 15 de Enero de 2016 11:54 am. Recuperado el 25 de abril de 2016 de: https://www.dnp.gov.co/programas/agricultura/Pagi nas/mision-para-la-transformacion-del-campocolombiano.aspx

[6] Dirección de Desarrollo Rural Sostenible. Diagnóstico de la pobreza rural. Colombia 20102014. 2015. Bogotá

[7] Fedesarrollo. Costos de Producción de Doce Productos Agropecuarios. 2012 (1.a ed.). Bogotá.

[8] Gasperi; D., Pennisi; G. , Rizzati; N. , Magrefi;F. , Bazzocchi; G., Mezzacapo; U. , ... Gianquinto; G.. Towards regenerated and productive vacant areas through urban horticulture: Lessons from Bologna, Italy. 2016. Sustainability (Switzerland), 8(12). Doi:10.3390/su8121347

[9] Gobernación de Santander. Plan de desarrollo departamental. 2016. mediante técnicas de programación, optimización, simulación y demás, generar escenarios que faciliten la toma de decisiones. A partir de la presente propuesta, se desarrolla una metodología fácilmente replicable sin mayor complejidad computacional, que toma como objetivo principal la resiliencia alimentaria, además de propender por la mejora en calidad de vida de los cultivadores mediante un marco de trabajo de bajo riesgo.

[10] Organización de Las Naciones Unidas. Objetivos de desarrollo sostenible I UNDP. 2016. Recuperado el 1 de enero de 2017 de: http://www.undp.org/content/undp/es/home/sustain able-development-goals.html

[11] Pachón-Ariza; Fabio Alberto. Food sovereignty and rural development: beyond food security Soberanía alimentaria y desarrollo rural: más allá de la seguridad alimentaria. 2013, 31(3), 362-377.

[12] Revista Dinero. ¿Cómo está compuesta la economía colombiana? 2019. Recuperado el 1 de febrero de 2017 de: http://www.dinero.com/economia/articulo/composici on-economia-colombiana-2015/214054

[13] Secretaría de Planeación Gobernación De Santander. Santander 2030 Síntesis del diagnóstico territorial de Santander. 2011. Bucaramanga.

[14] Talero Sarmiento; Leonardo Hernán, Escobar Rodríguez; Laura Yeraldin, y GARAVITO Hernandez; Edwin Alberto. Prices of agricultural products in Santander Colombia between 2012/06/16 and 2016/12/30. 2017. Bucaramanga. Doi:10.17632/c3x8prwxmx.1

[15] Talero Sarmiento; Leonardo Hernán, Rodríguez Torres; Leidy Tatiana, y DÍAZ Bohórquez; Carlos Eduardo. Definición y caracterización de los principales productos agrícolas cultivados en las provincias de García Rovira y Guanentá; como base para la propuesta de Primera Milla. 2016. Bucaramanga.

[16] Torres González; Jaime. Colombia: Logros en dos décadas de modelo de desarrollo aperturista - análisis según resultados de balanza comercial. 2014. Análisis político, 82(3), 212-235.

[17] Toth; Attila, Rendall; Stacy, y Reitsma; Femke. Resilient food systems: a qualitative tool for measuring food resilience. 2016. Urban Ecosystems, 19(1), 19-43. Doi:10.1007/s11252015-0489-X 


\section{Capítulo 11}

\section{UTILIZACÃO DA CURVA ABC COMO PROPOSTA DE MELHORIA PARA A GESTÃO DE ESTOQUES EM UMA CONFECÇÃO DE LINGERIES}

\section{Luciana Mendonça \\ Talyson Xavier Ribeiro}

Resumo: Atualmente as empresas para se manterem no mercado e serem competitivas, precisam de uma estratégia para a administração de materiais, principalmente no que diz respeito ao controle de estoques. Caso contrário seu desempenho e permanência estarão fortemente comprometidos. Com isso, para que a organização possa conhecer seus estoques e administrá-los de maneira inteligente, é necessário que se adote ferramentas de controle que permitam a análise do estoque como um todo. Diante disso, optou-se neste estudo pela utilização da classificação ABC, para identificar a classe dos itens mais representativos assim como dos itens menos relevantes em relação ao faturamento da empresa, a fim de estabeler critérios para a tomada de decisão entre manter ou descartar determinados produtos/modelos, visando à redução do estoque e consequentemente a redução dos custos. Quanto à coleta dos dados, foi utilizado a observação direta individual, a pesquisa bibliográfica, a pesquisa documental e a entrevista não estruturada. Já o tratamento dos dados baseou-se na seleção, codificação e tabulação dos mesmos. Por fim, com o estudo foi possível constatar que a classe $A$ é representada pelo maior faturamento, sendo $21,74 \%$ dos itens responsáveis por $50,53 \%$ do faturamento, enquanto o restante do faturamento esta dividido entre as classes $\mathrm{B}$ e $\mathrm{C}$.

Palavras-Chave: Curva ABC, Estoque, Lingerie. 


\section{INTRODUÇÃO}

Praticamente todas as empresas procuram de uma forma ou de outra, obter vantagem competitiva em relação aos seus concorrentes, atendendo prontamente seus clientes no momento e na quantidade desejada, o que pode ser facilitado por meio da administração eficaz dos estoques.

Por este motivo e por muitos outros existentes e até mesmo desconhecidos, o acompanhamento e o controle mais apurado dos estoques, passaram a fazer parte da organização moderna, onde busca-se um equilíbrio entre, sempre ter o produto disponível quando o cliente precisar, e não estocar em excesso empregando capital nas prateleiras dos estoques (SOUZA, 2007).

Uma administração ineficiente do estoque pode comprometer, de forma substancial, a utilização do capital investido pela empresa, sua produtividade e competitividade. Nesse contexto, o estoque passa a ser um item alvo para redução de custos, não apenas pela relevância da sua participação no custo total frente à margem de resultado das empresas, mas, principalmente, pelo valor aplicado nesse ativo, que afeta diretamente os resultados financeiros, o giro de estoque e o retorno sobre o capital investido pelos proprietários e acionistas (CASSIANO et al., 2007).

Os estoques podem ser de diferentes tipos, mas em geral são os materiais existentes em função de futuras necessidades. Logo, estocar é reservar os produtos/mercadorias para utilização/comercialização futura (OLIVEIRA, 2011).

A empresa em estudo possui vários tipos de estoque, e o tipo abordado neste estudo foi o estoque de produto acabado, uma vez que a mesma reconhece a importância de manter estoques para atender seus clientes, porém preocupa-se com o alto capital investido neste, fazendo-se necessário encontrar um equilíbrio, entre não produzir quantidades maiores que a demanda e nem deixar faltar produtos, impossibilitando 0 pronto atendimento dos clientes.

Com isso, este estudo teve como objetivo identificar a classe dos itens mais representativos assim como dos menos relevantes em relação ao faturamento da empresa, utilizando a classificação da curva ABC, afim de estabeler critérios para a tomada de decisão entre manter ou descartar determinados produtos/modelos, visando à redução do estoque e consequentemente a redução dos custos.

\section{REFERENCIAL TEÓRICO}

\subsection{ESTOQUE}

Estoque são todos os materiais, mercadorias ou produtos acumulados para uma futura utilização, de modo a satisfazer a necessidade dos usuários nas atividades da empresa, sendo 0 estoque gerado, consequência da impossibilidade de previsão exata da demanda (VIANA, 2006).

Ainda para o autor supracitado, existem três causas que exigem a permanência de estoques que são: a necessidade de continuidade operacional; a incerteza de demanda futura ou ao longo do tempo de planejamento; a pronta disponibilidade de material dos fornecedores e o cumprimento dos prazos de entrega.

Slack, Chambers e Johnston (2002), explicam que os estoques existem devido uma diferença entre o abastecimento de matériasprimas/insumos, e a demanda pelo produto acabado.

Diante disso, a importância dos estoques dentro de uma empresa, que não consegue prever quando seus pedidos chegarão é muito grande, e a sobrevivência da mesma pode depender diretamente da administração de seus estoques.

\subsection{ADMINISTRAÇÃO DE MATERIAL}

A empresa para se manter no mercado e ser competitiva, precisa de uma estratégia para a administração de materiais, principalmente no que diz respeito ao controle de estoques (SOUZA, 2007).

A Administração de materiais tem como principal função, o controle dos níveis de estoques, onde se deseja definir o mínimo de estoque que a empresa pode alcançar evitando a falta de materiais, mas por outro lado não desperdice dinheiro estocando produto sem necessidade, ou seja, o controle de estoque visa informar o que, quanto e quando comprar ou produzir, sendo de extrema importância dentro de uma empresa (POZO, 2002 apud SALVIANO et al., 2010).

Embora, a administração de materiais seja muito importante, os estoques da maioria das 
empresas são administrados com base em um modelo definido pela própria empresa, de acordo com suas atividades, necessidades de produção, seu investimento de capital, seu ambiente físico e seus fornecedores, assim os recursos investidos, variam muito dependendo do setor industrial em que a empresa faz parte. Logo, administrar o estoque é cuidar de uma parcela dos ativos da empresa. Daí a importância das empresas terem um departamento, setor ou divisão para cuidar e gerir os materiais em estoque seja eles quais forem (MARTINS \& ALT, 2009).

Assim, para que a organização possa conhecer seus estoques e administrá-los de maneira inteligente, é necessário que se adote ferramentas de controle que permitam a análise do estoque como um todo. Dentre as ferramentas de classificação de estoque, optou-se por estudar a curva ABC.

\subsection{CURVA ABC}

Em qualquer organização que possui mais de um item em estoque, alguns itens serão mais importantes do que outros, seja pela taxa de uso ou pelo valor consideravelmente alto (SLACK; CHAMBERS; JOHNSTON, 2002).

Pascoal (2008), ressalta que para manter um controle melhor do estoque e reduzir seu custo, sem comprometer o nível de atendimento, é importante classificar os itens de acordo com a sua importância relativa no estoque.

Assim surge a importância da classificação do estoque pela curva $A B C$, este método é antigo, mas muito eficaz e baseia-se no raciocínio do diagrama de Pareto ou curva 8020 (FIG. 1), desenvolvida pelo economista italiano Vilfredo Pareto em 1897, durante um estudo da distribuição da renda e da riqueza na Itália. Na época ele concluiu que grande percentagem da renda total estava concentrada nas mãos de uma pequena percentagem da população, na proporção de $80 \%$ a $20 \%$ respectivamente (BALLOU, 2006).

Figura 6 - Curva de Pareto para itens em estoque

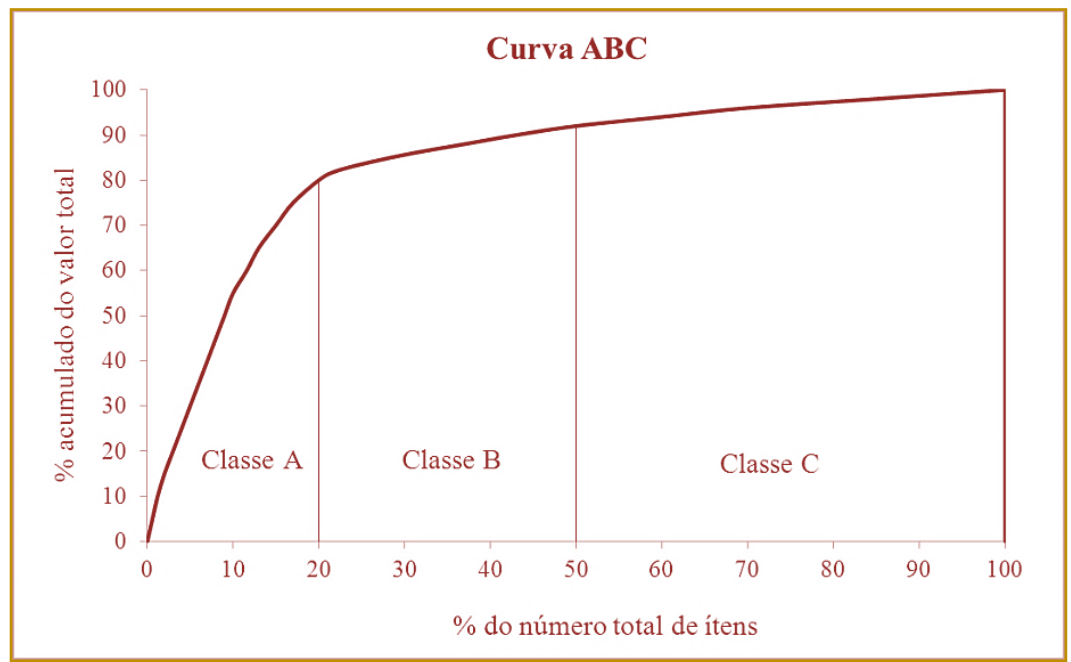

Fonte: Adaptado de Slack, Chambers e Johnston (2002, p. 404)

A curva $A B C$ é um método muito utilizado para análise de estoque e consiste basicamente na verificação do consumo dos itens de estoque, em valor monetário ou em quantidade e em certo espaço de tempo, para que eles possam ser classificados em classes (MARTINS \& LAUGENI, 2006).

Segundo Fenili, (2011), os itens podem ser classificados em três classes que são:
- Classe A: itens de maior relevância, ou seja, aqueles mais importantes de todos, de acordo com o valor ou a quantidade. Estima-se que 20\% dos itens em estoque correspondem a $80 \%$ do valor em estoque;

- Classe B: itens de importância intermediária. Estima-se que $30 \%$ dos itens em estoque correspondem a $15 \%$ do valor em estoque; 
- Classe C: itens de menor relevância em estoque. Estima-se que $50 \%$ dos itens em estoque correspondem a 5\% do valor em estoque.

Não existe forma totalmente aceita de dizer qual o percentual do total dos itens que pertencem à classe $A, B$ ou $C$. Os itens $A$ são os mais significativos, podendo representar algo entre $35 \%$ e $70 \%$ do valor movimento dos estoques, os itens B variam de $10 \%$ a $45 \%$, e os itens $C$ representam o restante (PASCOAL, 2008).

Para a classificação dos itens em estoque é necessário obter os dados das quantidades utilizadas/vendidas e o valor de cada item do estoque, normalmente no período de um ano. Com esses dados é possível elaborar uma tabela, em ordem decrescente, com o valor monetário da demanda anual dos itens utilizados, definindo aqueles que possuem valores altos como mais importantes, fazendo então, parte da classe A e posteriormente as classes B e C (MARTINS \& LAUGENI, 2006).

Embora a classificação com base no valor monetário e nas quantidades seja a mais utilizada e de grande importância para as empresas, vale ressaltar que outros fatores como: consequência da falta de estoque; incerteza de fornecimento e alta obsolescência ou risco de deterioração podem dizer que um item é mais importante que outro contribuindo para a classificação dos mesmos, pois certos itens não possuem um valor monetário alto e nem uma quantidade significativa, mas podem ocasionar problemas para a empresa caso faltem no estoque ou ainda percam seu valor por obsolescência (SLACK; CHAMBERS; JOHNSTON, 2002).

Segundo Pozo, (2002 apud SOUZA, 2007) a utilização da curva $A B C$ é extremamente vantajosa, pois através dela, é possível reduzir os estoques sem prejudicar a segurança, pois ela permite o controle rigoroso dos itens de classe $\mathrm{A}$, e mais ameno dos itens B e C.

Falcão (2008), afirma que para elaborar uma curva ABC, devem-se seguir os seguintes passos:

- Enumerar todos os itens que compõe o estoque;

- Relacionar a demanda mensal a cada item;

- Calcular sua demanda anual;
- Com base nos custos unitários, calcular os respectivos valores anuais;

- Somar o valor anual de todos os itens;

- Calcular a participação de cada item, através da divisão do valor anual de cada item pelo valor total anual de todos os itens.

De acordo com os aspectos citados, percebe-se que a elaboração da classificação da curva ABC com base em um bom levantamento dos dados, pode trazer benefícios para a empresa em relação ao controle do estoque, principalmente no que diz respeito à criticidade dos itens.

\section{METODOLOGIA}

\subsection{COLETA E TRATAMENTO DOS DADOS}

Quanto à técnica para coleta de dados foi utilizado a observação direta individual, a pesquisa bibliográfica, a pesquisa documental e a entrevista não assistemática. O tratamento dos dados baseou-se na seleção, codificação e tabulação dos mesmos.

A seleção consistiu em fazer uma análise cuidadosa de todo o material coletado, a fim de detectar falhas ou erros e, posteriormente, fazer a seleção adequada, assim como a codificação e tabulação dos mesmos. Analisando os dados constatou-se que, a empresa possui em seu estoque aproximadamente 270 modelos com grande variedade de cores e tamanhos, os quais pertencem a diferentes coleções (Essencial, Design Fhashion, Radiante, Beautiful Day, Ritmo da Luz, Move e Man), totalizando mais de 40.000 (quarenta mil) itens em estoque.

Diante disso, a fim de viabilizar este estudo optou-se por trabalhar com 46 modelos sendo 12 pertencentes à coleção Essencial e 34 à coleção Fashion. Os modelos selecionados são caracterizados por serem os produtos mais vendidos da empresa e que estão por mais tempo no mercado, existindo um histórico de vendas. Tal escolha também levou em consideração a diversidade de itens dentro destas coleções indo dos modelos básicos aos mais sofisticados com diferentes custos e volume de vendas como: peças avulsas, pijamas, camisolas e espartilhos.

Em seguida, os itens selecionados para o estudo, foram codificados, onde buscou agrupa-los por coleção atribuindo-lhes o seu código de identificação utilizado na empresa 
Quadro 1 - Itens selecionados para o estudo

\begin{tabular}{|c|c|c|}
\hline Itens & Código & $\begin{array}{ll}\text { Coleção essencial } & \text { Descrição }\end{array}$ \\
\hline 1 & 00001 & Conjunto básico em microfibra \\
\hline 2 & 00002 & Conjunto básico em microfibra \\
\hline 3 & 00383 & Conjunto em microfibra aro duplo \\
\hline 4 & 00388 & Conjunto em microfibra com base \\
\hline 5 & 00915 & Conjunto nadador em microfibra \\
\hline 6 & 01346 & Calcinha em microfibra \\
\hline 7 & 01415 & Conjunto em microfibra com alça tic tac \\
\hline 8 & 01421 & Conjunto em microfibra com alça tic tac com aro duplo \\
\hline 9 & 01495 & Conjunto em microfibra com bojo base \\
\hline 10 & 01840 & Fio duplo de new confort \\
\hline 11 & 02163 & Calcinha avulsa \\
\hline 12 & 02266 & Pijama básico em liganete \\
\hline \multicolumn{3}{|c|}{ Coleção Design Fashion } \\
\hline 13 & 00011 & Camisola em liganete \\
\hline 14 & 00284 & Conjunto drapeado com tule bordado \\
\hline 15 & 00366 & Conjunto em cotton laise e passa fitas \\
\hline 16 & 00416 & Fio dental duplo \\
\hline 17 & 00961 & Robe em liganete com guipure \\
\hline 18 & 00976 & Robe longo em liganete e guipure \\
\hline 19 & 01308 & Camisola em rendão com babado \\
\hline 20 & 01316 & Espartilho em microfibra \\
\hline 21 & 01360 & Camisola em liganete de onça \\
\hline 22 & 01565 & Calcinha gaia em microfibra \\
\hline 23 & 01758 & Espartilho madame d'orvilliers \\
\hline 24 & 02073 & Conjunto em microfibra com renda e pregas no bojo \\
\hline 25 & 02134 & Conjunto em microfibra com bojo drapeado \\
\hline 26 & 02189 & Conjunto em cetim plissado e renda \\
\hline 27 & 02198 & Camisola curta em liganete \\
\hline 28 & 02238 & Conjunto sensual com broche sofisticado \\
\hline 29 & 02281 & Conjunto inteiro em renda com bojo manta e strass \\
\hline 30 & 02309 & Conjunto em new confort, renda e detalhes de guipure \\
\hline 31 & 02346 & Camisola em rendão e tule liso em formato godê \\
\hline 32 & 02350 & Robe curto em liganete e renda nas mangas \\
\hline 33 & 02367 & Conjunto em renda, new confort, pregas de cetim e semi jóia \\
\hline 34 & 02373 & Conjunto Nova York com luva e saia de acessórios \\
\hline 35 & 02381 & Conjunto Londres em new confort, renda, semi jóia e alça trabalhada \\
\hline 36 & 02383 & Camisola sem bojo em liganete, renda e laço \\
\hline 37 & 02391 & Conjunto Lisboa com reforço de elástico na base e nas laterais \\
\hline 38 & 02398 & Conjunto Quebec duas calcinhas, guipure em detalhe na alça \\
\hline 39 & 02400 & Camisola longa em liganete e abertura lateral de renda \\
\hline 40 & 02401 & Conjunto poá preto com pérola, guipure e alça com detalhes \\
\hline 41 & 02361 & Pijama em liganete, tule liso e rendão de onça no bojo \\
\hline 42 & 02364 & Conjunto em new confort, renda e semi jóia. \\
\hline 43 & 01851 & Fio dental Ângela em liganete e rendinha \\
\hline 44 & 00794 & Caleçon em renda com elástico na cintura \\
\hline 45 & 00242 & Calcinha básica em microfibra \\
\hline 46 & 02363 & Persex em tule liso e fita \\
\hline
\end{tabular}

Fonte: Autora, (2016) 
A partir da seleção e codificação dos itens a serem analisados, foi necessário coletar novos dados referentes a eles, como a demanda mensal no período de 2014 e 2015, através do sistema operacional da empresa, que emitiu os relatórios de venda deste período. Os relatórios foram emitidos pelo sistema Millennium NetWork Ltda.

A tabulação dos dados foi realizada utilizando técnica manual com o auxílio do software Excel do pacote Office da Microsoft, por meio da disposição dos dados em tabelas e gráficos. A tabulação foi muito demorada, pois os dados coletados estavam em formato PDF, sendo necessário inseri-los um a um em uma planilha do Excel para depois manipulálos. Porém, o fato da empresa ser informatizada facilitou o levantamento e coleta de dados, bastando para tanto, consultar as informações necessárias em seu sistema operacional.

Após a tabulação, os itens foram classificados em três classes distintas, por meio da curva $A B C$, levando em consideração a sua importância no faturamento da empresa.

\subsection{CARACTERIZAÇÃO DA EMPRESA}

Neste estudo optou-se por não identificar a empresa por motivos de preservação de confidencialidade.

A empresa atua no setor de confecção de lingeries e se caracteriza pela fabricação e comercialização de sutiãs, calcinhas, camisolas, espartilhos, pijamas, robes e fitness. Atua no mercado há 21 anos e esta localizada na cidade de Juruaia-MG conhecida como "A Capital da Lingerie".

Atualmente, atende clientes por todo o país e no exterior, contando com 34 funcionários na produção, doze na comercialização e seis nos setores administrativos, totalizando 52 funcionários diretos. Além desses, a empresa trabalha com sistemas de subcontratação parcial para produção de algumas peças como: camisolas, robes e fitness e também para limpeza final das peças, mas fornece toda matéria-prima necessária como: tecido, rendas, bojos e aviamentos.

\section{RESULTADOS}

\subsection{ELABORAÇÃO DA CURVA ABC}

A TAB. 1 demonstra os cálculos para obtenção da curva $A B C$. Na coluna Total $(R \$)$, foi calculado o valor total de vendas para cada item, multiplicando-se o preço unitário pela quantidade de vendas. Já a coluna Total Acum. (R\$), foi obtida somando-se o total do item atual com o total do item anterior.

Por fim, os itens foram colocados em ordem decrescente pelo valor total de vendas (faturamento) e calculou-se as percentagens de faturamento dos itens em relação ao faturamento total e também as percentagens acumuladas, conforme demostrado abaixo:

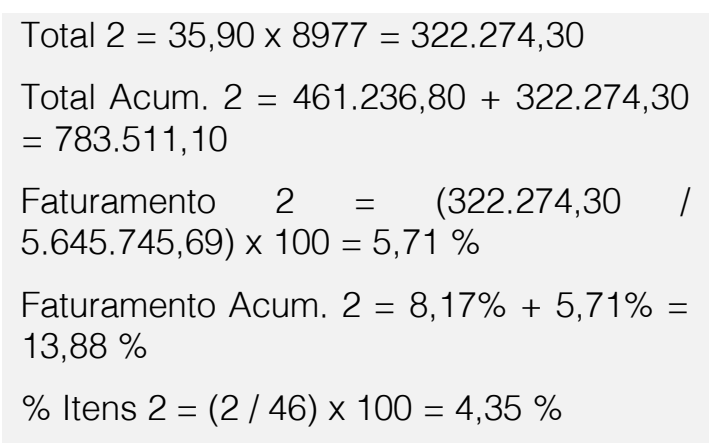


Tabela 1 - Dados iniciais de 01/01/2010 a 31/10/2015 para classificação ABC

\begin{tabular}{|c|c|c|c|c|c|c|c|c|}
\hline \multicolumn{9}{|c|}{ CURVA ABC DE FATURAMENTO } \\
\hline Itens & Código & $\begin{array}{l}\text { Preço } \\
(\mathrm{R} \$)\end{array}$ & $\begin{array}{l}\text { Vendas } \\
\text { (unid.) }\end{array}$ & Total $(\mathrm{R} \$)$ & $\begin{array}{l}\text { Total Acum. } \\
(R \$)\end{array}$ & $\begin{array}{c}\text { Faturame } \\
\text { nto } \%\end{array}$ & $\begin{array}{c}\text { Faturamento } \\
\text { Acum. } \%\end{array}$ & $\begin{array}{l}\text { Itens } \\
\%\end{array}$ \\
\hline 1 & 01758 & 93,90 & 4912 & 461236,80 & 461236,80 & 8,17 & 8,17 & 2,17 \\
\hline 2 & 02309 & 35,90 & 8977 & 322274,30 & 783511,10 & 5,71 & 13,88 & 4,35 \\
\hline 3 & 02189 & 37,90 & 8405 & 318549,50 & 1102060,60 & 5,64 & 19,52 & 6,52 \\
\hline 4 & 01316 & 75,90 & 4098 & 311038,20 & 1413098,80 & 5,51 & 25,03 & 8,70 \\
\hline 5 & 01495 & 29,90 & 10035 & 300046,50 & 1713145,30 & 5,31 & 30,34 & 10,87 \\
\hline 6 & 01308 & 55,90 & 4856 & 271450,40 & 1984595,70 & 4,81 & 35,15 & 13,04 \\
\hline 7 & 02073 & 36,90 & 7273 & 268373,70 & 2252969,40 & 4,75 & 39,91 & 15,22 \\
\hline 8 & 02134 & 36,90 & 5886 & 217193,40 & 2470162,80 & 3,85 & 43,75 & 17,39 \\
\hline 9 & 00388 & 23,90 & 8255 & 197294,50 & 2667457,30 & 3,49 & 47,25 & 19,57 \\
\hline 10 & 00961 & 69,90 & 2654 & 185514,60 & 2852971,90 & 3,29 & 50,53 & 21,74 \\
\hline 11 & 00915 & 23,90 & 7196 & 171984,40 & 3024956,30 & 3,05 & 53,58 & 23,91 \\
\hline 12 & 01360 & 42,90 & 3788 & 162505,20 & 3187461,50 & 2,88 & 56,46 & 26,09 \\
\hline 13 & 00383 & 23,90 & 6589 & 157477,10 & 3344938,60 & 2,79 & 59,25 & 28,26 \\
\hline 14 & 02266 & 34,90 & 4129 & 144102,10 & 3489040,70 & 2,55 & & 30,43 \\
\hline 15 & 00284 & 28,90 & 4816 & 139182,40 & 3628223,10 & 2,47 & 64,27 & 32,61 \\
\hline 16 & 00011 & 39,90 & 3469 & 138413,10 & 3766636,20 & 2,45 & 66,72 & 34,78 \\
\hline 17 & 02198 & 51,90 & 2656 & 137846,40 & 3904482,60 & 2,44 & 69,16 & 36,96 \\
\hline 18 & 02281 & 38,90 & 3419 & 9,10 & 4037481,70 & 2,36 & 71,51 & 39,13 \\
\hline 19 & 02238 & 52,90 & 2180 & 2,00 & 4152803,70 & 2,04 & 73,56 & 41,30 \\
\hline 20 & 02373 & 49,90 & 1866 & 3,40 & 4245917,10 & 1,65 & 75,21 & 43,48 \\
\hline 21 & 01415 & 24,90 & 3666 & 91283,40 & 4337200,50 & 1,62 & 76,82 & 45,65 \\
\hline 22 & 01840 & 8,90 & 9621 & 85626,90 & 4422827,40 & 1,52 & 78,34 & 47,83 \\
\hline 23 & 02381 & 39,90 & 2145 & 85585,50 & 4508412,90 & 1,52 & 79,86 & 50,00 \\
\hline 24 & 02398 & 42,90 & 1837 & 78807,30 & 4587220,20 & 1,40 & 81,25 & 52,17 \\
\hline 25 & 01421 & 24,90 & 3128 & 77887,20 & 4665107,40 & 1,38 & 82,63 & 54,35 \\
\hline 26 & 00416 & 7,90 & 9242 & 73011,80 & 4738119,20 & 1,29 & 83,92 & 56,52 \\
\hline 27 & 00976 & 86,90 & 833 & 72387,70 & 4810506,90 & 1,28 & 85,21 & 58,70 \\
\hline 28 & 01346 & 7,90 & 8811 & 69606,90 & 4880113,80 & 1,23 & 86,44 & 60,87 \\
\hline 29 & 00002 & 25,90 & 2682 & 69463,80 & 4949577,60 & 1,23 & 87,67 & 63,04 \\
\hline 30 & 00001 & 21,90 & 3140 & 68766,00 & 5018343,60 & 1,22 & 88,89 & 65,22 \\
\hline 31 & 01851 & 11,90 & 5675 & 67532,50 & 5085876,10 & 1,20 & 90,08 & 67,39 \\
\hline 32 & 02346 & 49,90 & 1237 & 61726,30 & 5147602,40 & 1,09 & 1,18 & 69,57 \\
\hline 33 & 02163 & 7,90 & 767 & 60640,40 & 5208242,80 & 1,07 & 92,25 & 71,74 \\
\hline 34 & 00794 & 9,90 & 5826 & 57677,40 & 5265920,20 & 1,02 & 93,27 & 73,91 \\
\hline 35 & 02350 & 54,90 & 1010 & 55449,00 & 5321369,20 & 0,98 & 94,26 & 76,09 \\
\hline 36 & 00366 & 29,90 & 1804 & 53939,60 & 5375308,80 & 0,96 & 95,21 & 78,26 \\
\hline 37 & 02391 & 33,90 & 1401 & 47493,90 & 5422802,70 & 0,84 & 96,05 & 80,43 \\
\hline 38 & 02367 & 36,90 & 1236 & 45608,40 & 5468411,10 & 0,81 & 96,86 & 82,61 \\
\hline 39 & 02401 & 35,90 & 972 & 34894,80 & 5503305,90 & 0,62 & 97,48 & 84,78 \\
\hline 40 & 01565 & 9,90 & 3482 & 34471,80 & 5537777,70 & 0,61 & 98,09 & 86,96 \\
\hline 41 & 00242 & 5,70 & 5561 & 31697,70 & 5569475,40 & 0,56 & 98,65 & 89,13 \\
\hline 42 & 02383 & 39,90 & 729 & 29087,10 & 5598562,50 & 0,52 & 99,17 & 91,30 \\
\hline 43 & 02361 & 39,90 & 686 & 27371,40 & 5625933,90 & 0,48 & 99,65 & 93,48 \\
\hline 44 & 02400 & 89,90 & 191 & 17170,90 & 5643104,80 & 0,30 & 99,95 & 95,65 \\
\hline 45 & 02364 & 32,90 & 79 & 2599,10 & 5645703,90 & 0,05 & 100,00 & 97,83 \\
\hline 46 & 02363 & 1,99 & 21 & 41,79 & 5645745,69 & 0,00 & 100,00 & 100,00 \\
\hline
\end{tabular}

Fonte: Autora, (2016) 
Nota: Os valores foram arredondados e as cores, amarelo, alaranjado e azul representam a divisão das classes $A, \quad B \quad e \quad C$ respectivamente.

Para simplificar o estudo, optou-se por trabalhar com a tabela de preços de destruidor, pois a empresa também trabalha com tabela de preços para atacado. Além disso, foi considerado que os itens analisados tiveram preços constantes ao longo do período em estudo. Logo todo e qualquer reajuste de preços independente do motivo foi desconsiderado.

$\mathrm{Na}$ divisão dos itens, foi adotado que os produtos responsáveis por 50,00\% do faturamento seriam classificados como classe A, $35,00 \%$ como classe B e os $15,00 \%$ restantes classificados como produtos classe C.

A partir disso, constatou-se que a classe A é representada pelo maior faturamento, sendo $21,74 \%$ dos itens responsáveis por $50,53 \%$ do faturamento ( $R \$ 2.852 .971,90)$, já na classe $B$ $36,96 \%$ dos itens correspondem a $34,68 \%$ do faturamento ( $R \$ 1.957 .535,00)$, e a classe $C$ representada por 19 itens ou 41,30\% da totalidade, correspondendo $\mathrm{R} \$$ 835.238,79 $(14,79 \%)$ do faturamento, como mostra o QUADRO 2.

Quadro 2 - Divisão das classes ABC

\begin{tabular}{|c|c|c|c|}
\hline Faturamento \% & № itens & Itens \% & Classe \\
\hline 50,53 & 10 & 21,74 & A \\
\hline 34,68 & 17 & 36,96 & B \\
\hline 14,79 & 19 & 41,30 & C \\
\hline
\end{tabular}

Assim a curva $A B C$ do faturamento foi plotada, conforme apresentado na FIG. 2.

Figura 7 - Curva $A B C$ de faturamento

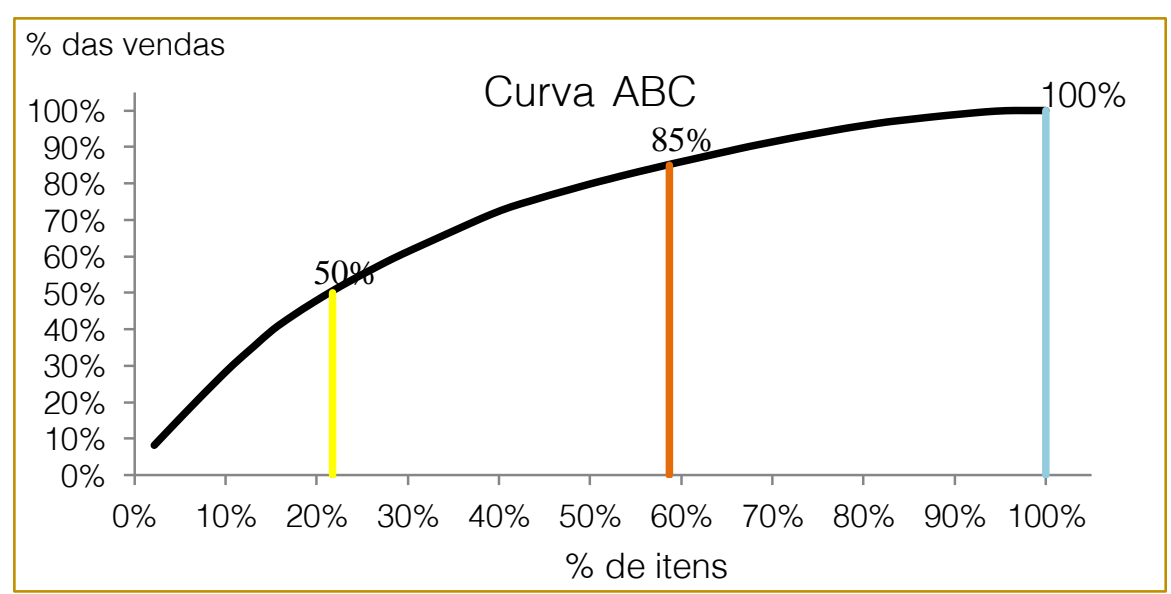

Fonte: Autora, (2016)

Com a curva $A B C$ de vendas por produto, foi possível identificar que os produtos classificados como A, são os mais vendidos e que apresentaram maior destaque nos rendimentos da empresa e por isso necessitam de maior atenção e controle do que os itens classificados como B e C.

\section{CONCLUSÃO}

Com este estudo, foi possível demonstrar como controlar os estoques de produto acabado em uma confecção de lingeries, utilizando a curva $A B C$ para classificação dos itens.

Acredita-se que a curva $A B C$ facilitará o controle dos itens em estoque, pois esta 
ferramenta permitirá que a empresa identifique entre seus produtos, quais deles garantem $50 \%$ do faturamento dando-lhes maior atenção, e quais são de baixa representatividade no faturamento e que, portanto não merecem muita atenção, devendo ocupar pouco espaço no estoque.

Diante disso, pode-se afirmar que o conhecimento dos itens em estoque, juntamente com sua classificação e boas práticas de controle, podem otimizar a gestão de estoque de produto acabado, reduzindo seus níveis, sem prejudicar o atendimento aos clientes.

Sugere-se que a empresa também utilize a classificação ABC como parâmetro para

\section{REFERÊNCIAS}

[1] Ballou, Ronald H. Gerenciamento da Cadeia de Suprimentos / Logística Empresarial. 5. ed. Porto Alegre, RS: Bookman, 2006.

[2] Cassiano, Cassio Sales. et al. A otimização da gestão de estoque de produto acabado no contexto logístico da indústria de tecelagem: o caso da indústria têxtil S/A. João Pessoa-PB: XIV Congresso Brasileiro de Custos, 2007.

[3] Falcão, Roberto Flores. Gestão de Estoques: uma ferramenta para a redução de custos. São Paulo-SP: Universidade de São Paulo (USP), 2008.

[4] Fenili, Renato. Administração de recursos materiais e patrimoniais para concurso: abordagem completa. São Paulo, SP: Método, 2011.

[5] Martins, Petrônio Garcia; ALT, Paulo Renato Campos. Administração de materiais e recursos patrimoniais. 3aㅡ ed. São Paulo: Saraiva, 2009.

[6] Martins, Petrônio Garcia; Laugeni, Fernando Piero. Administração da produção. $2^{\underline{a}}$ edição. São Paulo-SP: Saraiva, 2006.

[7] Oliveira, Maxwell Ferreira de. Metodologia científica: um manual para a realização de pesquisas em Administração. Catalão - GO: UFG, 2011. tomar suas decisões, quando precisar retirar algum modelo de linha, optando sempre pelos itens da classe $\mathrm{C}$, uma vez que estes são os menos representativos em relação ao faturamento e podem ser substituídos sem receio.

Por fim, os objetivos deste estudo foram alcançados e os resultados obtidos satisfatórios, porém, sugere-se que a empresa realize novos estudos, para conciliar a classificação $A B C$ com técnicas de previsão de demanda, para melhorar ainda mais seu controle de estoque.

[8] Pascoal, Janaína Araújo. Gestão Estratégica de Recursos Materiais: controle de estoque e armazenagem. 2008. 60f. Monografia (Bacharelado em Administração) Pró-Reitoria de Ensino de Graduação, Centro Universitário de João Pessoa, João Pessoa-PB, 2008.

[9] Salviano, Ana Caroline. et al. Estratégias de controle de estoques para redução de custos e desperdícios em uma empresa prestadora de serviço. João Pessoa-PB: Instituto Federal da Paraíba, 2010. Disponível em:

[10] <http://connepi.ifal.edu.br/ocs/index.php/c onnepi/CONNEPI2010/paper/viewFile/1216/739>. Acessado em 12 de Dezembro de 2015.

[11] Slack, Nigel; Chambers, Stuart; Johnston, Robert. Administração da Produção. $2^{2}$ edição. São Paulo. Atlas, 2002.

[12] Souza, Ciliane Cristina de. Análise da gestão de estoque do produto acabado mosarte. Tijucas-SC: Universidade do Vale do Itajaí, 2007. Disponível em: <http://siaibib01.univali.br/pdf/Ciliane\%20Cristina\% 20de\%20Souza.pdf?>. Acessado em 02 de Novembro de 2015.

[13] Viana, João José. Administração de materiais: um enfoque prático. São Paulo: Atlas, 2006. 


\section{Bapítulo 12}

\section{MODELO DE DIAGNÓSTICO DA MATURIDADE DO PROCESSO DE PLANEJAMENTO E CONTROLE DA PRODUCÃO FUNDAMENTADO NOS PRINCÍPIOS DA CONSTRUCÃO ENXUTA}

\section{Maria Luiza Abath Escorel Borges}

\section{Henrique Sérgio Rêgo de Holanda Sá Sobrinho}

Resumo: A indústria da Construção Civil tem adaptado técnicas gerenciais de setores industriais para sua realidade, com o intuito de eliminar desperdícios e aumentar a eficiência dos processos. É nesse cenário que surge a Construção Enxuta, conhecida internacionalmente por Lean Construction, filosofia baseada no Sistema Toyota de Produção, que visa melhorar o gerenciamento de informações, materiais e pessoas na construção civil. Com o objetivo de avaliar o grau de aplicação dos princípios da construção enxuta em trinta construtoras da capital paraibana, foi utilizado um questionário como ferramenta de coleta de dados para identificar, em termos percentuais, o desempenho atual de cada empresa estudada em relação a Lean Construction. Os gestores responsáveis pelas empresas mostraram por meio de suas respostas que existe a preocupação em adotar procedimentos de racionalização de processos e perdas.

Palavras-Chave: Lean Construction; Planejamento; Produção; Desperdício. 


\section{INTRODUÇÃO}

Nas últimas décadas, as empresas brasileiras vêm passando por transformações na busca contínua pela competitividade. Isso se deve às dificuldades geradas pela abertura da economia ao mercado estrangeiro, quando a Associação Brasileira de Normas Técnicas (ABNT) adotou, em 1990, as normas da série ISO 9000, publicada pela International Organization for Standardization (ISO), uma organização internacional cujo objetivo é padronizar as normas industriais. No mesmo período, o país passava por uma crise econômica, o que causou a queda do volume de financiamentos públicos para o mercado habitacional, agravando a situação das empresas do setor. Esse quadro as estimulou ainda mais a entrar na busca por competitividade, buscando melhorias de produtividade, qualidade e flexibilidade (HEINECK, 2004).

Depois de apresentar durante vários anos crescimento significativo, o mercado da construção civil no Brasil passa novamente por um período de estagnação. Diante de um cenário marcado por retração econômica e incertezas políticas, a Construção Civil registrou queda de 7,6\% em sua parcela do Produto Interno Bruto (PIB), segundo dados divulgados pelo Instituto Brasileiro de Geografia e Estatística (2016), sendo essa a queda mais acentuada desde 2003 , de $8,9 \%$. A rentabilidade do ramo já havia diminuído consideravelmente em 2014, o que fez com que o setor diminuísse suas atividades. Dessa forma, nos anos de 2014 e 2015, a Indústria da Construção Civil (ICC), representante de grande parte do PIB nacional (cerca de $11,3 \%$ em 2013), consequentemente sendo essencial para o desenvolvimento do país, registrou queda de aproximadamente $8,43 \%$ (CBIC, 2016).

Em meio a uma das circunstâncias mais adversas das últimas décadas, representantes do setor da construção civil afirmam que $\mathrm{o}$ atual momento é de as construtoras repensarem estratégias de mercado, aproveitando para enxugar custos e investir em planejamento e produtividade (LOTURCO, 2015). É nesse cenário que a Construção Enxuta, conhecida internacionalmente por Lean Construction, adquire notoriedade.

Partindo destas constatações, este trabalho visa contribuir com a comunidade científica, através de uma revisão sistemática da utilização dos princípios e ferramentas da Lean Construction como estratégia de planejamento e controle para a otimização de obras da Construção Civil, bem como fazer um estudo da utilização da filosofia enxuta em construtoras de João Pessoa.

\section{REVISÃO BIBLIOGRÁFICA}

\subsection{DESPERDÍCIO NA CONSTRUÇÃO CIVIL}

O modelo de gestão utilizado por grande parte das construtoras é baseado em processos de conversão, que transformam insumos em produtos intermediários ou finais. Porém, essa definição de produção tem ignorado, muitas vezes, algumas atividades que compõem os fluxos físicos entre as atividades de conversão, como por exemplo, a movimentação de materiais, de pessoas e de informações. Essas atividades são caracterizadas por não agregar valor ao produto (REZENDE et al., 2012). Segundo Formoso (2000), estima-se que dois terços (67\%) do tempo gasto por trabalhadores em um canteiro de obras são em atividades que não agregam valor.

Derivado de técnicas do Sistema Toyota de Produção, o modelo de gestão proposto pela Lean Construction tem, como objetivo principal, estudar a relação entre atividades de conversão e de fluxo, para reduzir ou até eliminar operações que não agreguem valor para aquele processo e que resultem em perdas de tempo e produtividade.

Formoso et al. (1996) define o termo "perda" como sendo algo muito além do que o desperdício de materiais. É qualquer ineficiência que ocorre no uso de equipamentos, materiais, mão de obra e capital, que acarrete em maiores quantidades àquelas necessárias para construção da edificação. Ou seja, perda é uma resposta quanto à execução de atividades desnecessárias que geram custos adicionais que não agregam valor. Shingo (1996) dividiu as perdas em sete categorias:

a) Perdas por superprodução: São aquelas que ocorrem por produção de um produto em quantidades superiores às necessárias, como, por exemplo: produção de argamassa para reboco em quantidade superior ao necessário;

b) Perdas por espera: Está relacionada com as atividades de fluxo de materiais e trabalhadores, como por 
exemplo, parada no serviço por conta de falta de equipamentos ou insumos;

c) Perdas por transporte: Está associada ao manuseio excessivo ou inadequado de materiais e componentes devido a uma má programação de atividades ou de um layout de canteiro ineficiente, como por exemplo, estoque de material distante do ponto de utilização;

d) Perdas no processamento em si: Está associada a falta de padronização nas atividades, ineficiência no método de trabalho e mão de obra desqualificada. São exemplos: quebra manual de blocos por de meios-blocos, rasgos na alvenaria para instalações elétricas e hidráulicas;

e) Perdas nos estoques: São aquelas que decorrem de estoques excessivos, devido a programação inadequada de compra, entrega do material ou erro na orçamentação, e que podem resultar em falta de local adequado para a disposição dos mesmos. São exemplos: deterioração do cimento por armazenamento em contato com o solo e pilhas muito altas;

f) Perdas no movimento: São aquelas que decorrem da execução de movimentações desnecessárias por parte dos trabalhadores, durante a realização de suas atividades, por conta de frentes de trabalho distantes, layout inadequado do canteiro, programação de uma sequência inadequada da atividade;

g) Perdas pela elaboração de produtos defeituosos: São aquelas que resultam em retrabalho ou redução no desempenho do produto final. Surgem da falta de integração entre o projeto e a execução, das deficiências do controle do processo produtivo ou da falta de treinamento dos funcionários. São exemplos: paredes fora de esquadro, descolamento de azulejos, falha na impermeabilização, entre outras.

Observando que existem tantos fatores que influenciam no processo de produção, a Lean Construction veio modificar $\mathrm{O}$ conceito tradicional de processo de produção, com a intenção de aumentar a eficiência global dos empreendimentos do setor, buscando eliminar o máximo possível de atividades como movimentação, espera e inspeção, que não agregam valor e consomem bastante tempo no processo produtivo. Esse pensamento enxuto teve início no Japão, através do Sistema Toyota de Produção (PAIXÃO, 2011).

\subsection{SISTEMA TOYOTA DE PRODUÇÃO}

Após a Segunda Guerra Mundial, Kiichiro Toyoda, fundador da Toyota Motor Company, percebeu que os americanos ainda estavam muito à frente da sua empresa no quesito produção e essa diferença de produtividade só poderia ser explicada pela existência de perdas no sistema de produção japonês. A partir daí, começou a estruturação de um processo para mudar esse cenário. Equipes de funcionários passaram a trabalhar juntos, tentando encontrar a melhor maneira para realizar as operações necessárias, identificando e eliminando perdas. Nesse processo de melhoria contínua, chamado Kaizen, cada trabalhador da linha de montagem, ao contrário do sistema de produção em massa, pudesse parar a linha de produção caso algum defeito fosse detectado (PICCHI, 2000).

Shingo (1996) diz que os trabalhadores aprenderam não só a identificar a raiz do problema, como também a sugerir a correção para que este não voltasse a acontecer, diminuindo consideravelmente o número de erros. Com isso, a prática do Kaizen resultou na redução da necessidade de retrabalho e o aumento da qualidade dos carros fabricados. Outra meta do Sistema Toyota de Produção, conhecido como Lean Production (Produção Enxuta), é reduzir os estoques finais ao trabalhar com pequenos lotes de produção e uma alta quantidade de entregas.

Diante disso tudo, o propósito maior da Lean Production é atender da melhor maneira as necessidades do cliente, fornecendo produtos e serviços da mais alta qualidade, ao mais baixo custo e no menor tempo possível. Tudo isso, garantindo um ambiente de trabalho onde segurança e moral dos trabalhadores é uma preocupação fundamental da gerência (WOMACK, 2004).

No ano de 1973, com a Crise do Petróleo, empresas no mundo inteiro enfrentaram pesados prejuízos, enquanto a Toyota continuou obtendo lucros, sendo uma das poucas a escapar dessa crise. Este fenômeno despertou a curiosidade das organizações e a Toyota ficou conhecida mundialmente (GHINATO, 2000). 


\subsection{LEAN CONSTRUCTION}

O termo "Lean" foi inicialmente utilizado no livro "The Machine that Changed the World" (A Máquina que Mudou o Mundo), de Womack, publicado em 1990 nos Estados Unidos. Trata-se de um amplo estudo divulgado pelo MIT (Massachussetts Institute of Technology) sobre a indústria automobilística, procurando avaliar as causas do sucesso da Toyota e o que poderia ser aprendido pelas indústrias estadunidenses.

A Lean Construction é a aplicação dos conceitos e princípios da Lean Production na construção civil. Esse conceito foi inicialmente apresentado pelo pesquisador finlandês Lauri Koskela, em 1992, ao publicar o Relatório Técnico no. 72 - Application of the New Production Philosophy to Construction, pela Universidade de Stanford, nos Estados Unidos da América. No relatório, ele adaptou os conceitos da Lean Production para a construção civil, propondo assim, a Lean Construction, e enumerou os seguintes onze princípios para a melhoria do fluxo da nova filosofia de gestão (DENARI, 2010):
a) Redução de atividades que não agregam valor;
b) Aumento do valor do produto através de uma consideração sistemática dos requisitos do cliente;
c) Redução da Variabilidade;
d) Redução do Tempo de Ciclo;
e) Simplificação pela minimização do número de passos e partes;
f) Aumento da flexibilidade na execução do produto;
g) Aumento da transparência no processo;
h) Foco no controle de todo processo;
i) Introdução da Melhoria Contínua ao Processo;
j) Balanceamento da Melhoria dos fluxos com a melhoria das conversões;
k) Benchmarking (aprendizado a partir das práticas adotadas em outras empresas).

Em uma revisão de seus postulados, realizada em 2000, na publicação de sua tese de doutorado, Koskela simplifica a produção enxuta, enunciando apenas três grandes princípios. Segundo ele, ser Lean é focar em transformação, fluxo e valor.
Focar em transformação é fazer bem feito o produto, cuidar da qualidade na sua execução e aplicar da melhor maneira o esforço produtivo de máquinas e operários. Focar em fluxo é não deixá-lo parar, garantindo a sua continuidade por alguma sistemática de planejamento da produção, idealmente aquelas que determinam que um produto só deva ser produzido se ele é requerido. Por fim, focar no valor é admitir a relevância do cliente no processo produtivo. A transformação e o fluxo só adquirem sentido se atenderem aos requisitos daqueles que vão usufruir dos bens ou serviços assim produzidos (HEINECK, 2004).

\section{PROCEDIMENTOS METODOLÓGICOS}

Com a finalidade de atingir os objetivos definidos neste estudo, o método de pesquisa utilizado foi desenvolvido sob dois enfoques. Primeiramente foram selecionadas fontes bibliográficas para a realização da referencial teórico abordando toda a filosofia Lean, desde a sua origem no Sistema Toyota de Produção até os dias atuais, bem como o cenário da construção civil no Brasil.

Posteriormente, foi elaborado um questionário na pesquisa de campo, o qual possuía três perguntas para cada um dos onze princípios da Lean Construction, além de perguntas questionando o nível de conhecimento do próprio entrevistado em relação ao assunto, o seu interesse em aplicar a filosofia, se acredita que a sua utilização pode melhorar o desempenho de uma obra e os possíveis obstáculos para uma empresa não querer utilizá-la. No total, foram quarenta e cinco perguntas por questionário aplicado.

O estudo se desenvolveu em trinta construtoras de edificações verticais localizadas na cidade de João Pessoa, todas presentes na lista do Sindicato da Indústria da Construção Civil de João Pessoa (SINDUSCON-JP), a fim de verificar, se as mesmas utilizam ou não a filosofia Lean em seus processos. Os meios utilizados para coletar os dados necessários à pesquisa foram entrevistas acompanhadas do questionário semiaberto. Os entrevistados foram profissionais ligados ao gerenciamento de obras. 


\section{RESULTADOS}

Inicialmente buscou-se determinar como os próprios entrevistados classificavam o seu conhecimento a respeito da filosofia Lean
Construction. A resposta poderia ser dada em cinco níveis, enumerados de zero a quatro, equivalendo, nessa ordem à nenhum, pouco, médio, bom e ótimo. O resultado desse quesito está exposto na Tabela 1 seguinte:

Tabela 1 - Conhecimento a respeito da Lean Construction

\begin{tabular}{|c|c|c|}
\hline Conhecimento & Frequência & Porcentual (\%) \\
\hline Nenhum & 0 & 0 \\
\hline Pouco & 9 & 30 \\
\hline Razoável & 13 & 43,3 \\
\hline Bom & 8 & 26,7 \\
\hline Muito bom & 0 & 0 \\
\hline Total & 30 & 100 \\
\hline
\end{tabular}

Fonte: Dados da pesquisa, 2016

Como pode ser visualizado, todos os entrevistados alegaram possuir algum conhecimento a respeito da Lean Construction. Quase metade deles disseram que têm um entendimento razoável, totalizando 43,3\%. Apenas oito pessoas responderam como tendo bom, e nove pensam saber pouco da filosofia enxuta.

Em relação ao conhecimento, foi feita outra análise utilizando a mediana do desempenho das empresas. Foi calculada a mediana de cem pontos. Como no total são trinta empresas, isso quer dizer que quinze empresas pontuaram acima de cem, e quinze abaixo de cem, já que a mediana é o valor que divide a amostra em duas partes iguais. A Tabela 2 mostra a distribuição das empresas de acordo com o conhecimento declaro, relacionando com as suas respectivas pontuações.

Tabela 2 - Relação do conhecimento declarado com a pontuação obtida

\begin{tabular}{|c|c|c|c|c|c|}
\hline Mediana & Nenhum & Pouco & Razoável & Bom & Ótimo \\
\hline Abaixo de 100 & 0 & 6 & 6 & 3 & 0 \\
\hline Acima de 100 & 0 & 3 & 7 & 5 & 0 \\
\hline Total & 0 & 9 & 13 & 8 & 0 \\
\hline
\end{tabular}

Fonte: Dados da pesquisa (2016)

Uma contradição observada é que das oito que responderam o questionário como tendo bom conhecimento em torno da construção enxuta, três empresas adquiriram pontuação abaixo da mediana. Ou seja, mesmo sabendo que a utilização da Lean Construction como modelo de gestão aumenta a eficiência global do empreendimento, a aplicação não acontece nas suas obras. Por isso, é preciso saber quais fatores impedem a prática Lean nessas construtoras. A Tabela 3 apresenta as respostas que os engenheiros deram para o principal entrave que impedem as construtoras, de uma maneira geral, não se utilizar essa metodologia de gestão. 
Tabela 3 - Principais entraves para a implantação da Lean Construction

\begin{tabular}{|c|c|c|}
\hline $\begin{array}{c}\text { Entraves } \\
\text { Custos de implantação (gastos com consultorias e } \\
\text { treinamentos) }\end{array}$ & 9 & 30 \\
\hline $\begin{array}{c}\text { Dificuldade dos funcionários em compreenderem a } \\
\text { filosofia }\end{array}$ & 7 & 23,3 \\
\hline Não confiar na expectativa de bons resultados & 3 & 10 \\
\hline $\begin{array}{c}\text { Não ser uma filosofia com técnicas disseminadas na } \\
\text { região }\end{array}$ & 11 & 36,7 \\
\hline Total & 30 & 100 \\
\hline
\end{tabular}

Fonte: Dados da pesquisa (2016)

A última opção foi a mais votada, com 36,7\%, que é onde entra a questão da cultura. As empresas têm medo ou receio de inovar e não dar certo, acarretando em prejuízo. Apesar disso, apenas três empresas não confiam em bons resultados aplicando a Lean Construction. Do restante, nove apontaram os custos de implantação como principal entrave e sete indicaram a dificuldade em compreender a filosofia. Para esse, existem consultorias especializadas em construção enxuta, atuando em conjunto com os fornecedores do setor da construção civil, revendo processos e métodos, afim de utilizar um melhor gerenciamento da obra.

Após apresentar toda a teoria da metodologia enxuta na construção, o questionário buscou também saber o interesse em aplicar esse modelo de gestão nas obras em questão. 0 quesito tinha cinco opões de resposta: nenhum, pouco, razoável, bom e ótimo. O resultado é apresentado na Tabela 4:

Tabela 4 - Interesse em aplicar a Lean Construction

\begin{tabular}{|c|c|c|}
\hline Interesse & Frequência & Porcentual (\%) \\
\hline Nenhum & 0 & 0 \\
\hline Pouco & 1 & 3,3 \\
\hline Razoável & 4 & 13,3 \\
\hline Bom & 16 & 53,3 \\
\hline Ótimo & 9 & 30 \\
\hline Total & 30 & 100 \\
\hline
\end{tabular}

Fonte: Dados da pesquisa (2016)

Ninguém disse não ter interesse, mas uma pessoa tem pouco, e quarto, razoável. Como já era esperado, a maior parte tem de bom a ótimo nível de interesse, representando vinte e cinco empresas, ou $83,3 \%$ do total. Isso mostra que a maior parte delas acredita nos benefícios desse modelo de gestão.

Partindo para a análise das perguntas relacionadas aos princípios da Lean Construction, todos eles possuíam pesos iguais, ou seja, o mesmo nível de importância.
Sabendo que eram onze princípios, que cada um possuía três perguntas, que cada pergunta possuía cinco níveis de respostas (1 - nunca, 2 - quase nunca, 3 - às vezes, 4 quase sempre, 5 - sempre), conclui-se que a pontuação máxima possível é de cento e sessenta e cinco pontos. Dividindo o somatório dos pontos de cada empresa por esse valor total, foi determinada a média do desempenho individual das mesmas. O resultado é mostrado na Tabela 5 adiante: 
Tabela 5 - Pontuação das empresas

\begin{tabular}{|c|c|c|c|c|c|}
\hline Empresa & Pontuação & Média $(\%)$ & Empresa & Pontuação & Média (\%) \\
\hline 1 & 111 & 67,27 & 16 & 109 & 66,06 \\
\hline 2 & 104 & 63,03 & 17 & 77 & 46,67 \\
\hline 3 & 97 & 58,79 & 18 & 112 & 67,88 \\
\hline 4 & 127 & 76,97 & 19 & 102 & 61,82 \\
\hline 5 & 63 & 38,18 & 20 & 104 & 63,03 \\
\hline 6 & 98 & 59,39 & 21 & 108 & 65,45 \\
\hline 7 & 95 & 57,58 & 22 & 103 & 62,42 \\
\hline 8 & 93 & 56,36 & 23 & 115 & 69,70 \\
\hline 9 & 111 & 67,27 & 24 & 91 & 55,15 \\
\hline 10 & 115 & 69,70 & 25 & 71 & 43,03 \\
\hline 11 & 84 & 50,91 & 26 & 105 & 63,64 \\
\hline 12 & 102 & 61,82 & 27 & 86 & 52,12 \\
\hline 13 & 82 & 49,70 & 28 & 96 & 58,18 \\
\hline 14 & 87 & 52,73 & 29 & 63 & 38,18 \\
\hline 15 & 103 & 62,42 & 30 & 70 & 42,42 \\
\hline
\end{tabular}

Fonte: Dados da pesquisa (2016)

Somando todas as pontuações e dividindo pelo número de construtoras, obteve-se a média geral de 96,1 pontos, que corresponde a $58,24 \%$ do total. Ou seja, pode-se dizer que cerca de $60 \%$ da filosofia enxuta é presente nas construtoras da cidade de João Pessoa, mesmo que inconscientemente. Os gestores responsáveis pelas empresas mostraram por meio de suas respostas que são adotados procedimentos de racionalização de processos e perdas.
As empresas que consideram adotar a Lean Construction não aplicam totalmente os princípios da filosofia. Talvez isso aconteça porque alguns deles são considerados menos importantes que outros, recebendo assim, menos atenção. Com a intenção de fazer a análise disso, a Tabela 6 ilustra a média individual deles, juntamente com os seus respectivos desvios padrões, bem como a média e desvio padrão geral.

Tabela 6 - Resultados dos princípios da Lean Construction

\begin{tabular}{|l|c|c|}
\hline \multicolumn{1}{|c|}{ Princípios } & Média & Desvio padrão \\
\hline Redução de atividades que não agregam valor & 9,5 & 1,432 \\
\hline $\begin{array}{l}\text { Aumento do valor do produto através de uma consideração } \\
\text { sistemática dos requisitos do cliente }\end{array}$ & 8,1 & 2,057 \\
\hline Redução da variabilidade & 10,13 & 1,978 \\
\hline Redução do tempo de ciclo & 7,8 & 1,883 \\
\hline Simplificação pela minimização do número de passos & 8,9 & 1,971 \\
\hline Aumento da flexibilidade na execução do produto & 8,07 & 2,18 \\
\hline Aumento da transparência no processo & 9,07 & 1,999 \\
\hline Foco no controle do processo global & 9,93 & 2,612 \\
\hline Introdução da melhoria contínua no processo & 8,3 & 1,86 \\
\hline Balanceamento da melhoria dos fluxos com a melhoria das & 8,77 & 2,012 \\
\hline conversões & 7,53 & 1,978 \\
\hline Benchmarking & 96,1 & 16,06 \\
\hline Desempenho geral & & \\
\hline
\end{tabular}

Fonte: Dados da pesquisa (2016) 
O princípio com maior média é o de reduzir a variabilidade. Do ponto de vista da construção enxuta, a variabilidade pode ser nos processos anteriores, relacionada aos fornecedores do processo; no próprio processo, relacionada à execução de alguma atividade; ou na demanda, relacionada aos desejos e necessidades dos clientes. É importante tentar simplificar ao máximo, pois a variabilidade tende a aumentar a parcela de atividades que não agregam valor e o tempo necessário para executar um produto.

A prática do benchmarking, princípio com média mais baixa, possibilita reconhecer que outra empresa pode executar um processo de maneira mais eficaz, para que possam ser adaptados à própria empresa. É fundamental fazer esse processo, para que a forma de gerenciamento e controle da produção da própria empresa possa ser otimizada. Uma das perguntas do questionário questionava diretamente se as empresas procuram técnicas de sucesso em outras e consideram como um modelo a ser espelhado. Para essa pergunta, quase metade das empresas responderam que nunca fazem isso, o que deixa a entender que elas consideram a metodologia própria tão eficiente que não precisa ser melhorada. As outras fazem uso de modelos bem-sucedidos como referências na execução da obra, porém, não com máxima consistência possível.
Ainda foi feita uma correlação entre pontuação obtida e o tempo de atuação da empresa no mercado, com o intuito de descobrir se há relação entre os dois parâmetros. O tempo médio de empresa é de 14,4 anos e como já foi visto, a pontuação media é de 96,1 pontos. A correlação avalia diretamente o grau de relacionamento entre duas variáveis distintas. Para o presente trabalho foi utilizada a Correlação de Pearson, um coeficiente que quantifica a força de associação linear entre $\mathrm{X}$ e $\mathrm{Y}$, descrevendo o quão bem uma linha reta se ajusta através de pontos no plano cartesiano.

Se os pontos ficam localizados exatamente sobre uma linha crescente então " $r=1$ ", e se ficam localizados exatamente sobre uma linha decrescente, " $r=-1$ ". Quanto mais perto de um, independente do sinal, maior é o grau de dependência estatística linear entre as variáveis. Por outro lado, quanto mais próximo de zero for o valor, menor será a força dessa relação. $O$ coeficiente tem um caráter adimensional, ou seja, ele é desprovido de unidade física que o defina. Não faz sentido interpretar uma correlação de 0,3 como sendo $30 \%$, por exemplo (BISQUERA, 2004). Na presente correlação, o tempo está representando o valor de $X$, em anos, e o desempenho o lugar de $\mathrm{Y}$, em pontos. $\mathrm{O}$ software IBM SPSS Statistics fez o cálculo e gerou o resultado apresentado na Tabela 7.

Tabela 7 - Correlação de Pearson entre tempo e desempenho

\begin{tabular}{|c|c|c|}
\hline Variáveis & Tempo & Desempenho \\
\hline Tempo & 1 & $0,571^{* *}$ \\
\hline Desempenho & $0,571^{* *}$ & 1 \\
\hline
\end{tabular}

A relação entre tempo e desempenho é de $0,571^{\star *}$, valor que classifica a correlação como sendo moderada positiva. Os dois asteriscos após o coeficiente expressam que a correlação é significativa no nível 0,01. Portanto, o software alegou que a hipótese nula, de que esse resultado aconteceu por acaso, é falsa e existe $99 \%$ de chance de acerto no Coeficiente de Pearson obtido pelo software. A correlação moderada positiva de 0,571 entre a média do tempo de atuação de cada empresa declarado na Receita Federal e o desempenho das mesmas em relação à utilização da Lean Construction é uma similaridade real e não acontece por acaso.

\section{CONSIDERAÇÕES FINAIS}

As respostas dadas pelos entrevistados indicam que a filosofia ainda é pouco disseminada na região. Os que afirmaram ter um bom nível de conhecimento a respeito do assunto, disseram que apenas leram e estudaram sobre. Deste modo, perguntas mais minuciosas são necessárias para que se possa obter uma resposta que esteja de acordo com a realidade, pois, não seria adequado atribuir o mesmo nível de conhecimento para alguém que estudou a filosofia e outro que tenha trabalhado com ela.

Também pode-se chegar à conclusão de que todos os entrevistados possuem interesse em 
aplicar a construção enxuta, mesmo que mínimo, e acreditam que sua utilização pode melhorar o desempenho de suas empresas. Isso leva a crer que existe espaço na construção civil para a implementação da filosofia. Porém, esse resultado entra em contradição com relação aos obstáculos enfrentados para essa implementação, pois as empresas alegaram o fato de não ser uma técnica muito difundida na região como o principal entrave. Assim, deve-se fazer conhecidos os conceitos e vantagens da aplicação do pensamento enxuto para todos os envolvidos na construção civil da cidade.

Em relação a aplicação dos princípios, notase uma variação na relevância que as empresas dão para cada um, mas reduzir a

\section{REFERÊNCIAS}

[1] Denari, Caio G. Aplicação dos princípios da construção enxuta em empresas construtoras. 2010. 67f. Monografia (Graduação em Engenharia Civil) - Universidade Federal de São Carlos. 2010

[2] Formoso, Carlos T. et al. As perdas na construção civil: conceitos, classificações e seu papel na melhoria do setor. 1996.

[3] Shingo, Shingeo; Sistemas de Produção com Estoque Zero: o Sistema Shingo para melhorias contínuas. Porto Alegre: Bookman Companhia Editora, 1996.

[4] Heineck, Luiz et al. Logística e Lógica na Lean Construction: Um Processo de Gestão Transparente na Construção de Edifícios. Fortaleza: Fibra Construções Ltda, 2004. $152 f$. variabilidade e focar no controle do processo global possuem maior relevância no quadro geral. Além disso, atender as considerações feitas pelos clientes é de comum importância para todas. Logo, é perceptível o valor desse princípio no dia-a-dia das construtoras, pois entender as necessidades dos clientes é característica primordial para a permanência no competitivo mercado da construção.

Diante disso, pode-se afirmar que o objetivo desse trabalho foi alcançado ao identificar o nível de aplicação da Lean Construction e o desempenho global de cada construtora, e concluir, que existe a preocupação nas empresas em otimizar seus processos produtivos e reduzir os desperdícios.

[5] Paixão, L. G. A.; Implementação de práticas da produção enxuta: um estudo de caso em uma fábrica de produtos de papel. 2011. 119p. Monografia (Graduação em Engenharia de Produção) - Universidade de São Paulo. 2011.

[6] Picchi, F. A.; Lean Thinking (Mentalidade Enxuta): Avaliação Sistemática do Potencial de Aplicação no Setor de Construção. In: Simpósio Brasileiro de Gestão da Qualidade e Organização do Trabalho no Ambiente Construído. 2001. Artigo técnico, Fortaleza.

[7] Rezende, Juliana S. et al. Identificação das práticas da filosofia Lean Construtoras de médio porte na cidade de Itabuna (BA), Engevista, V.14, dez. 2012

[8] Womack, James P., Mentalidade Enxuta nas Empresas: elimine os Desperdícios e Crie Riqueza. 7. ed. Ed. Rio de Janeiro: Campus, 2004. 


\section{Bapítulo 13}

\section{FORMULAÇÃO DE UMA POLÍTICA DE ESTOQUE PARA MATERIAIS MRO DE IMPLEMENTOS HIDRÁULICOS}

\section{Mateus Frechiani Bitte}

\section{Helio Zanquetto Filho}

Resumo: O presente artigo tem como objetivo apresentar a formulação de uma política de estoque de materiais de manutenção, reparo e operação (MRO), para implementos hidráulicos, por meio de um estudo prático realizado em uma empresa situada no estado do Espírito Santo. No desenvolvimento da pesquisa utilizou-se a classificação vital, essencial e desejável (VED), como suporte teórico para catalogar as peças e a distribuição de Poisson para calcular os níveis de compra de cada uma das peças. Todo o trabalho foi realizado com planilhas eletrônicas que possibilitaram visualizar os dados coletados em campo. Ao final da pesquisa, em uma comparação entre a política atualmente adotada e a política simulada pelo pesquisador, observou-se que a empresa teria uma economia significativa caso a política simulada fosse adotada. 


\section{INTRODUÇÃO}

O cenário atual do mercado tornou-se muito competitivo gerando mudanças rápidas que necessitam por parte das empresas respostas de igual velocidade com falhas reduzidas a quase zero. No dia a dia as empresas competem entre si com estratégias diferenciadas no mercado, produzindo muito com o mínimo possível de gastos sem perder o nível de serviço.

Nesse contexto, vale à pena destacar a importância da logística tanto como fator para o alcance de um nível de serviço ótimo para a empresa, quanto um setor alvo de economia. Em um estudo realizado por Resende e Sousa (2014), referente aos custos logísticos das empresas no país, destaca que as empresas, em geral, gastam $11,19 \%$ de seu faturamento com questões de logística.

Dentro desses gastos com logística encontram-se os gastos com estoque, sendo estes o terceiro grupo que mais influencia na formação do preço final do produto e possuem a segunda maior incidência nos custos logísticos, chegando a representar $19,06 \%$ dos custos (RESENDE e SOUSA, 2014).

Segundo Ching (2001) o estoque possui dois objetivos, o de custo, que reflete os custos totais de estoque, ou seja, custos de faltas, de manutenção e de aquisição, e o objetivo de nível de serviço, que está diretamente ligado ao objetivo de custo. Quanto maior o nível de serviço maior deverão ser os custos para atender a esse nível de serviço e a função da gestão do estoque é conciliar esses dois objetivos para que a empresa alcance o maior nível de serviço possível com o menor custo de estoque.

Os estoques podem ser divididos em quatro grupos segundo as definições de Corrêa (2012), sendo eles:

- Estoques de matéria primas e componentes comprados: itens necessários ao processo produtivo da empresa, que sofrerão algum processo de transformação.

- Estoque de material em processo: produtos que já foram adquiridos sofreram alguma mudança, mas ainda não estão prontos para a venda, se encontram em estágio semi-acabado.

- Estoque de produtos acabados: são produtos que já sofreram todas as mudanças necessárias e se encontram prontos para venda. Nesta classificação encaixam-se também os produtos para atender a pós-venda.

- Estoque de materiais para manutenção, reparo e operação (MRO): são produtos adquiridos não para se transformar em partes do produto, mas são necessários ao apoio da operação e atividade de produção. São exemplos desse estoque, peças sobressalentes, lubrificantes e consumíveis.

O presente trabalho dá enfoque ao estoque de materiais para manutenção, reparo e operação (MRO), comumente chamados de peças de reposição. Esse tipo de estoque possui um comportamento de demanda intermitente. Para a realização do estudo foi feita uma parceria com uma empresa que se dispôs a fornecer os dados e cooperar para a realização da simulação da formulação de uma nova política de estoques.

A empresa, denominada empresa $X$, é especializada na fabricação, manutenção e peças de reposição de guindaste veicular (conhecidos nacionalmente como "MUNCK" ou "GUINDAUTO"). A empresa está no mercado desde 1988 conquistando um espaço sólido e permanente no mercado, sob plena consequência de uma jornada rigorosa e exigente em equipamentos e mão de obra. A empresa prega sempre a conciliação da rentabilidade com o alto nível de serviço, buscando sempre atender as necessidades de seus clientes pelo menor preço possível. A empresa foi representante de duas grandes marcas no ramo de guindastes veiculares, hoje tendo um contrato com uma multinacional do ramo, aqui denominada DM. A empresa $X$ é representante exclusiva da marca DM no Espírito Santo e sul da Bahia, levando todos os clientes dessas áreas, interessados na instalação do equipamento ou em sua manutenção a procurar a empresa $\mathrm{X}$.

Atualmente a empresa possui um quadro de 10 funcionários fixos, sendo que 3 ocupam cargos administrativos, 1 no almoxarifado, 1 torneiro, 1 soldador, 1 montador, 2 mecânicos e 1 técnico em elétrica. O faturamento mensal gira em torno de $R \$ 70.000,00$. A empresa possui atualmente 6394 itens em estoque utilizados para a execução de em média 32 ordens de serviço por mês.

Estão cadastrados na empresa 826 clientes, tanto pessoas físicas como jurídicas, dentre 
esses clientes podemos destacar EDP, Vale do Rio Doce, Arcellor e Samarco. Além desses clientes a empresa atende as prefeituras da grande vitória e órgãos públicos como a Cesan. Esses clientes são responsáveis por um total de 620 equipamentos DM espalhados pelo território capixaba e sul da Bahia.

\section{REVISÃO BIBLIOGRÁFICA}

\subsection{CLASSIFICAÇÃO ABC}

Criada por Vilfredo Pareto no final do século XIX a curva ABC facilita os processos decisórios em diferentes situações. Sua utilização na gestão dos estoques é a de ordenar os itens conforme sua importância relativa, multiplicando-se o valor unitário de cada item por sua demanda em um espaço de tempo determinado, obtendo assim um valor percentual sobre todas as despesas com estoque. Em seguida, os itens serão agrupados em conjuntos denominados $\mathrm{A}, \mathrm{B}$ e $C$ de acordo com a importância relativa dos grupos (RODRIGUES, 2007).

A partir do resultado da classificação dos produtos Arnold (2012), define as prioridades e os tipos de controle para cada conjunto como:

- Itens A: alta prioridade. Controle cerrado com registros completos e precisos e com revisões regulares e frequentes.

- Itens B: prioridade média. Controles normais com bons registros, processo normal.

- Itens C: prioridade menor. Devem ser aplicados controles simples, garantir que os itens sejam suficientes e fazer pedidos de grandes quantidades e manter um estoque de segurança.

A partir da curva $A B C$ é possível identificar os produtos que possuem um maior custo de capital e definir uma política baseada em sua prioridade dentro das possíveis classificações. Normalmente a classificação ABC resolveria o problema para a classificação das peças e a definição do grupo de peças que deveriam ter um controle mais severo, mas o grande problema é que a importância das peças de reposição não pode ser definida através do maior custo de capital.
As peças de reposição podem ser classificadas de inúmeras formas, porém a classificação por criticidade da peça é mais indicada, pois a mesma leva em conta a criticidade da peça no processo produtivo da empresa. A criticidade das peças de reposição configura um importante medidor para a decisão da estocagem, ou não, e quais serão as políticas de estoque que serão aplicadas a ela (GAJPAL; GANESH; RAJENDRAN, 1994). Segundo Botter e Fortuin (2001) a classificação das peças entre alto giro e baixo giro não é mais suficiente, há a necessidade de uma análise mais aprofundada baseada em classificações de critério diferentes para a classificação mais apurada de cada peça.

A criticidade da peça é utilizada para a decisão da estocagem ou não do produto. São levados em consideração nessa análise não fatores quantitativos, mas fatores qualitativos que dizem respeito ao quão prejudicial será para o processo a falta dessa peça.

\subsection{CLASSIFICAÇÃO VED}

Tendo que a criticidade das peças é um importante fator de classificação das mesmas, o modelo VED (Vital, essencial e desejável) seria suficiente para classificar as peças em estoque e dar uma base melhor para o gerente de quais peças ele deveriam ter um controle mais rígido.

Segundo Gajpal, Ganesh e Rajendran (1994) a chave para a decisão de se manter uma peça em estoque ou não é avaliada a partir do nível de criticidade para o processo da organização. Gajpal, Ganesh e Rajendran (1994) propõem um modelo de classificação das peças de reposição através do modelo VED, para classificar as peças de acordo com estrutura hierárquica comparativa de três níveis que tem em seu topo o objetivo, no nível mediano os critérios necessários para alcançar os objetivos e em sua base os modos pelos quais os critérios podem ser classificados.

\subsection{DISTRIBUIÇÃO DE POISSON}

A demanda intermitente possui um comportamento que não se adapta a curva normal, ou seja, os modelos normalmente utilizados na literatura para a gestão de estoque não seriam eficazes. Um caminho 
para lidar com a situação das peças de reposição é considerar a demanda aderente a distribuição de Poisson. A distribuição de Poisson seria interessante, pois ela é discreta, ou seja, é possível calcular a probabilidade de certo nível de consumo com base na média histórica.

A distribuição Poisson pressupõe a independência entre eventos, ou seja, o nível de consumo do mês anterior não afetará o nível deste mês e o nível deste mês não afetará os meses seguintes, o que a torna muito útil devido ao fato do grande período de meses com demanda zero no caso das peças de reposição. Outro fator é que na distribuição de Poisson a variância é igual ao consumo médio em um determinado período (WANKE, 2003).

$\mathrm{Na}$ literatura encontramos alguns trabalhos que utilizam Poisson para a demanda intermitente, como é o exemplo de Silva (2009) que compara resultados aplicando a distribuição de Poisson, Gama, La Place e Normal. Podemos citar também Wanke e Andries (2010), que fazem uma análise da utilização da distribuição de Poisson para demandas intermitentes. Desse modo o pesquisador utilizou a distribuição de Poisson para a construção de uma política de estoque para as peças DM da empresa $X$.

A fórmula da distribuição de Poisson segundo Levine et al. (2015), pode ser descrita da seguinte forma:

$$
P(X=x / \lambda)=\frac{e^{-\lambda} \lambda^{x}}{x !}
$$

Sendo que:

- $P(X=x / \lambda)=$ probabilidade de que $X$ $=x$ eventos em uma área de oportunidades, conhecendo-se $\lambda$

- $\lambda=$ número esperado de eventos

- $e=$ constante matemática aproximada por 2,71328

- $x=$ número de eventos $(x=0,1,2, \ldots$, $\infty)$

Como já foi dito essa distribuição tem uma adaptação melhor ao modelo de demanda intermitente, pois é possível calcular a probabilidade de certo nível de consumo baseando-se na média histórica.

\section{METODOLOGIA}

\subsection{OBSERVAÇÃO}

Inicialmente o problema de pesquisa não estava definido, gerando assim a ideia de uma observação na empresa que se disponibilizou para a execução do trabalho. A observação tem um caráter exploratório, segundo Selltiz. et all.(1967), "a observação é o método básico para conseguir informação sobre o mundo que nos cerca". A observação foi utilizada para compreender como funcionava o almoxarifado da empresa $X, 0$ lócus da pesquisa.

A proximidade do pesquisador com a gestora da empresa possibilitou sua atuação entre o período de, 26 de maio de 2015 até 02 de junho de 2015, como auxiliar do gerente de estoques. A semana em que se iniciou a observação o gerente havia marcado para começar a arrumação e organização do estoque, o que propiciou a visualização geral da situação.

No período de observação o pesquisador atuou ativamente ao lado do gerente, como se fosse um funcionário. Identificou pontos que poderiam ser melhorados por parte da empresa em sua gestão de estoque, sendo eles:

\section{A organização do layout;}

Previsão da demanda;

Produtos mal acondicionados;

Acuracidade do estoque;

Falta de uma política de estoque;

Diante do tempo escasso para a realização de um trabalho que envolvesse todos os pontos destacados pelo pesquisador, optouse pela confecção do trabalho tendo como foco o item 5. A falta constante de materiais e o excesso de alguns deles em estoque reforça a falta de uma política de estoque que diferencie os produtos de acordo com sua importância e permita um controle de estoque mais severo sobre aqueles produtos mais importantes.

\subsection{COLETA DOS DADOS}

Essa etapa da pesquisa consistiu nos momentos em que o pesquisador foi até a empresa para coletar os dados que the interessavam para a análise da gestão de estoque utilizada pela empresa. O pesquisador procurou na empresa os dados de entrada e saída dos produtos nos últimos meses para entender qual era o 
comportamento da demanda dos produtos, como os controles de estoque eram feitos, como as compras eram realizadas e mais a frente à definição de um grupo foco de produtos para a construção de uma política de estoque.

\subsubsection{PRIMEIRA TENTATIVA}

O pesquisador em um primeiro momento levantou uma base de dados das entradas e saídas dos materiais em estoque do dia 1 de janeiro de 2014 até o dia 30 de junho de 2015. A tentativa de pegar dados com série histórica maior era de ter dados para análises futuras.

O problema aconteceu quando uma diferença significativa entre as saídas e entradas foi identificada. As entradas indicavam 5233 produtos, enquanto as saídas eram de 27619 produtos. A diferença grande entre entradas e saídas reflete a negligência da devida catalogação de entrada dos produtos recém movimentados. A auxiliar de estoque fez a observação de que a base de dados seria muito incerta mesmo em se tratando das saídas que eram feitas com mais rigor. Esse problema forçou o pesquisador a fazer uma segunda tentativa de coletar os dados.

\subsubsection{SEGUNDA TENTATIVA}

Em um segundo momento e tendo em vista o parecer da auxiliar de estoque o pesquisador utilizou uma base menor de 180 dias, do dia 01 de janeiro de 2015 até o dia 30 de junho do mesmo ano. Esse período segundo a auxiliar de estoque era mais confiável no que se referia às saídas, pois ela mesma havia assumido a função de dar entrada e saída nos materiais e confirmara a execução do serviço. De fato, a diferença entre as entradas e saídas caíram. Agora as saídas eram de 8365 produtos e as entradas de 4163 produtos. Apesar de a saída ser duas vezes maior que a entrada a auxiliar confirma que a saída está correta, ainda assim, evidenciando um nível de imperícia e negligencia por parte dos funcionários do almoxarifado. A base de dados apesar de ter um baixo índice de acuracidade é a mais segura para se trabalhar tendo em vista as bases que levam em conta períodos antes do inicio do ano de 2015, portanto foi utilizada no trabalho.

\subsection{TRATAMENTO DOS DADOS}

Os dados foram entregues em um arquivo de texto com as saídas e entradas diárias dos produtos, sendo necessária a transposição dos dados para o Excel e a construção de uma tabela dinâmica para a análise mais aprofundada dos dados. Foram movimentados 318 produtos em estoque no período em questão, fazendo-se necessário a classificação dos produtos que segundo a gestão seriam importantes de acordo com os parâmetros da classificação VED. Dentre o grupo de 318 todos foram classificados pelo gerente de estoque, porém devido à escassez de tempo houve a necessidade de escolher um grupo de peças menor para trabalhar.

No contexto da análise identificaram-se dois grandes grupos de peças contidas em estoque: o primeiro grupo são peças que podem ser compradas em uma gama de fornecedores ou até mesmo no varejo em caso de falta no estoque. O segundo grupo, objeto do trabalho, são as peças exclusivas da representante, ou seja, as peças DM. Essas peças DM não podem ser compradas de qualquer fornecedor e nem no varejo, são peças distribuídas exclusivamente pela matriz da empresa que se localiza no Rio Grande do Sul. De 318 peças 43 são peças DM, sendo que estas necessitam de um controle de estoque mais rigoroso e a definição de uma política de estoque firme devido à distância do fornecedor e o prazo de entrega variar de acordo com o modal de transporte, sendo 2 dias aéreo e 5 dias úteis terrestre.

\subsection{CLASSIFICAÇÃO DAS PEÇAS DM}

Das 43 peças DM escolhidas como foco do estudo foi feito uma entrevista com o gerente para descobrir qual era o lead time das peças, o preço dos modais, qual o mínimo de estoque e o máximo de seus estoques, de acordo com seu julgamento. Esse questionário teve o objetivo de entender melhor o lead time de suprimento, os possíveis modais e principalmente como era feita a gestão dessas peças, seus pontos de compra e as quantidades compradas por ordem. O lead time era fixo para todas as peças, sendo dividido em dois modais, $\mathrm{O}$ rodoviário (5 dias úteis) e o aéreo (2 dias).

Tendo como base o lead time de suprimento do modal de transporte rodoviário, o pesquisador criou uma "janela de tempo". 
Essa "janela de tempo" foi utilizada para a redução da demanda para semanal, e assim, baseando-se nesse lead time classificar o comportamento da demanda das peças.

$\mathrm{Na}$ literatura a demanda das peças se classifica entre fast-moving (demanda de alto giro) e slow-moving (demanda de baixo giro). O trabalho em questão trata de produtos com demanda slow-moving, onde existem mais três divisões segundo Silva (2009), sendo elas a intermitente, a lumpy e a altamente lumpy.

\section{ANÁLISES}

\subsection{CLASSIFICAÇÃO VED}

Baseado nos parâmetros discutidos com o gerente de estoque, descritos na metodologia, o gerente de estoques da empresa $X$ classificou as peças que tiveram movimentação no período de 01 de Janeiro de 2015 até 30 de Julho de 2015, assim sendo possível analisar quais peças são importantes para o processo produtivo da empresa.

Através da classificação foi possível observar que a empresa possui uma quantia de $61 \%$ de peças na categoria vital ao processo produtivo da mesma. Essas peças são de extrema importância para o processo produtivo da empresa e em tese não poderiam faltar em estoque, sendo necessário um controle de estoques rígido sobre elas. As peças essenciais representam 36\% das peças movimentadas no período estudado, são peças de uma importância média onde a necessidade de manter as mesmas em estoque será baseada no nível de capital que a empresa deseja deixar alocado no estoque. O grupo que representado por $3 \%$ das peças movimentadas é o das peças desejáveis, são peças que não necessitam de um controle rígido, ou seja, sua política pode ser mais branda.

O foco do trabalho se dá no grupo das peças DM, que são consideradas peças de extrema importância para o processo produtivo e são de vendas exclusivas da empresa X. Como foi possível observar as peças DM possuem 79\% de seus componentes classificados como vitais e $21 \%$ como essenciais, ou seja, grande parte de seus componentes é de extrema importância para o processo produtivo e não podem faltar em estoque. Soma-se a isso o fato de que essas peças tem um único fornecedor, a representada, que se localiza no Rio Grande do Sul.

\subsection{POLÍTICA DE ESTOQUE}

A empresa estudada utiliza uma política de estoque um tanto quanto rudimentar, baseada na lógica do estoque mínimo, sendo que este mínimo de estoque é definido através da experiência do gerente de estoque. Ressaltamos que, os volumes de compra dos produtos são definidos também pela experiência do gerente de estoque, ou seja, toda a gestão de estoque é feita de modo intuitivo.

A tabela 1 informa o produto, sua máxima ocorrida no período, à política atual adotada pelo gerente e o nível de serviço alcançado. Segundo Wanke (2003) a distribuição estatística de Poisson adapta-se muito bem quando se trata de estoques com comportamento intermitente. Levando isso em conta os níveis de serviço serão calculados utilizando a distribuição de Poisson, definindo o nível de serviço alcançado baseando-se na máxima histórica para um determinado volume de produtos comprados. 
Tabela 1 - Política de estoque atual

\begin{tabular}{|c|c|c|c|}
\hline Produto & $\begin{array}{l}\text { Máxima do } \\
\text { período }\end{array}$ & $\begin{array}{l}\text { Política } \\
\text { atual }\end{array}$ & Nível de serviço \\
\hline P1 & 2 & 8 & $99,98 \%$ \\
\hline P2 & 2 & 8 & $99,98 \%$ \\
\hline P3 & 6 & 8 & $84,72 \%$ \\
\hline P4 & 12 & 8 & $15,50 \%$ \\
\hline P5 & 4 & 8 & $97,86 \%$ \\
\hline P6 & 2 & 2 & $67,67 \%$ \\
\hline P7 & 2 & 6 & $99,55 \%$ \\
\hline P8 & 4 & 2 & $23,81 \%$ \\
\hline P9 & 1 & 1 & $73,58 \%$ \\
\hline P10 & 4 & 10 & $99,72 \%$ \\
\hline P11 & 2 & 2 & $67,67 \%$ \\
\hline P12 & 8 & 29 & $100,00 \%$ \\
\hline $\mathrm{P} 13$ & 6 & 42 & $100,00 \%$ \\
\hline P14 & 1 & 4 & $99,63 \%$ \\
\hline P15 & 2 & 2 & $67,67 \%$ \\
\hline P16 & 2 & 2 & $67,67 \%$ \\
\hline P17 & 10 & 100 & $100,00 \%$ \\
\hline P18 & 1 & 2 & $91,97 \%$ \\
\hline P19 & 1 & 2 & $91,97 \%$ \\
\hline P20 & 2 & 6 & $99,55 \%$ \\
\hline P21 & 1 & 2 & $91,97 \%$ \\
\hline P22 & 2 & 6 & $99,55 \%$ \\
\hline P23 & 1 & 2 & $91,97 \%$ \\
\hline P24 & 1 & 4 & $99,63 \%$ \\
\hline P25 & 1 & 4 & $99,63 \%$ \\
\hline P26 & 4 & 10 & $99,72 \%$ \\
\hline P27 & 1 & 2 & $91,97 \%$ \\
\hline P28 & 1 & 10 & $100,00 \%$ \\
\hline P29 & 1 & 4 & $99,63 \%$ \\
\hline P30 & 4 & 6 & $88,93 \%$ \\
\hline P31 & 3 & 6 & $96,65 \%$ \\
\hline P32 & 1 & 4 & $99,63 \%$ \\
\hline P33 & 1 & 10 & $100,00 \%$ \\
\hline P34 & 1 & 1 & $73,58 \%$ \\
\hline P35 & 1 & 2 & $91,97 \%$ \\
\hline P36 & 1 & 2 & $91,97 \%$ \\
\hline P37 & 1 & 4 & $99,63 \%$ \\
\hline P38 & 2 & 6 & $99,55 \%$ \\
\hline P39 & 2 & 20 & $100,00 \%$ \\
\hline P40 & 1 & 4 & $99,63 \%$ \\
\hline P41 & 1 & 2 & $91,97 \%$ \\
\hline P42 & 1 & 4 & $99,63 \%$ \\
\hline P43 & 1 & 4 & $99,63 \%$ \\
\hline
\end{tabular}

Em uma conversa com o gerente sobre um nível de serviço que fosse bom para a empresa, foi estabelecido um nível de serviço de $80 \%$. Esse nível de serviço segundo o gerente seria suficiente para atender a demandas consideradas emergenciais, enquanto os outros $20 \%$ seriam demandas que poderiam esperar por um frete aéreo ou terrestre de suas peças. 
Tendo em mente um nível de serviço de $80 \%$ o pesquisador construiu a tabela 2 com o objetivo de calcular o volume de compra por peça para alcançar aproximadamente o nível de serviço estabelecido. Essa aproximação posiciona-se sempre superior aos $80 \%$ de nível de serviço, pois dependendo do volume das peças é impossível chegar a $80 \%$ de nível de serviço pontualmente. A diminuição de uma unidade no volume de compra pode resultar em um decréscimo do nível de serviço muito grande.

Tabela 2 - Política de estoque proposta

\begin{tabular}{|c|c|c|c|}
\hline Produto & Máxima do período & Política proposta & Nível de serviço \\
\hline P1 & 2 & 3 & $85,71 \%$ \\
\hline P2 & 2 & 3 & $85,71 \%$ \\
\hline P3 & 6 & 8 & $84,72 \%$ \\
\hline P4 & 12 & 15 & $84,44 \%$ \\
\hline P5 & 4 & 6 & $88,93 \%$ \\
\hline P6 & 2 & 3 & $85,71 \%$ \\
\hline P7 & 2 & 3 & $85,71 \%$ \\
\hline P8 & 4 & 6 & $88,93 \%$ \\
\hline P9 & 1 & 2 & $91,97 \%$ \\
\hline P10 & 4 & 6 & $88,93 \%$ \\
\hline P11 & 2 & 3 & $85,71 \%$ \\
\hline P12 & 8 & 10 & $81,59 \%$ \\
\hline P13 & 6 & 8 & $84,72 \%$ \\
\hline P14 & 1 & 2 & $91,97 \%$ \\
\hline P15 & 2 & 3 & $85,71 \%$ \\
\hline P16 & 2 & 3 & $85,71 \%$ \\
\hline P17 & 10 & 13 & $86,45 \%$ \\
\hline P18 & 1 & 2 & $91,97 \%$ \\
\hline P19 & 1 & 2 & $91,97 \%$ \\
\hline P20 & 2 & 3 & $85,71 \%$ \\
\hline P21 & 1 & 2 & $91,97 \%$ \\
\hline P22 & 2 & 3 & $85,71 \%$ \\
\hline P23 & 1 & 2 & $91,97 \%$ \\
\hline P24 & 1 & 2 & $91,97 \%$ \\
\hline P25 & 1 & 2 & $91,97 \%$ \\
\hline P26 & 4 & 6 & $88,93 \%$ \\
\hline P27 & 1 & 2 & $91,97 \%$ \\
\hline P28 & 1 & 2 & $91,97 \%$ \\
\hline P29 & 1 & 2 & $91,97 \%$ \\
\hline P30 & 4 & 6 & $88,93 \%$ \\
\hline P31 & 3 & 4 & $81,53 \%$ \\
\hline P32 & 1 & 2 & $91,97 \%$ \\
\hline P33 & 1 & 2 & $91,97 \%$ \\
\hline P34 & 1 & 2 & $91,97 \%$ \\
\hline P35 & 1 & 2 & $91,97 \%$ \\
\hline P36 & 1 & 2 & $91,97 \%$ \\
\hline P37 & 1 & 2 & $91,97 \%$ \\
\hline P38 & 2 & 3 & $85,71 \%$ \\
\hline P39 & 2 & 3 & $85,71 \%$ \\
\hline P40 & 1 & 2 & $91,97 \%$ \\
\hline P41 & 1 & 2 & $91,97 \%$ \\
\hline P42 & 1 & 2 & $91,97 \%$ \\
\hline P43 & 1 & 2 & $91,97 \%$ \\
\hline
\end{tabular}

Fonte: O autor

Após a construção das duas tabelas com a política atual e política proposta, a tabela 3 fará a comparação entre as duas políticas através da diferença entre a quantidade de produtos na política atual e a proposta, multiplicando o resultado dessa diferença pelo preço do produto. A comparação será feita através do custo total geral, onde um 
resultado negativo significa uma economia e um resultado positivo um gasto excessivo em relação à política atual.

Tabela 3 - Diferença das políticas

\begin{tabular}{|c|c|c|c|c|c|}
\hline Produto & Política atual & Política proposta & Diferença & Custo do produto & Custo total \\
\hline P1 & 8 & 3 & -5 & $\mathrm{R} \$ 23,00$ & $-R \$ 115,00$ \\
\hline P2 & 8 & 3 & -5 & $\mathrm{R} \$ 10,98$ & $-R \$ 54,90$ \\
\hline P3 & 8 & 8 & 0 & $\mathrm{R} \$ 16,60$ & $\mathrm{R} \$ 0,00$ \\
\hline P4 & 8 & 15 & 7 & $\mathrm{R} \$ 16,60$ & $\mathrm{R} \$ 116,20$ \\
\hline P5 & 8 & 6 & -2 & $\mathrm{R} \$ 17,10$ & $-R \$ 34,20$ \\
\hline P6 & 2 & 3 & 1 & $\mathrm{R} \$ 27,86$ & $\mathrm{R} \$ 27,86$ \\
\hline P7 & 6 & 3 & -3 & $\mathrm{R} \$ 1,82$ & $-R \$ 5,46$ \\
\hline P8 & 2 & 6 & 4 & $\mathrm{R} \$ 25,15$ & $R \$ 100,60$ \\
\hline P9 & 1 & 2 & 1 & $\mathrm{R} \$ 25,15$ & $\mathrm{R} \$ 25,15$ \\
\hline P10 & 10 & 6 & -4 & $\mathrm{R} \$ 13,89$ & $-R \$ 55,56$ \\
\hline P11 & 2 & 3 & 1 & $\mathrm{R} \$ 151,20$ & $\mathrm{R} \$ 151,20$ \\
\hline P12 & 29 & 10 & -19 & $\mathrm{R} \$ 70,00$ & $-R \$ 1.330,00$ \\
\hline P13 & 42 & 8 & -34 & $\mathrm{R} \$ 95,00$ & $-R \$ 3.230,00$ \\
\hline P14 & 4 & 2 & -2 & $\mathrm{R} \$ 163,11$ & $-R \$ 326,22$ \\
\hline P15 & 2 & 3 & 1 & $\mathrm{R} \$ 18,25$ & $\mathrm{R} \$ 18,25$ \\
\hline P16 & 2 & 3 & 1 & $\mathrm{R} \$ 70,07$ & $\mathrm{R} \$ 70,07$ \\
\hline P17 & 100 & 13 & -87 & $\mathrm{R} \$ 1,99$ & $-\mathrm{R} \$ 173,13$ \\
\hline P18 & 2 & 2 & 0 & $R \$ 55,00$ & $\mathrm{R} \$ 0,00$ \\
\hline P19 & 2 & 2 & 0 & $\mathrm{R} \$ 26,27$ & $\mathrm{R} \$ 0,00$ \\
\hline P20 & 6 & 3 & -3 & $\mathrm{R} \$ 50,66$ & $-R \$ 151,98$ \\
\hline P21 & 2 & 2 & 0 & $R \$ 217,25$ & $R \$ 0,00$ \\
\hline P22 & 6 & 3 & -3 & $\mathrm{R} \$ 88,56$ & $-R \$ 265,68$ \\
\hline P23 & 2 & 2 & 0 & $\mathrm{R} \$ 18,07$ & $\mathrm{R} \$ 0,00$ \\
\hline P24 & 4 & 2 & -2 & $\mathrm{R} \$ 13,92$ & $-R \$ 27,84$ \\
\hline P25 & 4 & 2 & -2 & $\mathrm{R} \$ 126,70$ & $-R \$ 253,40$ \\
\hline P26 & 10 & 6 & -4 & $\mathrm{R} \$ 89,00$ & $-R \$ 356,00$ \\
\hline P27 & 2 & 2 & 0 & $\mathrm{R} \$ 34,00$ & $\mathrm{R} \$ 0,00$ \\
\hline P28 & 10 & 2 & -8 & $\mathrm{R} \$ 94,40$ & $-R \$ 755,20$ \\
\hline P29 & 4 & 2 & -2 & $R \$ 126,85$ & $-R \$ 253,70$ \\
\hline P30 & 6 & 6 & 0 & $\mathrm{R} \$ 47,04$ & $\mathrm{R} \$ 0,00$ \\
\hline P31 & 6 & 4 & -2 & $\mathrm{R} \$ 20,62$ & $-R \$ 41,24$ \\
\hline P32 & 4 & 2 & -2 & $\mathrm{R} \$ 14,24$ & $-R \$ 28,48$ \\
\hline P33 & 10 & 2 & -8 & $\mathrm{R} \$ 27,17$ & $-R \$ 217,36$ \\
\hline P34 & 1 & 2 & 1 & $R \$ 180,25$ & $\mathrm{R} \$ 180,25$ \\
\hline P35 & 2 & 2 & 0 & $\mathrm{R} \$ 101,66$ & $\mathrm{R} \$ 0,00$ \\
\hline P36 & 2 & 2 & 0 & $\mathrm{R} \$ 115,04$ & $R \$ 0,00$ \\
\hline P37 & 4 & 2 & -2 & $R \$ 126,88$ & $-\mathrm{R} \$ 253,76$ \\
\hline P38 & 6 & 3 & -3 & $\mathrm{R} \$ 121,91$ & $-\mathrm{R} \$ 365,73$ \\
\hline P39 & 20 & 3 & -17 & $\mathrm{R} \$ 60,00$ & $-R \$ 1.020,00$ \\
\hline P40 & 4 & 2 & -2 & $R \$ 247,00$ & $-R \$ 494,00$ \\
\hline P41 & 2 & 2 & 0 & $R \$ 194,92$ & $\mathrm{R} \$ 0,00$ \\
\hline P42 & 4 & 2 & -2 & $R \$ 247,00$ & $-R \$ 494,00$ \\
\hline P43 & 4 & 2 & -2 & $\mathrm{R} \$ 329,00$ & $-R \$ 658,00$ \\
\hline Total & 371 & 163 & -208 & & $-R \$ 10.271,26$ \\
\hline
\end{tabular}

Como é possível observar a política proposta trará uma economia de $\mathrm{R} \$ 10.271,26$ para a empresa. Essa economia é baseada no nível de serviço de $80 \%$ definido pelo gerente. Em sua maioria o gerente comprava peças em excesso que passavam um longo tempo em estoque, ou seja, o gerente alocava os recursos no estoque de forma errônea. 


\section{CONCLUSÕES:}

$\mathrm{Na}$ comparação entre as duas políticas foi possível observar que em 25 dos 43 produtos DM, o gerente estava fazendo uma compra excessiva de materiais, ou seja, ele estava alocando mais recursos que o necessário em estoque. Em 8 produtos o gerente estava comprando menos que o necessário, ocorrendo assim a falta desses produtos em estoque. Em 10 dos produtos o gerente estava de acordo com a política proposta pelo pesquisador, foram produtos em que ele comprou uma quantidade compatível com a demanda e um nível de serviço de $80 \%$.

\section{REFERÊNCIAS}

[1] Arnold, J.R Tony. Administração de materiais: uma introdução.1 ed. São Paulo: Atlas, 2012

[2] Botter, R., Fourtuin, L. Stocking strategy for service parts - a case study. International Journal of Operations \& Production Management, v. 20-6, p. 656-674, 2000.

[3] Ching, Hong Yuh. Gestão de estoques na cadeia de logística integrada - Supply chain. 2. Ed. São Paulo: Atlas, 2001.

[4] Corrêa, Henrique. L. Administração de produção e operações: manufatura e serviços: uma abordagem estratégica. 3 ed. São Paulo: Atlas, 2012.

[5] Gajpal, P.; Ganesh, L.; Rajendran, C. Criticality analysis of spare parts using the analytic hierarchy process. International Journal of Production Economics, v. 35, p. 293-298, 1994.

[6] Levine, David. M. et al. Estatística : teoria e aplicações : usando o Microsoft Excel em Português. Rio de Janeiro: LTC, 2015.

[7] Rodrigues, Paulo Roberto Ambrosio. Gestão estratégica de armazenagem. 2 ed. São Paulo: Aduaneiras, 2007.

[8] Resende, Paulo Tarso Vilela de; SOUSA, Paulo Renato de. Custos Logísticos no Brasil 2014. Fundação Dom Cabral: Núcleo de Logística, Supply Chain e Infraestrutura. São Paulo, 2014.
Os dados analisados apontam a necessidade da empresa $X$ em rever sua política de estoque, dar prosseguimento ao processo de classificação de seus produtos em estoque e a construir uma política par cada grupo de produtos baseando-se em sua criticidade. É necessário também que a empresa continue alimentando a base de dados para gerar resultados mais confiáveis e que reflitam melhor a realidade.

[9] Selltiz, C. et al. "Coleta de Dados: Métodos de Observação". In: Métodos de Pesquisa nas Relações Sociais. São Paulo, Ed. Herder e Editora da Universidade de São Paulo, cap. 7, pp. 265-311.

[10] Sharaf, M. A.; Helmy, H. A. A classification model for inventory management of spare parts. In: International Conference on Production, Industrial Engineering, Design and Control. Alexandria, Egypt: Pedac 2001. Proceedings...v. 1, p. 375-82.

[11] Silva, Gerson Luís Caetano da. Modelo de estoque para peças de reposição sujeitas à demanda intermitente e lead time estocástico. 2009. Dissertação (Mestrado em Engenharia de Produção) - Departamento de Engenharia de produção, Universidade Federal de Minas, Minas Gerais, 2009

[12] Wanke, Peter. A gestão de estoques de peças de reposição de baixo giro. Rio de Janeiro, $2003 . \quad$ Disponível em: $<$ http://www.ilos.com.br/web/gestao-de-estoquesde-pecas-de-reposicao-de-baixo-giro/>. Acesso em: 12/09/2015

[13] Wanke, Peter e Andries, Maria. Mapas de estoque aplicados à gestão de peças de reposição - Parte 1. Rio de Janeiro, 2010. Disponível em: $<$ http://www.ilos.com.br/web/mapas-de-estoqueaplicados-a-gestao-de-pecas-de-reposicao-parte1/>. Acesso em: 09/09/2015 


\section{Capítulo 14}

\section{MANUFATURA ENXUTA: OS DESAFIOS ENFRENTADOS PELAS EMPRESAS IMPLANTAÇÃO \\ Nayara Gimenez Barbosa}

Resumo: A administração é dividida em quatro áreas básicas, sendo uma delas a área de produção. Essa área busca desenvolver melhorias para a empresa ter vantagens no mercado que atua. Com isso, há empresas que desenvolvem seus modelos de produção, e esses modelos se difundem pelo mundo. Um modelo de produção que se difundiu pelo mundo foi a Manufatura Enxuta, que foi criada pela Toyota após a Segunda Guerra Mundial, quando as empresas japonesas estavam passando por dificuldades e, aos poucos, foi sendo reconhecida por todo o mundo. A Manufatura Enxuta possui uma filosofia de gerenciamento de produção, pois muda a forma de pensar e agir durante o processo, e possui princípios e ferramentas. A Manufatura Enxuta é considerada muito complexa; por esse motivo, muitas empresas enfrentam diversos desafios durante a implantação desse modelo de produção. Nesse trabalho, apresentam-se dois casos de empresas que implantaram a Manufatura Enxuta e, durante uma entrevista com os gestores e observações do processo produtivo, foram identificados alguns desafios. Foi possível perceber que alguns dos desafios aconteceram nos dois casos apresentados, mas também houve desafios que foram mais específicos em apenas um dos casos e, a partir disso, os desafios foram classificados como técnicos, humanos e externos.

Palavras-Chave: Manufatura Enxuta, Desafios, Administração, Gestores. 


\section{INTRODUÇÃO}

A área de produção é uma das áreas mais conhecidas da administração, juntamente com finanças, marketing e recursos humanos. Em vista disso, é interessante que, na área de produção, assim como nas demais, sejam desenvolvidas melhorias para se obter vantagem competitiva no mercado.

No caso de melhorias na área de produção pode ser a mudança de um produto ou até mesmo do sistema produtivo na empresa, como transformando-se numa empresa enxuta.

Muitas empresas ultrapassam diversos desafios para alcançar o sucesso de adoção da Manufatura Enxuta. Com essa pesquisa, busca-se identificar como os diversos tipos de gestores de diferentes áreas podem passar pelos mesmos desafios, e como este trabalho contribuirá para que se diminuam as dificuldades das empresas, através da experiência de terceiros, de modo a fazer um planejamento mais preciso e auxiliar os gestores a solucionar os problemas que irão surgir ao longo do processo de implantação.

\subsection{APRESENTAÇÃO DO TEMA}

Atualmente, as empresas estão preocupadas com seus processos produtivos, pois, nem sempre, produzir abundantemente significa lucros exorbitantes. A partir disso, as empresas querem melhorar seus processos, reduzir custos e ser mais competitivas, sendo esses uns dos maiores desafios das empresas atuais.

Essa nova visão despertou em várias empresas o interesse de implantar o sistema de Manufatura Enxuta. Sendo assim, é necessário saber se todas possuem estrutura para implantar, verificar as dificuldades que as mesmas podem ter, assim como se estão aptos para realizar as mudanças necessárias ao novo sistema.

Manufatura Enxuta é uma abordagem pluridimensional que abrange uma grande variedade de práticas de gestão, incluindo just-in-time, sistemas de qualidade, equipes de trabalho, células de manufatura, etc. em um sistema integrado. (ALBUQUERQUE, 2008, p.14)
Em suma, a Manufatura Enxuta é a integração de toda a organização, com um sistema de qualidade rígido, que produz à medida que os clientes precisam, a partir de suas necessidades; além de não haver estoques e nenhum tipo de desperdício.

Então, serão mostrados estudos de casos de empresas de ramos diferentes que implantaram a Manufatura Enxuta. Desse modo, serão mostrados quais os desafios que os gestores enfrentaram para implantar o sistema de produção em suas empresas, com o intuito de manter a qualidade de seus produtos no mercado.

A Manufatura Enxuta (ME) também é conhecida como Sistema Toyota de Produção ou Lean Manufacturing.

\subsection{OBJETIVOS}

O principal objetivo desta pesquisa é identificar os desafios que as empresas têm para gerenciar a implantação da Manufatura Enxuta.

Os objetivos secundários são: apresentar $\mathrm{O}$ sistema de Manufatura Enxuta; verificar os pontos fortes e fracos na implantação desse tipo de produção; descrever os tipos de desafios.

\subsection{JUSTIFICATIVA}

Nos dias de hoje, a área de produção está cada vez mais valorizada. Segundo Barros Filho(1998), durante algum tempo, a produção era considerada um mal necessário e, hoje, ela vem sendo revalorizada.

Situação similar vem ocorrendo com o sistema de produção Manufatura Enxuta que, por possuir uma grande variedade de conceitos como: just-in-time, zero defeitos, kanban, lead time, entre outros, dificulta a aplicação nas empresas que não possuem administradores experientes no assunto em seu quadro de funcionários.

É necessário, também, verificar se a empresa está hábil para a implantação do sistema de produção, pois podem aparecer diversos desafios nos processos, o que faz com que muitas empresas desistam, e por conseguinte, traz desvantagens, e não vantagens, à empresa. 


\subsection{METODOLOGIA}

O presente trabalho foi desenvolvida a partir de pesquisas bibliográficas e estudos de caso.

A pesquisa bibliográfica foi baseada nos trabalhos de diversos autores que acompanharam empresas e os gerentes dessas empresas no processo de implantação da Manufatura Enxuta. Além de artigos científicos e livros relacionados ao assunto de gerenciamento da Manufatura Enxuta.

O estudo de caso foi realizado em duas empresas industriais: ramo moveleiro e do ramo de injeção plástica e ferramentaria. As duas empresas são de pequeno porte e localizadas na Região Serrana do Estado do Rio de Janeiro.

Para compor o estudo de caso, foi realizado um acompanhamento do processo produtivo nas duas empresas e uma entrevista (anexo 1) com os gestores responsáveis pela inserção, para identificar a forma de implantação e quais foram os desafios enfrentados pelas empresas.

\section{MANUFATURA ENXUTA}

De acordo com Sobral (2008), "Administração é um processo que consiste na coordenação do trabalho dos membros da organização e na alocação dos recursos organizacionais para alcançar os objetivos estabelecidos de uma forma eficaz e eficiente". O mesmo autor também complementa que a administração pode ser dividida em várias áreas, de acordo com a organização, mas na maioria das empresas existem pelo menos quatro áreas funcionais básicas, conhecidas como: produção ou operações, marketing, finanças e recursos humanos. Sendo que é de responsabilidade da organização a interação das áreas.

Nesta pesquisa, o foco é a área de produção, podendo se dizer que é a área que movimenta toda a organização.

O sistema de operações é o conjunto de atividades e operações inter-relacionadas envolvidas na produção de bens ou prestação de serviços de uma organização, representando o modo como esta transforma os insumos em produtos ou serviços, agregando valor de forma a alcançar os objetivos organizacionais. (SOBRAL,2008,P.10)

A área de produção é importante por gerenciar as atividades do processo de transformação. Além do mais, esta área possui um papel estratégico para a empresa competir no mercado. Com isso, gerenciar esta área envolve diversas tarefas como: desenvolvimento do produto, capacidade de produção, escolha do método produtivo, planejamento e controle de quantidade a ser produzida, entre outras. É perceptivo como esta área é complexa, pois, de uma forma, ela envolve todas as demais áreas.

A partir disso, é muito importante que um gestor defina bem como será seu planejamento nas atividades dessa área. Como nesta pesquisa iremos discutir a respeito de um método de produção a ser implantado, é importante definir adequadamente o modelo de sistema de produção para a organização.

No momento atual, um dos métodos mais dinâmicos e flexíveis para o mundo globalizado que vivemos é o sistema da Manufatura Enxuta.

\subsection{HISTÓRIA DA MANUFATURA ENXUTA}

A Manufatura Enxuta é um sistema de produção que teve seu início na década de 50, no Japão, após a Segunda Guerra Mundial. Naquele momento, muitas empresas japonesas passavam por dificuldades, então os engenheiros japoneses Eiji Toyoda e Taiichi Ohno realizou uma visita na montadora de automóveis Ford e percebeu que o modelo de produção que eles realizavam (produção em massa), não seria possível implantar no Japão, por algumas limitações, como, por exemplo, o tamanho da empresa e a dificuldade de escoara grande quantidade de produtos a serem produzidos.

Com isso, os engenheiros Eiji Toyoda e Taiichi Ohno começaram a desenvolver um novo método de produção, com base na produção em massa. A Toyota foi a criadora e pioneira desse método, mas, segundo Womack (2004, p. 1) " todo mundo tentam agora adotar a produção enxuta, porém o caminho é cheio de obstáculos". Com a expansão desse sistema pelo mundo, começaram haver várias divergências e resistências na aceitação do sistema. No Brasil, esse sistema se tornou 
conhecido na década de 80, mas apenas na década de 90 começou a ganhar forças e reconhecimento.

O Lean Manufacturing é um sistema que "representa fazer mais com menos- menos tempo, menos espaço, menos esforço humano, menos maquinaria, menos material" (DENNIS,2008, p.31). A Manufatura Enxuta é um método de eliminar totalmente os desperdícios, que nada mais são que elementos que não agregam valor, apenas custos.

Ohno (1997) afirma que esse sistema é uma evolução do pensamento, porque exige que mudemos, fundamentalmente, nossas maneiras de pensar. A Manufatura Enxuta recebe diversas críticas, mas elas são ocasionadas por não conseguirem compreender o sistema.

O Lean Manufacturing introduziu uma nova forma de pensamento que o Lean Institute Brasil descreve como Lean Thinking( mentalidade enxuta).

Lean Thinking (ou Mentalidade Enxuta) é uma filosofia de estratégia de negócios para aumentar a satisfação dos clientes através da melhor utilização dos recursos. A gestão lean procura fornecer, de forma consistente, valor aos clientes com os custos mais baixos (PROPÓSITO), identificando e sustentando melhorias nos fluxos de valor primários e secundários (PROCESSOS), por meio do envolvimento das pessoas qualificadas, motivadas e com iniciativas (PESSOAS). O foco da implantação deve estar nas reais necessidades dos negócios e não na simples aplicação das ferramentas lean. (Lean Institute Brasil).

O pensamento Lean possui sete frases básicas, conforme Dennis (2008,p. 35):

- Pare a produção- para a produção nunca parar!

- Produza apenas o que o cliente pediu.

- Produza objetos um de cada vez e mova-os rapidamente pelo sistema.

- O que você acha?

- Temos padrões visuais simples para todas as coisas importantes.

- O pessoal mais próximo do trabalho desenvolve os padrões e chama os especialistas quando for necessário.

- Torne os problemas visíveis.

\subsection{FUNDAMENTOS DA MANUFATURA ENXUTA}

A Manufatura Enxuta é composta por cinco princípios básicos, de acordo com Seleme (2009) e Lean Institute Brasil. Sendo eles: Valor, Fluxo de Valor, Fluxo Continuo, Produção Puxada e Perfeição.

O primeiro princípio é a base dos demais, o Valor. Esse principio é definido, "valor é o que o cliente atribui ao bem ou serviço fornecido pela organização"(SELEME,2009,p. 138).

Fluxo de Valor é o princípio que se verifica o que necessita ser retirado do processo, ou seja, o que não agrega valor.

Fluxo Contínuo é o princípio que mostra que a Manufatura Enxuta tem um pensamento sistêmico. "Ao pensarmos de forma sistêmica, levamos em conta o processo seguinte e a interface com este, permitindo, assim, um ganho de produtividade com a não criação de estoques ou paradas desnecessárias" (SELEME,2009,p. 139)

Produção Puxada, talvez, o mais conhecido, e aquele em que o cliente determina a aceleração da produção. Através desse princípio, eliminamos os estoques desnecessários e, a partir disso, valorizamos o produto.

O ultimo princípio é a Perfeição. "A perfeição pode ser traduzida pela busca do aperfeiçoamento contínuo em direção a um estado ideal" (SELEME,2009,p.139).

\section{A busca pelo aperfeiçoamento continuo em direção a um estado ideal deve nortear todos os esforços da empresa em processos transparentes, em que todos os membros da cadeia tenham conhecimento profundo do processo como um todo, podendo dialogar e buscar continuamente melhores formas de se criar valor. (Lean Institute Brasil)}

\subsection{FERRAMENTAS DA MANUFATURA ENXUTA}

Durante o processo de implantação da pioneira da Manufatura Enxuta, Toyota, foram desenvolvidas diversas ferramentas ao longo do tempo.

A seguir será mostrado como cada ferramenta é utilizada na Manufatura Enxuta.

O Just-in-time é a ferramenta mais conhecida. Significa um processo de fluxo, ter um fluxo integralmente para conseguir alcançar 0 
estoque zero. O Just-in-time possui alguns outros componentes que auxiliam seu desempenho como: Kanban e Heijunka (nivelamento de produção).

- Kanban: o Kanban é como se fosse uma autorização para produzir. Essa ferramenta possui uma regra básica que é: nenhum item defeituoso pode ser enviado ao cliente, seja ele interno ou externo. Essa ferramenta impede totalmente a superprodução. Como resultado, não há necessidade de ter estoques.

- $\quad$ Heijunka (nivelamento de produção): a utilização do heijunka auxilia a empresa a calcular suas necessidades desde quantidade de funcionários na produção até maquinário.

Há outra ferramenta bastante conhecida, a padronização do trabalho, de acordo com Dennis (2008, p.66-67)

\section{O trabalho padronizado é uma ferramenta para desenvolver, confirmar e melhorar nosso método (processos). Um processo é simplesmente um conjunto de etapas ou ações com uma meta claramente definida. O processo diz ao membro da equipe o que deve fazer, quando fazer e em que ordem.}

A Manufatura Enxuta possui uma ferramenta que faz com que a empresa consiga alcançar o máximo de eficiência possível em suas tarefas, envolvendo todos os membros da empresa. Essa ferramenta é a Manutenção Produtiva Total.

Outra ferramenta é a " $5 S$ ", considerada uma ferramenta de suporte para as ferramentas anteriores. Essa ferramenta é apontada como a mais eficaz para a melhoria continua.

O "5S" é dividido em cinco palavras japonesas iniciadas com a letra "S", sendo elas: Seiri, Seiton, Seiketsu, Seiso e Shitsuke, traduzidas em: Separar, Classificar, Limpar, Padronizar e Manter.

A Manufatura Celular é mais uma ferramenta do sistema de produção Manufatura Enxuta. Segundo Aquilano, Chaves e Davis (2001) a manufatura celular aloca máquinas não parecidas em células para trabalhar em produtos que possuem pesos, formas e exigências de processamentos parecidos.
Outra ferramenta é o Mapeamento de Fluxo de Valor (MFV). Esta ferramenta utiliza uma linguagem por símbolos, para facilitar a visualização dos processos envolvidos, com o objetivo de eliminar os desperdícios.

Além dessas ferramentas já definidas e consideradas as mais conhecidas e utilizadas pelos praticantes da Manufatura Enxuta, existem outras que são mais raras utilizadas como: poka-yoke, troca rápida de ferramentas, balanceamento de linhas e planejamento Hoshin.

\subsection{ASPECTOS DA IMPLANTAÇÃO DA MANUFATURA ENXUTA NAS EMPRESAS}

Para implantar a Manufatura em uma empresa e deixa-las lean é preciso respeitar algumas exigências.

Um dos primeiros aspectos a respeitar é o de saber esperar, pois o processo é lento e demorado. Porém, mesmo no momento inicial da implantação, já é possível identificar resultados significativos.

Outro aspecto importante é utilizar como base da implantação recursos educacionais (treinamentos), a fim de explicar a todos os envolvidos na organização sobre a mudança e os objetivos. Pois o comprometimento deve abranger desde a alta gerencia até o chão de fabrica, para que todos possam auxiliar uns aos outros no processo de transição do sistema de produção.

Outro aspecto é a utilização da ferramenta Plan-Do-Check-Act, mais conhecido pela sigla PDCA. Essa ferramenta consegue verificar o passo-a-passo da implantação, sendo possível utilizá-la em todas as etapas do processo. É importante lembrar que a manufatura é um aprendizado constante.

Um aspecto indispensável na implantação do lean na empresa é que todos compreendam a necessidade de eliminar os desperdícios. Segundo Ohno (1997, p.53), "para implantar o Sistema Toyota de Produção na sua própria empresa, deve haver a compreensão integral do desperdício. A menos que todas as fontes de desperdício sejam detectadas e eliminadas, o sucesso será apenas sonho". Além do mais, a implantação da Manufatura Enxuta traz benefícios, como o gerenciamento de indicadores e a redução da dependência. A partir deste momento, serão apontados alguns desafios durante esse processo. 


\section{DESAFIOS DA MANUFATURA}

\section{ENXUTA}

Muitas empresas, quando começam fazer a implantação da Manufatura Enxuta, se planejam de maneira que não ocorram problemas e o sistema seja implantado com sucesso, gerando benefícios à empresa. Mas, algumas vezes, se esse planejamento for feito incorretamente, não forem analisados os possíveis acontecimentos internos e externos, é presumível que o caminho ao sucesso de implantação demore um pouco mais do que o planejado ou até mesmo não ocorra a finalização do projeto. Albuquerque (2008) comenta que as organizações devem estar conscientes dos problemas e das possíveis limitações no processo de implantação da Manufatura Enxuta.

Quando esses problemas e limitações ocorrem, muitas empresas têm a dificuldade de conseguir perceber em que parte da empresa está o problema. Por consequência, os gestores tendem a acreditar que o problema está na filosofia, nos conceitos, nos métodos e ferramentas da Manufatura Enxuta, e essas empresas começam a acreditar que esse sistema não se aplica à sua empresa ou o problema está na teoria do sistema. Mas, na verdade, o problema pode estar na forma como as organizações estão escolhendo e implantando os componentes da Manufatura Enxuta.

Muitas empresas podem começar a ter desafios antes mesmo de implantar, por crerem que não possuem necessidades como a Toyota tinha e/ou que esse sistema só atende às empresas no ramo automobilístico. Isso mostra que, se houvesse a implantação, já haveria problemas de entendimento da filosofia enxuta.

No decorrer do processo, os desafios vão surgindo e, em muitos casos existem fatores críticos para o sucesso da implantação enxuta. São eles, como cita Im e lee(aput Albuquerque 2008, p.53), "o comprometimento da alta gerência, participação da força de trabalho, treinamento, planejamento da implantação, reorganização dos processos produtivos, proximidade de fornecedores, redução de setup's e de velhas praticas contábeis, e qualidade."

Há casos que a alta gerência quer implantar o sistema rapidamente para poder ver resultados. Esse pode ser considerado um dos primeiros desafios aparente que ocorre, porém, a implantação é demorada e muitas vezes precisa-se de anos para atingir um nível maduro do sistema na organização, mas mesmo assim, no início, os resultados já são satisfatórios.

É preciso entender que a empresa necessita tratar a implantação como um projeto. Muitas implantações do Lean falham, porque não são tratadas como projetos. Um dos fatores que também desafia a implantação é a dificuldade das pessoas mudarem seus hábitos e atitudes. Como a implantação da Manufatura Enxuta é considera radical, ocorre resistência das pessoas às mudanças necessárias para a implantação do sistema. Quando a empresa possui funcionários antigos, eles, muitas vezes, afirmam que fazem tal tarefa há tanto tempo e sempre deu certo, ou pelo simples fato de não quererem perder status que possuem na empresa, o que pode atrapalhar o processo de implantação. As mudanças necessárias para implantar o sistema com êxito são mudanças consideradas complexas, que variam de organização para organização.

As pessoas têm resistência às mudanças, pois tudo isso ocorre de acordo com a cultura atual da empresa. Como Womack, Jones e Roos (2004) afirmam, "as dificuldades na difusão de esquemas participativos devem-se essencialmente às características da cultura organizacional das empresas instaladas no Brasil." Com isso, percebe-se que, no Brasil, esse desafio é muito relevante no momento de implantar o sistema de produção enxuto.

As pessoas têm dificuldade em compreender que, quando a empresa implanta a Manufatura Enxuta, os funcionários precisam ter autonomia.

Os próprios Stakeholders influenciam implantação como: estilo de governo no país, sindicatos, fornecedores, entre outros stakeholders que a empresa possuir.

\footnotetext{
O sistema japonês não é um modelo ideal de um sistema de distribuição enxuta por varias razoes e, em verdade, ele esta mudando. Entretanto, o pensamento dos produtores japoneses sobre a distribuição em seu mercado domestico e a maneira como as peças de seu sistema se encaixam entre si apontam para o sistema de distribuição enxuta do futuro, sistema dificilmente concebível no Ocidente. (WOMACK, JONES E ROOS, 2004, p.168)
} 
Os sindicatos podem ser considerados como um dos desafios bastante significativos, pelo simples fato de eles defenderem os interesses da mão-de-obra das organizações.

A política do país possui grande influência, por seus impostos, regras e até mesmo o nível de desenvolvimento do país em relação aos escoamentos de produção como: rodovias, portos, ferrovias, entre outros modais.

Outro desafio, quando ocorre a implantação, é que uma empresa não pode implantar a Manufatura Enxuta sob o foco no financeiro. A empresa precisa estar sempre implantando melhorias em seus processos através das ferramentas relacionadas à melhoria contínua, e verificar se com essas melhorias não ocorrem desperdícios. Um dos exemplos disso, como Cunha e Marque (2011) aborda, é a dificuldade de conseguir manter a sequência do trabalho padronizado.

Determinadas empresas possuem dificuldades de nivelar sua produção, que gera acúmulos pela empresa e, com isso, ocorrem desperdícios, estoques e a empresa não consegue atender aos princípios da Manufatura Enxuta, não se tornando enxuta. Isso se mostrou como um desafio, pois desde o início da Manufatura Enxuta até hoje, as empresas costumam ter essa dificuldade de controle de produção.

Quando uma empresa começa a inserção, percebe que em determinados setores precisa mudar o layout da área de produção. Esse processo precisa estar no planejamento da organização, os gestores precisam estar cientes que isso pode ocorrer para tornar $\mathrm{o}$ fluxo de produção contínuo.

Um dos desafios considerado difícil de controlar, pelo simples fato de ser um desafio do ambiente externo, são as mudanças que ocorrem no mercado. $\mathrm{Na}$ realidade, entretanto, o sistema de informações e as restrições na produção tornam a mudança relativamente difícil.

No caso das empresas brasileiras, a dificuldade é de ser brasileira. O Brasil tem grande diferença social e isso se reflete nas organizações, na forma de status dentro da empresa. Isso dificulta sobremaneira o processo de redução de barreiras hierárquicas, de melhorias das comunicações e do fluxo de informações. As empresas brasileiras são consideradas com resultados bastante significativos em relação à implantação da Manufatura Enxuta, mas mesmo assim, o sistema de produção fundamentalmente estruturado no Brasil é em torno da produção em massa.

A transição no Brasil vai ser difícil. $\bigcirc$ alto grau de verticalização, as diferenças históricas entre as partes envolvidas, os hábitos enraizados, as plantas antigas, certamente são alguns fatores que tomarão o processo bastante intricado. E, dependerá também das variáveis macroeconômicas. Porém, a facilidade de adotar formas mais flexíveis de trabalho e de produção é um elemento muito positivo. (WOMACK, JONES, ROOS, 2004, p.320)

Com isso, percebemos que os gestores enfrentam desafios internos e externos na organização.

\section{ESTUDO DE CASO}

Neste momento, será mostrado como empresas fizeram a implantação do sistema de produção Manufatura Enxuta.

\subsection{CASO A}

A empresa $A$, situada na região serrana do estado do Rio de Janeiro, é uma pequena empresa do segmento moveleiro e está há mais de 20 anos no mercado.

Por meio de consultoria, foi diagnosticado que a empresa precisaria mudar seu modelo de produção. Foi então que os gestores se informaram sobre modelos de produção que pudessem atender às necessidades da empresa. A partir disso, os gestores tiveram conhecimento sobre a Manufatura Enxuta.

Neste caso, como seria realizada essa transição de modelo de produção, eles fizeram cursos para saber como lidar com a Manufatura Enxuta dentro da empresa. Eles tiveram que fazer cursos, conversar com consultores especializados, pois os diretores não estavam compreendendo como seria o funcionamento da manufatura na prática, apenas compreendiam sua teoria, mas não conseguiam visualizar sua utilização na empresa.

A partir do momento que a equipe gestora tomou conhecimento de como funcionava a Manufatura Enxuta, montaram a forma de implantação. Nesse momento, eles tiveram o desafio de decidir de que forma se iniciaria a implantação, como seria o "ponto de partida" 
para a manufatura dentro da empresa. Foi, então, que os gestores preferiram recuar, voltar ao planejamento para adequar a forma de implantação da maneira mais adequada a seus funcionários. Os gestores começaram a verificar o que seus funcionários gostavam para poder adaptar, e verificaram que eles conversavam muito sobre esportes, então um dos gestores teve a ideia de fazer da Manufatura Enxuta um jogo. Foi montada para cada etapa do processo uma sequencia do jogo, através de um tabuleiro para cada time, que seria responsável por cada processo.

Cada time teria seu líder; nesse ponto de determinarem o líder para cada equipe, o processo teve uma pausa, pois a empresa estava com dificuldades de identificar lideranças. Antes da implantação em forma de jogo, a empresa montou uma cartilha explicando para os funcionários o que era esse novo modelo de produção, como funcionava, quais seriam as mudanças dentro da empresa, qual era o intuito delas, para no momento que fossem feito os primeiros passos da implantação as equipes já estivessem informadas de como seria 0 processo.

Essa equipe de desenvolvimento é a mesma até hoje, pois a empresa está sempre mantendo os métodos da Manufatura Enxuta. Mas se não houver acompanhamento, os funcionários acabam querendo fazer do seu jeito, esquecendo os princípios enxutos. Esse aspecto, o proprietário informou que é um dos maiores desafios, pois é considerado um desafio diário.

Um dos casos foi com a entrega por parte dos fornecedores, em que ocorriam certos atrasos, pois os mesmos não estavam compreendendo a nova forma de fabricação da empresa, por nenhum deles serem enxutos.

Alguns pontos que poderiam gerar certos impedimentos, a empresa ignorou, como foi o caso dos altos custos e dos sindicatos.

Dos objetivos que foram estipulados no inicio do planejamento de produção, apenas 40\% foram alcançados. Futuramente, a empresa espera alcançar o restante dos objetivos, ou parte desses objetivos.

Mesmo com vários acontecimentos no processo de implantação na empresa, em apenas dois meses, já tinha sido possível perceber um aumento de $60 \%$ em sua produtividade.

\subsection{CASO B}

A empresa $B$, situada na região serrana do estado do Rio de Janeiro, é uma pequena empresa do ramo de injeção plástica e ferramentaria, e está há mais de 30 anos no mercado.

A entrevista foi feita com o projetista da empresa, também responsável pela implantação da Manufatura Enxuta na empresa. Ele é um engenheiro de produção, já possuía conhecimentos sobre a Manufatura Enxuta e percebeu que a empresa estava com problemas de falta de espaço físico. Além disso, setor de ferramentaria da empresa tem a necessidade de ter um fluxo contínuo de produção, mas a produção antiga não possuía esse tipo de fluxo e acabava tendo problemas com excessos de produção, gerando problemas na empresa.

Então, o projetista levou à diretoria da empresa a ideia de implantar a Manufatura Enxuta, uma vez que ela tem vários setores. No momento inicial, o planejamento foi implantar no setor de ferramentaria onde ocorria o maior número de problemas, que atrapalhavam toda a empresa. Essa ideia foi aceita por toda a direção.

Quando se deu o início do planejamento, o setor de ferramentaria foi posto como prioridade. Não se montou uma equipe, apenas um dos funcionários fez a coordenação da implantação. Esse funcionário possuía responsabilidades para inserir a Manufatura Enxuta, como: treinar a equipe do setor que seria implantado, mapear os processos e definir as estratégias e metas.

Durante o momento da implantação, foi entregue material sobre a Manufatura Enxuta para que os funcionários ficassem cientes, e foi montado um treinamento para que eles obtivessem conhecimentos práticos da Manufatura Enxuta e internalizarem seus princípios enxutos, que no momento ainda está em processo de treinamento. Mas, mesmo com todos esses recursos, a equipe do setor de ferramentaria teve muita resistência para se adaptar às mudanças e acabou gerando uma comoção em todos os setores da empresa, em que não haviam sido implantadas as novas técnicas, criando receios com relação a essas mudanças, no momento em que fosse implantada a nova prática. 
Outra técnica utilizada para a implantação foi o uso das ferramentas da Manufatura Enxuta aos poucos. Como a empresa possui menos de um ano com o novo modelo de produção, ela inseriu, até o momento, apenas duas técnicas, just in time e 5S, porém está no planejamento estratégico da empresa a utilização das demais ferramentas ao longo do tempo.

O entrevistado informou que a empresa, durante os primeiros três meses, queria desistir da implantação, em razão dos custos serem muito altos; mas depois perceberam as vantagens e a possibilidade de mais benefícios que ainda estavam por vir. Com isso, continuaram com o investimento na Manufatura Enxuta dentro da empresa.

Em relação aos objetivos que precisavam ser alcançados com as novas medidas de produção, que eram melhor organização do espaço físico e fazer com que o setor de ferramentaria tivesse um melhor fluxo de produção, foram percebidos em um curto espaço de tempo, o alcance desses objetivos iniciais.

\section{OS DESAFIOS}

Constatou-se que a Manufatura Enxuta mostra resultados significativos em um curto período de tempo e ainda soluciona os problemas principais que a empresa necessita, como ocorreu nos dois casos A e B. Porém, durante o processo de decisão da implantação e até o aparecimento dos resultados, a empresa passa por alguns desafios.

Desafios estes que são prováveis que se incidam na maioria dos casos, não importando o ramo. Já outros desafios variam de empresa para empresa, de acordo com suas diferenças.

\subsection{DESAFIOS COMUNS}

Foi perceptível que as duas empresas estudadas, mesmo tendo suas diferenças, enfrentaram dois desafios idênticos para implantar, da melhor maneira possível, a Manufatura Enxuta.

\subsubsection{DIFICULDADE DO NÍVEL} OPERACIONAL

Nos dois casos ( $A$ e $B$ ), esse desafio foi o mais comentado pelos gestores, tanto que, na seção anterior (seção 4),está evidente o cuidado que as empresas tiveram para passar todos os ensinamentos para os funcionários, utilizando recursos como: cartilhas e treinamento.

\subsubsection{RESISTÊNCIA PARA MUDANÇAS}

As duas empresas, por já possuírem um longo tempo no mercado e ter alguns de seus funcionários há muitos anos na empresa, enfrentaram a questão da resistência, pois muitos não compreendiam o motivo da mudança, por fazerem o mesmo trabalho há tanto tempo e mostrarem resultados.

\section{DEMAIS DESAFIOS}

O caso A, por ter o modelo de produção em toda a empresa, apresentou mais desafios que o caso $B$, que está introduzindo o modelo aos poucos.

\subsection{DIFICULDADE DA DIRETORIA}

No caso A, foi possível identificar que mesmo a diretoria a favor da implantação, ocorreu a dificuldade de compreensão de como funcionava a Manufatura Enxuta. E, antes da implantação, toda diretoria precisou se preparar.

No primeiro momento, ocorreram atrasos para implantação, mas foi preciso que a diretoria tivesse total compreensão do que seria realizado. Com isso, percebemos que essa dificuldade de compreensão, um tempo depois, fez com que a empresa enfrentasse outro desafio, que veremos no próximo item o desafio da implantação.

\subsection{DESAFIO DA IMPLANTAÇÃO}

No caso A, foi possível perceber o nível de dificuldade da diretoria. Foi nessa etapa que a empresa precisou refazer o planejamento e iniciar novamente, pois teve o desafio de conseguir passar o que aprenderam da manufatura para a prática, e não conseguiram compreender como seria o "ponto de partida" para a empresa se tornar enxuta.

\subsection{MANTER O ESTILO LEAN}

A dificuldade de concepção do nível operacional gerou o desafio de manter o 
Lean. Manter o estilo Lean é um desafio diário, que fez com que a empresa $A$ precisasse estar sempre no controle dos processos para que não ocorressem desperdícios ou desvio no fluxo de produção, que faz com que a empresa vá perdendo seus princípios Lean.

Há uma grande probabilidade que esse desafio ocorra em razão de não manter uma liderança nas equipes de cada processo e, por conseguinte, não podendo desfazer a equipe de implantação.

\subsection{DIFICULDADE DE LIDERANÇA}

A dificuldade de liderança é um desafio que a empresa A precisa ficar receosa, pois não ter pessoas capacitadas ou com habilidades de liderança gera problemas na equipe de trabalho. Não ter uma pessoa preparada para o comando faz com que a equipe de implantação sempre tenha que existir, para poder controlar os processos.

\subsection{DESAFIO COM FORNECEDORES}

A relação com o fornecedor foi um desafio apenas do caso A. Essa relação, que no início teve algumas imperfeições, em razão de os fornecedores não serem lean e a empresa não saber como deveria manter essa relação, a fim de que eles pudessem atender e entregar os itens no tempo correto.

É preciso que as empresas estejam cientes de que mudanças dentro de uma empresa também geram mudanças em empresas a sua volta. Neste caso, a empresa teve dificuldades de comunicação com seus fornecedores.

\subsection{ALTOS CUSTOS}

Para implantar esse modelo de produção, a empresa precisa estar com "saúde" financeira para poder investir nessa melhoria, pois é preciso aplicar em treinamentos, consultorias terceirizadas, algumas modificações na empresa, entre outros fatores.

No caso B, a empresa, mesmo quando se deparou com esse empecilho, conseguiu equilibrar o que seria gasto, com os benefícios gerados, e percebeu que, mesmo os altos investimentos, que sairiam caro no primeiro momento, no futuro trariam benefícios gratificantes para todos na empresa. Mas até a empresa chegar a essa conclusão, a implantação quase foi interrompida. Precisou que os primeiros resultados aparecessem para a empresa conseguir identificar essa conclusão.

\subsection{TIPOS DE DESAFIOS}

Após vermos todos esses desafios que as empresas enfrentaram durante o processo de implantação, é perceptível que os obstáculos podem ser divididos em três tipos, como: fatores humanos, técnicos e externos.

Nos fatores humanos, pode-se verificar que a parte operacional teve dificuldade de compreensão da Manufatura Enxuta, e as equipes de trabalho das empresas resistiram para se adaptar às mudanças. Esses dois desafios foram apontados em todos os casos. Houve, ainda, a dificuldade de identificar um líder ( caso A).

Nos fatores técnicos, podem-se identificar os pontos de dificuldade de implantação, como foi no caso A. Outro caso que entraria nos fatores técnicos seria o de planejamento para os altos custos que a empresa enfrenta para a implantação, pois é preciso ter técnica para realizar um planejamento adequado, para que os custos não sejam um problema para a melhoria da empresa, como foi no caso B.

Nos fatores externos, seria abordado apenas o desafio que o caso $A$ teve com os fornecedores.

No quadro abaixo, quadro 1, estão resumidamente os desafios e suas classificações, entre humanos, técnicos e externos.

Quadro 1: Tipos de desafios

\begin{tabular}{|c|c|c|}
\hline Humanos & Técnicos & Externos \\
\hline $\begin{array}{l}\text { Compreensão da } \\
\text { Manufatura Enxuta }\end{array}$ & Dificuldade de implantação & Fornecedores \\
\hline Resistência a mudanças & Planejamento de Custos & \\
\hline Liderança de equipe & & \\
\hline
\end{tabular}

Fonte: Elaboração própria 


\section{CONCLUSÃO}

Quando uma empresa muda seu modelo de produção, a empresa precisa conseguir atravessar os desafios e superá-los para conseguir ter vantagens no mercado que atua. Quando uma empresa não consegue superar esses obstáculos, a empresa pode ter desvantagens competitivas.

No momento que a empresa decide pela implantação do sistema de produção enxuto, ou seja, Manufatura Enxuta, é um sistema que possui uma filosofia que a empresa precisa aderir e agregar em suas tarefas rotineiras.

Entretanto, mesmo com um planejamento, a empresa pode enfrentar certos desafios para conseguir implantar com êxito a Manufatura Enxuta. Durante os estudos de casos, foi

\section{BIBLIOGRAFIA}

[1] Albuquerque, Thiago P. de. Manufatura Enxuta: dificuldades identificadas para implantação em indústrias de manufatura. Dissertação de Mestrado. Núcleo de PósGraduação em Administração da Universidade Federal da Bahia, Bahia, 2008.

[2] Aquilano, Nicholas J; Chase, Richard B.; Davis, Mark M. Fundamentos da Administração da Produção. 3a ed. Porto Alegre: Bookman, 2001, $598 p$.

[3] Barros Filho, J.R, Tubino, D. F. O Planejamento e controle da produção nas pequenas empresas - uma metodologia de implantação.

http://www.techoje.com.br/bolttools_techoje/files/ar quivos/Planejamentoecontroledaproducaonaspequ enasempresas.pdf. Acesso em 20 mai. 2014.

[4] Cunha, Pedro Augusto da; Marques, Dani Marcelo Nonato. A implantação do sistema de Manufatura Enxuta em um processo produtivo. http://www.fatecgarca.edu.br/revista/Volume1/7.pdf - Acesso em 28 ago. 2014 possível concluir que muitos desafios são iguais para várias empresas, mas também existem desafios que não são comuns em todas, variam de acordo com a forma de implantação ou até mesmo a cultura da empresa. Sendo que os desafios podem ser de três tipos: humanos, técnicos e externos.

Com a análise dos desafios dos casos, foi possível concluir que um desafio gera outro, como foram os casos de dificuldade de compreensão da Manufatura Enxuta por parte da diretoria, que gerou o desafio de implantação, e até o desafio de comunicação com os fornecedores. Como, também, o desafio de ter um líder nas equipes de trabalho ocasionou o desafio de manter a filosofia lean na empresa.

[5] Dennis, Pascal. Produção Lean Simplificada. Tradução Rosalia Angelita Neumann Garcia. - 2a ed. Porto Alegre: Bookman, 2008, $190 p$.

[6] Ohno, Taiichi. O sistema Toyota de produção: além da produção em larga escala. Tradução Cristina Schumache. Porto Alegre: Bookman, 1997, 132p.

[7] Seleme,Robson. Métodos e Tempo: racionalizando a produção de bens e serviços. Curitiba: Ibpex,2009,160p.

[8] Sobral, Filipe; Alketa, Peci. Administração: teoria e prática no contexto brasileiro.São Paulo: Pearson Prentice Hall, 2008, 399p.

[9] Womack, James P; Jones, Daniel T; ROOS, Daniel.A máquina que mudou o mundo. Tradução: Ivo Korytowski. 18ª reimpressão, Rio de Janeiro: Elsevier, 2004, 343p.

[10] http://www.lean.org.br/o_que_e. aspx. Acesso em 27 mai. 2014.

[11] http://www.lean.org.br/5_principos.aspx. Acesso em 27 mai. 2014 


\section{Gapítulo 15}

\section{COMPOSTOS DE BENS E SERVICOOS NA GESTÃO DA PRODUCCÃO: UM ESTUDO DE CASO EM UMA EMPRESA DE MÓVEIS PLANEJADOS}

\section{Vitor Hugo dos Santos Garcia \\ Gelson da Silva Veda}

Rayanne Cristina Oliveira da Silva Araújo

Flávio de São Pedro Filho

Váldeson Amaro Lima

Resumo: Esta tarefa envolve elementos de Administração da Produção dos compostos de bens e serviços praticados na gestão de uma indústria de móveis planejados em Porto Velho, na Amazônia Brasileira. É uma pesquisa de natureza qualitativa, aplicando o método de Estudo de Caso e os procedimentos recomendados, como a coleta de dados por meio de entrevistas in loco, interpretação da relação causal, descritiva da funcionalidade e confronto entre a teoria e a prática do workplace profissional. O objetivo geral deste trabalho é estudar os compostos de bens-serviços na gestão da produção em uma empresa de móveis planejados. Como resultados entre o ofertado pela empresa e a demanda do cliente, observa-se interação tênue entre as partes, havendo avaliação de valor concentrada na qualidade no produto. O Controle da Qualidade realizado pelo setor de pós-venda e garantia dos serviços permitem os resultados eficazes desta produção, sendo a satisfação do cliente o principal indicador de sucesso do pacote oferecido. Quanto à gestão da inovação dos processos e dos negócios são propostos reestruturação no relacionamento, mediante estímulo ao crescimento apoiado nas sugestões de seus clientes e colaboradores. Este poderá interessar a empreendedores e gestores compromissados com inovação organizacional.

Palavras-Chave: Administração. Amazônia. Bens. Serviços. Gestão. Produção. 


\section{INTRODUÇÃO}

Neste estudo será tratado sobre pacote de valor de bens e serviços na gestão da produção em uma indústria de móveis planejados em Porto Velho. Os dados foram coletados através de pesquisa de campo e passam a ser confrontados com os elementos operacionais observados em uma plataforma que possibilitou a comparação entre a teoria e a prática. As divergências e as convergências são tratadas aqui em tópicos e subtópicos de modo a atender aos objetivos propostos. Uma proposta de inovação ao processo produtivo desta organização será oferecida como resultado da tarefa. O objetivo geral deste trabalho é estudar os compostos de bensserviços na gestão da produção em uma empresa de móveis planejados. Para isso se propõe trazer como objetivos específicos levantar elementos operacionais relativos aos compostos de bens e serviços na empresa em estudo (1), caracterizar as implicações nos resultados entre o ofertado pela empresa e a demanda do cliente (2), e apresentar elementos que permitam inovar o processo de relacionamento tendo como base o conteúdo considerado (3).

\section{REVISÃO TEÓRICA E CONCEITUAL}

Segundo Chiavenato (2004), através de pesquisas que visavam eleger formas novas e eficientes de administração surge a Teoria da Contingência, que marcou um passo além da Teoria dos Sistemas por afirmar que além de as organizações necessitarem conhecer seus ambientes e se condicionarem a eles, devem adaptar-se em prol da sobrevivência e crescimento. Sendo o ambiente uma peça vital para a compreensão dos mecanismos organizacionais, cada organismo precisa conhecer seu mercado e refletir cuidadosamente acerca dos seus projetos de produtos, serviços e pacotes de valor oferecidos. De acordo com Sartori (2004), pacote de valor ou oferta de valor é a combinação de elementos tangíveis e intangíveis que os clientes potenciais avaliam para decidir qual o produto em particular deve ser adquirido. O atual mercado caracteriza-se pela competitividade acirrada e inovação constante, o que exige do consumidor uma dinâmica na decisão sempre que recorre a uma atividade de compra ou aquisição.

A busca pela exclusividade e pelo melhor atendimento das expectativas representam os maiores objetivos dos clientes, gerando um grande desafio aos produtores de bensserviços, cuja responsabilidade se estende às duas vertentes da produção. A indústria de móveis planejados é um exemplo de fabricação de pacotes de valor, onde os consumidores buscam produtos adequados às suas necessidades e ainda serviço de qualidade aliado ao processo. As empresas manufatureiras vendem serviços há muito tempo. Porém, muitas consideravam que a maior parte da criação de valor de seus negócios vinha da produção e da venda de produtos.

Os serviços eram considerados residuais, necessários apenas para facilitar a venda dos produtos. Mattos (2012) adverte que na atualidade os serviços dominam as economias dos países e as empresas manufatureiras, por sua vez, buscam cada vez mais agregar serviços à suas estratégias; o autor se refere ainda sobre o movimento de servitização conhecido pela orientação estratégica da relação do cliente com o negócio. Para este estudioso o aumento da oferta de pacotes combinados de produtos e serviços otimiza resultado enquanto agrega valor e competitividade permitindo assim a concentração de clientela, embora tenha no Brasil as limitações impostas pelo Código de Defesa do Consumidor, que proíbe as conhecidas compras casadas.

Oliva \& Kallenberg (2003) também abordam sobre a servitização. Explicam que a característica de centralidade do cliente nas estratégias de servitização consiste em dois elementos, a saber, o voltado para os serviços orientados para o produto serem redirecionados para serviços orientados para os processos do cliente (1), e o que se refere às mudanças na natureza da interação com o cliente (2); este segundo deixa de ser baseada na transação em si, conhecida por transaction-based, para centrar-se no relacionamento ou relationship-based; desta forma a relação com o cliente se converge para os relacionamentos duradouros.

\subsection{ELEMENTOS OPERACIONAIS RELATIVOS AOS COMPOSTOS DE BENS-SERVIÇOS}

Conforme Erdmann (2000), o processo produtivo, caracterizado como o elemento contigenciador de tecnologia, pode ser analisado quanto ao fluxo de materiais, variedade dos produtos e tamanho de lote. Isto diz respeito ao tipo de produção, onde se 
tem em um extremo o fluxo contínuo com relativa variedade e o alto volume de produção. A situação intermediária é o fluxo intermitente, com produtos diversificados e consequentemente rotineiros nos tempos e nos diferentes lotes. O outro extremo é a produção por projetos específicos em que se produz um único produto ou alguns poucos. O autor ainda caracteriza a produção como produção contínua, intermitente repetitiva, intermitente sob encomenda e produção por projetos, como se demonstra na Figura 1 que segue.

Figura 1: Quatro estilos de produção

\begin{tabular}{|c|c|c|c|}
\hline Contínua & Intermitente repetitiva & $\begin{array}{c}\text { Intermitente sob } \\
\text { encomenda }\end{array}$ & Por projeto \\
\hline \multicolumn{2}{|c|}{ Fonte: Erdmann, 2000. }
\end{tabular}

Outro relevante aspecto operacional no processo produtivo é a simultaneidade entre a produção e consumo, o que implica nos mecanismos gerais de gestão da qualidade. No caso de alguns produtos físicos que são produzidos e depois consumidos, existe a possibilidade do estabelecimento do controle de qualidade sobre produto final mediante $\mathrm{o}$ fator tempo para a aferição. Conforme recomenda Erdmann (2000), no caso da simultaneidade de produção e consumo, a única alternativa que resta é o controle da qualidade do processo.

\subsection{IMPLICAÇÕES NOS RESULTADOS ENTRE O OFERTADO PELA EMPRESA E A DEMANDA DO CLIENTE}

Estudo em Corrêia \& Corrêia (2013) indica que ser cada vez mais frequentemente nos processos produtivos de bens-serviços os clientes efetuando contato direto com o sistema de produção. Quando a interação entre cliente e processo é tênue, o cliente tende a concentrar sua avaliação de valor e qualidade no produto. Quando a interação é grande, tende-se a avaliar produto e processo de forma mais equilibrada. O serviço não prescinde de pelo menos um contato ou "interação" entre cliente e o processo prestado.

Sob a perspectiva da busca pela qualidade em detrimento da satisfação do cliente presente nos processos, tem-se 0 Desdobramento da Função Qualidade (QFD). Este se iniciou no Japão como um sistema de qualidade com foco no fornecimento de produtos e serviços que satisfaçam aos customers, ou seja, pessoas às quais o projeto está sendo empreendido, conforme se trata em Akao \& Mazur (2003). Já Paladini (2008) acrescenta que o QFD trabalha com elementos vitais para organização. Introduz a metodologia de análise de valor, que aplicada a Gestão de Qualidade, investe principalmente na adequação de produtos e serviços à demanda. Ela contribui ainda para a fixação de padrões de avaliação da empresa, a qual está sobre a ótica de uma função vista não por sua potencialidade ou por suas características, mas pela contribuição efetiva na qualidade final do produto ou serviço, podendo atender ao que consumidor tem como noção de valor.

\subsection{TEORIAS SCHUMPETERIANAS PARA INOVAÇÃO EM PROCESSOS}

As teorias Schumpeterianas são tratadas em Moricochi \& Gonçalves (1994). De acordo com estes pesquisadores, a razão para que a economia saia de um estado de equilíbrio e entre em um processo de expansão é o surgimento de alguma inovação, que significa fazer as coisas diferentemente no reino da vida econômica, seja pela introdução de um novo bem, método de produção, novo mercado ou fonte nova de matéria-prima.

Estudo em Fontanini \& Carvalho (2005) trazem os fatores levantados por Schumpeter. Ali se encontram as inovações em processos como sendo as adoções de métodos de produção novos ou significativamente melhorados abordadas também em OCDE (2005). Permitem melhorias na produtividade, redução nos custos, aumento de vida produtiva de equipamentos e processos, dentre outros. Adicionalmente vem Bachmann \& Destefani (2008) com os processos como sendo as configurações das atividades usadas na condução das operações internas à empresa. Aqui, a inovação pressupõe o reprojeto de seus processos para buscar maior eficiência, maior qualidade ou um tempo de resposta, conhecido como tempo de ciclo menor. Estes autores afirmam que a inovação em processos pressupõe a adoção de novas práticas de gestão, tais como 
manual de boas práticas, reengenharia, just in time, e outros; e incluem a certificação de processos na tipologia indicada pela Certificação ISO 9001, ISO 14001, OHSAS 18001, ABNT, e outras.

$\mathrm{Na}$ gestão de inovações em processos, o sucesso depende, dentre outras coisas, da habilidade do desenvolvimento e implementação do processo da contínua inovação incremental. Segundo Fontanini \& Carvalho (2005), pode haver neste processo, ocasionais avanços significativos tais como a instalação de uma nova geração de equipamentos, automação e informatização de um processo. O sucesso dependerá da evolução contínua das mudanças.

\section{METODOLOGIA ADOTADA}

Este estudo desenvolveu-se numa abordagem qualitativa com o propósito de, a partir da coleta de dados por meio de entrevistas com os profissionais envolvidos na gestão da produção na empresa pesquisada, entender o funcionamento do objeto de estudo, confrontar tais dados com a teoria anteriormente apresentada na revisão teórica e apresentar as conclusões e resultados por meio da descrição detalhada dos itens discrepantes utilizando ainda gráficos, tabelas e diagramas para melhor demonstração das observações.

A pesquisa caracteriza-se por um estudo de caso como recomendado em Gil (2002), ou seja, é uma análise de natureza empírica que investiga um determinado fenômeno, geralmente contemporâneo, dentro do contexto de vida, quando as fronteiras entre o fenômeno e o contexto que ele se insere não são claramente definidas. Trata-se de um estudo exaustivo de um ou poucos objetos, de maneira que permita seu amplo e detalhado conhecimento, tarefa praticamente impossível mediante outros delineamentos.

No que se refere às entrevistas realizadas inloco, o objetivo foi de colher informações específicas sobre o tema, visto que os entrevistados acompanham a execução da produção, podendo deste modo contribuir com dados detalhados. Para Marconi \& Lakatos (2003), o objetivo da utilização das entrevistas é de obter informações pertinentes sobre determinado assunto ou problema. Através delas, é possível aprofundar o assunto colocado no protocolo e redirecionar, quando for o caso, de acordo com o roteiro elaborado previamente. Após reunir as informações foi realizada a análise e transformação dos dados, objetivando organizar e sintetizá-los de tal forma que possibilitassem o fornecimento de respostas ao problema proposto para a investigação nos objetivos.

\section{RESULTADOS DA PESQUISA}

Esta pesquisa desenvolveu-se em uma empresa de móveis planejados na cidade de Porto Velho. Os clientes são atraídos pela proposta de praticidade, qualidade e principalmente personalização de seus ambientes de acordo com sua necessidade, perfil e estilo. Sendo assim, os projetos desenvolvidos permitem infinitas possibilidades de formatos, medidas, acabamentos, texturas e cores buscando conseguir funcionalidade e aproveitamento completo dos espaços. O processo produtivo de um móvel planejado envolve três etapas distintas: elaboração e aprovação do projeto (1); fabricação dos móveis (2); e instalação, montagem e pós-venda (3). Na Figura 2 é apresentado o fluxograma das etapas de produção na empresa pesquisada: 
Figura 2: Fluxograma das etapas de produção na empresa

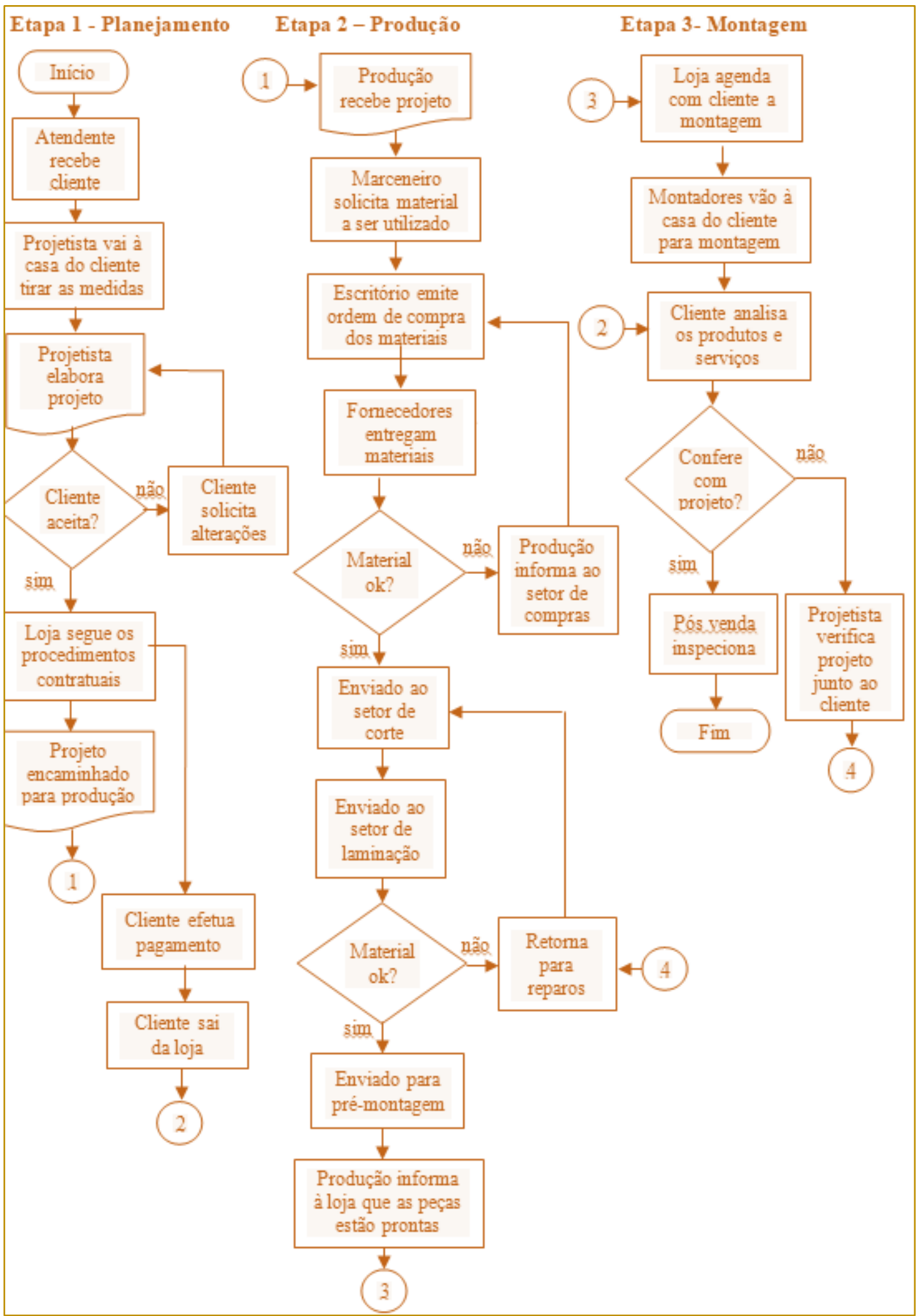

A etapa de elaboração do projeto apresenta a complexidade de que o cliente nem sempre tem uma ideia exata do que busca, cabendo a empresa, como prestadora de serviços, absorver as ideias e manifestá-las de forma a atender a expectativa do cliente. A segunda fase, relativa à fabricação dos bens - etapa de maior relevância a este estudo- é responsável por analisar os projetos e executá-los concretamente e efetivamente, atendendo a diversos requisitos modelados de forma única conforme especificação do 
cliente, não havendo possibilidade de estocagem de produtos pré-fabricados ou ate mesmo reaproveitamento de matéria-prima e peças sobressalentes. Na última etapa as ideias intangíveis do projeto e o produto pronto serão confrontados, havendo possibilidades escassas de reparação caso haja divergências. A satisfação do cliente será identificada nesta etapa da produção.

\subsection{LEVANTAMENTO DOS ELEMENTOS OPERACIONAIS RELATIVOS AOS COMPOSTOS DE BENS E SERVIÇOS NA EMPRESA EM ESTUDO.}

Ao levantar elementos operacionais relativos aos compostos de bens e serviços na empresa em estudo verificou-se que o modelo de produção adotado nesta fábrica pode ser analisado pela tipologia de produção única, onde a complexidade na estruturação produtiva é flexibilizada para atender à demanda de cada pedido, englobando suas variações específicas em formatos e tamanho.

É notória a flexibilização da estrutura e da equipe de produção para atender os projetos individualmente, ao passo que trabalham com vários projetos em simultaneidade, sendo a demanda constante e crescente. O Quadro 1 a seguir apresenta os aspectos principais da teoria dos estilos de produção explanados na revisão teórica, em confronto com a prática na empresa pesquisada:

Quadro 1:Teoria dos estilos de produção em confronto com a prática na empresa

\begin{tabular}{|l|l|l|}
\hline Estilos de produção & Descrição da teoria & $\begin{array}{l}\text { Como ocorre na empresa } \\
\text { pesquisada }\end{array}$ \\
\hline Fluxo contínuo & $\begin{array}{l}\text { Relativa variedade e o alto } \\
\text { volume de produção. }\end{array}$ & $\begin{array}{l}\text { Trabalham com vários projetos } \\
\text { em simultaneidade, sendo a } \\
\text { demanda constante e } \\
\text { crescente. }\end{array}$ \\
\hline $\begin{array}{l}\text { Fluxo intermitente repetitiva } \\
\text { ou sob encomenda }\end{array}$ & $\begin{array}{l}\text { Produtos diversificados e } \\
\text { consequentemente rotineiros } \\
\text { nos tempos e nos diferentes } \\
\text { lotes. }\end{array}$ & $\begin{array}{l}\text { Tipologia de produção única, } \\
\text { onde a complexidade na } \\
\text { estruturação produtiva é } \\
\text { flexibilizada para atender à } \\
\text { demanda de cada projeto. }\end{array}$ \\
\hline Produção por projetos & $\begin{array}{l}\text { Produz um único produto ou ou da } \\
\text { alguns poucos. }\end{array}$ & $\begin{array}{l}\text { lexibilização da estrutura e da } \\
\text { equipe de produção para } \\
\text { atender os projetos } \\
\text { individualmente. }\end{array}$ \\
\hline
\end{tabular}

Fonte: Elaborado pelos autores mediante observação in loco.

Pode-se perceber a partir do Quadro 1que a empresa analisada apresenta aspectos dos três possíveis estilos de produção definidos por Hermann (2000). Desse modo, no que se refere aos elementos operacionais, a prática concorda com a teoria exceto pelo fato de não se encaixar em apenas um estilo de produção.

\subsection{CARACTERIZAÇÃO DAS IMPLICAÇÕES NOS RESULTADOS ENTRE O OFERTADO PELA EMPRESA E A DEMANDA DO CLIENTE.}

A respeito das implicações nos resultados entre o ofertado pela empresa e a demanda do cliente infere-se da revisão teórica que os consumidores efetuam contato direto com o sistema de produção de bens-serviços. Quando a interação é tênue, o cliente tende a concentrar sua avaliação de valor e qualidade no produto. Quando a interação é grande, tende-se a avaliar produto e processo de forma mais equilibrada. Além disso, o serviço não prescinde de interação entre cliente e o processo prestado. Na empresa pesquisada, o contato com o sistema de produção ocorre do seguinte modo:

a) Interação é tênue onde a avaliação de valor concentra-se na qualidade no produto (concordando com a teoria).

b) O serviço prescinde de absoluta interação entre cliente e o processo (discordando da teoria). 
No que se refere à simultaneidade entre a produção e consumo, as implicações de controle da qualidade do processo podem variar mediante o fator tempo para a aferição, conforme demonstrado na Figura 3 que segue:

Figura 3: Implicações na lógica de controle da qualidade da simultaneidade produção-consumo

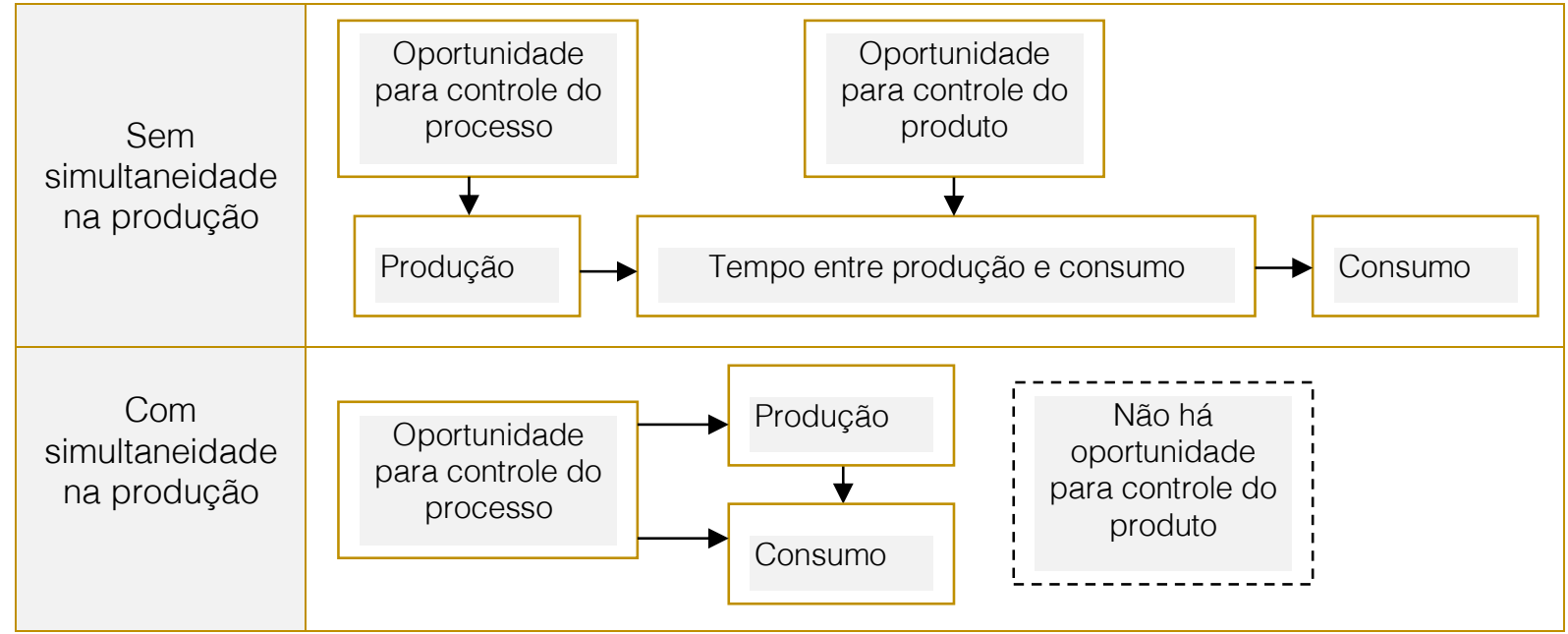

Fonte: Adaptado a partir de Corrêa \& Corrêa, 2013.

Sendo o objeto desta pesquisa uma empresa fabricante de móveis, onde obviamente não há simultaneidade entre a produção e o consumo, pode-se deduzir que há oportunidade para controle de processo durante a produção e oportunidade para controle do produto na fase que antecede o consumo (neste caso, instalação dos móveis). No entanto, o comportamento prático desta empresa apresenta algumas divergências a estas afirmações, conforme apresentado no Quadro 2:

Quadro 2: Teoria das implicações de controle da qualidade do processo sem simultaneidade entre a produção e o consumo em confronto com a prática na empresa

\begin{tabular}{|l|l|}
\hline \multicolumn{1}{|c|}{ Implicações da teoria } \\
$\begin{array}{l}\text { Oportunidade para interferir no processo de } \\
\text { produção. }\end{array}$ \\
$\begin{array}{l}\text { Interferência mínima do cliente durante a } \\
\text { produção, podendo interferir livremente apenas } \\
\text { no serviço de planejamento do produto (antes da } \\
\text { fabricação) e na etapa de montagem (depois da } \\
\text { fabricação). }\end{array}$ \\
\hline $\begin{array}{l}\text { Não há possibilidade significativa de de } \\
\text { interferência na qualidade do produto. A matéria- } \\
\text { produto. }\end{array}$ \\
$\begin{array}{l}\text { prima é padronizada e o cliente não acompanha } \\
\text { do processo produtivo a não ser que exija tal } \\
\text { circunstância (o que raramente ocorre). A } \\
\text { interferência se dará durante a instalação e } \\
\text { montagem, onde pequenos erros e distorções } \\
\text { em relação ao projeto poderão ser corrigidos. }\end{array}$ \\
\hline
\end{tabular}

Fonte: Elaborado pelos autores.

Levando em consideração o esforço empregado pela empresa na adequação de produtos e serviços à demanda, questiona-se como são fixados os padrões de avaliação do pacote de bens-serviços oferecidos pela empresa e as formas de avaliação da qualidade final do produto e/ou serviço. O controle da qualidade é realizado em duas 
etapas que sucedem 0 processo de produção:
a) Serviço de pós-venda: Um departamento exclusivo para acompanhamento de clientes no período pós-venda. São agendadas vistorias permitindo criar uma aproximação com o comprador, transmitindo segurança e mostrando o quanto ele poderá contar com a equipe e estrutura da empresa quando necessário.

b) Garantia dos serviços: Um dos diferenciais desta empresa é a garantia de cinco anos aos produtos que vende, englobando serviços de manutenção periódica e reposição de partes e componentes danificados após vistoria realizada.

Como esclarecido anteriormente, a opinião do cliente é considerada no processo de "consumo", mas não no aspecto do controle do processo, e sim em relação à manifestação da satisfação ou insatisfação perante o pacote oferecido. Este aspecto é comprovado quando o cliente retorna à loja demonstrando fidelização ou indica o trabalho a outros consumidores em potencial.

\subsection{ELEMENTOS PARA INOVAÇÃO NO PROCESSO DE RELACIONAMENTO TENDO COMO BASE O CONTEÚDO CONSIDERADO.}

$\mathrm{Na}$ perspectiva da gestão da inovação, o processo de relacionamento interno e com o mercado é importante aliado e fator determinante para o sucesso das inovações. O relacionamento interno por criar um ambiente propício ao surgimento de ideias inovadoras por parte dos colaboradores e, nesse sentido, valorizar o capital intelectual interno; e o relacionamento com o mercado por estabelecer canais de comunicação com clientes atuais e potenciais buscando conhecer suas necessidades e expectativas e dessa forma satisfazê-las de maneira inovadora como recomendado em SEBRAE (2011).
No relacionamento interno faz-se necessária o estabelecimento de uma linha de autoridade entre a gestão e a produção com a definição clara das funções inerentes a cada membro da equipe a fim de evitar desmandos típicos de pequenas empresas familiares e sem um comando claro. Feito isto, cabe a adoção de uma caixa de ideias como política de valorização das ideias dos colaboradores e método para impulsionar o surgimento de inovações.

Essa metodologia prevê a implantação de uma caixa tipo urna no setor de produção onde os colaboradores possam depositar suas ideias de melhorias e de inovação em formulário específico criado para tal fim. As ideias depositadas devem ser avaliadas pelos colaboradores e pela gestão a cada período acordado com a equipe, analisando sua aplicabilidade, possível retorno para a empresa e benefícios para colaboradores e clientes. Deve ser estabelecida por parte da empresa uma política de reconhecimento e recompensa pelas ideias avaliadas como aplicáveis a realidade da empresa.

O processo de relacionamento com o mercado deve ser proativo por parte da empresa para o estabelecimento de uma comunicação eficiente exigindo a manifestação do cliente para tentar entender suas necessidades e contribuindo para a melhoria contínua dos seus processos de produção. Uma maneira razoável de se fazer isso é com o serviço de pós-venda já implantado na empresa, porém deve ser dado um enfoque maior para possíveis incrementos e melhorias a partir das manifestações dos clientes. As empresas que conseguem transformar essas manifestações em resultados concretos (produtos mais adequados ao gosto do consumidor, ou processos melhores do ponto de vista de custo ou de sustentabilidade) têm significativa vantagem competitiva. Tais mudanças são apresentadas no Quadro 3: 
Quadro 3: Práticas de gestão do relacionamento para a inovação na empresa em estudo

Momento Atual
Perspectiva Futura

\begin{tabular}{|l|l|l|}
$\begin{array}{l}\text { Serviço de } \\
\text { acompanha a entrega e } \\
\text { instalação dos móveis para } \\
\text { avaliação da satisfação. }\end{array}$ & $\begin{array}{l}\text { Serviço de pós-venda como ferramenta do processo de } \\
\text { gestão da inovação captando ideias de melhoria contínua e } \\
\text { inovações incrementais dos clientes, com resultados } \\
\text { esperados no número de ideias inovadoras implantadas a } \\
\text { partir dos clientes. }\end{array}$ \\
\hline $\begin{array}{l}\text { Inexistência de programa interno } \\
\text { de captação de ideias e e e } \\
\text { sugestões de melhorias. }\end{array}$ & $\begin{array}{l}\text { Caixa de ideias como método para captação de ideias } \\
\text { inovadoras e instrumento da política de valorização dos } \\
\text { colaboradores, com resultados esperados na produtividade, } \\
\text { no número de ideias inovadoras válidas e na criação de um } \\
\text { ambiente propício à inovação. }\end{array}$ \\
\hline
\end{tabular}

Fonte: Elaborado pelos autores.

\section{CONCLUSÕES E SUGESTÕES}

A presente pesquisa buscou identificar os compostos de bens-serviços em uma empresa de móveis planejados na cidade de Porto Velho. Os dois princípios da servitização foram considerados nesta tarefa para interpretar os elementos operacionais dos compostos de bens-serviços. Não poderia ser diferente, pois ali se complementam o processo produtivo, a simultaneidade da produção-consumo, a participação do cliente e suas implicações e o desdobramento da função qualidade como forma de verificação dos resultados entre o ofertado pela empresa e demanda do cliente, bem como embasamento teórico acerca da proposta de inovação proposta nesta pesquisa. Tendo como referencial a teoria de servitização, três objetivos permearam esta análise: os elementos operacionais relativos aos compostos de bens - serviços na empresa estudada, a caracterização das implicações nos resultados entre o ofertado pela empresa e a demanda dos clientes e a apresentação de elementos que permitam inovar o processo de relacionamentos, tendo como base 0 conteúdo considerado.

A respeito do Objetivo Específico 1, observouse que mesmo em tipologia de produção única a estruturação produtiva é flexibilizada para atender à demanda de cada pedido, lembrando que a empresa trabalha com vários projetos em simultaneidade, sendo a demanda constante e crescente.

No que se refere ao Objetivo Específico 2, verificou-se que a interação entre o cliente e o processo é tênue, havendo avaliação de valor concentrada na qualidade no produto, embora este serviço prescinda de interação, indicando que o comportamento praticado na empresa apresenta divergências às teorias. 0 Controle da Qualidade realizado pelo setor de pós-venda e pela garantia dos serviços após o processo de produção garantem os resultados eficazes desta produção, sendo opinião e manifestação de satisfação do cliente os principais indicadores de sucesso do pacote de bens-serviços oferecido.

$\mathrm{Na}$ perspectiva da gestão da inovação, relativa ao Objetivo Específico 3, prevê-se a implantação de uma urna no setor de produção onde os colaboradores possam depositar suas ideias de melhorias e de inovação em formulário específico criado para tal fim. O processo de relacionamento com o mercado deve ser aprimorado dando um enfoque maior para possíveis incrementos e melhorias a partir das manifestações dos clientes. Desta forma, o crescimento da empresa estaria apoiado nas sugestões de seus clientes e colaboradores, sempre buscando o sucesso de seus processos de produção e prestação de serviços. 


\section{REFERÊNCIAS}

[1] Akao, Y. Mazur, G. H. The leading edge in QFD: past, present and future. International Journal of Quality \& Reliability Management, v. 20, n. 1, 2003.

[2] Bachmann, Dóran. L. DESTEFANI, JullyHeverly. Metodologia para estimar o Grau de Inovação nas MPE. Cultura do Empreendedorismo e Inovação. Curitiba, 2008.

[3] Chiavenato, Idalberto. Introdução à teoria geral da administração: uma visão abrangente da moderna administração das organizações.Rio de Janeiro: Elsevier, 2005.

[4] Corrêa, Henrique L.Corrêa, Carlos A. Administração de Produção e de Operações: uma abordagem estratégica. $2^{\underline{a}}$ Ed. São Paulo: Atlas, 2013.

[5] Erdmann, Rolf Herman. Administração da Produção: planejamento, programação e controle. Florianópolis: Papa Livro, 2000.

[6] Fontantini, José Ítalo Cândeo. Carvalho, Hélio Gomes de. As inovações incrementais em processos e seus fatores contribuintes em um ambiente industrial - um estudo de caso. Porto Alegre: XXV Encontro Nacional de Engenharia de Produção, 2005.

[7] Gil, A. C. Como elaborar projetos de pesquisa. 4. ed. São Paulo: Atlas, 2002.
[8] Marconi, Marina de Andrade; Lakatos, Eva Maria. Metodologia do trabalho científico. São Paulo: Editora Atlas, 2003. 5a ed.

[9] Mattos, Bruno Lanzi de. Impacto da servitização no modelo de negócio de empresas manufatureiras. Escola de administração de empresas de São Paulo. São Paulo: Fundação Getúlio Vargas, 2012.

[10] Moricochi, Luiz. Gonçalves, José Sidnei. Teoria do desenvolvimento econômico de Schumpeter: uma revisão crítica. São Paulo: Informações Econômicas, ago/1994. №8.

[11] Ocde-Manual de Oslo. Proposta de diretrizes para coleta e interpretação de dados sobre inovação tecnológica.São Paulo: Editora FINEP, 2005.

[12] Oliva, R. Kallenberg, R. Managing the transition from products to services. International Journal of Service Industry Management, Vol. 14, 2003.

[13] Paladini, Edson Pacheco. Gestão da qualidade: teoria e prática. $2^{\underline{a}}$ edição. São Paulo: Atlas, 2008.

[14] Sartori, Eloi. Gestão de Preços - Estratégia de Flexibilização, Fidelização de Clientes e Aumento da Rentabilidade. São Paulo: Atlas, 2004.

[15] Sebrae - Serviço Brasileiro de Apoio às Micro e Pequenas Empresas. Agentes Locais de Inovação: manual do participante. Brasília, 2011. 


\section{Gapítulo 16}

\section{APLICAÇÃO DE UMA REDE NEURAL ARTIFICIAL NA ESTIMAÇÃO DE VELOCIDADE DE UM MOTOR DE CORRENTE CONTÍNUA}

\section{Arlei Fonseca Barcelos}

\section{Juliana Ribas Monteiro}

\section{Wallace de Almeida Gomes}

Resumo: Com a evolução dos sensores, as variáveis dos processos têm exigido cada vez mais o menor número possível de intervenções na manutenção desses equipamentos, com isso os estudos em inteligência artificial têm se aprofundado cada vez mais com o objetivo de substituir um componente físico por um virtual com maior robustez e desempenho, reduzindo o custo de um projeto, além do crescimento da instrumentação virtual. A proposta desse trabalho é apresentar as etapas de construção de uma rede neural artificial (RNA) e implementá-la no software LabVIEW@ utilizando a placa NI USB-6009 para coletar dados em tempo real, para que então fosse avaliado o desempenho da rede neural artificial em tempo real. Nos resultados obtidos foi possível analisar seu acerto e comparar uma rede neural artificial modelada com dados obtidos de forma manual com uma modelada a partir de dados coletados em tempo real.

Palavras Chave: RNA - LabVIEW® - Coleta de dados - Desempenho - 


\section{INTRODUÇÃO}

O presente trabalho trata-se de uma aplicação de uma rede neural em uma planta (cadeira de rodas motorizada), onde foram obtidos dados de tensão, corrente e velocidade de um motor CC da cadeira através de uma placa de aquisição de dados, onde essas amostras serviram de treinamento para uma rede neural, que depois de estruturada forneceria os valores de velocidade para que então fosse comparada com um tacogerador verificando sua eficácia.

\subsection{HIPÓTESE, OBJETIVO E METODOLOGIA UTILIZADA}

O trabalho visa confirmar a hipótese de uma rede neural após ter sido estruturada para funcionar em uma aplicação prática e seu comportamento em tempo real, onde há a possibilidade de uma rede neural substituir um medidor de velocidade fazendo com que haja redução de custo em um projeto.

No trabalho apresentado por Mamani (2004), é demonstrada uma simulação de um projeto de uma rede neural onde a mesma é utilizada para estimação de velocidade de um veículo experimental.

O objetivo, então, é projetar uma rede neural fazendo uma aplicação prática de modo a avaliar seu desempenho para que futuramente seja embarcada.

A metodologia proposta no trabalho tem base nos experimentos realizados na planta sendo utilizados softwares de construção de redes neurais e implementação dos algoritmos da rede, onde através de gráficos e amostras de resultados foi possível avaliar o desempenho da mesma.

\section{REDES NEURAIS ARTIFICIAIS (RNA) \\ 2.1 DEFINIÇÃO}

A definição de uma rede neural vista como uma máquina adaptativa é um processador maciçamente paralelamente distribuído constituído de unidades de processamento simples, que tem a propensão natural para armazenar conhecimento experimental e torná-lo disponível para o uso. Ela se assemelha ao cérebro humano em dois aspectos:
- O conhecimento é adquirido pela rede a partir de seu ambiente de trabalho através de um processo de aprendizagem;

- Forças de conexão entre neurônios, conhecidas como pesos sinápticos, são utilizadas para armazenar o conhecimento adquirido.

O procedimento utilizado para realizar o processo de aprendizagem é chamado de algoritmo de aprendizagem que tem como função modificar os pesos sinápticos da rede de uma forma ordenada para alcançar um objetivo de projeto desejado (HAYKIN, 2001).

\subsection{PROPRIEDADES DAS RNA'S}

O uso das redes neurais pode oferecer as seguintes capacidades segundo Haykin (2001): não linearidade; mapeamento de entrada-saída; adaptabilidade; resposta a evidências; informação contextual; tolerância a falhas; uniformidade de análise e projeto; analogia neurobiológica.

\subsection{MODELO DE UM NEURÔNIO}

Como explica Haykin (2001), um neurônio é uma unidade de processamento de informação que é fundamental para a operação de uma rede neural, a Figura 1 a seguir mostra o modelo de um neurônio onde é possível identificar três elementos básicos de um modelo neuronal:

1. Um conjunto de elos de conexão (ou conjunto de sinapses), cada um caracterizado por um peso ou força própria. Especificamente, um sinal $x_{j}$ na entrada da sinapse j conectada ao neurônio $k$ é multiplicado pelo peso sináptico $w_{k j}$.

2. O somador para somar os sinais de entrada ponderados pelas respectivas sinapses do neurônio (combinador linear).

3. Uma função de ativação para restringir a amplitude da saída de um neurônio. A função de ativação é também referida como função restritiva já que restringe (limita) o intervalo permissível de amplitude do sinal de saída a um valor finito. 
Figura 8: Modelo não linear de um neurônio

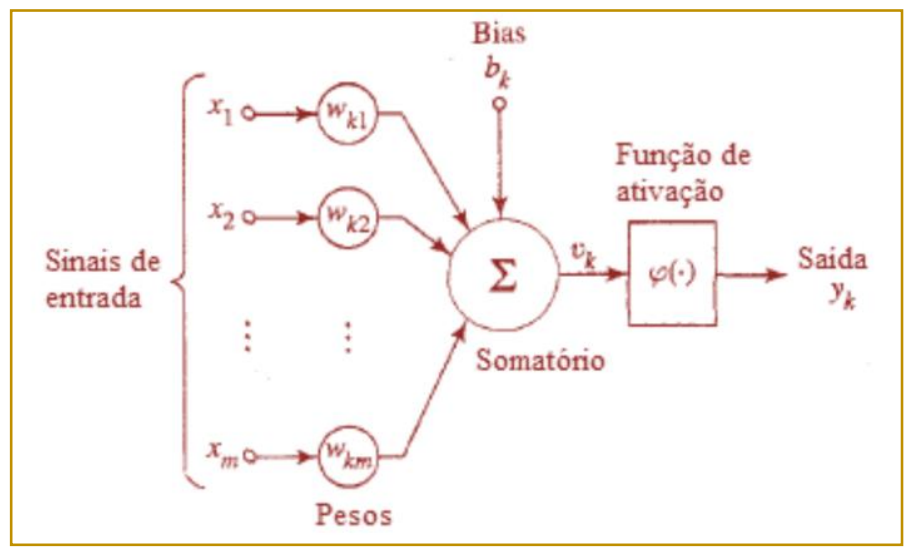

Fonte: HAYKIN, 2001

O bias, representado por bk, tem o efeito de aumentar ou diminuir a entrada líquida da função de ativação, dependendo se ele é positivo ou negativo, respectivamente. Assim, pode-se descrever um neurônio $k$ por meio das seguintes Equações 1 e 2:

$$
\begin{aligned}
& U k=\sum_{j=1}^{m} W k j * X j \\
& Y k=\varphi *(U k+B k)
\end{aligned}
$$

Onde $x 1, x 2, \ldots, x m$ são os sinais de entrada, Wk1, Wk2,..., Wkm são os pesos sinápticos dos neurônios, Uk é a resposta da multiplicação dos pesos com os sinais de entrada,

Bk é o bias que é um parâmetro externo do neurônio, $\varphi($.$) é a função de ativação,$ potencial de ativação do neurônio ou campo local induzido e Yk é a resposta de saída do neurônio.

\subsection{FUNÇÃO LINEAR}

É similar a função linear por partes, diferenciando por não ter limites, logo sua função pode ser visualizada pela Equação 3 e pelo Gráfico 1:

Gráfico 4: Função de ativação linear

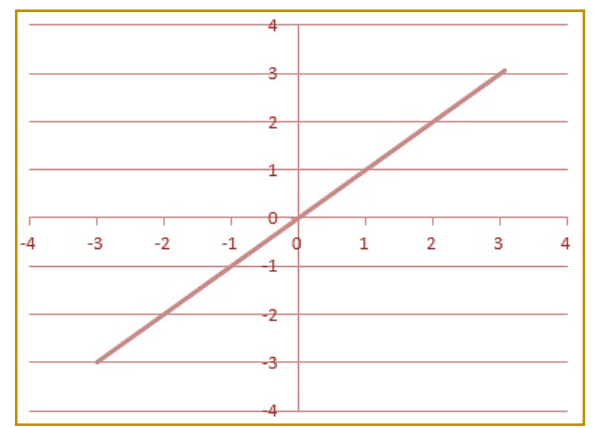


Este tipo de função foi utilizada pela equipe na construção da rede neural artificial.

\subsection{RES NEURAIS FEEDFORWARD}

São redes que propagam o sinal somente no sentido positivo, ou seja, a propagação do sinal ocorre da entrada para a saída. Para redes pertencentes nesta classe, as saídas de seus neurônios podem somente ser conectar com neurônios pertencentes da próxima camada. São exemplos de redes dessa arquitetura: perceptron de uma camada, perceptron multicamadas e rede neural (RN) função de base radial, conforme Figura 2.

Este tipo de arquitetura foi utilizado pela equipe na construção da rede neural.

Figura 2: Multicamadas (feedforward). Fonte Haykin, 2001

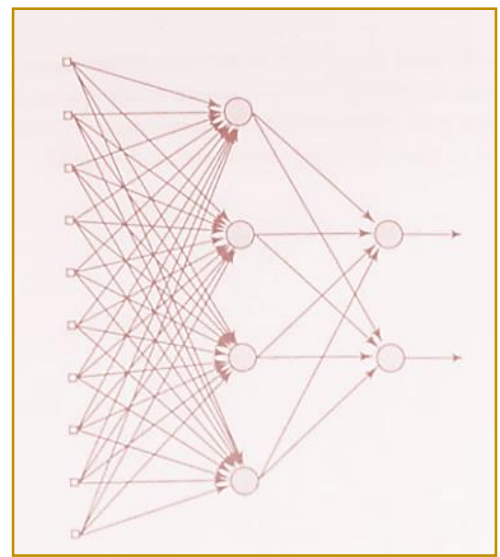

\section{CONSTRUÇÃO DA RNA ATRAVÉS DOS SOFTWARES}

O software NEUROSOLUTIONS $®$ é uma ferramenta de desenvolvimento de redes neurais gráficas para Windows. Esse software de última geração combina um design de interface modular com a implementação do procedimento de aprendizado avançado utilizando o Excel, onde o usuário através da tabela pode construir a rede neural, tendo como vantagens a possibilidade de analisar a tendência para os novos dados, embora por ser um processo gráfico, não há possibilidade de extração dos valores das sinapses da rede para uma implementação física da mesma. Este software foi utilizado apenas como forma didática para aprendizado sobre redes neurais artificiais.

O software MATLAB尺 desenvolvido pela The MathWorks, Inc, é um sistema interativo e uma linguagem de programação baseados numa matriz, onde as soluções e problemas são expressos em linguagem matemática. Através da utilização do mesmo é possível realizar análise numérica, operações com matrizes, construção de gráficos e criação de interfaces com o usuário. Este software foi utilizado no desenvolvimento do trabalho para modelagem das redes neurais artificiais.
Uma das principais vantagens do software MATLAB ${ }^{\circ}$ é a facilidade de escrever e depurar um programa, se comparado a outras linguagens de programação (tais como C, Basic, Pascal ou Fortran). Além disso, possui diversas funções matemáticas, matriciais e gráficas que simplificam e minimizam a estrutura do programa. Diferente do NEUROSOLUTIONS $\Theta$, possui tanto a forma gráfica, como em linhas de comando na construção da rede neural, além da capacidade de fornecer os valores das sinapses da rede para uma futura implementação.

\subsection{DESENVOLVIMENTO DA APLICAÇÃO DE UMA REDE NEURAL}

Segundo Mamani (2004), os passos necessários para o desenvolvimento de aplicações utilizando redes neurais artificiais são os seguintes: coleta de dados; separação em conjuntos; configuração da rede; treinamento da rede; teste da rede; e integração da rede. 


\section{DESENVOLVIMENTO DA REDE NEURAL ARTIFICIAL}

Para o desenvolvimento da RNA foi necessário obter valores de tensão ( $V$, corrente $(A)$ e velocidade (RPM).

\subsection{RNA MODELADA COM DADOS COLETADOS MANUALMENTE}

Houve a necessidade da coleta manual para uma "pré" avaliação do funcionamento da RNA.

\subsubsection{COLETA MANUAL}

Os dados foram coletados utilizando um amperímetro DC digital (em série), um voltímetro DC digital (em paralelo) e um tacômetro digital. Foram coletados 501 valores de tensão, corrente e velocidade apenas com a roda livre.

\subsubsection{DESENVOLVIMENTO DA RNA NO $M A T L A B \otimes$}

Foram coletadas manualmente 501 amostras. Foram separadas 490 amostras para a criação e treino da rede neural para que as restantes, no caso 11, fossem testadas através do próprio algoritmo da rede.
A rede foi criada com os seguintes parâmetros:

- Tipo de rede: Feed-forward backpropagation.

- Função de treinamento: trainlm (Levenberg-Marquardt backpropagation).

- Função de adaptação: learngdm.

- Função de desempenho: MSE.

- Número de camadas: 2.

- Número de camadas escondidas: 1.

- Número de neurônios da camada escondida: 3.

- Função de ativação da camada escondida: linear.

- Função de ativação da camada final: linear.

Nesta fase, foi necessária a mudança da função de ativação de sigmoidal para linear, pois com esta função foi possível alcançar um resultado satisfatório, esta rede foi treinada com 2000 épocas e obteve 90,689\%. O algoritmo da rede é apresentado na Equação 4:

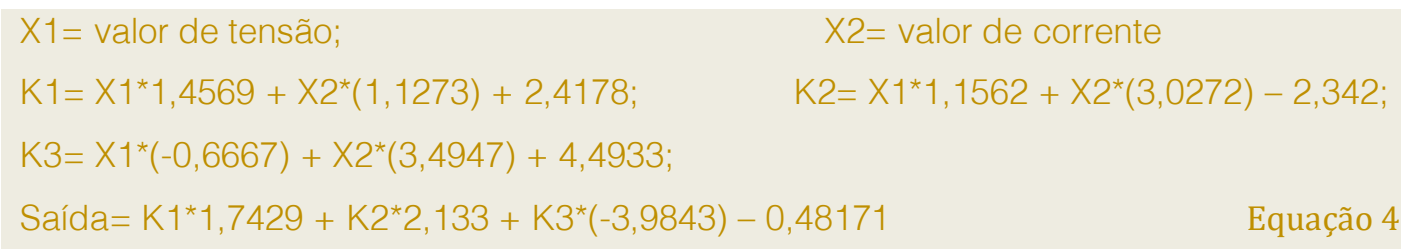

\subsection{RNA MODELADA COM DADOS} AQUISITADOS EM TEMPO REAL

Primeiramente foi desenvolvido um programa para coletar dados em tempo real para que pudesse ser desenvolvida a RNA. Foram coletados 87.781 dados de tensão $(V)$, corrente $(A)$ e velocidade $(R P M)$, dentro do limite de variação da fonte de 0 a $5 \mathrm{~V}$, com intervalos de $0,1 \quad V$. Esses valores são referentes a roda livre e a aplicação de torque.

\subsubsection{PLACA DE AQUISIÇÃO DE DADOS}

Foi escolhida a placa da National Instruments USB-6009 data acquisition (DAQ) (Figura 3). 
Figura 3: NI USB-6009.

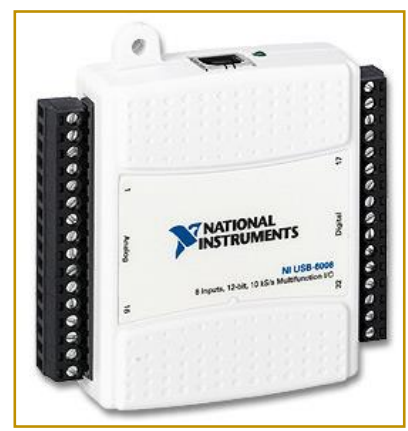

Fonte: www.ni.com

Ela possui compatibilidade com o LabVIEW®, utilizado para fazer a instrumentação virtual. Como é uma placa que só lê sinal (níveis de tensão), foi necessário utilizar o sensor de corrente por efeito hall que gera um diferencial de tensão correspondente a uma corrente. A tensão teve que ser reduzida, pois a placa lê no máximo $10 \mathrm{~V}$, na entrada analógica. Foi necessário também utilizar um tacogerador, pois a placa não possui velocidade suficiente para lê os pulsos do enconder que se encontra na planta.

\subsubsection{DIVISOR RESISTIVO}

Para a leitura da tensão foi necessário limitar a tensão a $10 \mathrm{~V}$, já que o motor é de $24 \mathrm{~V}$. Assim fez 0 seguinte divisor resistivo (Equação 5):

\section{$V$ Entrada $=2,4 \times$ VSaída}

Equação 5

\subsubsection{SENSOR DE CORRENTE POR EFEITO HALL}

ACS714LLCTR-30A-T. Sua leitura é de -30 $A$ a

O sensor de corrente utilizado foi por efeito

hall do fabricante Allegro, modelo

$$
I=\frac{2,5-V}{66 \times 10^{-3}}
$$

Equação 6

Onde: I é a corrente em $A$; $V$ é a tensão em $V$; $66 \times 10^{-3}$ é a sensibilidade $(\mathrm{m} V / A)$.

\subsubsection{TACOGERADOR}

O tacogerador foi cedido por uma empresa, como não havia nenhuma descrição de qual era o modelo foi necessário realizar um ensaio na planta para descobrir sua curva de tensão versus velocidade. A Equação 7 da velocidade lida pelo tacogerador é:

$$
\text { Velocidade }=-0,06991+(342,0129 \mathrm{~V}) \quad \text { Equação } 7
$$

Onde: Velocidade é a velocidade da roda (RPM); V é a tensão ( $V$. 


\subsubsection{CIRCUITO ELÉTRICO (ACIONAMENTO, CONTROLE E AQUISIÇÃO DE DADOS)}

O funcionamento do circuito baseia-se da seguinte forma: o pino 3 do PIC recebe a variação tensão (entrada analógica) que faz com que ocorra a variação do PWM. O pino 16 é a saída PWM que passa pelo optoacoplador e chega ao gate do MOSFET. A função do optoacoplador é fazer a isolação do circuito de controle do circuito de acionamento. Com a variação da largura do pulso, o MOSFET é chaveado, e a energia que chega ao motor é proporcional a essa variação. Assim com a variação de energia no motor controla-se a velocidade. O pino 20 que vai até o LED é apenas para indicar que o programa está sendo executado. A Figura 4 abaixo mostra o circuito de controle e acionamento do motor bem como o circuito para aquisição de dados em tempo real.

Figura 4: Circuito de controle e acionamento do motor CC

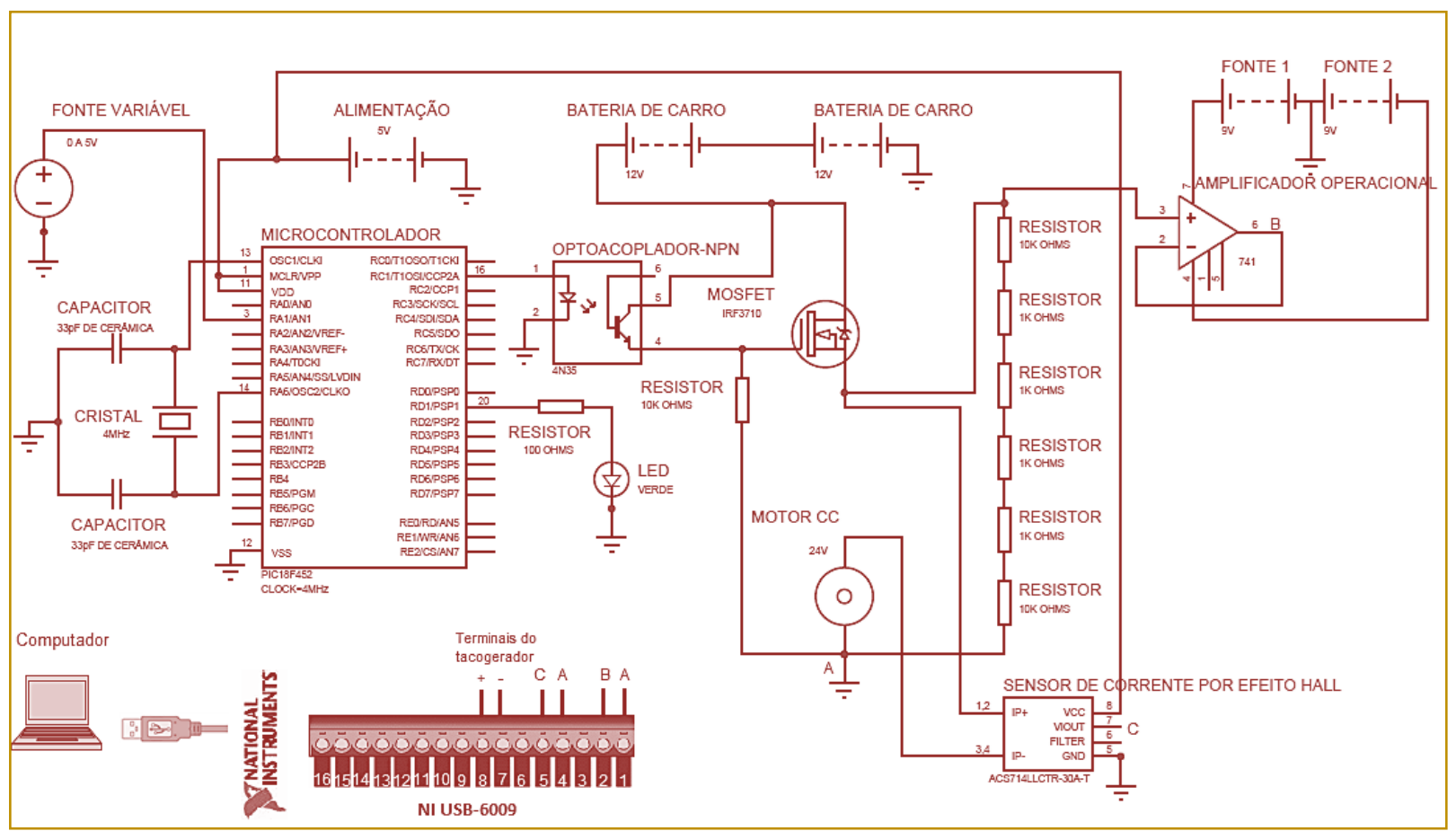

\section{SOFTWARE PARA AQUISIÇÃO DE DADOS}

Foi utilizado o software LabVIEW $\circledast$ para aquisição de dados. O diagrama de blocos é mostrado na Figura 5 e o painel frontal na Figura 6. 
Figura 5: Diagrama de blocos para coletar dados

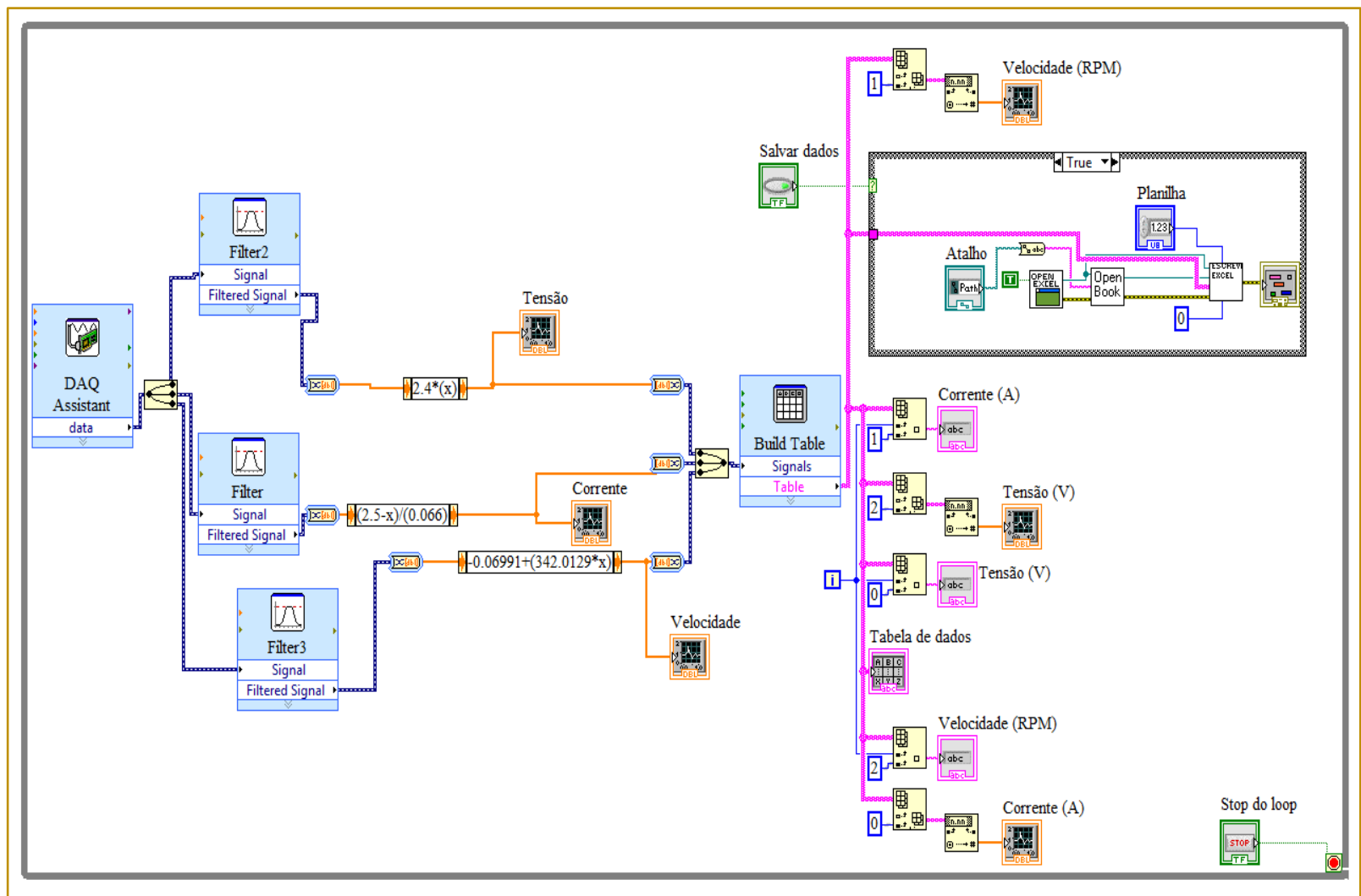

Figura 6: Painel frontal para coletar dados

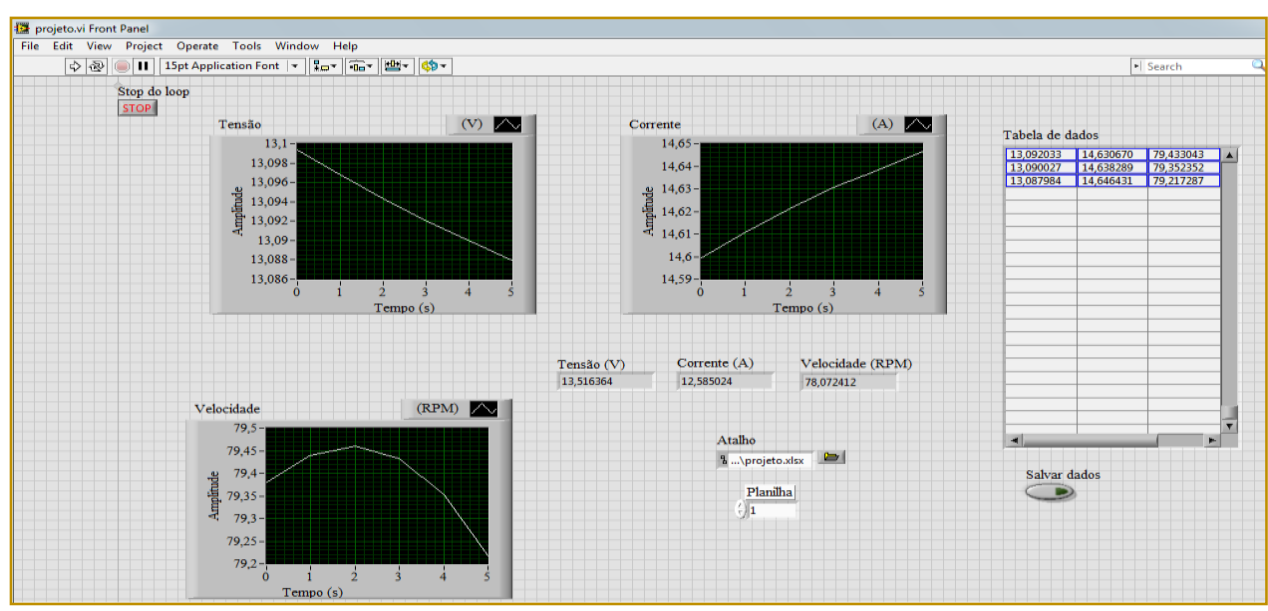

\subsubsection{DESENVOLVIMENTO DA RNA NO MATLAB®}

Foram coletadas pelo circuito de aquisição de dados 87.781 amostras (2000 épocas), dos valores de tensão, corrente e velocidade, de modo que foi criada uma nova rede com os seguintes parâmetros (Figura 7):

- Tipo de rede: Feed-forward
- Função de treinamento: trainlm (Levenberg-Marquardt backpropagation).

- Função de adaptação: learngdm.

- Função de desempenho: MSE.

- Número de camadas: 2.

- Número de camadas escondidas: 1.

- Número de neurônios da camada escondida: 3. 
- Função de ativação da camada escondida: linear.

- Função de ativação da camada final: linear.

Figura 7: Aspecto RNA criada no MATLAB®

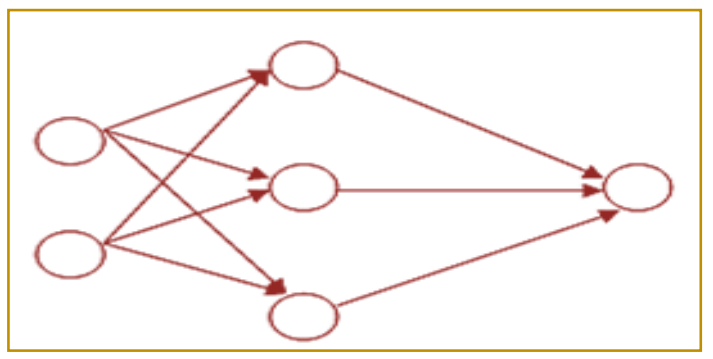

Onde foi obtida uma correlação de 98,754\%

conforme mostra o Gráfico 2.

Gráfico 2: Informações do resultado da nova rede

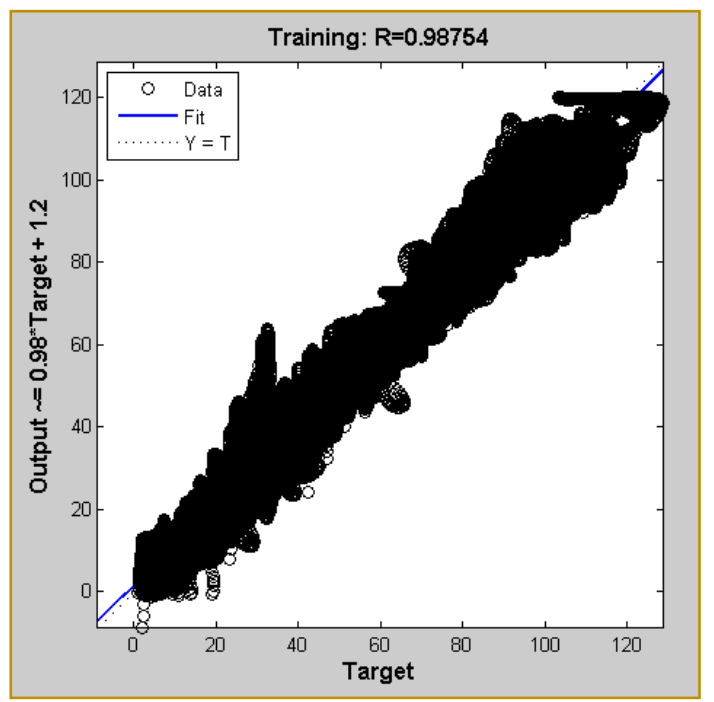

Após isto, foi criada também uma RNA mudando apenas sua função de ativação para sigmoidal, porém apresentou um valor de eficiência praticamente igual à anterior. Devido a semelhanças entre os valores das redes que usam função linear e sigmoidal, foi decidido implementar a rede que utilizou a função de ativação linear devido a praticidade de implementação da mesma, para isso os valores das sinapses e bias foram extraídos e o algoritmo da rede chegou na Equação 8:

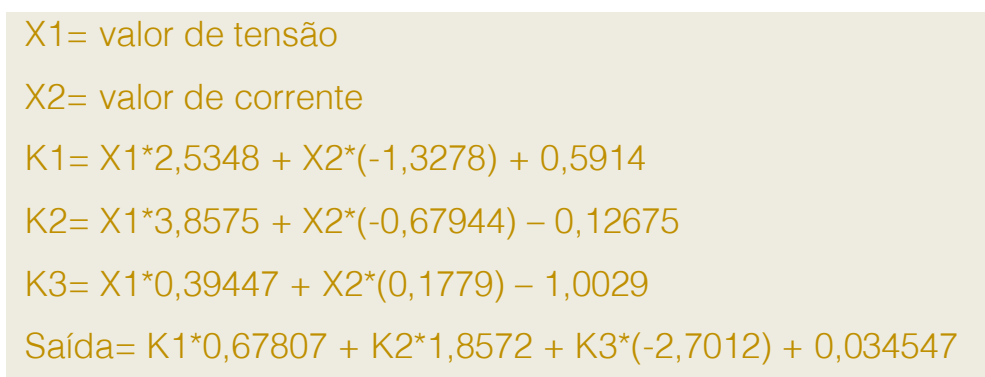

Equação 8 


\subsection{PROGRAMA DESENVOLVIDO NO} LABVIEW@ PARA TESTAR AS RNA'S

Posteriormente com a RNA desenvolvida, mostrada na própria seção 4, obteve-se sua modelagem e foi incluída no programa para coletar dados em tempo real, servindo também para validar (seção 5) seu funcionamento. Foi também testada a RNA modelada com dados obtidos de forma manual.

Foi desenvolvida a programação no diagrama de blocos, mostrada na Figura 8 e desenvolvido um supervisório no painel frontal, conforme Figura 9.

Figura 8: Diagrama para validar a RNA

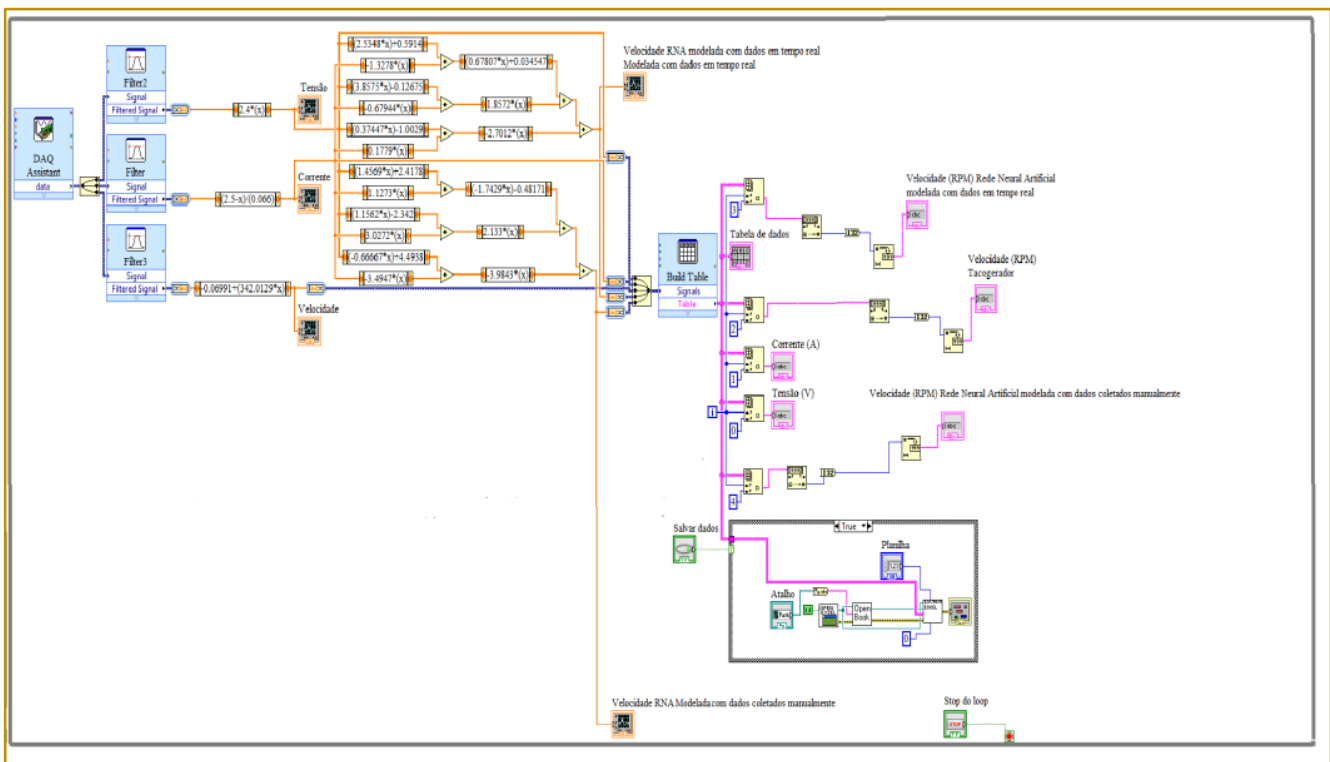

Figura 9: Supervisório

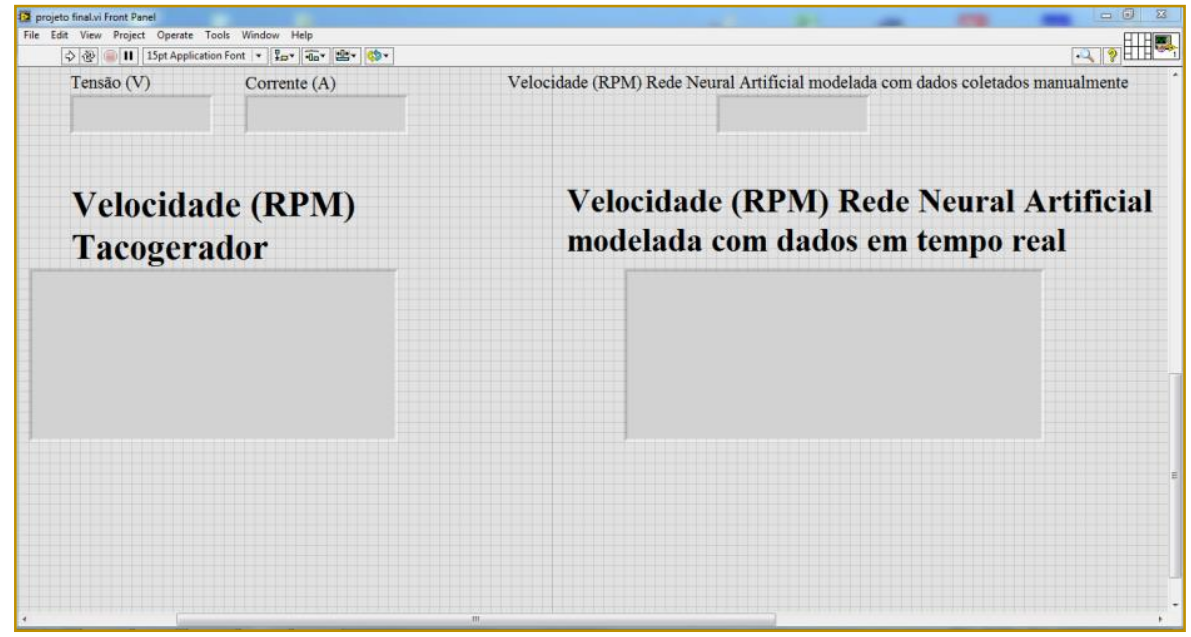


As Equações 5, 6 e 7, citadas na seção 4, foram colocadas no diagrama de blocos do LabVIEW®. A aquisição de dados era parada com o stop do loop. Os dados eram registrados nas colunas da tabela, tensão $(V)$, corrente $(A)$ e velocidade em (RPM), respectivamente e eram salvos numa planilha de Excel.

\section{RESULTADOS PRÁTICOS OBTIDOS}

Após as RNA's serem modeladas e implementadas no LabVIEW®, como descrito na seção 4, foram salvas algumas amostras para analisar sua eficiência.

A RNA modelada com dados coletados de forma manual foi testada apenas com roda livre, pois foi treinada com valores sem torque.

Já a RNA modelada com dados coletados em tempo real foi testada com roda livre e com aplicação de torque, conforme explica a Figura 10.

Figura 10: RNA's, dos treinos até a validação

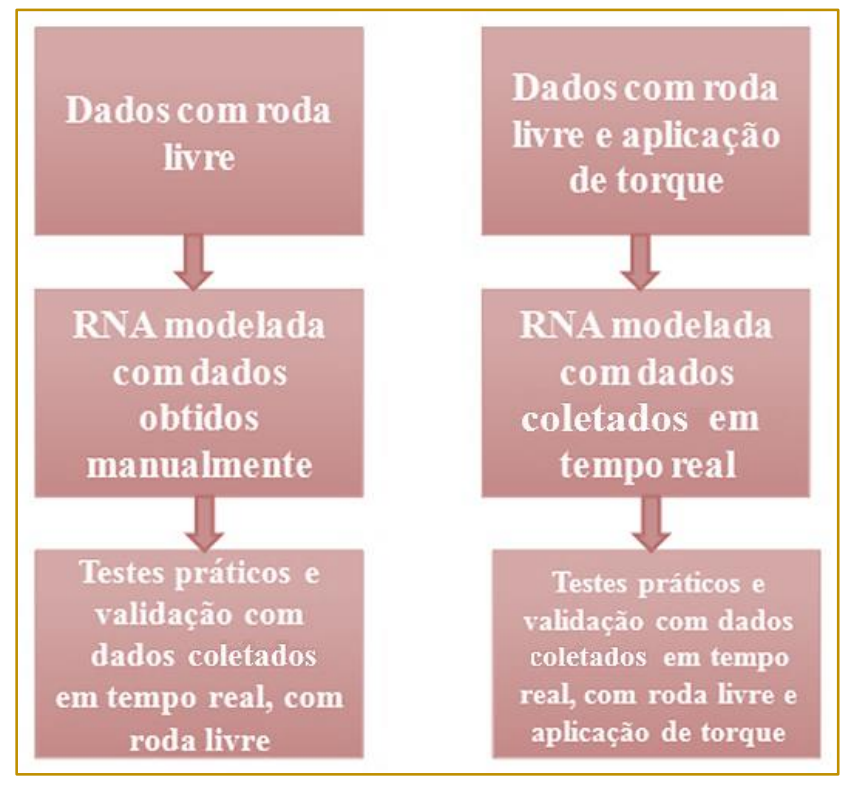

\subsection{RESULTADOS DA RNA MODELADA COM DADOS COLETADOS MANUALMENTE}

Dentro de 4.400 amostras diferentes, com a utilização do Excel, através da Equação 9, que calcula o erro percentual e das funções
MÉDIA (com ABS, em módulo) e DESVPAD (do próprio Excel), que calculam a média aritmética e o desvio padrão respectivamente, foi encontrado um valor de erro percentual (médio) de $28,41132126 \%$ e um desvio padrão de 17,0738896.

$$
\text { erro percentual }(\%)=\left|\frac{\text { velocidade tacogerador }- \text { velocidadeRNA }}{\text { velocidade RNA }} \times 100\right| \text { Equação } 9
$$

Foi plotado o Gráfico 3 para analisar a dispersão apresentada pela RNA. 
Gráfico 3: Dispersão dos valores da RNA modelada com dados obtidos manualmente

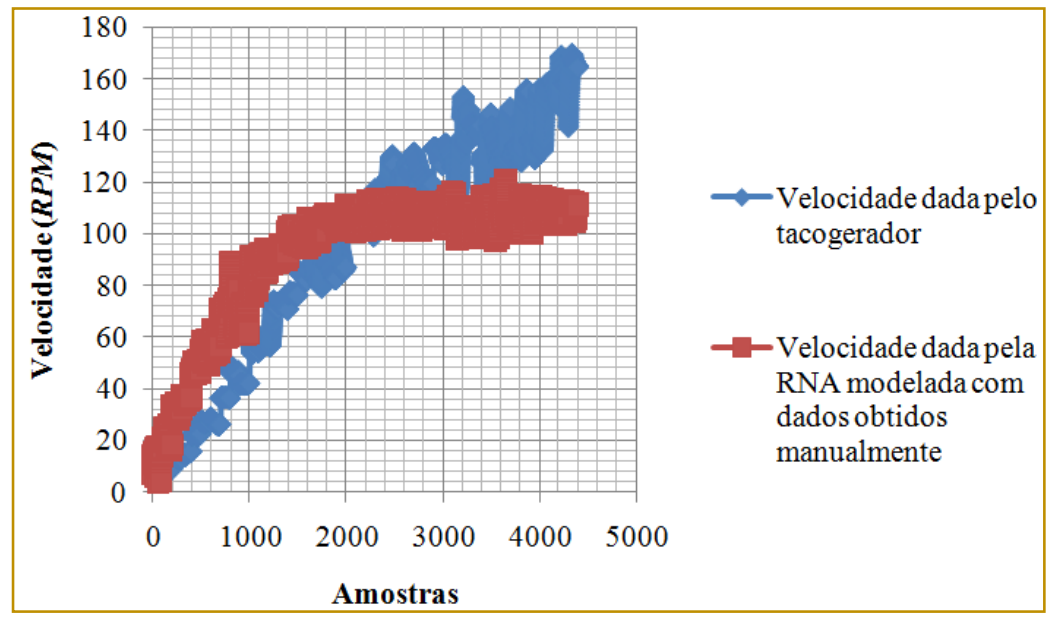

Deve-se levar em consideração que essa RNA foi treinada com valores coletados manualmente e foi testada com valores coletados em tempo real.

A sua correlação (eficiência) no NERUROSOLUTIONS® foi de $98,7 \%$ e no MATLAB® foi de 90,689\% (seção 4), ambos valores bons, mas na prática apresentou menos eficiência, com valores maiores no erro percentual (médio) e no desvio padrão. Podese também observar a dispersão, seu afastamento da velocidade dada como referência (do tacogerador) no Gráfico 3. Percebe-se também que ela erra mais com valores mais altos de velocidade.

\subsection{RESULTADOS RNA MODELADA COM DADOS AQUISITADOS EM TEMPO REAL}

\subsubsection{LIVRE}

Dentro de 4.339 amostras diferentes, com a utilização do Excel, através da Equação 20, que calcula o erro percentual e das funções MÉDIA (com ABS, em módulo) e DESVPAD (do próprio Excel), que calculam a média aritmética e o desvio padrão respectivamente, foi encontrado um valor de erro percentual (médio) de 15,3994467\% e um desvio padrão de 11,09586093.

Foram plotados os Gráficos 4 e 5 para analisar a dispersão apresentada pela RNA.

Gráfico 4: Dispersão dos valores do tacogerador

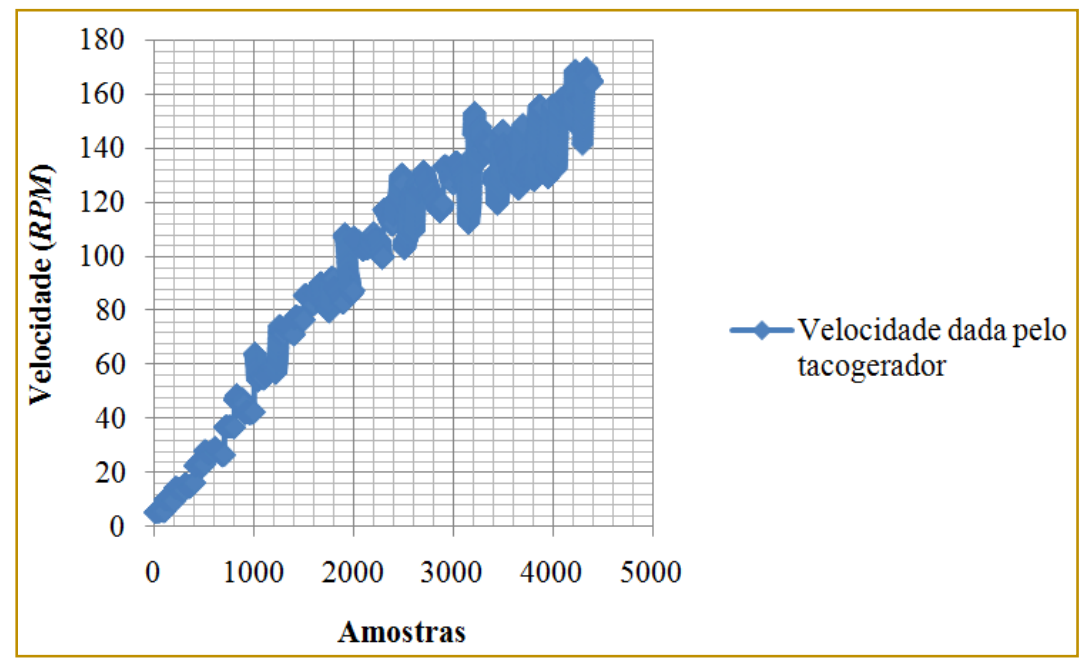


Gráfico 5: Dispersão dos valores da RNA modelada com dados coletados em tempo real sem aplicação de torque

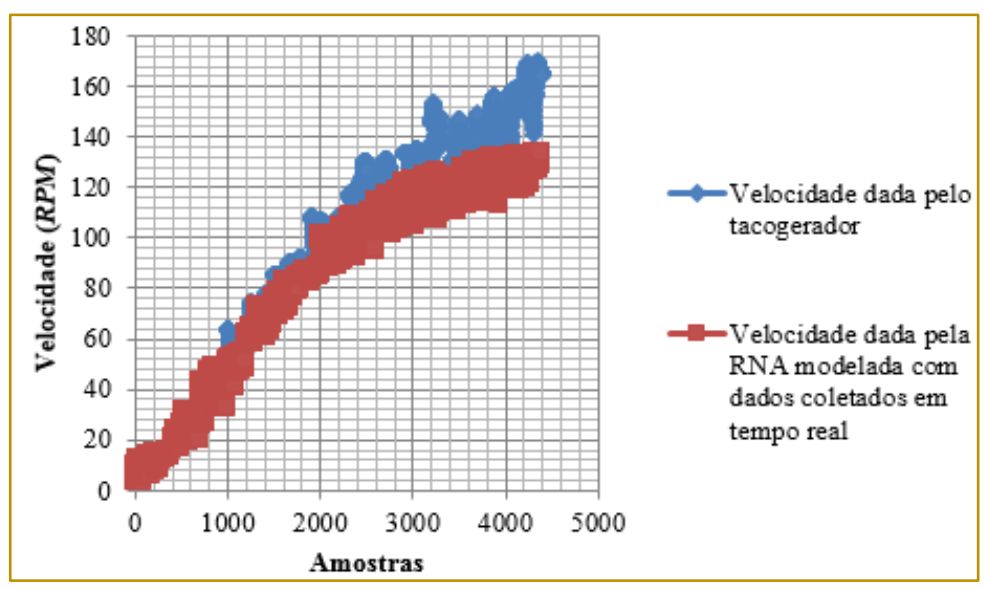

A sua correlação (eficiência) no MATLAB® foi de $98,754 \%$ (seção 4), valor muito bom mas na prática apresentou menos eficiência, com valores maiores no erro percentual (médio) e no desvio padrão. Pode-se também observar a dispersão, seu afastamento da velocidade dada como referência (do tacogerador) no Gráfico 5 com valores mais altos de velocidade.

\subsubsection{COM APLICAÇÃO DE TORQUE}

Dentro de 4.458 amostras diferentes, com a utilização do Excel, através da Equação 20, que calcula o erro percentual e das funções MÉDIA (com ABS, em módulo) e DESVPAD (do próprio Excel), que calculam a média aritmética e o desvio padrão respectivamente, foi encontrado um valor de erro percentual (médio) de 18,55514606\% e um desvio padrão de 12,54645041.

Foram plotados os Gráficos 6 e 7 para analisar a dispersão apresentada pela RNA.

Gráfico 6: Dispersão dos valores do tacogerador com aplicação de torque

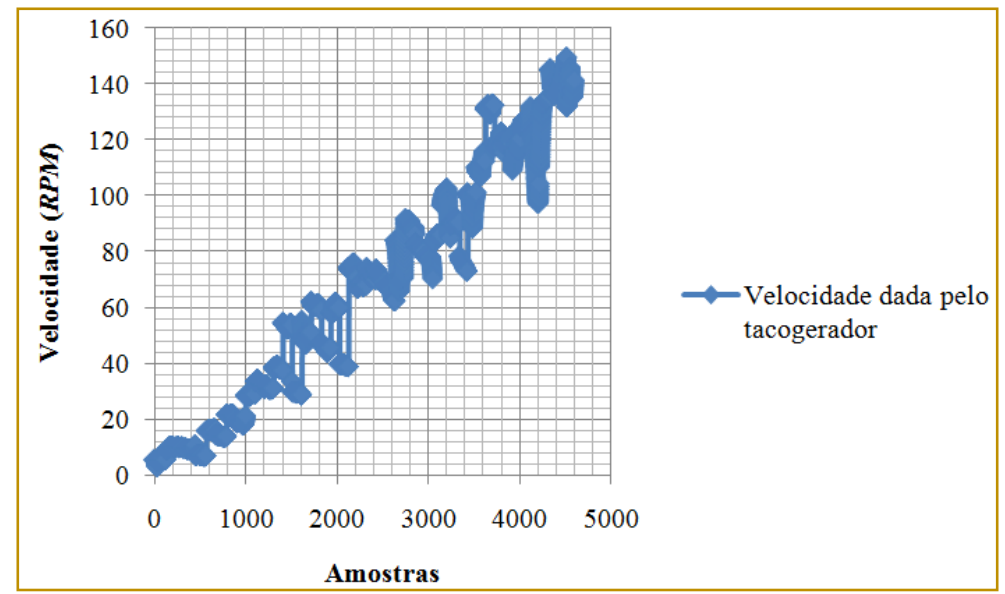


Gráfico 7: Dispersão dos valores da RNA modelada com dados coletados em tempo real com aplicação de torque

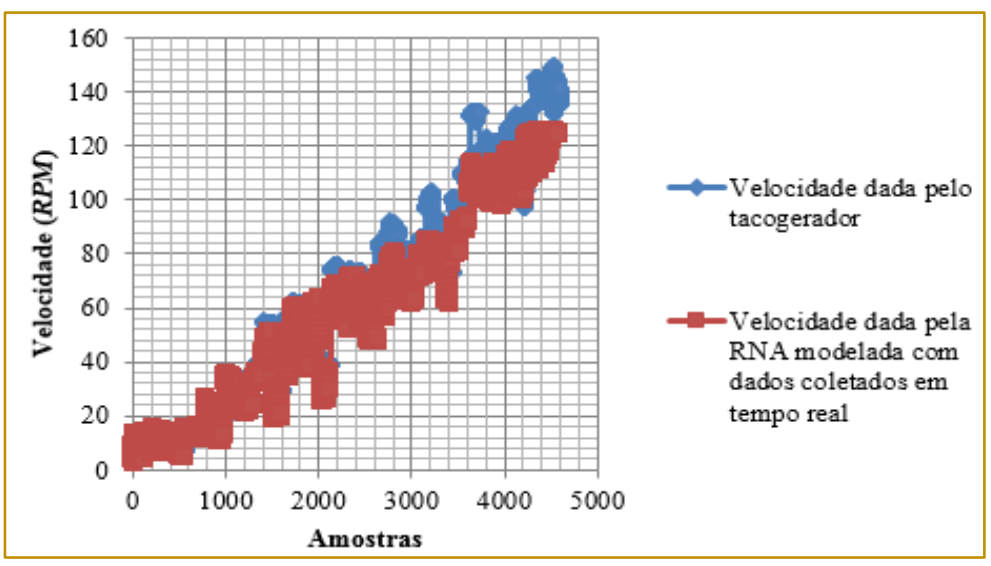

A sua correlação (eficiência) no MATLAB® foi de $98,754 \%$ (seção 4), valor muito bom mas na prática apresentou menos eficiência, com valores maiores no erro percentual (médio) e no desvio padrão. Pode-se também observar a dispersão, seu afastamento da velocidade dada como referência (do tacogerador) no Gráfico 7 ao longo dos valores de velocidade.

\section{CONSIDERAÇÕES FINAIS}

A primeira proposta da equipe foi embarcar a RNA na planta. Para a construção da RNA foi necessário o entendimento dos softwares NERUROSOLUTIONS® e MATLAB® que demonstraram grande eficiência e praticidade na criação da RNA. Com alguns problemas encontrados, dificuldades em encontrar referências com aplicações práticas da RNA e o tempo gasto na resolução desses, essa proposta teve que ser abandonada. Com isso, os esforços foram voltados para o desenvolvimento e implementação de uma RNA no software, de modo a validar o desempenho da RNA na prática comparando seus resultados. Para viabilizar o projeto foi criada uma RNA através de amostras coletadas manualmente, em seguida foi realizado o desenvolvimento de uma aquisição de dados em tempo real, com aplicação da instrumentação virtual, utilizando o software LabVIEW $®$ pode-se perceber a flexibilidade e facilidade nas alterações e testes no desenvolvimento do hardware. Para que então baseado nesses dados fosse possível criar uma nova rede, que seria implementada para obter resultados em tempo real, de modo a avaliar seu desempenho para uma futura substituição de um medidor de velocidade.
A RNA construída com dados obtidos de forma manual apresentou maior dispersão, ou seja, menos acerto que a RNA construída com dados coletados em tempo real, devido à diferença de velocidade, sensibilidade, precisão e erros de observação e operação dos instrumentos de medição utilizados quando comparados com a placa NI USB6009.

O desempenho da RNA construída com dados coletados em tempo real foi melhor, sem aplicação de torque. Com valores altos de velocidade ela começa a apresentar um erro maior ou distanciar mais do valor apresentado pelo tacogerador. Percebeu-se que o tacogerador e tacômetro apresentaram pequenas variações de velocidade devido a um pequeno desbalanceamento da roda, influenciando no comportamento da RNA. A placa NI USB-6009 juntamente com a versão 2012 do LabVIEW® e o computador pessoal utilizado apresentaram também alguns problemas, tais como estouro de memória, mesmo quando os dados eram coletados em tempo real (mesmo seu limite de memória não ter alcançado a metade) e também para os primeiros cinquenta valores coletados, quando se iniciava o processo de aquisição apresentavam incoerência, sendo considerados valores equivocados.

O trabalho impôs a equipe a capacidade de resolver os problemas encontrados durante o projeto utilizando a pesquisa e o método científico, de forma que ao observar o problema foi buscado a explicação para o mesmo propondo a resolução, com as ferramentas disponíveis de forma contínua de aperfeiçoamento. E no decorrer do trabalho, foi bastante estudado as teorias sobre RNA's, que foi de grande contribuição para o 
conhecimento dos integrantes da equipe. Trabalhou o lado da pesquisa científica, onde foi correlacionada a teoria com a prática.

\section{REFERÊNCIAS}

[1] Haykin, S. Redes neurais: princípios e prática. 2. ed. Porto Alegre: Bookman, 2001.

[2] Mamani, A. B. A. Utilização de redes neurais no controle da velocidade de um veículo experimental. 2004. p. 122. Dissertação

\section{AGRADECIMENTOS}

Os autores agradecem a Associação Educacional Dom Bosco.

(Mestrado em Engenharia Elétrica) Universidade de Campinas. Campinas, 2004.

[3] Ni. Ni USB-6009. Disponível em: < www.ni.com>. Acesso em: 6 mai. 2013. 


\section{Capítulo 17}

\section{GESTÃO DA TECNOLOGIA DA PRODUÇÃO: UM ESTUDO DE CASO SOBRE LAYOUT DE UM DATACENTER}

\section{Marcone Freitas dos Reis \\ Mariana de Carvalho Fernandes \\ Auricélio da Silva Leite de Oliveira \\ Leticia de Oliveira dos Santos \\ Marcos do Espirito Santo da Paixão}

Resumo: A empresa abordada para o estudo de caso deste trabalho, é líder na gestão de TI (responsável por armazenar, captar e transmitir informações importantes para seus clientes). As melhorias apresentadas no layout têm o objetivo de melhorar internamente a locomoção, a visualização entre os postos de trabalho e a prestação do serviço. O investimento nos sistemas de informação é a forma que as empresas encontram de administrar suas funções de administração interna. A busca por melhorias em tecnologia de forma constante garante a competitividade da empresa e aumenta a satisfação do cliente.

Palavras Chave: Gestão da tecnologia - Segurança - Informação - Layout - 


\section{INTRODUÇÃO}

Líder em gestão de infraestrutura de Tecnologia da Informação (TI), gestão de aplicações e gestão processos de negócios na América Latina, a organização que será analisada neste estudo, é uma empresa brasileira que busca soluções em parcerias proporcionando o que é de melhor para empresas que buscam seus serviços.

Segundo Las Casas (2008), o produto final de um serviço é sempre um sentimento. Os clientes ficam satisfeitos ou não conforme suas expectativas. Portanto, a qualidade do serviço é variável de acordo com o tipo de pessoa. Sendo uma companhia que preza pela excelência, a empresa apoia seus clientes com serviços através de tecnologias inovadoras e atuação consultiva impulsionando seus clientes a inovar.

A qualidade total em serviços engloba, além dos clientes externos, todos os que com ela interagem, ou seja, funcionários e administradores. A razão disso é que os serviços, sendo atos, desempenho e ação, pressupõem que cada pessoa próxima ao indivíduo é considerada um cliente (LAS CASAS, 2008).

Tendo seu negócio voltado para a TI, a empresa é responsável por armazenar, gerenciar e disseminar os dados para os clientes. Com o tempo perdido em manutenção de equipamentos, redes, links, atualizações e outros aspectos relacionados a $\mathrm{Tl}$, as empresas deixam de se preocupar com as decisões estratégicas realmente importantes e necessárias para gerar receita e crescimento empresarial. Um datacenter se posiciona com o intuito de ajudar as empresas a manter o foco na atividade principal e compreenderem a opção de utilizar a TI de forma aliada e estratégica, ajudando a reduzir os custos, investimentos, e aumentando a disponibilidade das informações tão valiosas para sobreviver no mercado competitivo atual.

A inovação tecnológica, como o próprio nome diz, tem o desenvolvimento de tecnologias como base para a inovação nas organizações. O sucesso de uma empresa, principalmente as industriais, muitas vezes está associado à aplicação do conhecimento científico e tecnológico aos seus produtos (FILHO, 2013).

Investir em sistemas de informação é a maneira que as empresas têm de administrar suas funções de produção internas, bem como de lidar com as demandas dos atores-chave presentes em seu entorno (KENNETH et al., 2007).
A busca por melhorias, mudanças e ideias inovadoras, são fundamentais para as empresas que desejam se manter competitivas e se destacar no mercado. Diante desses pontos abordados, o artigo tem o objetivo de apresentar a análise de uma empresa no momento em que foram realizas melhorias internas com mudanças de layout, facilitando o deslocamento dos funcionários e melhorando a comunicação durante a operação dos equipamentos. Ao longo do estudo, serão apresentados os resultados obtidos e como a situação se relaciona com os conceitos de gestão da tecnologia da produção.

\section{METODOLOGIA}

Para a elaboração da pesquisa científica deste estudo foram realizadas buscas de metodologias que a classifica quanto aos fins e quanto aos meios.

Quanto aos fins esta pesquisa pode ser classificada como: aplicada, pois é voltada para à aquisição de conhecimentos com vistas à aplicação numa situação específica; exploratória por tornar o problema mais explícito, construir hipóteses ou considerar os mais variados aspectos relativos a situação estudada ; e explicativa por ser capaz de identificar fatores que determinam a ocorrência de fenômenos, aprofundando o conhecimento da realidade, pois têm como finalidade aplicar a razão, o porquê das coisas (GIL, 2010).

Neste estudo, foram realizadas visitas no local para obter dados variados que fundamentaram a análise do estudo. Dados estes que foram capazes de colaborar para a construção de hipóteses e identificar como a mudança do layout trouxe benefícios para a execução do serviço oferecido.

Quanto aos meios o estudo é classificado como: pesquisa bibliográfica e estudo de casos. Bibliografia é o conjunto dos livros escritos sobre determinado assunto, por autores conhecidos e identificados ou anônimos, pertencentes a correntes de pensamento diversa entre si, ao longo da evolução da humanidade (RUIZ, 2009). Logo é uma classificação do estudo pois os autores pesquisaram dados através de bibliografias para a construção do artigo científico.

O estudo de caso é definido por Yin (2005) como uma investigação empírica usada no contexto atual para averiguar fenômenos e coletar dados, permitindo contextualizar e arraigar o entendimento acerca do problema. Neste sentido, o estudo também se enquadra nesta 
classificação por apresentar dados coletados de uma empresa para serem analisados.

\section{FUNDAMENTAÇÃO TEÓRICA}

\subsection{GESTÃO DE SERVIÇOS}

O serviço é um fluxo de trabalho realizado em processo e um processo é muito intensivo de mão de obra. A tecnologia permite ofertar os serviços a partir de máquinas e equipamentos, com pouca ou nenhuma participação de mão de obra humana, com essa intensificação torna o setor de serviço mais produtivo. Meirelles (2006) aborda que as evoluções tecnológicas no campo da informática e das telecomunicações causam grande mudanças na produção e consumo de serviços.

Com avanço das tecnologias na área de serviços as empresas que trabalham com muitos dados passaram a terceirizar a gestão desses dados, pois é necessário um infraestrura crescente e isso pode custar muito dinheiro. Segundo a Equipe Cloudster (2015) terceirizando esse serviço paga-se para as empresas provedoras somente o que se utiliza, a empresa deixa de conviver com vários fornecedores de hardware, rede de dados e elétrica, nobreaks, operadoras de telecom e de serviços de TI.

Através das tecnologias de computação em nuvem podemos deslocar parte da infraestrutura para datacenters, gerenciados por empresas provedoras desse serviço, diminuindo assim os custos e tempo anteriormente gastos. Dessa forma, as empresas mantem o foco no negócio (INTEL, 2010 apud VANDRESEN e MAGALHÃES, 2013).

Nuvem é o compartilhamento de recursos, onde o provedor tem uma grande quantidade de recursos para oferecer e por isso ele consegue manter um preço baixo o suficiente para que as empresas consigam contratar o serviço e utilizar com vantagens e pagar somente pelos recursos utilizados, economizando com a infraestrutura (SILVA e CAMPOS, 2015).

\subsection{GESTAO DA TECNOLOGIA E INOVAÇÃO}

O mundo e o mercado estão sujeitos a mudanças, todos os dias surgem novas oportunidades e ameaças, fazendo com que se procure adaptar o planejamento constantemente as novas realidades. A rapidez em que ocorre essas mudanças, faz a empresa pensar em sua sobrevivência e manutenção, dessa maneira surge conceitos importantes de gestão tecnológica. Assim, a gestão tecnológica se tornou fonte de ganho competitivo pelas empresas (FENG e LI, 2007, apud ROCHA; MELLO; NORONHA, 2013).

Segundo Termaguide (1999, apud NATUME; CARVALHO; FRANCISCO, 2008), a gestão tecnológica é fundamental para qualquer negócio, pois auxilia na administração de todas as operações existentes dentro da empresa de forma eficaz, podendo reduzir riscos de comerciais aumentando sua flexibilidade e capacidade de resposta frente às frequentes mudanças de mercado. Sendo assim, a sobrevivência de qualquer negócio está ligado e depende diretamente de um gerenciamento tecnológico bem estruturado.

As tecnologias quando bem administradas podem aumentar sua visão para o futuro podendo prever possíveis inovações dentro da empresa e assim estar a frentes dos concorrentes, além de aumentar sua eficiência e eficácia em processos e recursos existentes.

\subsection{GESTÃO DA TECNOLOGIA DA INFORMAÇÃO}

Gestão é a ação que procura garantir a utilização eficaz dos recursos disponibilizados pelo negócio, afim de serem atingidos os objetivos. A gestão otimiza o funcionamento através de tomadas de decisões racionais baseados em coleta e análise de dados e informações relevantes. Então a gestão busca o emprego racional e eficiente daqueles recursos que na maioria das vezes são escassos dentro da organização (ALMEIDA et al., 2016)

A Gestão da tecnologia da informação entende o processo de administrar a infraestrutura responsável pela captura (Obtenção da informação); armazenagem (banco de dados, plantinhas); transmissão de informação (transformar essa informação capturada em uma nova geração de informação), visando apoiar a atividade administrativa. Então a gestão da tecnologia da informação trabalha com tecnologias de transmissão, processamento e comunicação, esse gestor vai lidar com equipamentos, processos, programas, software, métodos e todos que envolve manutenção e troca. Esses equipamentos estão em constante evolução, e isso implica em fatores como preço, valor, custo benefício entre outros (SOUSA; AGOSTINO; OLIVEIRA, 2016).

A gestão da informação abrange o gerenciamento da informação em si, enfatiza a geração e o uso da informação pelos recursos. 
O responsável pela área do negócio determina se a informação é valiosa para organização (VALENTIM, 2008).

\subsection{LAYOUT}

Consiste da organização racional de todos os recursos e tecnologias necessárias para a obtenção em nível operacional dos objetivos da indústria, materializando-se na forma como esses recursos serão dispostos no espaço. Para melhorar os recursos de produção e aumentar a produtividade, as empresas precisam aproveitas o potencial de estruturar equipamentos e processos da forma mais oportuna possível (MOREIRA, 2008).

Segundo Viana (2002 apud, REIS et al., 2016), o significado de layout é um arranjo físico onde está exposto de que forma as pessoas, máquinas e equipamentos estão posicionados na fábrica, para assim encontrar a melhor forma possível de combinar as instalações, equipamentos, mão de obra e outros itens que fazem parte da atividade industrial.

Para Martins e Laugeni (2012), a elaboração do layout é uma atividade multidisciplinar que alcança diversas áreas da empresa. Por isso, é importante utilizar a experiência de todos na elaboração, na apuração e na determinação de soluções. Para Moreira (2008) elaborar o layout de uma certa empresa significar tomar decisões sobre a forma como serão ordenados, nessa empresa, os centros de trabalhos que aí devem continuar.

Oliveira (2009 apud, CARDOSO, 2011) aponta que um layout adequado propicia à empresa uma maior economia e também produtividade, com base em uma boa organização dos instrumentos de trabalho e por meio da utilização otimizada dos equipamentos de trabalho e das pessoas que estão alocadas no sistema.

A alteração do layout pode ter a finalidade de: buscar as metas competitivas por melhorar o fluxo de materiais e informações; maximizar a eficiência na utilização de recursos humanos e equipamentos; elevar a conveniência dos clientes e vendas; diminuir os riscos dos funcionários por considerar a ergonomia dos processos; aumentar a moral dos trabalhadores e facilitar a comunicação entre as áreas envolvidas no sistema (KOSTROW, 1996 apud REIS et al., 2016).

De acordo com Tam e Li (1991, apud FERNANDES; STRAPAZZON; CARVALHO, 2013) por mais que a área de atividade principal do negócio onde está sendo desenvolvido um estudo para introdução de um novo layout seja completamente diferente da outra, a complexidade encontrada será bastante semelhante uma com a outra, e as metas também, diminuir custos, aumentar a qualidade do trabalho, aperfeiçoar o fluxo de produção.

\section{ESTUDO DE CASO}

Ao longo deste tópico, serão apresentadas informações sobre a empresa que fundamentaram o desenvolvimento da pesquisa. Por questões de segurança, a empresa foi descaracterizada.

A pesquisa apresentará uma proposta de solução para a empresa, como resultado da análise realizada diante da atual situação da unidade. Considerando que o foco é melhorar o desempenho da unidade, a análise priorizou encontrar os gargalos e "ataca-los". Tais gargalos foram encontrados e notou-se que a mudança de layout pode favorecer em diversos aspectos da unidade. Logo, a seguir serão apresentadas as análises da situação atual e da proposta, com um olhar de gerência.

\subsection{APRESENTAÇÃO DA EMPRESA}

A empresa presta serviços em mais de 30 países do mundo, e está presente no mercado há mais de 15 anos. É reconhecida por fazer a gestão de operações críticas com agilidade, segurança e flexibilidade. Os serviços de tecnologia de informação que a empresa oferece, contam com uma autentica infraestrutura, na qual possibilita manipular uma parcela crescente de serviços com uniformidade, confiança e segurança da informação através da rapidez a diversidade da tecnologia.

Tais aspectos proporcionam um papel importante para a empresa. Pois é responsável pela gestão de negócios mais críticos de seus clientes, e seu bom desempenho os tornam mais competitivos no mercado.

\subsection{SISTEMAS}

O estudo de caso foi realizado em uma unidade da empresa situada no Rio de Janeiro, que possui um data center com uma estrutura de mais de $5.000 \mathrm{~m}^{2}$, no qual é composto por diferentes sistemas responsáveis pelo desempenho dos serviços oferecidos pela empresa. 
- Sistema elétrico: com três subsistemas que garantem o fornecimento de energia continuamente para alimentar todos os equipamentos da área, responsáveis por gerar o serviço oferecido pela empresa.

- Sistema de refrigeração: atua constantemente para manter a temperatura ideal de operação, principalmente nas áreas que tendem a um superaquecimento devido ao ininterrupto funcionamento de equipamentos.

- Sistema de proteção contra incêndio: quando necessário, será capaz de conter o incêndio sem que as maquinas sejam danificadas.

- Sistema de supervisão e controle:

\subsection{MUDANÇA DO LAYOUT}

É primordial que o sistema de supervisão e aquisição de dados (scada), esteja em perfeita sintonia com todas as áreas do datacenter, para que a empresa consiga atingir suas obrigações com seus clientes. Diante disso, ao analisar as rotinas dos processos e as atividades dos funcionários no local, estudos indicaram uma mudança no layout da área, como proposta de melhoria no desempenho dos serviços oferecidos pela empresa.

\subsubsection{LAYOUT ATUAL}

- A unidade apresenta os seguintes espaços, conforme apresentado na figura 1 a seguir:

- Hall Social, e as salas de reunião para recepção de visitante;

- Área administrativa;
- $\quad$ Operação, manutenção e armazenagem de equipamentos;

- Sala de equipamentos incluindo sala de servidores para hospedagem e co-location e sala de telecomunicações;

- Sala de equipamentos dos segmentos energia elétrica e ar condicionado;

- Grupo Moto Gerador e tanque de combustível geralmente localizado em área externa ao IDC.

Um dispositivo é responsável por monitorar a oscilação da energia fornecida pela Concessionária. Quando há falta dessa energia, identificada pelo sistema, em 20 milissegundos ele monitoutomaticamente corta a alimentacão e todo o monitora o funcipnamento permanennte de to do os sistemas responsáveis baterias. $\mathrm{O}$ gerador, um dos elementos de todo o sistema de eletricidade do data center, é acionado automaticamente e leva 2 minutos até que esteja em plena capacidade de assumir toda carga das baterias. Porém, há casos em que a operação do sistema automático não é feita por completo. Em momentos como esse, é necessário realizar a normalização do sistema manualmente.

O processo de normalização é realizado pelo operador que, deve vestir o EPI (Equipamento de Proteção Individual) recomendado na sala elétrica, e se deslocar pelo corredor até chegar à sala de equipamentos onde deve ser realizada a normalização. Após a realização, o colaborador pode comunicar a operação pelo rádio ou voltar para sala elétrica e observar no painel de controle se ela foi feita corretamente, pelo sinal luminoso demonstrado no painel do scada, caso esse sinal indique algum erro o colaborador deve voltar e corrigir. Essa normalização deve imprescindivelmente ser precisa, pois a autonomia do subsistema de baterias é de apenas 20 minutos. 
Figura 1: Layout atual

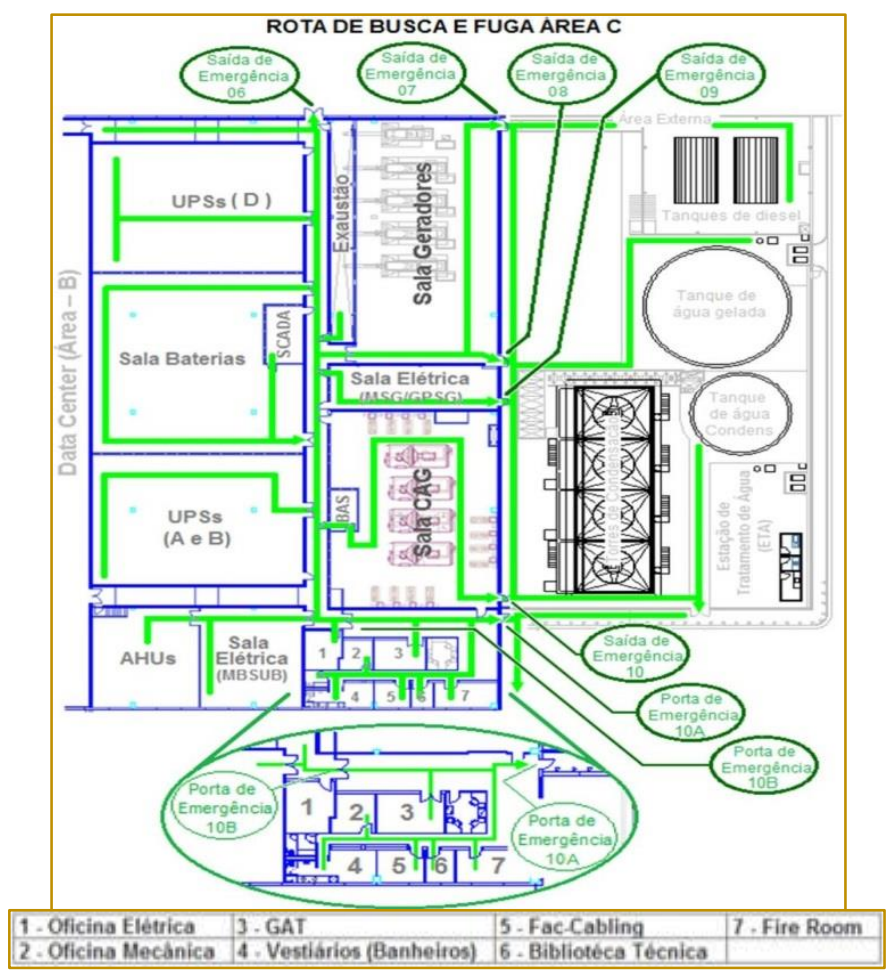

Em situações como essa, é possível perceber que, no layout atual, o deslocamento entre as salas é dificultado, devidos as salas controladas ficarem próximas umas das outras, porém, com acesso apenas pelo corredor. Isso provoca uma lentidão na realização do processo, pois tal dificuldade de acesso causa um deslocamento consideravelmente longo, intensificando o risco de ficar sem energia elétrica, pois no momento da normalização, durante a falta de energia da concessionária, o sistema é alimentado pelo banco de baterias até que os geradores assumam novamente toda carga.

A figura também mostra as salas de controles (mecânica CBAS, elétrica, scada) que não possuem contato visual com as salas controladas (refrigeração CAG, sala de geradores, UPSs, sala de baterias). De acordo com o layout atual as áreas de controles se encontram separadas, em salas independentes, o que força a utilização de telefones (ramal) e rádios comunicadores na comunicação interna durante os momentos críticos de operações e falta de energia. Dessa forma o processo de normalização é dificultado, pois com o ruído dos equipamentos e uso do EPI abafador, obrigatório na área dos equipamentos, o contato pelo rádio está sujeito a falhas na comunicação que aumenta a possibilidade de erro na comunicação.

\subsubsection{LAYOUT PROPOSTO}

A unidade apresenta os seguintes espaços, conforme apresentado na figura 2.

A criação do mezanino trouxe a possibilidade do contato visual com as salas controladas, e através dos vidros se consegue ver todo o processo de normalização e quais funcionários estão realizando as mesmas. A comunicação visual proporciona uma condição de segurança para todos, já que com um sinal de positivo o responsável pela normalização pode confirma a execução da mesma.

A instalação de portas de acesso entre as salas controladas é para efeito de redução do trajeto na execução da normalização, pois para o responsável pela normalização ter acesso a outra sala era necessário executar um trajeto longo com o seu cartão de acesso. Com as portas de acesso entre as salas esse tempo foi minimizado e o risco de o datacenter ficar sem energia também. 
Figura 2: Layout proposto

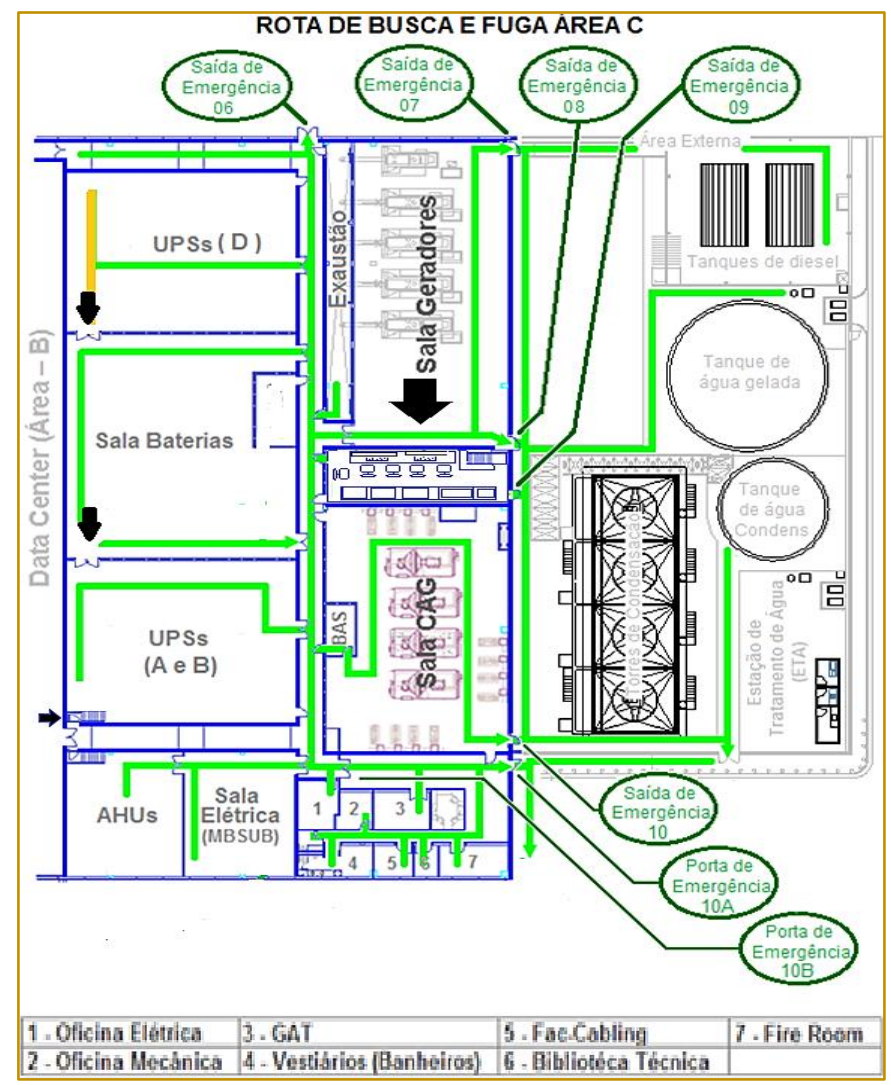

As salas de controles (CBAS, Elétrica, SCADA) passam para uma mesma sala, assim todos os controles do data center são monitorados no mesmo ambiente, aumentando a interação entre as áreas. Centralizando todo sistema, torna o controle da informação mais eficiente e mais seguro, pois essas salas compartilham informações a todo momento, onde o CBAS controla a temperatura interna dos equipamentos dentro das UPSs, e em caso de falta de energia os equipamentos são desligados, nesse caso a sala elétrica deve comunicar o desligamento.

Em caso de visita do cliente, o layout se torna mais dinâmico e atrativo, devido o contato visual através das janelas de vidro que ele terá com todas as salas interligadas.

\section{CONCLUSÃO}

Por fornecer um bem intangível ao cliente, através das mais avançadas tecnologias a fim de garantir a satisfação do cliente, a empresa conquistou o mercado, tornando-se uma das melhores em toda América Latina. Tal reconhecimento se consolidou devido a toda atenção que é mobilizada para garantir a segurança da informação.

O novo layout permitirá uma melhoria na execução deste serviço. A redução da movimentação nas áreas, tem o propósito de reduzir o tempo das atividades normalização evitando que funcionários realizem trajetos não proveitosos. A nova localização do mezanino ampliará o controle visual, proporcionando a visualização de todos setores, e a movimentação dos funcionários. Tal condição trará vantagens para a comunicação entre os funcionários.

Os ambientes em que são realizadas as manobras, sofrem com ruídos gerados pelos maquinários presentes, logo a comunicação por rádio dos funcionários que operam neste local é prejudicada. O novo mezanino possibilitará a comunicação visual entre supervisão e operação, facilitando a transferências de informações e de forma segura, livre de falhas. Vale ressaltar, que qualquer passo mal executado nessa atividade, pode causar um impacto negativo na entrega do serviço ao cliente.

Outras melhorias também foram ressaltadas com a mudança de layout. A nova sala de controle, com todos os controles do data center em um mesmo ambiente, proporcionará melhorias que certamente impactam no desempenho da empresa, pois a comunicação entre os controles se tornará muito mais rápida. A resposta para uma tomada de decisão pode atingir um 
espaço de tempo bastante curto, instantâneo em alguns casos mais simples. É notório que essa agilidade impacta na entrega do serviço.

Um outro aspecto relevante também foi identificado na proposta de layout, quanto a segurança. O novo espaço evitará o trânsito de pessoas nas áreas mais restritas. O local é passível de visitas dos clientes, e com a mudança, eles só terão acesso ao necessário para a gestão do seu negócio, nada além do que é preciso, como acontece no layoutatual.

Diante dos fatos apresentados, pode-se concluir

\section{REFERÊNCIAS}

[1] Almeida, Kassia Raquel de; Burin, Julia Maria; Volan, Tainara; Sychocki, Taise; Balsanello, Jean Paulo. Estudo de caso: aplicação do lean healthcare em um centro de especialidades odontológicas. ENEGEP, 2016. Disponível em: < http://www.abepro.org.br/biblioteca/TN_STO_226_3 24_29236.pdf > Acesso: 21 mai. 2017

[2] Cardoso, Marilicy Maia Guerra. Organização, sistemas e métodos. Maringá-PR, 2011

http://www.ead.cesumar.br/moodle2009/lib/ead/arq uivosApostilas/748.pdf

[3] Casas, Alexandre Luzzi Las. Qualidade total em serviços: conceitos, exercícios, casos práticos. 6aㅡ Edição. São Paulo: Atlas, 2008.

[4] Cloudster, Equipe. Economia: Porque migrar seu datacenter para a Nuvem é um bom negócio. 2015. Disponível em $<$ http://www.cloudster.com.br/economia-porquemigrar-seu-datacenter-para-a-nuvem-e-um-bomnegocio/> Acesso: 11 mai. 2017

[5] Cury, Antônio. Organização e métodos: uma visão holística. $8^{\circ}$ edição. São Paulo: Atlas, 2009.

[6] Fernandes, Giovani; Strapazzon, Rafael; Carvalho, Andriele de Pra. Layout de empresas e seus Benefícios. ENEGEP, 2013. Disponível em: $<$ http://www.abepro.org.br/biblioteca/enegep2013_ tn_sto_177_010_23292.pdf> Acesso: 18 mai. 2017

[7] Filho, Fernando Luiz Freitas. Gestão da Inovação: teoria e prática para implementação. São Paulo: Atlas, 2013.

[8] Laudon, Kenneth C.; Laudon, Pane P. Sistemas de informações gerenciais. $7^{\circ}$ edição. São Paulo: Pearson Prentice Hall, 2007.

[9] Martins, Petrônio Garcia; Laugeni, Fernando Pietro. Administração da produção fácil. São Paulo: Saraiva, 2012.

[10] Meirelles, Dimária Silva e. Características das firmas e dos setores de serviço segundo o Processo de trabalho: uma análise exploratória multivariada. 2006. Disponível em que a empresa lida com a gestão de tecnologia da produção para entregar aos clientes o serviço oferecido. E na busca por aperfeiçoar seus processos, o estudo justifica como a solução pode impactar no desempenho da entrega ao seu cliente. A proposta para eliminar gaps e falhas na comunicação que casualmente geram problemas na execução das atividades, como consequência, atraso na entrega, insatisfação cliente, tem o intuito de garantir ainda mais a segurança da informação, aspecto primordial da relação entre a empresa em estudo e o cliente

<http://www.anpec.org.br/encontro2006/artigos/A0 6A174.pdf>. Acesso: 11 mai. 2017

[11] Moreira, Daniel Augusto. Administração da Produção e Operações. $2^{\circ}$ edição. São Paulo: Cengage Learning, 2008.

[12] Natume, Rosane Yoshida; Carvalho, Hélio Gomes de; Francisco, Antonio Carlos de. O uso de Práticas de Gestão de Tecnologia e Inovação em uma empresa de médio porte do estado do Paraná. Revista de Economía Política de las Tecnologías de la Información y Comunicación, vol. X, n. 1, enero - abr. / 2008. Disponível em:<http://www.pg.utfpr.edu.br/ppgep/Ebook/Ebook\%202008/2008\%20-\%20PERIODICO/6. pdf> Acesso: 13 mai 2017.

[13] Reis, Marcone F. dos; Nascimento, Andrei; Paixão, Alexandre C. da; Dias, Fabricio C.; Santos, Marcos dos. Proposta de melhoria do layout produtivo: estudo de caso de uma gráfica na cidade do Rio de Janeiro. SIMEPRO, 2016. Disponível em: < http://www.dep.uem.br/simepro/anais/index.php/si mepro/simepro/pa per/view/276/187> Acesso: 20 mai. 2017

[14] Rocha, Giseli Valentim; Mello, Carlos Henrique Pereira; Noronha, Juliana Caminha. Uso de mapeamento tecnológico para gestão de tecnologia em empresas incubadas de base tecnológica: caso de empresa de automação hospitalar ENEGEP, 2013. Disponível em:<http://www.abepro.org.br/biblioteca/enegep20 13_TN_STO_184_049_22256.pdf> Acesso: 11 mai. 2017

[15] Seleme, Robson. Automação da produção: uma abordagem gerencial. Curitiba: InterSaberes, 2013

[16] Silva, Ivan Menerval da; Campos, Fernando Celso. Big data e cloud computing perpectivas de uso em engenharia de produção: uma análise bibliométrica de 2004 - 2014. ENEGEP, 2015.2 Disponível em:<http://www.abepro.org.br/biblioteca/TN_STO_ 213_261_27525.pdf> Acesso: 21 mai. 2017 
[17] Sousa, Ricardo de Oliveira; Agostino, Icaro Romolo Sousa; Oliveira, Ricardo Daher. A implantação de um sistema de informações para o monitoramento e análise de falhas: um estudo aplicado ao processo de manutenção industrial de equipamentos portuários. ENEGEP, 2016. Disponível em:<http://www.abepro.org.br/biblioteca/TN_STO_ 226_321_28640.pdf> Acesso: 21 mai. 2017

[18] Valentim, Marta Lígia Pomim. Gestão da informação e gestão do conhecimento em ambientes organizacionais: conceitos e compreensões. Tendências da Pesquisa Brasileira em Ciência da Informação, Vol. 1, n 1, 2008. Disponível <http://inseer.ibict.br/ancib/index.php/tpbci/article/ view/110/151> Acesso: 21 mai. 2017

[19] Vandresen, Rogério Schueroff; Magalhaes, Willian Barbosa. Conceitos e aplicações da computação em nuvem. Paranavaí:UNIPAR, 2013. Disponível

em:<http://ftp.unipar.br/ seinpar/2013/artigos/Roge rio\%20Schueroff\%20Vandresen.pdf> Acesso: 21 mai. 2017

[20] YIN, Robert. K. Estudo de caso: planejamento de métodos. Porto Alegre: Bookman, 2005 


\section{Capítulo 18}

\section{ANÁLISE DA VIABILIDADE DA UTILIZACCÃO DO SOFTWARE WAREHOUSE MANAGEMENT SYSTEM NA GESTÃO DE ARMAZENAGEM DE PRODUTOS E MATERIAIS}

Maurício Massami Kuroda

José Tomadon Júnior

Resumo: Neste trabalho, foi realizada uma análise da viabilidade da utilização de software Warehouse Management System (WMS) na gestão de armazenagem de produtos e materiais, por meio da revisão sistemática da literatura. Para a realização da análise foram selecionados dois trabalhos, uma dissertação e um artigo, contendo em ambos os estudos de casos com ótimos dados sobre a implantação do WMS em empresas e sobre desenvolvedores do WMS. Dos trabalhos selecionados foram estudadas duas empresas desenvolvedoras do WMS e cinco empresas usuárias do WMS, na qual, foram analisados e comparados os motivos que levaram as empresas a implantar o WMS, as dificuldades do processo de implantação do WMS segundo os usuários e os desenvolvedores, as funcionalidades do WMS implantado por cada empresa e desenvolvidas por cada desenvolvedor e os benefícios oferecidos pelo WMS tanto das empresas usuárias quando dos desenvolvedores. A realização da análise possibilitou confirmar a viabilidade do uso do WMS por empresas principalmente as de grande porte que trabalham com uma grande quantidade de mercadorias em seus armazéns. Tal afirmação se deve a resolução dos problemas contida nos motivos de cada empresa e de muitos outros benefícios obtidos pelas empresas com a implantação do WMS.

Palavras chave: WMS, Armazenagem, Empresa. 


\section{INTRODUÇÃO}

Muitos empresários se questionam se há agregação de valor ao produto na armazenagem ou se há somente agregação de custos envolvidos no processo. Para um melhor entendimento imaginemos uma geladeira que pode ser considerada como um armazém onde as pessoas utilizam para armazenar os produtos adquiridos num supermercado e fazem retiradas para 0 consumo. Qual seria o valor de possuir um litro de leite para consumir no momento em que the der vontade? Se não houvesse o leite armazenado, toda vez que a pessoa desejasse tomar um copo de leite haveria a necessidade de se deslocar até o supermercado ou padaria para então tomar o seu copo de leite. E qual seria o custo disso, do deslocamento até o supermercado toda vez que se deseja beber um copo de leite? Pode-se assim ter a percepção do nível de importância do processo de armazenagem e a redução dos custos que o processo produziria principalmente para uma empresa (TOMPKINS; SMITH, 1998). Ter o produto certo, no lugar certo e no momento certo é os fatores que agregam valor ao produto no processo de armazenagem (JUNIOR; SPEJORIM, 2012).

O processo de armazenagem está incluído dentro da logística de distribuição e de suprimento que por muito tempo foi alocado em locais inadequados, pois a armazenagem não era visto como uma estratégia de logística para as empresas (BRAGA et al., 2008). Com o passar do tempo, foi apurado que o processo de armazenagem gerava altos custos às empresas (MOURA, 1997). A partir dessas verificações o processo de armazenagem começou a ganhar sua devida importância nas estratégias das organizações principalmente na redução de custo dos produtos.

Segundo Moura (1997), a maior parte dos custos de armazenagem continuará ocorrendo, pois a maior parte deles está ligada ao ambiente físico, a movimentação dos equipamentos, aos colaboradores e a tecnologia. Assim, é possível compreender a necessidade da otimização do espaço físico por meio de estratégias e ferramentas facilitando a identificação do local de cada produto (BRAGA et al., 2008).

Para Musetti e Veríssimo (2003), com uma eficiente gestão de armazenagem é possível reduzir estoques, aperfeiçoar a movimentação de equipamentos, otimizar o uso do armazém,atender rapidamente o cliente e a linha de produção, reduzir material obsoleto, etc. Assim,existe a possibilidade de reduzir os custos, melhorar a integração do processo de armazenagem com outros processos, assim como, melhorar o atendimento ao cliente.

Devido à complexidade da gestão de armazenagem uma solução foi encontrada na tecnologia da informação (TI), por meio da utilização de sistemas como o Sistema de Gestão de Armazenagem (WMS, do inglês Warehouse Management System), que são basicamente softwares que recebem informações relacionadas ao armazém e conforme as necessidades da organização o software retorna um feedback para uma melhor movimentação, armazenagem, separação e expedição dos produtos (VERÍSSIMO; MUSETTI, 2003).

Este trabalho tem como objetivo principal verificar a viabilidade da utilização do WMS por meio de uma análise comparativa entre empresas usuárias do sistema WMS. Para que o objetivo principal seja alcançado é necessária atingir alguns objetivos específicos como: Analisar os motivos que levaram as empresas a implantarem o WMS; Analisar as dificuldades encontradas durante a implantação do WMS; Analisar as funcionalidades do WMS utilizado por cada empresa e Analisar os benefícios obtidos pelas empresas após a implantação do WMS. Para auxiliar as análises foram utilizadas também informações obtidas de desenvolvedores do WMS.

\section{REFERENCIAL TEÓRICO}

\subsection{ARMAZENAGEM}

A armazenagem é definida como a gestão econômica do espaço disponível e necessário da organização para estocar produtos incluindo atividades de localização, dimensionamento da área, disposição dos produtos e materiais, recuperação de estoque, projetos de carga e descarga e a organização do armazém (RODRIGUES et al., 2010).

Segundo Paoleschi (2014), o processo de armazenagem é uma das atividades que mais agrega valor ao produto na cadeia de suprimentos, pois conta com um sistema de armazenamento racional tanto de matérias primas quanto de produtos. Na produção, a armazenagem movimenta e controla a 
estocagem dos produtos acabados e semi acabados da forma mais eficiente possível gerando um melhor atendimento aos clientes.

Diversas empresas buscam reduzir custos e aumentar a produtividade em seus armazéns e centros de distribuição, sendo um dos principais motivos dos estudos da gestão de armazenagem dentro das organizações, que além de contribuir na competitividade estratégica da organização também contribui agregando valor ao cliente final (KOSTER et al., 2007).

A principal função da armazenagem é gerenciar os elementos, espaço e tempo disponível, visando o uso desses dois fatores da forma mais eficiente possível que engloba os sistemas de fluxos materiais, informações e pessoas (BANZATO et al., 2010).

Segundo Moura (1998), são dez as atividades da armazenagem: Recebimento do produto; Identificação e endereçamento do produto para estoque; Envio do produto para o estoque; Localização do produto no estoque; Separação dos produtos para atender aos pedidos; Agrupamento dos pedidos para conferência final; Embalagem dos pedidos para expedição; Carregamento dos pedidos; Expedição dos pedidos e Registrar as atividades da armazenagem.

Segundo Moura (1997) o objetivo principal da armazenagem é potencializar a efetiva utilização dos recursos. Sendo que para o autor os objetivos básicos são: Potencializar o uso de mão de obra, o uso de equipamentos, o uso de espaço disponível, o uso de energia, o giro de estoque, guarda segura de todos os itens, o controle contra perdas, o atendimento ao consumidor, a produtividade e reduzir custos.

Moura (1997) classifica os armazéns de acordo com o seu ciclo, ou seja, armazém de produção e armazém de distribuição. Segundo Fiegenbaum (2009) o armazém de produção tem como objetivo a estocagem do material designado ao ciclo de produção e o armazém de distribuição tem como objetivo a estocagem de produtos destinados a venda.

\subsection{WAREHOUSE MANAGEMENT SYSTEM}

O WMS é um sistema de gestão fundamentado em um software que otimiza atividades da armazenagem, por meio de gestão de informação eficiente e finalização das tarefas, comum elevado grau de controle e precisão do inventário (BANZATO, 2004). Segundo o referido autor, estas informações gerenciadas são obtidas das transportadoras, fabricantes, sistemas de informação de negócios, clientes e fornecedores, que são utilizadas para realizar de forma eficiente as atividades de receber, inspecionar, estocar, separar, embalar e expedir mercadorias.

De acordo com Rodrigues (1999) sistema WMS é uma combinação de equipamentos e sistemas de controle que tem como função deslocar, armazenar e coletar produtos com exatidão e velocidade dependendo do nível de automação do armazém, além disso, estes sistemas reduzem o tempo de movimentação dos operadores e o uso de leitores ópticos e códigos de barras, reduzem o tempo gasto na procura e na documentação dos pedidos.

Para sucupira (2004) os objetivos do sistema WMS são: Aumentar a acurácia das informações de estoque; Aumentar a agilidade e a qualidade das atividades e Aumentar a produtividade do pessoal e dos equipamentos do armazém.

Sucupira (2004) também cita as principais funções de um sistema WMS: Rastrear as operações; Gerar inventários físicos e rotativos; Planejar e controlar a capacidade dos armazéns; Determinar as características de uso de cada local de armazenagem; Classificar os itens; Controlar lotes; Controlar datas de liberação das quarentenas e situações de controle da qualidade; Separar pedidos; Interface com clientes e fornecedores; Calcular o número de embalagens de despacho e listas de conteúdo; Auxiliar no controle rotas e no carregamento de veículos.

Devido à complexidade da parte operacional do processo de armazenagem há a necessidade de uso da tecnologia de suporte para possibilitar uma maior eficiência na operação (MOELLER, 2011).Algumas tecnologias que podem ser utilizadas para auxiliar as atividades da armazenagem são: Código de barras que possibilita guardar diversas informações do produtos; Coletores de código de barras que fazem a leitura das informações contidas nos códigos de barras; RFID (Rádio Frequency Identification) que possibilita a detecção online do posicionamento dos produtos e Antena receptora que capta o sinal emitido pelo RFID (LUDWIG; GOOMAS, 2007).

De acordo com Banzato (2005), a implantação do WMS possibilita aprimorar as 
atividades da empresa de duas formas, reduzindo os custos e melhorando os serviços oferecidos aos clientes. Tais questões são otimizadas pelas seguintes razões: Melhoria da acuracidade do estoque; Melhoria na utilização do espaço disponível; Minimização de erros operacionais; Aumento da produtividade; Redução da necessidade de papeis para documentar informações; Melhoria no controle de carga de trabalho e no gerenciamento operacional; Apoio do processo de aumento do valor agregado; Redução do tempo de pedido em espera; Otimização do percurso da separação de pedidos e Estocagem otimizada. Todos esses benefícios são alcançados pelo uso total das funcionalidades disponibilizadas pelo sistema WMS.

Embora o WMS possibilite diversos benefícios, Banzato et al. (2010) destacam algumas dificuldades à serem enfrentadas para que essas vantagens possam ser alcançadas:Alto investimento inicial; Baixo conhecimento da ferramenta pelos colaboradores; Resistência a mudança por parte dos colaboradores; Necessidade de treinamento e capacitação do pessoal envolvido na operação; Necessidade de remodelar e adaptar o processo operacional; Integralização entre hardware, software e colaboradores.

\section{METODOLOGIA}

Esta pesquisa, quanto aos fins, classifica-se como exploratória e descritiva que segundo Vergara (1998) uma pesquisa exploratória é definida como aquela que é realizada em áreas de pouco conhecimento sistematizado e por isso não contém estimativas em sua fase inicial, porém, a medida que a pesquisa vai se desenrolando hipóteses podem vir à surgir espontaneamente.Pesquisa descritiva é aquela que apresenta características bem compreensivas e delineadas de determinada população ou fenômeno e que estabelece relações entre as variáveis.

A pesquisa é do tipo exploratório devido ao baixo nível de conhecimento a respeito do assunto abordado e tipo descritivo pelo fato da pesquisa incluir a atividade de definir as características da implantação do sistema WMS pelas empresas e o estudo e a comparação entre as implantações para determinar a viabilidade da sua implantação na gestão de armazenagem das empresas.
Quanto aos meios, o estudo recorreu à revisão bibliográfica como forma de investigação, mais especificamente como uma revisão bibliográfica sistemática que de acordo com Galvão e Pereira (2014) é um tipo de investigação focada em uma questão bem definida que tem como objetivo identificar,selecionar, avaliar e sintetizar as evidências expressivas e disponíveis.

Inicialmente identificaram-se as bibliografias relacionadas à pesquisa, neste caso, relacionado à implantação do WMS nas empresas. Feito a identificação das bibliografias selecionou-se os trabalhos nas quais possuem estudos de caso de implantação do sistema WMS nas empresas. Após a seleção das bibliografias avaliou-se os trabalhos selecionados verificando os dados contidos nos estudos de casos como os motivos que levaram as empresas a implantar - sistema WMS, as funções dos WMS implantada por cada empresa, os benefícios obtidos após a implantação do WMS e as dificuldades encontradas durante a implantação do WMS. Avaliado as bibliografias foi realizado a sintetização dos trabalhos, ou seja, eleger os trabalhos com estudos de casos que possuem informações, citadas na etapa de avaliação, que possam ser realizada uma análise comparativa para verificar a viabilidade da utilização do WMS.

\section{DADOS OBTIDOS}

\subsection{DESENVOLVEDORES}

Esta seção é constituída das seguintes informações: Dados dos desenvolvedores, Dificuldades de implementação do WMS, Funcionalidades de seus WMS e Benefícios fornecidos pelo WMS.

\subsubsection{DESENVOLVEDOR X}

O Desenvolvedor $X$ é uma empresa especializada no desenvolvimento de sistemas para o aperfeiçoamento da operação logística na cadeia de suprimentos e possuem cerca de 500 colaboradores distribuídos nas unidades de Goiânia, São Paulo, Rio de Janeiro, Joinville, Porto Alegre, Fortaleza, Recife e Belém.

As principais dificuldades na implantação do WMS para o Desenvolvedor $X$ são: Alto investimento inicial; Preparação cultural; Apoio da diretoria; Mapeamento dos processos organizacionais e Cadastramento 
das informações. Uma das maiores dificuldades para a aquisição e implantação do WMS é referente a questão financeira, principalmente para as micro e pequenas empresas (SORIANO, 2013).

O sistema é uma ferramenta que auxilia as empresas usuárias a alcançar um alto índice de eficiência operacional, no entanto, a maior parte dos clientes chegam a utilizar no máximo 50\% dos recursos disponibilizados pelo sistema e dos 150 clientes do Desenvolvedor $X$ apenas 10\% utilizam mais que $50 \%$ dos recursos oferecidos pelo sistema. As empresas usuárias utilizam o sistema para aprimorar as operações e não buscam soluções que possam originar novos ganhos operacionais, ou seja, uma falta de visão estratégica por parte das empresas (SORIANO, 2013).

De acordo com Soriano (2013), os benefícios oferecidos pelo WMS do Desenvolvedor X, são as seguintes: Recebimento mais rápido e assertivo; Maior controle e agilidade na armazenagem; Separação de pedidos mais rápida e assertiva; Inventários mais precisos; Minimização da ociosidade; Redução da ocorrência de erros operacionais; Melhoria do nível de serviço prestado; Tomada de decisão baseada em fatos; Acompanhamento da operação online e em tempo real.

\subsubsection{DESENVOLVEDOR Y}

A empresa está no mercado desde 1994 atuando como desenvolvedora de software sendo sua especialidade o WMS. Os usuários de seus softwares são divididos em quatro segmentos: atacadista/distribuidor; indústria, operadores logísticos e varejistas. Possui cerca de 70 funcionários colaborando no crescimento da empresa distribuídos em duas unidades, São Paulo e Ribeirão Preto.

De acordo com Soriano (2013), para o Desenvolvedor $Y$ as dificuldades encontradas no processo de implantação do WMS são: Investimento inicial (empresas de pequeno porte);Mudança cultural; Apoio da diretoria; Definição dos processos de negócio e Cadastramento de informações.

Praticamente todas as funcionalidades do WMS tanto do Desenvolvedor $X$ quando o do Desenvolvedor $Y$ foi mencionado na literatura, dessa maneira, o WMS dos dois desenvolvedores possuem as mesmas funcionalidades (SORIANO, 2013). O WMS tanto do Desenvolvedor $X$ quanto do
Desenvolvedor $Y$ possui as seguintes funcionalidades: Agendamento do recebimento; Captação de notas fiscais dos fornecedores via EDI; Cálculo dos recursos necessários para o recebimento; Gestão de portaria; Convocação ativa para recebimento; Priorização de desembarque; Controle de divergências no recebimento; Análise da fragmentação dos espaços; Sugestão de reorganização de estoque; Gestão de lotes; Gestão de Validade (do inglês Shelf-Life Management); Classificação do status do item; Convocação ativa para armazenagem; Setorização dos locais de armazenagem; Cadastramento das restrições físicas de armazenagem; Endereçamento automático pela Curva ABC; Reabastecimento automático do picking; Realização de inventários cíclicos e estáticos; Convocação ativa para separação e conferência; Ondas de separação parametrizada por regras pré-definidas; Cálculo dos recursos necessários para a separação de pedidos; Picking, priorizando clientes e/ou rotas; Definição de percurso lógico para separação; Controle de separação em tempo real; Conferência dupla de expedição; Ocupação do armazém; Visualização gráfica do armazém em 3D online; Detalhamento do inventário; Registro de entradas e saídas por produto, endereço e operador; Resumo de todas as operações; Análise do desempenho da operação de recebimento; Análise do desempenho da operação de separação de pedidos; Análise do desempenho no atendimento dos pedidos; Análise por produto, volume, transação, período e funcionário; Parametrização dos tempos médios por tarefa; Registro do tempo gasto em tarefas; Análise de produtividade por operador, equipe, tarefa ou turno; Planejamento de carga de trabalho; Rastreabilidade das tarefas; Definição de atividades prioritárias por operador e Distribuição automática de tarefas pendentes.

Os benefícios que podem ser obtidos pelos usuários do WMS do Desenvolvedor Y são: Recebimento eficiente; Maior controle da operação de armazenagem; Maior velocidade e minimização dos erros na separação de pedidos; Melhor acuracidade de estoque; Redução da ociosidade operacional; Minimização de erros operacionais; Aprimoramento do nível de serviço; Relatórios de suporte gerencial e Acompanhamento da operação online e em tempo real. 


\subsection{EMPRESAS USUÁRIAS}

Esta seção é constituída das seguintes informações: Dados das empresas usuárias do WMS; Motivos da implantação do WMS; Dificuldades na implantação do WMS; Funcionalidades do WMS e Benefícios obtidos após a implantação do WMS.

\subsubsection{EMPRESA A}

A Empresa A sediada em Ribeirão Preto possui em torno de 150 funcionários e 20 deles atuam no setor logístico e o faturamento mensal da empresa é de aproximadamente três milhões de reais. A empresa trabalha com 1.200 Itens mantidos em Estoque (SKU, do inglês Stock Kevin Units) em uma área disponível de 3.360 metros quadrados.

Em 2011, a distribuidora apresentou dificuldades na gestão da armazenagem, tanto com a acuracidade de estoque quanto no controle de lotes e monitoramento da eficiência das operações de recebimento e expedição realizadas pelos colaboradores. Essas dificuldades motivaram a empresa a implantar o sistema WMS como um meio para a resolução dos problemas.

Durante a implantação do WMS, a principal dificuldade era em relação ao fator cultural, no qual, os colaboradores ligados a operação demonstravam resistência em função da nova configuração de trabalho aplicado pelo WMS. Para um funcionamento eficiente do sistema WMS é necessário a conscientização e a colaboração de todos da empresa, tanto do setor da diretoria quanto do setor operacional (SORIANO, 2013).

O WMS utilizado pela Empresa $A$ é o desenvolvido pelo desenvolvedor $Y$, logo, as funcionalidades da Empresa A está localizada no tópico 4.1.2. Desenvolvedor $Y$.

Os benefícios obtidos após a implantação do WMS foram a melhor organização do estoque, controle apurado dos lotes, rastreabilidade dos produtos, minimização dos erros operacionais, melhoria na visibilidade e acuracidade do estoque. Isso tudo, colaborou para um melhor atendimento ao cliente com um prazo de entrega mais curto. Outros benefícios segundo Soriano (2013) obtidos pela empresa são maior velocidade do processo de separação, aprimoramento do processo de devolução e satisfação dos colaboradores.

\subsubsection{EMPRESA B}

Com filial em Ribeirão Preto, a Empresa B está presente em 21 estados brasileiros e possui mais de 22 mil colaboradores. Seu faturamento chega a 168 milhões de reais ao ano. A empresa atua em duas áreas distintas, o atacado e o autosserviço. Enquanto o autosserviço atende pessoas físicas com mais de 11.000 produtos $O$ atacado atende empresas com aproximadamente 2.500 SKU.

A implantação do WMS ocorreu no setor de atacado em 2010. O fator principal que motivou tal ação foi a dificuldade no controle de estoque chegando a constatar no inventário físico uma discrepância de400 mil reais, ou seja, problemas de acuracidade no estoque (SORIANO, 2013).

De acordo Soriano (2013), durante o processo de implantação a maior dificuldade encontrada foi em relação à disciplina na execução das atividades imposta pelo WMS que tem como princípio a não realização de movimentos desnecessários e não permitidos pelo sistema. Fazer com que todos os envolvidos executassem da forma correta as atividades impostas pelo WMS foi o maior problema a ser enfrentado.

O WMS utilizado pela Empresa B é o desenvolvido pelo desenvolvedor $Y$, logo, as funcionalidades da Empresa $B$ estão localizadas no tópico 4.1.2. Desenvolvedor Y.

Soriano (2013) identificou que o principal benefício obtido após a implantação doWMS no Atacado B foi o aumento do controle operacional, em que houve uma minimização do problema inicial de acuracidade de estoque. Outros benefícios obtidos pela implantação do WMS foram: Aumento da velocidade de recebimento; Aumento da velocidade de separação de pedidos; Aumento na velocidade de identificação de falhas; Minimização de erros de conferência no recebimento; Melhor utilização do espaço disponível; Melhor visualização do estoque; Minimização de erros na separação do pedido; Minimização de erros de conferência no carregamento.

\subsubsection{EMPRESA C}

A Empresa C sediada em Ribeirão Preto é uma das maiores representantes do grupo Coca-Cola no Brasil. Em 2013 a empresa possuía mais 25.000 pontos de vendas distribuídos por 131 cidades ofertando 340 
SKU. A empresa em estudo possui 200 funcionários.

Os principais motivos para a implantação do WMS foram o alto volume de erros operacionais e consequentemente a baixa acuracidade de estoque (SORIANO, 2013).

Mesmo com a realização de treinamentos ligados a operação, houve dificuldade na adaptação dos colaboradores em função da forma de trabalho proposta pelo WMS (SORIANO, 2013).

O WMS implantado na Empresa $C$ possui as seguintes funcionalidades: Programação e sequenciamento do recebimento; Controle de portaria e pátio; Controle de lotes (rastreabilidade); Gerenciamento de devoluções; Programação e sequenciamento da separação de pedidos; Priorização de atividades; Inventário (Acuracidade de estoque); Distribuição e controle da carga de trabalho; Monitoramento do desempenho do colaborador e Monitoramento e controle de produtividade por atividade.

Pode-se dizer que com a implantação do WMS houve benefícios como a minimização de problema de acuracidade de estoque, minimização dos erros de separação e conferência, tanto no recebimento quanto na expedição dos produtos, aprimoramento na rastreabilidade dos produtos e um melhor controle de estoque e devoluções (SORIANO, 2013).

\subsubsection{EMPRESA D}

A Empresa $D$ atua na área de armazenagem e distribuição, localizada em Contagem, Minas Gerais. As operações realizadas pela Empresa D são divididas em prestação de serviço de armazenagem para uma empresa da área alimentícia e em armazenagem e distribuição de variados produtos de empresas do setor alimentício e de produtos de beleza.

Segundo a empresa os motivos que levaram a implantação do WMS foram a grande quantidade de produtos com que trabalha, a busca por agilidade em suas operações e uma melhor acuracidade de estoque de produtos (RIBEIRO; SILVA; BENVENUTO, 2005).

De acordo com a empresa as principais dificuldades encontradas no processo de implantação do WMS foram às transmissões por RFID que inicialmente o número de antenas era insuficiente, as características das embalagens que dificultavam a transmissão de dados e a adaptação dos sistemas às condições reais de operações do armazém (RIBEIRO; SILVA; BENVENUTO, 2005). Além disso, devido à reestruturação da empresa teve-se descontentamento por parte dos colaboradores.

Conforme Ribeiro, Silva e Benvenuto (2005) o WMS utilizado pela empresa prestadora de serviços logísticos possui as seguintes funcionalidades: Localização dos paletes; Seleção de palete para expedição; Controle de datas e dados de qualidade; Rastreabilidade do produto por lote de fabricação; Convocação ativa de operadores; Planejamento e controle de capacidade de estocagem; Cadastramentos de itens e a Definição das características de uso de cada local de armazenagem.

De acordo com, Ribeiro, Silva e Benvenuto (2005), os benefícios obtidos com a implantação do WMS foram maior agilidade nos processos e no controle de mercadorias, interface do WMS de fácil entendimento ao usuário, melhoria ao atendimento ao cliente, possibilidade do produto vencer no estoque igual a zero, redução do tempo de liberação e de permanência do produto no armazém e redução de custos e de desperdícios.

\subsubsection{EMPRESA E}

A Empresa E está localizado no estado de São Paulo. O CD (Centro de Distribuição) da Empresa $\mathrm{E}$ armazena as seguintes linhas de produtos: Seca que não necessitam de cuidados especiais; Climatizados que são os chocolates e Refrigerados que são os iogurtes. As operações realizadas dentro do centro de distribuição são resumidas em recebimento do produto, armazenagem do produto e expedição do produto.

Os motivos que levaram a empresa a implantar o WMS foram à busca por uma melhor operação logística por meio do gerenciamento eficaz de informações, uma maior precisão do inventário e um alto nível de controle de serviços prestados (RIBEIRO; SILVA; BENVENUTO, 2005).

Segundo a empresa usuária do WMS as principais dificuldades deparadas durante $\mathrm{O}$ processo de implantação foram: Cadastrar todo o estoque no inventário, Treinar os colaboradores com pouco conhecimento em relação a sistemas automatizados e o ajuste 
da primeira para a segunda versão do WMS. E conforme Ribeiro, Silva e Benvenuto (2005), devido à reestruturação organizacional houve descontentamento de alguns colaboradores.

As funções exercidas pelo WMS são as seguintes: Cadastrar mercadoria no processo de receber; Determinar o local de armazenagem da mercadoria; Convocar ativamente os operadores tanto para armazenar o produto como para expedir; Levantar a situação temporal das mercadorias, colaboradores e atividades cadastradas no banco de dados do WMS; Monitorar os serviços executados; Gerar arquivos para a conferência física e Rastrear produtos.

De acordo com Ribeiro, Silva e Benvenuto (2005), os principais benefícios obtidos após a implantação do WMS foram: Agilidade nos processos; Redução das horas de trabalho; Aumento da produtividade; Melhoria no gerenciamento de estoque; Melhoria no gerenciamento de processos; Garantia de qualidade das informações; Redução de custo e desperdícios e melhoria ao atendimento ao cliente. Um ponto negativo apontado pela empresa foi o alto custo de manutenção dos equipamentos.

\section{ANÁLISE DOS DADOS}

Analisando os motivos que levaram as empresas a implantarem o sistema é percebido um motivo similar nas empresas usuárias do WMS, que é o problema de acuracidade de estoque, isso ocorre quando a quantidade de produtos tanto informatizados quanto manual não confere com a quantidade real no armazém, ou seja, um inventário de baixa confiabilidade. Outro motivo em comum entre quatro das cinco empresas são as dificuldades relacionada às operações: Baixa eficiência das operações de recebimento e expedição; Alto volume de erros operacionais; Dificuldades nas operações de armazenagem; Dificuldades nas operações de logística. O gráfico da Figura 1 mostra tais similaridades de motivos entre as empresas usuárias.

Figura 1 - Motivos que levaram as empresas a implantarem o WMS.

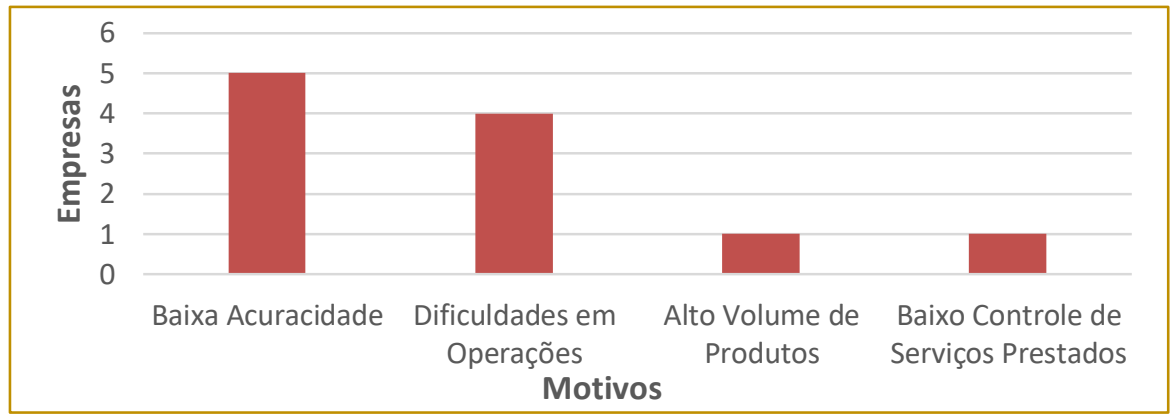

No caso das dificuldades, as cinco empresas usuárias do WMS tiveram dificuldades envolvendo colaboradores. Na empresa A os colaboradores apresentavam resistência ao trabalho aplicado pelo WMS e falta compreensão, na empresa B os colaboradores tinham dificuldades na execução correta das atividades aplicadas pelo WMS, na empresa C apresentava dificuldades de adaptação das atividades impostas pelo WMS, na empresa $C$ havia dificuldades no treinamento dos colaboradores que possuíam pouco conhecimento do WMS e descontentamento de uma parte dos colaboradores e na empresa $D$ descontentamento de uma parte dos colaboradores. O gráfico da Figura 2 mostra as dificuldades deparadas durante a implantação do WMS. 
Figura 2 - Dificuldades encontradas durante a implantação do WMS.

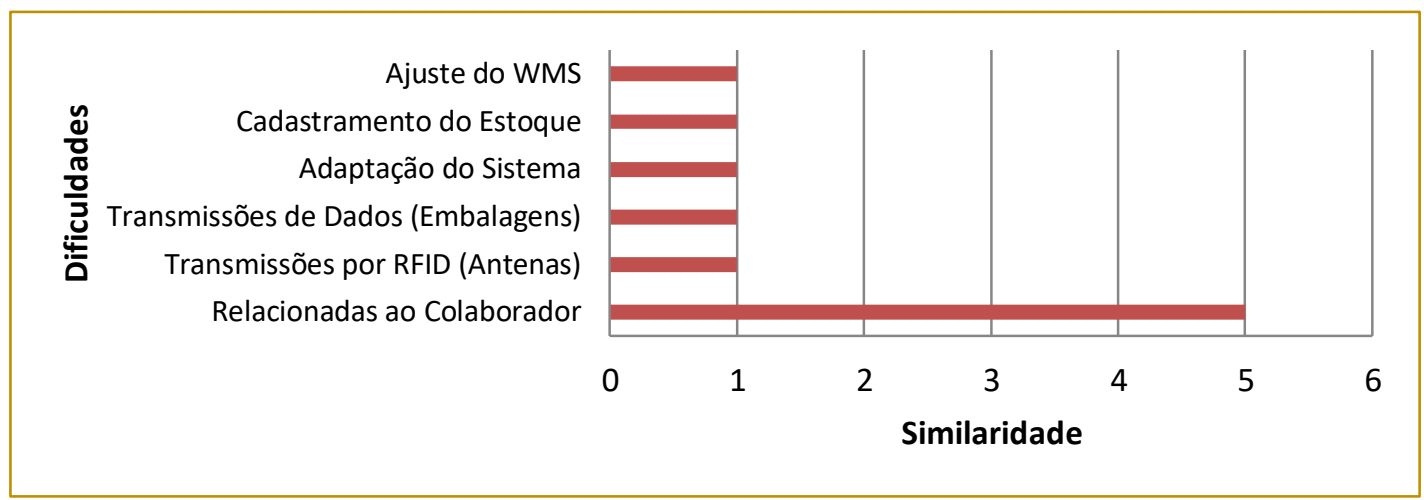

Igualmente como nas empresas usuárias os desenvolvedores citaram como dificuldades no processo de implantação do WMS fatores relacionados aos colaboradores, a preparação cultural e a mudança cultural que podem afetar parte dos colaboradores que não estão muito simpatizados ou que possui pouco conhecimento da ferramenta de gestão de armazenagem. Outra dificuldade de acordo com os colaboradores é o alto investimento financeiro para a implantação do sistema WMS.

Segundo o desenvolvedor $X$, uma das maiores dificuldades de implantação do sistema e a questão financeira, isso devido ao alto valor a ser investido pela empresa para a aquisição do produto, tal valor se torna mais evidente levando em conta as pequenas e médias empresas podendo chegar com facilidade nos 200.000 reais.

Nas cinco empresas usuárias é possível destacar quatro funcionalidades em comum do WMS utilizado por cada empresa: Rastreabilidade dos produtos; Inventário (Acuracidade de estoque); Convocação ativa dos operadores; Funções de monitoramento como, por exemplo, operações, produtividade, mercadorias e colaboradores.

São muitas as funções disponíveis pelo WMS que auxiliam no gerenciamento do estoque desde o processo de recebimento do produto até o processo de expedição do produto. Utilizando todas as funcionalidades do WMS de forma correta é possível obter diversos benefícios que influencia diretamente na qualidade de serviços prestados aos clientes.

De acordo com o Desenvolvedor $X$ a maior parte dos seus clientes utiliza no máximo 50\% das funcionalidades disponíveis do WMS e apenas $10 \%$ dos seus clientes utilizam mais de $50 \%$ das funcionalidades, ou seja, um aproveitamento incompleto do WMS que reflete nos benefícios que poderiam ser obtidos se as empresas utilizassem a totalidade do WMS (SORIANO, 2013).

Analisando e comparando os motivos da implantação do Warehouse Management System e os benefícios obtidos após a implantação do WMS pelas empresas estudadas, é possível verificar que os problemas iniciais que levaram a implementação do WMS foram sanados com destaque aos problemas de baixa acuracidadede estoque, na qual, todas as empresas tinham e de dificuldades operacionais, onde, quatro das cinco empresas tinham.

A colaboração de toda a empresa é de grande importância na implantação do sistema WMS. Analisando a dificuldade em relação aos colaboradores e os benefícios obtidos após a implantação do sistema WMS, a Distribuidora A cita como um dos benefícios obtidos a satisfação dos colaboradores, logo, as dificuldade relacionadas aos colaboradores transformou-se em satisfação do mesmo após a implantação do WMS.

Verifica-se também que todas as empresas obtiveram benefícios relacionados ao gerenciamento de estoque (Produtos Armazenados) e gerenciamento de processos (Receber, Armazenar, Separar e Expedir).

Mesmo com todas as dificuldades para a implementação, tanto o custo quanto os problemas relacionados aos colaboradores, as empresas usuárias conseguiram resolver os problemas iniciais e ainda obter diversos benefícios em função do WMS implantado, logo, a utilização do WMS é viável em relação ao custo/benefícios principalmente para as empresas de grande porte que trabalha com 
uma grande quantidade de produtos e possui uma grande área de armazenagem.

\section{CONCLUSÃO}

São de extrema importância o alto controle de todas as mercadorias, atividades e colaboradores envolvidos no processo de armazenagem desde o recebimento do produto do fornecedor até a expedição para o cliente. A utilização do WMS pelas empresas auxilia no controle do processo de armazenagem gerando diversos benefícios às empresas usuárias, melhorando no atendimento ao cliente, reduzindo custos e se tornando mais competitivo no mercado.

Em relação as empresas usuárias do WMS, na qual, foram analisadas os problemas iniciais, principalmente 0 referente a acuracidade e as operações da armazenagem, em que, todas tinham em comum, foram solucionados com a implantação do WMS, além disso, muitos outros benefícios foram obtidos como, por exemplo, melhoria no gerenciamento de estoque e gerenciamento de processos de armazenagem, por meio desses dados podese averiguar a viabilidade da utilização do WMS pelas empresas no gerenciamento de

\section{REFERÊNCIAS}

[1] Banzato, E. Sistemas de controle e gerenciamento do armazém (wms). Linha]. [Consult. 28 de setembro de 2016]. Disponível em: http://www.guiadelogistica.com.br/ARTIGO261.htm, 2004.

[2] Banzato, E. Tecnologia da informação aplicada à logística. [S.I.]: INSTITUTO IMAM, 2005.

[3] Banzato, E. e. a. Atualidades na armazenagem. 3. ed. [S.I.]: São Paulo: IMAM, 2010.

[4] Braga, L. M.; Pimenta, C. M.; Vieira, J. G. V. Gestão de armazenagem em um supermercado de pequeno porte. Revista P\&D em Engenharia de Produção, v. 8, p. 57-77, 2008.

[5] Fiegenbaum, A. Vantagens do software wms no gerenciamento do cd das lojas Certel. 2009.

[6] Galvão, T. F.; Pereira, M. G. Revisões sistemáticas da literatura: passos para sua elaboração. Epidemiologia e Serviços de Saúde, Coordenação-Geral de desenvolvimento da Epidemiologia em Serviços/Secretaria de Vigilância em Saúde/Ministério da Saúde, v. 23, n. 1, p. 183184, 2014. armazenagem desde 0 processo de recebimento até o processo de expedição.

Analisando as dificuldades encontradas durante a implantação do sistema WMS e os benefícios obtidos após a implantação, verificou-se que uma das dificuldades em comum entre as cinco empresas era relacionada ao colaborador e um dos benefícios obtidos citados pela distribuidora $A$ foi a satisfação dos colaboradores.

Já em relação às funcionalidades do WMS de cada empresa, de acordo com 0 desenvolvedor $\mathrm{X}$ a quantidade de benefícios obtidos por meio da utilização do sistema WMS está associada ao uso de suas funcionalidades, na qual, caso as empresas utilizem apenas parte das funções disponíveis, os mesmos alcançarão apenas parte de todos os benefícios possíveis de se obter. Além disso, não valerá de nada utilizar a totalidade do sistema WMS se não usar o sistema da forma correta. Neste trabalho não foi possível analisar o percentual das funções do sistema WMS utilizadas pelas empresas, devido ao fato de não haver informações relacionadas ao assunto em questão nas bibliografias pesquisadas, tal assunto fica como uma proposta de trabalhos futuros.

[7] Junior, I. d. B.; spejorim, W. Gestão estratégica de armazenagem. [S.I.]: Curitiba: IESDE Brasil S.A., 2012.

[8] KOSTER, R. D.; LE-DUC, T.; ROODBERGEN, K. J. Design and control of warehouse order picking: A literature review. European Journal of Operational Research, Elsevier, v. 182,n. 2, p. 481-501, 2007.

[9] Ludwig, T. D.; Goomas, D. T. Performance, accuracy, data delivery, and feedback methods in order selection: A comparison of voice, handheld, and paper technologies. Journal of Organizational Behavior Management, Taylor \& Francis, v. 27, n. 1, p. 69-107, 2007

[10] Moeller, K. Increasing warehouse order picking performance by sequence optimization. Procedia-Social and Behavioral Sciences, Elsevier, v. 20, p. 177-185, 2011.

[11] Moura, R. A. Armazenagem e distribuição física. [S.I.]: São Paulo: IMAM, 1997.

[12] Moura, R. A. Sistema e técnicas de movimentação e armazenagem de materiais. [S.I.]: São Paulo: IMAM, 1998.

[13] Paoleschi, B. Estoques e armazenagem. 1. ed. [S.I.]: São Paulo: Érica, 2014. 
[14] Rodrigues, A. M. Estratégias de picking na armazenagem. Instituto COPPEAD de Administração, Centro de estudos em Logística. Universidade Federal do Rio de Janeiro- RJ, 1999.

[15] Ribeiro, P. C. C.; Silva, L. A. F.; Benvenuto, S. R. d. S. Uso de tecnologia da informação em operações logísticas de armazenagem. 2005.

[16] Rodrigues, E. F. et al. Logística integrada aplicada a um centro de distribuição: Comparativo do desempenho do processo de armazenagem após a implementação de um sistema de gerenciamento de armazém (wms). VII Simpósio de Excelência em Gestão e Tecnologia-SEGeT. Resende-RJ, 2010.

[17] Soriano, F. F.Gestão de armazenagem: Uma análise do sistema de gestão wms. Tese (Doutorado) - Universidade de São Paulo, 2013.
[18] Sucupira, C. Gestão de depósitos e centros de distribuição através dos softwares wms. Disponível em: http://www. cezarsucupira.com.br/artigos111.htmi. Acesso em, v. 26, p. 05-06, 2017.

[19] Tompkins, J. A.; Smith, J. D. The warehouse management handbook. [S.I.]: Tompkinspress, 1998.

[20] Vergara, S. C. Projetos e relatórios de pesquisa em administração projetos e relatórios de pesquisa em administração projetos e relatórios de pesquisa em administração. São Paulo: Atlas, 1998

[21] Veríssimo, N.; Musetti, M. A. A tecnologia de informação na gestão de armazenagem. Encontro Nacional de Engenharia de Produção, ENEGEP Ouro Preto, v. 23, 2003. 


\section{Bapítulo 19}

\section{CARGA DE TRABALHO MENTAL: ANÁLISE BIBLIOMÉTRICA DE LITERATURA}

\section{Tiago Machado e Silva}

Sergio Luiz Ribas Pessa

Resumo: A carga de trabalho mental caracteriza-se como um reflexo da tensão mental, dependendo da tarefa realizada, do ambiente e das condições operacionais específicas, juntamente com a capacidade do trabalhador em responder a essas demandas. Da mesma forma que as demais análises ergonômicas, a análise da carga de trabalho mental depende da aplicação de ferramentas ou métodos específicos, os quais podem variar dependendo do contexto específico da aplicação, da categoria de trabalhadores analisada, do país de aplicação, da disponibilidade de recursos e/ou do ergonomista. Buscando descobrir os principais trabalhos de análise da carga de trabalho mental, foi realizada uma revisão sistemática da literatura, a qual envolveu uma análise bibliométrica do portfólio selecionado. Os resultados apontaram para 85 artigos alinhados com os objetivos e critérios estabelecidos na pesquisa, dos quais foram destacados os autores, os periódicos, e as palavras-chave. Ergonomics, Applied Ergonomics e Surgical Endoscopy and Other Interventional Techniques destacaram-se como principais periódicos. Mental workload, workload e NASA-TLX destacaram-se como palavras-chave.

Palavras chave: Carga mental, Carga cognitiva, Carga de trabalho, Ergonomia, Revisão sistemática. 


\section{INTRODUÇÃO}

A ergonomia consiste no estudo das interações entre as pessoas e a tecnologia, a organização e o ambiente, buscando intervenções e projetos para melhorar a segurança, o conforto, o bem-estar e a eficácia das atividades humanas, de forma integrada (IIDA, 2005).

O surgimento da Ergonomia data de 1949, quando cientistas e pesquisadores se reuniram na Inglaterra (IIDA, 2005), mas o seu real desenvolvimento ocorreu durante a II Guerra Mundial, por meio dos esforços conjuntos entre tecnologia, ciências humanas e biológicas, usando de médicos, psicólogos, antropólogos e engenheiros, para resolver problemas causados pela operação de equipamentos militares complexos (DUL; WEERDMEESTER, 2004).

A abordagem ergonômica deve basear-se no princípio de que o trabalho deve ser adaptado ao homem e não o contrário, buscando maior humanização, criando um ambiente confortável e que encoraje o colaborador a desenvolver suas habilidades (SILVA; DE OLIVEIRA LUCAS, 2009). As condições de trabalho podem ser avaliadas por muitos fatores, como pela jornada e carga de trabalho, ambiente físico, material e equipamentos, ambiente saudável e estresse (SILVA; DE OLIVEIRA LUCAS, 2009).

Com o desenvolvimento dos conceitos da ergonomia, foi buscada a diminuição do número de acidentes e erros, além da procura pela redução do esforço, estresse e doenças ocupacionais, envolvendo a saúde, a segurança e a satisfação do trabalhador (IIDA, 2005). Além disso, uma característica da ação ergonômica é que além dela se basear na capacidade de mobilizar conhecimentos e métodos adaptados a cada situação, ela visa uma ação, ou seja, não se contenta apenas com um conhecimento sobre as situações do trabalho (DANIELLOU; BÉGUIN, 2007).

Na prática, a aplicação ergonômica acontece em três etapas: (i) análise do quadro técnico, econômico, social e político da empresa, (ii) análise da demanda e (iii) análise ergonômica do problema (LAVILLE, 1997). É na terceira etapa que é estabelecido um diagnóstico especializado para cada demanda, por meio de métodos de estudos sistemáticos (LAVILLE, 1997).

Desde a década de 70 são desenvolvidos roteiros para execução de análises ergonômicas, alguns dos quais se tornaram modelos e serviram de bases para outras propostas metodológicas (LIMA, 2004). Esses roteiros são os métodos, ferramentas e normas, que são utilizados na análise ergonômica. Segundo Masculo e Vidal (2013), "o método ergonômico consiste no uso de recursos dos campos de conhecimento que possibilitem averiguar, levantar, analisar e sistematizar o trabalho e suas condições, através de instrumentos qualitativos e quantitativos".

Como a ergonomia busca estudar o relacionamento entre o homem e o seu trabalho, ela contempla todas as variáveis intervenientes desse processo (CARDOSO; GONTIJO, 2012). Dessa forma, torna-se importante estudar a carga de trabalho, tanto física como mental.

A carga física geralmente é descrita em termos de postura errada ou restrita, uso de força, movimentos repetitivos, falta de recuperação e combinação desses fatores (HANSSO et al., 2009).

A carga de trabalho mental pode ser caracterizada como um reflexo da tensão mental, resultado da realização de uma tarefa, em determinado ambiente e em condições operacionais específicas, juntamente com a capacidade do trabalhador em responder a essas demandas, tendo como objetivo de mensuração o custo mental de executar atividades para presumir o desempenho do operador e do sistema (CAIN, 2007). A avaliação da carga de trabalho mental busca níveis mais altos de conforto, satisfação, eficiência e segurança no local de trabalho, sendo um ponto chave na pesquisa e desenvolvimento de interfaces homemmáquina (RUBIO; MARTíN; PUENTE, 2004).

Diversos autores classificam em categorias as ferramentas utilizadas para avaliar a carga de trabalho mental: Lean e Shan (2012) dividem os métodos em subjetivos, por meio de questionários, e objetivos; para Byrne (2011) a avaliação deve incluir no mínimo uma medida da carga de trabalho primária, uma medida objetiva e uma medida subjetiva; Galy, Cariou e Mélan (2012) separam as categorias em medidas subjetivas, medidas de desempenho e medidas psicofisiológicas; já para Meshkati, Rahimi e Dawes (1995) existem quatro categorias, sendo elas medidas de tarefa primária, medidas de tarefa secundária, medidas de classificação 
subjetivas e medidas fisiológicas.

Este artigo tem seu foco na seleção de artigos que avaliam a carga mental do trabalhador. Dessa forma, o objetivo reside na identificação dos principais autores, dos principais periódicos e das principais palavras-chave dos trabalhos que avaliam a carga de trabalho mental do trabalhador, com aplicação prática.

\section{METODOLOGIA}

A natureza desta pesquisa é aplicada, pois possui interesse na aplicação, utilização e consequências práticas do conhecimento (GIL, 2008). A estratégia de pesquisa é particular, pois os resultados dependem do contexto estudado, não gerando necessariamente a repetibilidade, caso seja replicado o processo de pesquisa (GIFFHORN et al., 2007). A abordagem do problema foi feita de forma quantitativa (MIGUEL et al., 2012). Do ponto de vista dos objetivos, a pesquisa é classificada como exploratória, pois pretende proporcionar visão geral acerca de determinado fato (GIL, 2008) e do ponto de vista dos procedimentos técnicos condiz com a pesquisa bibliográfica, desenvolvida a partir de material já elaborado (GIL, 2008).

A metodologia empregada foi a da revisão sistemática de literatura, a qual é considerada um estudo secundário, tendo como fonte de dados os estudos primários, que são os artigos científicos usados como portfólio para revisão (GALVÃO; PEREIRA, 2014). As revisões sistemáticas de literatura são investigações científicas que adotam um método pré-planejado, com procedimentos de busca, seleção e análise bem delineados e definidos (SCHÜTZ; SANT'ANA, 2011). Além disso, métodos sistemáticos são utilizados para possibilitar uma análise mais objetiva dos resultados e evitar viés (MANCINI; SAMPAIO, 2007).

Para isso, o primeiro passo foi a definição da pergunta de pesquisa: Quais os principais autores que estudam a carga de trabalho mental? Quais os principais periódicos que publicam sobre ergonomia cognitiva? Quais as principais palavras-chave utilizadas nos trabalhos que analisam a carga de trabalho mental?

Foi realizada uma busca em bases eletrônicas de dados, com o tema de carga mental. As palavras-chave escolhidas para compor a seleção foram: carga cognitiva, carga mental, ergonomia cognitiva e ergonomia mental. Foram selecionadas três bases de dados: ScienceDirect, Scopus e Web Of Science. Além disso, o período de análise escolhido foi entre os anos de 2000 e 2017. A base ScienceDirect é a principal base de dados da Elsevier e combina autoridade, textos científicos completos e publicações técnicas e de saúde com funcionalidades inteligentes e intuitivas. A base de dados Web Of Science é mundialmente conhecida e dá origem ao Journal Citation Report (JCR), o qual lista o fator de impacto dos periódicos científicos (LACERDA; ENSSLIN; ENSSLIN, 2014). Já a base Scopus é o maior banco de dados científicos do mundo, se considerar o período entre 2000 e 2011 (GUERRERO-BOTE; MOYA-ANEGÓN, 2012).

As palavras-chave foram traduzidas para 0 inglês e assim a busca foi realizada com a seguinte combinação: "cognitive workload" OR "mental workload" OR "cognitive ergonomics" OR "mental ergonomics". Além disso, as buscas limitaram-se aos campos título, resumo e palavras-chave das publicações e foram filtrados apenas artigos publicados em revistas, periódicos e anais de congressos.

Com os critérios acima estabelecidos foram encontradas 361 publicações na base de dados ScienceDirect, 1.983 resultados na base Web Of Science e 1.256 artigos na base de dados Scopus. Para o gerenciamento dessas publicações, foi utilizado o administrador bibliográfico gratuito Mendeley Desktop. Assim, após passar todas as publicações encontradas para o Mendeley Desktop e checar os arquivos duplicados, restaram 2.449 documentos para serem analisados nas etapas posteriores.

Para avaliação crítica das publicações, primeiramente foi realizada a leitura do título das 2.449 publicações, onde foram retirados os artigos em que o título não indicava a análise da carga de trabalho mental com o uso de ferramentas ou métodos e também foram eliminados os artigos de revisão de literatura, sendo excluídos 1.588 artigos, restando 861 para análises posteriores.

Na sequência, observou-se a relevância dos 861 trabalhos, por meio do número de citações no Google Acadêmico. O artigo mais citado recebeu 711 citações. Como linha de corte foi estabelecida 9 citações, representando 95\% das citações, equivalente 
a 354 publicações. Outros 507 artigos foram citados menos de 9 vezes, dos quais 200 artigos não tiveram nenhuma citação. Como os artigos publicados mais recentemente possuem uma probabilidade menor de serem citados, dos 507 artigos que receberam menos de 9 citações foram selecionadas as publicações de 2016 e 2017, as quais representaram 121 artigos, para se juntarem com as 354 publicações relevantes. Dessa forma, após essa etapa restaram 475 artigos para prosseguimento da seleção do portfólio final.

A etapa posterior consistiu na leitura do resumo dos 475 artigos restantes. Excluíramse as publicações em que o resumo explicitava tratar-se apenas de uma revisão sobre determinada ferramenta, sem nenhuma aplicação prática em trabalhadores. Assim, após leitura dos 475 resumos, restaram 261 artigos para leitura na íntegra. Dos 261 artigos desejados para leitura na íntegra, 22 não estavam disponíveis eletronicamente, restando 239 publicações para leitura integral.

A leitura das 239 publicações foi feita lendose a introdução, a metodologia e a conclusão, para ver se os artigos estavam alinhados com o objetivo e a pergunta de pesquisa. Dessa forma, foram mantidos os artigos que possuíam a aplicação de algum método ou ferramenta para avaliação da carga de trabalho mental. Assim, o portfólio bibliográfico final contou com 85 artigos, para posteriores análises.

A Figura 1 apresenta de forma resumida todos os passos acima descritos.

As principais informações dos 85 artigos selecionados como portfólio bibliográfico (PB) foram levantadas, para posterior análise bibliométrica, envolvendo $\mathrm{o}$ ano de publicação, o número de citações no Google Acadêmico, os autores, os periódicos e as palavras-chave.

Figura 1 - Passos metodológicos

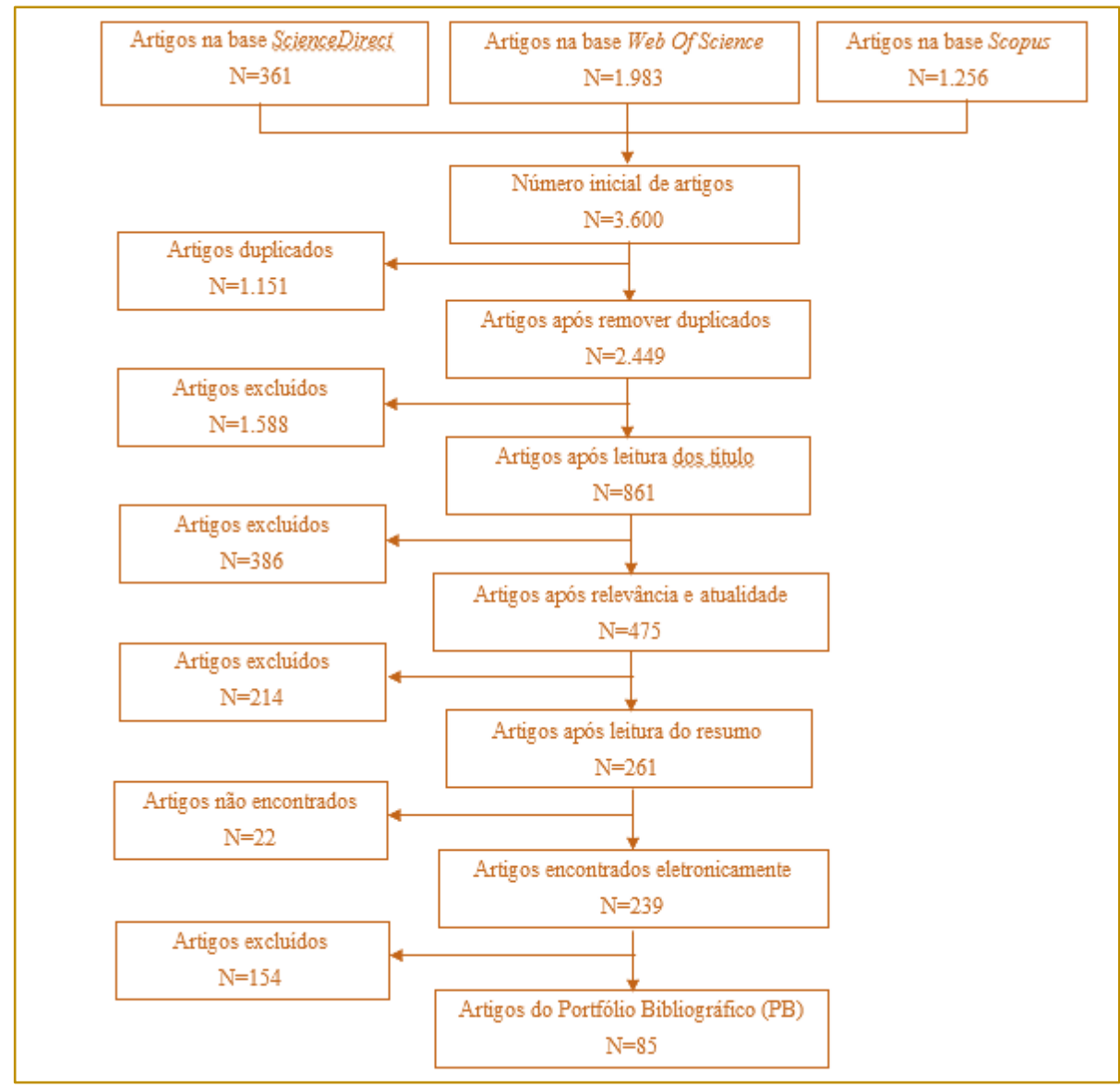




\section{RESULTADOS E DISCUSSÕES}

Todos os anos pesquisados possuíam publicações no PB: 1 artigo de 2000, 4 artigos de 2001, 3 artigos de 2002, 2 artigos de 2003, 3 artigos de 2004, 3 artigo de 2005, 5 artigos de 2006, 6 artigos de 2007, 4 artigos de 2008, 3 artigos de 2009, 6 artigos de 2010, 5 artigos de 2011, 7 artigos de 2012, 5 artigos de 2013, 3 artigos de 2014, 3 artigos de 2015, 19 artigos de 2016 e 3 artigos de 2017. A maior concentração de artigos compreendeu o intervalo de 2010 a 2017, com 60\% das publicações, com o ano de 2016 possuindo $22 \%$ dos artigos.

Por meio do número de citações dos artigos no Google Acadêmico 3 apresentaram maior destaque: (WILSON, 2002) com 280 citações, (BERGUER; SMITH; CHUNG, 2001) com 247 citações e (AYAZ et al., 2002) com 227 citações. Além disso, 4 outros artigos tiveram entre 100 e 200 citações (WILSON; RUSSELL,
2003; METZGER; PARASURAMAN, 2001; LAHELMA et al., 2005; AHLSTROM; FRIEDMAN-BERG, 2006).

Quanto a autoria, os artigos apresentaram entre 1 e 10 autores: 1 artigo com 1 autor, 14 artigos com 2 autores, 9 artigos com 3 autores, 16 artigos com 4 autores, 17 artigos com 5 autores, 12 artigos com 6 autores, 5 artigos com 7 autores, 8 artigos com 8 autores, 2 artigos com 9 autores e 1 artigo com 10 autores.

Foram encontrados 357 autores diferentes nas publicações do PB. 10 autores foram destaques, com 3 publicações cada: Banu Onaral, Ben Willems, Bin Zheng, Glenn F. Wilson, Hasan Ayaz, Koji Murai, Kurtulus Izzetoglu, Patricia A. Shewokis, Scott Bunce e Tuomo K. Leino. Outros 29 autores tiveram 2 publicações no PB. A Figura 2 apresenta a relação dos autores com o número de artigos no PB, com o mínimo de 2 artigos.

Figura 2 - Autores com mais de duas publicações no PB

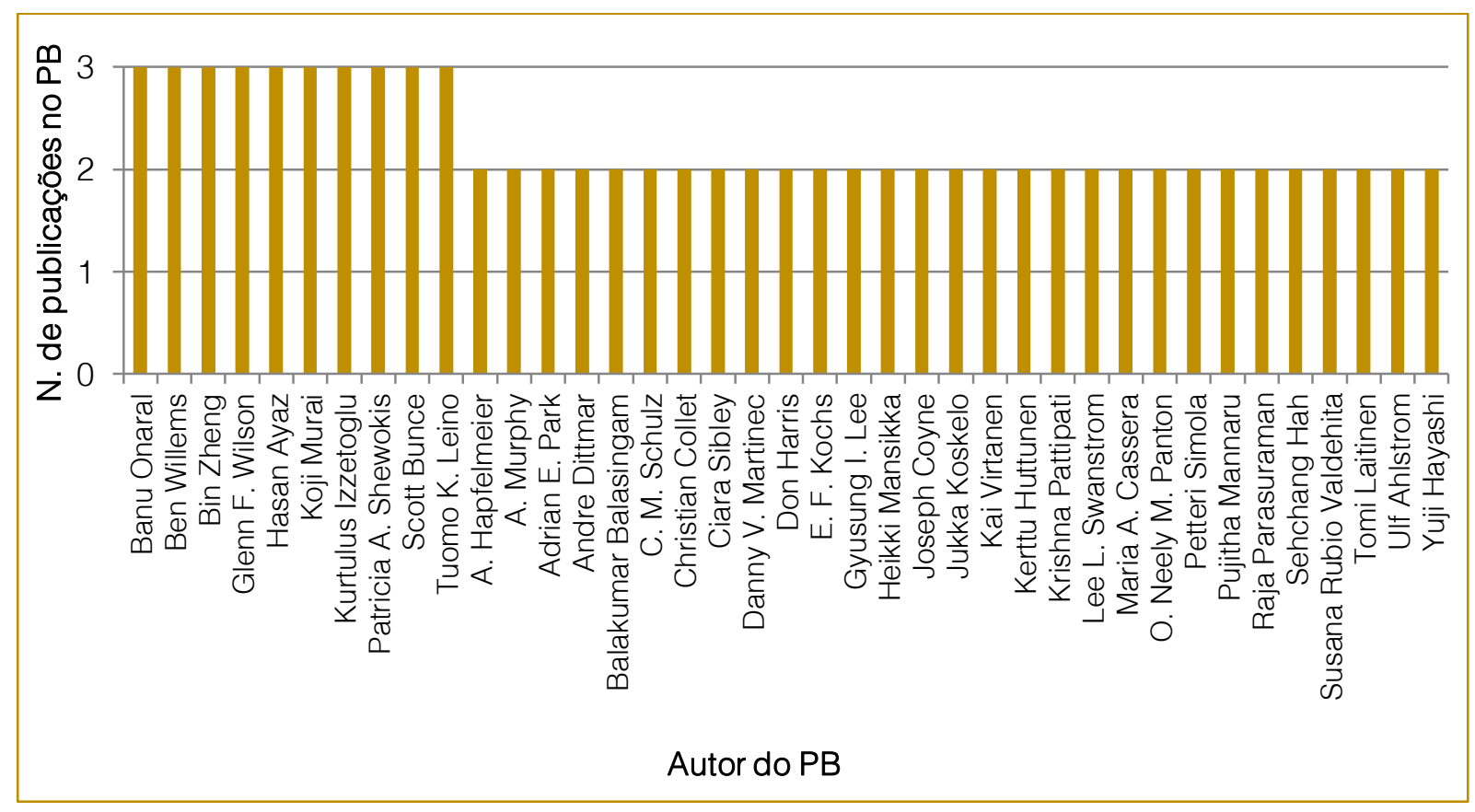

Fonte: Autoria própria (2017)

Buscando identificar os periódicos do portfólio mais relevantes para o tema carga de trabalho mental, realizou-se o cruzamento do número de vezes que o periódico aparecia no portfólio bibliográfico com o número de vezes que o periódico aparecia nas referências do PB, conforme Figura 3. Nesse gráfico entraram os periódicos que possuíam pelo menos 2 artigos no PB ou apareciam no mínimo 10 vezes nas referências dos artigos do PB.

Foram encontrados 58 periódicos diferentes no PB, com o maior destaque para o periódico "Ergonomics", com 7 artigos no portfólio bibliográfico e 154 publicações nas referências do PB. Os periódicos "Applied Ergonomics" e "Surgical Endoscopy and Other Interventional Techniques" destacaram-se dentro do PB, com 5 artigos cada. Já dentro 
das referências destacaram-se os periódicos "Human Factors" e "Aviation, Space and Environmental Medicine", com 114 e 81 artigos nas referências do PB, respectivamente. Nenhum periódico brasileiro foi encontrado no PB.

Figura 3 - Número de publicações das referências e dos artigos do PB por periódico

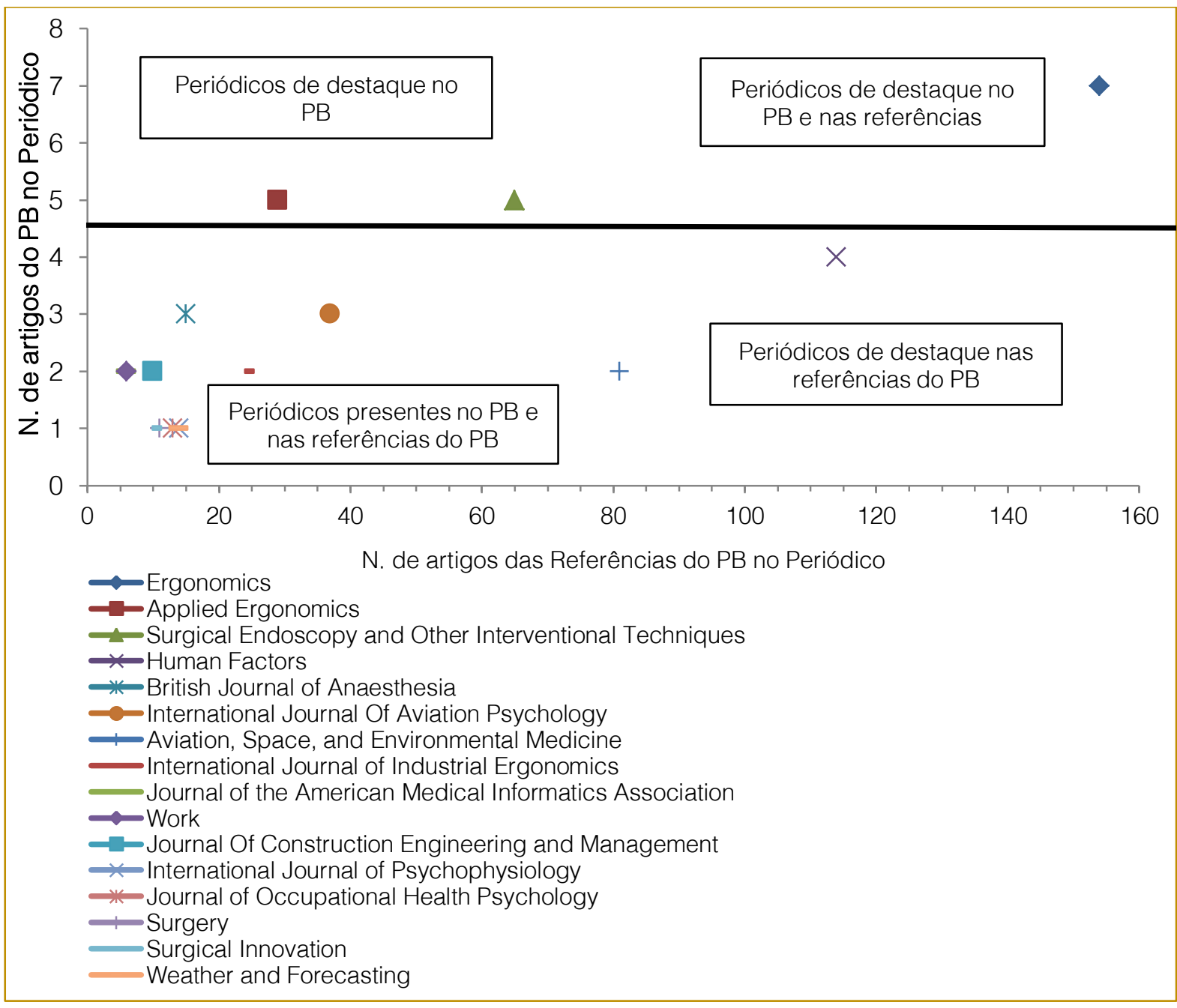

No portfólio bibliográfico foram encontradas 207 palavras-chave diferentes. 34 delas foram usadas em mais de um artigo, representando $43 \%$ das palavras-chaves. Dessas 34 palavras-chave, duas foram empregadas na atual pesquisa: "mental workload" e "cognitive workload". O principal destaque foi a palavrachave "mental workload", aparecendo em 24 trabalhos, seguida das palavras "workload" e "NASA-TLX", citadas 14 e 8 vezes, respectivamente. Ainda a palavra-chave "stress" foi utilizada 7 vezes, as palavraschave "air traffic control" e "heart rate" apareceram 6 vezes e a palavra "heart rate variability" foi empregada 5 vezes. Todas as demais palavras-chave foram usadas em menos de 5 trabalhos.

A Figura 4 apresenta essas 34 palavras-chave usadas em mais de um artigo, com as palavras-chave utilizadas na atual pesquisa circuladas em vermelho. 
Figura 4 - Palavras-chave do PB

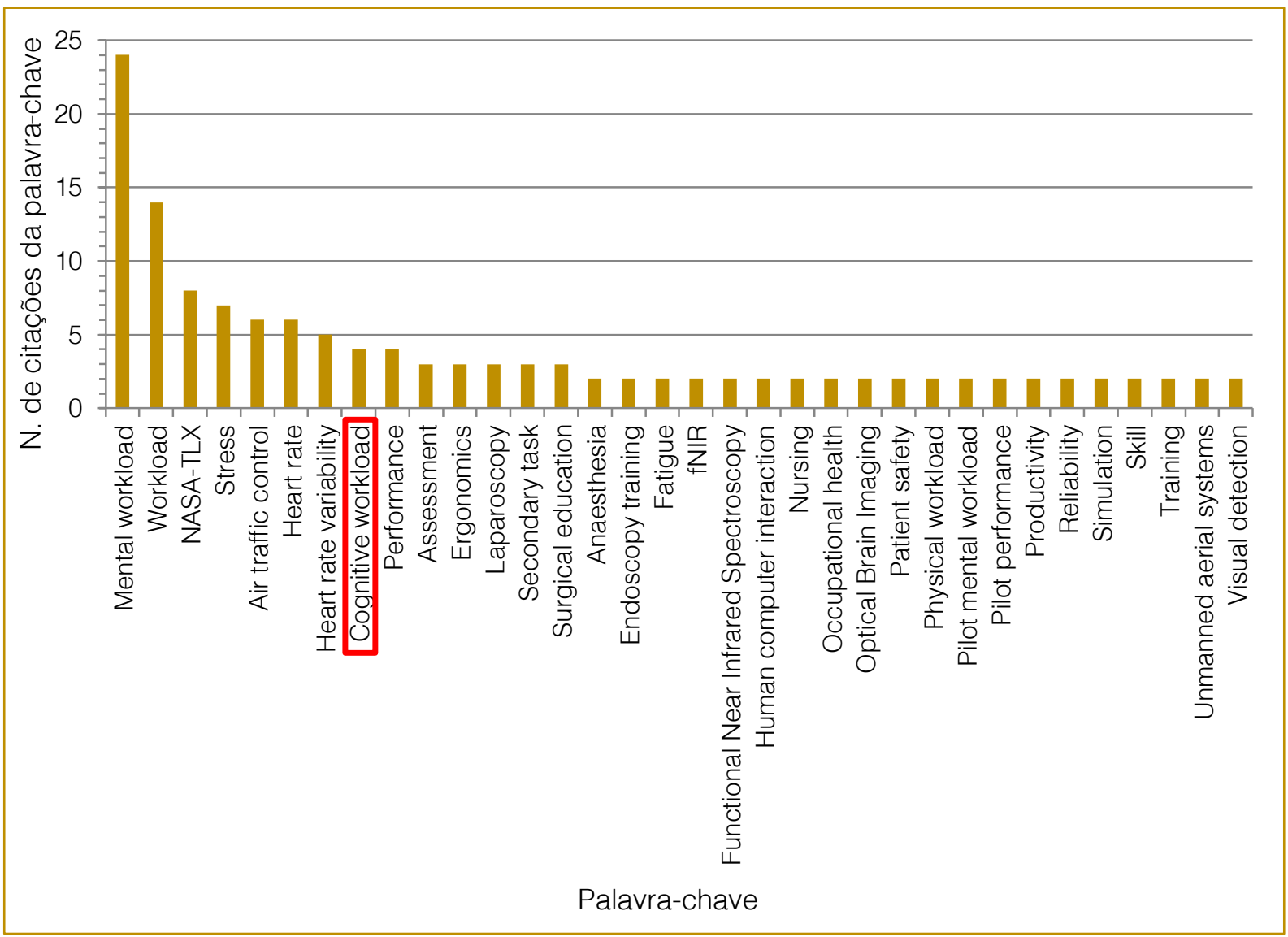

Fonte: Autoria própria (2017)

\section{CONCLUSÕES}

A revisão sistemática de literatura mostrou-se uma metodologia adequada na busca dos principais autores, principais periódicos e principais palavras-chave utilizadas em artigos que avaliam a carga de trabalho mental, analisando um portfólio bibliográfico final constituído por 85 artigos, publicados entre 2000 e 2017 e alinhados com a

\section{REFERÊNCIAS}

[1] Ahlstrom, U.; Friedman-Berg, F. J. Using eye movement activity as a correlate of cognitive workload. International Journal of Industrial Ergonomics, v. 36, n. 7, p. 623-636, 2006.

[2] Ayaz, $\mathrm{H}$. et al. Optical brain monitoring for operator training and mental workload assessment. Neuroimage, v. 59, n. 1, p. 36-47, 2012.

[3] Berguer, R.; Smith, W. D.; Chung, Y. H. Performing laparoscopic surgery is significantly more stressful for the surgeon than open surgery. pesquisa.

Os principais periódicos encontrados foram os periódicos "Ergonomics", "Applied Ergonomics", "Surgical Endoscopy and Other Interventional Techniques", "Human Factors" e "Aviation, Space and Environmental Medicine", e as palavras-chave mais utilizadas foram "mental workload", "workload" e "NASA-TLX".

Surgical endoscopy, v. 15, n. 10, p. 1204-1207, 2001.

[4] Byrne, A. Measurement of mental workload in clinical medicine: a review study. Anesthesiology and pain medicine, v. 1, n. 2, p. 90, 2011.

[5] Cain, B. A review of the mental workload literature. Defence Research And Development Toronto (Canada), 2007.

[6] Cardoso, M. D. S.; Gontijo, L. A. Avaliação da carga mental de trabalho e do desempenho de medidas de mensuração: NASA TLX e SWAT. Gestão \& Produção, v. 19, n. 4, p. 873-884, 2012. 
[7] Daniellou, F.; Béguin, P. Metodologia da ação ergonômica: abordagens do trabalho real. Ergonomia, p. 281-301, 2007.

[8] Dul, J.; Weerdmeester, B. Ergonomia prática. Rev. ampl. São Paulo: Edgard Blücher, 2004.

[9] Galvão, T. F.; Pereira, M. G. Revisões sistemáticas da literatura: passos para sua elaboração. Epidemiologia e Serviços de Saúde, v. 23, n. 1, p. 183-184, 2014.

[10] Galy, E.; Cariou, M.; Mélan, C. What is the relationship between mental workload factors and cognitive load types?. International Journal of Psychophysiology, v. 83, n. 3, p. 269-275, 2012.

[11] Giffhorn, E. et al. Construção de um Modelo de Avaliação do Desempenho de Empresas terceirizadas com a utilização da metodologia MCDA-C: Um Estudo de Caso. 2007.

[12] Gil, A. C. Métodos e técnicas de pesquisa social. 6. ed. Editora Atlas SA, 2008.

[13] Guerrero-BOTE, V. P.; Moya-Anegón, F. A further step forward in measuring journals' scientific prestige: The SJR2 indicator. Journal of Informetrics, v. 6, n. 4, p. 674-688, 2012.

[14] Hansson, G. et al. Physical workload in various types of work: Part I. Wrist and forearm. International Journal of Industrial Ergonomics, v. 39, n. 1, p. 221-233, 2009.

[15] lida, I. Ergonomia: Projeto e produção. São Paulo: Editora Edgard Blucher, 2005

[16] Lacerda, R. T. D. O.; Ensslin, L.; Ensslin, S. $R$. Research opportunities in strategic management field: a performance measurement approach. International Journal of Business Performance Management, v. 15, n. 2, p. 158-174, 2014

[17] Lahelma, E. et al. Occupational class inequalities across key domains of health: results from the Helsinki Health Study. The European Journal of Public Health, v. 15, n. 5, p. 504-510, 2005

[18] Laville, A. Ergonomia. Tradução: Márcia Maria Neves Teixeira. São Paulo: Editora Pedagógica Universitária Ltda, 1997.

[19] Lean, Y.; Shan, F. Brief review on physiological and biochemical evaluations of human mental workload. Human Factors and
Ergonomics in Manufacturing \& Service Industries, v. 22, n. 3, p. 177-187, 2012.

[20] Lima, J. Bases teóricas para uma Metodologia de Análise Ergonômica. In: 4ํํำ Congresso Internacional de Ergonomia e Usabilidade de Interfaces, Rio de Janeiro/RJ. 2004.

[21] Mancini, M. C., \& Sampaio, R. F. Estudos de revisão sistemática: um guia para síntese criteriosa da evidência científica. Rev bras fisioter, v. 11, n. 1, p. 83-9, 2007.

[22] Masculo, F. S.; Vidal, M. C. Ergonomia: Trabalho adequado e eficiente. Elsevier Brasil, 2013

[23] Meshkati, N. et al. Techniques in mental workload assessment. 1995.

[24] Metzger, U.; Parasuraman, R. The role of the air traffic controller in future air traffic management: An empirical study of active control versus passive monitoring. Human Factors, v. 43, n. 4, p. 519-528, 2001.

[25] Miguel, P. A. C. Metodologia de pesquisa em engenharia de produção e gestão de operações. Elsevier, 2012.

[26] Rubio, S. et al. Evaluation of subjective mental workload: A comparison of SWAT, NASATLX, and workload profile methods. Applied Psychology, v. 53, n. 1, p. 61-86, 2004.

[27] Schütz, G. R.; Santos, S. G. D; Sant'ana, A. S. S. Política de periódicos nacionais em Educação Física para estudos de revisão/sistemática. Rev. bras. cineantropom. desempenho hum, v. 13, n. 4, p. 313-319, 2011.

[28] Silva, A. A.; de Oliveira Lucas, E. R. Abordagem ergonômica do ambiente de trabalho na percepção dos trabalhadores: estudo de caso em biblioteca universitária. Revista ACB, v. 14, n. 2 , p. 382-406, 2009.

[29] Wilson, G. F. An analysis of mental workload in pilots during flight using multiple psychophysiological measures. The International Journal of Aviation Psychology, v. 12, n. 1, p. 3-18, 2002.

[30] Wilson, G. F.; Russell, C. A. Operator functional state classification using multiple psychophysiological features in an air traffic control task. Human Factors, v. 45, n. 3, p. 381-389, 2003. 


\section{Gapítulo 20}

\section{MANUAL PARA O DESENVOLVIMENTO DE EMBALAGENS DE ALIMENTOS PREPARADOS CONGELADOS}

\section{Harry Rodrigues Júnior \\ Marco Aurelio de Carvalho}

Resumo: Mudanças nos hábitos alimentares, nas políticas de segurança alimentar e nos estilos de vida da população tem modificado os padrões de projeto das embalagens dos alimentos. Estas mudanças são visíveis nas funções essenciais das embalagens. Tais funções quais precisam adequar-se à diversidade dos requisitos dos alimentos industrializados, especialmente produtos de preparados e congelados. Neste contexto de desenvolvimento de produtos, questiona-se o aprofundamento de pesquisa às funções das embalagens nestas categorias de produtos exercidas pelos designers industriais das embalagens, identificando parâmetros que atendam as especificidades dos alimentos, bem como o cenário produtivo, as exigências de mercado e a análise de materiais disponíveis para o desenvolvimento dos produtos - embalagens. Para mapear o contexto de denvolvimento de produto, esta investigação busca delimitar as principais funções e características exigidas das embalagens para alimentos preparados congelados, bem como os métodos, práticas e requisitos deste tipo de projeto. Como resultado dessa investigação foi elaborado um manual para profissionais envolvidos nas estratégias e projetos de embalagens. Para avaliar este manual, realizou-se uma amostragem com dois perfis profissionais semelhantes de designers de embalagens. Os resultados apontaram a necessidade de ampliação na interlocução entre as áreas de desenvolvimento (projeto de produto e alimentos), reforçando a carência de materiais para consultas e referências, reunidas de forma objetiva e sistemática formatados em materiais consistentes às análises e validações de embalagens para alimentos preparados congelados.

Palavras chave: Manual de Desenvolvimento, Design de Embalagem, Embalagem para Alimentos Congelados, Método de Desenvolvimento de Embalagem, Processos de Embalagem. 


\section{INTRODUÇÃO}

Assim como os diversos segmentos impactados pela competitividade e expansão de mercado nas últimas décadas, a indústria de embalagens vêm sofrendo as transformações gradativas e constantes em seus processos produtivos e práticas de projeto. Os imperativos da busca de novas soluções e da inovação nos produtos e serviços exigem a reinvenção de métodos e práticas, em uma nova relação com as informações, com o conhecimento e de certo, com o potencial de criatividade orientados para tal.

Conforme aponta Boylston (2009, p.10), as embalagens passam por transformações em seus processos produtivos (quanto à tecnologias e materiais), em sua comunicação (quanto à linguagem gráfica e elementos informacionais) e por derivado, nas metodologias e técnicas para sua concepção e criação por designers industriais ou projetistas. Saindo de uma concepção enfática em "vender mais, em maior quantidade e em baixo custo" (p.10-11) das últimas décadas, a indústria de embalagem teve que migrar esforços para uma nova estrutura de negócio, aberta aos aspectos sustentáveis, às inovações formais e a novas configurações de produtos e funções.

O projeto de embalagens, assim como o projeto de diversos outros produtos industriais, está inserido no processo de desenvolvimento de produtos (BRAMKLEV, 2007; CHANDRA; YAMBRACH; MCPROUD, 2015). Estes procedimentos são compostos por análises e sínteses que demandam das equipes de desenvolvimento de projeto a decomposição do problema indesejado em múltiplos subitens possíveis de serem resolvidos (CARVALHO, 1999).

O desenvolvimento de embalagens de alimentos exige a interrelação entre áreas muito específicas. Em primeiro lugar, a engenharia de embalagens, na sistematização de processos e métodos produtivos para as soluções tecnológicas (BRODY et. al, 2008). O design de embalagens, nos processos de configuração formal, estéticos e comunicativos de um produto (AZZI et. Al, 2012) e por fim, as ciências dos alimentos, nos domínios das características e propriedades do produto alimentar (EMBLEM; EMBLEM, 2013).

Inserido neste contexto, este artigo parte da perspectiva do designer industrial e/ou projetista de embalagens, considerando a hipótese de compilar algumas abordagens e práticas de desenvolvimento de embalagens, apreciadas em um manual, visando definir as necessidades associadas ao segmento de alimentos preparados congelados. Essa compilação está formatada como um checklist das características que as embalagens propõem sob análise, em uma classificação voltada às funções das embalagens, objetivando a solução de um problema específico decomposto de projeto de produto.

\section{CARACTERIZAÇÃO DO SETOR DE EMBALAGENS PARA ALIMENTOS}

Conforme mencionam (WALLIS; WEIL; MADI, 2012), o crescimento do mercado tem sido impulsionado por uma série de tendências gerais, como a urbanização crescente, investimentos em construção, a expansão do setor de saúde e o rápido desenvolvimento ainda evidente nas economias emergentes, incluindo China, Índia, Brasil e alguns países da Europa Oriental. A Tabela 1 demonstra o crescimento e previsão de vendas de embalagens para alimentos e outros segmentos nas indústrias de bens de consumo nas regiões citadas.

Tabela 1 - Participação por segmento de bens de consumo

\begin{tabular}{|l|c|c|}
\hline \multicolumn{1}{|c|}{ Segmento } & Participação 2010 & $\begin{array}{c}\text { Crescimento estimado } \\
2010-2015\end{array}$ \\
\hline Alimentos & $51,0 \%$ & $3 \%$ \\
\hline Bebidas & $18 \%$ & $3 \%$ \\
\hline Outros & $20 \%$ & $3 \%$ \\
\hline
\end{tabular}

Fonte: Adaptado de Wallis, Weil, Madi (2012,p.13)

A indústria de alimentos representa $51 \%$ do crescimento de mercado dos países citados, seguido pela indústria de bebidas, com $18 \%$. Dentre os materiais mais utilizados por essas 
indústrias na média mundial, o papel e papelão equivalem a $31 \%$, seguido dos plásticos (21\%) e flexíveis (19\%), conforme apresentado na Tabela 2.

Tabela 2 - Participação global de materiais para embalagem de bens de consumo

\begin{tabular}{|c|c|c|c|c|c|}
\hline Material & $\begin{array}{l}\text { Valor } \\
2010\end{array}$ & Participação & $\begin{array}{l}\text { Valor } 2015 \\
\text { (estimativa) }\end{array}$ & Participação & $\begin{array}{l}\text { Taxa de } \\
\text { crescimento } \\
\text { anual }\end{array}$ \\
\hline Papel & 209 & $31 \%$ & 254 & 30 & 3,2 \\
\hline Plástico & 142 & 21 & 203 & 24 & 6,2 \\
\hline Flexíveis & 128 & 19 & 169 & 20 & 4,7 \\
\hline Metal & 101 & 15 & 118 & 14 & 2,6 \\
\hline Vidro & 47 & 7 & 51 & 6 & 1,2 \\
\hline Outros & 41 & 6 & 42 & 3 & 0,7 \\
\hline Total & 675 & & 845 & & 3,8 \\
\hline
\end{tabular}

Fonte: Adaptado de Wallis, Weil, Madi (2012,p.14)

As embalagens de alimentos preparados congelados, por exemplo, estão entre os 20 maiores mercados de papel cartão no Brasil e no período entre 2011 a 2015, tiveram um crescimento de demanda de $12 \%$, equivalentes a 35 bilhões de unidades estimadas produzidas em 2015.
As embalagens de alimentos preparados congelados, por exemplo, estão entre os 20 maiores mercados de papel cartão no Brasil e no período entre 2011 a 2015, tiveram um crescimento de demanda de $12 \%$, equivalentes a 35 bilhões de unidades estimadas produzidas em 2015, conforme a Tabela 3.

Tabela 3 - Faturamento dos maiores segmentos de alimentos no Brasil (R\$ Bilhões)

\begin{tabular}{|c|c|c|c|c|c|}
\hline Produto & $\begin{array}{c}2008 \\
\text { (bilhões) }\end{array}$ & $\begin{array}{c}2009 \\
\text { (bilhões) }\end{array}$ & $\begin{array}{c}2010 \\
\text { (bilhões) }\end{array}$ & $\begin{array}{c}2011 \\
\text { (bilhões) }\end{array}$ & $\begin{array}{l}\text { Crescimento } \\
\text { Médio }\end{array}$ \\
\hline Carne & 61 & 58,5 & 66 & 80,1 & $7,00 \%$ \\
\hline Frutas e vegetais & 14,8 & 14,9 & 15,6 & 17,7 & $4,60 \%$ \\
\hline Supergelados & 5,1 & 5,6 & 6,5 & 7,7 & $10,80 \%$ \\
\hline Conservas de pescado & 2 & 2,3 & 2,5 & 2,7 & $7,80 \%$ \\
\hline
\end{tabular}

Fonte: Adaptado de Wallis, Weil, Madi (2012,p.14)

Conforme apresentado no Quadro 3 os produtos supergelados (i.e. alimentos preparados congelados) obtiveram crescimento (cerca de 11\%) no período de 2008 a 2011, apontando como uma continuidade positiva de desenvolvimento econômico (WALLIS; WEIL; MADI, 2012, p.27). Estas tabelas apresentam um panorama da embalagem para alimentos no Brasil (e no mundo).

\subsection{A EMBALAGEM PARA ALIMENTO PREPARADO CONGELADO}

Considerando a necessidade de acompanhar as tendências nos comportamentos de consumo e oportunidades de incrementos nas embalagens, o setor produtivo de embalagens para alimentos no Brasil está expandindo em pesquisas de comportamento de consumo e mercado., como mostra o relatório de Brasil Pack Trends 2020 (SARANTÓPOULOS; REGO, 2012).

Atualmente os Alimentos Preparados Congelados (APCs) abordam diversas técnicas de congelamento. Apesar deste processo ser bem sucedido quanto à preservação e integridade do alimento, seu sucesso dependerá diretamente da qualidade, projeto e desempenho da embalagem aplicada (MACHADO, 2000; EMBLEM; EMBLEM, 2013; SUN, 2012; PAINE 1992; 1996; COLES; MCDOWEL; KIRWAN, 2012).

A característica principal do processo de congelamento é manter o alimento com um aspecto visual e sensorial agradável, ressaltando a embalagem como responsável 
pela integridade do alimento, que evita que a umidade "queime" (i.e. queima a frio) $e$ danifique a superfície do alimento (YAM; LEE 2012; COLES; MCDOWELL; KIRWAN, 2012; MACHADO, 2000;ARDITO; ALVES, 1994; ORTIZ; MADI; ALVIM, 1986).

Alimentos Preparados Congelados (APCs) usualmente são aquecidos em fornos elétricos, convencionais ou de micro-ondas, a depender do modo de preparo. Esta disponibilidade de preparo, é considerado um atributo de conveniência da embalagem.

$O$ design de embalagens aborda os conceitos de marketing, que atribuem os elementos comunicacionais às embalagens. As embalagens neste contexto mercadológico, exercem o papel de atrair e reter a atenção do consumidor. Conforme mencionam Azzi, Battini e Sgarbossa (2012, p.440) as embalagens, especialmente de alimentos, atraem a atenção ao produto, "reforçando a visibilidade e proporcionando um método atraente para transmitir valores e persuadir virtudes ao produto". Identificados tais valores, estes fatores nos pontos de venda, são primordiais à comercialização dos produtos alimentícios.

Conforme abordado, fatores como proteção, acondicionamento, comunicação e conveniência influenciam diretamente no desenvolvimento de Embalagem para Alimento Preparado Congelado (EAPC). Dessa forma, atenta-se para o estudo destas funções como parte primordial do desenvolvimento de projetos de embalagens.

Conforme Klimchuk e Krasovec (2013); De Azeredo, Faria e Brito (2012); Piergiovanni e Limbo (2010); Han (2005); Robertson (2013); Yam (2009); Kirwan (2013); Gurgel (2007); de Carvalho (2008) as principais funções das embalagens são:

a) proteção;

b) acondicionamento;

c) comunicação;

d) conveniência.

Para estas funções, foram investigados critérios identificados em literaturas específicas sobre funções das embalagens. Estes critérios impactam nas tomadas de decisão nos projetos pois influenciam diretamente nas concepções e gerações de alternativas. A Tabela 4 identificam vinte e nove critérios distribuídos nas quatro funções essenciais identificadas.

Tabela 4 - Premissas das funções essenciais das embalagens de alimentos

\begin{tabular}{|c|c|c|c|}
\hline $\begin{array}{l}\text { Função: } \\
\text { proteger }\end{array}$ & $\begin{array}{l}\text { Função: } \\
\text { comunicar }\end{array}$ & $\begin{array}{l}\text { Função: } \\
\text { acondicionar }\end{array}$ & $\begin{array}{c}\text { Função: } \\
\text { conveniência }\end{array}$ \\
\hline Resistir a impactos & $\begin{array}{l}\text { Possuir identidade no } \\
\text { Ponto de Venda }\end{array}$ & Acomodar o alimento & $\begin{array}{l}\text { Desempenhar } \\
\text { abertura }\end{array}$ \\
\hline $\begin{array}{l}\text { Do oxigênio } \\
\text { atmosférico }\end{array}$ & $\begin{array}{l}\text { Possuir qualidade } \\
\text { perceptível }\end{array}$ & Ser impermeável & $\begin{array}{l}\text { Desempenhar } \\
\text { fechamento }\end{array}$ \\
\hline $\begin{array}{l}\text { De odores } \\
\text { contaminantes }\end{array}$ & Ser ergonômica & Permitir expansão & $\begin{array}{l}\text { Facilitar } \\
\text { descongelamento }\end{array}$ \\
\hline Da exposição da luz & Facilitar a interação & $\begin{array}{l}\text { Possuir baixa } \\
\text { permeabilidade }\end{array}$ & Permitir radiação \\
\hline $\begin{array}{l}\text { Reter perda de } \\
\text { umidade }\end{array}$ & Ser informativa & $\begin{array}{l}\text { Possuir bom } \\
\text { desempenho físico- } \\
\text { mecânico }\end{array}$ & Possibilitar reuso \\
\hline $\begin{array}{l}\text { Ser hermética, } \\
\text { inodora e atóxica }\end{array}$ & $\begin{array}{l}\text { Previnir consumo } \\
\text { ocasional indevido }\end{array}$ & \multirow{4}{*}{ Ser modular } & $\begin{array}{l}\text { Permitir } \\
\text { fracionamento }\end{array}$ \\
\hline \multirow{3}{*}{$\begin{array}{l}\text { Servir de barreira a } \\
\text { gorduras e de } \\
\text { microoganismos }\end{array}$} & $\begin{array}{l}\text { Informar aspectos } \\
\text { educativos }\end{array}$ & & \multirow{3}{*}{ Facilitar reciclagem } \\
\hline & $\begin{array}{l}\text { Informar aspectos } \\
\text { essenciais }\end{array}$ & & \\
\hline & $\begin{array}{l}\text { Informar aspectos } \\
\text { promocionais }\end{array}$ & & \\
\hline
\end{tabular}

Fonte: Adaptado de SOARES et. al (2012), DE AZEREDO; FARIA; BRITO, (2012),ROBERTSON (2013), HUI et. Al, (2004), ROBINSON (2012), COLES; MCDOWELL; KIRWAN (2003), AZZI et. Al (2012) SUN, (2012) ADLER-NISSEN et. al(2013) e YAM (2009). 
O projetista de embalagem, quando identifica os requisitos do produto e contextos dos ciclos de vida da embalagem e alimento, deve perceber os múltiplos níveis de investigação das quais as funções das embalagens possibilitam serem exploradas e validadas aos projetos de embalagens, conforme Robertson (2013, p.6) aponta que "embora existam alguns padrões e métodos fornecidos como orientação para o Design Universal (DU), estas características não refletem todos os requisitos de embalagem para os consumidores". Assim, outros critérios podem e devem ser incorporados às funções apresentadas, conforme a natureza do produto.

Entende-se que a relevância do tema envolve necessariamente, um diálogo entre áreas diversas, ao que se refere a projetos, tecnologias e regulamentações. Projetistas de embalagens estão inseridos neste contexto de pesquisa amplo e diversificado, contando com um conjunto extenso de recomendações, sujeitas a constantes variações devido a aperfeiçoamentos tecnológicos, dinâmicas de mercado, comportamentos de consumo e demandas.

Em relação aos projetos de embalagens, os autores Marsh e Bugusu (2007), De La Fuente (2014), Sarantópoulos e Rego (2012); Wallis, Weil e Madi (2012) consideram essenciais ao projeto explorar as tecnologias dos materiais para embalagens, compreender as demandas e os diferentes contextos dos consumidores, bem como seguir todas as regulamentações que abordam a segurança do alimento ao consumidor.

Quanto às funções das embalagens, os autores das ciências dos alimentos como: de Azeredo, Faria e Brito (2012), Robinson
(2012), Soares et. al (2012), Sun (2012), Twede (2012), Robertson (2013), Emblem e Emblem (2013) apontam que as tecnologias precisam acompanhar as finalidades de um produto, atento aos requisitos mercadológicos e produtivos, e também, às necessidades específicas que cada produto alimentício exige das embalagens.

\subsection{MÉTODOS DE DESENVOLVIMENTO DE PROJETOS DE EMBALAGENS}

A apresentação das metodologias de desenvolvimento de embalagem nesta seção tem como finalidade compreender, ainda que de modo generalista, o modo como designers industriais e/ou projetistas resolvem problemas em projetos de embalagens. É sabido que os processos industriais podem diversificar o modo como estas metodologias são utilizadas no cotidiano de projeto. Mas percebe-se que existe uma linha comum entre as metodologias voltadas ao desenvolvimento de embalagens, $O$ que nos permite compreender como um manual pode dar suporte às etapas iniciais.

A proposta deste modelo é orientar o designer industrial e/ou projetista durante o uso do manual de desenvolvimento de embalagens, portanto compreender estas metodologias é parte de um processo de reflexão sobre um potencial passo a passo de projeto. A seguir, são apresentados quatro métodos de desenvolvimento de embalagens, selecionados por perfil de desenvolvimento e projeto, de épocas e abordagens que permite compreender a diversidade entre 0 conhecimento de designers industriais e engenheiros de embalagens. 
Tabela 5 - Premissas das funções essenciais das embalagens de alimentos

\begin{tabular}{|c|c|c|c|c|}
\hline Fases & $\begin{array}{l}\text { Moura e Banzato } \\
\text { (1997) }\end{array}$ & $\begin{array}{l}\text { Mestriner } \\
\text { (2005) }\end{array}$ & $\begin{array}{l}\text { Merino, Merino e } \\
\text { Carvalho (2009) }\end{array}$ & Boyston (2009) \\
\hline $\begin{array}{l}\text { Planejamento } \\
\text { inicial }\end{array}$ & \multirow{2}{*}{$\begin{array}{l}\text { Levantamento } \\
\text { de dados }\end{array}$} & $\begin{array}{l}10 \text { pontos de } \\
\text { iniciação de } \\
\text { projeto }\end{array}$ & $\begin{array}{l}\text { Identificar } \\
\text { demandas }\end{array}$ & Pesquisa inicial \\
\hline Problematização & & briefing & $\begin{array}{l}\text { Identificar aspectos } \\
\text { mercadológicos }\end{array}$ & Design \\
\hline Análises & $\begin{array}{l}\text { Desenvolvimento } \\
\text { da embalagem }\end{array}$ & $\begin{array}{l}\text { Estudo de } \\
\text { campo }\end{array}$ & \multirow{3}{*}{$\begin{array}{l}\text { Sistematizar } \\
\text { informações }\end{array}$} & $\begin{array}{l}\text { Revisão com } \\
\text { equipe e cliente }\end{array}$ \\
\hline $\begin{array}{ll}\text { Sínteses } & \text { de } \\
\text { informações } & \end{array}$ & $\begin{array}{l}\text { Construção do } \\
\text { protótipo }\end{array}$ & \multirow{2}{*}{$\begin{array}{l}\text { Estratégias } \\
\text { de design }\end{array}$} & & \multirow{2}{*}{$\begin{array}{l}\text { Persquisa } \\
\text { mercado }\end{array}$} \\
\hline $\begin{array}{ll}\text { Geração } & \text { de } \\
\text { alternativas } & \end{array}$ & $\begin{array}{ll}\text { Teste } & \text { da } \\
\text { embalagem }\end{array}$ & & & \\
\hline $\begin{array}{l}\text { Desenvolvimento } \\
\text { da solução }\end{array}$ & \multirow{2}{*}{$\begin{array}{l}\text { Revisar a } \\
\text { embalagem }\end{array}$} & \multirow{2}{*}{ Desenhos } & \multirow{2}{*}{ Prototipar } & \multirow{2}{*}{ Ações responsivas } \\
\hline $\begin{array}{ll}\text { Ajustes } & \text { e } \\
\text { acabamentos } & \end{array}$ & & & & \\
\hline $\begin{array}{l}\text { Implementação } \\
\text { do projeto }\end{array}$ & $\begin{array}{l}\text { Especificação } \\
\text { para produção }\end{array}$ & Implantação & $\begin{array}{l}\text { Validar } \\
\text { especificar }\end{array}$ & $\begin{array}{l}\text { Produção } \\
\text { distribuição }\end{array}$ \\
\hline
\end{tabular}

Fonte: Adaptado de Moura e Banzato (1997), Mestriner (2005), Merino; Merino, Carvalho (2009) e Boylston

(2009)

Conforme Moskovitz et. al (2013) o aumento da complexidade dos projetos de embalagens, exigem métodos projetuais mais flexíveis, preparados para rearranjos e etapas passíveis de repetições de ações ou supressão do objetivo de projeto. Porém, é conveniente ressaltar, que a complexidade ao correlacionar a prática projetual de conhecimentos multidisciplinares a uma perspectiva sistêmica de projeto, pois exige dos projetistas, diferentes níveis de experiência, conhecimento e fluência, de diversas linguagens profissionais.

\subsection{MANUAIS PARA DESENVOLVIMENTO DE EMBALAGENS}

Manuais para o desenvolvimento de produtos concentram informações estruturadas para a pesquisa, desenvolvimento e operações em diversos campos do conhecimento. Propiciam ao profissional e pesquisador, estruturar suas pesquisas com análise crítica, em linguagem compreensivel com acesso rápido para montar referências e dados essenciais que poderão ser usados pelo pesquisador em instituições de pesquisa e/ou em processos de desenvolvimento de produtos.

Handbook of Frozen Food Processing and Packaging (SUN, 2012) a) Fundamentos de congelamento: princípios de congelamento e impactos a diferentes sistemas de embalagens;

b) Instalações de ambientes para congelamento, armazenagem e logística;

c) Qualidade e segurança alimentar e regulamentos aplicados aos APCs;

d) Monitoramento e técnicas de medição da qualidade;

e) Tecnologias eemergentes em APCs;

f) Embalagens para APCs: soluções em embalagens e dispositivos de embalagem;

g) Tendências em embalagens para APCs.

A Handbook of Food Packaging (PAINE, 1992) e The Packaging User's Guide (PAINE, 1996)

a) Introdução à embalagem: contextos históricos, mercadológicos e tecnológicos.

b) Design de Embalagem: gerenciamento de projeto, tendências, tecnologias e processos 
de impressão que afetam as embalagens de APCs

c) Materiais de embalagens: celulósicos, polímeros, metais e ceâmicas;

d) Maquinário de embalamento individual e fracionados

e) Unitização de alimentos em embalagens;

f) Aspectos de migração e contaminação de alimentos por embalagens;

g) Propriedades dos alimentos preparados: frescos, congelados, resfriados e solúveis.

h) Propriedades de vegetais, frutas e cereais;

i) Embalagens para Alimentos congelados: aspectos comerciais, tipos, métodos de congelamento e resfriamento;

j) Processos de aquecimento de alimentos: convencional, micro-ondas, ultarvioleta e alta pressão;

k) Embalagens para alimentos desidratados;

1) Outras formas de alimentos processados e suas embalagens

Manual ANVISA (2014)

a) Definições e regulamentações ANVISA;

b) Regulamentos aplicados aos materiais de embalagens de alimentos;

C) celulósicas: Portaria n. 177/99;

d) elastoméricas: RDC n. 123/2001

e) metálicas: Lei no 9.832/99;

f) vidro, porcelana, cerâmicas: Portaria n. $27 / 96$

g) plásticos: RDC N.105/99

h) plásticos PET recuperados: RDC n.20/2008

i) Corantes e pigmentos; RDC n.52/2010

j) Migração: orientações da RDC N.51/2010
Buscou-se autores e instituições que apresentem referências em manuais para o desenvolvimento de embalagens. Cada manual aborda assuntos específicos direcionados aos modelos de desenvolvimento atribuído aos projetistas de embalagens. Nestes manuais há seções direcionadas para temas específicos como: processamento e embalagem de alimentos congelados, embalagens para alimentos, tecnologias para embalagens de alimentos, princípios e práticas sobre regulamentos de embalagens para alimentos e diretrizes sobre embalagens sustentáveis para alimentos.

Estas particularidades dos manuais ampliam as possibilidades de explorar os conteúdo em suas hierarquias, relevâncias e contribuições para a elaboração de um manual de desenvolvimento de embalagens para alimentos.

Com estas referências identificadas, validamse para esta pesquisa, caminhos seguros para a elaboração de conteúdo e orientações aos temas essenciais que devem ser abordados em um manual de desenvolvimento para embalagem de alimentos congelados.

\section{METODOLOGIA PARA A ELABORAÇÃO DO MANUAL EAPC}

O desenvolvimento do Manual EAPC foi guiado a partir dos objetivos propostos, das análises do referencial teórico e da pesquisa com potenciais usuários do manual, considerando suas práticas de pesquisa/projeto para um segmento específico da indústria alimentícia.

O eixo principal desta investigação é explorar elementos perceptíveis de identificação direta, tais como os requisitos funcionais das embalagens. Esta abordagem conforme representa a Figura 6, delimitam os contextos propostos pelos autores Rundh (2013, p. 1548); Piergiovanni e Limbo (2010, p.3-6); Han (2005, p.5) ; Robertson (2013, p.1-4); Yam (2009, p. 869-871) ao que se referem sobre questões de funcionalidade essencial das embalagens para alimentos.

Utilizou-se neste método para avaliar a versão do manual a entrevista semi-estruturada, cujo objetivo é prover a interação entre as partes (i.e. pesquisador-pesquisado), permitindo obter dados referentes aos diversos aspectos do conteúdo, conforme Gil (1995, p. 114), flexibilizando o conteúdo do instrumento em 
uma reflexão mais aberta sobre a experiência profissional dos entrevistados.

A escolha dos profissionais entrevistados, deu-se a partir de contatos realizados pelo autor, na seleção mais diversificada possível, contando com engenheiros químicos, engenheiros em bioprocessos de alimentos, empresários do ramo alimentício, nutricionistas, chefs de cozinha, supervisores de qualidade de alimentos, representantes de vendas de embalagens e designers de embalagens.

A interpretação dos dados, durante os testes das versões e respostas dos questionários, foi feita a partir da situação de projeto de embalagem para alimentos preparados congelados, bem como considerada a formação e experiência profissional dos entrevistados.

\subsection{DESIGN THINKING}

O método proposto por Ambrose e Harris (2011) compõe-se da elaboração testável do manual, que permeia o trabalho como um todo e aborda os principais elementos funcionais das EAPCs. No caso do Manual EAPC imagina-se que o uso está disseminado em diversos papéis e tarefas e portanto, saber a opinião dos envolvidos foi uma das diretrizes do projeto.

No cenário de design de produtos, as metodologias de "Design Thinking" apresentam ciclos que se adaptam a esse interesse de pesquisa, propondo o uso de ciclos de desenvolvimento como base para o diálogo com os sujeitos envolvidos no uso do produto (BROWN, 2010; AMBROSE; HARRIS, 2011).

Nos processos Design Centrado no Usuário DCU, geralmente utilizam-se como etapas metodológicas a sequência de sete passos, conforme mencionam AMBROSE; HARRIS (2011, p.11).

a) Definir: briefing/conceito, um completo entendimento sobre o problema direcionam para soluções mais próximas às soluções a serem desenvolvidas;

b) Pesquisar: teorias, ao abordar o assunto em um nível introdutório, a linguagem expressa do conteúdo pretende atingir distintos grupos de desenvolvedores de embalagens ou equipes, bem como a finalidade didática de apresentar a esses profissionais os termos e normas utilizados no segmento;

c) Ideação: geração de ideias: elaboração de alternativas e testes de manuais com usuários;

d) Prototipação: construção, asta versão foi elaborada a partir das críticas e apontamentos observados nas gerações de alternativas;

e) Seleção: escolha da alternativa; contou com ajustes das seções, subseções, estrutura textual e visual das versões testadas;

f) Testes: uso e implementação; entregando a solução ao problema de projeto. Esta etapa propicia uma boa oportunidade para observar as situações de uso e avaliar os possíveis aprimoramentos do material produzido. Após as rodadas de desenvolvimento (geração de alternativas e protótipos), coletando informações com desenvolvedores de embalagens para alimentos e ampliando o escopo de pesquisa com identificação de perfis profissionais variados, na intenção de ampliar as abordagens de projeto, esta etapa de uso e implementação exige a realização de um experimento com os potenciais usuários deste manual.

g) Aprendizado: aplicação dos conhecimentos e feedback, constatase que o resultado da aplicação do Manual EAPC são de relevância e podem ser aplicados à concepção de embalagens para alimentos preparados congelados.

Observa-se que na geração de alternativa e prototipagem houve a necessidade de dialogar com participantes de diferentes campos de atuação profissional e não somente de desenvolvedores de embalagens, para ampliar o campo de atuação da pesquisa e compreender as diversas métricas de qualidade de conteúdo de manuais e/ou guias de referência.

Resalta-se que o Manual EAPC permite ser ajustado e aprimorado pois os conteúdos estão em preparados para receberem novas características de evolução das funcionalidades das embalagens para alimentos. 


\section{O MANUAL PARA O DESENVOLVIMENTO DE EAPCS}

As seções e subseções do Manual EAPC descritas neste capítulo resgatam as fundamentações teóricas abordadas na seção 2.

O conteúdo do Manual EAPC está segmentado em sete seções, sendo a seção Introdução, descrevendo o objetivo do manual, as atividades iniciais de análise de embalagens e a apresentação do manual, as outras seções estão distribuídas como:

a) Seção 1: requisitos de projeto: Oito Etapas para o uso do manual; Características dos alimentos preparados congelados; Características das embalagens para alimentos e Orientações para rotulagem;

b) Seção 2: funções das embalagens: Função: $\quad$ Proteger; $\quad$ Função: Comunicar; Função: Acondicionar e Função: Servir;

c) Seção 3: tipos de embalagens: Tabela de tipos de embalagens;

d) Seção 4: regulamentos: Regulamentos para alimentos congelados e Órgãos e entidades

e) Seção 5: estudo de caso: Exemplo de uso formulário Oito Etapas e Manual EAPC; , Atividades iniciais de análise de embalagens e Aplicação do formulário Oito Etapas e manual;

f) Seção 6: referências: Para saber mais; Órgãos, legislações e normas;

g) Seção 7: siglas e glossário.

\subsection{APLICAÇÃO DESCRITIVA DO MODELO PROPOSTO}

Com a finalização do desenvolvimento do Manual EAPC, foi realizado um experimento para verificar as características do material elaborado. Participaram do experimento duas projetistas de embalagens de diferentes habilidades e vivências profissionais, com o intuito de validar o uso do Manual EAPC.

Para a coleta das observações utilizou-se um das informações digitalizadas no formulário online, acompanhado de anotações do pesquisador. Ao final do experimento, as participantes foram entrevistadas sobre a relevância da pesquisa e as dificuldades ou dúvidas encontradas durante o processo.

Em sua entrevista, a participante "A" comentou sobre a praticidade de uso do manual, bem como sobre o tempo despendido. Reforçou o valor de uso de um guideline que permita reunir as informações técnicas.

$\mathrm{Na}$ entrevista da participante "B", foi comentado por ela a relevância de um checklist para acompanhar os níveis de detalhamento exigidos no desenvolvimento de embalagens. Ela apontou também que, para realizar as conclusões deste experimento, sua preferência seria realizar uma atividade em campo, e somente depois buscaria informações sobre o tema. Comentou sobre a importância da integração entre as atividades de metodologia de projetos de embalagens com os regulamentos vigentes e atualizados.

Por fim, as respostas das participantes "A" e "B" contribuíram para avaliar o material instrucional desenvolvido. Observou-se neste experimento, quando comparadas as respostas gerais, a participante " $A$ " alcançou o triplo de quantidade de informações, comparada as respostas da participante "B". Observa-se que os níveis de experiência e habilidades das designers são semelhantes em tempo de atuação e experiência no segmento de projetos de embalagens.

\section{CONCLUSÕES}

A busca por soluções que melhorem a qualidade de informação disponível a designers industriais e projetistas de embalagens é um desafio para projetos que pretendam ser inovadores, bem como o tempo de desenvolvimento e acesso às informações disponíveis na área, variáveis impactantes na tomada de decisões de projeto.

Por meio de um levantamento diversificado sobre as funções das embalagens e a ciência dos alimentos voltada a desenvolvimento de produto, essa investigação propôs compilar e organizar conteúdos relevantes para designers industriais e projetistas de embalagens.

A partir da fundamentação teórica específica de áreas como embalagens de alimentos, metodologias de projeto de embalagem e análise de manuais de projeto, foi proposta a criação de um manual que pudesse dar 
suporte ao desenvolvimento de produto.

A metodologia de desenvolvimento do Manual EAPC reforçou a necessidade de interlocução entre áreas e com os envolvidos em projetos dessa natureza, especialmente em relação a diversidade de informações relevantes para projetos de embalagens de alimentos preparados congelados. Nessas etapas, procurou-se estabelecer um eixo de elaboração que permitisse envolver várias áreas, e ainda, valorizar os conteúdos da fundamentação teórica pesquisada. Os protótipos foram testados e elaborados em parceria com profissionais do setor de alimentos e gráfico/design.

Com o intuito de compreender o real uso do manual EAPC, submeteu-se a sua validação

\section{REFERÊNCIAS}

[1] Ambrose, G.; Harris, P.Design thinking. Porto Alegre: Bookman, 2011.

[2] Anvisa. Gerência Geral de Alimentos. Rotulagem Nutricional Obrigatória às Indústrias de Alimentos: manual de orientação. Brasília, 2005. 44p. Disponível em: < http://portal.anvisa.gov.br/wps/wcm/connect/5f53be 80474583c58ee8de3fbc4c6735/manual_industria.p df?MOD=AJPERES >. Acesso em: 11 de ago. 2015.

[3] Ardito, E.; Alves, R. Embalagem para alimentos congelados. Coletânea do Instituto de Tecnologia de Alimentos, Campinas, v.24, n.1, p.11-28, jan./jun., 1994. Disponível em: < http://www.ital.sp.gov.br/cetea/adi.php > Acesso em: 29 jun. 2015.

[4] Azzi, A.; Battini, D.; Persona, A; Sgarbossa, F. Packaging Design: General Framework and Research Agenda. Packaging Technology and Science. Veneza, Itália, v.25, p.435-456, jan. 2012. Disponível em: < http://10.1002/pts.993 > Acesso em: 3 jan. 2016 .

[5] Bramklev, C. Towards Integrating Product and Package Development. 2007. 81p. Tese (Doutorado em Logística) - Departament of Design Sciences, Faculty of Engineering, Universidade de Lund, Suécia, 2007. Disponível em: < http://lup.lub.lu.se/luur/download?func=downloadFil e\&recordOld $=609815 \&$ fileOId $=610071>$ Acesso em 02 de abr. De 2016.

[6] Boylston, S. Designing sustainable packaging. Londres: Laurence King, 2009.

[7] Brody, A.;Bugusu, B.; Han, J.; Sand, C.; Mchugh, T. Innovative food packaging solutions. Journal of Food Science, v. 7, n.8, 2008. Disponível em: < http:// www.ift.org/ /media/ Knowledge\%20Center/Science de uso em um cenário simulado, cujo experimento apontou que a quantidade de informações obtidas com um manual de informações compiladas é maior em número de tópicos e ainda, aproxima o designer industrial e projetista da nomenclatura específica da área, servindo como aprendizado sobre o conhecimento específico. Embora o tempo não tenha sido uma variável positiva, considerando que o experimento durou quase o mesmo entre os dois cenários - com ou sem uso de manual, reforça-se que a quantidade de informações obtidas, além de superior, apresentou um grau de precisão maior em terminologia e conceitos, finalidade de aprendizado para os quais os manuais de desenvolvimento se propõem.

[8] \%20Reports/Scientific\%20Status\%20Sum maries/InnovFoodPkg_1008.pdf > Acesso em: 13 de out. 2015.

[9] Carvalho, M. Modelo prescritivo para a solução criativa de problemas nas etapas iniciais do desenvolvimento de produtos. 1999. $167 \mathrm{f}$. Dissertação (Mestrado em Engenharia de Produção) - Programa de Pós-Graduação em Engenharia de Produção, Universidade Federal de Santa Catarina, Florianópolis, 1999.

[10] De Azeredo, H.M.; Faria, J..Brito, E. Embalagens e suas Interações com os Alimentos. Fundamentos de estabilidade de alimentos. Brasília: EMBRAPA, 2aㅡ ed. rev. e ampl, p. 225-251, 2012.

[11] Emblem, A; Emblem, H. Packaging technology: fundamentals, materials and processes. 1aㅡ ed. Sawston, Cambridge: Woodhead Publishing Limited, 2013.

[12] Gil, A. Métodos e Técnicas de Pesquisa Social. 6a Ed. São Paulo: Atlas, 2010.

[13] Han, J. New technologies in food packaging:overview. Innovation in Food Packaging. Plano, Texas, Cap. 1, p. 3-11. 2005. Disponível em: $<$

http://www.sciencedirect.com/science/article/pii/B9 780123116321500334 > Acesso em: 09 de set. 2015.

[14] Marsh, K.; Bugusu, B. Food Packaging: Roles, Materials and Environmental Issues. Journal of Foods Science, v. 72, n³, p.39-55, 2007. Disponível em: < http: doi: 10.1111/j.17503841.2007.00301.x > Acesso em: 11 de abr. De 2016.

[15] Mestriner, F. Design de embalagem: Curso básico. São Paulo: Pearson Prentice Hall, 2002. 
[16] Design de embalagem: Curso avançado. 2.ed. São Paulo: Pearson Prentice Hall, 2005.

[17] Merino, E.; Merino, G; Carvalho, L.Guia de Orientação para o Desenvolvimento de Embalagens. Revista D.: Design, Educação, Sociedade e Sustentabilidade., v. 2, n², 2009. Disponível em: <

[18] http://seer.uniritter.edu.br/index.php/revista design/article/view/124 > Acesso em: Abr. 2014.

[19] Moura, R.; Banzato, J. Embalagem, unitização \& conteinerização. 2.ed.São Paulo, SP: IMAM, 1997. v.3, 354p.
[20] Piergiovanni, L.; Limbo, S. Food packaging: materiali, tecnologie e qualità degli alimenti. Ed. Springer, 2010.

[21] Robertson, G. L. Food packaging: principles and practice. 3‥ ed., Boca Raton, Florida: CRC Press, 2013. 704p.

[22] Twede, D. The Birth of Modern Packaging: Cartons, Cans and Bottles. Journal of Historical Research in Marketing, v. 4, n 2, p. 245-272, 2012. Disponível em: http://www.emeraldinsight.com/doi/pdfplus/10.1108 /17557501211224449 > Acesso em: 09 de mar. 2016 . 


\section{Gapítulo 21}

\section{ANÁLISE ERGONÔMICA DENTRO DE UM POSTO ADMINISTRATIVO EM UMA ESCOLA PÚBLICA DO MUNICIPPIO DE MANAUS-AM}

\section{Andrew Silva do Nascimento}

\section{Wanderson Ramos Serrão}

\section{Paola Souto Campos}

Resumo: Este projeto tem como objetivo principal fazer uma avaliação ergonômica do posto de trabalho do setor administrativo de uma Instituição de ensino fundamental e propor soluções baseadas nos resultados dessa avaliação, as irregularidades ergonômicas encontradas estavam nos objetos de uso contínuo da trabalhadora. A ideia é apresentar uma proposta à melhoria ao ambiente de trabalho e informações e concretizações de ações sobre segurança e saúde no trabalho. O método utilizado foi elaboração de um questionário sobre a avaliação do posto de trabalho e entregue ao colaborador. Este questionário foi escolhido pelo fato de envolver todo o posto de trabalho e por ter sido desenvolvido, e tem o intuito de avaliar as condições do posto de trabalho de forma geral. A aplicação do questionário confirmou o alto risco de Distúrbio Osteomuscular Relacionado ao Trabalho (DORT) e a necessidade de melhorias nas condições de trabalho desta categoria profissional, como a estimulação de ginásticas laborais, para diminuir a fadiga, melhoria ou troca de assentos, mesas, apoio ao pé, para da melhor comodidade ao colaborador, são soluções para que o colaborador desenvolva seu trabalho com eficácia.

Palavras chave: Ergonomia, Escola, Posto de trabalho. 


\section{INTRODUÇÃO}

A ergonomia pode ser definida como o estudo das atividades humanas em termos de esforço físico, intelectual, relacionamento e dedicação. Essa foi a primeira definição proposta pelo cientista polonês Wojciech Jastrzebowski, em 1857. A palavra ergonomia vem do grego, no qual ergo significa trabalho e nomos leis naturais. Esse conceito tenta agrupar quatro naturezas distintas em apenas uma, a natureza físico-motora, a estéticosensorial, a mental-intelectual e a espíritomoral. (MÁSCULO ET AL., 2011 p.9)

Ergonomia é o estudo da adaptação do trabalho ao homem. Refere-se não apenas às máquinas e equipamentos, como, também, a toda a situação que envolva o relacionamento entre o homem e seu trabalho. Portanto, a ergonomia procura a adaptação confortável e produtiva entre o ser humano e seu trabalho, tornando-se, atualmente, uma medida de prevenção de lesões e acidentes, visando ao aumento da produtividade (IIDA, 1998).

Os benefícios de um ambiente ergonomicamente ajustado são muitos, como a redução de tensão nas articulações, músculos, tendões, ossos, do stress físico e mental e a prevenção de problemas maiores, desde lesões por esforço repetitivo, até complicações de saúde maiores. Para a ergonomia, as condições de trabalho são representadas por um conjunto de fatores interdependentes, que atuam direta ou indiretamente na qualidade de vida das pessoas e nos resultados do próprio trabalho. Sendo assim, seu objetivo fundamental é contribuir para a satisfação das necessidades humanas no ambiente de trabalho, incluindo a promoção de saúde e de bem-estar.

Portanto, para que não haja lesões musculares, dores e fadiga, levando a lesões às vezes irreversíveis, o posto de trabalho deve está adequado ao colaborador ou usuário. Em virtude desta realidade, é necessário buscar uma melhor adequação do posto de trabalho ao indivíduo que nele atua, de acordo com o perfil populacional e a área de atuação profissional. Por isso esse estudo visa uma avaliação ergonômica em um departamento da empresa no qual foram levantados pontos essenciais, que contribuem para um bom desenvolvimento das atividades, como iluminância, ruído, mobiliário adequado à função, com o objetivo de melhorias no ambiente de trabalho, bem como na qualidade e organização na tarefa desenvolvida.

\section{REFERENCIAL TEÓRICO}

\subsection{TRABALHO SENTADO E ANTROPOMETRIA}

O trabalho sentado traz conforto, evitando posições forçadas no corpo, reduz o consumo de energia, traz alívio para as pernas, e consequentemente fornece a melhor circulação do sangue pelos membros. Porém também existem desvantagens para esse tipo de trabalho, como a flacidez dos músculos da barriga, além da provável cifose, além de poder causar danos aos membros e à coluna lombar (MÁSCULO ET AL., 2011).

A pressão nas nádegas e nas coxas reduz a circulação local, o que pode provocar formigamento e dormência, além de dor, inchaço etc. Para diminuir esses problemas é necessário utilizar cadeiras adequadas para o tamanho do trabalhador. Podemos definir antropometria a partir daí, que é o estudo das medidas humanas, que são importantes para que sejam determinadas as posturas ideais para cada posto. Sendo assim, o grande problema da antropometria é que cada indivíduo tem suas próprias dimensões, o que significa que a altura boa para uma pessoa, não é a ideal para todas as outras pessoas.

Se o assento for muito alto, toda a coxa estará fortemente apoiada sobre o assento, inclusive a parte próxima ao joelho, enquanto os pés ficarão em balanço total ou parcial. Isso pode diminuir a circulação sanguínea, por espremer os vasos sanguíneos e nervos que estão presentes na região. Já quando o assento é baixo demais os autores afirmam que uma grande parte do peso do corpo estará apoiada sobre uma região muito restrita das nádegas, causando dor no local. Com a diminuição do ângulo do joelho, o mesmo problema da circulação da cadeira muito alta também se verifica.

Outro problema está relacionado ao posicionamento das costas nas cadeiras. A hérnia de disco pode ocorrer não apenas em trabalhos pesados, mas também em trabalhos leves na posição sentada. Isso se dá pelo enfraquecimento da parede do disco, consequência da postura forçada. Para amenizar esses impactos um assento na cadeira ideal seria aquele que fosse móvel e ajustável à altura do indivíduo, podendo assim acompanhar o movimento do corpo. Esse 
instrumento suporta parte do corpo, diminuindo a pressão sobre a coluna. Um apoio para a parte inferior da coluna também é bem-vindo quando mantém a curvatura a mais natural possível. Outra sugestão seria um apoio para a cabeça, que ajuda a manter o pescoço em uma posição mais confortável. Pausas também podem evitar a fadiga na região da coluna cervical.

O campo visual do ser humano alcança uma faixa de $30^{\circ}$, sendo dividido em dois campos: 15 para cima e 15 para baixo. Recomendase que quando esteja inclinado para frente $o$ pescoço atinja no máximo entre $20^{\circ}$ e $30^{\circ}$, e quando em trabalhos prolongados, essa faixa não deve ultrapassar 15․ Com relação aos membros superiores. Para prevenir possíveis problemas para os ombros, a mesa e o assento devem ser ajustados de forma a permitir que os ombros permaneçam relaxados, os cotovelos estejam abaixados e próximos ao corpo (até 15ำ com braço em ângulos de $85^{\circ}$ a $110^{\circ}$ ). A Figura 1 mostra a posição ideal para o pescoço com um ângulo de $20^{\circ}$ e na parte direita a posição errada, nesse caso com $50^{\circ}$ de inclinação.

Figura 1 - Posição do pescoço: ideal à esquerda e errada à direita

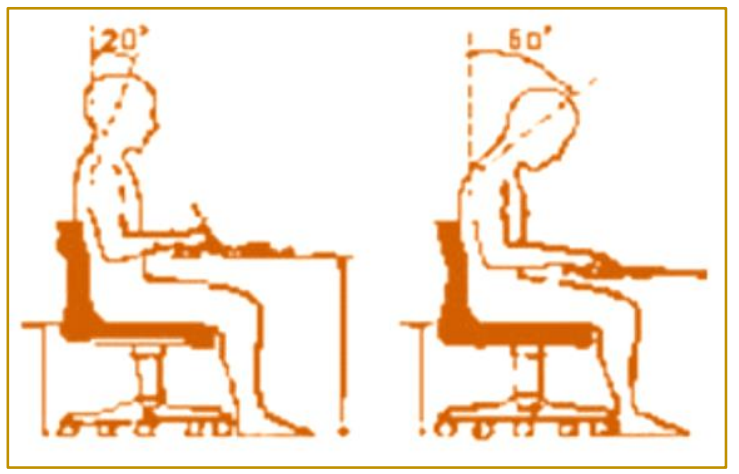

Fonte: Elementu Vitalle (2012)

Segundo a NR-17 (2012): "17.3.3 Os assentos utilizados nos postos de trabalho devem atender aos seguintes requisitos mínimos de conforto: a) altura ajustável à estrutura do trabalhador e à natureza da função exercida; b) características de pouca ou nenhuma conformação na base do assento; c) borda frontal arredondada; d) encosto com forma levemente adaptada ao corpo para proteção da região lombar".

\subsection{DOENÇAS OCUPACIONAIS DE ORIGEM BIOMECÂNICA}

A lesão aguda está associada a esforços que excedem o limite de tolerância na estrutura musculoesquelética, e normalmente aparecem após esforços de grande intensidade. Por outro lado, a lesão cumulativa relaciona-se com a repetição de tarefas, e a constante aplicação de força sobre uma estrutura específica. Isso leva ao desgaste da estrutura, e a redução da tolerância do ponto onde é ultrapassado seu limite. Esse tipo de lesão representa maior desgaste de estrutura e tem se tornado bastante comum em postos de trabalho com tarefas repetitivas.

Lombalgia é a dor na região da coluna lombar. É um sintoma e não uma doença, sendo que $90 \%$ da população apresentaram ou vão apresentar pelo menos um episódio de dor durante a vida. Não difere por gênero, porém com o passar dos anos as mulheres começam a sentir mais o sintoma devido à menopausa e como consequência da osteoporose. A lombalgia é a segunda causa de procura médica causada por doenças crônicas, superando o câncer, o acidente vascular cerebral e até mesmo a AIDS. Nos países desenvolvidos é a principal incapacidade em trabalhadores com idade inferior a 45 anos.

As DORT, conhecidas no passado como Lesões por Esforços Repetitivos (LER), são lesões cumulativas de esforço excessivo e inadequado em ossos, nervos, tendões e músculos. São comuns em membros superiores, como mãos, punhos, braços, antebraços, ombros e coluna cervical. Encontram-se entre as recomendações para a redução de impactos das DORT a diminuição da pressão em trabalhos, seja de ordem física 
ou psicológica, a redução da repetição de tarefas e o estabelecimento de pausas. Também podem ser promovidos ajustes no posto de trabalho no que diz respeito aos móveis, que permitam uma postura mais saudável e confortável, obedecendo às formas antropométricas do trabalhador, dentro das tarefas abordadas.

\subsection{CONDIÇÕES AMBIENTAIS}

O índice de temperatura efetiva não deve ultrapassar o valor de $28^{\circ} \mathrm{C}$. Porém esse valor não analisa a sobrecarga térmica, como fatores de tempo de exposição, calor radiante e o que diz respeito à atividade do trabalhador. Além do mais, a Norma Regulamentadora (NR-15), sobre questões de higiene do trabalho, não considera as variações climáticas regionais. Nem tampouco as vestimentas, a idade, a cor da pele, a obesidade etc. Dessa forma, considera-se somente o calor artificial para fins que possam caracterizar insalubridade, o que não é o caso de uma sala de aula em temperatura ambiente. Segundo a NR-17 (2012), no item 5.2-b, é considerada índice de temperatura efetiva entre $20^{\circ} \mathrm{C}$ e $23^{\circ} \mathrm{C}$. Para manter essa faixa de temperatura é indicado em dias quentes que ventiladores sejam ligados, além da abertura de janelas e portas para a circulação do ar. Nos dias frios, roupas adequadas devem ser utilizadas.

Segundo Blucher (2005), a temperatura e a umidade ambiental, influi diretamente no desempenho do trabalho humano. Um ambiente termicamente bem projetado pode contribuir para a diminuição da carga de stress mental, aumento do nível de concentração, redução da hiperemia e, por conseguinte, aumento de eficiência na elaboração das tarefas (SILVA, 1996).

\subsection{AMBIENTES COM COMPUTADORES}

Para as atividades em que os trabalhos devam ser realizados sentados, a partir da análise ergonômica do trabalho, poderá ser exigido suporte para os pés, que se adapte ao comprimento da perna do trabalhador; Sempre que o trabalho puder ser executado na posição sentada, o posto de trabalho deve ser planejado ou adaptado para esta posição. Para trabalho manual sentado ou que tenha de ser feito em pé, as bancadas, mesas, escrivaninhas e os painéis devem proporcionar ao trabalhador condições de boa postura, visualização e operação e devem atender aos seguintes requisitos mínimos: ter altura e características da superfície de trabalho compatíveis com o tipo de atividade, com a distância requerida dos olhos ao campo de trabalho e com a altura do assento; ter área de trabalho de fácil alcance e visualização pelo trabalhador; ter características dimensionais que possibilitem posicionamento e movimentação adequados dos segmentos corporais. (NR 17).

Para ambientes com computadores, as condições térmicas deverão proporcionar conforto aos trabalhadores. Nas atividades que envolvam leitura de documentos para digitação, datilografia ou mecanografia deve: ser fornecido suporte adequado para documentos que possa ser ajustado proporcionando boa postura, visualização e operação, evitando movimentação frequente do pescoço e fadiga visual; ser utilizado documento de fácil legibilidade sempre que possível, sendo vedada a utilização do papel brilhante, ou de qualquer outro tipo que provoque ofuscamento.

Baseado na norma brasileira que regulamenta as instalações de ar condicionado - NBR 5858 (ABNT, 1983) - é afirmado que a temperatura deve ser mantida entre vinte e quatro e vinte e seis graus (estável e igual em todos os pontos da sala) e a UR (umidade relativa) deve ser conservada em níveis entre quarenta e sessenta por cento.

\subsection{ILUMINAÇÃO NO AMBIENTE DE TRABALHO}

De acordo com a norma regulamentadora 17 (Ergonomia), em todos os locais de trabalho deve haver iluminação adequada, natural ou artificial, geral ou suplementar, apropriada à natureza da atividade.

A iluminação geral deve ser uniformemente distribuída e difusa; A iluminação geral ou suplementar deve ser projetada e instalada de forma a evitar ofuscamento, reflexos incômodos, sombras e contrastes excessivos; Os níveis mínimos de iluminamento a serem observados nos locais de trabalho são os valores de iluminâncias estabelecidos na NBR 5413, norma brasileira registrada no INMETRO; A medição dos níveis de iluminamento previstos no subitem 17.5.3.3 deve ser feita no campo de trabalho onde se realiza a tarefa visual, utilizando-se de luxímetro com fotocélula corrigida para a 
sensibilidade do olho humano e em função do ângulo de incidência.

Diante da iluminação o nível de iluminamento interfere diretamente no mecanismo fisiológico da visão e também na musculatura que comanda o movimento dos olhos. (BLUCHER, 2005). Sendo assim, uma iluminação adequada é fundamental para o desenvolvimento da tarefa, influenciando decisivamente no comportamento do usuário e na sua eficiência. Foi utilizado um luxímetro digital para aferir o nível de iluminação do ambiente de trabalho. O procedimento se deu conforme recomendações das normas NBR 5413 que em ambientes de sala de aula, a iluminância deve estar entre duzentos e quinhentos luxes, para salas de reuniões deve estar numa faixa de cento e cinquenta a trezentos luxes. Outro fator aferido no posto de trabalho foram a existência de computadores, pois o posto de trabalho com computadores exige do colaborador atenção, de modo que a visão fica presa a tela do monitor, as mãos ficam sobre o teclado para a digitação, isto pode ocasionar a fadiga visual, dores musculares no pescoço e ombros, e dores nos tendões dos dedos.Com esse checklist é possível avaliar a cadeira, mesa de trabalho, teclado, monitor de vídeo, a interação, layout e o sistema do trabalho. A aplicação se deu no dia dezessete de agosto, pelo período da manhã, com a participação de apenas uma colaboradora, que atua no posto em estudo.

\subsection{ORGANIZAÇÃO DO TRABALHO.}

A organização do trabalho deve ser adequada às características psicofisiológicas dos trabalhadores e à natureza do trabalho a ser executado. A organização do trabalho, para efeito desta NR, deve levar em consideração, no mínimo: as normas de produção; o modo operatório; a exigência de tempo; a determinação do conteúdo de tempo; o ritmo de trabalho; o conteúdo das tarefas.

Nas atividades que exijam sobrecarga muscular estática ou dinâmica do pescoço, ombros, dorso e membros superiores e inferiores, e a partir da análise ergonômica do trabalho, deve ser observado o seguinte: todo e qualquer sistema de avaliação de desempenho para efeito de remuneração e vantagens de qualquer espécie deve levar em consideração as repercussões sobre a saúde dos trabalhadores; devem ser incluídas pausas para descanso; quando do retorno do trabalho, após qualquer tipo de afastamento igual ou superior a 15 (quinze) dias, a exigência de produção deverá permitir um retorno gradativo aos níveis de produção vigentes na época anterior ao afastamento.

Nas atividades de processamento eletrônico de dados, deve-se, salvo o disposto em convenções e acordos coletivos de trabalho, observar o seguinte: o empregador não deve promover qualquer sistema de avaliação dos trabalhadores envolvidos nas atividades de digitação, baseado no número individual de toques sobre o teclado, inclusive o automatizado, para efeito de remuneração e vantagens de qualquer espécie; o número máximo de toques reais exigidos pelo empregador não deve ser superior a 8.000 por hora trabalhada, sendo considerado toque real, para efeito desta NR, cada movimento de pressão sobre o teclado; o tempo efetivo de trabalho de entrada de dados não deve exceder o limite máximo de 5 (cinco) horas, sendo que, no período de tempo restante da jornada, o trabalhador poderá exercer outras atividades, observado o disposto no art. 468 da Consolidação das Leis do Trabalho, desde que não exijam movimentos repetitivos, nem esforço visual; nas atividades de entrada de dados deve haver, no mínimo, uma pausa de 10 minutos para cada 50 minutos trabalhados, não deduzidos da jornada normal de trabalho; quando do retorno ao trabalho, após qualquer tipo de afastamento igual ou superior a 15 (quinze) dias, a exigência de produção em relação ao número de toques deverá ser iniciado em níveis inferiores do máximo estabelecido na alínea "b" e ser ampliada progressivamente.

\section{METODOLOGIA}

Escolhido o tema e permitido o projeto naquele setor, foi realizada uma pesquisa bibliográfica para levantar informações e compor a base a respeito do tema abordado, por meio de diversas fontes como artigos, livros de ergonomia e teses. A pesquisa foi realizada em uma escola privada da cidade de Manaus, no período de 1 de junho de 2017 a 29 de junho de 2017. O tamanho da amostra é de apenas 1 colaborador, haja visto que somente aquele colaborador atuava no local de trabalho estudado. Logo após, um questionário sobre a avaliação do posto de trabalho foi entregue ao colaborador. Este 
questionário foi escolhido pelo fato de envolver todo o posto de trabalho e tem o intuito de avaliar as condições do posto de trabalho e bem-estar do colaborador junto a seu posto de trabalho, podendo ser consultado no Anexo 1. Com esse checklist é possível avaliar a cadeira, mesa de trabalho, teclado, monitor de vídeo, a interação, layout e o sistema do trabalho.

A partir dos resultados do questionário, medidas de correção foram determinadas para a postura do colaborador e do posto de trabalho, aumentado assim a satisfação do mesmo, melhorando sua produtividade e evitando doenças ocupacionais.

\section{ANÁLISE E RESULTADO}

A análise realizada neste trabalho com a colaboradora da escola particular, afirma que não apresenta nenhum problema de saúde aparente, porém, sente dores na lombar, formigamento nas mãos e dormência nos pés. Assim como na pesquisa realizada por Soares \& Santos,2016, no qual sua entrevistada relata ter dores ocasionais nas costas e nos braços ao realizar movimentos e abaixar-se para atender os alunos, e nas pernas. Em média, passa 4 horas por dia em pé, com um intervalo de 15 minutos. Além do esforço físico direto, há também a necessidade de elevar a voz continuamente, e o estresse gerado pelo desgaste mental ocasionado. Para os problemas encontrados, pode-se afirmar que foram ocasionados pelo ambiente estar inadequado para a execução de suas atividades segundo as normas regulamentadoras.

Em relação ao espaço na realização do trabalho, os principais problemas encontrados foram: tomadas abaixo de $75 \mathrm{~cm}$, não há tomada a $1 \mathrm{~m}$ de distância da colaboradora, dificuldades para acessar portas USB's e há interferências que prejudicam o posicionamento do corpo (caixas, estabilizador, cesto de lixo) debaixo da mesa.

Principais problemas da mesa: não é o tipo de móvel adequado para a função, não tem altura apropriada e não permite regulagem, não há acessório próprio para o ajuste da altura do monitor, não há espaço para afastar o monitor para frente ou para trás e não há espaço para que a colaboradora guarde um objeto pessoal, como observa-se na figura 1.

$\mathrm{Na}$ cadeira, foi encontrado: o regulador de altura está quebrado, altura da cadeira não é adequada ao colaborador, o apoio dorsal não oferece apoio firme, não há regulagem do apoio dorsal, braços da cadeira não são reguláveis e estão quebrados e prejudicam a aproximação do colaborador até o seu posto, como observa-se nas figuras 2 e 3.

Alguns demonstrativos de imagens do ambiente de trabalho da colaboradora em suas atividades de trabalho e alguns detalhes observados diante das figuras retiradas, definindo onde exatamente encontram-se as incoerências.

Figura 2 - tela do monitor em altura inadequada

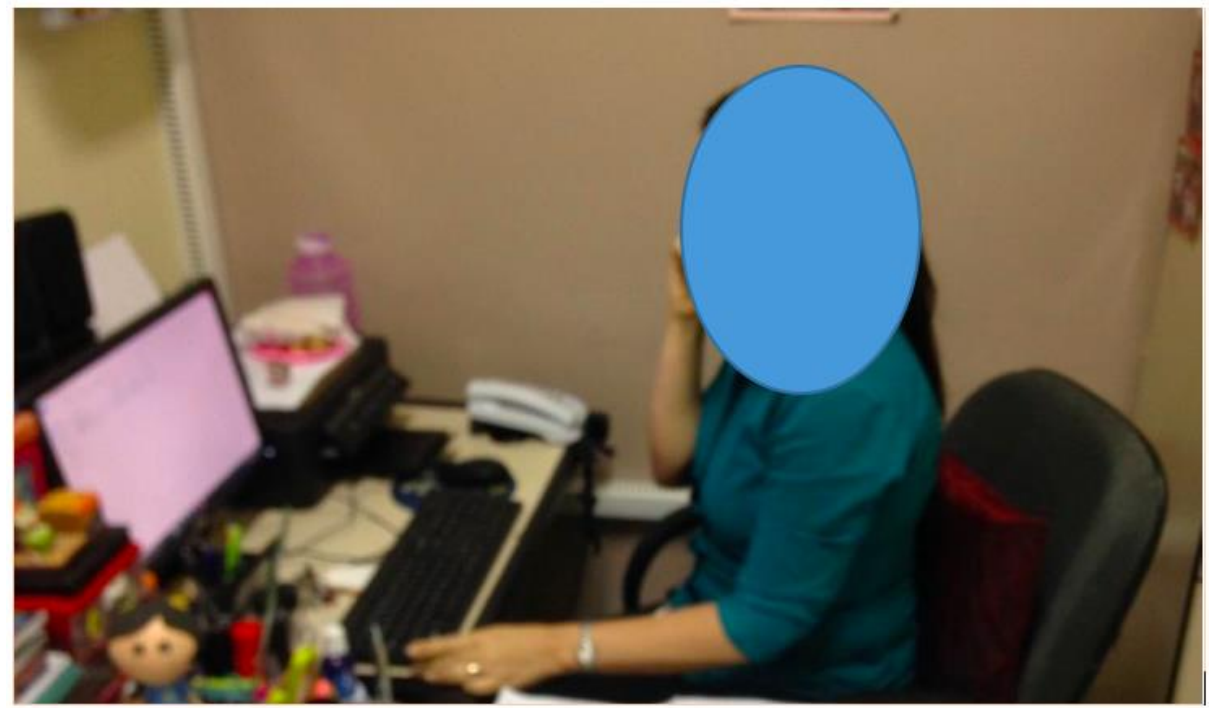


Figura 3 - apoio dos pés com mau apoio das costas

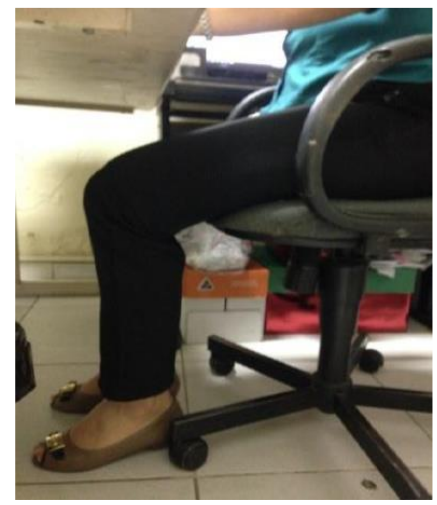

Figura 5 - cadeira com apoio para lombar quebrado

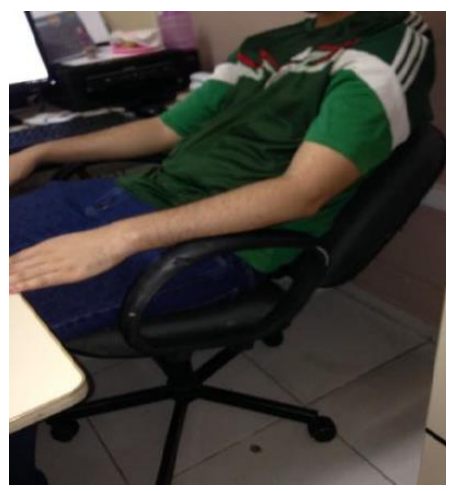

No que cita a NR 17(Ergonomia) sobre os assentos utilizados nos postos de trabalho devem atender aos seguintes requisitos mínimos de conforto: altura ajustável à estatura do trabalhador e à natureza da função exercida; características de pouca ou nenhuma conformação na base do assento; borda frontal arredondada; encosto com forma levemente adaptada ao corpo para proteção da região lombar.

Sobre as atividades que envolvam leitura de documentos para digitação, datilografia ou mecanografia deve:

Ser fornecido suporte adequado para documentos que possa ser ajustado proporcionando boa postura, visualização e operação, evitando movimentação frequente do pescoço e fadiga visual; ser utilizado documento de fácil legibilidade sempre que possível, sendo vedada a utilização do papel brilhante, ou de qualquer outro tipo que provoque ofuscamento.
Figura 4 - posição dos pés com apoio das costas

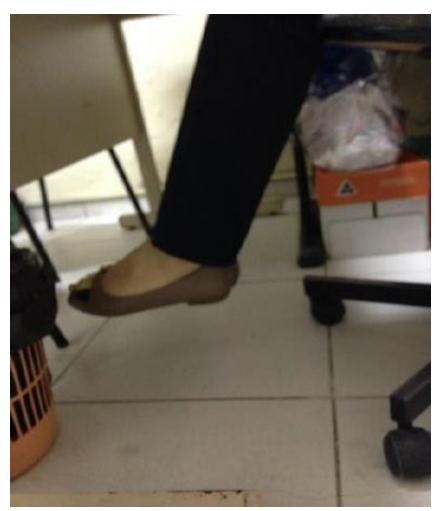

Figura 6 - colaboradora tendo que utilizar almofada para apoiar a coluna.

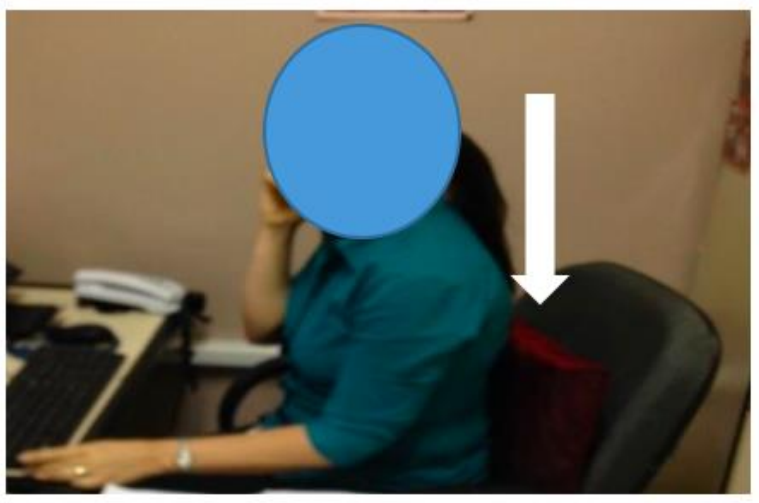

E também cita que os equipamentos utilizados no processamento eletrônico de dados com terminais de vídeo devem observar o seguinte: condições de mobilidade suficientes para permitir o ajuste da tela do equipamento à iluminação do ambiente, protegendo-a contra reflexos, e proporcionar corretos ângulos de visibilidade ao trabalhador; O teclado deve ser independente e ter mobilidade, permitindo ao trabalhador ajustá-lo de acordo com as tarefas a serem executadas; A tela, o teclado e o suporte para documentos devem ser colocados de maneira que as distâncias olho-tela, olho- teclado e olho-documento sejam aproximadamente iguais; Serem posicionados em superfícies de trabalho com altura ajustável. Por meio dessas melhorias que citamos, verificamos que simples mudanças nesse setor administrativo é de suma importância e tem um resultado de $25 \%$ a $30 \%$ mais eficaz e significativo comparando com o trabalho feito por Soares \& Santos, 2016, no qual o mesmo cita muitas mudanças, acompanhamentos e ajustes, 
tento assim propostas mais complexas, exigindo mais cuidados e atenção.

A seguir existem os itens avaliados e suas respectivas propostas de melhorias, a partir dos resultados obtidos com a análise, tivemos algumas recomendações para o ajuste do posto em questão, porém não foi autorizado alterá-lo. As recomendações propostas foram feitas baseadas na NR17 e estão descritas na tabela a seguir:

Tabela 1 - Demonstrativo de possíveis soluções para o posto de trabalho em questão

\begin{tabular}{|c|l|}
\hline \multicolumn{2}{|c|}{ Pontos com Incoerências } \\
\hline Posição sentada por longo período & $\begin{array}{l}\text { Ginástica laboral em equipe; Aquisição de apoio para os } \\
\text { pés. }\end{array}$ \\
\hline Cadeira & $\begin{array}{l}\text { Apoio para o dorso com regulagem de altura; } \\
\text { Apoio dorsal com regulagem do ângulo; } \\
\text { Apoio para o antebraço com regulagem de altura; }\end{array}$ \\
\hline Teclado & Não há necessidade de alterações; \\
\hline Monitor & Regulagem de altura; \\
\hline \multirow{2}{*}{ Layout } & $\begin{array}{l}\text { Substituição da mesa; } \\
\text { Substituição da cadeira; } \\
\text { Inserir tomadas próximo da colaboradora; }\end{array}$ \\
\hline
\end{tabular}

\section{CONCLUSÃO}

É de responsabilidade do empregador tornar o ambiente de trabalho mais propício, para que os funcionários possam desenvolver suas tarefas de maneira tranquila, sem que isso acarrete reclamações. Quando alguns itens, como iluminância, ruído, organização, estresse, adequação do mobiliário é analisada periodicamente, fica caracterizada uma prevenção e uma atenção, por parte do empregador, que gera uma maior confortabilidade aos funcionários, garantindo assim que suas atividades corram de maneira adequada.

Diante do referido estudo, neste artigo podese informar muito bem no que diz respeito a

\section{REFERÊNCIAS}

[1]. NR-17- Ergonomia, Manual de Legislação, 72. ed. São Paulo: Atlas, 2013 e.

[2]. IIDA, I. Ergonomia - Projeto e Produção. São Paulo: Edgard Blücher Ltda., 1998.

[3]. GIL, A. C. Métodos e Técnicas de Pesquisa Social. 5 ed. São Paulo: Atlas, 2005.

[4]. Métodos e Técnicas de Pesquisa Social. 5 ed. São Paulo: Atlas, 2007. LIDA, I. Ergonomia: projeto e produção. São Paulo: Edgard Blucher, 1990.

[5]. MARCONI, M. de A. Técnicas de pesquisa: planejamento e execução de pesquisas, amostragens e técnicas de pesquisa, elaboração, análise e interpretação de dados. 6 ed. São Paulo: Atlas, 2006. ambiente de trabalho de muitas escolas, na qual foram aferidas no ambiente de trabalho acerca da localização de mobiliário e equipamentos, do ponto de vista da eficiência na movimentação humana. As condições ambientais como temperatura, umidade, ruídos, iluminação, ventilação devem proporcionar situações de produção de tal forma que reduzam esforços orientados para fadiga ou para riscos de acidentes, vocacionada para as virtudes e capacidades do indivíduo. Avaliar os riscos presentes no ambiente de trabalho dos servidores técnicoadministrativos é tarefa fundamental, tanto para a promoção da saúde do trabalhador, como também para um bom desempenho das suas atividades laborais.

[6]. MÁSCULO, Francisco Soares; VIDAL, Mario Cesar (org.). Ergonomia: Trabalho Adequado e Eficiente. $1^{\circ}$ edição. Rio de Janeiro: Elsevier/ABEPRO, 2011. 648 p.

[7]. SALIBA, Tuffi Messias; CORRÊA, Márcia Angelim Chaves. Insalubridade e Periculosidade Aspectos Técnicos e Práticos. 10ำ edição. São Paulo: LTr, 2011. 284 p. SILVA, M.J.P. da. Comunicação tem remédio - a comunicação nas relações interpessoais em saúde. São Paulo: Gente, 1996.

[8]. SOARES, O. A K; SANTOS, S. A G. Análise ergonômica do posto de trabalho - Professora de escola publíca. Relatório Científico do XXIV Seminário de Iniciação Científica da Universidade Regional do Estado do Rio Grande do Sul- Unijuí. pp. 2. Unujuí, 2016. 


\section{APÊNDICE}

Questionário realizado com a colaboradora para obtenção de dados da pesquisa em questão

Idade:

Sexo: ( ) Masculino ( ) Feminino

Escolaridade:

( ) ${ }^{12}$ grau completo

( ) $1^{2}$ grau incompleto

( $12^{\circ}$ grau completo

( $12^{\circ}$ grau incompleto

( $)^{2}$ grau completo

( $)^{9}$ grau incompleto

Tipo de Contrato:( ) Efetivo ( ) Contrato temporário( ) Trabalhador avulso

1. Tempe ratura no seu ambiente de trabal ho（ ) Alto ( ) Médio ( ) Baixo

2. Ruido no seu ambiente de trabalho( ) Alto ( ) Médio ( ) Baixo

3. Iluminaçăo no seu ambiente de trabalho( )sufidiente ( ) insuficiente( ) natural

4. Vibraç̋es no seu ambiente de trabalho( ) Alto ( ) Médio ( ) Baixo

5. Ae rodispersóides no seu ambiente de trabal ho( ) sim ( )năo

6. Postura de trabal ho adotada( ) satisfatória( ) insatisfatória ( ) não sabe

7. Condiç̧̃es da mesa de trabalho( ) sim ( ) não

8. Condiçz̄es de assento de trabalho( ) sim ( ) não

9. Condiçб̃es doespaço de trabalho( ) sim ( ) não

10. Qualidade de ferramentas e equipamentos de trabalho ( ) sim ( ) năo

11. Quantidade de fe rramentas e equipamentos de trabal ho( ) sim ( ) năo

12. Qualidade de manutençăo de equipamentos ( ) ótima ( ) Boa ( ) razoável ( ) ruim

13. Número de funcionários para a real izaçăo do trabalho( ) sim ( ) năo

14. Te mpo de pausas (inclusive intervalo para almoço e lanche（ ) satisfatória ( )insati sfatória

15. Horas extras( ) sim ( ) não

16. Folgas (descanso semanal)( ) sim ( ) năo

17. Relacionamento comcolegas dosetor( )ótima ( )Boa ( ) razoável ( ) ruim 
Alutary 


\section{ANDREW SILVA DO NASCIMENTO}

Graduado em Engenharia de Produção pelo Centro Universitário do Norte

\section{ARLEI FONSECA BARCELOS}

Professor MSc. Arlei Fonseca Barcelos, mestrado na COPPE/UFRJ- Controle e Automação. Trabalha a 25 anos na Companhia Siderúrgica Nacional como Especialista em Sistema de Automação e Controle, 25 anos de magistério ministrando disciplinas nas áreas de Engenharia Eletrônica, Automação e Controle com diversas orientações de projetos de fim de curso. Professor em cursos de Pós-graduação nas áreas de Automação e Controle com orientação nas monografias dos pós-graduandos.

\section{AURICÉLIO DA SILVA LEITE DE OLIVEIRA}

Bacharel em engenharia de produção pela Faculdade SENAI/CETIQT RJ. 8 anos de experiência em atendimento ao cliente, com expertise em empreendedorismo.

\section{BIANKA COUTINHO ALVIM FIGUEIRA MENDES}

Mestre em Administração pela Unigranrio, Especialização em Gestão Empresarial pela Ferlagos e Graduada em Administração pela Unigranrio. Docente do Ensino Superior há 13 anos, Administradora e Consultora.

\section{CECÍLIA ROCHA GONÇALVES}

Graduada em Engenharia de Produção, pela Universidade Federal de Ouro Preto, graduação complementar pela University of Nebraska-Lincoln e Missouri University of Science and Technology. Fluente em Inglês, domínio intermediário de Espanhol. Participação em projetos de pesquisa. Vivência no setor de qualidade, produção e administrativo em uma indústria de láteos. Conhecimento avançado no Pacote Office. Curso Green Belt Six Sigma.

\section{CEZAR AUGUSTO ROMANO}

Doutor e Mestre em Engenharia de Produção pela Universidade Federal de Santa Catarina, graduado em Engenharia Civil pela Universidade Federal do Paraná. É Professor Titular da Universidade Tecnológica Federal do Paraná (UTFPR) onde atua desde 1979. Foi DiretorGeral do Campus Medianeira da UTFPR (1992-1996) e Vice-Reitor da UTFPR (1996-2002). Diretor-Geral do Campus Curitiba (2014-2017), Conselheiro Eleito do Conselho Universitário (COUNI) e do Conselho de Planejamento e Administração (COPLAD). É Professor Permanente do Programa de Pós-Graduação em Engenharia Civil (PPGEC) e do Mestrado Profissional em Administração Pública (PROFIAP) atuando nas áreas de estratégia, planejamento, gestão com foco na produtividade organizacional.

\section{CHRISTIANE WAGNER MAINARDES KRAINER}

Possui graduação em Engenharia Civil pela Universidade Federal do Paraná (1994), Mestrado em Engenharia Civil pela Universidade Tecnológica Federal do Paraná (2012), Doutoranda em Engenharia Civil pela Universidade Tecnológica Federal do Paraná (2017), MBA em Marketing pela Fundação Getúlio Vargas (FGV). Professor colaborador de Engenharia Civil da Universidade Federal do Paraná e pesquisadora da Universidade Tecnológica Federal do Paraná. Atua nos seguintes temas de pesquisa: supply chain, logística, gestão integrada da produção, relacionamento interorganizacional, gestão da construção com foco na produtividade organizacional e gestão do conhecimento. 


\section{DANIELLE FREITAS SANTOS}

Doutoranda em Engenharia de Produção pelo Programa de Pós-Graduação em Engenharia de Produção da Universidade Federal de Pernambuco - UFPE. Mestre em Engenharia de Produção pelo Programa de Pós Graduação em Engenharia de Produção da Universidade Federal de Pernambuco - UFPE. Bacharel em Engenharia de Produção pela Universidade Federal de Campina Grande - UFCG. Bacharel em Administração de Empresas pela Universidade Federal de Campina Grande - UFCG.

\section{EDILAINE GONÇALVES ARAÚJO}

Graduanda em Engenharia de Produção pelo Instituto Federal de Minas Gerais- IFMG Campus Congonhas. Possui curso Técnico em Edifcações, formada também pelo IFMG Campus Congonhas.Trabalha como estagiária no Setor de Compras e Licitações no Departamento de Administração e Planejamento do IFMG - Campus Congonhas. Desenvolveu um Projeto de Pesquisa e Extensão com o IFMG em parceria com IPHAN e Prefeitura Municipal de Congonhas relacionado à Acessibilidade no Patrimônio Histórico e Artístico Cultural na cidade de Congonhas.

\section{EDWIN ALBERTO GARAVITO HERNÁNDEZ}

Professor Associado da Universidade Industrial de Santander. Mestre em engenharia industrial, especialista em gestão de produção. Especialista em ensino universitário. Pesquisador do grupo de pesquisa em Otimização e organização de processos produtivos, administrativos e logísticos - OPALO.

\section{EMERSON SANTOS AGUIAR}

Mestre em Pesquisa Operacional - UNIFESP/ITA. Bacharel em Engenharia de Produção pela Universidade Federal de Campina Grande - UFCG.

\section{FABRICIO DA COSTA DIAS}

Doutorando em Engenharia na UFF, Mestre em Engenharia Civil (UFF) e graduado em Engenharia de Produção e Química com atuação do Centro de Pesquisa e Desenvolvimento Leopoldo Américo Miguêz de Mello (PETROBRAS/CENPES). Atualmente trabalha na área de Gestão Empresarial, Planejamento Estratégico, Gerenciamento de Projetos de Pesquisa e Desenvolvimento Tecnológico, Controle Orçamentário, Indicadores de Gestão (BSC), Controle de Bem Patrimonial, Planejamento de Projetos de Assistência Técnica Científica, Maturidade Tecnológica (Technology Readiness Levels - TRL), Regulamentação e Legislação do Petróleo (Termo de Cooperação e Conteúdo Local), Química do Petróleo, Auditoria de Qualidade, Segurança, Meio Ambiente e Saúde Ocupacional (QSMS). Na área acadêmica é professor da Universidade Veiga de Almeida (UVA) para o curso de Engenharia do Petróleo e Gás Natural e Engenharia de Produção. Professor da Universidade do Grande Rio (UNIGRANRIO) do curso de Engenharia de Produção. Atuando na orientação de dezenas de alunos de engenharia para realização de projeto final de curso de graduação, além de ter participado em centenas de bancas de monografias na Universidade Veiga de Almeida (UVA), na Universidade do Grande Rio (UNIGRANRIO) e no SENAI/CETIQT. E também possui diversas publicações em periódicos nacionais e internacionais. 


\section{FILIPE DE CASTRO QUELHAS}

Doutorando em Sistemas de Gestão Sustentáveis pelo Laboratório de Tecnologia, Gestão de Negócios e Meio Ambiente (LATEC) da Escola de Engenharia da Universidade Federal Fluminense (UFF), Mestre em Administração pelo programa de pós-graduação stricto sensu de mestrado em administração do IBMEC-RJ, participou como avaliador de artigos para o XX SEMEAD da FEA-USP em 2017. Autor em diversos artigos científicos publicados em periódicos e congressos. Possui MBA em Gestão pela Qualidade Total concluído pelo LATEC/UFF, MBA em desenvolvimento gerencial avançado com ênfase em gestão de pessoas também pelo LATEC / UFF, todos os créditos concluídos do mestrado em Engenharia de Transportes da COPPE / UFRJ, pós-graduação em Administração de Empresas completa em parceria da escola de pós - graduação em Administração Pública e de Empresas com a Escola de Pós-Graduação em Economia da Fundação Getúlio Vargas (FGV). É pós-graduado MBA em Administração da Produção e Logística, pós-graduado em Gestão de Recursos Humanos, pós-graduado em Gestão Empresarial, pós-graduado em Docência do Ensino Superior, pós-graduado em Administração Escolar e Planejamento, pósgraduado em Gestão Competitiva no Varejo, pós-graduado em direito do trabalho e pósgraduado em Direito Administrativo, todos pela Universidade Cândido Mendes (UCAM). Possui curso de graduação sequencial em Empreendedorismo e Inovação concluído pelo Departamento de Empreendedorismo da Universidade Federal Fluminense (UFF), pósgraduação em políticas e gestão em segurança pública pela FACIBRA e graduado em administração. Foi oficial da área de administração na Marinha do Brasil, tendo sido chefe da divisão de pessoal e presidente do comitê de gestão organizacional. Foi oficial da área de administração do Instituto Militar de Engenharia (IME). Atualmente é oficial da área de administração no comando do exército e tutor no curso de pós-graduação em Gestão em Administração Pública do Cead / UFF.

\section{FLÁVIO DE SÃO PEDRO FILHO}

Pós-Doutor em Gestão e Economia pela Universidade da Beira Interior (UBI), Covilhã, Portugal. Doutor em Administração pela Universidade de São Paulo (USP). Doutor em Gestão de Empresas pela Universidad Autónoma de Asunción (UAA). Mestre em Engenharia de Produção pela Universidade Federal de Santa Catarina (UFSC). Especialista em Planejamento (UFBA) e em Engenharia de Produção (UFSC). Bacharel em Administração pela EAUFBA. Professor da Fundação Universidade Federal de Rondônia (UNIR). Coordenador do Grupo de Pesquisa em Gestão da Inovação e Tecnologia (GEITEC/UNIR).

\section{GABRIEL AUGUSTO RODRIGUES DE FREITAS}

Graduado em engenharia de produção pela instituição UNIFESO - CENTRO UNIVERSITÁRIO SERRA DOS ÓRGÃOS, tendo forte atuação na área comercial de software.

\section{GEANDRA ALVES QUEIROZ}

Doutoranda em Engenharia de Produção na Universidade Federal de São Carlos. Mestra em Engenharia de Produção pela Escola de Engenharia de São Carlos - Universidade de São Paulo (EESC-USP) na área de Processos e Gestão de Operações e na linha de pesquisa Sustentabilidade em Processos Produtivos.Graduada em Engenharia de Produção pela Universidade de Franca (2012).Possui especialização em Ciências Ambientais. Tem experiência em Engenharia de Produção, com ênfase em Projetos Sustentáveis, Planejamento e Controle da Produção e Desenvolvimento de Produtos. 


\section{GELSON DA SILVA VEDA}

Acadêmico em Administração no Centro Universitário Cesumar. Pesquisador e membro do Grupo de Pesquisa em Gestão da Inovação e Tecnologia (GEITEC/UNIR). Atua como assistente administrativo em uma loja de decoração de interiores.

\section{HARRY RODRIGUES JÚNIOR}

Harry Rodrigues Júnior é designer de produtos, com especializações em design de embalagens e em engenharia de produção. É mestre em engenharia mecânica e de materiais, com ênfase na área de engenharia de manufatura, linha de desenvolvimento integrado de produto. Atua profissionalmente no desenvolvimento de produtos, embalagens e serviços. Atualmente tem trabalhado com a aplicação de realidade aumentada ao design de produtos.

\section{HELIO ZANQUETTO FILHO}

Graduado em Engenharia Civil pela Universidade Federal do Espírito Santo (1991), Mestre em Engenharia de Produção pela Pontifícia Universidade Católica do Rio de Janeiro (1994) e doutor em Engenharia de Produção pela PUC-Rio (2003). Atualmente é professor Associado do Departamento de Administração da Universidade Federal do Espírito Santo (UFES). Tem experiência na área de Gestão de Operações e Redes Produtivas, atuando principalmente nas seguintes áreas: gestão de redes interorganizacionais, gestão da cadeia de suprimentos, gestão logística de transporte, gestão do processo produtivo, gestão de fornecedores e gestão de processos.

\section{HENRIQUE SÉRGIO RÊGO DE HOLANDA SÁ SOBRINHO}

Possui graduação em Engenharia Civil pela Universidade Federal da Paraíba (2009) e MBA em Gestão Eficaz de Obras e Projetos pela Universidade Cruzeiro do SUL (2012). Tem experiência na área de Engenharia Civil, com ênfase em Planejamento de Obras e Projeto.

\section{JAQUELINE GUIMARÃES BORGES}

Pós-graduanda em Controladoria, Finanças e Planejamento Tributário pelo Centro Universitário Municipal de Franca. Graduada em Engenharia de Produção pelo Centro Universitário Municipal de Franca (2017). Possui experiência em pesquisa nas áreas de Produção Enxuta e Gestão Estratégica. Tem experiência profissional em Engenharia de Produção, como foco no Planejamento e Controle da Produção. Experiência Profissional em Administração, como foco em Planejamento Estratégico, Controladoria e Finanças.

\section{JEFFERSON AUGUSTO KRAINER}

Doutorando em Engenharia Civil pela Universidade Tecnológica Federal do Paraná (2017), Mestre em Ciência, Gestão e Tecnologia da Informação pela Universidade Federal do Paraná (2013), possui Bacharelado em Direito pela Faculdade de Direito de Curitiba (1995). Professor colaborador da Universidade Estadual do Paraná nos cursos de Ciências Sociais e pesquisador da Universidade Tecnológica Federal do Paraná. Atua nos seguintes temas de pesquisa: construção civil, supply chain, logística, gestão integrada da produção, relacionamento interorganizacional, gestão da construção com foco na produtividade organizacional e gestão do conhecimento. 


\section{JOSÉ TOMADON JÚNIOR}

Graduado em Engenharia de Produção pela Universidade Estadual do Paraná, Campus Campo Mourão. Mestre e Doutor em Engenharia Química pela Universidade Estadual de Maringá. Professor do Magistério Superior na Universidade Tecnológica Federal do Paraná.

\section{JOSEMAR COELHO FELIX}

Possui graduação em Bacharelado em Ciência e Tecnologia pela Universidade Federal de São João Del Rei e atualmente estuda Engenharia de Produção no Instituto Federal de Minas Gerais-Campus Congonhas. Tem experiências acadêmicas nas áreas de informática e educação, atuando principalmente nos seguintes temas: inclusão digital-educativa, popularização da ciência, educação empreendedora, inovação tecnológica e Experimento Fatorial para desenvolvimento de qualidade na indústria. Também está como estagiário na MRS Logística, especificamente na Gerência de Manutenção de Vagões-MG trabalhando na área de segurança e produtividade ferroviária.

\section{JULIANA RIBAS MONTEIRO}

Professora no Instituto Federal do Rio de Janeiro (IFRJ) e Doutoranda em Engenharia Elétrica pela Universidade Federal de Itajubá (UNIFEI). Mestre em Engenharia Elétrica (Sistemas de Controle) pela UNIFEI. Graduação em Engenharia Elétrica com ênfase em Eletrônica pela Faculdade de Engenharia de Resende e Curso Técnico em Eletrônica pela Escola Técnica Pandiá Calógeras. Dissertação de Mestrado nas áreas: Controle de Processos e Inteligência Artificial (Fuzzy Sets e Rough Sets). Trabalho de Conclusão da Graduação realizado na área da Inteligência Artificial (Redes Neurais Artificiais). Experiência em indústrias das áreas: Siderúrgica, Automotiva e Nuclear.

\section{JUNE TABAH}

Mestre em Desenvolvimento Regional em cadeias produtivas e políticas públicas; pósgraduação com Especialização em Engenharia de Segurança do Trabalho, e Graduada em Engenharia de Produção, Eletricista pelo Centro Universitário FEI - Faculdade de Engenharia Industrial de São Bernardo do Campo-SP. Atualmente é membro da Comissão Assessora de área do INEP MEC; é docente e Chefe de departamento na Engenharia de Produção do Centro Universitário Municipal de Franca Uni-FACEF; é membro pleno da congregação e docente do Curso Superior de Tecnologia em Gestão da Produção Industrial da Faculdade de Tecnologia de Franca - \&quot;Dr. Thomaz Novelino\&quot; - FATEC Franca; é docente na Arquitetura e Administração da Universidade de Franca - Unifran; docente em EaD no Curso de Gestão Empresarial em Gestão Ambiental na FATEC São Paulo do Centro Paula Souza; e Participa do Conselho Gerencial administrativo e de engenharia em empresa de Ribeirão Preto-SP.

\section{KÉLLEN BÁRBARA NASCIMENTO FURTADO}

Graduanda em Engenharia de Produção pelo Instituto Federal de Minas Gerais- IFMG Campus Congonhas. Possui curso profissionalizante em Gestão de Pessoas e Liderança, trabalha como estagiária no Departamento de Gestão de Pessoas e Capacitação . Atuou como tutora de Cálculo I nos cursos de Engenharia de Produção e Mecânica. Foi aluna destaque em 2010, ao receber pelo Ministério da Ciência e Tecnologia o certificado de Menção Honrosa pelo desempenho na 5 o Olimpíada Brasileira de Matemática das Escolas Publicas (OBMEP-2009). Desenvolveu um projeto de extensão com o IFMG relacionado a OBMEP. Atua em trabalho voluntário de evangelização de jovens como coordenadora do movimento Getsemani. 


\section{LAURA YERALDIN ESCOBAR RODRIGUEZ}

Engenheira Industrial. Pesquisadora do grupo de pesquisa em Otimização e organização de processos produtivos, administrativos e logísticos - OPALO da Universidade Industrial de Santander.

\section{LEONARDO HERNÁN TALERO SARMIENTO}

Mestrando em engenharia industrial. Pesquisador do grupo de pesquisa em Otimização e organização de processos produtivos, administrativos e logísticos - OPALO da Universidade Industrial de Santander.

\section{LETICIA DE OLIVEIRA DOS SANTOS}

Graduação em engenharia de produção SENAI/CETIQT RJ. Técnica em segurança do trabalho CEFET/RJ. Experiencia de 1 ano e 4 meses na função de técnica na construtora Agenor Ribeiro

\section{LÍGIA DO CARMO MARTINS DAMASCENO}

Mestre em Administração pela Unigranrio, MBA em Gestão Empresarial pelaFUNCEFET e Graduada em Administração pela Unigranrio. Docente do Ensino Superior há 10 anos, Administradora e Consultora.

\section{LUANA ALVES COTA SOUZA}

Graduada em Engenharia de Produção, pela Universidade Federal de Ouro Preto. Domínio intermediário do idioma inglês. Participação em palestras e mini cursos, com profissionais atuantes no mercado de trabalho. Vivência atual no ambiente de escritório, desempenhando as funções de elaborar planilhas e relatórios, emitir notas fiscais de compra e venda, além das funções administrativas, em geral. Conhecimento avançado no Pacote Office e perfil de profissional empenhado, comprometido, com facilidade para trabalhar em equipe e de rápida adaptação.

\section{LUCIANA MENDONÇA}

Engenheira de Produção pelo Instituto Federal de Minas Gerais- Campus Bambuí e Técnica em Eletrotécnica pela Escola Estadual de Furnas. Experiência em Gestão, planejamento e controle de produção no segmento de lingeries; Monitoramento de desempenho produtivo; Análise de layout; Controle de qualidade e Aplicação de cronoanálise em células de manufatura para balanceamento de produção.

\section{LUCIANA RODRIGUES PIRES}

Mestranda em Engenharia de Produção pela Universidade Federal de São Carlos (UFSCar). Graduada em Engenharia de Produção pelo Centro Universitário Municipal de Franca (2017). Realizou iniciação científica com bolsa fomentada pelo CNPq, nas áreas de Produção Enxuta e Estratégia Empresarial. Possui experiência em pesquisa nas áreas de Produção Enxuta e Gestão Estratégica. Tem experiência profissional em Engenharia de Produção, como foco no Planejamento e Controle da Produção. 


\section{MARCO AURÉLIO DE CARVALHO}

Marco A. de Carvalho é engenheiro mecânico, com mestrado e doutorado em engenharia de produção. Suas áreas de atuação são a engenharia de produtos e o gerenciamento de projetos. Em especial, tem trabalhado com métodos de criatividade na engenharia, Teoria da Solução de Problemas Inventivos (TRIZ), Inovação Sistemática, Teoria Geral da Inovação (TGI) e biomimética. É professor da Universidade Tecnológica Federal do Paraná (UTFPR). É autor do livro Inovação em Produtos, co-autor do livro 121 Heuristics for Solving Problems, organizador do livro Aplicações e Casos em Gestão do Desenvolvimento de Produtos e autor de várias outras publicações tecnológicas e científicas. É membro da ASME, European TRIZ Association e do Instituto de Inovação e Gestão do Desenvolvimento de Produtos.

\section{MARCONE FREITAS DOS REIS}

Doutorando e Mestre em Engenharia Civil pela UFF. Especialista em Gerenciamento de Projetos pela UERJ, possui graduação em Engenharia de Produção pela UERJ. Tem 10 anos de experiência em indústrias, com expertise nas áreas de Produção, Logística, Gestão de Manutenção, Gestão da Qualidade e Lean Manufacturing. É Consultor Sênior na TOTVS S.A. e Professor do Curso de Engenharia de Produção do SENAI CETIQT.

\section{MARCOS DO ESPIRITO SANTO DA PAIXÃO}

Técnico Eletrotécnico; Graduação SENAI Cetiqt Riachuelo Centro Tecnológico da Indústria Química e Têxtil; Artigo Abramam-Eficiência Energética em Data Center-2017; Técnico Operador Mantenedor via supervisório de toda Planta de TI; Técnico de Manutenção de Utilidades Pleno.

\section{MARCOS DOS SANTOS}

Comandante (Marinha do Brasil) - Senior Data Scientist - Project Manager ,Professor do Programa de Pós-graduação em Sistemas e Computação do Instituto Militar de Engenharia (IME), Membro Permanente do Comitê de IoT, Manufatura e Cidades Inteligentes da ASSESPRO, Doutorando em Engenharia de Produção - Sistemas, Apoio à Decisão e Logística - UFF, Mestre em Engenharia de Produção - Pesquisa Operacional - COPPE/UFRJ e Especialista em Instrumentação Matemática - UFF.

\section{MARIA LUIZA ABATH ESCOREL BORGES}

Possui graduação em Engenharia Civil pelo Centro Universitário de João Pessoa - UNIPÊ (2016). Atualmente é mestranda em Engenharia Civil na área de Processos Construtivos pela Universidade Federal do Rio Grande do Norte (UFRN) e pós-graduanda no MBA em Plataforma BIM pelo Instituto Brasileiro de Educação Continuada (INBEC). Tem experiência nas áreas de Lean Construction e BIM.

\section{MARIANA DE CARVALHO FERNANDES}

Graduada em Engenharia de Produção pela Faculdade Senai/Cetiqt (2017). Possui participação nos congressos de Engenharia com apresentação de artigo científicos ENFEPRO (2017), EMEPRO (2016), ICIEOM (2016). Atualmente iniciando no mercado de trabalho na área Administrativa. Tem interesse por teoria da decisão e ciência dos dados. 


\section{MARIO SANTOS DE OLIVEIRA NETO}

Graduado em Engenharia Elétrica pela USU - Universidade Santa Úrsula, e com Mestrado Strictu Senso em Engenharia de Produção, com concentração na área de Transporte e Logística pela PUC-RJ (bolsista Capes com dedicação exclusiva), tem 25 anos de sólida experiência adquirida nas áreas de logística, operações, serviços, facilities e comercial em empresas de médio e grande porte dos segmentos de varejo, de transporte de cargas e de passageiros, telecomunicações e de serviços, atuando diretamente em toda a cadeia de suprimentos. Também tendo participado de projetos no segmento de consultoria empresarial, desenvolvimento de estudos e implantação de projetos logísticos. Atualmente é professor para engenharia de produção no UNIFESO - Centro Universitário Serra dos Órgãos.

\section{MATEUS BITTE}

Graduado em Administração pela Universidade Federal do Espírito Santo e mestrando em Administração pela mesma universidade. Tem interesse de pesquisa na área de Gestão de Operações com ênfase em análises estatísticas e matemáticas.

\section{MAURÍCIO MASSAMI KURODA}

Estudante de Bacharelado em Engenharia Mecânica pela UTFPR, Universidade Tecnológica Federal do Paraná. Já atuou como Assessor de Projetos no departamento de projetos da Empresa Júnior de Engenharia Mecânica da UTFPR campus Cornélio Procópio. Estagiou numa empresa da área automobilística da Incubadora de Inovações Tecnológicas da UTFPR.

\section{MAYARA FERNANDA SILVA E SANTOS}

Graduada em Engenharia de Produção pela Universidade Federal de Ouro Preto (UFOP). Realizou mobilidade acadêmica na Alemanha pela Technische Universität Bergakademie Freiberg. Atuação em projetos universitários e monitoria. Possui quatro artigos publicados em congressos nacionais.

\section{MAYRA CRISTINA SILVA SANTOS}

Graduada em Engenharia de Controle e Automação pela Universidade Federal de Ouro Preto (UFOP) e mobilidade acadêmica na Alemanha pela Technische Universität Bergakademie Freiberg. Atuação em projetos universitários e tutoria. Possui dois artigos publicados em congressos nacionais.

\section{NATALI DE FREITAS ALVES}

Estudante de graduação do curso de engenharia de produção do UNIFESO- Centro Universitário Serra dos Órgãos.

\section{NAYARA GIMENEZ BARBOSA}

Formada em Administração de Empresas com ênfase em Sistema da Informação pela Faculdade Arthur Sá Earp Neto (FASE). Pós-Graduada em MBA de Gestão Estratégica da Manutenção e Produção pela Universidade Federal Fluminense (UFF). Pós-Graduada em Gestão da Segurança do Alimento pelo Serviço Nacional de Aprendizagem Comercial (SENAC). Atualmente trabalho como Administradora de uma Indústria Alimentícia. 


\section{PAOLA CAMPOS}

Doutorado em Diversidade Biológica pela Universidade Federal do Amazonas, atuando como docente no Centro Universitário do Norte- UNINORTE/LAUREATE nos cursos de Exatas e na pós graduação.

\section{RAFAEL CEZAR MENEZES}

Possui graduação em Engenharia de Produção Mecânica pela PUC - Pontifícia Universidade Católica do Rio de Janeiro, especialização em Logística Empresarial pela COPPEAD/UFRJ, mestrado em Logística - Sistemas de Transportes pela PUC - Pontifícia Universidade Católica do Rio de Janeiro, e pós-graduação em Engenharia de Planejamento de Empreendimentos da Indústria de Petróleo e Gás pelo programa PROMINP (Programa de Mobilização da Indústria do Petróleo). Certificado em Supply Chain Analytics e Supply Chain Fundamentals pelo MITMassachusetts Institute of Technology. Atualmente é professor dos cursos de Administração e Engenharia do UNIFESO - Centro Universitário Serra dos Órgãos e Engenheiro de Produção concursado da empresa Petrobras Distribuidora S.A.

\section{RAYANNE CRISTINA OLIVEIRA DA SILVA ARAÚJO}

Mestranda no Programa de Pós-Graduação Mestrado em Administração da Fundação Universidade Federal de Rondônia (PPGA/UNIR). Graduada em Administração pela Fundação Universidade Federal de Rondônia (UNIR). Administradora registrada no CRA-RO (n 5435RD). Pesquisadora do Centro de Estudos Interdisciplinar em Desenvolvimento Sustentável da Amazônia (CEDSA).

\section{ROBERT CRUZOALDO MARIA}

Possui graduação em Engenharia de Produção pela Universidade Federal de Ouro Preto e mestrado em Engenharia Mineral também pela Universidade Federal de Ouro Preto. Foi coordenador do curso de Engenharia de Produção e Diretor de Pesquisa e Extensão do IFMG Campus Congonhas. Atualmente é professor do curso de Engenharia de Produção, do curso Técnico em Mecânica e Diretor de Ensino do Instituto Federal Minas Gerais - Campus Congonhas.

\section{RUBEN HUAMANCHUMO GUTIERREZ}

Professor Titular da Universidade Federal Fluminense. Doutor (1997) e Mestre (1990) pela COPPE/UFRJ (CApes 6) Rio de Janeiro. Possui graduação- "Universidad Nacional de Trujillo/ Peru" (1985). Tem experiência empresarial (20 anos em empresas lideres WCM incluindo consultoria), e docente (25 anos) em Gestão e Melhoria de PROCESSOS, Qualidade,Gestão de Projetos. Avaliação EVTE de Projetos, Maturidade de Projetos e Processos; Estratégias de Negócios; e Analise Financeira e Fluxos de Caixa ; Leciona temas de PROCESSOS e Gestão; Estratégias Cenários e Mercados; Competitividade, Portfolio e Desempenho empresarial; Projetos e Serviços; Multicritério e Decisões, SIG -Sistemas de Informação Gerencial, e Gestão Integrada. Publicou em coautoria 4 livros sobre GESTÃO DE PROCESSOS, e também 7 capítulos de livros. Publicou vários artigos em revistas conceituadas. Publicou 105 artigos em eventos como ENEGEP, ENANPAD, SIMPEP, SIMPOI, EPIO (Argentina), CORS (Canadá) etc. Foi palestrante em diversos eventos. Orientou com sucesso 61 dissertações de mestrado, e 53 outros trabalhos de conclusão de cursos como TCC, MBA etc. Participei de mais de 360 bancas de avaliação Atuou ainda em sociedades cientificas como ABEPRO, SOBRAPO, CLADEA. E atua desde 1995 como referee e colaborador em eventos como ENEGEP, ENANPAD, SIMPEP, SIMPOI, EPIO / ENDIO (Argentina) etc. Atua também como revisor e referee de revistas nacionais e internacionais GEPROS, G\&P (Gestão e Produção), Produção online, S\&G (Sistemas e Gestão), African Journal of Business management, Revista Ingenieria Industrial etc. 


\section{RUBENS AGUIAR WALKER}

Doutorando em Engenharia de Produção pela UFF, com mestrado pela COPPE UFRJ e graduação pela PUC - RIO. Experiência Internacional com ótimas referencias. Atuação em grandes empresas, como a Volkswagen, no setor de produção. Experiência em logística na distribuição de produtos. Docente no curso de Engenharia de Produção com desenvolvimento de protótipos e processo. Pesquisa sobre utilização lúdica de para desenvolvimento de jogos e competições acadêmicas. Caracteriza a atuação pela integração da otimização nos modelos de gestão.

\section{SALVADOR PEREIRA DE CARVALHO JUNIOR}

Graduado em Engenharia de Produção pela Universidade Federal de Ouro Preto (UFOP). Foi bolsista do programa ciência sem fronteiras nível graduação pela CAPES na University of Illinois em Chicago (EUA). Durante esse período de intercâmbio, foi pesquisador Assistente nível graduação durante o Summer de 2015 no Departamento de Engenharia Industrial da Mercer University (EUA). Possui artigos publicados em congressos nacionais nas áreas de Pesquisa Operacional e Planejamento e Controle da Produção.

\section{SERGIO LUIZ RIBAS PESSA}

Engenheiro Mecânico UNISINOS (1988), Mestre em Engenharia e Ciência dos Materiais graduado pela Universidade Estadual de Ponta Grossa (2005), Doutor em Engenharia de Produção UFRGS(2010) Professor da Universidade Tecnológica Federal do Paraná nos cursos de: Graduação: - Tecnologia em Manutenção Industrial, - Engenharia Mecânica; PósGraduação Lato Senso: - Engenharia de Segurança do Trabalho - Engenharia de Produção Programa de Stricto Senso: - Engenharia de Produção e Sistemas - PPGEPS - UTFPR/PB. Pesquisas e atuação nas áreas: - Engenharia Mecânica: - Manutenção industrial (Gestão e Avaliação); - Manutenção e Avaliação de Frotas; - Desenvolvimento de Materiais Compósitos (Funcionais e Estruturais) - Ergonomia e Segurança do Trabalho - Ageing e ICT, - Metodos de Avaliação Ergonômica e Ergonomia Ocupacional - Gestão de Sistemas de Ergonomia e Segurança do Trabalho.

\section{TALITA RAMOS BARCELLOS}

Engenheira de Produção pela Unigranrio (2016) com atuação em Cadeia de Suprimentos.

\section{TALYSON XAVIER RIBEIRO}

Engenheiro de Produção pela Universidade de Itaúna- Minas Gerais e Técnico em Agricultura e Zootecnia pelo Instituto Federal de Minas Gerais- Campus Bambuí. Experiência em Mapeamento e simulação de processos industriais; Controle de qualidade e monitoramento de processos; Experiência em pesquisas socioeconômicas e levantamento de dados; Análise e dimensionamento de capacidade em equipamentos voltados para beneficiamento de café; Comércio agropecuário de insumos e implementos para a cafeicultura.

\section{TIAGO MACHADO E SILVA}

Mestrando do Programa de Pós-Graduação em Engenharia de Produção e Sistemas (PPGEPS), na área de Ergonomia. Engenheiro Mecânico formado pela UTFPR - Universidade Tecnológica Federal do Paraná, Campus Pato Branco. Atua como professor no Senai - PR. Participou da Empresa Júnior de Mecânica, h7 - Pesquisa e Desenvolvimento e foi VicePresidente do Centro Acadêmico de Engenharia Mecânica (CAEM-Pb). Participou de projetos em Aspersão Térmica. 


\section{VÁLDESON AMARO LIMA}

Doutorado em Administração em andamento pela Universidade Municipal de São Caetano do Sul (USCS). Especialização Lato Sensu em Educação Empreendedora pela Pontifícia Universidade Católica do Rio de Janeiro (PUC-Rio). Mestre em Administração pela Universidade Federal de Rondônia (UNIR) e Bacharelado em Administração de Empresas com Habilitação em Marketing pela Faculdade Barão do Rio Branco (FAB/UNINORTE). Professor EBTT de Administração no Instituto Federal de Educação, Ciência e Tecnologia de Rondônia (IFRO). Membro do Grupo de Estudos e Pesquisa em Inovação e Sustentabilidade da Amazônia (GEPISA).

\section{VINICIUS MARQUES DA SILVA FREITAS}

Graduado em Administração (FACNEC). Experiência profissional como Administrador Responsável Técnico, com conhecimento em análise de performance de equipes com foco na reestruturação de setores, melhoria de desempenho, redução de perdas e custos. Atualmente cursando Engenharia de Produção na Universidade Federal Fluminense (UFF).

\section{VITOR HUGO DOS SANTOS GARCIA}

Acadêmico em Administração pela Fundação Universidade Federal de Rondônia (UNIR). Representante do comitê Gestor Startup, Gestor de projetos na Associação Júnior Achievement e Instituto norte Amazônia de Apoio ao terceiro Setor - Inats. Consultor de negócios e prospecção de novos mercados. Palestrante.

\section{WALLACE DE ALMEIDA GOMES}

Engenheiro Eletricista / Eletrônico, AEDB (Faculdade de Engenharia de Resende). Técnico em Eletrônica, Escola Técnica Pandiá Calógeras - Volta Redonda. Surveyor Senior (RSV CBO Manoella - Oceaneering). Experiência em atividades propostas pela Gerência de Manutenção e Inspeção Submarina (Petrobras - MIS).

\section{WANDERSON RAMOS SERRÃO}

Graduado em Engenharia de Produção pelo Centro Universitário do Norte 


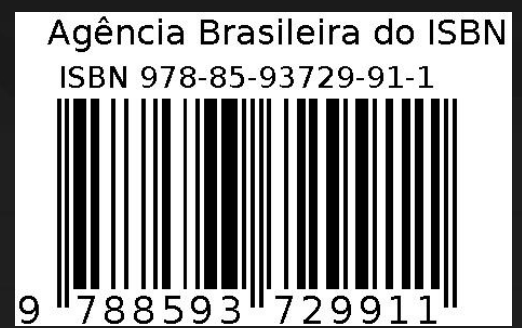

